\begin{tabular}{l} 
2. To: (Receiving Organization) \\
Distribution \\
\hline 5. Proj//Prog/Dept//Div.: \\
PROJECT W-030 \\
\hline
\end{tabular}

8. Originator Remarks:

FINAL REPORT of Phase-2 operational testing of W-030 Integrated System.

Project W-030 provides the $\mathrm{AY} / \mathrm{AZ}$ tank farms ventilation upgrade.

11. Receiver Remarks: 11A. Design Baseline Document? [] Yes [x] No

3. From: (Originating Organization)
6. Design Authority/ Design Agent/Cog.
Engr.: W.M. Harty

4. Related EDT No:

NA

7. Purchase Order No.:

NA

9. Equip./Component No.:

NA

10. System/Bldg/Facility:

AY/AZ Tank Farms

12. Major Assm. Dwg. No.:

NA

13. Permit/Permit Application No.:

NA

14. Required Response Date:

IMMEDIATE

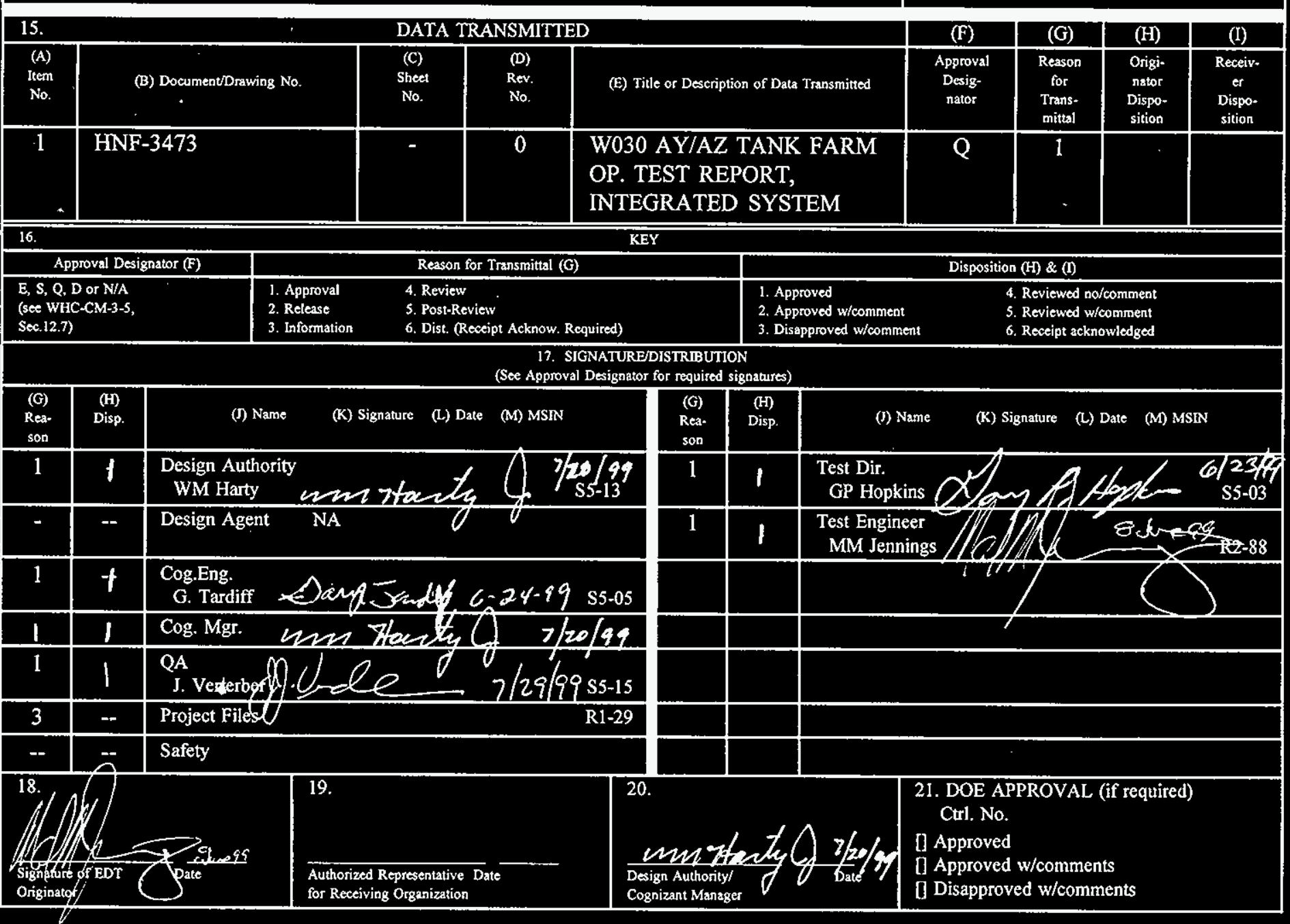

BD-7400-172-2 (05/96) GEF097 


\section{OPERATIONAL TEST REPORT, INTEGRATED SYSTEM TEST (VENTILATION UPGRADE)}

\section{FT CLIFTON}

LOCKHEED MARTIN HANFORD COMPANY, Richland, WA 99352

U.S. Department of Energy Contract DE-AC06-96RL13200

EDT/ECN: $\mathbf{6 2 6 7 1 1}$

Org Code: $79 \mathrm{C} 00$

B\&R Code: EW3130010
UC: 2030

Charge Code: 106891 (COA FA20)

Total Pages: $2 * 0$

Key Words: TEST, COOLING, VENTILATION, UPGRADE

Abstract: Operational Final Test Report for Integrated Systems, Project W-030 (Phase 2 test, RECIRC \& HIGH-HEAT Modes). Project W-030 provides a ventilation upgrade for the four Aging Waste Facility tanks, including upgraded vapor space cooling and filtered venting of tanks AY101, AY102, AZ101, AZ102.

TRADEMARK DISCLAIMER. Reference herein to any specific commercial product, process, or service by trade name, trademark, manufacturer, or otherwise, does not necessarily constitute or imply its endorsement, recommendation, or favoring by the United States Government or any agency thereof or its contractors or subcontractors.

Printed in the United States of America. To obtain copies of this document, contact: Document Control Services, P.O. Box 950, Mailstop H6-08, Richland WA 99352, Phone (509) 372-2420; Fax (509) 376-4989.

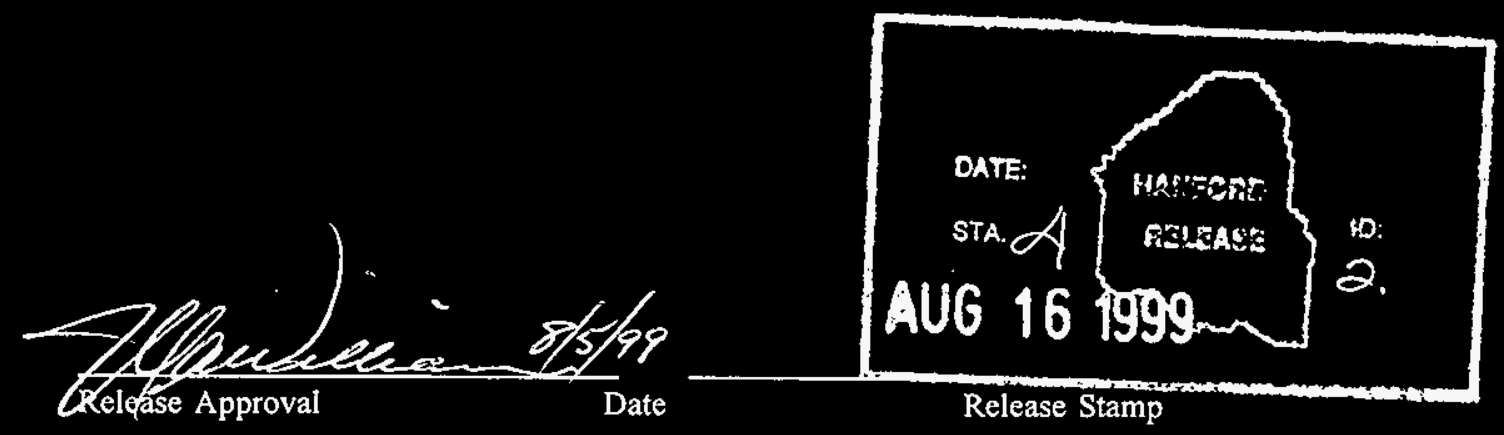

\section{Approved for Public Release}




\section{TABLE OF CONTENTS}

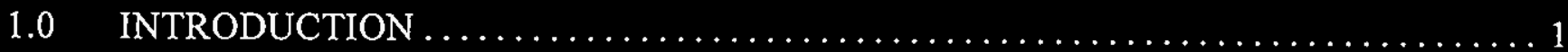

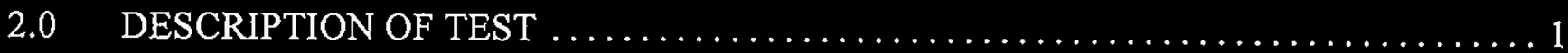

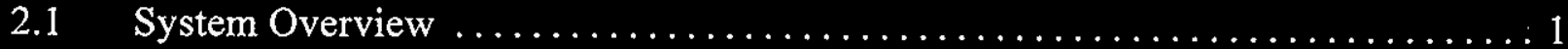

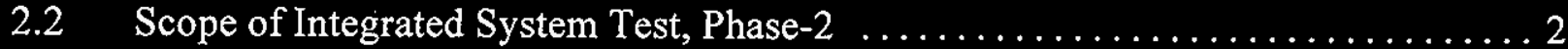

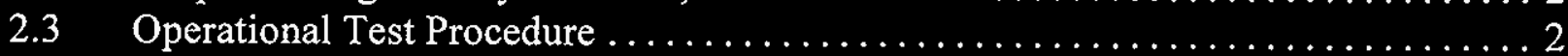

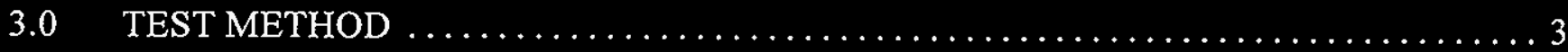

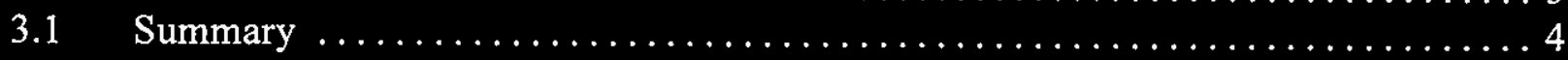

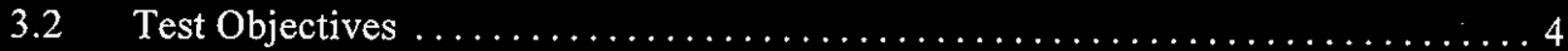

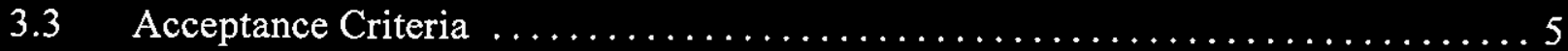

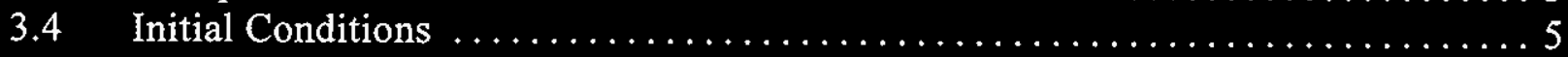

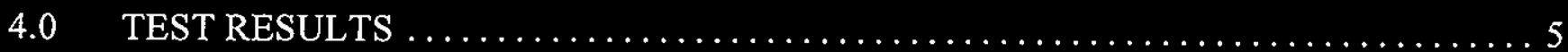

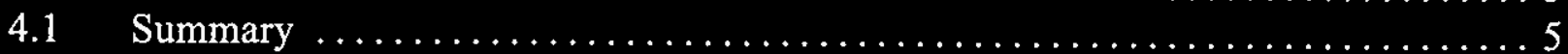

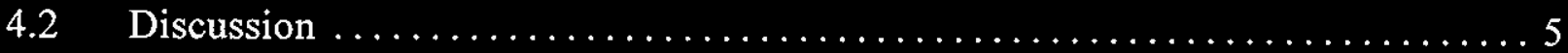

4.3 Test Exceptions .......................................... 13

5.0 CONCLUSIONS AND RECOMMENDATIONS $\ldots \ldots \ldots \ldots \ldots \ldots \ldots \ldots \ldots \ldots \ldots$

APPENDIX 1 - BYPASS, Maximum Flow, Train-B (A-11) ................... 17

APPENDIX 2 - BYPASS, Primary Vent Train Switchover, B-A (A-12) . . . . . . . . . . 21

APPENDIX 3 - BYPASS, Maximum Flow, Train-A (A-13) . . . . . . . . . . . . . . 23

APPENDIX 4 - RECIRC, Primary Vent Condenser Evaluation (B-3) . . . . . . . . . . . . . 26

APPENDIX 5 - AY101 Hi-Heat, Steady-State (B-4)... . . . . . . . . . . . . . . . . . . . . . . 29

APPENDIX 6 - AY101 Hi-Heat, Tank Pressure Control (B-5) . . . . . . . . . . . . . . 36

APPENDIX 7 - AY101 Hi-Heat, Vent Train Switchover, A-B (B-6).. . . . . . . . . . . . . 38

APPENDIX 8 - AY102 Hi-Heat, Steady-State (B-7)... ...................... 40

APPENDIX 9 - AY102 Hi-Heat, Tank Pressure Control (B-8) . . . . . . . . . . . . . . . . . 46

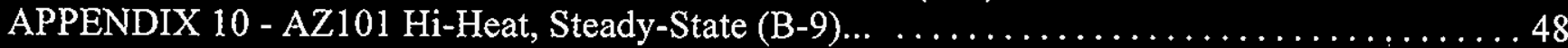

APPENDIX 11 - AZ101 Hi-Heat, Tank Pressure Control (B-10). . . . . . . . . . . . . . . 54

APPENDIX 12 - AZ101 Hi-Heat, Vent Train Switchover, B-A (B-11).. . . . . . . . . . . . . 56

APPENDIX 13 - AZ102 High-Heat, Steady-State (B-12) . . . . . . . . . . . . . . . . . 58

APPENDIX 14 - AZ102 High-Heat, Tank Pressure Control (B-13) . . . . . . . . . . . . . 64

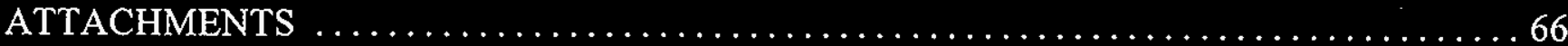

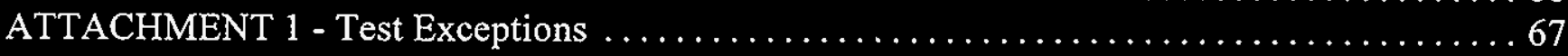

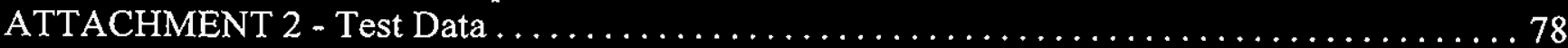

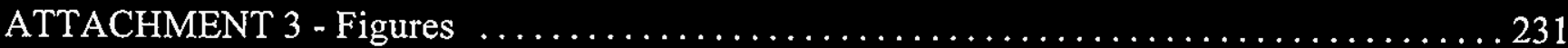




\section{LIST OF TABLES}

Table 1

Table 2

Table 3

Table 4

Table 5

Table 6

Table 1-1

Table 1-2

Table 1-3

Table 2-1

Table 2-2

Table 3-1

Table 3-2

Table 3-3

Table 4-1

Table 5-1

Table 5-2

Table 5-3

Table 5-4

Table 6-1

Table 7-1

Table 7-2

Table 8-1

Table 8-2

Table 8-3

Table 8-4

Table 9-1

Table 10-1

Table 10-2

Table 10-3

Table 10-4

Table 11-1

Table 12-1

Table 12-2

Table 13-1

Table 13-2

Table 13-3

Table 13-4

Table 14-1
Summary of Test Objectives

Summary of POTP Test Issues

Summary of Tank Vacuum Achieved

Recirc (K4) Fan Dp Comparison

Recirc (K4) Condenser DP Comparison . .

Summary of Conditions For High-Heat Mode

Pri. Vent Filter Train-B \& Stack, OTP Sec. A-11

Pri Vent System, Condenser \& HEME, OTP Sec. A-11 . . . . . . . . . . . . . . . . 19

Pri. Vent System, Condenser \& HEME, OTP Sec. A-11 . . . . . . . . . . . . . . . 20

Waste Tank Conditions, OTP Section A-11 .................... 20

System Conditions, OTP Section A-12 ....................... 22

Waste Tank Conditions, OTP Section A-12 .................... 22

Pri. Vent Filter Train-A and Stack, OTP Sec. A-13 .................. 24

Pri. Vent System, Condenser \& HEME, OTP Sec. A-13 ............... 25

Waste Tank Conditions, OTP Sec. A-13 ..................... 25

Pri. Vent Condenser Conditions, OTP Sec. B-3 .................. 28

Tank AY101 Hi-Heat Conditions, OTP Sec. B-4 ................. 32

System Conditions, AY101 Hi-Heat, OTP Sec. B-4 ................. 33

Tank AY101 Hi-Heat Conditions, OTP Sec. B-4 . . . . . . . . . . . . . . . . 34

System Conditions, AY101 Hi-Heat, OTP Sec. B-4 ................ 35

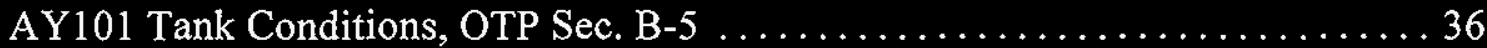

System Conditions, OTP Sec. B- 6 . . . . . . . . . . . . . . . . . . . . . . . 39

Waste Tank Conditions, OTP Sec. B-6 ............................ 39

Tank AY102 Hi-Heat Conditions, OTP Sect. B-7 . . . . . . . . . . . . . . . . . 42

System Conditions, AY102 Hi-Heat, OTP Sec. B-7 . . . . . . . . . . . . . 43

Tank AY102 Hi-Heat Conditions, OTP Sec. B-7 . ................. 44

System Conditions, AY102 High-Heat, OTP Sec. B-7 . . . . . . . . . . . 45

AY102 Tank Conditions, OTP Sec. B-8 ....................... 47

Tank AZ101 Hi-Heat Conditions, OTP Sec. B-9 ................... 50

System Conditions, AZ101 Hi-Heat, OTP Sec. B-9 . . . . . . . . . . . . . 51

Tank AZ101 Hi-Heat Conditions, OTP Sec. B-9 ................. 52

System Conditions, AZ101 Hi-Heat, OTP Sec. B-9 ................ 53

AZ101 Tank Conditions, OTP Sec. B-10 ....................... 55

System Conditions, OTP Sec. B-11 ... . . . . . . . . . . . . . . . . 57

Waste Tank Conditions, OTP Sec. B-11 ....................... 57

Tank AZ102 Hi-Heat Conditions, OTP Sec. B-12 ................. 60

System Conditions, AZ102 Hi-Heat, OTP Sec. B-12 . . . . . . . . . . . . . . 61

Tank AZ102 Hi-Heat Conditions, OTP Sec. B-12 ................. 62

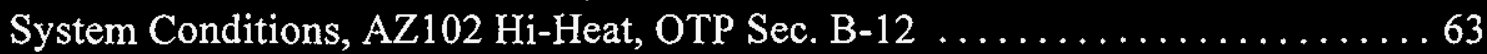

AZ102 Tank Conditions, OTP Sec. B-13 ......................6 65 


\section{FIGURES}

Figure 1

Figure 2

Figure 4-1 through 4-4

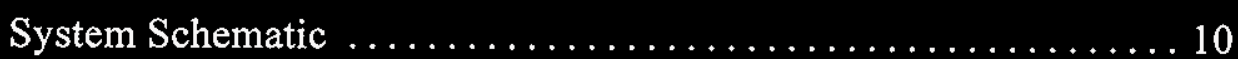

K4 Fan Curve ......................... Attachment 3

Data Plots of Primary Vent Cooling Evaluation ....... Attachment 3

\section{REFERENCES}

1. WHC-SD-600-FDC-001 Rev. 4, Functional Design Criteria for the Tank Farm Ventilation Upgrade, Project $W-030$.

2. OTP-T-W030-001 Rev. B-3 and B-4, W-030 Operational Test Procedure, Integrated System Test.

3. HNF-SD-W030-TD-008 Rev. 1, PREOPERATIONAL TEST FINAL REPORT, INTEGRATED SYSTEM TEST, VENTILATION UPGRADE; NUMATEC HANFORD COMPANY, January 16, 1998.

4. HNF-3472 Rev. 0, W030 OPERATIONAL TEST REPORT (PHASE 1), NUMATEC HANFORD COMPANY, November 17, 1998.

5. Hanford Drawing, H-2-131000, Revision 2, (June 1998); DRAWING LIST (FOR W-030 PROJECT)

6. HNF-4563 Rev. 0, W030 OPERATIONAL TEST REPORT FOR CATHODIC PROTECTION, LOCKHEED MARTIN HANFORD COMPANY, Date TBD (not yet released at this writing). 


\subsection{INTRODUCTION}

The overall objective of operational testing is to demonstrate that integrated system operation meets design functions and requirements. Design requirements are defined in WHC-SD-600-FDC001, Functional Design Criteria for the Tank Farm Ventilation Upgrade, Project W-030, reference 1 , along with related supplemental criteria. Operational testing is performed and reported in three phases.

This report provides a summary of test results for Phase-2 of the operational integrated system test of the 241-AZ-702 ventilation system. Phase-1 testing, restricted to a stack effluent discharge regulatory limit of $80 \%$ of the $1000 \mathrm{scfm}$ design, was previously completed and reported in reference 4 . Phase-2 testing (at full unlimited flow) completes all required operational testing for Project W-030 tank ventilation/cooling with the exception of the Air Lift Circular demonstration that will be completed at a later date (to be reported through formal revision of this document). The Cathodic Protection system is being tested separately (reference 6).

Phase-2 testing was performed in accordance with OTP-T-W030-001 Rev. B-5, W-030 Operational Test Procedure, Integrated System Test (OTP, reference 2). Testing was performed during October and November of 1998; the RECIRC and HIGH-HEAT Modes were fully tested. Results of each section of the OTP are summarized in the appendices.

Attachment 2 of this report provides a copy of the applicable portions of the test procedure, with actual test data as recorded in the field. It should be noted that the system had been operating successfully for more than six months prior to Phase-2 OTP testing; system startup in March 1998 followed a lengthy and comprehensive preoperational test program (Reference 3). The Phase-1 OTP testing was completed in August 1998; lessons-learned were incorporated into Phase-2 testing.

\subsection{DESCRIPTION OF TEST}

\subsection{System Overview}

The system is controlled automatically by the Monitor and Control System (MCS). The test included operation and testing of the following 702-AZ systems:

- $\quad$ Primary Vent (PV) System, K1, consisting of four 500-scfm tank-air-inlet stations with automatic tank-pressure control valve; four tank-air-outlet flow-control valves; a final chiller-cooled moisture condenser, one High-Efficiency Mist Eliminator (HEME), two parallel 1000-cubic feet per minute (scfm) Air Cleanup Trains (each with a 20-HP fan, electric heater, and final filters), and the primary tank exhaust stack monitor; the filters include a primary HEPA, HEGA, and final HEPA (High Efficiency Particulate Air, High Efficiency Gas Adsorber).

- Recirculation Vent System, K4, consisting of four tank-ventilation cooling loops, each including one nominal $580 \mathrm{scfm}$ fan, a cooling condenser, moisture separator, and interconnecting valved piping. 
- Recirculation Cooling System, EW, consisting of four recirculation water-glycol cooling loops, each including a redundant pair of recirculation pumps, an evaporative cooling tower, and interconnecting valved piping.

- $\quad$ Primary Vent Condenser Cooling System, AZCW, consisting of one air-cooled water chiller (nominal 40 refrigerant tons), two centrifugal circulating water pumps with expansion tank, one 500-gallon thermal storage tank, and piping connecting these components to the primary vent system condenser.

- Primary Vent Condensate Drain System, consisting of an in-cell 80-gallon condensate collection tank with remote sampling and drain piping connected to in-farm catch tank 241-AZ-151.

Figure 1 shows a simple overall system schematic diagram which is based on W-030 design Process and Instrument Diagrams (P\&IDs); a complete list of W-030 drawings is found on the official drawing list on reference 5 . For the major components mentioned above, detailed requirements and capacity information may be found in the W-030 procurement specifications, listed in reference 5 .

\subsection{Scope of Integrated System Test, Phase-2}

The system was initially verified to be in normal BYPASS or RECIRC Mode of operation in accordance with approved operating procedures. All instruments were verified to have been calibrated and that tank pit sealing had been completed. The test covered RECIRC and HIGH-HEAT Mode testing at stack flows up to the maximum capability of $1050 \mathrm{scfm}$, and included the sections noted in Table 1 below. Normal steady-state conditions were observed along with system performance following various defined changes in system configuration. Complete parametric data was recorded at each observed condition.

\subsection{Operational Test Procedure (OTP)}

The approved OTP was prepared and released as a facility operating procedure document in accordance with HNF-IP-0842. It consists of two parts: Attachment A - BYPASS Mode and Attachment B RECIRC and HIGH-HEAT Modes. The full OTP text is available on the Hanford Network (PROCINFO). Revision B-5 was prepared specifically for Phase-2. The final OTP section defines testing of the system when challenged by activation of existing Air Lift Circulators in tanks AZ101 and AZ102, to be performed later.

\section{$2.4 \quad$ Issues from Pre-Operational Test (POTP)}

Preoperational (cold) testing was accomplished under eight POTP procedures, and completed in October 1997; the integrated system cold test was reported under reference 3 . The latter identified several Test Exceptions and other issues for further investigation in final testing as summarized in Table 2 below. Some were closed in Phase-1. The remaining open issues are discussed in 4.2.6 below and are considered resolved and closed with the release of the test report. 
Table 1. Summary of Test Objectives

\begin{tabular}{|c|c|}
\hline $\begin{array}{c}\text { Procedure } \\
\text { Section, Mode } \\
\text { (See Notes) } \\
\end{array}$ & $\begin{array}{l}\text { Test Objectives } \\
\text { OTP-W030-001, Phase-2 and }-3\end{array}$ \\
\hline $\begin{array}{l}\text { A-11, BYPASS } \\
\text { or RECIRC }\end{array}$ & $\begin{array}{l}\text { Ensure PV Train-B can achieve design maximum system flow rate (BYPASS or } \\
\text { RECIRC Mode). }\end{array}$ \\
\hline $\begin{array}{l}\text { A-12, BYPASS } \\
\text { or RECIRC }\end{array}$ & $\begin{array}{l}\text { Demonstrate smooth switchover from PV-Train-B to Train-A, using MCS Macro } \\
\text { (BYPASS or RECIRC). }\end{array}$ \\
\hline $\begin{array}{l}\text { A-13, BYPASS } \\
\text { or RECIRC }\end{array}$ & $\begin{array}{l}\text { Ensure PV Train-A can achieve design maximum system flow rate (BYPASS or } \\
\text { RECIRC Mode). }\end{array}$ \\
\hline $\begin{array}{l}\text { B-3, RECIRC } \\
(3.9-3.24) \\
\end{array}$ & $\begin{array}{l}\text { Document the system effects of variations over a range of temperature settings for the } \\
\text { Primary Vent Condenser (new section added by recent OTP revision). }\end{array}$ \\
\hline $\begin{array}{l}\text { B-4, AY101 } \\
\text { High-Heat }\end{array}$ & $\begin{array}{l}\text { Ensure stable steady-state operation with tank AY } 101 \text { in High-Heat Mode, others in } \\
\text { RECIRC Mode; dry and wet cooling towers. }\end{array}$ \\
\hline $\begin{array}{l}\text { B-5, AY101 } \\
\text { High-Heat }\end{array}$ & $\begin{array}{l}\text { Ensure ability to vary tank pressure-control setpoints during AY101 High-Heat Mode } \\
\text { operation. }\end{array}$ \\
\hline $\begin{array}{l}\text { B-6, AY101 } \\
\text { High-Heat }\end{array}$ & $\begin{array}{l}\text { Ensure continued stable steady-state system operation following PV-Train switchover } \\
\text { (A to B) with AY101 in High-Heat Mode. }\end{array}$ \\
\hline $\begin{array}{l}\text { B-7, AY } 102 \\
\text { High-Heat }\end{array}$ & $\begin{array}{l}\text { Ensure stable steady-state operation with tank AY102 in High-Heat Mode, others in } \\
\text { RECIRC Mode; dry and wet cooling towers. }\end{array}$ \\
\hline $\begin{array}{l}\text { B-8, AY } 102 \\
\text { High-Heat }\end{array}$ & $\begin{array}{l}\text { Ensure ability to vary tank pressure-control setpoints during AY102 High-Heat Mode } \\
\text { operation. }\end{array}$ \\
\hline $\begin{array}{l}\text { B }-9, \text { AZ101 } \\
\text { High-Heat }\end{array}$ & $\begin{array}{l}\text { Ensure stable steady-state operation with tank AZ101 in High-Heat Mode, others in } \\
\text { RECIRC Mode; dry and wet cooling towers. }\end{array}$ \\
\hline $\begin{array}{c}\text { B-10, AZ101 } \\
\text { High-Heat }\end{array}$ & $\begin{array}{l}\text { Ensure ability to vary tank pressure-control setpoints during AZ101 High-Heat Mode } \\
\text { operation. }\end{array}$ \\
\hline $\begin{array}{l}\text { B-11, AZ101 } \\
\text { High-Heat }\end{array}$ & $\begin{array}{l}\text { Ensure continued stable steady-state system operation following PV-Train switchover } \\
\text { (B to A) with AZ101 in High-Heat Mode. }\end{array}$ \\
\hline $\begin{array}{l}\text { B-12, AZ102 } \\
\text { High-Heat }\end{array}$ & $\begin{array}{l}\text { Ensure stable steady-state operation with tank AZ102 in High-Heat Mode, others in } \\
\text { RECIRC Mode; dry and wet cooling towers. }\end{array}$ \\
\hline $\begin{array}{l}\text { B-13, AZ102 } \\
\text { High-Heat }\end{array}$ & $\begin{array}{l}\text { Ensure ability to vary tank pressure-control setpoints during AZ102 High-Heat Mode } \\
\text { operation. }\end{array}$ \\
\hline $\begin{array}{c}\text { (Later) } \\
\text { B-15, AZ102 } \\
\text { ALC } \\
\end{array}$ & $\begin{array}{l}\text { Ensure safe and stable steady-state system operation during activation of selected Air- } \\
\text { Lift Circulators. }\end{array}$ \\
\hline
\end{tabular}

NOTES: $\quad$ 1. $\quad$ Procedure section A-11 refers to Section 11 of Attachment A. This nomenclature is used throughout this report.

2. Sections A-1, A-2, B-1, B-2 were also implemented, but they include only preparation and setup steps. 
Table 2. Summary of POTP Test Issues

\begin{tabular}{|c|c|c|}
\hline TE OR ISSUE & DESCRIPTION & STATUS \\
\hline 004 & Excessive tank in-leakage & Closed in Phase-1. \\
\hline 019 & Spurious "keep-alive" (KA) alarms & Closed in Phase-1. \\
\hline 032 & Spurious peer-peer alarms & Closed in Phase-1. \\
\hline 035 & Suspect chiller-related data & Closed in Phase-1. \\
\hline 036 & Wind-effects on atmosphere reference probe & Closed in Phase-1. \\
\hline 041 & LCU-1 erratic behavior & Closed in Phase-1. \\
\hline 045 & Spurious KA alarms & Closed in Phase-1. \\
\hline 074 & Recirc-loop diff. pressure & Closed. See 4.2.6 \\
\hline 086 & Spurious stack CAM alarm & $\begin{array}{l}\text { Non-recurring. Considered } \\
\text { Closed. See 4.2.6 }\end{array}$ \\
\hline $\begin{array}{l}\text { HIGH-HEAT } \\
\text { VACUUM }\end{array}$ & Excessive tank vacuum in HIGH-HEAT Mode & Closed. See 4.2.6 \\
\hline HIGH-HEAT DP & $\begin{array}{l}\text { Unexpected DP values across } \mathrm{K} 4 \text { condensers in } \\
\text { HIGH-HEAT }\end{array}$ & Closed. See 4.2.6 \\
\hline
\end{tabular}

\subsection{TEST METHOD}

\subsection{Summary}

All test actions were initiated and verified from the appropriate MCS graphic screen on the operator console in the central control room. The central control room is located inside Control Building 241AZ-271. The test procedure identified when it was necessary to initiate actions or verify response locally. The system was operated in full automatic mode and controlled by the MCS to the maximum extent possible. When switching between operating modes (BYPASS, RECIRC and HIGH-HEAT), designated manual valves were repositioned by operator personnel at the Recirulcation (K4) Cooling Modules inside the Tank Farm.

\subsection{Test Objectives}

The overall objective of operational integrated system testing is to verify satisfactory and stable integrated system operation of the tank ventilation system in all intended modes of service and to collect sufficient baseline operating data to confirm its heat-removal capacity. The primary objective for Phase-2 testing of the OTP is to demonstrate satisfactory system operation in the RECIRC and HIGH-HEAT Modes in accordance with design requirements. Specific objectives by section are listed in Table 1 above.

\subsection{Acceptance Criteria}


The specific acceptance criteria for each parameter are stated in the OTP data tables and repeated herein in the test results summaries of the appendices to this report.

\subsection{Initial Conditions}

Before starting this test, the 241-AZ-702 ventilation system was determined to be operating normally in accordance with applicable plant operating procedures, with each tank in the BYPASS or RECIRC Mode. Detailed prerequisite conditions are presented in OTP Section 4.0, included herein as part of Attachment 2; these include:

- $\quad$ pretest briefing;

- walkdown inspection

- document calibration and signature verifications

- component availability

- no interfering MCS alarms

Unless otherwise noted, the nominal setpoints for certain key parameters are as follows:

- Tank vacuum and exhaust flow control valves in automatic mode;

- Tank vacuum set at -2 inches water column (in wc);

- $\quad$ PV Train heaters set for $25^{\circ} \mathrm{F}$ (temperature rise across heater);

- $\quad$ PV water chiller set for approximately $36^{\circ} \mathrm{F}$ outlet temperature;

- $\quad$ PV Fan speed under auto control based on PV Train inlet vacuum.

\subsection{TEST RESULTS}

\subsection{Summary}

The results of the Phase-2 integrated-system operational test are considered fully acceptable. A detailed description of test results is discussed below and in Appendices 1-14 (one for each OTP section performed). Numerous Test Exceptions (TEs) were recorded. These are discussed below and listed in Attachment 1; none significantly influenced test results. There were no Non-Conformance Reports. All tests in this report were performed with all tanks in RECIRC or HIGH-HEAT Modes. No further BYPASS Mode testing was considered necessary following Phase-1 tests. The discussion below is presented in terms and order of the general test objectives. All open issues from preoperational (POTP) and Phase-1 tests are considered closed, also discussed below.

\subsection{Discussion}

\subsubsection{Primary Vent System Maximum Flow.}

OTP Sections A-11 (Train-B) and A-13 (Train-A) successfully operated the PV system at peak flow. Results were closely consistent for each train, with both operating within the Acceptance Criteria of 900-1050 scfm. The data was also closely consistent with POTP results (reference 3, Attachment K). Since the status of the $\mathrm{K} 4$ cooling system is not documented for this section, its effects on peak system 
flow is unknown (e.g. if more or less condensing were taking place). Test Exceptions TE-001 (item 5), -006 (item 4), and -007 were noted, related to PV Condenser DP, main manifold vacuum, and heater temperatures; see discussions in 4.3. The maximum manifold vacuum achieved was about $20 \mathrm{in}$. wc ( a greater vacuum was achieved in Phase-1, 23 in. wc, because of reduced airflow). This performance is considered acceptable. See Appendix-1 and -3 for details.

\subsubsection{Primary Vent Train Switchover at Maximum Flow}

OTP Sections A-12 and B-6 successfully initiated an automatic switchover from PV Train-B to TrainA and back again. In B-6, tank AY101 was operating in High-Heat Mode. Operator personnel accomplished the change by a simple MCS Macro command at the interface terminal. The same TEs were recorded as described in 4.2.1 except that TE-006 was not encountered in Section B-6 because of a higher degree of system stabilization. See Appendix-2 and -7 for details.

\subsubsection{Primary Vent Condenser Evaluation}

In Phase-1, TE-001 (item 5) noted higher than expected PV Condenser Air DP. Accordingly, OTP Section B-3 was expanded to include an evaluation of the effects of condensing-rate on air DP. The test was performed with the system in normal RECIRC Mode at maximum stack airflow (although the degree of recirculation-cooling is not known). Initially maximum PV condensing was occurring, then the chiller was stopped and the resulting transient was recorded, during which the Condenser DP decreased and stack airflow increased. Indeed, at the end of the period, total airflow reached its highest level to date as the chiller was re-started. Since the status of the K 4 cooling system is not documented for this section, its effects on peak system flow is unknown (e.g. if more or less condensing were taking place). "The same TEs as in 4.2.1 were noted. See Appendix 4 for details.

\subsubsection{High-Heat Mode Steady State.}

Steady-State High-Heat Mode operation was tested in Appendices B-4, B-7, B-9, and B-12 for all tanks. Each tank was successfully operated in High-Heat Mode for the first time. Table-6 below summarizes key parameters for each tank in each test. The target tank-vacuum setpoint of 2.0 in wc was able to be tightly-controlled for each tank in High-Heat; however, for AZ102 (with the least inleakage) the least vacuum obtainable was 2.3 in wc with its inlet valve full open. In most cases, the other three tanks experience minimal impact when any tank is in High-Heat, however, certain negative effects are notable; with other tanks in High-Heat :

- Tank AY101 is the most impacted; its exhaust valve moves from a mid-range position to full open in attempting to achieve setpoint and in some cases falls short; tank vacuum is diminished when $\mathrm{AZ}$ tanks are in High-Heat,

- AY102 does not lose vacuum, but its exhaust valve moves from mid-range to near-fullopen,

- $\quad$ even tight-sealed AZ102 cannot maintain vacuum setpoint when AZ101 is in HighHeat.

A concern raised in pre-operational testing appears laid to rest, i.e., excessive tank vacuum in High- 
Heat Mode. This final testing reveals sufficient tank inleakage to preclude this problem. In the former tests, as postulated in the test report (reference 3), the problem was apparently due to the DP losses in the temporary test apparatus.

Test Exceptions -001 (item 5), -006 (items 1 - 5), -007 were noted. See 4.3 for discussion. See Appendices 5, -8, -10, and -13 for all High-Heat detailed test results.

A point of interest in Table- 6 is that AZ102 is sufficiently leak-tight that the inlet-station control valve is continuously admitting air, even at the relatively-modest exhaust rate of $110 \mathrm{scfm}$ (suggesting that its normal exhaust rate could be reduced).

In High-Heat Mode, the airflow through the tank, Condenser and Fan is once-through and therefore is precisely known to be $500 \mathrm{scfm}$ because of the K1-2 flow control. Using this data, the flow characteristics of the Fan and Condenser might be "calibrated" to then evaluate their performance in RECIRC mode. Some attempt has been made to do this in the appendices, however, there is insufficient data for a comprehensive analysis.

\subsubsection{Change Tank Pressure Setpoints in High-Heat Mode}

OTP Sections B-5, B-8, B-10, B-13 successfully demonstrated the ability to change tank-vacuum setpoints (over a range from 0.5 to 3.0 inches wc) for a tank operated in High-Heat Mode.

Due to the flow resistance (DP) of the tank inlet stations, the minimum vacuum was limited, depending on the amount of uncontrolled inleakage. TE-008 documents this circumstance for all tanks. Table-3 summarizes the results. See appendices $6,9,11,14$ for detailed results.

\begin{tabular}{||c|c|c|c|c|}
\hline \multicolumn{5}{|c|}{$\begin{array}{r}\text { TABLE 3 - SUMMARY OF TANK VACUUM ACHIEVED } \\
\text { (See 4.2.5; Acceptance Criteria = Setpoint } \pm 0.5)\end{array}$} \\
\hline $\begin{array}{l}\text { Tank Vacuum } \\
\text { Achieved, in. wc }\end{array}$ & AY101 & AY102 & AZ101 & AZ102 \\
\hline \hline $\begin{array}{c}\text { Minimum } \\
(\text { Setpoint =0.5) }\end{array}$ & 1.3 & 1.2 & 1.7 & 2.3 \\
\hline $\begin{array}{c}\text { Maximum } \\
\text { (Setpoint =3.0) }\end{array}$ & 2.9 & 3.0 & 3.0 & 3.0 \\
\hline
\end{tabular}

\subsubsection{Previous Open Issues.}

As stated in 2.4 above, Phase-1 OTP testing left several open issues. These are discussed below.

1. Remaining POTP Issues.

a) TE-074 identified three K4 fans exhibiting DP values (at 16-17 inches wc) outside the acceptance criteria of $<16$ in. wc. The TE report noted deferral of this to the Project 
W030 OAC Punchlist, Item 45. However, this TE was actually resolved in the final report (reference 3 ) via re-testing, with corrected criteria and should have been closed. Even so, the test report text (par. 4.3.2 and Appendix 7 of reference 3) describes other similar violations which were not noted in a TE report.

Accordingly, and subsequent to this OTP, the acceptance criteria was expanded to cover this unanticipated fan performance, but new additional TEs were found (TE-006). Table- 4 provides a comparison of values from the POTP test with those obtained in this OTP test.

Since generally speaking, fan DP is inversely proportional to its flow rate, the data is consistent with K4 Condenser DP data (as shown in Table 4) and with the fan curve (see Figure 2 in Attachment 3). Increasing Condenser DP reflects greater airflow, with a corresponding decrease in Fan DP. However, there is insufficient data for a comprehensive comparison. This issue was not considered in Phase-1 since very little RECIRC testing was done at that time.

The current data is somewhat consistent with the POTP for all fans and is now believed to be normal; the TEs have been accepted on the basis that until now, the actual operating characteristics of this equipment were only speculative. The currently observed performance characteristics were not fully anticipated.

b) TE-086 identified several spurious alarms of the stack Continuous Air Monitor (CAM). This was deferred to final testing to be investigated if repeated (par. 4.3.4, reference 3 ). However, no further alarms occurred, and thus, the TE is considered closed.

c) One of two non-TE issues to be further investigated was the effect of excessive tankvacuum created during High-Heat testing. As speculated in the POTP test report (reference 3, par. 4.3.1), this problem was apparently related to the temporary test apparatus. It did not occur in this test, and is considered closed. See 4.2.4.

d) The second non-TE issue (Appendix 7 of reference 3) pertains to unexpected DP values across the $\mathrm{K} 4$ Condensers in High-Heat Mode, i.e., the DP is much lower in High-Heat Mode than in RECIRC. Even though the acceptance criteria was widened in this OTP (based on Phase-1 experience), additional TEs were encountered (TE-006).

Table- 5 provides a comparison of values from the POTP test with those obtained in this OTP test. The table also compares the DP with the maximum condensing (WET tower), and minimum condensing (DRY tower) modes, using the cooling water temperature as the distinguishing basis. Even though the towers were wet in the POTP test, minimal condensing is assumed since the moisture loading was very low (only ambient outdoor air was used). It is noted that the highest DP values occur in RECIRC Mode (peak airflow) with maximum condensing; in RECIRC Mode with minimal condensing, the DP is slightly less (less airflow). The lowest DPs are seen in High-Heat Mode with mimimal condensing (less airflow, fixed at $500 \mathrm{scfm}$ ). However, there is 
insufficient data for a comprehensive comparison.

The current data is somewhat consistent with the POTP for all $\mathrm{K} 4$ condensers and is now believed to be normal; the TEs have been accepted on the basis that until now, the actual operating characteristics of this equipment were only speculative. The currently observed performance characteristics were not fully anticipated.

2. Phase-1 OTP Issues

a). In the Phase-1 OTP test report (reference 4), TE-001 listed 10 items (related to OTP Attachment-B, Table 3-1) where acceptance criteria was inappropriate, and it promised resolution in Phase-2 (i.e., lessons learned). As a result, the Phase-2 OTP was revised accordingly prior to testing, correcting most of the applicable acceptance criteria throughout the document for those tests not yet performed; one item was missed however, resulting in several Test Exceptions noted herein. See Attachment 1 for more discussion.

b) Appendix 1 (reference 4) discussion suggests that better inlet-station data would be expected in Phase 2, since the inlet stations were tagged as out-of-service during phase1 tests. Better data was obtained in these tests; but some data was still unobtainable for similar reasons.

c) Appendix 2 (reference 4) recommended exploring the problem of excessive DP across the PV Condenser. This was accomplished in this OTP and reported herein in Appendix 4.

\subsubsection{Other OTP Issues}

a) The OTP data tables include many sections for which no data was available. In all of these cases, the problem relates to inlet stations that are out of service for administrative reasons. This missing data is not believed to significantly detract from test results.

b) Many hand-recorded data entries appear suspect due to inconsistency with other data, or representing physically impossible conditions. These include tank AZ102 data in OTP Table 12-2 (data is inconsistent with Table 12-1) and numerous entries concerning the $\mathrm{K} 4$ Condenser cooling water temperatures (where water temperature decreases across the condenser). These have been noted in appendices and in Attachment 2 herein.

c) Not all intended $\mathrm{K} 4$ cooling data was collected since it appears that in some cases the Cooling Towers were not functioning properly. This is evidenced by observing water temperatures that should be very near ambient dry-bulb with a DRY tower, or near wetbulb with a WET tower. Without this data, it is not possible to fully analyze K4 heat removal capabilities. 


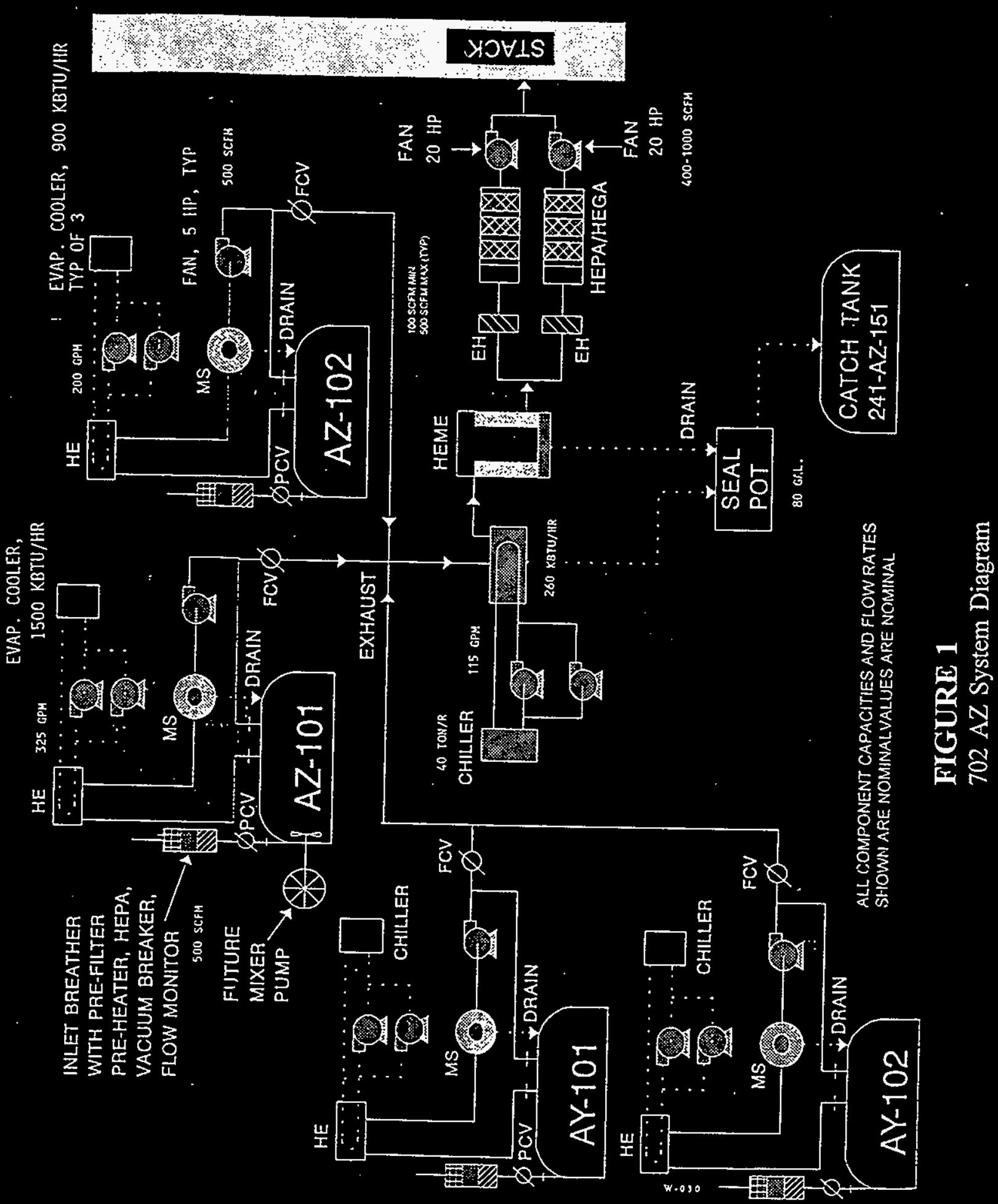


W-030 OPERATIONAL TEST REPORT (PHASE 2)

$\mathrm{HNF}-3473$

Rev. 0, Page 11

\begin{tabular}{|c|c|c|c|c|c|c|c|c|}
\hline \multicolumn{9}{|c|}{$\begin{array}{c}\text { TABLE 4 - K4 FAN DP COMPARISON } \\
\text { (See 4.2.6; Current Acceptance Criteria = 15-18 in. wc) }\end{array}$} \\
\hline \multirow{2}{*}{$\begin{array}{c}\text { Operating } \\
\text { Condition } \\
(2) \\
\end{array}$} & \multicolumn{2}{|c|}{ AY101 } & \multicolumn{2}{|c|}{ AY102 } & \multicolumn{2}{|c|}{ AZ101 } & \multicolumn{2}{|c|}{$\mathrm{AZ} 102$} \\
\hline & OTP & POTP & OTP & POTP & OTP & POTP & OTP & POTP \\
\hline RECIRC, WET & 15.5.5-17 & (2) & 16.2 & (2) & $17.4^{\circ}$ & (2) & 16.2 & (2) \\
\hline RECIRC, DRY & 14.1-15.1 & 17.3 & 13.9 & 17.2 & 16.9 & 16.5 & 15.6 & $11.9(1)$ \\
\hline HI-HEAT, WET & 19.5 & (4) & no data & (4) & no data & (2) & $16.8(3)$ & (2) \\
\hline HI-HEAT, DRY & no data & (4) & 19.4 & (4) & 20.6 & $21.8(1)$ & 19.1 & 16.9 \\
\hline
\end{tabular}

(1) Below Acceptance Criteria limit $(16 \pm 4)$ in POTP.

(2) See Table 5 for other notes.

\begin{tabular}{|c|c|c|c|c|c|c|c|c|}
\hline \multicolumn{9}{|c|}{$\begin{array}{l}\text { TABLE } 5 \text { - K4 CONDENSER DP COMPARISON } \\
\text { (See 4.2.6; Current Acceptance Criteria }=8-12 \text { in. wc) }\end{array}$} \\
\hline \multirow{2}{*}{$\begin{array}{l}\text { Operating } \\
\text { Condition } \\
(2)\end{array}$} & \multicolumn{2}{|c|}{ AY101 } & \multicolumn{2}{|c|}{ AY102 } & \multicolumn{2}{|c|}{ AZ101 } & \multicolumn{2}{|c|}{$\mathrm{AZ} 102$} \\
\hline & OTP & POTP & OTP & POTP & OTP & POTP & OTP & POTP \\
\hline RECIRC, WET & $11.6 \cdot 12.9$ & (2) & 12.6 & (2) & 12.3 & (2) & 12.3 & (2) \\
\hline RECIRC, DRY & $10.3-11.2$ & 10.9 & 10.2 & 10.8 & 11.8 & 10.1 & $11.7-12$ & 8.3 \\
\hline HI-HEAT, WET & 8.2 & (4) & no data & (4) & no data & (2) & $6.2(3)$ & (2) \\
\hline HI-HEAT, DRY & no data & (4) & 5.5 & (4) & 4.6 & $3.4(I)$ & 6.2 & $4.6(I)$ \\
\hline
\end{tabular}

(1) Below Acceptance Criteria limit $(10 \pm 4)$ in POTP.

(2) Assumptions: $\quad$ a) Cooling Tower WET or DRY based on observed water temperatures;

b) POTP tower is effectively DRY since process air stream moisture loading is very low.

(3) Suspect data, as many recorded values in OTP Table 12-2 inconsistent. (4) Not tested. 


\begin{tabular}{|c|c|c|c|c|}
\hline \multicolumn{5}{|c|}{$\begin{array}{l}\text { TABLE } 6 \text { - SUMMARY CONDITIONS FOR HIGH-HEAT MODE } \\
\text { (See } 4.2 .4) \\
\text { PV Manifold vacuum }=19.5-20.3 \text { in. wc., PV Airflow }=950-1000 \mathrm{scfm} \text {. } \\
\text { Tank vacuum setpoint= } 2.0 \mathrm{in} \text {. wc. } \\
\text { Values in brackets represent RECIRC Mode data prior to High-Heat Mode (if change } \\
\text { was notable); PV manifold vacuum was } 14 \text { in. wc during RECIRC Mode. }\end{array}$} \\
\hline Tank/Condition & AY101 & AY102 & AZ101 & $\mathrm{AZ} 102$ \\
\hline AY101 in High-Heat & \multicolumn{4}{|c|}{ See Appendix 5} \\
\hline Tank Vacuum, in wc & $2.0[1.3]$ & 0.8 & 1.1 & 2.0 \\
\hline $\begin{array}{l}\text { Exh., scfm } \\
\text { (Setpoint) }\end{array}$ & $\begin{array}{c}492-502 \\
(500)\end{array}$ & $\begin{array}{c}208-215 \\
(220)\end{array}$ & $\begin{array}{c}108-116 \\
(110)\end{array}$ & $\begin{array}{c}108-120 \\
(110)\end{array}$ \\
\hline Exh. (K1-2) Valve \% Open & $45 \% \quad[77]$ & $99 \% \quad[56]$ & $26 \%[24]$ & $61 \%[43]$ \\
\hline Inlet (K1-1) Valve \% Open & $55 \%[0]$ & $\operatorname{nr}(1)$ & $0 \%$ & $22 \%$ \\
\hline AY102 in High-Heat & \multicolumn{4}{|c|}{ See Appendix 8} \\
\hline Tank Vacuum & $1.7[1.4]$ & $2.0[1.2]$ & 1.3 & 2.1 \\
\hline $\begin{array}{l}\text { Exh., scfm } \\
\text { (Setpoint) }\end{array}$ & $\begin{array}{c}194-207 \\
(200) \\
\end{array}$ & $\begin{array}{c}497-503 \\
(500) \\
\end{array}$ & $\begin{array}{c}110-118 \\
(110)\end{array}$ & $\begin{array}{c}109-116 \\
(110)\end{array}$ \\
\hline Exh. (K1-2) Valve \% Open & $100 \% \quad[51]$ & $35 \% \quad[41]$ & $23 \%$ & $27 \%$ \\
\hline Inlet (K1-1) Valve \% Open & $0 \%$ & $36 \% \quad[0]$ & $0 \%$ & $22 \%$ \\
\hline AZ101 in High-Heat & \multicolumn{4}{|c|}{ See Appendix 10} \\
\hline Tank Vacuum & $0.8[1.0]$ & 0.7 & $2.0[0.9]$ & $1.5[2.1]$ \\
\hline $\begin{array}{l}\text { Exh., scfm } \\
\text { (Setpoint) }\end{array}$ & $\begin{array}{c}173-181 \\
200 \\
\end{array}$ & $\begin{array}{c}210-214 \\
(210)\end{array}$ & $\begin{array}{c}497-508 \\
(500)\end{array}$ & $\begin{array}{l}81-83 \\
(110)\end{array}$ \\
\hline Exh. (K1-2) Valve \% Open & $100 \%[41]$ & $86 \%[37]$ & $32 \%[19]$ & $100 \%[25]$ \\
\hline Inlet (K1-1) Valve \% Open & $0 \%$ & $\operatorname{nr}(1)$ & $60 \%[0]$ & $0 \% \quad[22]$ \\
\hline AZ102 in High-Heat & \multicolumn{4}{|c|}{ See Appendix 13} \\
\hline Tank Vacuum & $0.7[1.0]$ & 0.8 & 0.9 & $2.3[1.9]$ \\
\hline $\begin{array}{l}\text { Exh., scfm } \\
\text { (Setpoint) }\end{array}$ & $\begin{array}{c}163-169 \\
(200) \\
\end{array}$ & $\begin{array}{c}193-198 \\
(220)\end{array}$ & $\begin{array}{c}106-108 \\
(110)\end{array}$ & $\begin{array}{c}495-505 \\
(500)\end{array}$ \\
\hline Exh. (K1-2) Valve \% Open & $100 \% \quad[89]$ & $99 \% \quad[85]$ & $67 \% \quad[26]$ & $39 \%[100]$ \\
\hline Inlet (K1-1) Valve \% Open & $0 \%$ & $0 \%$ & $\operatorname{nr}(1)$ & $97 \% \quad[02]$ \\
\hline
\end{tabular}

(1) The K1-1 valve position not recorded due to inoperative inlet station; however, the value is assumed to be $0 \%$, since the tank vacuum was below setpoint. 


\subsection{Test Exceptions}

It may appear that many Test Exceptions were encountered during the test. In fact, there was a small group of TEs which repeatedly occurred in almost every section due to inappropriate acceptance criteria. The current acceptance criteria have evolved as the system characteristics at all modes have become more fully understood. A summary discussion of these TEs is presented below; the individual approved TE Reports are included in Attachment 1. Also, appropriate notations are shown as footnotes to the summary data tables in the appendices. All have been accepted with approved dispositions.

TE-001, item \# 5. Primary Vent (K1) Condenser Air Differential Pressure (DP) exceeds acceptance criteria limit of $\leq 11$ inches wc at maximum flow rates. This TE was first documented and accepted in Phase 1; following that test, the limit was increased from $10 \mathrm{in}$. wc. to the current limit. The current TEs are approved herein as accepted also, based on the fact that this testing for the first time pushed the system to its true limits. This TE is noted in 14 data tables of this report, always at peak PV system flow.

TE-006, item \#1. All four K4 Vent Condenser Air DPs slightly exceed acceptance criteria limit of 812 inches wc when operating in RECIRC Mode with the cooling towers in WET Mode (maximum condensing). This performance has been accepted on the basis that the condition is not unexpected and is consistent with similar findings for the PV condenser; and this is the first experience with this condition on most of the tanks (although AY102 was tested in Phase 1). This condition is noted in 7 data tables of this report. It should be noted however, that the data recorded in Phase 2 for AY102 is inconsistent with Phase 1; the reason is unknown.

TE-006, Item \#2. Three of the four K4 Vent Condensers Air DPs were below the acceptance criteria when operating in High-Heat Mode with the cooling tower in DRY Mode (minimum condensing). This condition is acceptable and is believed to result from lower airflow in the High-Heat Mode (500 scfm) than in RECIRC Mode (the airflow reduction is due to the increased system resistance effected by throttling the tank exhaust flow control [K1-2] valve) and because the DP is observed to be lower with minimum condensing. These results are quite consistent with the results of pre-operational tests. No other High-Heat data is available. When cooling towers were in WET Mode, DP was within or above the limit for those tanks having valid data. This exception is noted in 5 data tables of this report.

TE-006, item \#3. All four K4 Vent Fan Air DPs displayed values outside the acceptance criteria (1518 inches wc) under different circumstances. Each exceed the limit when operating in High-Heat Mode (19.1 - 20.6); this condition is acceptable as normal, as it is believed to be due to increased system resistance discussed above (item \#2). One set of data for AZ102 exhibited a lower DP value (Table 13-3), but this data is suspect due to several inconsistencies. In RECIRC Mode, Each fan exhibited a lower DP when little condensing was taking place (DRY Tower) than with maximum condensing; and AY101 an AY102 both were below the limit; otherwise all were within the limit. This exception is noted in 10 data tables of this report (plus 2 more where it would have appeared had the parameter been displayed therein).

TE-006, item \#4. PV Heater Differential Temperature (DT) (and/or the related heater outlet 
temperature) exceeded the limit of $25 \pm 2{ }^{\circ} \mathrm{F}$ (or the calculated outlet \pm 2 ) on several occasions in 4 data tables of this report related to the first 4 test segments of the OTP. This is considered acceptable, as the system apparently had not fully stabilized when these data points were recorded. Control was fully maintained thereafter.

TE-006, item \#5 Procedural error; Data table 7-2 calls for PV Train-A data, but instructions call for Train-B in service.

TE-007. PV Manifold (Filter Train inlet header) vacuum setpoint was not achieved on many occasions and was outside the limit of "Setpoint \pm 0.5 ". This condition is considered acceptable since the setpoint is arbitrary, and in most cases, it is set higher than the fan is capable in order to force the fan to operate at maximum speed (to ensure maximum system flow). This exception is noted in 15 data tables of this report. In two instances, this TE was cited to explain why AY101 exhaust flow is below setpoint (as noted in Tables 10-2 and 13-2 herein).

TE-008. In High-Heat Mode, tank vacuum cannot be reduced below a certain value, which depends on tank tightness and inlet-station DP. In each of the 4 test sections confirming the ability to change tank vacuum setpoints in High-Heat Mode, the minimum setpoint levels called for could not be achieved. This is acceptable, since tank vacuum remained within safe limits and there is no known purpose for achieving these minimum values in High-Heat Mode. The test objective, to demonstrate the ability to easily change setpoints, was met.

TE-009. Tank exhaust flow was below setpoint limits ( $\pm 20 \mathrm{scfm}$ ) on tanks AY101 and AZ102 when AZ101 is in High-Heat Mode. This is acceptable since the flow setpoints are somewhat arbitrary and tank vacuum was safely maintained (albeit marginal). This TE was cited in 3 tables of this report.

TE-010. As with TE-009, tank exhaust flow was below setpoint limits ( $\pm 20 \mathrm{scfm}$ ) on tanks AY101 and AY102 in peak-flow situations and is acceptable for the same reasons. This TE was cited in 3 tables of this report.

\subsection{Conclusions and Recommendations}

The 241-702-AZ system operates satisfactorily as expected in all modes. The following primary objectives and design requirements were demonstrated, and related recommendations are offerred:

1. The Primary Vent (PV) exhaust system, Trains A \& B, provides within $10 \%$ of the nominal maximum air flow rate of $1000 \mathrm{scfm}$ under normal operating conditions; and the PV Trains can be easily switched by simple operator action at the MCS operator terminal.

Recommendation: Peak flow may be affected by the degree of recirculation (K4) cooling taking place; any such effects should be evaluated.

2. Each tank can be safely operated in both the RECIRC and High-Heat Ventilation Modes and the system performs as designed. 
3. While operating in High-Heat Mode,

- exhaust flow from each tank is controlled in a stable manner,

- exhaust flow from each tank is less than in the RECIRC Mode as evidenced by lower Condenser DP and greater Fan DP,

- tank vacuum was not excessive as was experienced during preoperational testing,

- tank vacuum control can be easily adjusted over a wide range of settings for the High-Heat tank without seriously impacting safe operations on the other tanks (even though tank vacuum control in other tanks is somewhat diminished), and - the PV Fan/Filter Trains can be easily and quickly switched by simple operator command with no noticeable offset in observed parameters.

Recommendation - If High-Heat operation is used often, it is recommended that inlet station HEPA filters be monitored for plugging, so as to ensure against excessive tank vacuum. However, its use should be minimized due to negative impact on other tanks.

4. Recirculation-cooling functions as designed; currently, because of reduced in-tank heat generation, the cooling systems are barely challenged (as evidenced by little or no cooling water temperature increase across the cooling condensers); Cooling Towers can be operated in either WET or DRY Mode, however, during summer conditions, very little cooling takes place in DRY Mode (except for the hottest tanks), or when Tower fans are off. Tank cooling is likely greater in RECIRC Mode than in High-Heat Mode because of greater airflow.

Recommendation - Monitor cooling action to ensure that maximum Cooling Tower effectiveness is realized and that the cooling system is not actually heating the tank.

5. Tank vacuum was easily maintained within acceptance limits, however in some instances, it was marginal due to uncontrolled in-leakage. By comparing overall inlet and outlet flow data, the tanks appear to rate as follows for leak-tightness, from best to worst: AZ102, AZ101, AY101, AY102.

Recommendation - Efforts to seal tank inleakage shoud be continued.

6. The MCS operator terminals are sufficiently user-friendly to permit the operator to record large amounts of test data very quickly. However, some of the data recorded for this test appear suspect and raise validity questions.

Recommendation - Because this activity leaves room for error, future tests should require that backup data be recorded by the MCS.

7. The PV Condenser exhibits a higher air differential pressure (DP, loss) than expected at peak exhaust air flow, thereby impacting system capacity. However, the DP was demonstrated to be a function of the degree of condensing taking place (a direct function 
of the condensing temperature) and thus could be mitigated by optimizing the moisture removal rate.

Recommendation - Continue to evaluate primary condensing requirements and effects over a range of chiller temperature settings.

This Phase-2 testing completes all required operational testing except for Section B-15, Air Lift Circulators. 
APPENDIX 1 - BYPASS/RECIRC Mode, Maximum System Flow, Train-B (Section A-11)

\subsection{INTRODUCTION}

This appendix summarizes operational testing performed under OTP Attachment A, section 11. The test demonstrated system capability to achieve design maximum airflow with Primary Vent (PV) Fan/Filter Train-B in service (see Appendix 3 for discussion of identical test using Train-A).

\subsection{DESCRIPTION OF TEST}

This paragraph describes OTP requirements for this section. Initial conditions were established as described in 3.4 above. The system was initially verified to be in normal RECIRC Mode and stable. Important setpoints were verified or established as follows:

- $\quad$ PV Fan/Filter Train-B in service;

- PV Manifold Controller matching setpoints (PIC-AZK1-1A/1B), set for $-30 \mathrm{in}$. wc or as required for stable operation;

- Tank exhaust (outlet) flow rates at designated minimum levels.

While ensuring that the system remains stable, AY101 and AY102 tank exhaust flow control valves were adjusted to obtain the design exhaust stack flow rate of $1050 \mathrm{scfm}$ or the maximum achievable. After achieving and maintaining initial stable conditions for a minimum of 15 minutes, parametric data was recorded in Table 11-1; results are summarized in section 4 below.

\subsection{TEST OBJECTIVES}

With PV Train-B in operation, establish and document stable system operation in the BYPASS or RECIRC Mode at the maximum achievable exhaust stack flow; obtain baseline data and demonstrate system capability.

\subsection{TEST RESULTS}

Results of the test were satisfactory as shown in the tables below; important setpoints are shown for controlled variables. All test objectives were met; three minor Test Exceptions (TEs) were noted; the TEs do not affect test results or objectives; see discussion in 4.3 of the summary report and Attachment 1. Although the system did manage to achieve a maximum flow within acceptance criteria, it fell short of the design rate of $1000 \mathrm{scfm}$. Important data parameters are summarized in Tables 1-1, 1-2, 1-3 below.

The difference between tank exhaust (outlet) air flow rates and the inlet rates is due to tank inleakage and is seen to be consistent in most of the data of all the OTP sections. The difference between the stack exhaust flow and sum of the tank outlet flows is believed attributable to exhaust from Catch Tank 241-AZ-151. 
APPENDIX 1 - BYPASS/RECIRC Mode, Maximum System Flow, Train-B (Section A-11)

\subsection{CONCLUSION}

At the RECIRC Mode conditions established for this test, Train B maximum PV system flow rate is $929 \mathrm{scfm}$, slightly less than the $1000 \mathrm{scfm}$ design goal. The actual operating status of the recirculation systems is undocumented; optimizing K4 cooling may improve peak PV system flow rate. 
APPENDIX 1 - BYPASS/RECIRC Mode, Maximum System Flow, Train-B (Section A-11)

Table 1-1 Primary Vent Filter Train-B and Stack, OTP Section A-11 (OTP Table 11-1)

\begin{tabular}{|c|c|c|c|c|}
\hline Parameter & $\begin{array}{l}\text { Actual } \\
\text { Valne }\end{array}$ & $\begin{array}{c}\text { Setpoint } \\
\text { Value }\end{array}$ & $\begin{array}{c}\text { Acceptance } \\
\text { Criteria } \\
\end{array}$ & $\begin{array}{c}\mathrm{TE} \\
\text { Note) }\end{array}$ \\
\hline PV Manifold Vacuum, in. wc & 20.7 & 30 & Setpoint \pm 0.5 & $007(1)$ \\
\hline Heater Differential Temperature, ${ }^{\circ} \mathrm{F}$ & 29 & 25 & Setpoint \pm 2 & $006(2)$ \\
\hline $\begin{array}{l}\text { Filter Differential Pressure, } \\
\text { HEPA \#1, in. wc }\end{array}$ & 0.8 & N/A & $<5$ & - \\
\hline HEGA, in. wc & 1.5 & N/A & $<1.75$ & - \\
\hline HEPA \#2, in. wc & 0.7 & N/A & $<5$ & - \\
\hline Exhaust Fan Speed, rpm & 3632 & N/A & N/A & - \\
\hline Motor Load, $\%$ & 52 & $\mathrm{~N} / \mathrm{A}$ & N/A & - \\
\hline Exhaust Stack Air Flow, scfm & 929 & N/A & $900-1050$ & - \\
\hline Temperature, ${ }^{\circ} \mathrm{F}$ & 87 & N/A & $N / A$ & - \\
\hline
\end{tabular}

(1) Test Exception TE-007; PV Manifold vacuum setpoint is above fan capability; see par. 4.3.

(2) Test Exception TE-006, item \#4; heater differential temperature is outside of acceptance criteria due to insufficient stabilization at peak flow; this condition also led to 2 other TEs not recorded here. Test objective is not impacted. See 4.3 . 
APPENDIX 1 - BYPASS/RECIRC Mode, Maximum System Flow, Train-B (Section A-11)

Table 1-2 Primary Vent System, Condenser \& HEME, OTP Section A-11 (OTP Table 11-1)

\begin{tabular}{|c|c|c|c|}
\hline Parameter & $\begin{array}{l}\text { Actual } \\
\text { Value }\end{array}$ & $\begin{array}{c}\text { Acceptance } \\
\text { Criteria } \\
\end{array}$ & $\begin{array}{c}\mathrm{TE} \\
\text { (Note) }\end{array}$ \\
\hline Condenser Water & - & - & - \\
\hline Flow, gpm & 119 & $95-130$ & $=$ \\
\hline Inlet $\Upsilon$ emperature, ${ }^{\circ} \mathrm{F}$ & 37 & $35-55$ & $=$ \\
\hline Outlet Temperature, ${ }^{\circ} \mathrm{F}$ & 40 & N/A & $=$ \\
\hline Condenser Air & - & - & $=$ \\
\hline Differential Pressure, in. wc & 11.9 & $\leq 11$ & $001(1)$ \\
\hline Inlet Temperature, ${ }^{\circ} \mathrm{F}$ & 80 & N/A & $=$ \\
\hline Outlet Temperature, ${ }^{\circ} \mathrm{F}$ & 45 & $40-60$ & $=$ \\
\hline Condensate Flow, gpm & 0.1 & N/A & - \\
\hline HEME Differential Pressure, in. wc & 4.5 & $<10$ & - \\
\hline $\begin{array}{l}\text { Test Exception TE-001, item } \\
\text { (AC) limit. See 4.3. }\end{array}$ & & & \\
\hline
\end{tabular}

Table 1-3 Waste Tank Conditions, OTP Section A-11 (OTP Table 11-1)

\begin{tabular}{||c|c|c|c|c|c|}
\hline \multicolumn{1}{|c|}{ Parameter } & AY101 & AY102 & AZ101 & AZ102 & $\begin{array}{c}\text { Acceptance } \\
\text { Criteria }\end{array}$ \\
\hline Inlet Flow, scfm & 73 & 95 & $\mathrm{nr}(1)$ & 0 & < outlet flow \\
\hline Vacuum, in. wc & 2.0 & 1.9 & 1.3 & 2.0 & $0.5-3.0$ \\
\hline Outlet Flow, scfm & 329 & 344 & 109 & 113 & setpoint \pm 20 \\
\hline $\begin{array}{l}\text { Setpoint, scfm } \\
\text { Control Valve Position, } \\
\% \text { Open }\end{array}$ & 100 & 92 & $19(2)$ & 22 & N/A \\
\hline
\end{tabular}

(1) Inlet station out of service, no data available.

(2) Considered too close to the limit to justify a TE (i.e., within system accuracy). 
APPENDIX 2 - BYPASSIRECIRC Mode, PV Train Switchover, B to A, Section A-12

\subsection{INTRODUCTION}

This appendix summarizes operational testing performed under OTP Attachment A, section 12. The test demonstrated acceptable system performance in RECIRC Mode during Primary Vent (PV) Fan/Filter Train switchover (B to A) while operating at maximum PV system flow rate.

\subsection{DESCRIPTION OF TEST}

This paragraph describes OTP requirements for this section. Initial conditions were established as described in 3.4 above. The system was initially verified to be in normal RECIRC Mode and stable following testing of OTP section A-11. Important setpoints were verified or established as follows:

- PV Fan/Filter Train B in service at maximm flow;

- PV Manifold Controller setpoints (PIC-AZK1-1A/1B), set for -30 in. wc or as required for stable operation;

- Tank Flow rates at designated minimum levels.

After ensuring that the system was stable, parametric data was recorded and then the standby PV Train (A) was placed into service using the MCS Macro command. After stabilization, final data was recorded. The macro command performs all of the necessary MCS logic functions in a predetermined order so as to accomplish a near-bumpless transfer.

\subsection{TEST OBJECTIVES}

Ensure that stable system operation can be demonstrated before and after a normal PV Train switchover in the RECIRC Mode at maximum system flow.

\subsection{TEST RESULTS}

Stable control was established and observed before and after the changeover action. Setpoints are shown in the table for relevant controlled variables. Important recorded data is given in tables 2-1 and 2-2 below; initial and final values were similar. Results were satisfactory as shown in the tables below. Test objectives were met. Two minor TEs were noted which do not affect test results or objectives; see 4.3 above and Attachment 1 for discussion.

It is noted that stable control was maintained even though the PV manifold pressure setpoints of the two trains were slightly different.

\subsection{CONCLUSIONS}

The test objective was met. The PV Fan/Filter Trains can be easily switched by operator personnel using the MCS macro command with no system instability expected. 
APPENDIX 2 - BYPASSIRECIRC Mode, PV Train Switchover, B to A (Section A-12)

Table 2-1. System Conditions, OTP Section A-12 (OTP Table 12-1)

\begin{tabular}{||l|c|c|c|c|}
\hline \multicolumn{1}{|c|}{ Parameter } & $\begin{array}{c}\text { Initial value } \\
\text { PV Train B }\end{array}$ & $\begin{array}{c}\text { Final value } \\
\text { PV Train A }\end{array}$ & $\begin{array}{c}\text { Acceptance } \\
\text { Criteria }\end{array}$ & $\begin{array}{c}\text { TE } \\
\text { (Note) }\end{array}$ \\
\hline $\begin{array}{l}\text { PV Manifold Vacuum, in. } \\
\text { wc (Setpoint) }\end{array}$ & $\begin{array}{l}20.7 \\
(30)\end{array}$ & $\begin{array}{c}20.8 \\
(25)\end{array}$ & Setpoint \pm 0.5 & 007 (1) \\
\hline PV Stack Flow, scfm & 929 & 935 & $900-1050$ & - \\
\hline $\begin{array}{c}\text { Heater Diff. Temp., }{ }^{\circ} \mathrm{F} \\
\text { (Setpoint = 25) }\end{array}$ & 29 & 25 & Setpoint \pm 2 & $006(2)$ \\
\hline $\begin{array}{l}\text { PV Condenser Diff. Press., } \\
\text { in. wc }\end{array}$ & 11.9 & 11.4 & $\leq 11$ & $001(3)$ \\
\hline \hline
\end{tabular}

(1) Test Exception TE-007; PV Manifold vacuum setpoint is above fan capability; see par. 4.3.

(2) Test Exception TE 006 , item \#4; See Table 1-1 above.

(3) Test Exception TE-001, item \#5; PV Condenser DP exceeds Acceptance Criteria (AC) limit. See 4.3.

Table 2-2. Waste Tank Conditions, OTP Section A-12 (OTP Table 12-1)

\begin{tabular}{||l|c|c|c|c|c|}
\hline \multicolumn{1}{|c|}{ Parameter } & AY101 & AY102 & AZ101 & AZ102 & $\begin{array}{c}\text { Acceptance } \\
\text { Criteria }\end{array}$ \\
\hline $\begin{array}{l}\text { Inlet Flow, scfm, Initial } \\
\text { Final }\end{array}$ & $\begin{array}{c}73 \\
98\end{array}$ & $\begin{array}{c}95 \\
78\end{array}$ & $\mathrm{nr}(1)$ & $\begin{array}{l}0 \\
0\end{array}$ & < outlet \\
\hline $\begin{array}{l}\text { Tank Vacuum, in. wc, } \\
\text { Initial \& Final (Setpoint=2.0) }\end{array}$ & 2 & 1.9 & 1.3 & 2 & $0.5-3.0$ \\
\hline $\begin{array}{l}\text { Outlet Flow, scfm, Initial } \\
\text { Final }\end{array}$ & 329 & 344 & 109 & 110 & setpoint \pm 20 \\
\hline - Setpoint, scfm & 340 & 340 & 110 & 110 & N/A \\
\hline \hline
\end{tabular}


APPENDIX 3 - BYPASS/RECIRC Mode, Maximum System Flow, Train-A (Section A-13)

\section{$1.0 \quad$ INTRODUCTION}

This appendix summarizes operational testing performed under OTP Attachment A, section 13. The test demonstrated system capability to achieve design maximum air flow with Primary Vent (PV) Fan/Filter Train-A in service (see Appendix 1 for results of identical test using Train-B).

\subsection{DESCRIPTION OF TEST}

This paragraph describes OTP requirements for this section. Initial conditions were established as described in 3.4 above. The system was initially verified to be in normal RECIRC Mode and stable. Important setpoints were verified or established as follows:

- PV Fan/Filter Train-A in service;

- PV Manifold Controller matching setpoints (PIC-AZK1-1A/1B), set for -30 in. wc or as required for stable operation;

- Tank Exhaust flow rates returned to designated minimum levels.

While ensuring that the system remains stable, AZ101 and AZ102 tank exhaust flow control valves were adjusted to obtain the design exhaust stack flow rate of $1050 \mathrm{scfm}$ or the maximum achievable. After obtaining initial stable conditions, parametric data was recorded in Table 13-1; results are summarized in section 4 below.

\subsection{TEST OBJECTIVES}

With PV Train-A in operation, establish and document stable system operation in the BYPASŚ or RECIRC Mode at the maximum achievable exhaust stack flow from each tank; obtain baseline data and demonstrate system capability.

\subsection{TEST RESULTS}

Results of the test were satisfactory as shown in the tables below; important setpoints are shown for controlled variables. All test objectives were met; three minor Test Exceptions (TEs) were noted; the TEs do not affect test results or objectives; see discussion in 4.3 of the summary report and Attachment 1. Although the system did manage to achieve a maximum flow within acceptance criteria, it fell short of the design rate of $1000 \mathrm{scfm}$. Important data parameters are summarized in Tables 3-1, 3-2, 3-3 below.

\subsection{CONCLUSIONS}

At the RECIRC Mode conditions established for this test, Train B maximum PV system flow rate is $923 \mathrm{scfm}$, slightly less than the $1000 \mathrm{scfm}$ design goal. The actual operating status of the recirculation systems is undocumented; optimizing K4 cooling may improve peak PV system flow rate. 
APPENDIX 3 - BYPASS/RECIRC Mode, Maximum System Flow, Train-A (Section A-13)

Table 3-1 Primary Vent Filter Train-A and Stack, OTP Section A-13 (OTP Table 13-1)

\begin{tabular}{||c|c|c|c|c||}
\hline \multicolumn{1}{|c|}{ Parameter } & $\begin{array}{c}\text { Actual } \\
\text { Value }\end{array}$ & $\begin{array}{c}\text { Setpoint } \\
\text { Value }\end{array}$ & $\begin{array}{c}\text { Acceptance } \\
\text { Criteria }\end{array}$ & $\begin{array}{c}\text { TE } \\
\text { (Note) }\end{array}$ \\
\hline PV Manifold Vacuum, in. wc & 20.8 & 30 & Setpoint \pm 0.5 & $007(1)$ \\
\hline Heater Differential Temperature, ${ }^{\circ} \mathrm{F}$ & 24 & 25 & Setpoint \pm 2 & $006(2)$ \\
\hline $\begin{array}{l}\text { Filter Differential Pressure, } \\
\text { HEPA \#1, in. wc }\end{array}$ & 0.8 & N/A & $<5$ & - \\
\hline $\begin{array}{l}\text { HEGA, in. wc } \\
\text { HEPA \#2, in. wc }\end{array}$ & 1.5 & N/A & $<1.75$ & - \\
\hline \begin{tabular}{l} 
Exhaust Fan Speed, rpm \\
\hline Motor Load, \%
\end{tabular} & 0.7 & N/A & $<5$ & - \\
\hline $\begin{array}{l}\text { Exhaust Stack Air Flow, scfm } \\
\text { Temperature, }{ }^{\circ} \mathrm{F}\end{array}$ & 4631 & N/A & N/A & - \\
\hline \hline $\begin{array}{l}\text { Test Exception TE-007; PV Manifold vacuum setpoint is above fan capability; see par. } 4.3 . \\
\text { Test Exception TE-006, item \# 4; See Table 1-1 above. }\end{array}$ & N/A & N/A & - \\
\hline $\begin{array}{l}(1) \\
(2)\end{array}$ & 923 & N/A & $900-1050$ & - \\
\hline
\end{tabular}


APPENDIX 3 - BYPASS/RECIRC Mode, Maximum System Flow, Train-A (Section A-13)

Table 3-2 Primary Vent System, Condenser \& HEME, OTP Section A-13 (OTP Table 13-1)

\begin{tabular}{|c|c|c|c|}
\hline Parameter & $\begin{array}{l}\text { Actual } \\
\text { Value } \\
\end{array}$ & $\begin{array}{c}\text { Acceptance } \\
\text { Criteria } \\
\end{array}$ & $\begin{array}{c}\mathrm{TE} \\
\text { (Note) }\end{array}$ \\
\hline Condenser Water & - & - & - \\
\hline Flow, gpm & 119 & $95-130$ & - \\
\hline Inlet Temperature, ${ }^{\circ} \mathrm{F}$ & 38 & $35-55$ & - \\
\hline Outlet Temperature, ${ }^{\circ} \mathrm{F}$ & 40 & N/A & - \\
\hline Condenser Air & - & - & - \\
\hline Differential Pressure, in. wc & 11.6 & $\leq 11$ & $001(1)$ \\
\hline Inlet Temperature, ${ }^{\circ} \mathrm{F}$ & 80 & N/A & - \\
\hline Outlet Temperature, ${ }^{\circ} \mathrm{F}$ & 44 & $40-60$ & - \\
\hline Condensate Flow, gpm & 0.1 & N/A & - \\
\hline HEME Differential Pressure, in. wc & 4.6 & $<10$ & - \\
\hline
\end{tabular}

Table 3-3 Waste Tank Conditions, OTP Section A-13 (OTP Table 13-1)

\begin{tabular}{|c|c|c|c|c|c|c|c|}
\hline & Parameter & AY101 & AY102 & AZ101 & AZ102 & $\begin{array}{l}\text { Acceptance } \\
\text { Criteria }\end{array}$ & $\begin{array}{c}\mathrm{TE} \\
\text { (Note) }\end{array}$ \\
\hline \multicolumn{2}{|c|}{ Inlet Flow, scim } & 106 & 246 & (2) & 0 & $<$ outlet flow & - \\
\hline \multicolumn{2}{|c|}{ Vacuum, in. wc } & 2.0 & 1.9 & 1.2 & 1.9 & $0.5-3.0$ & - \\
\hline \multicolumn{2}{|c|}{ Outlet Flow, scfm } & 335 & 360 & 111 & 111 & setpoint \pm 20 & $010(1)$ \\
\hline \multicolumn{2}{|c|}{ Setpoint, scfm } & 400 & 400 & 110 & 110 & N/A & - \\
\hline \multicolumn{2}{|c|}{$\begin{array}{l}\text { Control Valve Position, } \\
\% \text { Open }\end{array}$} & 100 & 99 & $18(3)$ & 21 & $>20 \%$ open & - \\
\hline $\begin{array}{l}\text { (1) } \\
\text { (2) } \\
(3)\end{array}$ & $\begin{array}{l}\text { Test Exception TE } \\
\text { limit. See } 4.3 \text {. } \\
\text { Inlet station out of } \\
\text { Considered too clo }\end{array}$ & $\begin{array}{l}\text { AY101, } \\
\text { ce, no dat } \\
\text { the limit }\end{array}$ & $\begin{array}{l}102 \text { tank e } \\
\text { ailable. } \\
\text { stify a TE }\end{array}$ & e., within & tem acc & system has $\mathrm{r}$ & $\mathrm{d}$ its \\
\hline
\end{tabular}


APPENDIX 4 - RECIRC Mode, Primary Vent Condenser Evaluation (B-3)

\subsection{INTRODUCTION}

This appendix summarizes results of operational testing performed under OTP Attachment B, Section 3 , steps $3.9-3.24$. The test evaluated system performance characteristics at different condensing temperatures in the PV Condenser, especially the air pressure drop across the condenser. This section was added because other test sections have revealed higher than expected condenser pressure drop.

\subsection{DESCRIPTION OF TEST}

This paragraph describes OTP requirements for this section. Initial conditions were established as described in 3.4 above. The system was initially verified to be in normal RECIRC Mode and stable, with PV Train A in service. Important setpoints were verified or established as follows:

- All Cooling Towers in normal WET operation.

- PV Condenser water inlet temperature normal at $38-42^{\circ} \mathrm{F}$;

- PV Manifold Controller matching setpoints (PIC-AZK1-1A/1B), set for -30 in. wc or as required for minimum tank flow rates;

- Tank outlet flow rates at designated levels to achieve peak stack flow;

- PV Heater differential temperature control set at $20^{\circ} \mathrm{F}$;

With the system operating normally, initial parametric data was recorded. Then the PV condenser water chiller was stopped using an applicable MCS screen command; circulating pumps remained $O N$. As the condenser water temperature increased, periodic changed-value data was recorded over five intervals to reflect the resulting system transient conditions. The chiller was restarted as planned when the PV stack air temperature reached $100^{\circ} \mathrm{F}$ (so as not to threaten the stack CAM cutout interlock).

\subsection{TEST OBJECTIVES}

Characterize PV Condenser pressure loss performance over a range of temperatures and document any unusual system effects from same.

\subsection{TEST RESULTS}

Based on Test Log notes, the chiller was offline about 7 hours beginning at 3:20 AM, Sept. 25, 1998 . During this 7-hour transient, Condenser Water Inlet Temperature warmed from $38^{\circ} \mathrm{F}$ to $68^{\circ} \mathrm{F}$. With no other imposed changes, Exhaust Fan (stack) flow increased $7 \%$ from $942 \mathrm{scfm}$ to $1009 \mathrm{scfm}$, while Condenser DP decreased from an excessive $12.6 \mathrm{in.}$ wc to only $7.7 \mathrm{in.}$ wc. The PV Manifold vacuum dropped accordingly from 21 to $18 \mathrm{in.}$ wc with no change in fan speed. Relevant data for several key parameters was collected at short intervals by the MCS and has been plotted to more effectively describe the transient. These plots are named Figure 4-1 through 4-4 and are presented in Attachment 3.

The HEME DP increase (from 4.7 to 5.3 in. wc) could be related either to increased air flow or 
APPENDIX 4 - RECIRC Mode, Primary Vent Condenser Evaluation (B-3)

increased moisture loading or both. No change was observed in condensate flow rate; this is not surprising because the storage volume of the condensate seal-pot tank would tend to mask short-term fluctuations. Regarding the HEPA/HEGA filters, no significant increase in pressure loss was noted, and no moisture was detected in the filter-plenum sight gages.

The status of the recirculation (K4) cooling systems is not documented for this section; the degree of cooling (condensing) could impact primary cooling performance.

Two unexplained anomalies are noted in the data: (1) Over the course of the test, air temperature entering the PV condenser gradually decreased from $80^{\circ} \mathrm{F}$ to $76^{\circ} \mathrm{F}$. There is insufficient data to determine if this change is due simply to the $7 \%$ increase of system airflow, or if some system configuration change occurred during the test. (2) Final system stack air flow of $1020 \mathrm{scfm}$ (after restoring chiller operation) is greater than previously achieved.

\subsection{CONCLUSIONS}

It is clear that there is a direct relationship between condensing temperature and overall system performance; specifically, the air pressure loss (DP) across the condenser appears to be significantly affected by the amount of moisture collecting on the tube surfaces. More data is needed in order to fully document system performance, but it appears certain that peak system airflow could be increased (if needed) by optimizing tank vent cooling. One area that should be further explored is the effect of various degrees of recirculation cooling which directly affects the amount of moisture entering the PV Condenser. These results also fortunately show that the system might be operated safely for several hours with the PV condenser offline. 


\begin{tabular}{|c|c|c|c|c|c|c|c|c|c|}
\hline & •ənss! s!̣ & Idxa uo & dLO s: & $\varepsilon \triangleright$ & 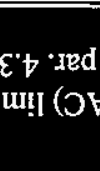 & ؛ & des & 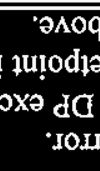 & 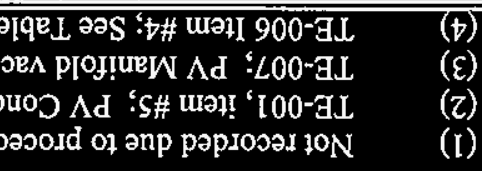 \\
\hline$(b) 900$ & 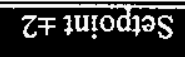 & $6 \mathrm{I}$ & $\overline{6 \mathrm{I}}$ & $6 \mathrm{I}$ & $\overline{\overline{6 I}}$ & 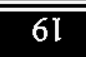 & $8 \mathrm{II}$ & $\overline{\overline{S Z}}$ & 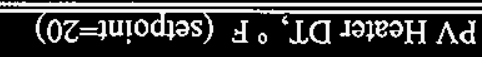 \\
\hline 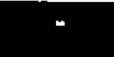 & $\mathrm{V} / \mathrm{N}$ & $9 S \mathcal{L E}$ & $6 Z 9 \varepsilon$ & $\varepsilon £ 9 \varepsilon$ & $0 \& 9 \varepsilon$ & o\&gE & $829 \varepsilon$ & 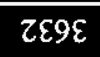 & uUdI 'pards ueg 1sneyxg $\Lambda \mathrm{d}$ \\
\hline$(\varepsilon)<00$ & 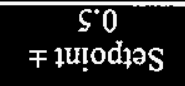 & $6 \mathrm{LI}$ & $6 \angle \mathrm{I}$ & $9.6 \mathrm{I}$ & $0 z$ & $\varepsilon 0 \tau$ & 9.02 & 6.02 & $\begin{array}{c}(0 \mathcal{E}=\text { Ju!nodjos } \\
\text { oM 'u! 'unnov } \Lambda \text { ploy!uew } \Lambda d\end{array}$ \\
\hline- & $\mathrm{d}_{0} 00 \mathrm{I} \mathrm{S}$ & \$8 & $00 \mathrm{I}$ & 76 & 16 & $\angle 8$ & $\overline{\varepsilon 8}$ & $\$$ & d。 "dual d!V YOEIS $\Lambda \mathrm{d}$ \\
\hline- & uyos OSOI $>$ & 0ZOI & $600 \mathrm{I}$ & $8 \subseteq 6$ & $8 \mathfrak{8 S 6}$ & 996 & $\varepsilon 96$ & 276 & uyos 'MOIJ YJEAS $\Lambda d$ \\
\hline- & $\mathbf{V} / \mathbf{N}$ & (1) $\mathbf{x u}$ & I0 & I.0 & I'0 & 10 & I'0 & $I^{\prime} 0$ & 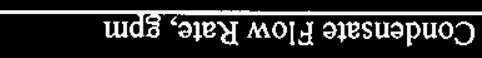 \\
\hline- & $\bar{\nabla} / \mathrm{N}$ & $\overline{\mathcal{S}^{\prime} \mathcal{\varepsilon}}$ & $\overline{9^{\circ} \mathcal{\varepsilon}}$ & $\overline{\tau \varepsilon}$ & $\bar{\tau} \mathcal{\varepsilon}$ & $\overline{Z \cdot \varepsilon}$ & $\tau^{*} \varepsilon$ & $\overline{0 \cdot \bar{\varepsilon}}$ & 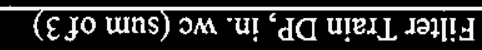 \\
\hline- & SM 'u! $0 \mathrm{I}>$ & (I)IU & $\overline{\varepsilon S}$ & $0^{\prime \prime S}$ & 6 & 86 & 8.7 & $L b$ & JM 'u! 'd GW GWH \\
\hline 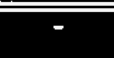 & $08=0 t$ & (I) ru & $\overline{89}$ & $\overline{19}$ & $\overline{\angle S}$ & $\overline{\varepsilon S}$ & $\overline{87}$ & $\overline{t a t}$ & d. 'düL lapno d!V 'puos \\
\hline- & $\overline{\mathrm{V} / \mathrm{N}}$ & (I)Iu & $9 L$ & $8 L$ & $6 L$ & $\overline{6 L}$ & $6 L$ & 08 & 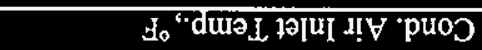 \\
\hline (Z) 100 & OM 'UI II 5 & (1) rut & $\overline{L L}$ & ह0I & $8.0 \mathrm{I}$ & I'II & t'II $^{\prime}$ & $\overline{9} Z \mathbf{Z I}$ & 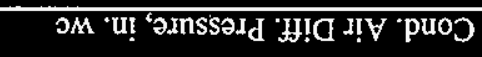 \\
\hline 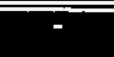 & $\overline{\mathrm{V} / \mathrm{N}}$ & 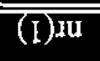 & 89 & 09 & $\overline{\mathrm{SS}}$ & $\overline{\text { IS }}$ & $\overline{96}$ & $\overline{\overline{0 t}}$ & 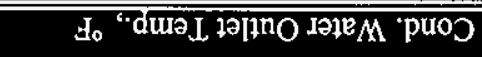 \\
\hline- & $0 \varepsilon I-S 6$ & $(\mathfrak{l}) \mathrm{ru}$ & $\overline{I Z I}$ & IZI & $\overline{I Z I}$ & $0 Z I$ & $6 \mathrm{II}$ & $6 \mathrm{II}$ & 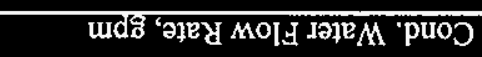 \\
\hline$\overline{-}$ & $\overline{S L-S \mathcal{E}}$ & (I) $1 \mathrm{u}$ & 89 & 09 & $\overline{S S}$ & $0 S$ & $\overline{S t}$ & $8 \varepsilon$ & 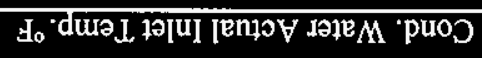 \\
\hline \multirow{2}{*}{$\begin{array}{c}(\Leftrightarrow) \mathrm{ON}) \\
\mathrm{gL}\end{array}$} & \multirow{2}{*}{ 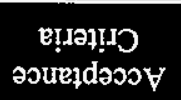 } & \multirow[b]{2}{*}{ ןеu! } & \multirow[b]{2}{*}{ 'xew } & \multirow[b]{2}{*}{09} & \multirow[b]{2}{*}{ SS } & \multirow[b]{2}{*}{ os } & \multirow[b]{2}{*}{ SD } & \multirow[b]{2}{*}{ [ย!ฺ! } & Lejoutede $\mathrm{d}$ \\
\hline & & & & & & & & & 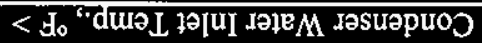 \\
\hline
\end{tabular}

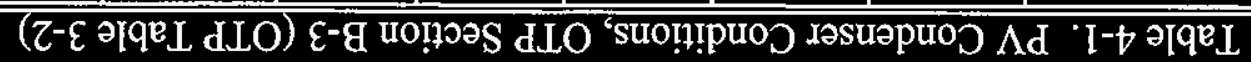

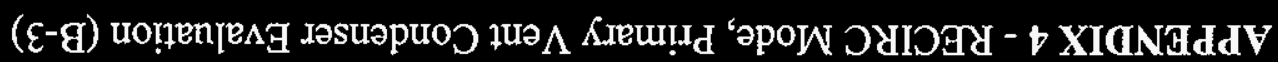

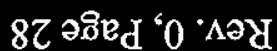

$\varepsilon L t \mathcal{E}-\mathrm{HNH}$

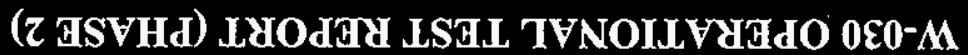


APPENDIX 5 - HIGH-HEAT Mode, AY101, Steady State (Section B-4).

\subsection{INTRODUCTION}

This appendix summarizes operational testing performed under OTP Attachment B, Section 4. The test demonstrated acceptable steady-state system performance with tank AY101 in HIGH-HEAT Mode with its cooling tower in both wet and dry modes. This test is notable in that it marks the first occasion of operating any tank in High-Heat Mode.

\subsection{DESCRIPTION OF TEST}

This paragraph describes OTP requirements for this section. Initial conditions were established as described in 3.4 above. The system was initially verified to be in stable operation with all tanks in RECIRC Mode. Important setpoints and conditions were verified or established as follows:

- PV Train-A in service;

- AY101 Cooling Tower in DRY Mode, all others in WET Mode.

- All tank pressure controls set at -2.0 in. wc;

- PV Manifold Controller matching setpoints (PIC-AZK1-1A/1B), and tank exhaust flow control valves set as required for designated minimum tank flow rates;

After obtaining initial stable conditions, parametric data was recorded in Table 4-1. Then tank AY101 was placed in HIGH-HEAT Mode according to approved operating procedures. The steps required to place any tank in High-Heat Mode are as follows:

- Allign the tank's manual isolation valves (at the $\mathrm{K} 4$ equipment module) for once-through air flow (open valves $\mathrm{K} 4-1, \mathrm{~K} 4-2$, close $\mathrm{K} 4-3$, 1nd K4-4);

- Ensure K4 Fan ON;

- Select High-Heat Mode on the proper MCS screen to ensure correct configuration;

- Increase PV Manifold vacuum setpoint for peak flow (in this case, from -14 to -20 in. wc;

- Set High-Heat tank exhaust flow at $500 \mathrm{scfm}$.

After reaching observed stable conditions, a second set of data was recorded. The system was then allowed to maintain steady-state conditions for a 4-hour period with data recorded each hour.

In the second part of this test, the AY101 Cooling Tower was placed in WET Mode; parametric data was then recorded in Table 4-2 every 15 minutes for a total of 5 data sets. Results are summarized Section 4 below.

\subsection{TEST OBJECTIVES}

Demonstrate and document stable system operation in the RECIRC and HIGH-HEAT Modes for tank AY101 and obtain heat removal data for the purpose of assessing system cooling capability. 
APPENDIX 5 - HIGH-HEAT Mode, AY101, Steady State (Section B-4).

\subsection{TEST RESULTS}

Results of the test were satisfactory as shown in tables 5-1 through 5-4 and as discussed below; important setpoints are shown for controlled variables. All test objectives were met, all setpoints were achieved. Stable control was demonstrated at all setpoints for all parameters. Seven minor Test Exceptions (TEs) were noted. The TEs do not affect test results or objectives; see discussion in 4.3 of the summary report and Attachment 1. There were no significant effects on the 3 other tanks when AY101 was placed in High-Heat Mode.

\subsection{Control of Tank Vacuum}

A major concern raised in preoperational testing was the ability to control internal pressure (vacuum) in High-Heat Mode. Reference 3 describes excessive vacuum developed in all tanks due to the limitation of the inlet stations (with their temporary test ducting apparatus) to provide adequate makeup air at the higher exhaust from the tank. This test successfully demonstrated ideal control of tank vacuum: the setpoint of $2.0 \mathrm{in}$. wc was maintained in a stable manner, with both the inlet and outlet control valves operating in midrange positions.

\subsection{Recirculation (K4) Condenser Air Flow}

Condenser air flow DP dropped from 11.2 (RECIRC) to 8.2 in. wc (High-Heat), indicating reduced flow from the RECIRC Mode (RECIRC airflow cannot be directly measured). This conclusion is supported by other data: (1) K4 Fan DP is increased (from 15.1 to 19.6 in. wc), and (2) fan motor current is reduced proportionally (5.3 to $4.3 \mathrm{amps}$ ). An inspection of the manufacturer's fan curve supports this conclusion and suggests that airflow is much greater than expected (perhaps more than $700 \mathrm{scfm}$ with the cooling tower operating, and more when it is offline). A copy of the curve is included in Figure 2, Attachment 3.

Because air flow through the condenser is precisely known in the High-Heat Mode (500 scfm), its DP characteristics might be used to approximate airflow in RECIRC Mode. Such an analysis is left for others.

\subsection{Recirculation (K4) Condenser Cooling}

Because the heat load in this tank is much lower than the system design basis, the condenser and cooling tower are hardly taxed. This observation is evidenced by the insignificant rise in cooling water temperature across the condenser. Thus, estimating the effective heat removal can only be based on the airflow conditions (not on cooling water); the following simple assumptions are used to yield approximate results:

fully saturated tank air at $500 \mathrm{scfm}$;

enthalpy based on ASHRAE data for standard pressure at saturated conditions; 
APPENDIX 5 - HIGH-HEAT Mode, AY101, Steady State (Section B-4).

Heat removal depends on the cooling tower operating mode and ambient weather conditions, especially wet-bulb (for tower in WET Mode) and dry-bulb (DRY Mode) temperatures. For this tank and the summerlike ambient conditions at the time, the average heat removal in the WET Mode is estimated at about 34,000 BTU per hour. Heat removal in the RECIRC Mode is expected to be much greater in proportion to the airflow increase, but not approaching the design basis is 1 million BTU per hour. Additional data is needed to fully assess heat removal.

\subsection{CONCLUSIONS}

The system operates as designed in High-Heat mode. 


\begin{tabular}{|c|c|c|c|c|c|}
\hline \multicolumn{6}{|c|}{ 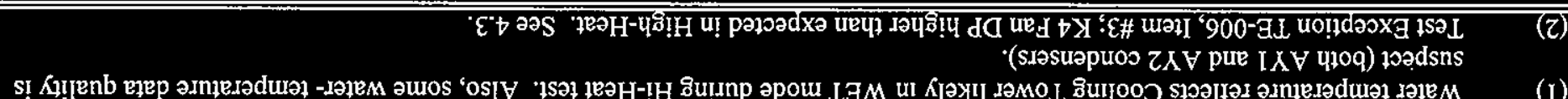 } \\
\hline - & 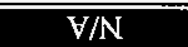 & $s^{\prime \prime} t$ & $\overline{\varepsilon \neq \hbar}$ & $\overline{\varepsilon S \mathcal{S}}$ & 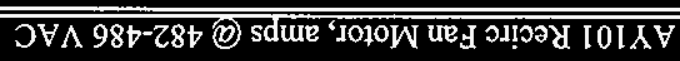 \\
\hline (z) 900 & $8 \mathrm{8I-SI}$ & 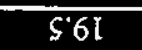 & $9 \cdot 6 \mathrm{I}$ & $I^{\prime} \mathcal{S} \mathrm{I}$ & 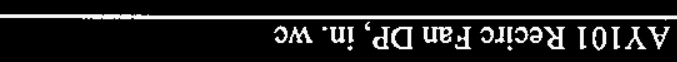 \\
\hline- & $2 \mathrm{I}-8$ & $2 \cdot 8-1.8$ & $\bar{\tau} 8$ & ZII & 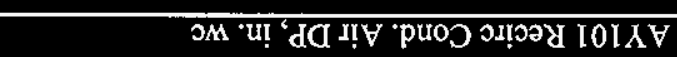 \\
\hline- & $0 \varepsilon z-06 \mathrm{I}$ & $L I Z-\mathcal{S I Z}$ & 912 & LIZ & 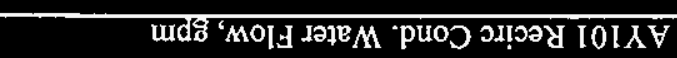 \\
\hline (I) & $\mathbf{V} / \mathrm{N}$ & $89-\angle 9$ & $\$ 9$ & $Z L$ & 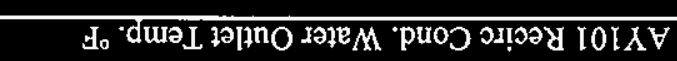 \\
\hline (I) & $\mathrm{V} / \mathrm{N}$ & $89-99$ & 99 & $\overline{Z L}$ & 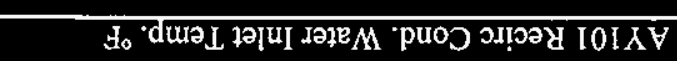 \\
\hline- & $\bar{V} / \mathrm{N}$ & $\overline{69-\angle 9}$ & $\angle 9$ & $9 L$ & 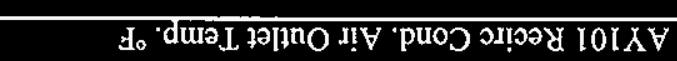 \\
\hline- & $\forall / N$ & \$8-28 & $\varepsilon 8$ & 98 & 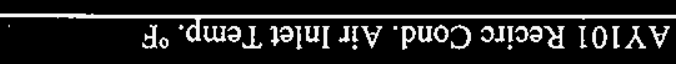 \\
\hline- & $\varepsilon$ ol 50 & $z$ & $\tau$ & $\varepsilon$ & $(z=$ lu! \\
\hline- & $\mathrm{V} / \mathrm{N}$ & SS & $\overline{\varepsilon S}$ & 0 & 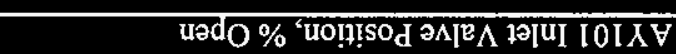 \\
\hline- & Mold 'Чxas & $96 \varepsilon-t 8 \varepsilon$ & $\varepsilon I t$ & 0 & 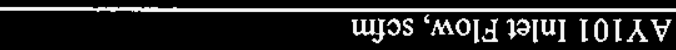 \\
\hline- & uədo \%0z< & $\overline{S b-t b}$ & $\mathcal{S t}$ & $\overline{L L}$ & 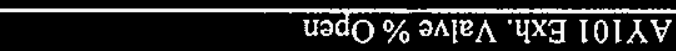 \\
\hline- & ozf lu!̣dies & $20 s-26 t$ & $00 \mathrm{~S}$ & I6I & 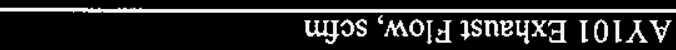 \\
\hline- & $\mathrm{V} / \mathrm{N}$ & $00 S$ & $00 S$ & 002 & 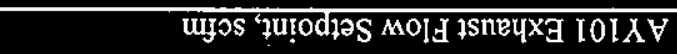 \\
\hline \multirow{2}{*}{$\begin{array}{l}(\text { (OION) } \\
\text { BL }\end{array}$} & \multirow{2}{*}{ 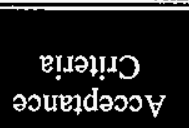 } & \multirow{2}{*}{ 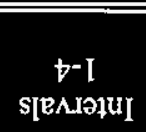 } & \multirow{2}{*}{ 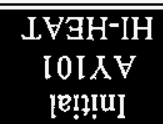 } & \multirow{2}{*}{$\begin{array}{l}\text { Jylogy } \\
\text { I0IXV } \\
\text { [ย!!!u! }\end{array}$} & səңәurese $\mathrm{d}$ \\
\hline & & & & & $<<$ uoln!puoग lol $\mathrm{AV}$ yue $\mathrm{L}$ \\
\hline
\end{tabular}

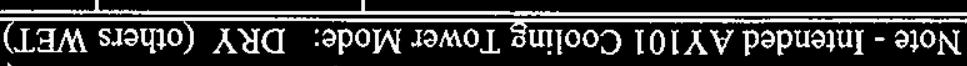

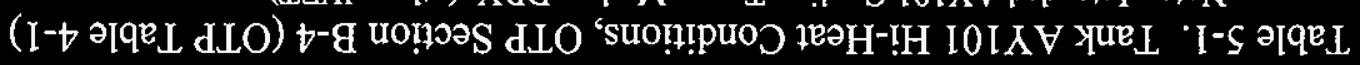

•( 
APPENDIX 5 - HIGH-HEAT Mode, AY101, Steady State (Section B-4).

Table 5-2. System Conditions, AY101 High-Heat, OTP Section B-4 (OTP Table 4-1) Note - Intended AY101 Cooling Tower Mode: DRY (others WET)

\begin{tabular}{|c|c|c|c|c|c|}
\hline Tank AY101 Condition $\gg$ & \multirow{2}{*}{$\begin{array}{c}\text { Initial } \\
\text { AY101 } \\
\text { RECIRC } \\
\end{array}$} & \multirow{2}{*}{$\begin{array}{c}\text { Initial } \\
\text { AY101 } \\
\text { HI-HEAT } \\
\end{array}$} & \multirow{2}{*}{$\begin{array}{c}\text { Intervals } \\
1-4\end{array}$} & \multirow{2}{*}{$\begin{array}{l}\text { Acceptance } \\
\text { Criteria }\end{array}$} & \multirow{2}{*}{$\begin{array}{c}\mathrm{TE} \\
\text { (Note) }\end{array}$} \\
\hline Parameter & & & & & \\
\hline AY10I Exhaust Flow,(from Table 5-1 above) & 191 & 500 & $492-502$ & $N / A$ & - \\
\hline AY102 Exhaust Flow, scfm $\quad$ (setpoint $=220$ ) & 216 & 214 & $208-215$ & Setpoint \pm 20 & - \\
\hline AZ101 Exhaust Flow, scfm $\quad$ (setpoint $=110)$ & 108 & 108 & $109-116$ & Setpoint \pm 20 & - \\
\hline AZ102 Exhaust Flow, scfm $\quad$ (setpoint $=110)$ & 106 & 112 & $108-120$ & Setpoint \pm 20 & 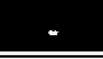 \\
\hline AY102 Tank Vacuum, in. wc & 0.8 & 0.8 & 0.8 & 0.5 to 3 & - \\
\hline AZ101 Tank Vacuum, in. wc & 1 & 1.1 & 1.1 & 0.5 to 3 & - \\
\hline AZ102 Tank Vacuum, in. wc $\quad$ (setpoint $=2)$ & 2.1 & 2 & 2 & 0.5 to 3 & - \\
\hline PV Exhaust Stack Flow, scfm & 655 & 997 & $995-1000$ & $760-1050$ & - \\
\hline $\begin{array}{l}\text { PV Exhaust Manifold Vacuum, in. wc } \\
\text { (setpoint) }\end{array}$ & $\begin{array}{l}14.2 \\
(14)\end{array}$ & $\begin{array}{l}20.0 \\
(21) \\
\end{array}$ & $\begin{array}{l}20.1 \\
(21) \\
\end{array}$ & Setpoint \pm 0.5 & $007(1)$ \\
\hline PV Cond. Air DP, in. wc & 8.8 & 12 & 12.1 & $\leq 11$ & $001(2)$ \\
\hline PV Cond. Air Inlet Temp., ${ }^{\circ} \mathrm{F}$ & 83 & 81 & 81 & N/A & - \\
\hline PV Cond. Air Outlet Temp., ${ }^{\circ} \mathrm{F}$ & 46 & 46 & $45-46$ & $40-60$ & - \\
\hline PV Cond. Water Inlet Temp., ${ }^{\circ} \mathrm{F}$ & 38 & 38 & 38 & $35-55$ & - \\
\hline PV Cond. Water Outlet Temp. ${ }^{\circ} \mathrm{F}$ & 40 & 41 & $39-40$ & N/A & - \\
\hline PV Cond. Water Flow, gpm & 118 & 119 & 119 & $95-130$ & $=$ \\
\hline PV HEME DP, in. wc & 3.2 & 5 & 5 & $<10$ & - \\
\hline $\begin{array}{l}\text { Test Exception TE-007; PV Manifold } \\
\text { Test Exception TE-001, item \#5; PV C }\end{array}$ & $\begin{array}{l}\text { setpoin } \\
\text { DP e }\end{array}$ & $\begin{array}{l}\text { tan capa } \\
\text { eptance }\end{array}$ & $\begin{array}{l}\text { par. } 4.3 \\
\mathrm{AC}) \lim \end{array}$ & & \\
\hline
\end{tabular}




\begin{tabular}{|c|c|c|c|c|}
\hline \multicolumn{5}{|c|}{ 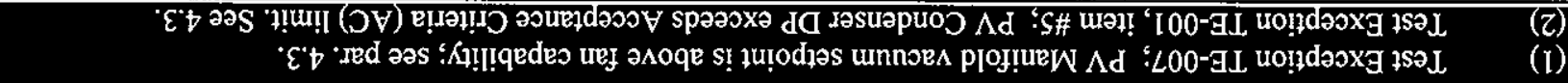 } \\
\hline- & OI > & $0^{\circ} \mathrm{S}-6^{\circ} \mathrm{t}$ & $\overline{\mathrm{S}}$ & PM 'u! 'dQ GWGH $\Lambda \mathrm{d}$ \\
\hline 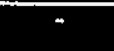 & $0 \varepsilon I-\varsigma 6$ & $6 \mathrm{II}-8 \mathrm{II}$ & $6 \mathrm{II}$ & 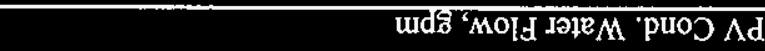 \\
\hline- & $\overline{\nabla / N}$ & $\overline{I b * 6 \varepsilon}$ & It & 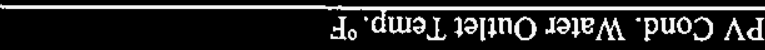 \\
\hline- & SS-SE & $\overline{6 \varepsilon-8 \varepsilon}$ & $\overline{6 \varepsilon}$ & 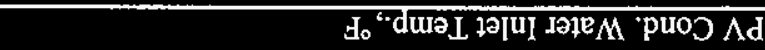 \\
\hline- & $09-0 t$ & St & St & 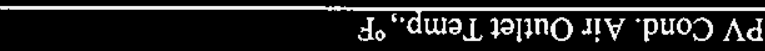 \\
\hline- & $\overline{\mathrm{V} / \mathrm{N}}$ & 18 & 18 & 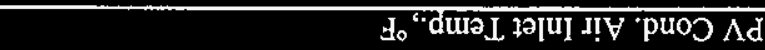 \\
\hline (z) 100 & IIS & $\bar{I} Z \mathrm{II}$ & I'ZI & गM 'u! 'd J!V 'puoj $\Lambda d$ \\
\hline$(\mathrm{I}) \angle 00$ & S"0干 Ju!Odias & 02 & {$[\cdot 02$} & 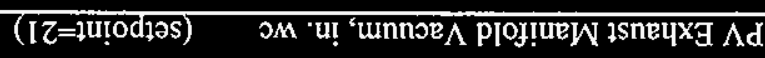 \\
\hline$\overline{-}$ & OSOI-09L & $200 \mathfrak{l}-\angle 66$ & 266 & ungS 'MOIJ XOE'S 1SneYXG $\Lambda \mathrm{d}$ \\
\hline$\overline{-}$ & V/N & $10 s-06 t$ & $\overline{I O S}$ & 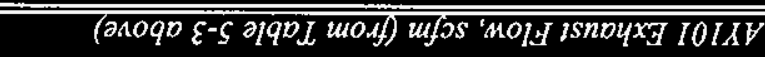 \\
\hline \multirow{2}{*}{$\begin{array}{l}(210 N) \\
\text { GL }\end{array}$} & \multirow{2}{*}{ 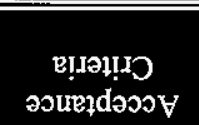 } & \multirow{2}{*}{$\begin{array}{c}t-I \\
\text { sensəzuI }\end{array}$} & \multirow{2}{*}{$\begin{array}{c}\text { LVGH'IH } \\
\text { I0I } X V \\
\text { [E!?!uI }\end{array}$} & дәңәшеле $\mathrm{d}$ \\
\hline & & & & 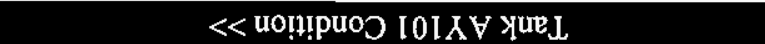 \\
\hline
\end{tabular}

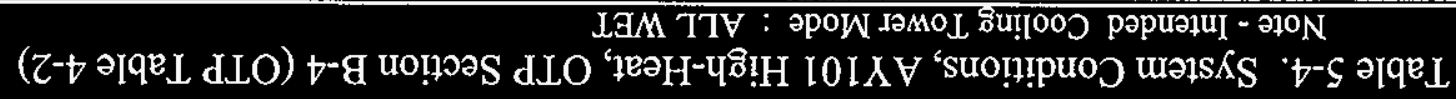

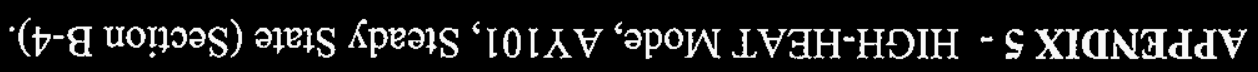

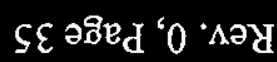

$\varepsilon L \downarrow \varepsilon-\mathrm{dNH}$

\author{
( 7 GSVHd) JYOdGY LSGL TVNOILVYGdO OE0-M
}


APPENDIX 6 - AY101 HIGH-HEAT, Change Tank Pressure Setpoints (Section B-5).

\subsection{INTRODUCTION}

This appendix summarizes operational testing performed under OTP Attachment B, Section- 5. The test demonstrated acceptable system performance in HIGH-HEAT Mode over a range of pressure control setpoints for tank AY101.

\subsection{DESCRIPTION OF TEST}

This paragraph describes OTP requirements for this section. Initial conditions were established as described in 3.4 above. The system was initially verified to be operating in a stable condition with tank AY101 in HIGH-HEAT Mode and other tanks in RECIRC Mode. PV Train A was in service. Important setpoints or conditions were verified or established as follows:

PV Manifold Controller matching setpoints (PIC-AZK1-1A/1B), set as required to achieve designated tank flow rates.

Tank AY101 exhaust flow control set at 500 scfm;

Other tank exhaust flow controls set at minimum designated flow rate;

Tank AY101 pressure control setpoint placed at $-0.5 \mathrm{in}$. wc;

Other tank pressure control setpoints set for $-2.0 \mathrm{in}$. wc;

After obtaining initial stable conditions, parametric data was recorded. Then the tank pressure control setpoint for tank AY101 was decreased in -0.5 inch wc increments to -3.0 . No other variables were changed. Results are summarized Section 4 below.

\section{0} TEST OBJECTIVES

Establish and document stable system operation in the HIGH-HEAT Mode over a range of tank pressure setpoints.

\subsection{TEST RESULTS}

Only data for tank AY101 was recorded and results are as expected. Test objectives were met except for minimum tank vacuum control. Initially, with the tank vacuum set for -0.5 in. wc, vacuum was 1.3 in. wc with the inlet pressure control valve full open, i.e. the inlet station was unable to introduce sufficient air to offset the $500 \mathrm{scfm}$ exhaust (TE-008). Only at a setpoint of -1.5 and greater, was the vacuum under control.

\subsection{CONCLUSIONS}

Changing and controlling tank pressure setpoint in High-Heat Mode is easily done. However, 1.5 in. wc is the lowest vacuum achievable, and this is a function of the inlet station pressure loss and thus the condition of the inlet station HEPA filters. 


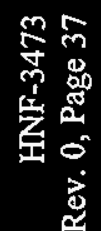

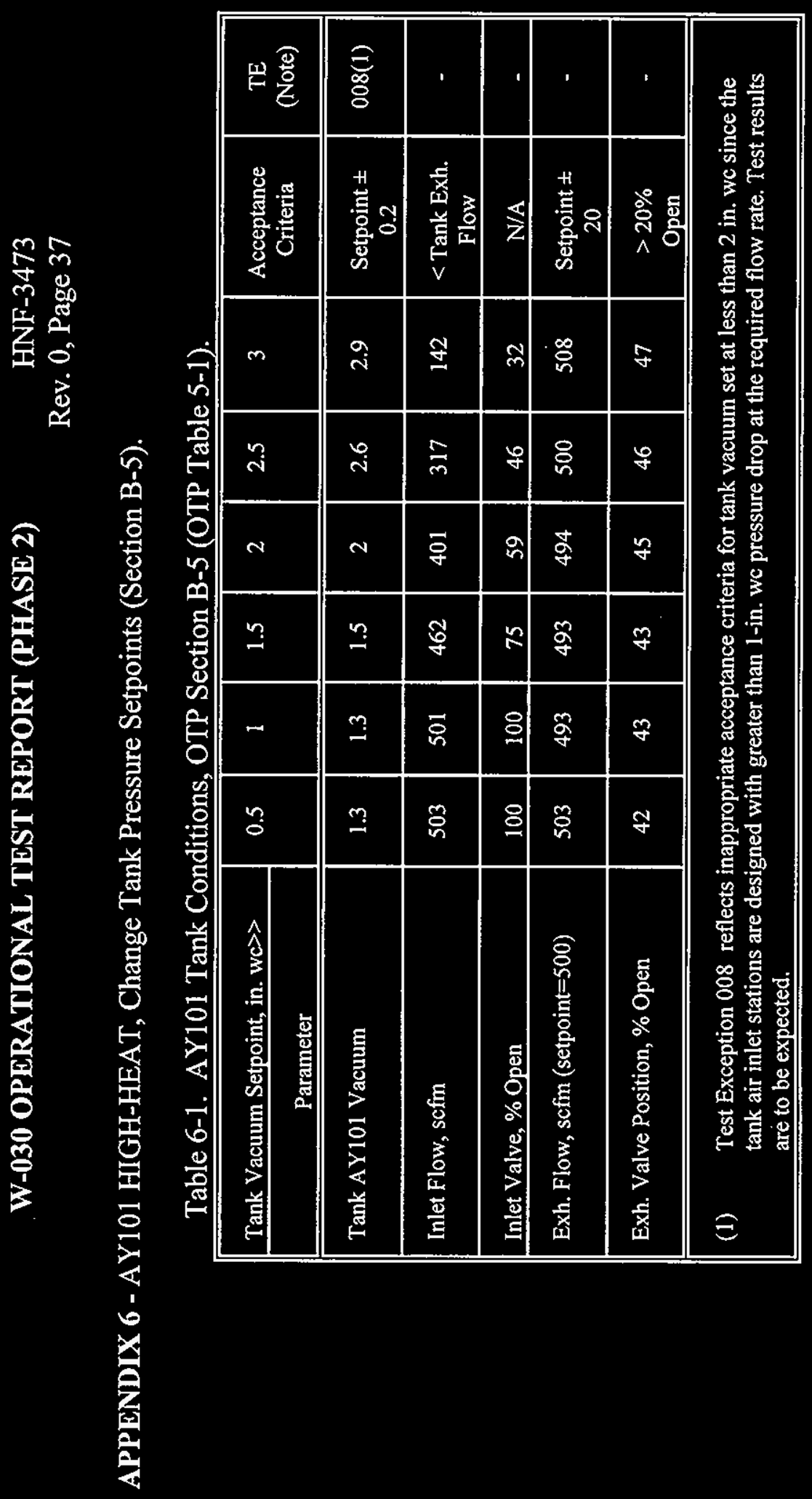


APPENDIX 7 - AY101 HIGH-HEAT Mode, PV Train Switchover (Section B-6).

\subsection{INTRODUCTION}

This appendix summarizes operational testing performed under OTP Attachment B, Section 6. The test demonstrated acceptable system performance in HIGH-HEAT Mode during PV Train switchover using the MCS MACRO control.

\subsection{DESCRIPTION OF TEST}

This paragraph describes OTP requirements for this section. Initial conditions were established as described in 3.4 above. The system was initially verified to be operating in a stable manner with AY101 in HIGH-HEAT Mode, all other tanks in RECIRC Mode, and Fan/Filter Train-A in service. The PV manifold pressure and heater temperature setpoints were verified to have matching setpoints. Initial parametric data was recorded in Table 6-1.

While ensuring that the system remains stable, Fan-1B and Heater 1-B were selected and run on the MCS MACRO screen (by design, MCS control of the Filter Train is made by selecting the heater). After system stabilization, a new data set was recorded.

\subsection{TEST OBJECTIVES}

Establish and document stable system operation in the HIGH-HEAT Mode during changeover to standby PV Train.

\subsection{TEST RESULTS}

Results of the test were satisfactory as shown in the tables below; important setpoints are shown for controlled variables. All test objectives were met; one minor Test Exception (TE) was noted; the TE does not affect test results or objectives; see discussion in 4.3 of the summary report and Attachment 1. Important data parameters are summarized in Tables 7-1 and 7-2 below.

All recorded data is as expected except for AY101 inlet flow which unexplainably increased from 276 to $321 \mathrm{scfm}$ during the transient. The most likely reason is that the system had not fully stablized when the data was recorded. Setpoint control was maintained for all parameters.

\subsection{CONCLUSIONS}

The Primary Vent Train switching can be easily accomplished by the operator personnel using automatic MCS action as designed, with no instability. 
APPENDIX 7 - AY101 HIGH-HEAT Mode, PV Train Switchover (Section B-6).

Table 7-1. System Conditions, OTP Section B-6 (OTP Table 6-1)

\begin{tabular}{|c|c|c|c|c|}
\hline Parameter & $\begin{array}{c}\text { Initial value } \\
\text { (Train- } A)\end{array}$ & $\begin{array}{c}\text { Final value } \\
\text { (Train-B) }\end{array}$ & $\begin{array}{c}\text { Acceptance } \\
\text { Criteria } \\
\end{array}$ & $\begin{array}{c}\text { TE } \\
\text { (Note) }\end{array}$ \\
\hline PV Manifold Vacuum, in. wc $\quad($ Setpoint $=21)$ & 20.1 & 19.3 & Setpoint \pm 0.5 & $007(1)$ \\
\hline PV Stack Flow, scfm & 998 & 982 & $760-1050$ & - \\
\hline Heater Diff. Temp., ${ }^{\circ} \mathrm{F} \quad($ Setpoint $=25)$ & 24 & 27 & Setpoint \pm 2 & - \\
\hline PV Condenser Diff. Press., in. wc & 12.1 & 11.7 & $\leq 11$ & $001(1)$ \\
\hline $\begin{array}{l}\text { Test Exception TE-007; PV Manifold } \\
\text { Test Exception TE-001, item \#5; PV }\end{array}$ & $\begin{array}{l}\text { setpoin } \\
\text { DP e }\end{array}$ & $\begin{array}{l}\text { apabil } \\
\text { nce } \mathrm{Cr}\end{array}$ & $\begin{array}{l}4.3 . \\
\text { limit. See } 4 .\end{array}$ & \\
\hline
\end{tabular}

Table 7-2. Waste Tank Conditions, OTP Section B-6 (OTP Table 6-1)

\begin{tabular}{|c|c|c|c|c|c|c|}
\hline \multicolumn{2}{|l|}{ Parameter } & $\begin{array}{c}\text { AY101 } \\
\text { (HI-HEAT) }\end{array}$ & AY102 & AZ101 & AZ102 & $\begin{array}{c}\text { Acceptance } \\
\text { Criteria }\end{array}$ \\
\hline Inlet Flow, scfm, & $\begin{array}{r}\text { Initial } \\
\text { Final } \\
\end{array}$ & $\begin{array}{l}276 \\
321 \\
\end{array}$ & * & $\begin{array}{l}0 \\
0 \\
\end{array}$ & $\begin{array}{l}0 \\
0\end{array}$ & N/A \\
\hline $\begin{array}{l}\text { Tank Vacuum, in. wc } \\
\text { (Setpoint=2) }\end{array}$ & $\begin{array}{r}\text { Initial } \\
\text { Final }\end{array}$ & $\begin{array}{l}2.1 \\
2.0\end{array}$ & $\begin{array}{l}0.9 \\
0.9\end{array}$ & $\begin{array}{l}1.1 \\
1.1\end{array}$ & $\begin{array}{l}1.9 \\
2.0\end{array}$ & $0.5-3.0$ \\
\hline Outlet Flow, scfm, & $\begin{array}{r}\text { Initial } \\
\text { Final } \\
\end{array}$ & $\begin{array}{l}493 \\
499 \\
\end{array}$ & $\begin{array}{l}212 \\
213 \\
\end{array}$ & $\begin{array}{l}113 \\
112 \\
\end{array}$ & $\begin{array}{l}108 \\
107 \\
\end{array}$ & setpoint \pm 20 \\
\hline Setpoint, scfm & & 500 & 220 & 110 & 100 & N/A \\
\hline Valve position, \% Open, & $\begin{array}{r}\text { Initial } \\
\text { Final }\end{array}$ & $\begin{array}{l}44 \\
44\end{array}$ & $\begin{array}{l}99 \\
99\end{array}$ & $\begin{array}{l}26 \\
25\end{array}$ & $\begin{array}{l}56 \\
54\end{array}$ & $>20 \%$ Open \\
\hline
\end{tabular}

No data; inlet station out of service. 
APPENDIX 8 - HIGH-HEAT Mode, AY102, Steady State (Section B-7).

\subsection{INTRODUCTION}

This appendix summarizes operational testing performed under OTP Attachment $B$, Section 7 . The test demonstrated acceptable system performance with tank AY102 in HIGH-HEAT Mode with its cooling tower in both wet and dry modes. This test marks the first occasion of this tank operating in High-Heat Mode.

\subsection{DESCRIPTION OF TEST}

This paragraph describes OTP requirements for this section. Initial conditions were established as described in 3.4 above. The system was initially verified to be in stable operation with all tanks in RECIRC Mode. Important setpoints and conditions were verified or established as follows:

- PV Train-B in service;

- All tank pressure controls set at -2.0 in. wc;

- PV Manifold Controller matching setpoints (PIC-AZK1-1A/1B), and tank exhaust flow control valves set as required for designated minimum tank flow rates;

- All Cooling Towers in WET Mode.

After obtaining initial stable conditions, parametric data was recorded in Table 7-1. Then tank AY102 was placed in HIGH-HEAT Mode (and its cooling tower placed in DRY Mode) according to approved operating procedures; the steps required to do this are similar to those described in Appendix 5 for tank AY101. After reaching observed stable conditions, a second set of data was recorded. The system was then allowed to maintain steady-state conditions for a 4-hour period with data recorded each hour.

In the second part of this test, the AY102 Cooling Tower was placed in WET Mode; parametric data was then recorded in Table 7-2 every 15 minutes for a total of 5 data sets. Results are summarized in Section 4 below.

\subsection{TEST OBJECTIVES}

Demonstrate and document stable system operation in the RECIRC and HIGH-HEAT Modes for tank AY102 and obtain heat removal data for the purpose of assessing system cooling capability.

\subsection{TEST RESULTS}

Results of the test were satisfactory as shown in tables 8-1 through 8-4 and as discussed below; important setpoints are shown for controlled variables. All test objectives were met, all setpoints were achieved. Stable control was demonstrated at all setpoints for all parameters. Thirteen minor Test Exceptions (TEs) were noted. The TEs do not affect test results or objectives; see discussion in 4.3 of the summary report and Attachment 1. Results were generally consistent with those of Appendix 5. There were no significant effects on the 3 other tanks when AY102 was placed in High-Heat Mode. 
APPENDIX 8 - HIGH-HEAT Mode, AY102, Steady State (Section B-7).

\subsection{Control of Tank Vacuum}

As discussed in Appendix 5, this test also successfully demonstrated ideal control of tank vacuum: the setpoint of $2.0 \mathrm{in}$. Wc was maintained in a stable manner, with both the inlet and outlet control valves operating in midrange positions.

\subsection{Recirculation (K4) Condenser Air Flow}

Condenser air flow DP dropped from 12.6 (RECIRC) to $5.5 \mathrm{in.} \mathrm{wc} \mathrm{(High-Heat),} \mathrm{indicating} \mathrm{reduced}$ flow from the RECIRC Mode (RECIRC airflow cannot be directly measured). This conclusion is supported by other data: The K4 Fan DP is increased from 16.2 to 19.5 in. wc ( fan motor current was not affected). Using the approach discussed in Appendix 5, RECIRC-Mode air flow isagain estimated to be greater than $700 \mathrm{scfm}$, but an analysis is left for others.

\subsection{Recirculation (K4) Condenser Cooling}

Because the heat load in this tank is much lower than the system design basis, the condenser and cooling tower are hardly taxed, as evidenced by the insignificant rise in cooling water temperature across the condenser. For this tank and the summerlike ambient conditions at the time, the average heat removal in the DRY Mode is NIL (in fact, some data suggests the tank air is being WARMED by the cooling water); heat removal in the WET mode cannot be assessed since the data indicates that the tower was only operated in the DRY Mode during High-Heat operation, however it might be expected to similar to that of Tank AY101 as discussed in Appendix 5. The cooling capacity of this condenser also has a design basis of 1 million BTU per hour. Additional data is needed to fully assess heat removal.

\subsection{CONCLUSIONS}

The system operates as designed in High-Heat mode. 
APPENDIX 8 - HIGH-HEAT Mode, AY102, Steady State (Section B-7).

Table 8-1. Tank AY102 Hi-Heat Conditions, OTP Section B-7 (OTP Table 7-1)

\begin{tabular}{|l|c|c|c|c|c||}
\hline \multicolumn{1}{|c|}{ Tank AY102 Condition >> } & $\begin{array}{c}\text { Initial } \\
\text { AY102 } \\
\text { RECIRC }\end{array}$ & $\begin{array}{c}\text { Initial } \\
\text { AY102 } \\
\text { HI-HEAT }\end{array}$ & $\begin{array}{c}\text { Intervals } \\
1-4\end{array}$ & $\begin{array}{c}\text { Acceptance } \\
\text { Criteria }\end{array}$ & $\begin{array}{c}\text { TE } \\
\text { (Note) }\end{array}$ \\
\hline \hline Required AY102 Cooling Tower Mode & WET & DRY & DRY & NA & - \\
\hline \hline AY102 Exhaust Flow Setpoint, scfm & 210 & 500 & 500 & N/A & - \\
\hline AY102 Exhaust Flow, scfm & 212 & 499 & $497-503$ & Setpoint \pm 20 & - \\
\hline AY102 Exh. Valve \% Open & 41 & 35 & 35 & $>20 \%$ Open & - \\
\hline AY102 Inlet Flow, scfm & 0 & 115 & 115 & <Exh. Flow & - \\
\hline AY102 Inlet Valve Position, \% Open & 0 & 36 & 36 & N/A & - \\
\hline AY102 Tank Vacuum, in. wc $\quad$ (setpoint=2) & 1.2 & 2 & 2.1 & 0.5 to 3 & - \\
\hline AY102 Recirc Cond. Air Inlet Temp. ${ }^{\circ}$ F & 80 & 81 & $79-82$ & N/A & - \\
\hline AY102 Recirc Cond. Air Outlet Temp. ${ }^{\circ}$ F & 64 & 83 & $81-86$ & N/A & - \\
\hline AY102 Recirc Cond. Water Inlet Temp. ${ }^{\circ}$ F & 61 & 78 & $83-85$ & N/A & $(4)$ \\
\hline AY102 Recirc Cond. Water Outlet Temp. ${ }^{\circ}$ F & 65 & 81 & $82-85$ & N/A & $(4)$ \\
\hline AY102 Recirc Cond. Water Flow, gpm & 209 & 219 & 218 & $190-230$ & - \\
\hline AY102 Recirc Cond. Air DP, in. wc & 12.6 & 5.5 & $5.4-5.5$ & 8-12 & $006(2)$ \\
\hline AY102 Recirc Fan DP, in. wc & 16.2 & 19.5 & 19.4 & 15-18 & $006(3)$ \\
\hline AY102 K4 Fan Motor, amps @ 477-483 VAC & 4.2 & 4 & 4.2 & N/A & - \\
\hline \hline
\end{tabular}

(1) All other Cooling Towers WET.

(2) Test Exception TE-006, Item \#1 and 3; K4 Condensers DP higher than expected in RECIRC Mode (with WET Tower) and Fan DP higher than expected in High-Heat. See 4.3.

(3) Test Exception TE-006, Item \#2; AY102 K4 Condenser DP is lower than expected in High-Heat Mode.

(4) Some condenser water- temperature data quality is suspect (both AY1 and AY2 condensers). 


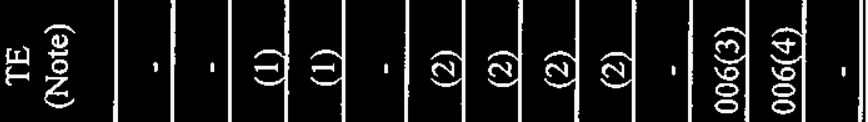

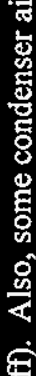

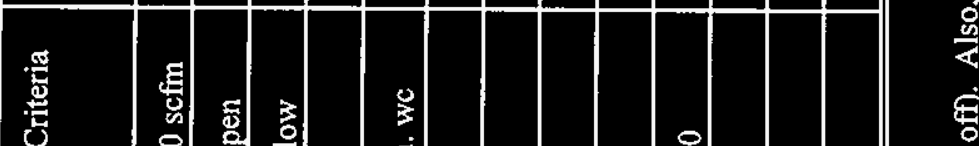

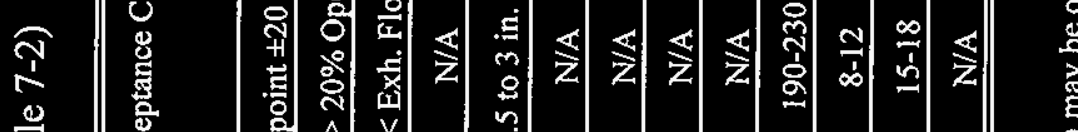

要

政

完

ก

兽

递

ตุ

密

胥 总

节 突

造

疍

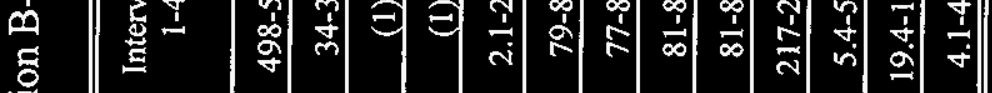

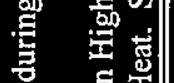

造 $\stackrel{0}{\circ}$

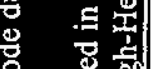

牙

$\Leftrightarrow$ क

E

8 \&

a

要

웡

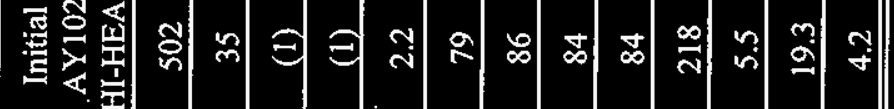

尊江

范

:

하잉

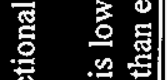

을

它

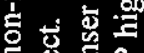

产高宫

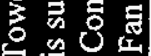

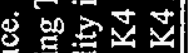

害密察

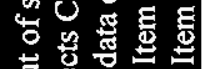

흐원

署

วิ

흘 空

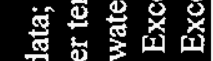

䵧

产

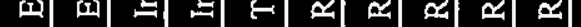

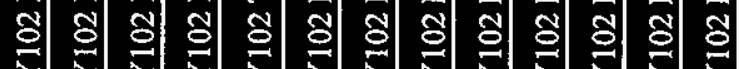

ฮิ อิษ 
APPENDIX 8 - HIGH-HEAT Mode, AY102, Steady State (Section B-7).

Table 8-4. System Conditions, AY102 High-Heat, OTP Section B-7 (OTP Table 7-2) Note - Intended Cooling Tower Mode : ALL WET

\begin{tabular}{|c|c|c|c|c|}
\hline Tank AY102 Condition $\gg$ & \multirow{2}{*}{$\begin{array}{l}\text { Initial } \\
\text { AY102 } \\
\text { HI-HEAT } \\
\end{array}$} & \multirow{2}{*}{$\begin{array}{c}\text { Intervals } \\
1-4\end{array}$} & \multirow{2}{*}{$\begin{array}{c}\text { Acceptance } \\
\text { Criteria }\end{array}$} & \multirow{2}{*}{$\begin{array}{c}\mathrm{TE} \\
\text { (Note) }\end{array}$} \\
\hline Parameter & & & & \\
\hline AY102 Exhaust Flow, scfm (from Table 8-3 above) & 502 & $498-508$ & $N / A$ & - \\
\hline pV Exhaust Stack Flow, scfm & 939 & $943-952$ & $760-1050$ & - \\
\hline PV Exhaust Manifold Vacuum, in. wc (setpoint=21) & 20.5 & $20.4-20.5$ & $\begin{array}{l}\text { Setpoint } \\
\pm 0.5\end{array}$ & $007(1)$ \\
\hline PV Cond. Air DP, in. wc & 11.9 & 12 & $\leq 11$ & $001(2)$ \\
\hline PV Cond. Air Inlet Temp., ${ }^{\circ} \mathrm{F}$ & 84 & 85 & N/A & - \\
\hline PV Cond. Air Outlet Temp., ${ }^{\circ} \mathrm{F}$ & 46 & 46 & $40-60$ & $\rightarrow$ \\
\hline PV Cond. Water Inlet Temp., ${ }^{\circ} \mathrm{F}$ & 38 & $37-39$ & $35-55$ & - \\
\hline PV Cond. Water Outlet Temp. ${ }^{\circ} \mathrm{F}$ & 40 & 39.41 & N/A & - \\
\hline PV Cond. Water Flow, gpm & 119 & $118-119$ & $95-130$ & - \\
\hline PV HEME DP, in. wc & 4.8 & 4.8 & $<10$ & - \\
\hline \multicolumn{5}{|c|}{$\begin{array}{l}\text { (1) Test Exception TE-007; PV Manifold vacuum setpoint is slightly above fan capability; see par. 4.3. Recording this } \\
\text { TE is questionable, since this instrument is associated with the standby PV Filter Train. } \\
\text { Test Exception TE-001, item \#5; PV Condenser DP exceeds Acceptance Criteria (AC) limit. See 4.3. }\end{array}$} \\
\hline
\end{tabular}


APPENDIX 9 - AY102 HIGH-HEAT, Change Tank Pressure Setpoints (Section B-8).

\section{$1.0 \quad$ INTRODUCTION}

This appendix summarizes operational testing performed under OTP Attachment B, Section- 8 . The test demonstrated acceptable system performance in HIGH-HEAT Mode over a range of pressure control setpoints for tank AY102.

\subsection{DESCRIPTION OF TEST}

This paragraph describes OTP requirements for this section. Initial conditions were established as described in 3.4 above. The system was initially verified to be operating in a stable condition with tank AY102 in HIGH-HEAT Mode and other tanks in RECIRC Mode. PV Train B was in service.

Important setpoints or conditions were verified or established as follows:

- Tank AY102 exhaust flow control set at $500 \mathrm{scfm}$;

- Other tank exhaust flow controls set at minimum designated flow rate;

- Tank AY102 pressure control setpoint placed at -0.5 in. wc;

- Other tank pressure control setpoints set for $-2.0 \mathrm{in}$. wc;

- PV Manifold Controller matching setpoints (PIC-AZK1-1A/1B), set as required to achieve designated tank flow rates.

After obtaining initial stable conditions, parametric data was recorded. Then the tank pressure control setpoint for tank AY102 was decreased in -0.5 inch wc increments to -3.0 . No other variables were changed. Results are summarized Section 4 below.

\subsection{TEST OBJECTIVES}

Establish and document stable system operation in the HIGH-HEAT Mode over a range of tank pressure setpoints.

\subsection{TEST RESULTS}

Only data for tank AY102 was recorded and results are as expected and similar to AY101 (Appendix 6). Test objectives were met except for minimum tank vacuum control. Initially, with the tank vacuum set for $-0.5 \mathrm{in}$. wc, vacuum was $-1.2 \mathrm{in}$. wc with the inlet pressure control valve full open, i.e. the inlet station was unable to introduce sufficient air to offset the $500 \mathrm{scfm}$ exhaust (TE-008). Only at a setpoint of -1.5 and greater, was the vacuum under control.

\subsection{CONCLUSIONS}

Changing and controlling tank pressure setpoint in High-Heat Mode is easily done. However, 1.5 in. $\mathrm{wc}$ is the lowest vacuum achievable, and this is a function of the inlet station pressure loss and thus the condition of the inlet station HEPA filters. 
APPENDIX 9 - AY102 HIGH-HEAT, Change Tank Pressure Setpoints (Section B-8).

Table 9-1. AY102 Tank Conditions, OTP Section B-8 (OTP Table 8-1).

\begin{tabular}{|c|c|c|c|c|c|c|c|c|}
\hline Tank Vacuum Setpoint, in. wc>> & \multirow[t]{2}{*}{0.5} & \multirow[t]{2}{*}{1} & \multirow[t]{2}{*}{1.5} & \multirow[t]{2}{*}{2} & \multirow[t]{2}{*}{2.5} & \multirow[t]{2}{*}{3} & \multirow[t]{2}{*}{ Acceptance Criteria } & \multirow{2}{*}{$\begin{array}{c}\mathrm{TE} \\
\text { (Note) }\end{array}$} \\
\hline Parameter & & & & & & & & \\
\hline Tank AY102 Vacuum & 1.2 & 1.2 & 1.5 & 1.9 & 2.5 & 3 & Setpoint \pm 0.2 & $008(1)$ \\
\hline Inlet Flow, scfim & (2) & $(2)$ & (2) & $(2)$ & (2) & $(2)$ & $<$ Tank Exh. Flow & (2) \\
\hline Inlet Valve, \% Open & 100 & 100 & 51 & 28 & 34 & 0 & N/A & - \\
\hline Exh. Flow, sctm (setpoint=500) & 506 & 504 & 500 & 495 & 505 & 501 & Setpoint \pm 20 & - \\
\hline Exh. Valve Position, \% Open & 31 & 31 & 31 & 32 & 34 & 34 & $>20 \%$ Open & \\
\hline $\begin{array}{ll}\text { (1) } & \text { Test Exception TE-008; } \\
& \text { stations are designed wit } \\
\text { (2) } & \text { Not recorded, Inlet statio }\end{array}$ & & & & & & & $\begin{array}{l}\text { tan } 2 \text { in. wc } \\
\text { sults are to b }\end{array}$ & \\
\hline
\end{tabular}


APPENDIX 10 - HIGH-HEAT Mode, AZ101, Steady State (Section B-9).

\section{$1.0 \quad$ INTRODUCTION}

This appendix summarizes operational testing performed under OTP Attachment B, Section 9. The test demonstrated acceptable system performance with tank AZ101 in HIGH-HEAT Mode with its cooling tower in both wet and dry modes. This test marks the first occasion of this tank operating in High-Heat Mode.

\subsection{DESCRIPTION OF TEST}

This paragraph describes OTP requirements for this section. Initial conditions were established as described in 3.4 above. The system was initially verified to be in stable operation with all tanks in RECIRC Mode. Important setpoints and conditions were verified or established as follows:

- PV Train-B in service;

- All tank pressure controls set at $-2.0 \mathrm{in}$. wc;

- PV Manifold Controller matching setpoints (PIC-AZK1-1A/1B) and tank exhaust flow set as required for designated minimum tank flow rates;

- All Cooling Towers in WET Mode, all others in WET Mode.

After obtaining initial stable conditions, parametric data was recorded in Table 9-1. Then tank AZ101 was placed in HIGH-HEAT Mode (and its cooling tower placed in DRY Mode) according to approved operating procedures; the steps required to do this are similar to those described in Appendix 5 for tank AY101. After reaching observed stable conditions, a second set of data was recorded. The system was then allowed to maintain steady-state conditions for a 4-hour period with data recorded each hour.

In the second part of this test, the AZ101 Cooling Tower was placed in WET Mode; parametric data was then recorded in Table 9-2 every 15 minutes for a total of 5 data sets. Results are summarized in Section- 4 below.

\section{TEST OBJECTIVES}

Demonstrate and document stable system operation in the RECIRC and HIGH-HEAT Modes for tank AZ101 and obtain heat removal data for the purpose of assessing system cooling capability.

\subsection{TEST RESULTS}

Results of the test were satisfactory as shown in tables 10-1 through 10-4 and as discussed below; important setpoints are shown for controlled variables. All test objectives were met, all setpoints were achieved. Stable control was demonstrated at all setpoints for all parameters. Thirteen minor Test Exceptions (TEs) were noted. The TEs do not affect test results or objectives; see discussion in 4.3 of the summary report and Attachment 1. Results were generally consistent with those of Appendix 5. There were no significant effects on the 3 other tanks when AZ101 was placed in High-Heat Mode. 
APPENDIX 10 - HIGH-HEAT Mode, AZ101, Steady State (Section B-9).

\subsection{Control of Tank Vacuum}

As discussed in Appendix 5, this test also successfully demonstrated ideal control of tank vacuum: the setpoint of $2.0 \mathrm{in}$. wc was maintained in a stable manner, with both the inlet and outlet control valves operating in midrange positions.

\subsection{Recirculation (K4) Condenser Air Flow}

Condenser air flow DP dropped from 12.6 (RECIRC) to 5.5 in. wc (High-Heat), indicating reduced flow from the RECIRC Mode (RECIRC airflow cannot be directly measured). This conclusion is supported by other data: The K4 Fan DP is increased from 16.2 to 19.5 in. wc ( fan motor current was not affected). Using the approach discussed in Appendix 5, RECIRC flow is again estimated to be greater than $700 \mathrm{scfm}$, but the analysis is left for others.

\subsection{Recirculation (K4) Condenser Cooling}

Because the heat load in this tank is lower than the system design basis, the condenser and cooling tower are hardly taxed, as evidenced by the small rise in cooling water temperature across the condenser. Thus, estimating the effective heat removal can only be based on the airflow conditions (not on cooling water); the following simple assumptions are used to yield approximate results:

- fully saturated tank air at $500 \mathrm{scfm}$;

- enthalpy based on ASHRAE data for standard pressure at saturated conditions;

Heat removal depends on the cooling tower operating mode and ambient weather conditions, especially wet-bulb (for tower in WET Mode) and dry-bulb (DRY Mode) temperatures. For this tank and the summerlike ambient conditions at the time, the average heat removal in the DRY Mode is estimated at about 130,000 BTU per hour. Heat removal with the tower in the WET Mode cannot be directly determined since no such data was taken during this High-Heat test, but it would be expected to substantially greater. Heat removal in the RECIRC Mode is expected to be greater still in proportion to the airflow increase but not approaching the design basis is 1.6 million BTU per hour. Additional data is needed to fully assess heat removal.

\subsection{CONCLUSIONS}

The system operates as designed in High-Heat mode. 


\section{W-030 OPERATIONAL TEST REPORT (PHASE 2)}

HNF-3473

Rev. 0, Page 50

APPENDIX 10 - HIGH-HEAT Mode, AZ101, Steady State (Section B-9).

Table 10-1. Tank AZ101 Hi-Heat Conditions, OTP Section B-9 (OTP Table 9-1)

\begin{tabular}{|c|c|c|c|c|c|}
\hline Tank AZ101 Condition $\gg$ & \multirow{2}{*}{$\begin{array}{c}\text { Initial } \\
\text { AZ101 } \\
\text { RECIRC } \\
\end{array}$} & \multirow{2}{*}{$\begin{array}{c}\text { Initial } \\
\text { AZ101 } \\
\text { HI-HEAT } \\
\end{array}$} & \multirow{2}{*}{$\begin{array}{c}\text { Intervals } \\
1-4\end{array}$} & \multirow{2}{*}{$\begin{array}{c}\text { Acceptance } \\
\text { Criteria }\end{array}$} & \multirow{2}{*}{$\begin{array}{c}\text { TE } \\
\text { Note) }\end{array}$} \\
\hline Parameter & & & & & \\
\hline AZ101 Required Cooling Tower Mode & $W E T$ & $D R Y$ & $D R Y$ & $N A$ & (1) \\
\hline AZ101 Exhaust Flow Setpoint, scfm & 110 & 500 & 500 & N/A & - \\
\hline AZ101 Exhaust Flow, scfm & 108 & 508 & 497-503 & Setpoint \pm 20 & - \\
\hline AZ101 Exh. Valve \% Open & $19(4)$ & 32 & 32 & $>20 \%$ Open & (4) \\
\hline AZ101 Inlet Flow, scfm & 0 & 286 & $284-287$ & $\leq$ Exh. Flow & - \\
\hline AZ101 Inlet Valve Position, \% Open & 0 & 60 & 60 & N/A & - \\
\hline AZ101 Tank Vacuum, in. wc (setpoint=2) & 0.9 & 2 & 2 & 0.5 to 3 & - \\
\hline AZ101 Recirc Cond. Air Inlet Temp. ${ }^{\circ} \mathrm{F}$ & 122 & 121 & $122-123$ & N/A & $=$ \\
\hline AZ101 Recirc Cond. Air Outlet Temp. ${ }^{\circ} \mathrm{F}$ & 87 & 88 & $89-90$ & N/A & - \\
\hline AZ101 Recirc Cond. Water Inlet Temp. ${ }^{\circ} \mathrm{F}$ & 85 & 85 & $88-90$ & N/A & (5) \\
\hline AZ101 Recirc Cond. Water Outlet Temp. ${ }^{\circ} \mathrm{F}$ & 86 & 86 & $88-91$ & N/A & (5) \\
\hline AZ101 Recirc Cond. Water Flow, gpm & 335 & 334 & $331-337$ & $300-340$ & $=$ \\
\hline AZ101 Recirc Cond. Air DP, in. wc & 11.8 & 4.7 & $3.7-4.6$ & $8-12$ & $006(2)$ \\
\hline AZ101 Recirc Fan DP, in. wc & 16.9 & 20.6 & 20.6 & $15-18$ & $006(3)$ \\
\hline AZ101 Recirc Fan Motor, amps @ 483-490 VAC & 4.9 & 3.8 & 3.8-3.9 & N/A & $=$ \\
\hline \multicolumn{6}{|c|}{$\begin{array}{l}\text { (1) All other Cooling Towers WET. } \\
\text { (2) Test Exception TE-006 Item \#2; K4 Condenser DP is lower than expected in High-Heat Mode. } \\
\text { (3) Test Exception TE-006 Item \#3; K4 Fan DP higher than expected in High-Heat. See 4.3. } \\
\text { (4) Considered too close to the limit to justify a TE (i.e., within system accuracy). } \\
\text { (5) Water temperature reflects Cooling Tower non-functional or in DRY mode during initial (fan may be off). Also, some condenser air and } \\
\text { water- temperature data quality is suspect. (AY1, AY2, and AZ2 condensers). }\end{array}$} \\
\hline
\end{tabular}

HNF -3473 Rev. 0, Page 50 


\begin{tabular}{|c|c|c|c|c|c|}
\hline & $\$$ 'Julodzas $\mathrm{MOJ}$ & 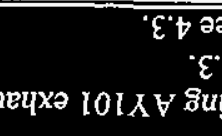 & 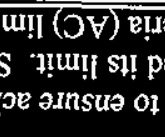 & 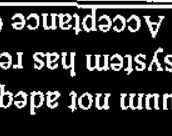 & 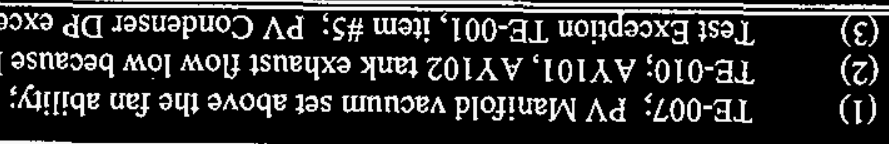 \\
\hline- & $0 \mathrm{I}>$ & $\mathcal{S}$ & s & $\bar{\varepsilon} \mathcal{E}$ & $\overline{\partial M}$ 'u! 'dG a \\
\hline- & $0 \varepsilon I-\$ 6$ & $6 I I-8 I I$ & $8 \mathrm{II}$ & $8 I I$ & 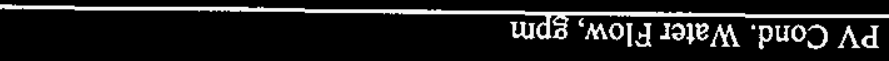 \\
\hline- & $\mathrm{V} / \mathrm{N}$ & $I \bar{b}-6 \bar{\varepsilon}$ & $0 b$ & $\overline{0 b}$ & $\mathfrak{d}_{0}$ 'dur \\
\hline- & $\mathcal{S S} \mathfrak{S \mathcal { E }}$ & $8 \varepsilon-L \varepsilon$ & $8 \bar{\varepsilon}$ & $8 \mathcal{E}$ & 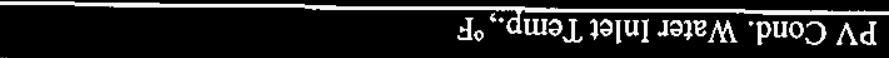 \\
\hline- & $09-0 t$ & $\angle t-9 b$ & $9 b$ & 96 & 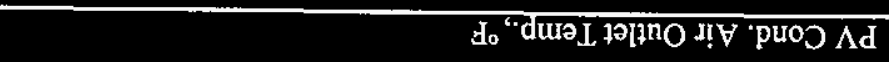 \\
\hline " & $\mathbf{V} / \mathbf{N}$ & $58-t 8$ & 68 & 18 & 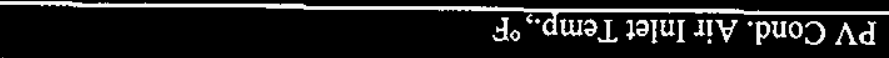 \\
\hline$(\varepsilon) 100$ & IIS & trZI & $\overline{b Z I}$ & $\varepsilon 9$ & 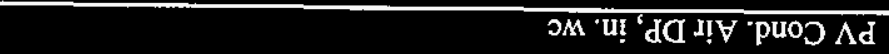 \\
\hline (I) $\angle O O$ & SOF IU!Odras & $(I Z) S^{\prime} 6 I$ & $(I 2) 96 I$ & $(8: 2 \mathrm{II}) \mathrm{ZI}$ & 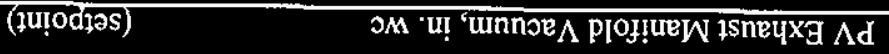 \\
\hline- & OSOI-09L & $200 \mathrm{I}-686$ & 666 & I89 & 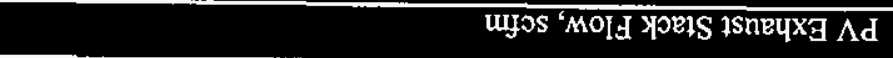 \\
\hline- & $\varepsilon 0150$ & $\overline{S ! I}$ & $\overline{S T}$ & $\bar{\Gamma} \bar{\tau}$ & 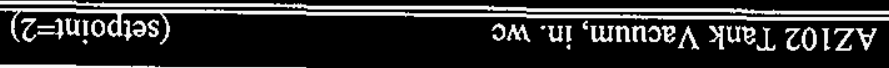 \\
\hline- & $\varepsilon 07 \varsigma^{\circ} 0$ & $\angle \mathscr{L}$ & $\bar{L} \overline{0}$ & $L^{\prime} 0$ & 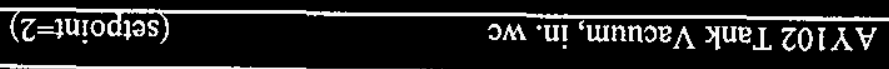 \\
\hline- & $\varepsilon 0150$ & 80 & 8.0 & I & 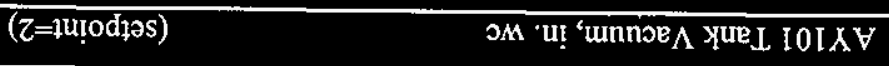 \\
\hline (2)0I0 & ozғ ju!odzas & E8-18 & 28 & $90 \mathrm{I}$ & uyos 'MOIA isney Xag ZOIZV \\
\hline - & OZF 1U!OdFS & $(0 \mathrm{IZ}) \triangleright \mathrm{IZ}-\mathrm{ZIZ}$ & $(0 \mathrm{Iz}) \overline{0 \mathrm{I} z}$ & $(0 z Z) 9 I Z$ & Uifos 'MOJd ISneyXa ZOIXV \\
\hline$(\mathrm{I}) \angle O O$ & 0Zғ Ju!odias & $I 8 I-\varepsilon L I$ & $6 \mathrm{LI}$ & $\overline{Z 6 I}$ & uyos 'MOld 1SneuxG IOI $X V$ \\
\hline- & $B / N$ & $t 0 s-\angle 6 t$ & $80 S$ & $\overline{80 I}$ & 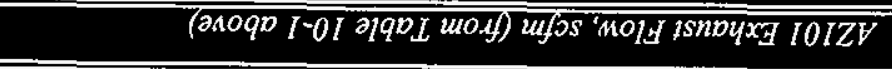 \\
\hline \multirow{2}{*}{$\begin{array}{l}(210 N) \\
\text { GL }\end{array}$} & \multirow{2}{*}{ 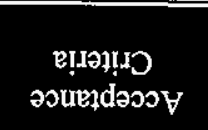 } & \multirow{2}{*}{ 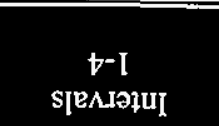 } & \multirow{2}{*}{$\begin{array}{c}\text { LVGH-IH } \\
\text { I0IZY } \\
\text { IE!!!uI }\end{array}$} & \multirow{2}{*}{ 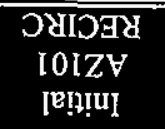 } & səzəurexed \\
\hline & & & & & 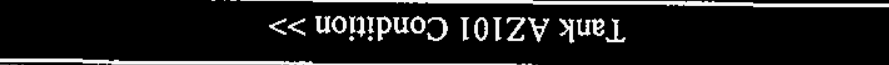 \\
\hline
\end{tabular}

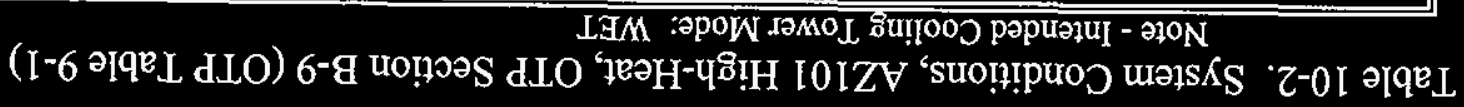

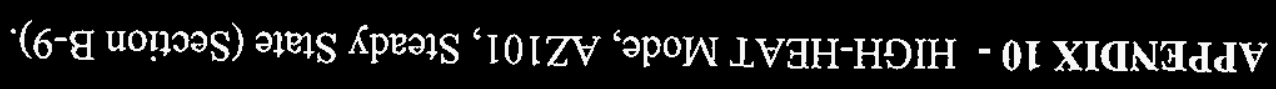

IS วิือ d 0 “ $\Lambda \partial y$

$\varepsilon L \neg \varepsilon-H N H$

( 


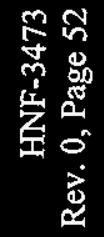

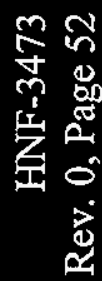

出造

융 क्षे

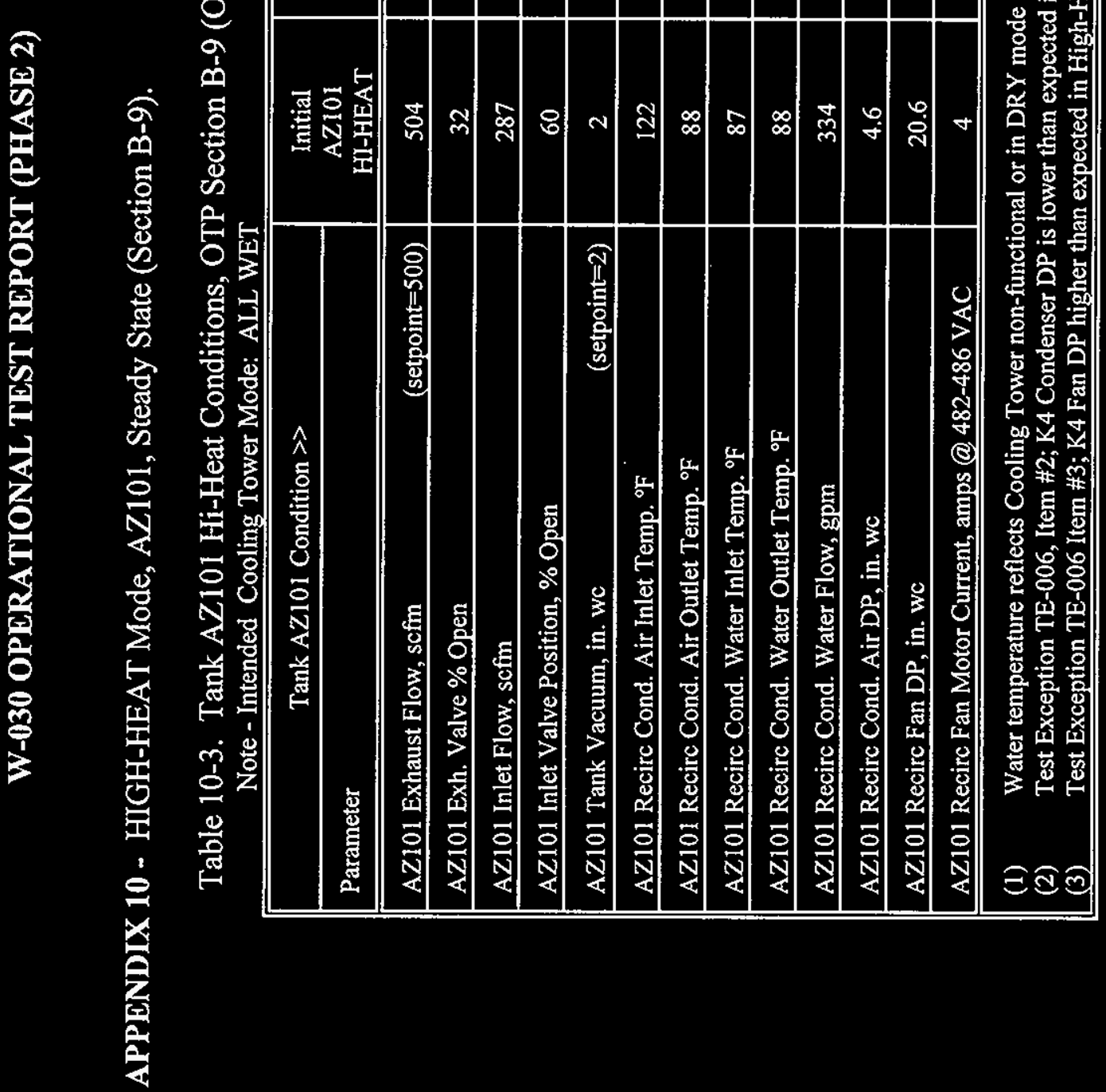




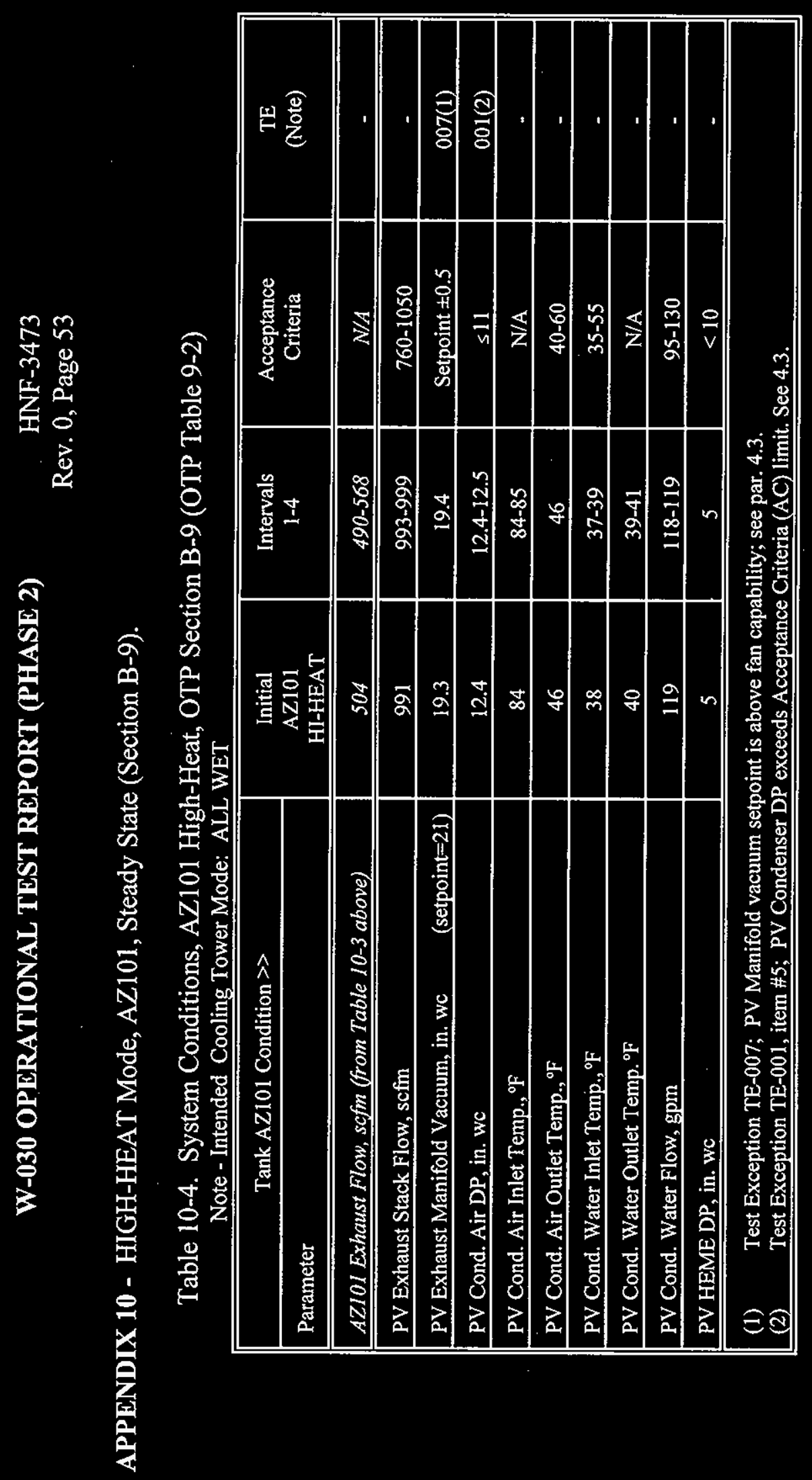

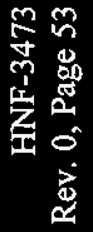


APPENDIX 11 - AZ101 HIGH-HEAT, Change Tank Pressure Setpoints (Section B-10).

\subsection{INTRODUCTION}

This appendix summarizes operational testing performed under OTP Attachment $\mathrm{B}$, Section-10. The test demonstrated acceptable system performance in HIGH-HEAT Mode over a range of pressure control setpoints for tank AZ101.

\subsection{DESCRIPTION OF TEST}

This paragraph describes OTP requirements for this section. Initial conditions were established as described in 3.4 above. The system was initially verified to be operating in a stable condition with tank AZ101 in HIGH-HEAT Mode and other tanks in RECIRC Mode. PV Train B was in service. Important setpoints or conditions were verified or established as follows:

- Tank AZ101 exhaust flow control set at 500 scfm;

- Other tank exhaust flow controls set at minimum designated flow rate;

- Tank AZ101 pressure control setpoint placed at -0.5 in. wc;

- Other tank pressure control setpoints set for $-2.0 \mathrm{in}$. wc;

- PV Manifold Controller matching setpoints (PIC-AZK1-1A/1B), set as required to achieve designated tank flow rates.

After obtaining initial stable conditions, parametric data was recorded. Then the tank pressure control setpoint for tank AZ101 was decreased in -0.5 inch wc increments to -3.0. No other variables were changed. Results are summarized Section 4 below.

\subsection{TEST OBJECTIVES}

Establish and document stable system operation in the HIGH-HEAT Mode over a range of tank pressure setpoints.

\subsection{TEST RESULTS}

Only data for tank AZ101 was recorded and results are as expected and similar to AY101 (Appendix 6). Test objectives were met except for minimum tank vacuum control. Initially, with the tank vacuum set for -0.5 in. wc, vacuum was -1.7 in. wc with the inlet pressure control valve full open, i.e. the inlet station was unable to introduce sufficient air to offset the $500 \mathrm{scfm}$ exhaust (TE-008). Only at a setpoint of -1.5 and greater, was the vacuum under control.

\subsection{CONCLUSIONS}

Changing and controlling tank pressure setpoint in High-Heat Mode is easily done. However, 1.5 in. wc is the lowest vacuum achievable, and this is a function of the inlet station pressure loss and thus the condition of the inlet station HEPA filters. 
APPENDIX 11 - AZ101 HIGH-HEAT, Change Tank Pressure Setpoints (Section B-10).

Table 11-1. AZ101 Tank Conditions, OTP Section B-10 (OTP Table 10-1).

\begin{tabular}{||l|c|c|c|c|c|c|c|c|}
\hline \hline \multicolumn{1}{|c|}{ Tank Vacuum Setpoint, in. wc>> } & 0.5 & 1.0 & 1.5 & 2.0 & 2.5 & 3.0 & $\begin{array}{c}\text { Acceptance } \\
\text { Criteria }\end{array}$ & $\begin{array}{c}\text { TE } \\
\text { (Note) }\end{array}$ \\
\hline \hline Tank AZ101 Vacuum & 1.7 & 1.7 & 1.7 & 2.0 & 2.6 & 3.0 & Setpoint \pm 0.2 & $008(1)$ \\
\hline Inlet Flow, scfm & 352 & 350 & 353 & 288 & 266 & 220 & $\begin{array}{c}\text { < Tank Exh. } \\
\text { Flow }\end{array}$ & - \\
\hline Inlet Valve, \% Open & 98 & 98 & 98 & 61 & 52 & 42 & N/A & - \\
\hline Exh. Flow, scfm (setpoint=500) & 507 & 506 & 503 & 507 & 508 & 499 & Setpoint \pm 20 & - \\
\hline Exh. Valve Position, \% Open & 32 & 32 & 32 & 32 & 34 & 35 & $>20 \%$ Open & - \\
\hline \hline
\end{tabular}

(1) Test Exception TE-008; reflects inappropriate acceptance criteria for tank vacuum set at less than 2 in. wc since the tank air inlet stations are designed with greater than 1 -in. wc pressure drop at the required flow rate. Test results are to be expected. 
APPENDIX 12 - AZ101 HIGH-HEAT Mode, PV Train Switchover (Section B-11).

\subsection{INTRODUCTION}

This appendix summarizes operational testing performed under OTP Attachment $\mathrm{B}$, Section 11 . The test demonstrated acceptable system performance in HIGH-HEAT Mode during PV Train switchover using the MCS MACRO control.

\subsection{DESCRIPTION OF TEST}

This paragraph describes OTP requirements for this section. Initial conditions were established as described in 3.4 above. The system was initially verified to be operating in a stable manner with AZ101 in HIGH-HEAT Mode, all other tanks in RECIRC Mode, and Fan/Filter Train-B in service. The PV manifold pressure and heater temperature setpoints were verified to have matching setpoints. Initial parametric data was recorded in Table 11-1.

While ensuring that the system remains stable, Fan-1A and Heater 1-A were selected and run on the MCS MACRO screen (by design, MCS control of the Filter Train is made by selecting the heater). After system stabilization, a new data set was recorded.

\subsection{TEST OBJECTIVES}

Establish and document stable system operation in the HIGH-HEAT Mode during changeover to standby PV Train.

\subsection{TEST RESULTS}

Results of the test were satisfactory as shown in the tables below; important setpoints are shown for controlled variables. All test objectives were met; one minor Test Exception (TE) was noted; the TE does not affect test results or objectives; see discussion in 4.3 of the summary report and Attachment 1 . Important data parameters are summarized in Tables 7-1 and 7-2 below.

All recorded data is as expected except for AZ101 exhaust flow which unexplainably increased from 495 to $512 \mathrm{scfm}$ during the transient. The most likely reason is that the system had not fully stablized when the data was recorded. Setpoint control was maintained for all parameters.

\subsection{CONCLUSIONS}

The Primary Vent Train switching can be easily accomplished by the operator personnel using automatic MCS action as designed, with no instability. 
APPENDIX 12 - AZ101 HIGH-HEAT Mode, PV Train Switchover (Section B-11).

Table 12-1. System Conditions, OTP Section B-11 (OTP Table 11-1)

\begin{tabular}{|c|c|c|c|c|}
\hline Parameter & $\begin{array}{l}\text { Initial value } \\
\text { (Train-B) }\end{array}$ & $\begin{array}{l}\text { Final value } \\
\text { (Train-A) }\end{array}$ & $\begin{array}{c}\text { Acceptance } \\
\text { Criteria }\end{array}$ & $\begin{array}{c}\text { TE } \\
\text { (Note) } \\
\end{array}$ \\
\hline PV Manifold Vacuum, in. wc $\quad($ setpoint $=21)$ & 19 & 19.4 & Setpoint \pm 0.5 & $007(1)$ \\
\hline PV Stack Flow, scfm & 999 & 992 & $760-1050$ & - \\
\hline Heater Diff. Temp., ${ }^{\circ} \mathrm{F}$ & 24 & 27 & Setpoint \pm 2 & . \\
\hline PV Condenser Diff. Press., in. wc & 12 & 12.1 & $\leq 11$ & $001(2)$ \\
\hline $\begin{array}{l}\text { TE-007; PV Manifold vacuum setpoint is abo } \\
\text { TE-001, item } \# 5 \text {; PV Condenser DP exceeds }\end{array}$ & $\begin{array}{l}\text { ability; see } \\
\text { e Criteria (A }\end{array}$ & & & \\
\hline
\end{tabular}

Table 12-2. Waste Tank Conditions, OTP Section B-11 (OTP Table 11-1)

\begin{tabular}{|c|c|c|c|c|c|c|}
\hline Parameter & AY101 & AY102 & $\begin{array}{c}\text { AZ101 } \\
\text { (HI-HEAT) }\end{array}$ & AZ102 & $\begin{array}{c}\text { Acceptance } \\
\text { Criteria }\end{array}$ & $\begin{array}{c}\text { TE } \\
\text { (Note) }\end{array}$ \\
\hline Inlet Flow, scfm, & $\begin{array}{l}0 \\
0 \\
\end{array}$ & $\begin{array}{l}(1) \\
(1) \\
\end{array}$ & $\begin{array}{l}288 \\
289 \\
\end{array}$ & $\begin{array}{l}0 \\
0\end{array}$ & N/A & (1) \\
\hline $\begin{array}{l}\text { Tank Vacuum, in. wc, } \\
\text { (setpoint=2) }\end{array}$ & $\begin{array}{l}0.8 \\
0.8 \\
\end{array}$ & $\begin{array}{l}0.7 \\
0.7 \\
\end{array}$ & $\begin{array}{l}2.0 \\
2.0\end{array}$ & $\begin{array}{l}1.5 \\
1.5 \\
\end{array}$ & $0.5-3.0$ & - \\
\hline Outlet Flow, scfm, & $\begin{array}{l}181 \\
180 \\
\end{array}$ & $\begin{array}{l}209 \\
206 \\
\end{array}$ & $\begin{array}{l}495 \\
512 \\
\end{array}$ & $\begin{array}{l}79 \\
85 \\
\end{array}$ & setpoint \pm 20 & - \\
\hline Setpoint, scfm & 200 & 210 & 500 & 110 & N/A & - \\
\hline Vlv., \% Open, & $\begin{array}{l}100 \\
100\end{array}$ & $\begin{array}{l}80 \\
80 \\
\end{array}$ & $\begin{array}{l}33 \\
33 \\
\end{array}$ & $\begin{array}{l}100 \\
100\end{array}$ & $>20 \%$ Open & - \\
\hline
\end{tabular}


APPENDIX 13 - HIGH-HEAT Mode, AZ102, Steady State (Section B-12).

\subsection{INTRODUCTION}

This appendix summarizes operational testing performed under OTP Attachment B, Section 12. The test demonstrated acceptable system performance with tank AZ102 in HIGH-HEAT Mode with its cooling tower in both wet and dry modes. This test marks the first occasion of this tank operating in High-Heat Mode.

\subsection{DESCRIPTION OF TEST}

This paragraph describes OTP requirements for this section. Initial conditions were established as described in 3.4 above. The system was initially verified to be in stable operation with all tanks in RECIRC Mode. Important setpoints and conditions were verified or established as follows:

- PV Train-A in service;

- All tank pressure controls set at -2.0 in. wc;

- PV Manifold Controller matching setpoints (PIC-AZK1-1A/1B) and tank exhaust flow control set as required for designated minimum tank flow rates;

- All Cooling Towers in WET Mode.

After obtaining initial stable conditions, parametric data was recorded in Table 12-1. Then tank AZ102 was placed in HIGH-HEAT Mode according to approved operating procedures; the steps required to do this are similar to those described in Appendix 5 for tank AY101. After reaching observed stable conditions, a second set of data was recorded. The system was then allowed to maintain steady-state conditions for a 4-hour period with data recorded each hour.

In the second part of this test, the AZ102 Cooling Tower was placed in WET Mode; parametric data was then recorded in Table 12-2 every 15 minutes for a total of 5 data sets. Results are summarized Section 4 below.

Demonstrate and document stable system operation in the RECIRC and HIGH-HEAT Modes for tank AZ102 and obtain heat removal data for the purpose of assessing system cooling capability.

\subsection{TEST RESULTS}

Results of the test were satisfactory as shown in tables 13-1 through 13-4 and as discussed below; important setpoints are shown for controlled variables. All test objectives were met, all setpoints were achieved. Stable control was demonstrated at all setpoints for all parameters. Thirteen minor Test Exceptions (TEs) were noted. The TEs do not affect test results or objectives; see discussion in 4.3 of the summary report and Attachment 1. Results were generally consistent with those of Appendix 5. There were no significant effects on the 3 other tanks when AZ102 was placed in High-Heat Mode. 
APPENDIX 13 - HIGH-HEAT Mode, AZ102, Steady State (Section B-12).

\subsection{Control of Tank Vacuum}

Stable control of tank vacuum was maintained; however since this tank is apparently more tightlysealed than the other tanks, tank vacuum reached 2.3 in. wc in High-Heat Mode, with the inlet pressure-control valve full open. The outlet flow control valve was operating in midrange position.

\subsection{Recirculation (K4) Condenser Air Flow}

Condenser air flow DP dropped from 11.9 (RECIRC, WET Tower) to 6.3 in. wc (High-Heat, DRY Tower), indicating reduced flow from the RECIRC Mode (RECIRC airflow cannot be directly measured). This conclusion is supported by other data: The K4 Fan DP is increased from 15.8 to 19.1 in. wc and fan motor current dropped from 4.5 to 3.8. Using the approach discussed in Appendix 5 , RECIRC flow is estimated to also be greater than $700 \mathrm{scfm}$ with no condensing. When the cooling tower was placed in WET Mode (maximum condensing), the Condenser DP doubles to $12.6 \mathrm{in}$. wc; this inconsistency causes the data of table 13-3 to appear suspect (especially considering the large difference in the condenser inlet temperature in tables 13-1 and 13-3).

\subsection{Recirculation (K4) Condenser Cooling}

Because the heat load in this tank is lower than the system design basis, the condenser and cooling tower is hardly taxed, as evidenced by the small rise in cooling water temperature across the condenser. Thus, estimating the effective heat removal can only be based on the airflow conditions (not on cooling water); the following simple assumptions are used to yield approximate results:

fully saturated tank air at $500 \mathrm{scfm}$; enthalpy based on ASHRAE data for standard pressure at saturated conditions;

Heat removal depends on the cooling tower operating mode and ambient weather conditions, especially wet-bulb (for tower in WET Mode) and dry-bulb (DRY Mode) temperatures. For this tank and the summerlike ambient conditions at the time, the average heat removal in the DRY Mode is estimated at about 75,000 BTU per hour. Heat removal with the tower in the WET Mode cannot be directly determined since no reliable data was taken during this High-Heat test (too much inconsistency between tables 13-1 and 13-3). Heat removal in the RECIRC Mode is expected to be substantially greater in proportion to the airflow increase but not approaching the design basis is 1 million BTU per hour. Additional data is needed to fully assess heat removal.

\subsection{CONCLUSIONS}

The system operates as designed in High-Heat mode. To control tank vacuum, it will be more important for this tank to keep the inlet station HEPA filters clean. More data is needed to assess cooling capacity. 


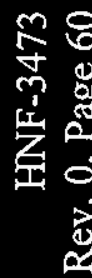

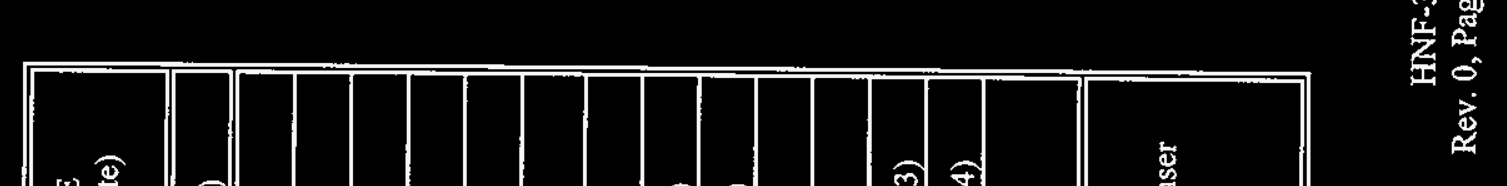

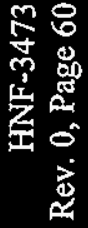

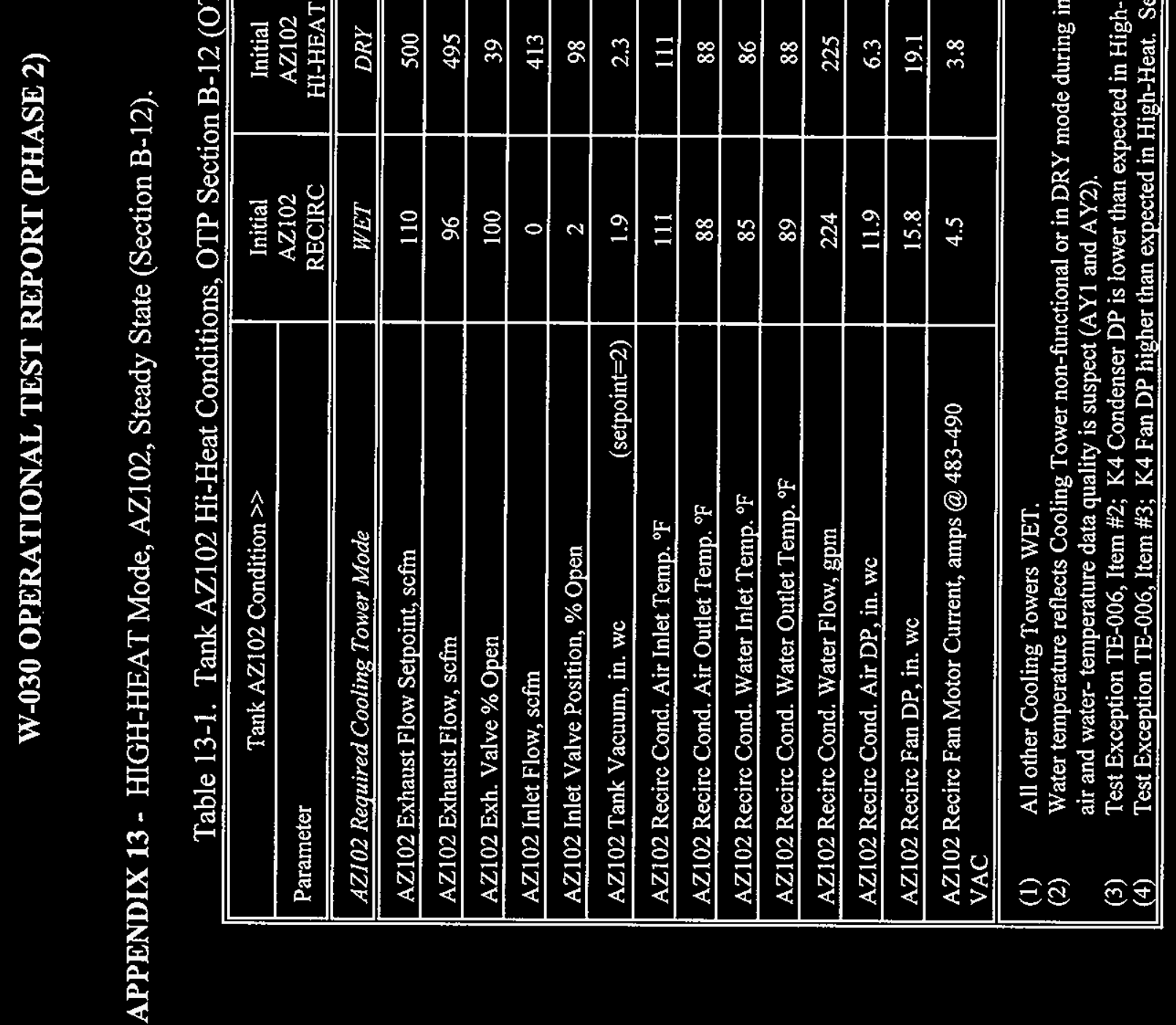




\section{W-030 OPERATIONAL TEST REPORT (PHASE 2)}

HNF-3473

Rev. 0, Page 61

APPENDIX 13 - HIGH-HEAT Mode, AZ102, Steady State (Section B-12).

Table 13-2. System Conditions, AZ102 High-Heat, OTP Section B-12 (OTP Table 12-1) Note - Cooling Tower Mode : WET

\begin{tabular}{|c|c|c|c|c|c|}
\hline Tank AZ102 Condition $\gg$ & Initial & Initial & Intervals & Acceptance & TE \\
\hline Parameter & $\begin{array}{c}\mathrm{A} 2102 \\
\text { RECIRC } \\
\end{array}$ & $\begin{array}{c}\text { AZ102 } \\
\text { HI-HEAT } \\
\end{array}$ & & Criteria & (Note) \\
\hline AZ102 Exhaust Flow, scfm (from Table 13-1 above) & 96 & 495 & $498-505$ & $N / A$ & - \\
\hline AY101 Exhaust Flow, scfm & 193 & 165 & $163-169$ & Setpoint \pm 20 & $010(1)$ \\
\hline AY102 Exhaust Flow, scfm & 212 & 193 & $195-198$ & Setpoint \pm 20 & - \\
\hline AZ101 Exhaust Flow, scfm & 106 & 106 & $106-108$ & Setpoint \pm 20 & - \\
\hline AY101 Tank Vacuum, in. wc & 1 & 0.7 & 0.7 & 0.5 to 3 & - \\
\hline AY102 Tank Vacuum, in. wc & 0.9 & 0.8 & 0.8 & 0.5 to 3 & - \\
\hline AZ101 Tank Vacuum, in. wc & 1 & 0.9 & 0.9 & 0.5 to 3 & 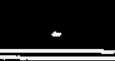 \\
\hline PV Exhaust Stack Flow, scfim & 614 & 998 & $994-998$ & $760-1050$ & - \\
\hline PV Exhaust Manifold Vacuum, in. wc & $1414)$ & $19.9(21)$ & $19.7-19.8(21)$ & Setpoint \pm 0.5 & $007(2)$ \\
\hline PV Cond. Air DP, in. wc & 9.5 & 12.6 & $12.4-12.5$ & $\leq 11$ & $001(3)$ \\
\hline PV Cond. Air Inlet Temp., ${ }^{\circ} \mathrm{F}$ & 81 & 85 & $86-87$ & N/A & - \\
\hline PV Cond. Air Outlet Temp., ${ }^{\circ} \mathrm{F}$ & 45 & 46 & 47 & $40-60$ & - \\
\hline PV Cond. Water Inlet Temp., ${ }^{\circ} \mathrm{F}$ & 40 & 39 & 38 & $35-55$ & - \\
\hline PV Cond. Water Outlet Temp. ${ }^{\circ} \mathrm{F}$ & 41 & 41 & 41 & N/A & - \\
\hline PV Cond. Water Flow, gpm & 119 & 119 & $118-120$ & $95-130$ & - \\
\hline PV HEME DP, in. wc & 3 & 5 & 5 & $<10$ & - \\
\hline
\end{tabular}

(1) TE-010; AY101, AY102 tank exhaust flow low because PV system has reached its limit. See 4.3.

(2) TE-007; PV Manifold vacuum set higher than fan can obtain; vacuum not adequate to achieve AY101 exhaust flow setpoint. See 4.3 .

(3) TE-001, item \#5; PV Condenser DP exceeds Acceptance Criteria (AC) limit. See 4.3. 
APPENDIX 13 - HIGH-HEAT Mode, AZ102, Steady State (Section B-12).

Table 13-3. Tank AZ102 Hi-Heat Conditions, OTP Section B-12 (OTP Table 12-2)

Note - AZ102 Cooling Tower in WET MODE.

\begin{tabular}{|c|c|c|c|c|}
\hline Tank AZ102 Condition >> & & Intervals & Acceptance & TE \\
\hline Parameter & $\begin{array}{c}\text { AZ102 } \\
\text { HI-HEAT } \\
\end{array}$ & & & \\
\hline AZ102 Exhaust Flow, scfm & 500 & $493-497$ & Setpoint \pm 20 & - \\
\hline AZ102 Exh. Valve \% Open & 39 & 39 & $>20 \%$ Open & - \\
\hline AZ102 Inlet Flow, scfm & 410 & $405-412$ & sExh. Flow & - \\
\hline AZ102 Inlet Valve Position, \% Open & 97 & 97 & N/A & - \\
\hline AZ102 Tank Vacuum, in. wc & 2.4 & 2.4 & 0.5 to 3 & - \\
\hline AZ102 Recirc Cond. Air Inlet Temp. ${ }^{\circ} \mathrm{F}$ & 84 & $83-85$ & N/A & (1) \\
\hline AZ102 Recirc Cond. Air Outlet Temp. ${ }^{\circ} \mathrm{F}$ & 65 & $64-67$ & N/A & - \\
\hline AZ102 Recirc Cond. Water Inlet Temp. ${ }^{\circ} \mathrm{F}$ & 65 & $63-64$ & N/A & (3) \\
\hline AZ102 Recirc Cond. Water Outlet Temp. ${ }^{\circ} \mathrm{F}$ & 64 & 66 & N/A & (3) \\
\hline AZ102 Recirc Cond. Water Flow, gpm & 226 & $224-227$ & $190-230$ & \\
\hline AZ102 Recirc Cond. Air DP, in. wc & 12.6 & $12.6-12.7$ & $8-12$ & $\begin{array}{c}(1) \\
006(2) \\
\end{array}$ \\
\hline AZ102 Recirc Fan DP, in. wc & 16.8 & 16.8 & $15-18$ & (1) \\
\hline AZ102 Recirc Fan Motor, amps @ 483-490 VAC & 5 & 4.9-5.1 & N/A & (1) \\
\hline
\end{tabular}

(1) Data inconsistent with Table 13-1 and is suspect.

(2) Test Exception TE-006, Item \# 1; K4 DP higher than limit in High-Heat Mode, however, this data is suspect based on inconsistency in Condenser inlet temperature compared with Table 13-1.

(3) Some condenser-DP and air and water- temperature data quality is suspect. Data reflects inconsistent or impossible conditions (suspect). 
APPENDIX 13 - HIGH-HEAT Mode, AZ102, Steady State (Section B-12).

Table 13-4. System Conditions, AZ102 High-Heat, OTP Section B-12 (OTP Table 12-2) Note - AZ102 Cooling Tower in WET MODE.

\begin{tabular}{|c|c|c|c|c|}
\hline Tank AZ102 Condition >> & & Intervals & Acceptance & $\mathrm{TE}$ \\
\hline Parameter & $\begin{array}{c}\text { AZ102 } \\
\text { HI-HEAT }\end{array}$ & & & \\
\hline AZ102 Exhaust Flow, scfm (from Table 13-3 above) & 500 & 493-497 & $N / A$ & - \\
\hline PV Exhaust Stack Flow, scfm & 991 & $997-999$ & $760-1050$ & - \\
\hline PV Exhaust Manifold Vacuum, in. wc (setpoint=21) & 19.6 & 19.7 & Setpoint \pm 0.5 & $007(1)$ \\
\hline PV Cond. Air DP, in. wc & 12.5 & 12.5 & $\leq 11$ & $001(2)$ \\
\hline PV Cond. Air Inlet Temp., ${ }^{\circ} \mathrm{F}$ & 87 & 87 & N/A & - \\
\hline PV Cond. Air Outlet Temp., ${ }^{\circ} \mathrm{F}$ & 47 & $46-47$ & $40-60$ & - \\
\hline PV Cond. Water Inlet Temp. ${ }^{\circ} \mathrm{F}$ & 37 & $37-39$ & $35-55$ & - \\
\hline PV Cond. Water Outlet Temp. ${ }^{\circ} \mathrm{F}$ & 40 & $39-41$ & N/A & - \\
\hline PV Cond. Water Flow, gpm & 119 & 119 & $95-130$ & - \\
\hline PV HEME DP, in. wc & 4.9 & 4.9-5.0 & $<10$ & - \\
\hline $\begin{array}{l}\text { Test Exception TE-007; PV Manifold vac } \\
\text { Test Exception TE-001, item \#5; PV Cond }\end{array}$ & Acce & $i a$ & & \\
\hline
\end{tabular}


APPENDIX 14 - AZ102 HIGH-HEAT, Change Tank Pressure Setpoints (Section B-13).

\section{$1.0 \quad$ INTRODUCTION}

This appendix summarizes operational testing performed under OTP Attachment B, Section-13. The test demonstrated acceptable system performance in HIGH-HEAT Mode over a range of pressure control setpoints for tank AZ102.

\subsection{DESCRIPTION OF TEST}

This paragraph describes OTP requirements for this section. Initial conditions were established as described in 3.4 above. The system was initially verified to be operating in a stable condition with tank AZ102 in HIGH-HEAT Mode and other tanks in RECIRC Mode. PV Train A was in service.

Important setpoints or conditions were verified or established as follows:

Tank AZ102 exhaust flow control set at $500 \mathrm{scfm}$;

Other tank exhaust flow controls set at minimum designated flow rate;

Tank AZ102 pressure control setpoint placed at -0.5 in. wc;

Other tank pressure control setpoints set for -2.0 in. wc;

PV Manifold Controller matching setpoints (PIC-AZK1-1A/1B), set as required to achieve designated tank flow rates.

After obtaining initial stable conditions, parametric data was recorded. Then the tank pressure control setpoint for tank AZ102 was decreased in -0.5 inch wc increments to -3.0 . No other variables were changed. Results are summarized Section 4 below.

\subsection{TEST OBJECTIVES}

Establish and document stable system operation in the HIGH-HEAT Mode over a range of tank pressure setpoints.

\subsection{TEST RESULTS}

Only data for tank AZ102 was recorded and results are as expected and similar to AY101 (Appendix 6). Test objectives were met except for minimum tank vacuum control. As stated earlier, this tank is more tightly sealed than the others. Initially, with the tank vacuum set for $-0.5 \mathrm{in}$. wc, vacuum was $2.3 \mathrm{in}$. wc with the inlet pressure control valve full open, i.e. the inlet station was unable to introduce sufficient air to offset the $500 \mathrm{scfm}$ exhaust (TE-008). Only at a setpoint of -2.5 and greater, was the vacuum under control.

\section{0}

\section{CONCLUSIONS}

Changing and controlling tank pressure setpoint in High-Heat Mode is easily done. However, 2.5 in. wc is the smallest vacuum achievable, and this is a function of the inlet station pressure loss and thus the condition of the inlet station HEPA filters. 


\section{W-030 OPERATIONAL TEST REPORT (PHASE 2)}

HNF-3473

Rev. 0, Page 65

APPENDIX 14 - AZ102 HIGH-HEAT, Change Tank Pressure Setpoints (Section B-13).

Table 14-1. AZ102 Tank Conditions, OTP Section B-13 (OTP Table 13-1).

\begin{tabular}{|c|c|c|c|c|c|c|c|c|}
\hline Tank Vacuum Setpoint, in. wc $>$ & 0.5 & 1 & 1.5 & 2 & 2.5 & 3 & Acceptance & TE \\
\hline Parameter & & & & & & & Criteria & (Note) \\
\hline Tank AZ102 Vacuum & 2.3 & 2.4 & 2.4 & 2.4 & 2.5 & 3 & Setpoint \pm 0.2 & $008(1)$ \\
\hline Inlet Flow, scfm & 407 & 409 & 408 & 408 & 380 & 282 & $<$ Tank Exh. & - \\
\hline Inlet Valve, \% Open & 97 & 98 & 97 & 97 & 68 & 59 & N/A & - \\
\hline Exh. Flow, scfm & 509 & 502 & 502 & 506 & 502 & 505 & Setpoint \pm 20 & - \\
\hline Exh. Valve Position, \% Open & 39 & 39 & 39 & 39 & 39 & 40 & $>20 \%$ Open & - \\
\hline $\begin{array}{l}\text { TE-008; reflects inappropriate } \\
\text { designed with greater than 1-i }\end{array}$ & & & & & & & $\begin{array}{l}\text { nk air in } \\
\text { cted. }\end{array}$ & \\
\hline
\end{tabular}




\section{ATTACHMENTS}

\section{TEST EXCEPTIONS}

\section{TEST DATA}

3. FIGURES 


\section{ATTACHMENT 1}

\section{TEST EXCEPTIONS}


See approved copies of actual TE reports on the following pages.

TEST EXCEPTION SUMMARY

Phase 1 and 2

\begin{tabular}{|c|c|c|c|}
\hline $\begin{array}{c}\text { TE, } \\
\text { Phase }\end{array}$ & $\begin{array}{l}\text { OTP SECTIONS } \\
\text { AFFECTED } \\
\end{array}$ & DESCRIPTION & ACTION \\
\hline 001 & $\begin{array}{l}A-4,-5,-7,-10 \\
B-3\end{array}$ & $\begin{array}{l}\text { Inappropriate or incorrect acceptance criteria }(A C) \text { for } \\
\text { several parameters; all of these were corrected in } \\
\text { subsequent OTP revisions. }\end{array}$ & $\begin{array}{l}\text { None. No } \\
\text { retest } \\
\text { required. }\end{array}$ \\
\hline $\begin{array}{l}002 \\
I\end{array}$ & $A-5,-9$ & Same. & Same \\
\hline $\begin{array}{ll}003 \\
1\end{array}$ & $A-4$ & $\begin{array}{l}\text { Exhaust fans unable to generate required header vacuum. } \\
\text { AC should have reflected that maximum vacuum was } \\
\text { unknown. }\end{array}$ & $\begin{array}{l}\text { None. No } \\
\text { retest } \\
\text { required. }\end{array}$ \\
\hline 004 & $A-5,-7$ & Various $A C$ was unreasonable for the test or in error. & $\begin{array}{l}\text { None. No } \\
\text { retest } \\
\text { required. }\end{array}$ \\
\hline $\begin{array}{l}005 \\
1\end{array}$ & $A-6$ & Same. & Same. \\
\hline $\begin{array}{l}001 \\
2\end{array}$ & $\begin{array}{l}A-11,-12,-13, B-3,-4 \\
-6,-7,-9,-11,-12\end{array}$ & PV Condenser DP exceeds AC limits at peak flow. & $\begin{array}{l}\text { None. No } \\
\text { retest. }\end{array}$ \\
\hline $\begin{array}{l}006, \\
2\end{array}$ & $\begin{array}{l}A-11,-12,-13, B-3,-4 \\
-7,-9,-12\end{array}$ & $\begin{array}{l}\text { Various parameters outside AC limits (PV Heater DT, K4 fan } \\
\text { DP, K4 Condenser DP). }\end{array}$ & Same. \\
\hline $\begin{array}{l}007, \\
2\end{array}$ & $\begin{array}{l}A-11,-12,-13, B-3,-4 \\
-6,-9,-11,-12\end{array}$ & $\begin{array}{l}\text { PV inlet manifold vacuum below setpoint } \mathrm{AC} \text { at peak flow. } \\
\text { Similar to TE- } 003 \text {. }\end{array}$ & Same \\
\hline $\begin{array}{l}008, \\
2\end{array}$ & $B-5,-8,-10,-13$ & Tank vacuum exceeds minimum setpoints AC in High-Heat. & Same \\
\hline $\begin{array}{l}009 \\
2\end{array}$ & B-9,-11 & $\begin{array}{l}\text { Some tank exhaust flows below setpoint when AZ101 in High- } \\
\text { Heat. }\end{array}$ & Same \\
\hline $\begin{array}{l}010 \\
2\end{array}$ & $A-13, B-9,-12$ & Similar. & Same. \\
\hline
\end{tabular}


HNF-3473

TEST EXCEPTION REPORT

REV. 0, Page 69

TEST PROCEOURE NO. \& SECTION:

OTP-W030-001, Revision B-5. Various

sections as noted

\begin{tabular}{ll|l}
\hline TEST NAME: & W030 Operational Test \\
Procedure Integrated System Test & T.E. NUMBER: \\
& TE-001
\end{tabular}

DESCRIPTION OF PROBLEM:

Additional exceptions for Phase-2. similar to Item $\# 5$ of TE-001. Phase 1. At peak system airflow. Primary Vent Condenser differential pressure (DP), PDI-AZK18-1, is greater than acceptance criteria (AC) limit of $\leq 11$ inches water column (in. WC).

$\begin{array}{llc}\text { Section } & \text { Page } & \text { Value observed } \\ \text { A11 } & 183 & 11.9 \\ \text { A12 } & 191 & 11.9 .11 .4 \\ \text { A13 } & 199 & 11.6 \\ \text { B3 } & 222.223 & 12.6 .11 .4 .11 .2 \\ \text { B4 } & 240 & \text { Same (redundant table) } \\ \text { B4 } & 249 & 12.1 \\ \text { B6 } & 261 & 12.1 .11 .7 \\ \text { B7 } & 277 & 12.1 .11 .9 \\ \text { B7 } & 287 & 11.9-12.1 \\ \text { B9 } & 304 & 12.4 \\ \text { B9 } & 313 & 12.4-12.5 \\ \text { B11 } & 325 & 12-12.1 \\ \text { B12 } & 341 & 12.6-12.4 \\ \text { B12 } & 350 & 12.5\end{array}$

ST ENGINEER:

See Original OTP for Signatures

This Sheet Included for Reference Only.

IMPACT ON TESTING: $\square$ HOLD FOR RESOLUTION $x$ CONTINUE

See Original orp for Signatures

This Sheet Included for Reference Only.

ORG:

DATE:

PIC

DATE

OISPOSITION (Completed by Test Engineer):

The disposition for each of these instances is the same. The AC is inappropriate for these tests, as the performance characteristics of the condenser were not fully known prior to the tests: the actual values were consistent throughout. Section B3 of the OTP explores this issue.

No re-test is required.

DISPOSITION AND RETEST REQUIREMENTS BY:

See Original OTP for Signatures.

This Sheet Included for Reference Only.

TEST ENGINEER DATE

QAE CONCURRENCE WITH DISPOSITION (if required):

See Original OTP for Signatures

This Sheet Included for Reference Only.
DISPOSITION ACTIONS COMPLETE:

See Original OTP for Signature

This Sheet Included for Reference Only.

TEST DIRECTOR DATE

RETEST COMPLETE:

See Original OTP for Signatures

This Sheet Included for Reference only.

TEST OIRECTOR DATE 


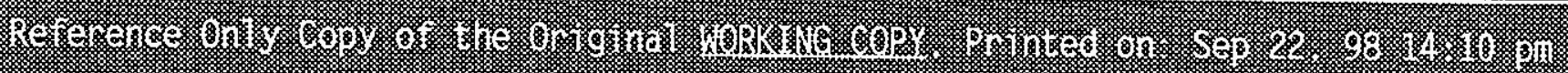

HNF-3473

TEST EXCEPTION REPORT

REV. 0, Page 70

TEST PROCEOURE NO. \& SECTION:

OTP-W030-001, Revision B-5, Various

sections as noted

TEST NAME: W030 Operational Test

Procedure Integrated System Test

TE-006

Page 1 of 3

DESCRIPTION OF PROBLEM: Certain parameters gave data readings outside acceptance criteria (AC) allowed in various data tables.

See attached list of occurences.

TEST ENGINEER:

See Original OTP for Signatures.

This Sheet Included for Reference Only.

ORG:

DATE:
IMPACT ON TESTING: $\square$ HOLD FOR RESOLUTION $x$ CONTINUE

See Original OTP for Signatures.

This Sheet Included for Reference Only.

PIC DATE

OISPOSITION (Completed by Test Engineer):

Acceptable. AC is inappropriate (too stringent) for the these tests as system performance for certain parameters was not fully developed and understood. Items 1-3 of attached list involve the K4 Condenser and/or fan as noted.

For item 4 in the list, the system had not stabilized when data was recorded. Item 5 relates to a procedural error. No re-test is required. See attached list of occurrences.

DISPOSITION AND RETEST REQUIREMENTS BY:

See Original OTP for Signatures.

This Sheet Included for Reference Only.

TEST ENGINEER DATE

QAE CONCURRENCE WITH DISPOSITION (if required):

See Original OTP for Signatures.

This Sheet Included for Reference Only.

QA ENGINEER

DATE
DISPOSITION ACTIONS COMPLETE:

See Original OTP for Signatures.

This Sheet Included for Reference Oniy.

TEST DIRECTOR DATE

RETEST COMPLETE:

See Original OTP for Signatures.

This Sheet Included for Reference Onily.

TEST DIRECTOR

DATE 
HNF-3473

REV. 0, Page 71

\begin{tabular}{|c|c|c|c|c|c|c|c|c|c|c|c|c|}
\hline 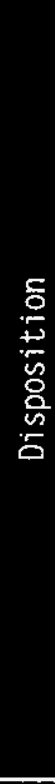 & 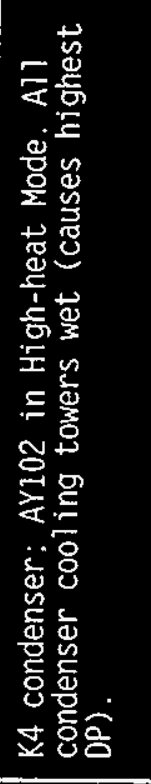 & 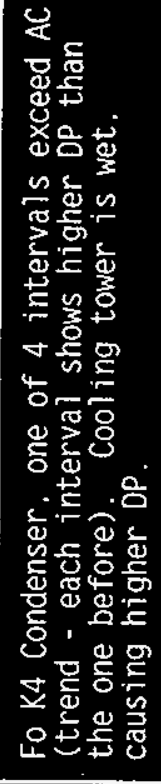 & 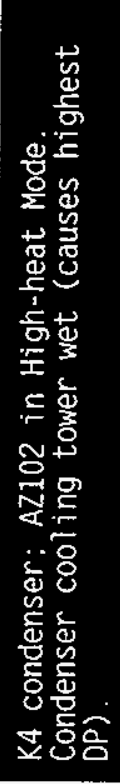 & 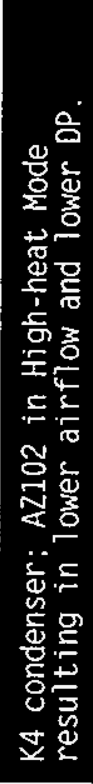 & 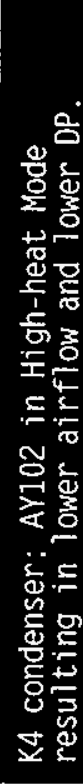 & 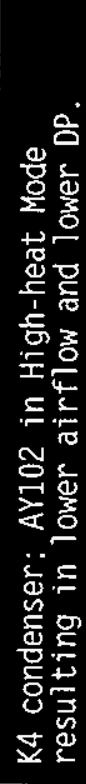 & 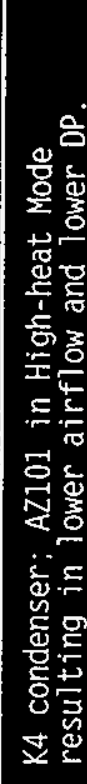 & 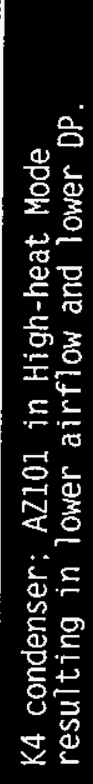 & 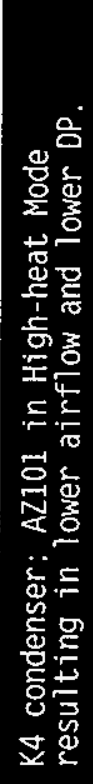 & 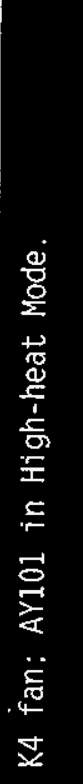 & $\begin{array}{l}\text { D્ } \\
\text { 总 }\end{array}$ & 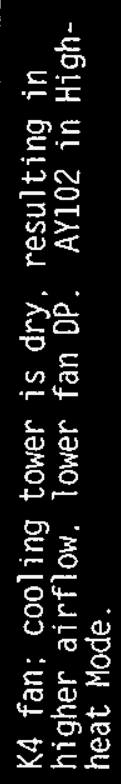 \\
\hline$\frac{9}{\stackrel{9}{5}}$ & $\begin{array}{l}\text { nलm } \\
\text { ํㅟำ }\end{array}$ & $\stackrel{\nabla}{\sim}$ & 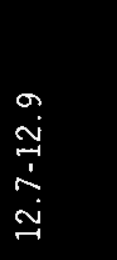 & $\overrightarrow{6}^{-1}$ & $\begin{array}{l}\text { م) } \\
\dot{4} \\
\dot{8} \\
0\end{array}$ & م" & $\stackrel{\vec{r}}{\vec{r}}$ & $\begin{array}{l}\infty \\
\dot{j} \\
\dot{1} \\
\dot{\infty} \\
\dot{m}\end{array}$ & $\begin{array}{l}m \\
\stackrel{1}{1} \\
\dot{1}\end{array}$ & $\begin{array}{l}\infty \\
\dot{n}\end{array}$ & $\begin{array}{l}\dot{0} \\
\stackrel{9}{\sigma}\end{array}$ & 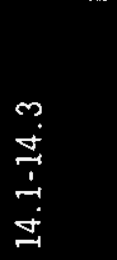 \\
\hline $\begin{array}{l}\overrightarrow{0} \\
\stackrel{0}{0} \\
\stackrel{\sim}{\sim}\end{array}$ & $\Sigma$ & $\underline{\Sigma}$ & 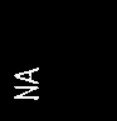 & 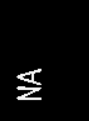 & $\geqq$ & 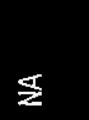 & 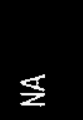 & $\$$ & $\Sigma$ & $\$$ & $\$$ & $\$$ \\
\hline $\mathbb{Z}$ & 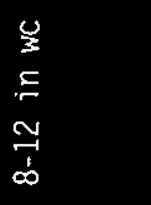 & $\begin{array}{l}\cong \\
\Xi \\
\cong \\
\dddot{\Xi}\end{array}$ & 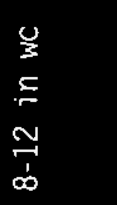 & 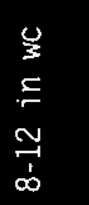 & 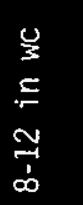 & 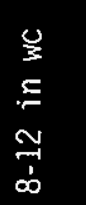 & 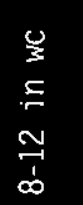 & 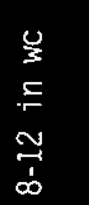 & 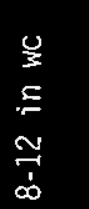 & 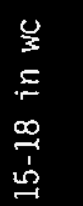 & 密 & 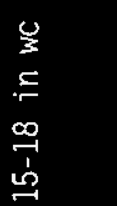 \\
\hline 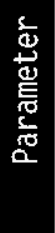 & 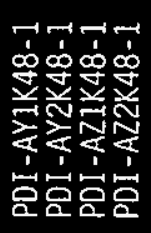 & 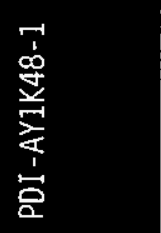 & 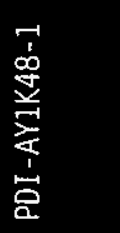 & 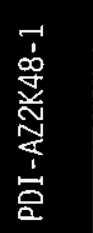 & 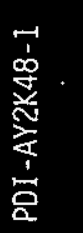 & 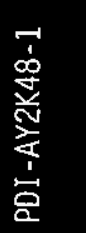 & 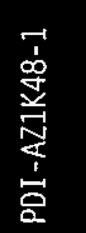 & 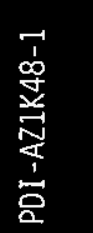 & 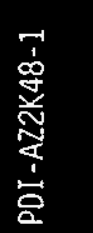 & 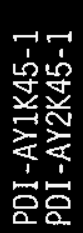 & 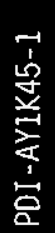 & 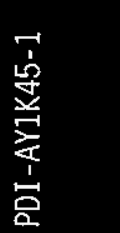 \\
\hline 凹 & $\rightarrow$ & - & $\neg$ & $\rightarrow$ & $\sim$ & $\sim$ & $\sim$ & $\sim$ & $\sim$ & $\infty$ & m & $m$ \\
\hline 횽 & 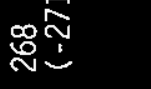 & ஜ̊ & ભ్లి & মे & 옹 & ర్ల & के & ల్ల & ల్లి & స్ల్ల్ & 怘 & $\begin{array}{l}\mathscr{\infty} \\
\stackrel{\sim}{\sim}\end{array}$ \\
\hline$\stackrel{\Phi}{\infty}$ & ষ & 욤 & $\ddot{\infty}$ & $\infty$ & 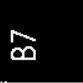 & $\infty$ & 8 & $\infty$ & $\vec{\infty}$ & 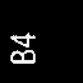 & চ্口 & $\infty$ \\
\hline
\end{tabular}




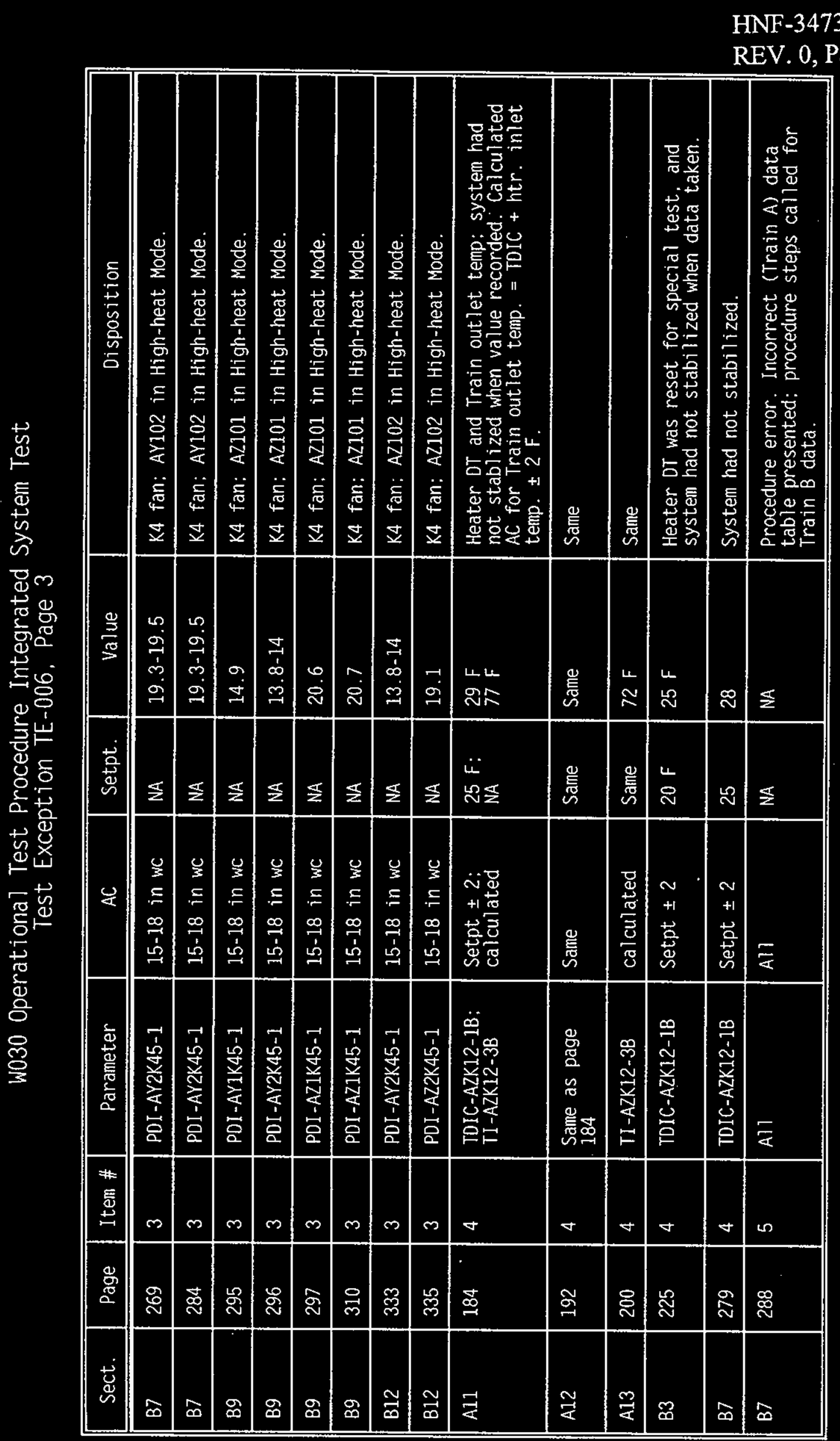




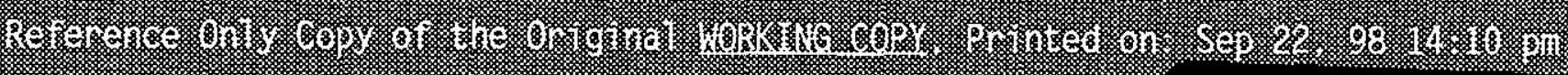

HNF-3473

TEST EXCEPTION REPORT

REV. 0, Page 73

TEST PROCEDURE NO. \& SECTION:

OTP-W030-001, Revision B-5, Various

sections as noted

\begin{tabular}{l|l} 
TEST NAME: & W030 Operational Test \\
Procedure Integrated System Test & T.E. NUMBER: \\
& TE-007 \\
& Page 1 of 2
\end{tabular}

DESCRIPTION OF PROBLEM:

Data for Primary Vent Inlet manifold vacuum below setpoint acceptance limit in several test sections. See attached list of occurences.

TEST ENGINEER:

See Original oTp for Signatures.

This Sheet Included for Reference Only.

ORG: $\quad$ DATE:

DISPOSITION (Completed by Test Engineer):

Acceptable. AC is inappropriate (too stringent) for the these tests as system performance for certain parameters was not fully developed and understood. In most of these instances, this parameter (which controls fan speed) is set greater than the fan can achieve under the required conditions, in order to force the fan to peak performance. In other cases. the table was in error. Manifold vacuum is negatively impacted by the effect of operating the exhaust fan in series with the $K 4$ fans (which tend to pressurize the manifold). Insufficient experience had been obtained with these operating modes to predict this phenomena.

See attached list of occurrences.

DISPOSITION AND RETEST REQUIREMENTS BY:

See Original OTP for Signatures.

This Sheet Included for Reference Only.

TEST ENGINEER DATE

QAE CONCURRENCE WITH DISPOSITION (if required):

See Original OTP for Signatures.

This Sheet Included for Reference Only.

QA ENGINEER

DATE
IMPACT ON TESTING: $\square$ HOLO FOR RESOLUTION $X$ CONTINUE

See Original OTP for Signatures.

This Sheet Included for Reference Only.

PIC DATE

QA EIGIMEER

DISPOSITION ACTIONS COMPLETE:

See Original OTP for Signatures.

This Sheet Included for Reference Only.

TEST DIRECTOR DATE

RETEST COMPLETE:

See Original OTP for Signatures.

This Sheet Included for Reference Only.

TEST DIRECTOR DATE

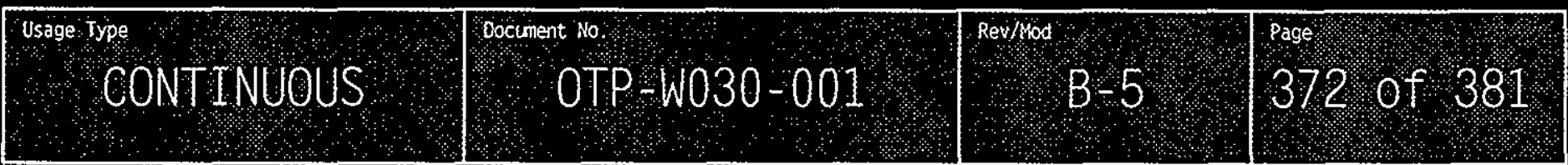


Test Exception

007 . Page 2 of 2

\begin{tabular}{|c|c|c|c|c|c|c|}
\hline Section & Page & Parameter & $A C$ & Setpt. & Value & Disposition \\
\hline A11 & 184 & PI-AZKI-1B & $\begin{array}{l}\text { Setpt } \pm 0.5 \\
\text { in wc vacuum }\end{array}$ & 30 & 20.7 & $\begin{array}{l}\text { Manifold vacuum below setpoint. OK; } \\
\text { parameter set. greater than fan can } \\
\text { achieve. to force fan to peak. }\end{array}$ \\
\hline $\mathrm{A} 12$ & 192 & $\begin{array}{l}\text { PI-AZK1-1B, } \\
\text { PI-AZKI-1A }\end{array}$ & Same & $\begin{array}{l}30 \\
25 \\
\end{array}$ & $\begin{array}{l}20.7 \\
20.8\end{array}$ & $\begin{array}{l}\text { Same; these } 2 \text { devices measure same } \\
\text { parameter. }\end{array}$ \\
\hline $\mathrm{A} 13$ & 200 & PI-AZK1-1A & Same & 30 & 20.8 & $\begin{array}{l}\text { Manifold vacuum below setpoint. OK; } \\
\text { parameter set greater than fan can } \\
\text { achieve. to force fan to peak. }\end{array}$ \\
\hline B3 & 227 & PI-AZK1-1B & Same & 30 & $17.4-20.5$ & $\begin{array}{l}\text { Same. However, this data sheet (Train B) } \\
\text { is redundant (to Train A) and need not } \\
\text { have been completed. }\end{array}$ \\
\hline B4 & 242 & PI-AZKI-1A & Same & 21 & 20 & $\begin{array}{l}\text { Manifold vacuum below setpoint. OK: } \\
\text { parameter set greater than fan can } \\
\text { achieve. to force fan to peak. }\end{array}$ \\
\hline B4 & 250 & PI-AZK1-1A & Same & 21 & 19.9 & Same. \\
\hline B6 & 262 & $\begin{array}{l}\text { PI-AZK1-1A. } \\
\text { PI-AZK1-1B }\end{array}$ & Same & 21 & $\begin{array}{l}20.1 \\
19.3\end{array}$ & Same \\
\hline B7 & 288 & PI-AZK1-1A & Same & 21 & 20.4 & Same (marginal TE) \\
\hline B9 & 295 & FI-AY1K1-2 & $\begin{array}{l}\text { Setpt } \pm 20 \\
\text { scfm }\end{array}$ & 200 & $173-179$ & $\begin{array}{l}\text { Tank AY1 exhaust flow low when AZ1 in } \\
\text { Hi-Heat. Condition is unexpected but } \\
\text { acceptable. Setpoint is arbitrary. }\end{array}$ \\
\hline B9 & 306 & PI-AZK1-1B & $\begin{array}{l}\text { Setpt } \pm 0.5 \text { in } \\
\text { wc vacuum }\end{array}$ & 21 & $19.4-19.6$ & $\begin{array}{l}\text { Manifold vacuum below setpoint. OK: } \\
\text { parameter set greater than fan can } \\
\text { achieve. to force fan to peak. }\end{array}$ \\
\hline B9 & 314 & PI-AZK1-1B & Same & 21 & $19.3-19.5$ & Same \\
\hline B11 & 326 & $\begin{array}{l}\text { PI-AZK1-1B. } \\
\text { PI-AZK1-1A }\end{array}$ & Same & 21 & $\begin{array}{l}19 \\
19.4\end{array}$ & Same \\
\hline $\mathrm{B} 12$ & 332 & FI-AY1K1-2 & $\begin{array}{l}\text { Setpt } \pm 20 \\
\text { scfm }\end{array}$ & 200 & $163-167$ & $\begin{array}{l}\text { Tank AY1 exhaust flow low when AZ1 in } \\
\text { Hi-Heat Condition is unexpected but } \\
\text { acceptable. Setpoint is arbitrary. }\end{array}$ \\
\hline B12 & 343 & PI-AZK1-1A & $\begin{array}{l}\text { Setpt } \pm 0.5 \text { in } \\
\text { wC vacuum }\end{array}$ & 21 & $19.7-19.9$ & $\begin{array}{l}\text { Manifold vacuum below setpoint. OK: } \\
\text { parameter set greater than fan can } \\
\text { achieve, to force fan to peak. }\end{array}$ \\
\hline B12 & 351 & $P I-A Z K 1-1 A$ & Same & 21 & 19.6 & Same \\
\hline
\end{tabular}




\section{TEST EXCEPTION REPORT}

TEST PROCEDURE NO. \& SECTION:

OrP-W030-001, Revision B-5. Various sections as noted

OESCRIPTION OF PROBLEM:

Tank vacuum more negative than setpoint during High-Heat testing of tank-pressurecontrol process.

Section Page Tank, lowest vacuum achieved (in. wc)

B5 254

B8 292

B10 $\quad 318$

B13 355

TEST ENGINEER:

See Original OTP for Signatures.

This Sheet Included for Reference Only.

ORG:

DATE:

DISPOSITION (Completed by Test Engineer):

In High-Heat Mode at $500 \mathrm{scfm}$, inlet pressure control valve 100\% open, but tank vacuum cannot be reduced below that limited by the inlet station pressure loss (DP) and current level of tank in-leakage. Acceptable, since there is no known need to meet the lower vacuum levels. Test objectives met. No re-test required.

OISPOSITION AND RETEST REQUIREMENTS BY:

See Original OTP for Signatures.

This Sheet Included for Reference Only.

TEST ENGINEER DATE

QAE CONCURRENCE WITH DISPOSITION (if required):

See Original OTP for Signatures.

This Sheet Included for Reference Oniy.

QA ENGINEER

DATE
AY101, 1.3

AY102, 1.2

AZ101, 1.7

AZ102, 2.3
HNF-3473

REV. 0, Page 75

TE-008
IMPACT ON TESTING: $\square$ HOLD FOR RESOLUTION $x$ CONTINUE

See Origina? OTP for Signatures.

This Sheet Included for Reference Only.

PIC DATE

\begin{tabular}{|ll|l} 
QA ENTINEER DIRECTOR & DATE
\end{tabular}

\begin{tabular}{|c|c|c|c|}
\hline Isage type & 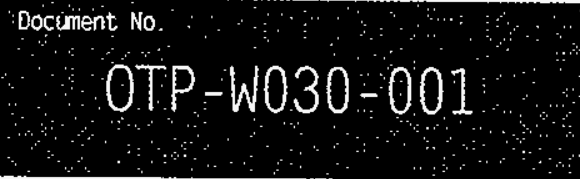 & $\begin{array}{r}\text { Rev/Mod } \\
\mathrm{B}-5\end{array}$ & 372 of 381 \\
\hline
\end{tabular}




\section{TEST EXCEPTION REPORT}

TEST PROCEOURE NO. \& SECTION

0TP-W030-001. Revision B-5, Various sections as noted
TEST NAME: W030 Operational Test Procedure Integrated System Test
HNF-3473

REV. 0, Page 76

DESCRIPTION OF PROBLEM:

Tank exhaust flow for TANKS AY101. AZ102 (FI-AY1K1-2, FI-AZ1K1-2) below setpoint during High-Heat tests, with $\mathrm{Kl}-2$ flow control valve $100 \%$ open. $A C=$ setpoint \pm 20 scfm.

$\begin{array}{lllll}\text { Section } & \text { Page } & \text { Tank } & \text { Setpoint } & \text { Value } \\ \text { B9 } & 298 & \text { AZ102 } & 110 & 80-83 \\ \text { B11 } & 321 & \text { AY101 } & 200 & 180 \\ \text { B11 } & 324 & \text { AZ102 } & 110 & 79-85\end{array}$

TEST ENGINEER:

See Original OTP for Signatures.

This Sheet Included for Reference Only.

ORG:

DATE:
IMPACT ON TESTING: $\square$ HOLD FOR RESOLUTION X CONTINUE

See Original OTP for Signatures.

This Sheet Included for Reference only.

PIC DATE

DISPOSITION (Completed by Test Engineer):

Accept. Similar to TE-007. Setpoints are arbitrary.

OISPOSITION AND RETEST REQUIREMENTS BY:

See Original OTP for Signatures.

This Sheet Included for Reference Only.

TEST ENGINEER

DATE

QAE CONCURRENCE WITH DISPOSITION (if required):

See Original OTP for Signatures.

This Sheet Included for Reference Only.

QA ENGINEER DATE
DISPOSITION ACTIONS COMPLETE:

See Original OTP for Signatures.

This Sheet Included for Reference Only.

TEST DIRECTOR

DATE

RETEST COMPLETE:

See Original OTP for Signatures.

This Sheet Included for Reference Only.

TEST DIRECTOR

DATE 


\section{TEST EXCEPTION REPORT}

\begin{tabular}{l|l|l|l}
$\begin{array}{l}\text { TEST PROCEOURE N0. \& SECTION: } \\
\text { OTP-W030-001. Revision 8-5. Various } \\
\text { sections as noted }\end{array}$ & $\begin{array}{l}\text { TEST NAME: W030 Operationa] Test } \\
\text { Procedure Integrated System Test }\end{array}$ & T.E. NUMBER: \\
TE-010
\end{tabular}

DESCRIPTION OF PROBLEM:

Tank exhaust flow for TANKS AY101. AY102 (FI-AY1K1-2, FI-AY1K1-2) below setpoint during High-Heat tests, with $\mathrm{Kl}-2$ flow control valve $100 \%$ open. $\mathrm{AC}=$ setpoint \pm 20 scfm.

$\begin{array}{lllll}\text { Section } & \text { Page } & \text { Tank } & \text { Setpoint } & \text { Value } \\ \text { A13 } & 197 & \text { AY101, 102 } & 400 & 335,360 \\ \text { B9 } & 295 & \text { AY101 } & 200 & 173-179 \\ \text { B12 } & 332 & \text { AY101 } & 200 & 163-169\end{array}$

TEST ENGINEER:

See Original OTP for Signatures.

This Sheet Included for Reference Only.

ORG:

$$
\text { DATE: }
$$

IMPACT ON TESTING: $\square$ HOLO FOR RESOLUTION $x$ CONTINUE

See Original OTP for Signatures.

This Sheet Included for Reference Only.

OISPOSITION (Completed by Test Engineer):

Accept. Similar to TE-007 and -009. Setpoints are arbitrary.

DISPOSITION AND RETEST REQUIREMENTS BY:

See Original OTP for Signatures.

This Sheet Included for Reference Only.

TEST ENGINEER DATE

QAE CONCURRENCE WITH OISPOSITION (if required):

See Original OTP for Signatures.

This Sheet Included for Reference Only.

QA ENGINEER

DATE
DISPOSITION ACTIONS COMPLETE:

See Original OTP for Signatures.

This Sheet Included for Reference Only.

TEST DIRECTOR DATE

RETEST COMPLETE:

See Original OTP for Signatures.

This Sheet Included for Reference Oniy.

TEST DIRECTOR

DATE
Rev/lHod

$B-5$
Page 372 of 381 


\section{ATTACHMENT 2}

\section{TEST DATA}

Note: This attachment includes actual OTP copy with test instructions and annotated field data only; for administrative sections, prerequisites, setup steps, signatures, etc, see the Phase1 test report, reference 4. 


\section{TABLE OF CONTENTS}

\subsection{PURPOSE}

2.0 INFORMATION

\subsection{SCOPE}

2.2 TERMS AND DEFINITIONS

2.3 RESPONSIBILITIES

2.4 REFERENCES

2.5 SAFETY

2.6

2.7

2.8

RADIATION AND CONTAMINA

2.9

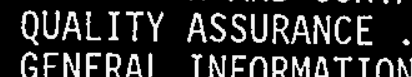

3.0 RECORDS

LIMITS AND PRECAUTIONS

4.0 PREREQUISITES

5.0 PROCEDURE

ATTACHMENT A - BYPASS MODE OPERATIONAL TESTING

1.0 INFORMATION.

2.0 INITIAL CONDITIONS

3.0 VENT TRAIN A - STEADY STATE OPERATION

4.0 VENT TRAIN A - CHANGE SETPOINTS

5.0 TANK EXHAUST FLOW- CHANGE SETPOINTS

6.0 TANK PRESSURE - CHANGE SETPOINTS

7.0 PRIMARY VENT FAN SWITCHOVER

8.0 PRIMARY FAN AND SILTER TRAR . . . . . . . . 144

9.0 VENT TRAIN B - STEADY STATEN SWITCHOVER (A to B) ...... 151

10.0 VENT TRAIN B - CHANGE SETPOITERATION ........... 160

11.0 VENT TRAIN B - MAXIMUM FLOH RATE.$\cdots 172$

12.0 PRIMARY FAN AND FILTER TRAIN SWITCHOVER ${ }^{\circ} \cdot 0^{\circ} \cdot 180$

13.0 VENT TRAIN A - MAXIMUM FLOW RATE

ATTACHMENT B - RECIRC AND HIGH HEAT MODE OPERATIONAL TESTING ..... 201

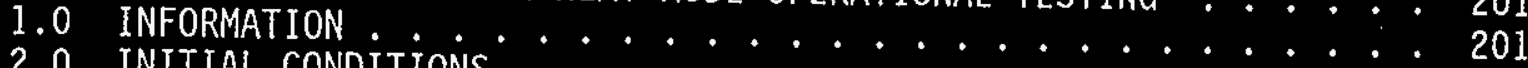

2.0 INITIAL CONDITIONS 3.0 . . . . . . . . . 203

3.0 RECIRC MODE - STEADY STATE OPERATION $\therefore 205$

4.0 AY10I HIGH HEAT - STEADY STATE OPERATION $\vdots \cdots \cdots . . \cdots 229$

5.0 AY101 HIGH HEAT - TANK PRESSURE CONTROL $\therefore . \cdots 252$

6.0 AY101 HIGH HEAT - FAN AND FILTER TRAIN SWITCHOVER $\left(A^{*} \text { to B }\right)^{*}:{ }^{*} 255$

7.0 AY102 HIGH HEAT - STEADY STATE OPERATION ........ 266

8.0 AY102 HIGH HEAT - TANK PRESSURE CONTROL ......... 290

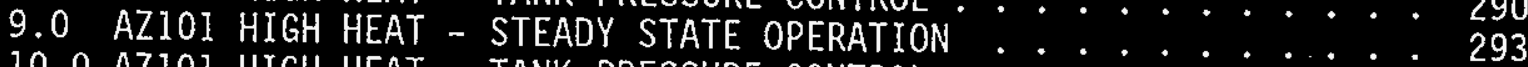

10.0 AZ101 HIGH HEAT - TANK PRESSURE CONTROL ..... 316

11.0 AZ101 HIGH HEAT - FAN AND FILTER TRAIN SWITCHOVER (B to $\dot{A}) \cdot \cdot \cdot 319$

12.0 AZ102 HIGH HEAT - STEADY STATE OPERATION ........ 330

13.0 AZ102 HIGH HEAT - TANK PRESSURE CONTROL.......... 353

14.0 SECURE FROM TESTING .............. 356 


\section{ATTACHMENT A - BYPASS MODE OPERATIONAL TESTING (Cont.)}

\subsection{VENT TRAIN B - MAXIMUM FLOW RATE}

\section{CAUTION}

This section cannot be performed prior to lifting of the 1 imitations cited in the Project $W-030$ NOC limiting the maximum flow rate of the exhauster to $800 \mathrm{scfm}$.

11.1 ENSURE Exhaust Fan $A Z-K 1-5-1 B$ and Filter Train $B$ are in service.

11.2 ENSURE that the recirculation ventilation systens for tanks AY101, AY102, AZ101, and AZ102 are in the BYPASS Or TLCXRE mode of operation.

11.3 ENSURE the primary vent manifold pressure setpoints PIC-AZK1-1A and PIC-AZK1-

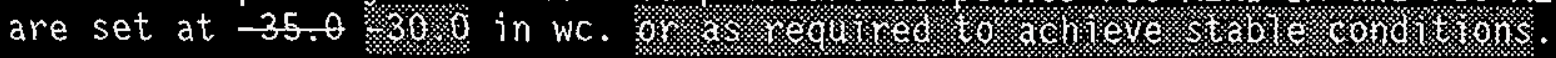

\section{CAUTION}

In the following steps, DO NOT exceed an indicated stack flow rate of 10001050 scfm.

11.4 ADJUST the tank exhaust flow rates for tanks AY101 and AY102 to approximately 150 sefm- 湔o

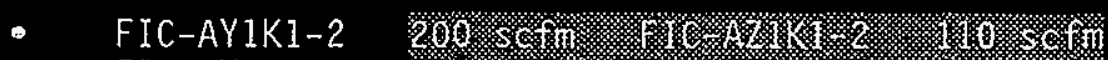

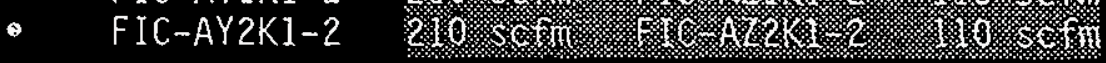

11.5 INCREASE tank exhaust flow control setpoints for tanks A $Z 101$ and AY $\geq 102$ to approximate $7 \mathrm{y}-350$ sefm fromeacf tank 1050 s. . m

- FIC-A $\quad$ ZIKIKI-2

- $\quad F C-A Y Z Z K I-2$

: $:$ G VERIFY stable fan operation (no surging) by observing stack fior rate FI-AZKifor 15 minutes.

i:.7 RECORD data in TABLE $11-1$.

Test Engineer:

Test Engineer:

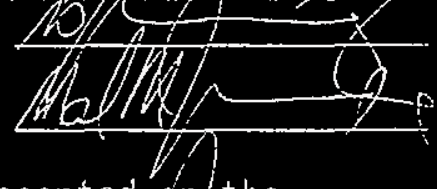

31.8 VERIFY that the data recorded in Table 11-l is the data presented on/the appicicable Mcs graphic screen.

QCHerom Engineer:

11.9 VERIFY that NO unexpected alarms or conditions occurred associated with this section of testing and that the data in TABLE $11-1$ is in the

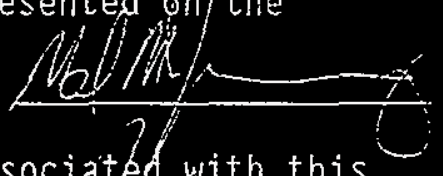

Test Engineer:

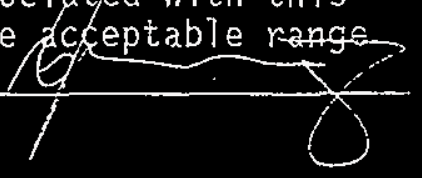




\section{ATTACHMENT A - BYPASS MODE OPERATIONAL TESTING (Cont.)}

TABLE 11-1 Vent Train B Maximum Flow Rate

\begin{tabular}{|c|c|c|c|c|}
\hline MCS PARAMETERS & VENT TRATN B & $\begin{array}{l}\text { ACCEPTANCE } \\
\text { CRITERIA }\end{array}$ & LIMIT & $\begin{array}{l}\text { PASS/ } \\
\text { FAIL }\end{array}$ \\
\hline \multicolumn{5}{|c|}{ MCS Graphic Screen 15PriIn.v } \\
\hline $\begin{array}{l}\text { AY101 iniet Air Flow } \\
\text { FI-AY1K1-1 (15Priln.v) }\end{array}$ & 73 & $\leq$ FIAY $1 \times 1-2$ & N/A & Ress \\
\hline $\begin{array}{l}\text { AY101 Tank Pressure } \\
\text { PI-AYIK1-1 (15Priln.v) }\end{array}$ & $-2,0$ & -0.53 to -3.0 & $\begin{array}{c}-.3>x>-6 \text { in } \\
W C \\
w 030-8 D-001\end{array}$ & Pass 6 \\
\hline $\begin{array}{l}\text { AY101 Exhaust Air Flow SETPOINT } \\
\text { FIC-AY1K1-2 (15PriIn.V) }\end{array}$ & 340 & $N / A$ & $N / A$ & N/A \\
\hline $\begin{array}{l}\text { AY } 101 \text { Exhaust Air Flow } \\
\text { FI-AY1K1-2 (15PriIn.V) }\end{array}$ & 329 & $\begin{array}{c}\text { setpoint } \pm 20 \\
\text { scfm }\end{array}$ & $N / A$ & Pass \\
\hline 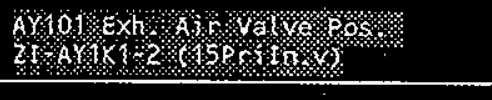 & 100 & row & 的 & Ress \\
\hline $\begin{array}{l}\text { AY102 Intet Air flow } \\
\text { FI-AY2K1-1 (15PriIn.v) }\end{array}$ & 95 & $\leq$ FIAYZK1-2 & $N / A$ & Pass \\
\hline $\begin{array}{l}\text { AY102 Tank Pressure } \\
\text { PI-AY2K1-i (15Priln.v) }\end{array}$ & -1.9 & -0.53 to -3.0 & $\begin{array}{c}-.3>x>-6 \text { in } \\
W C \\
. W 030-R D-001 \\
\end{array}$ & Pass \\
\hline $\begin{array}{l}\text { AY } 102 \text { Exhaust Air flow SETPOINT } \\
\text { FIC-AY2K } 1-2\left(15 P_{r i} \text { In.v) }\right.\end{array}$ & 340 & N/A & $\mathrm{N} / \mathrm{A}$ & A \\
\hline $\begin{array}{l}\text { AY102 Exhaust Air Flow } \\
\text { FI-AYZK1-2 (15Priln.V) }\end{array}$ & 344 & $\underset{\text { scfm }}{\operatorname{setpoint}} \pm 20$ & N/A & Pess \\
\hline 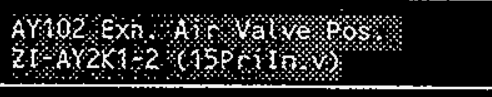 & 92 & 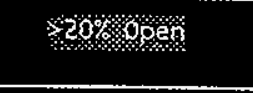 & bre & Pass \\
\hline $\begin{array}{l}\text { AZ101 inlet Air Flow } \\
\text { FI-AZ1Ki-i (15PriIn.V) }\end{array}$ & -150 & $\leq$ FIAZ1K1-2 & $N / A$ & $\begin{array}{ll}2 & 1 \\
\text { ress } & 0\end{array}$ \\
\hline $\begin{array}{l}\text { AZ10! iank Prassure } \\
\text { D:-A?tK1- }(150+i \text { in.v) }\end{array}$ & -1.3 & $\begin{array}{l}-0.33 \text { to }-3.0 \\
\text { in WC }\end{array}$ & $\begin{array}{c}-.3>x>-6 \text { in } \\
\text { HE } \\
\text { W930-20-003 }\end{array}$ & Ess \\
\hline 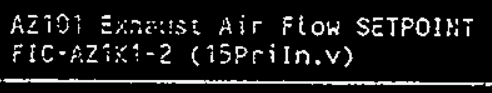 & 110 & $N / \hat{n}$ & $\mathrm{~N} / \mathrm{A}$ & $N / A$ \\
\hline $\begin{array}{l}\text { AZ701 Exnouse Air flon } \\
\text { BI-Az1Ki-Z (15Priln.V) }\end{array}$ & 109 & $\begin{array}{c}\text { setooint }: 20 \\
\text { scffit }\end{array}$ & $N / A$ & rics \\
\hline 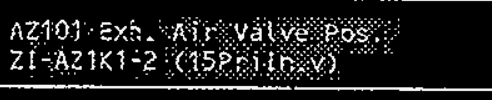 & 19 & $220 \% 0 \%$ & $y$ & icss 6 \\
\hline 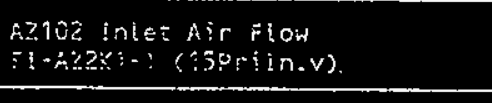 & 0 & $\leq F$ FAZZKK1-2 & $i v / i$ & Pass $-7 / 7$ \\
\hline $\begin{array}{l}\text { A2102 indx Pressure } \\
\text { Pi-kZ2Ki-i (15Pri!n.v) }\end{array}$ & $\div 2,0$ & $\begin{array}{l}0.53 \text { to }-5.0 \\
\text { in wo }\end{array}$ & $\begin{array}{r}-.3>x>-6 \text { in } \\
\text { wic } \\
\text { WO30-RD-001 } \\
\end{array}$ & Tases \\
\hline $\begin{array}{l}\text { AZ102 Exnaust Air flow SETPOINT } \\
\text { FIC-AZ2K:-2(15Priln.v) }\end{array}$ & $1 / 0$ & $N / A$ & N/A & SHA \\
\hline
\end{tabular}

\begin{tabular}{|c|c|c|c|c|}
\hline TONTIVIOS & 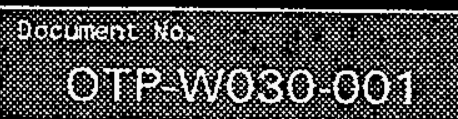 & B-5. & (2) & 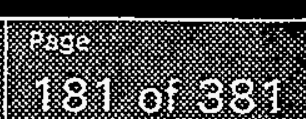 \\
\hline
\end{tabular}


TABLE 11-1 Vent Train B Maximum Flow Rate

\begin{tabular}{|c|c|c|c|c|}
\hline MCS PARAMETERS & VENT TRAIN B & $\begin{array}{l}\text { ACCEPTANCE } \\
\text { CRITERIA }\end{array}$ & LIMIT & $\begin{array}{l}\text { PASS } \\
\text { FAIL }\end{array}$ \\
\hline $\begin{array}{l}\text { AZ102 Exhaust Air flow } \\
\text { FI-AZ2K1-2 (15PriIn-V) }\end{array}$ & 113 & $\underbrace{\text { sctm }}_{\text {setpoint }} \pm 20$ & $\mathrm{~N} / \mathrm{A}$ & Puss b \\
\hline 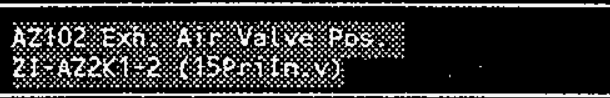 & 22 & 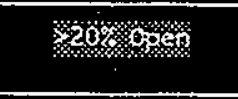 & \% & pesa \\
\hline
\end{tabular}

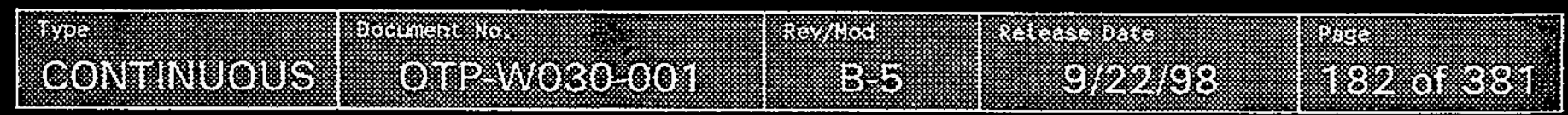




\section{ATTACHMENT A - BYPASS MODE OPERATIONAL TESTING (Cont.)}

TABLE 11-1 Vent Train B Maximum Flow Rate (Continued)

\begin{tabular}{|l|l|l|l|l|}
\hline \multicolumn{1}{|c|}{ MCS PARAMETERS } & VENT TRAIN B & $\begin{array}{c}\text { ACCEPTANCE } \\
\text { CRITERIA }\end{array}$ & LIMIT & PASS/ \\
\hline FAIL
\end{tabular}

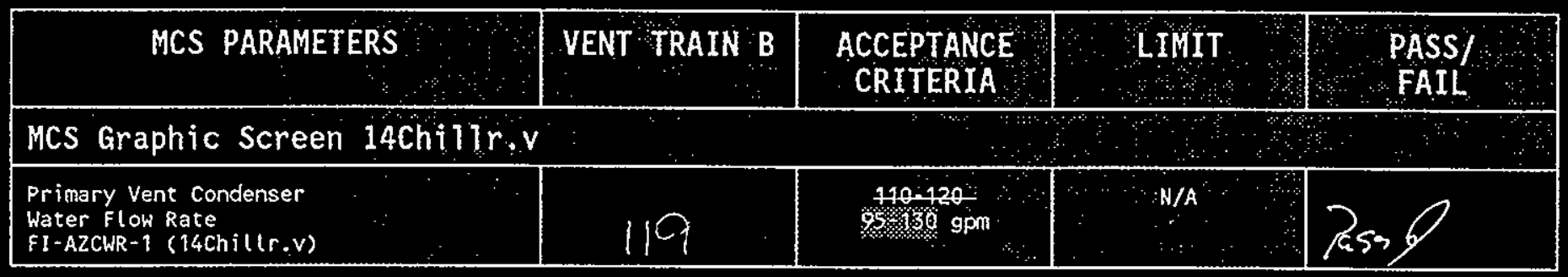

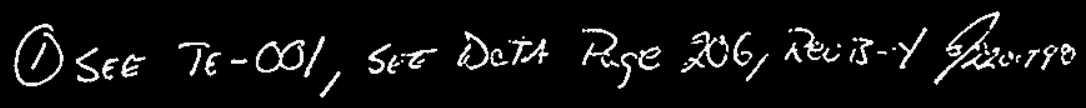

\begin{tabular}{|c|c|c|c|c|}
\hline 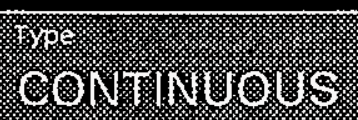 & 1. & $3=\frac{1}{8}$ & (3) & 1.82 or. 8.81 \\
\hline
\end{tabular}




\section{ATTACHMENT A - BYPASS MODE OPERATIONAL TESTING (Cont.)}

TABLE 11-1 Vent Train B Maximum Flow Rate (Continued)

MCS PARAMETERS

\section{VENT TRAIN B}

\section{ACCEPTANCE CRITERIA}

\begin{tabular}{l|l} 
LIMIT & $\begin{array}{c}\text { PASS/ } \\
\text { FAIL }\end{array}$
\end{tabular}

PASS/
FAIL

MCS Graphic Screen 17PriExh.V

Primary Vent Filter Train

Heater Differential Temperature

SETPOINT TDIC-AZK12-18, (17PriEXh.v)

Primary Vent filter Train

Heater Differential Temperature

TDI-AZK12-1B, (17PriEXh.V)

Primary Vent filter Train Differential Pressure, $1^{\text {st }}$ HEPA POI-AZK14-1B (17PriEXh.v)

Primary Vent filter Train

Differential Pressure, HEGA

POI-AZK110-1B (17PriEXh.V)

Primary Vent Filter Train Differential Pressure, $2^{\text {nd }}$ HEPA

PDI-AZK14-28 (17PriExh:V)

Primary Vent Filter Train

Outlet Temperature

TI-AZK12-3B (17PriExh.v)

Primary Vent filter Train

Inlet Pressure SETPOINT

PI-AZK1-18 (17Pr IEXh.V)

Primary Vent Filter Train

Inlet Pressure

PI-AZK1-18 (17PriEXh:V)

Primary Exhaust Fan AZ-K1-5-1B

Motor Current

II-AZK15-18 (17PriExh.V)

Primary Exhaust Fan AZ-K1-5-18

Fan Speed

SI-AZK15-1B (17PriExh.V)

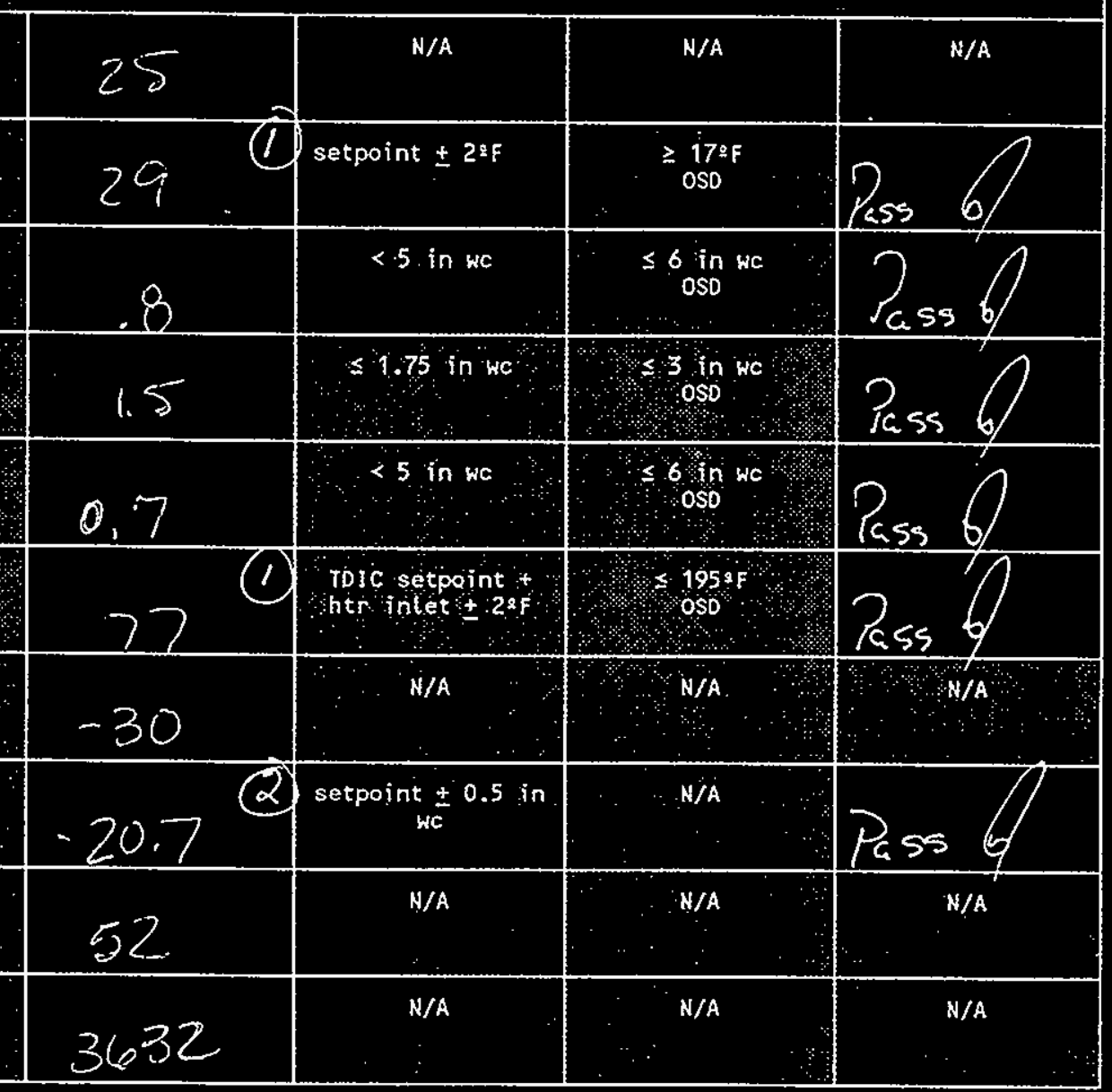

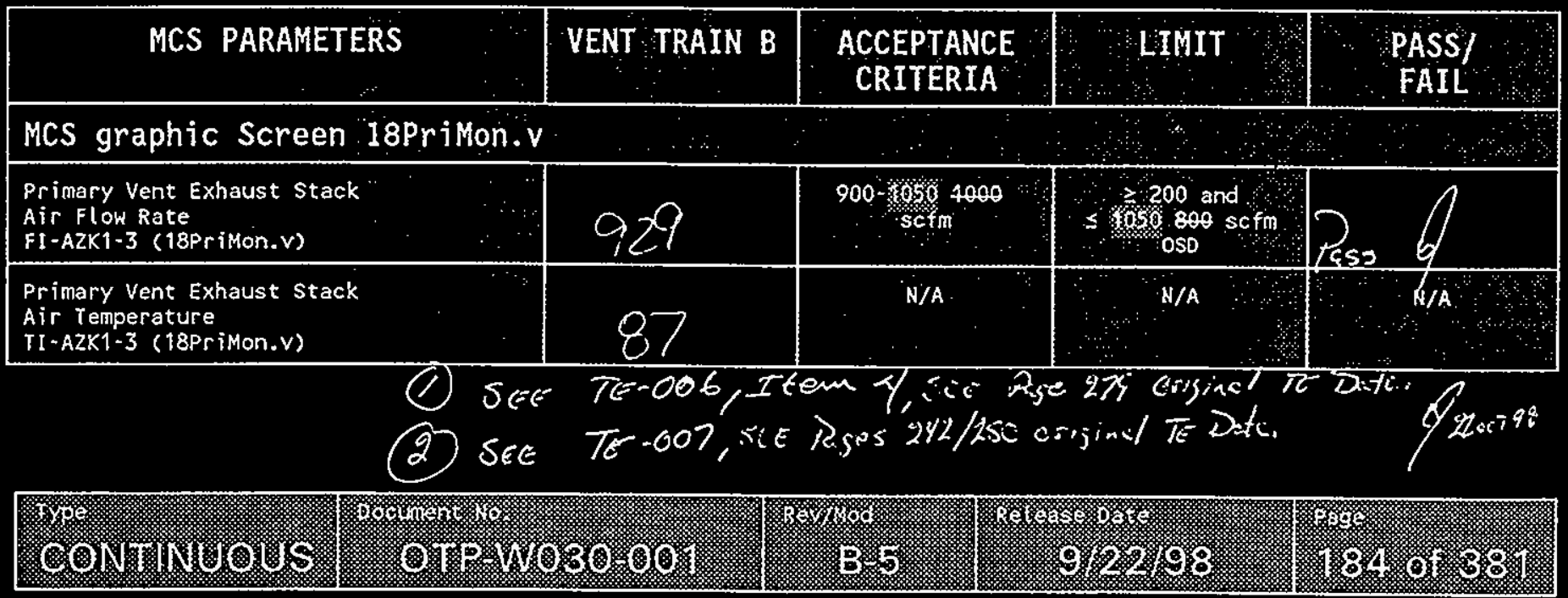




\section{ATTACHMENT A - BYPASS MODE OPERATIONAL TESTING (Cont.)}

\subsection{PRIMARY FAN AND FILTER TRAIN SWITCHOVER (B to $A$ )}

\section{CAUTION}

This section cannot be performed prior to lifting of the limitations cited in the Project $W-030$ NOC I imiting the maximum flow rate of the exhauster to $800 \mathrm{scfm}$.

12.1 ENSURE Exhaust Fan $A Z-K 1-5-1 B$ and $F i l$ ter Train $B$ are in service. BIJUEC

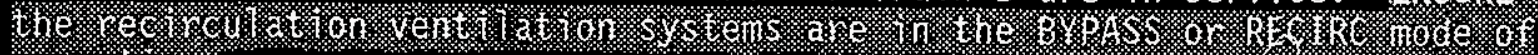
operation.
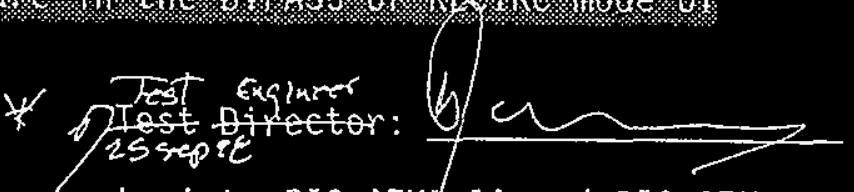

12.2 ENSURE the primary vent manifold pressure setpoints PIC-AZKI-1A and PIC-AZK1-

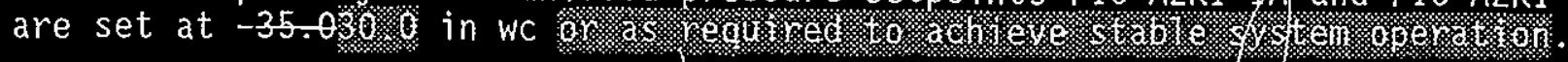

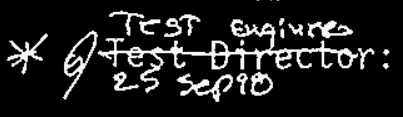

12.3 ENSURE the tank exhaust flow rates for tanks AY101 and AY102 dre set at

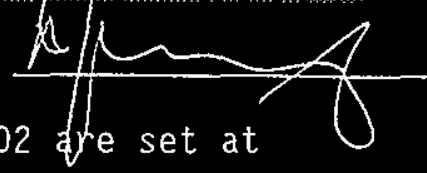
approximately 150 sefm as
- FIC-AYIKI-2
350. $s$ a.
- FIC-AY2K1-2

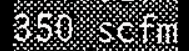

12.4 ENSURE the tank exhaust flow control setpoints for tanks AZ101 and AZ102 are set at approximately 350 -sefm-from-each-tank

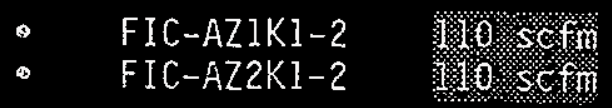

12.5 ENSURE heater temperature differential setpoints TDIC-AZK12-IA and TDIC-AZK12-IS match.

12.5 RECORD Initial Value data in TABLE 12-1.

12.7 SELECT "Fan-1A" on MCS MACRO graphic screen $25 \mathrm{mExhst.v.}$

Test Engineer:

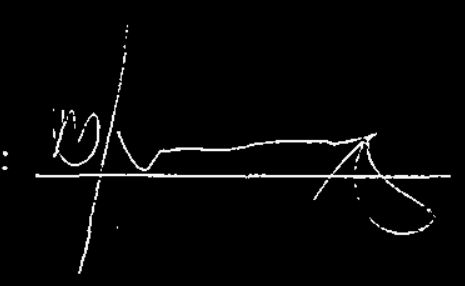

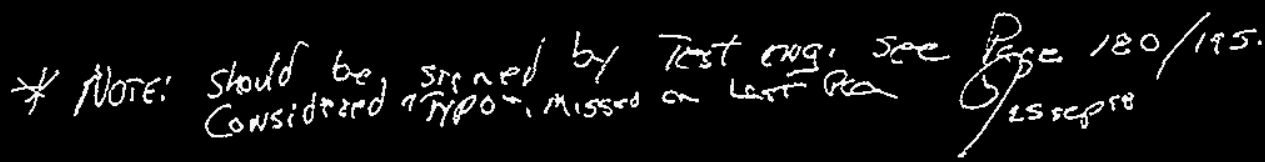

\begin{tabular}{|c|c|c|c|c|}
\hline 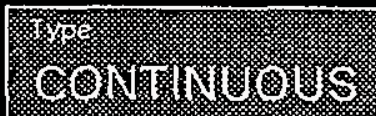 & 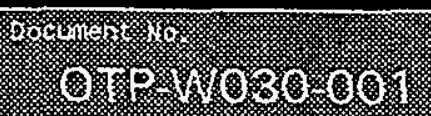 & 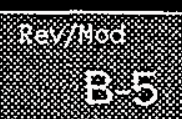 & 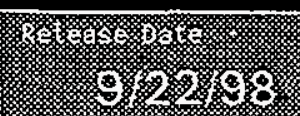 & 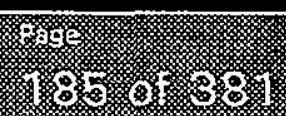 \\
\hline
\end{tabular}




\section{ATTACHMENT A - BYPASS MODE OPERATIONAL TESTING (Cont.)}

12.8 SELECT "Heater-1A" on MCS MACRO graphic screen 25mExhst.v.

12.9 RUN Exhaust MACRO.

12.10 CHECK the following conditions on MCS graphic 17PriExh.v.:

$\begin{array}{lll}\text { Fan-1A: } & \text { ON } \\ \text { Fan-1B: } & \text { STANDBY } \\ \text { Heater-1A: } & \text { ON } \\ & \text { Heater-1B: } & \text { STANDBY }\end{array}$

12.11 CHECK Chiller AND Pump-1A or Pump-1B ON at MCS graphic 14Chillr.v.

NOTE - In the following step, the system is stable when tank exhaust flow rates are within $\pm 20 \mathrm{scfm}$ of the Initial Value, and primary tank pressures ar within \pm 0.2 in wc of the Initial Values. Allow a mimimum of 15 minutes after changing any setpoint before recording data.

12.12 ALLOW the system to stabilize AND RECORD Final Value data in TABLE 12-1.

12.13 VERIFY that no unexpected a7arms or conditions occurred

Test Engineer:

this section of testing and that the data in TABLE 12-1 acceptable range.

Test Engineer:
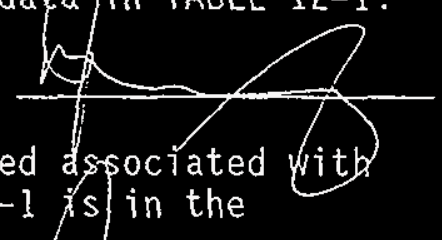

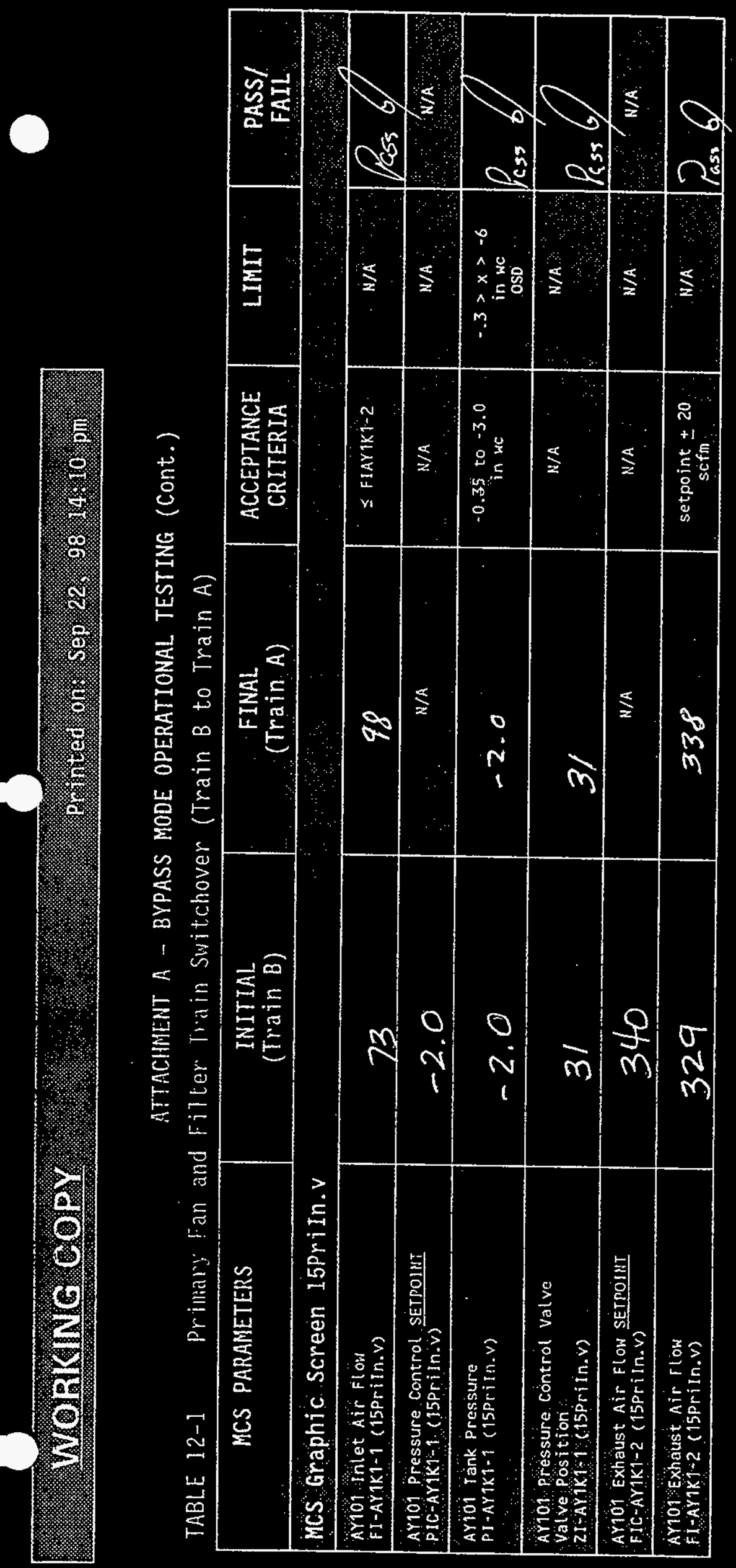

HNF-3473

REV. 0, Page 87

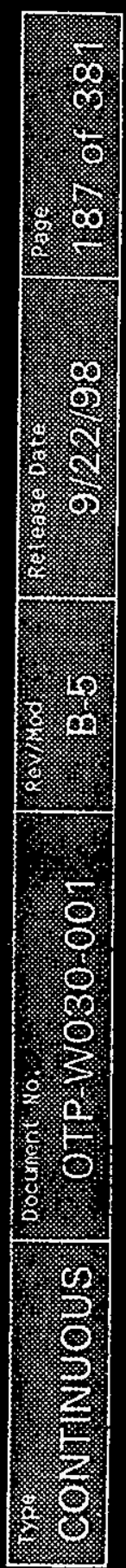


ATTACIMENT A - BYPASS MODE OPERATIONAL TESTING (Cont.)

TABLE 12-1 Primary in and Filler liain switchover (Train B to Train A) (Continued)

\begin{tabular}{|c|c|c|c|c|c|}
\hline MCS PARAMETERS & $\begin{array}{l}\text { INITIAL } \\
\text { (Train B) }\end{array}$ & $\begin{array}{l}\text { FINAL } \\
(\text { Train } A)\end{array}$ & $\begin{array}{l}\text { ACCEPTANCE } \\
\text { CRITERIA }\end{array}$ & LIMIT & $\begin{array}{l}\text { PASS/ } \\
\text { FAIL }\end{array}$ \\
\hline \multicolumn{6}{|c|}{ MCS Graphic Screen 15PriIn.V (Continued) } \\
\hline 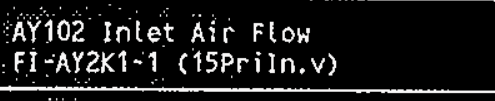 & 95 & 78 & $\leq$ FIAYZK1-2 & $N / A$ & 205 \\
\hline $\begin{array}{l}\text { AY102 pressure control SETPOINT } \\
\text { PIC-AY2K1-1:(15PriIn.V) }\end{array}$ & -2.0 & $\mathrm{~N} / \mathrm{A}$ & $N / A$ & $\mathrm{~N} / \mathrm{A}$ & \\
\hline $\begin{array}{l}\text { AY102 Yank Pressure } \\
\text { PI-AY2K1-1 (15PriIn.v) } \\
\text { PIn }\end{array}$ & -1.9 & -1.9 & -0.35 to -3.0 & $\begin{array}{l}-.3>x>-6 \\
\text { in wC } \\
\text { OSD }\end{array}$ & \\
\hline $\begin{array}{l}\text { Ay } 102 \text { pressure Control Valve } \\
\text { Valve position } \\
21-A Y 2 K 1-1 \text { (15Pri.In.V) }\end{array}$ & 0 & $\theta$ & $N / A$ & $N / A$ & \\
\hline $\begin{array}{l}\text { AY } 102 \text { Exhaust Air Flow SETPOINT } \\
\text { FIC-AYZK1-2 (1SPri In.V) }\end{array}$ & 340 & $N / A$ & $N / A$ & $N / A$ & $\therefore$ \\
\hline $\begin{array}{l}\text { AY } 102 \text { Exhaust Air Flow } \\
\text { FI AY 2K1-2 (15PriIn.V) }\end{array}$ & 344 & 341 & $\begin{array}{c}\text { setpoint } \\
\text { scfm }\end{array}$ & $N / A$ & Rass \\
\hline
\end{tabular}

\begin{tabular}{|c|c|c|c|c|}
\hline 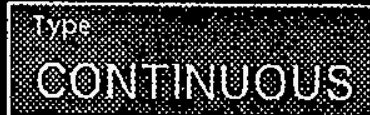 & Oocimient & ( & R. & 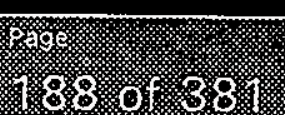 \\
\hline
\end{tabular}


ATTACIMENT A - BYPASS MODE OPERATIONAL TESTING (Cont.)

TABLE 12-1 Primar". Fan and filler lrain Switchover (Train B to Train A) (Continued)

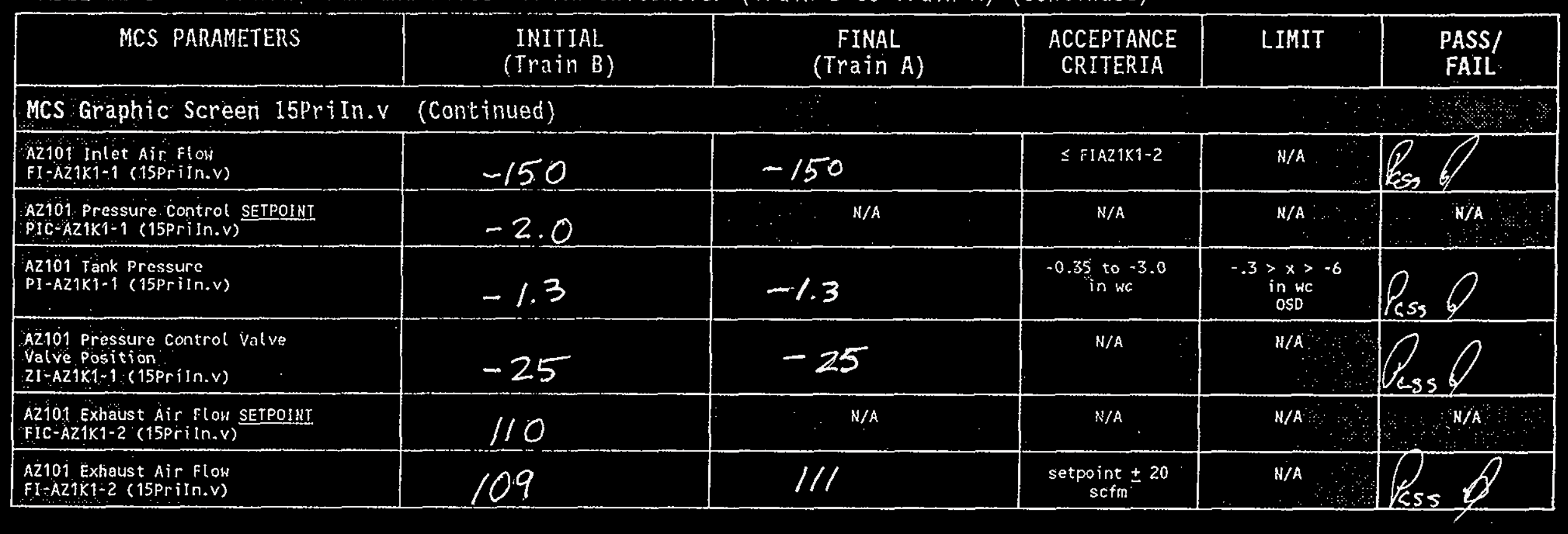

\begin{tabular}{|c|c|c|c|c|}
\hline - & 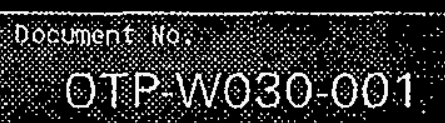 & \%1 & 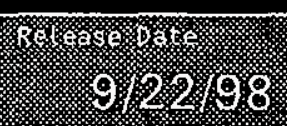 & 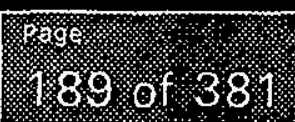 \\
\hline
\end{tabular}


ATTACHMENT A - BYPASS MODE OPERATIONAL TESTING (Cont.)

TABLE 12-1 Primary Fan and Filter lrain Switchover (Train B to Train A) (Continued)

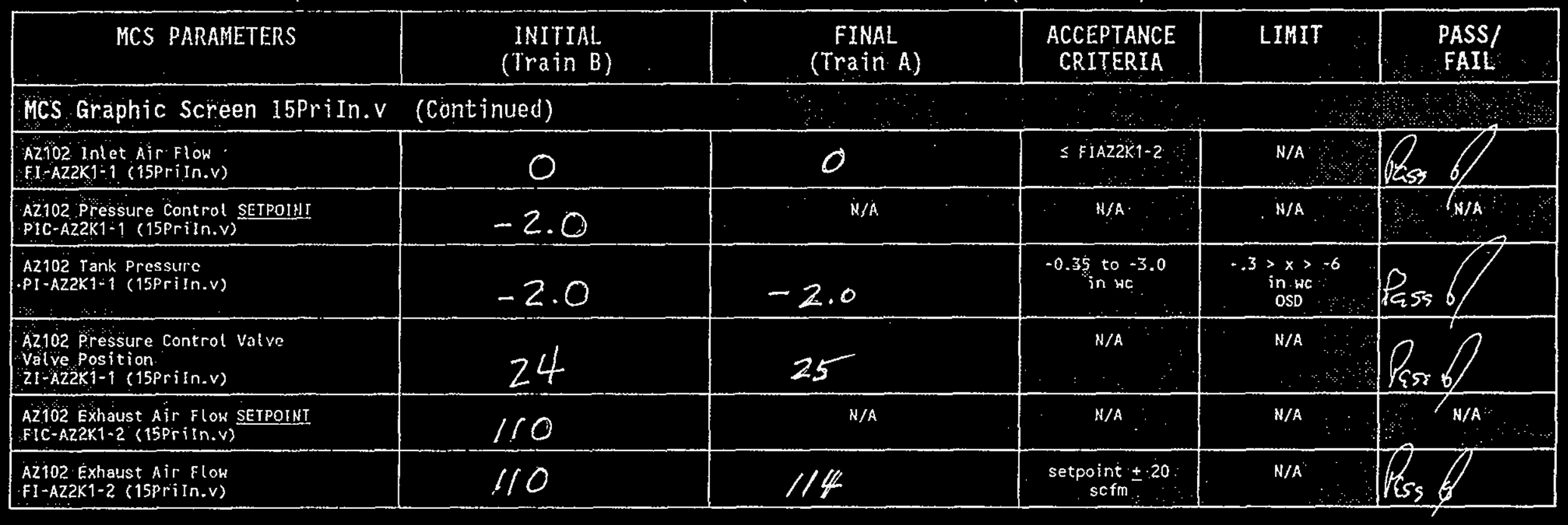

\begin{tabular}{|c|c|c|c|c|}
\hline * & cocompento & 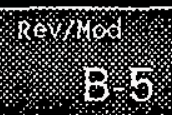 & (3. & $196.01 .58 \%$ \\
\hline
\end{tabular}




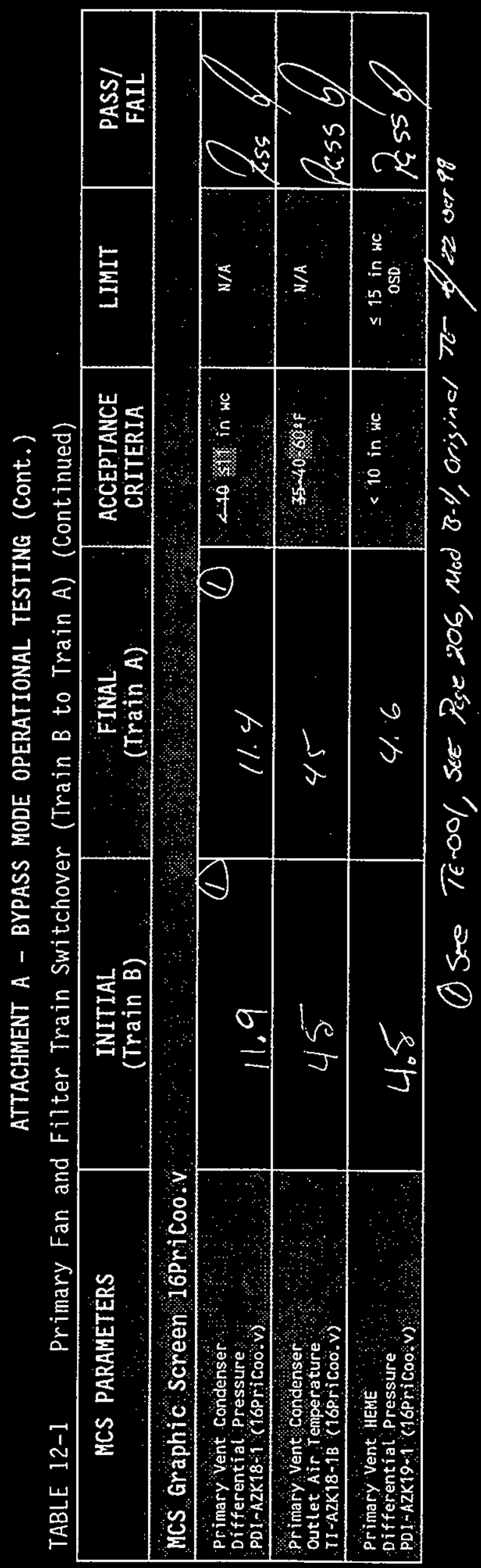

HNF-3473

REV. 0, Page 91

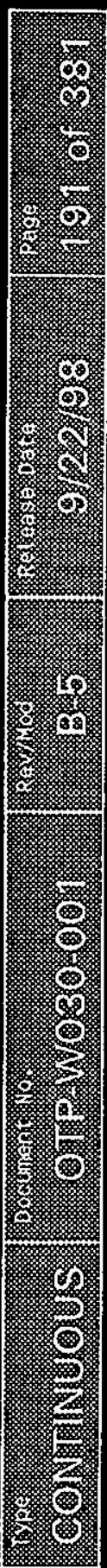


ATTACHMENT A - BYPASS MODE OPERATIONAL TESTING (Cont.)

TABLE 12-1 Primary Fan and Filter Train Switchover (Train B to Train A) (Continued)

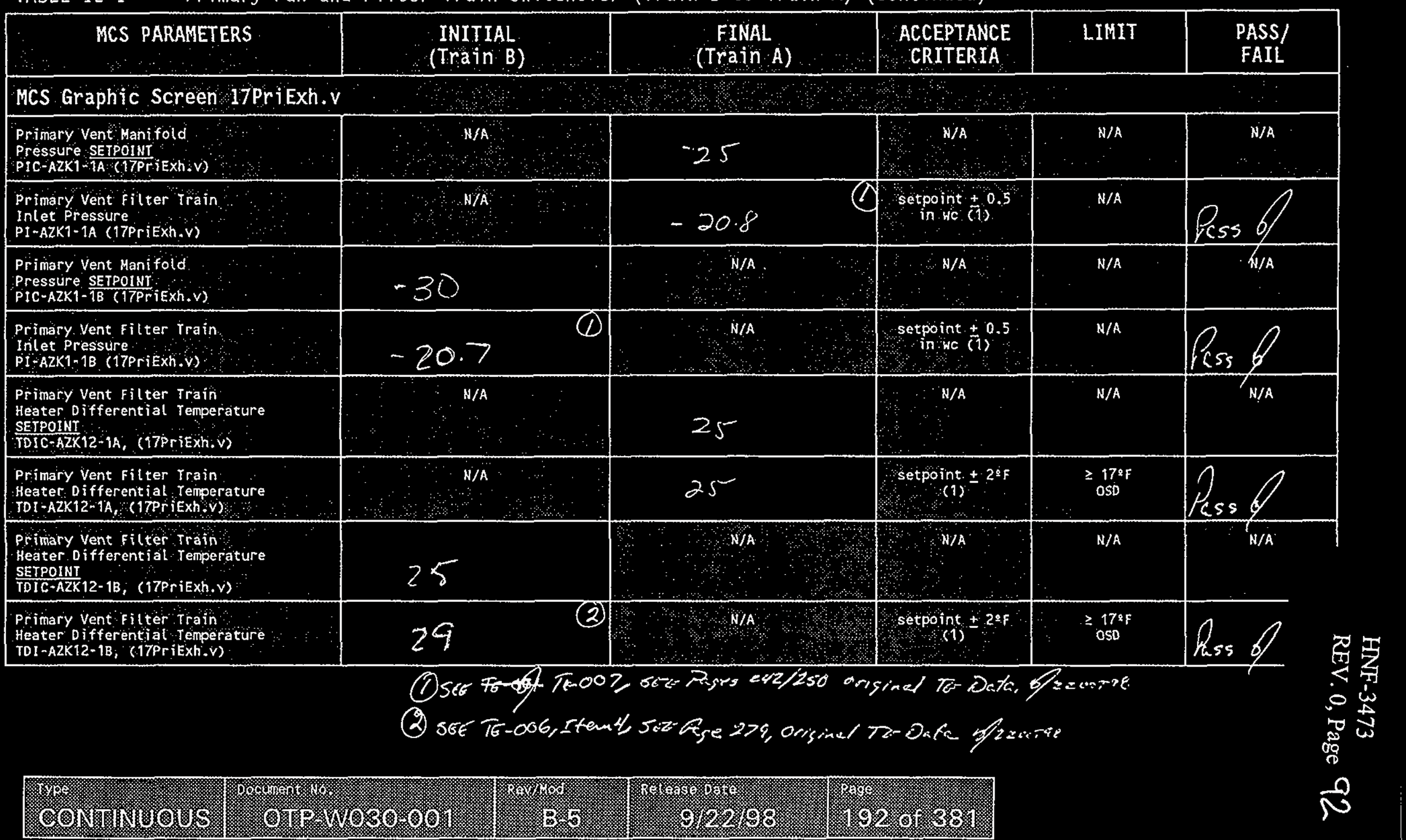




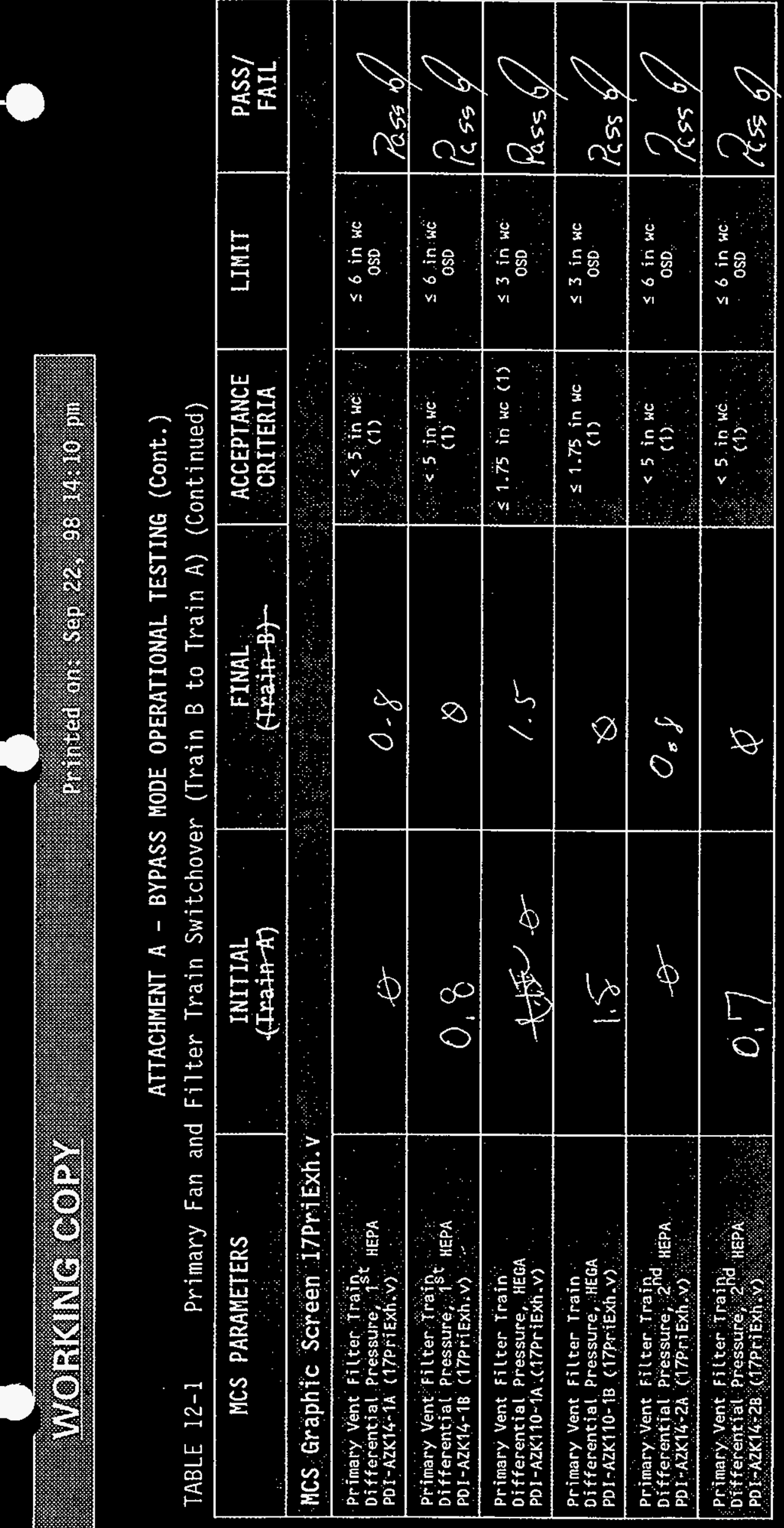

HNF-3473

REV. 0, Page 93

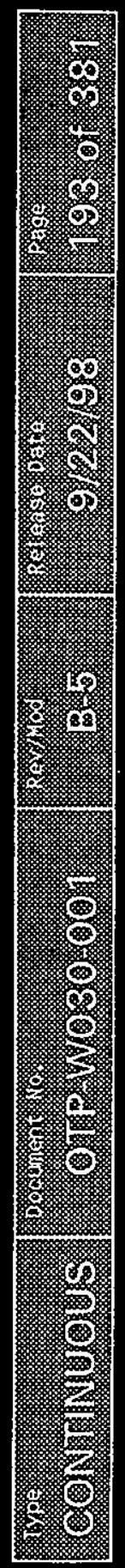


ATTACHMENT A - BYPASS MODE OPERATIONAL TESTING (Cont.)

TABLE 12-1 Primary i an and Filler irain Switchover (Train B to Train A) (Continued)

\begin{tabular}{|c|c|c|c|c|c|}
\hline MCS PARAMETERS & $\begin{array}{l}\text { INITIAL } \\
(\text { Train B) }\end{array}$ & $\begin{array}{l}\text { FINAL } \\
\text { (Train } A)\end{array}$ & $\begin{array}{l}\text { ACCEPTANCE } \\
\text { CRITERIA }\end{array}$ & LIMIT & PASS/ \\
\hline \multicolumn{6}{|c|}{ MCS Graphic Screen 17priExh.V } \\
\hline $\begin{array}{l}\text { Primary Vent Filter Irain } \\
\text { out let Temperature } \\
\text { T1-AZK12-3A (17PriExh-V) }\end{array}$ & 74 & 74 & $\begin{array}{l}\text { Tolc setpoint: } \\
\text { htr inlet } \pm 2 \% \mathrm{~F} \\
\text { (1) }\end{array}$ & $\begin{array}{l}\leq 1952 \mathrm{~F} \\
\text { OSD }\end{array}$ & \\
\hline $\begin{array}{l}\text { Primary vent filter Train } \\
\text { outlet Temperature } \\
\text { TI-AZKi2-3B (17PriEXh.v) }\end{array}$ & & 4 & $\begin{array}{l}\text { roic setpoint }+ \\
\text { htr inlet } \pm 22^{2} \\
\text { (1) }\end{array}$ & $\begin{array}{c}\leq 1952 F \\
\text { OSD }\end{array}$ & $7_{455}$ \\
\hline
\end{tabular}

\begin{tabular}{|c|c|c|c|c|c|}
\hline CS PARAMETERS & $\begin{array}{l}\text { INITIAL } \\
(\text { Train B) }\end{array}$ & $\begin{array}{c}\text { FINAL } \\
\text { (Train A) }\end{array}$ & $\begin{array}{l}\text { ACCEPTANCE } \\
\text { CRITERIA }\end{array}$ & LIMIT & PASS/ \\
\hline \multicolumn{6}{|c|}{ MCS Graphic Screen 18 PriMon.V } \\
\hline $\begin{array}{l}\text { Primary Stack Flow } \\
\text { FI-AZK1-3 (18PriMon.V) }\end{array}$ & 929 & 72 & 900- $\frac{105 i \sin }{\text { sctm }} .1000$ & $\begin{array}{l}\quad 200: \text { and } \\
\leq \quad 800 \text { scfm } \\
\text { OSD }\end{array}$ & $\operatorname{Ress}$ of \\
\hline
\end{tabular}

Note (1) Acceptable range is for the inservice vent train only.

\begin{tabular}{|c|c|c|c|c|}
\hline 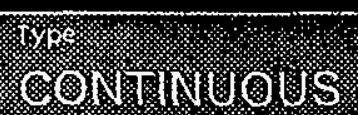 & foocriont & 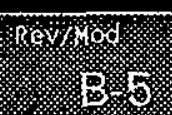 & 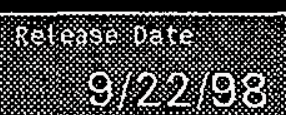 & 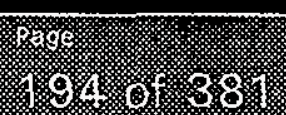 \\
\hline
\end{tabular}




\section{ATTACHMENT A - BYPASS MODE OPERATIONAL TESTING (Cont.)}

\subsection{VENT TRATN A - MAXIMUM FLOW RATE}

\section{CAUTION}

This section cannot be performed prior to lifting of the limitations cited in the Project $\mathrm{W}-030$ NOC 1 imiting the maximum flow rate of the exhauster to $800 \mathrm{scfm}$.

13.1 ENSURE Exhaust Fan AZ-K1-5-1A and Filter Train $A$ are in service.

13.2 ENSURE that the recirculation ventilation systems for tankS AY101, AY102, AZ101, and AZ102 are in the BYPASS 0. SRE. mode of operation.

13.3 ENSURE the primary vent manifold pressure setpoints PIC-AZKI-1A and PIC-AZK1-F3 are set at 35.0 .

\section{CAUTION}

In the following steps, do not exceed an indicated stack flow rate of $10001050 \mathrm{scfm}$.

13.4 ENSURE the tank exhaust flow rates for tanks-AY101-and AY102 to-approximatel

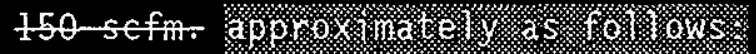

- FIC-AYIK1-2 \%

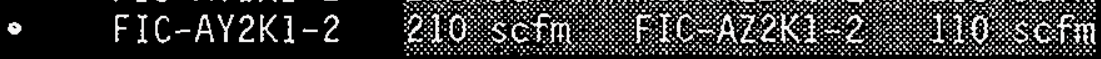

13.5 ENSURE the tank exhaust flow control setpoinis for tanks A $\$ 101$ and $A \otimes Z 102$ to

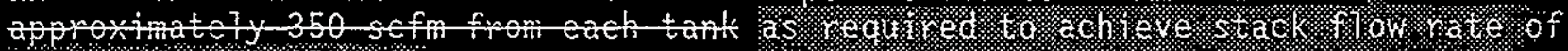
$1050 \%$. $01.1 \%$.

- FIC-AXZZIKI-2

- FIC-AYZZKI-2

13.6 VERIFY stable fan operation (no surging) by observing stack flow prate FI-AZKI for 15 minutes.

13.7 RECORD data in TABLE 13-1.

Test Engineer:

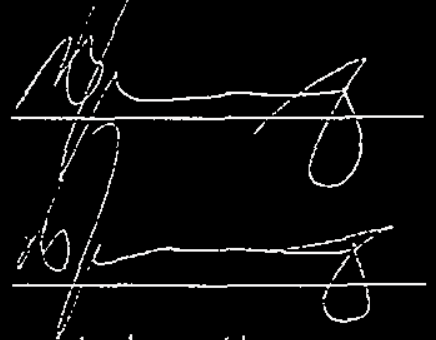

13.8 VERIFY that the data recorded in Table 13-1 is the data presented on the applicable MCS graphic screen.
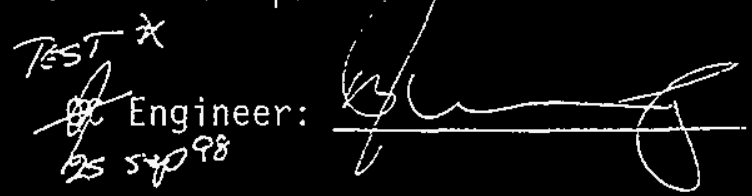

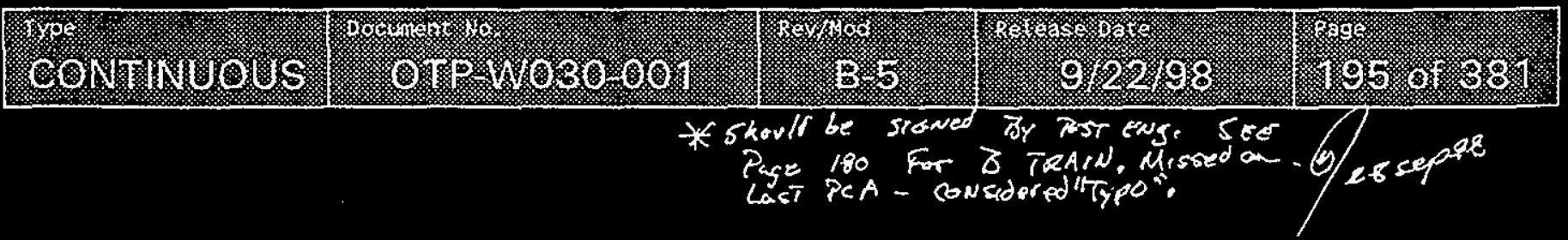




\section{ATTACHMENT A - BYPASS MODE OPERATIONAL TESTING (Cont.)}

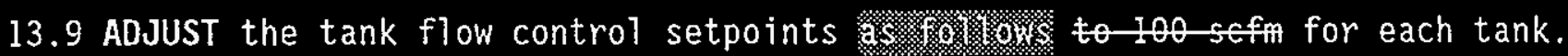

- FIC-AZIKI-1 1

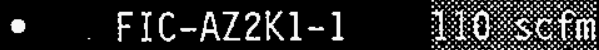

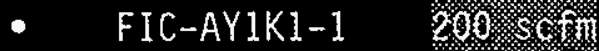

- FIC-AY2K1-1 ZIF

13.10 ADJUST the primary vent manifold pressure setpoints PIC-AZKI-1A and PIC-AZK1-1B to -15.0 in wC.

13.11 VERIFY that no unexpected alarms or conditions occurred associated with this section of testing and that the data in TABLE 13-1 isp in the acceptable range.

Test Engineer:

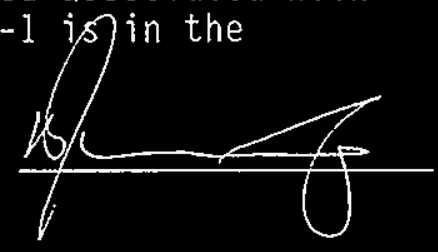

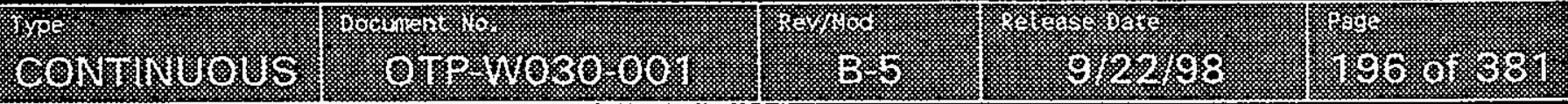




\section{ATTACHMENT A - BYPASS MODE OPERATIONAL TESTING (Cont.)}

TABLE 13-1 Vent Train A Maximum Flow Rate

\begin{tabular}{|c|c|c|c|c|}
\hline MCS PARAMETERS & VENT TRAIN $A$ & $\begin{array}{l}\text { ACCEPTANCE } \\
\text { CRITERIA }\end{array}$ & LIMIT & $\begin{array}{l}\text { PASS } \\
\text { FAIL }\end{array}$ \\
\hline \multicolumn{5}{|l|}{ MCS Graphic Screen 15PriIn.V } \\
\hline $\begin{array}{l}\text { AY101 Intet Air Flow } \\
\text { FI-AYKK1-1 (15PriIn.v) }\end{array}$ & 106 & $\leq$ FIAY $1 K 1-2$ & $\mathrm{H} / \mathrm{A}$ & $\operatorname{losa} \sqrt{1}$ \\
\hline $\begin{array}{l}\text { AY101 Tank Pressure } \\
\text { PI-AY1K1-1 (15PriIn.v) }\end{array}$ & -2.0 & $\begin{array}{c}-0.53 \text { to }-3.0 \\
\text { in we }\end{array}$ & $\begin{array}{c}-.3>x>-6 \text { in } \\
W C \\
\text { W030-RD-001 }\end{array}$ & $\sqrt{\operatorname{cosi} 4}$ \\
\hline $\begin{array}{l}\text { AY101 Exhaust Air flow SETPOINT } \\
\text { FIC-AY } 31-2(15 \text { PriIn.V) }\end{array}$ & 160 & $N / A$ & $N / A$ & \\
\hline $\begin{array}{l}\text { AY101 Exhaust Air flow } \\
\text { FI-AY1X1-2 (15PriIn.V) }\end{array}$ & 335 & $\begin{array}{l}\text { setpoint } \\
\text { scfm }\end{array}$ & N/A & 55 \\
\hline AY O & 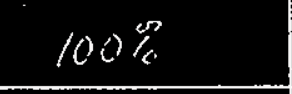 & \%o\% & 彩 & Pases \\
\hline $\begin{array}{l}\text { AY } 102 \text { Inlet Air Flow } \\
\text { FI-AY2K1-1. (15Priln.v) }\end{array}$ & 246 & $\leq$ FIAYZK1-2 & $\begin{array}{c}\quad N / A \\
\vdots \quad \\
\end{array}$ & \\
\hline $\begin{array}{l}\text { AY102 Tank Pressure } \\
\text { PI-AY2K1-1 (15PriIn.v) }\end{array}$ & -1.9 & -0.5 to -3.0 & $\begin{array}{c}.3>x>-6 \text { in } \\
\text { W030-RD - } 001\end{array}$ & Pass \\
\hline $\begin{array}{l}\text { AY102 Exhaust Air Flow SETPOINT } \\
\text { FIC-AY2K1-2 (15Priln.v) }\end{array}$ & 400 & N/A $\because \because$ & $N / A$ & N/A $:$ \\
\hline $\begin{array}{l}\text { AY102 Exhaust Air flow } \\
\text { FI-AY2K } 1-2(15 \text { Priln.v) }\end{array}$ & 360 & $\underset{\text { scfm }}{\text { setpoint } \pm 20}$ & H/A & Pass \\
\hline 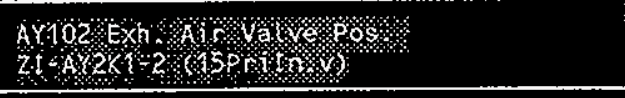 & $9 \% 6$ & $70 \%$ o & K & Pass \\
\hline $\begin{array}{l}\text { Az101 In!e: Air Flow } \\
\text { FI-Az1K1-1 (15PriIn.V) }\end{array}$ & $-i(1)$ & $\leq F I A Z 1 K 1-2$ & $M / A$ & Russ \\
\hline $\begin{array}{l}\text { Az101 iank Pressure } \\
\text { Pi-Az1K?-i (15Priln.v) }\end{array}$ & -1.2 & $\begin{array}{l}-0.53 \text { to }-3.0 \\
\text { in wC }\end{array}$ & $\begin{array}{c}-.5>x>-6 \text { in } \\
\text { WC } \\
\text { WO30-RD-001 }\end{array}$ & \\
\hline 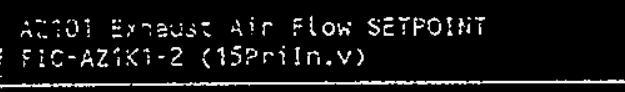 & $\therefore \therefore$ & $\cdot \quad H / A$ & $\mathrm{~N} / \mathrm{A}$ & $N / A$ \\
\hline 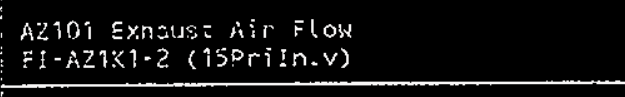 & $\therefore i$ & $\begin{array}{c}\text { serpoint } \pm 20 \\
\text { scim }\end{array}$ & $N / A$ & 10550 \\
\hline 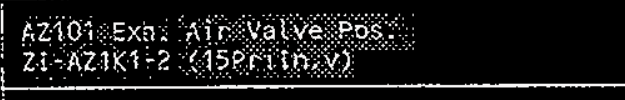 & is: & $20 \%$ oog & He & $2 \csc \theta$ \\
\hline 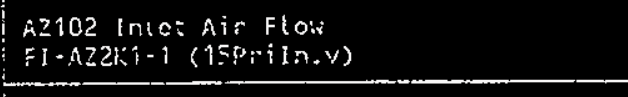 & $\hat{\vdots}$ & $\leq F I A Z 2 K 1-2$ & $N / A$ & PCos \\
\hline 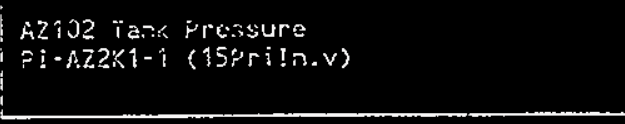 & $-i$ & $\begin{array}{l}-0.53 \text { to }-3.0 \\
\text { in WC }\end{array}$ & $\begin{array}{c}-.5>x>-6 \text { in } \\
\text { Wic } \\
\text { W030-Ro-001 }\end{array}$ & Ocsio \\
\hline $\begin{array}{l}\text { AZ102 Exnaust Air Flow SETPOINT } \\
\text { FIC-AZ2Ki-2 (15PriIn.V) }\end{array}$ & 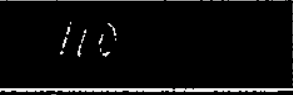 & $N / A$ & $N / A$ & ln/A \\
\hline
\end{tabular}

\begin{tabular}{|c|c|c|c|c|}
\hline \%oNH) & 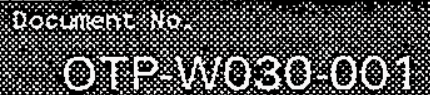 & 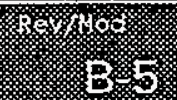 & 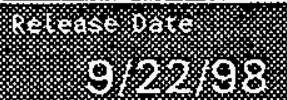 & 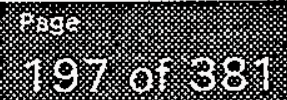 \\
\hline
\end{tabular}


TABLE 13-1 Vent Train A Maximum Flow Rate

\begin{tabular}{|c|c|c|c|c|}
\hline MCS PARAMETERS & VENT TRAINA & $\begin{array}{l}\text { ACCEPTANCE } \\
\text { CRITERIA }\end{array}$ & LIMIT & $\begin{array}{l}\text { PASS } \\
\text { FAIL } \\
\end{array}$ \\
\hline $\begin{array}{l}\text { Az102 Exhaust Air flow } \\
\text { FI-AZ2K1-2 (15Prifn.v) }\end{array}$ & $1 / 1$ & setpoint \pm 20 & N/A. & Pass 6 \\
\hline 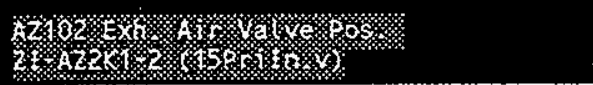 & $21 \%$ & $28 \%=0=0$ & 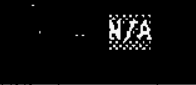 & Pess \\
\hline
\end{tabular}

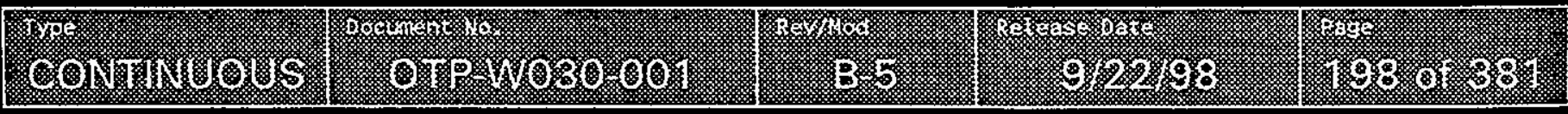




\section{ATTACHMENT A - BYPASS MODE OPERATIONAL TESTING (Cont.)}

TABLE 13-1 Vent Train A Maximum Flow Rate (Continued)

\begin{tabular}{|l|c|c|c|c|}
\hline \multicolumn{1}{|c|}{ MCS PARAMETERS } & VENT TRAIN A & $\begin{array}{c}\text { ACCEPTANCE } \\
\text { CRITERIA }\end{array}$ & LIMIT & PASS/ \\
FAIL
\end{tabular}

\begin{tabular}{|c|c|c|c|c|}
\hline $\begin{array}{c}\text { MCS PARAMETERS } \\
\\
\end{array}$ & VENT TRAIN A & $\begin{array}{l}\text { ACCEPTANCE } \\
\text { CRITERIA }\end{array}$ & LIMIT & $\begin{array}{l}\text { PASS } \\
\text { FAIL }\end{array}$ \\
\hline \multicolumn{5}{|l|}{ MCS Graphic Screen 14Chilir.v } \\
\hline $\begin{array}{l}\text { Primary vent Condenser } \\
\text { Water Flow Rate } \\
\text { FI-AZCWR-1 (14Chillr.v) }\end{array}$ & 119 & 110n 120 & $N / A$ & 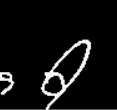 \\
\hline
\end{tabular}

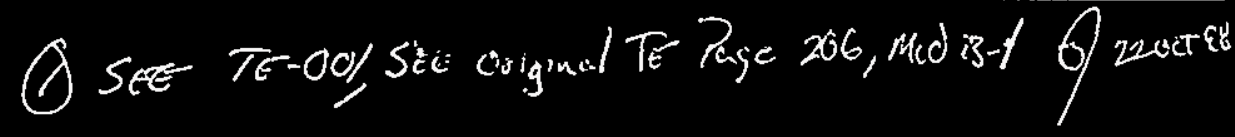

\begin{tabular}{|c|c|c|c|c|}
\hline - & 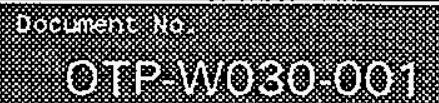 & 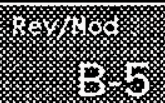 & 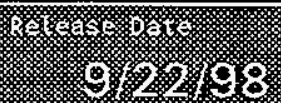 & 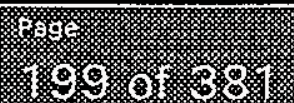 \\
\hline
\end{tabular}


ATTACHMENT A - BYPASS MODE OPERATIONAL TESTING (Cont.)

TABLE 13-1 Vent Train A Maximum Flow Rate (Continued)

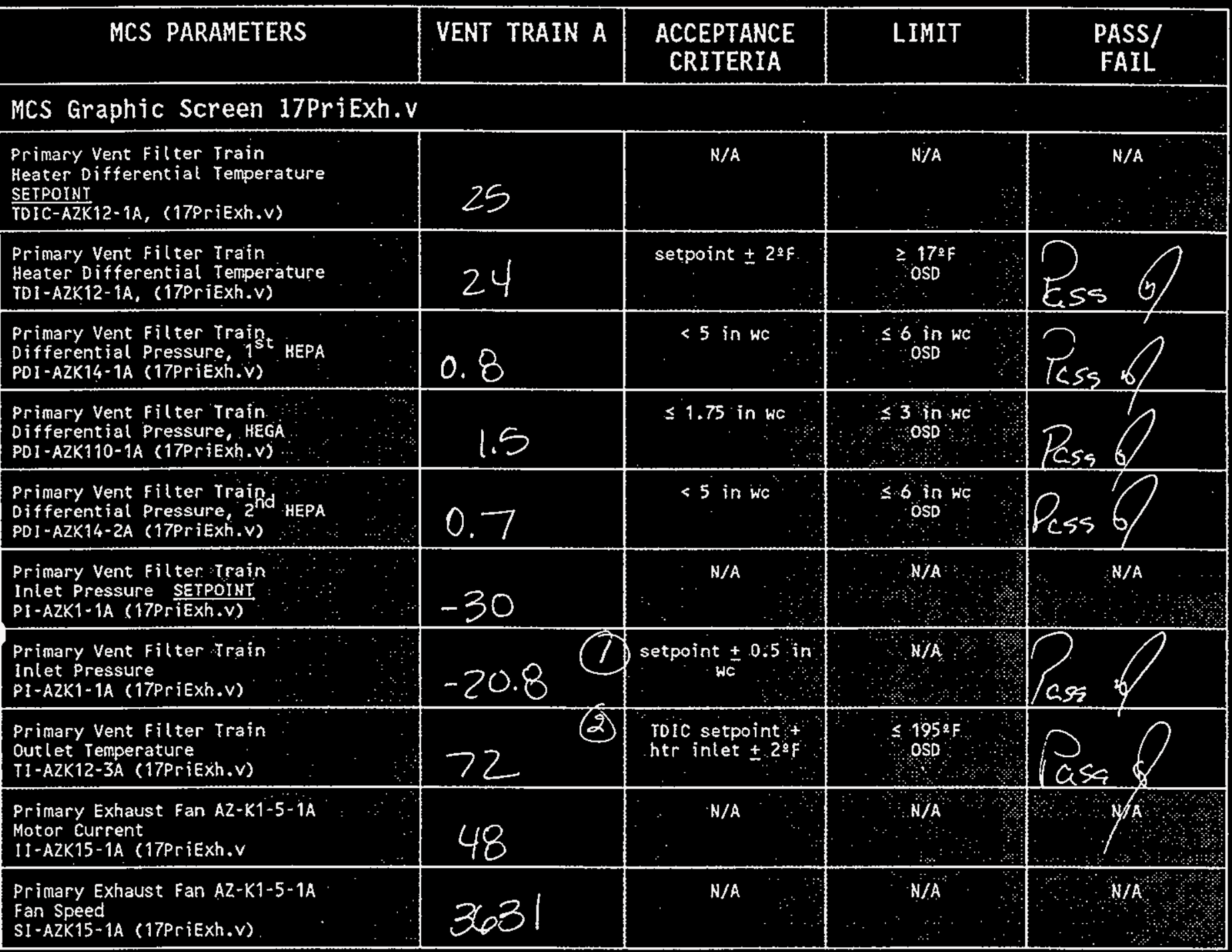

\begin{tabular}{|c|c|c|c|c|c|}
\hline MCS PARAMET & IERS & VENT TRAIN A & $\begin{array}{l}\text { ACCEPTANCE } \\
\text { CRITERIA }\end{array}$ & LIMIT & $\begin{array}{l}\text { PASS/ } \\
\text { FAIL }\end{array}$ \\
\hline \multicolumn{6}{|c|}{ MCS graphic Screen 18PriMon.v } \\
\hline \multicolumn{2}{|c|}{$\begin{array}{l}\text { Primary Vent Exhaust stack } \\
\text { Air Flow Rate } \\
\text { Fl-AZK1-3 (18Primon.v) }\end{array}$} & 923 & 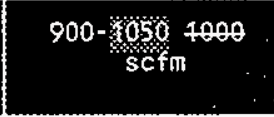 & $\begin{array}{l}\leq 200 \text { and } \\
\leq 800 \text { scfm } \\
\text { oso }\end{array}$ & $\operatorname{rcss}_{5}$ \\
\hline \multirow[t]{2}{*}{$\begin{array}{l}\text { Primary vent Exhaust Stac } \\
\text { Air Temperature } \\
\text { I1-AZK1-3 (18PriMon.v) }\end{array}$} & 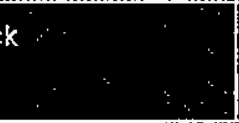 & 87 & $N / A$ & $\mathrm{~N} / \mathrm{A}$ & $\sqrt{ } / \mathrm{A}$ \\
\hline & & $\begin{array}{l}\text { SEE TE-OC } \\
\text { SEE TE-O }\end{array}$ & $\begin{array}{l}7 \text { sie } 3 \text { ge, } 244 \\
\text { teen } 4, \text { set }\end{array}$ & 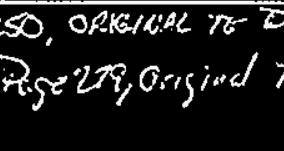 & EData. $b / \mathrm{CL}$ \\
\hline 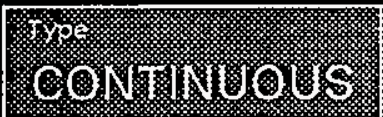 & 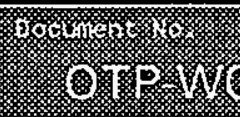 & 1. & 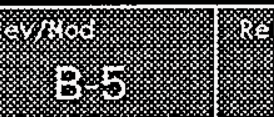 & 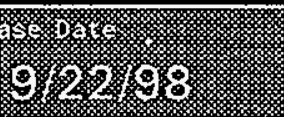 & 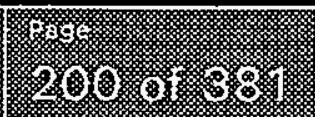 \\
\hline
\end{tabular}




\section{ATTACHMENT B - RECIRC AND HIGH HEAT MODE OPERATIONAL TESTING (CONt.)}

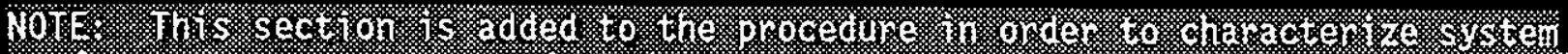

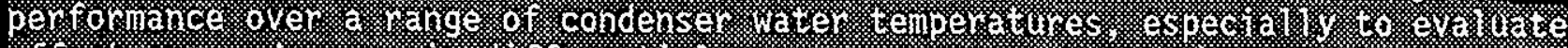

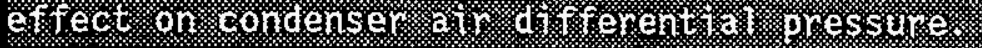

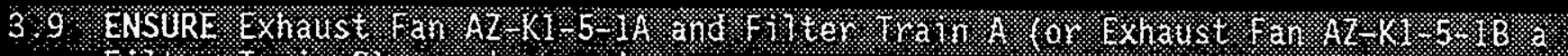

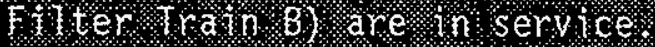

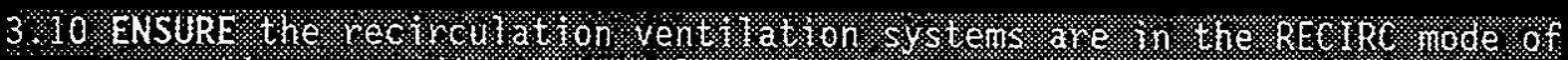

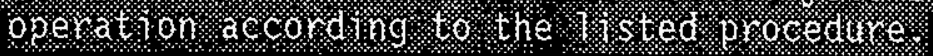

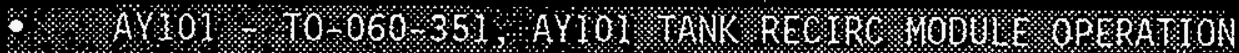

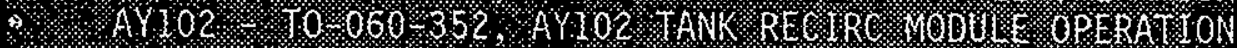

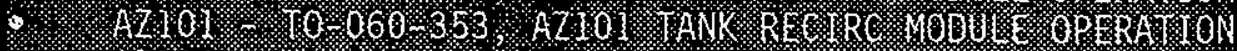

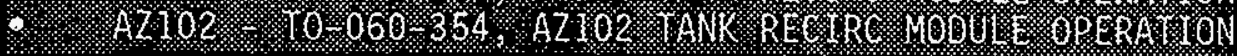

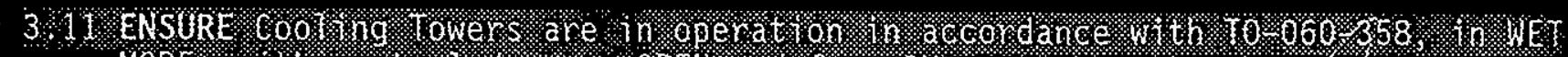

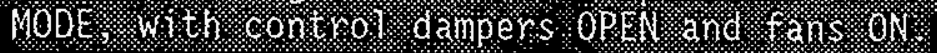

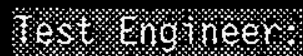

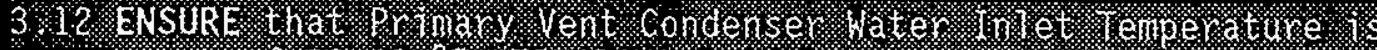

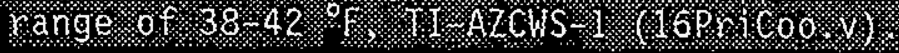

r s.

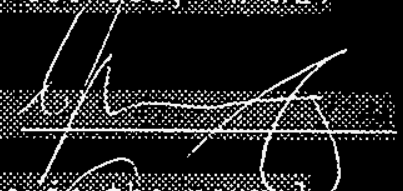

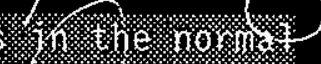

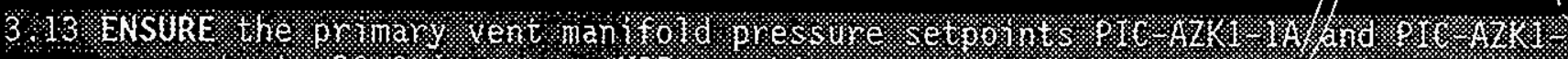

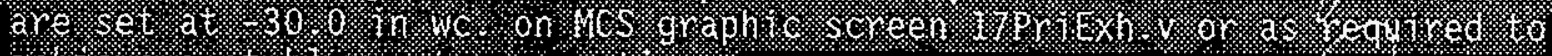
achere a static stren operatron.

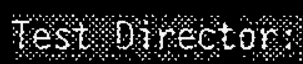

\section{QAUTIONS}

¿. Ir tha fojowing steps do not exceed an irijcated stack fiow rate ỗ $\$ 050 \% \mathrm{cth}$, on stack temperature 01 $100 \%$ degres. $F$

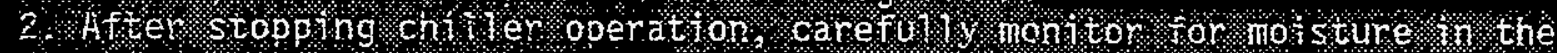

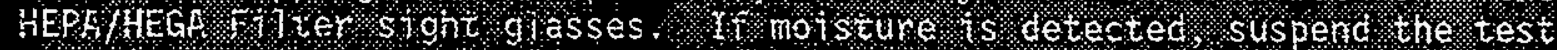
cf this sectort:

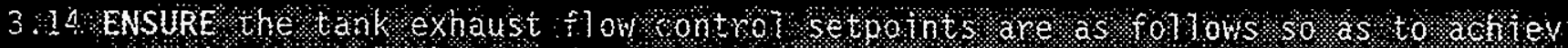

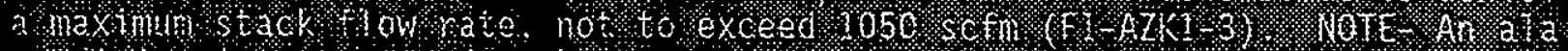

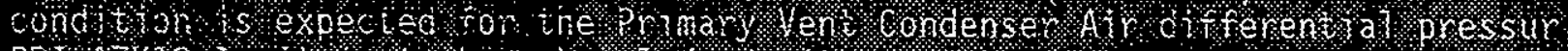

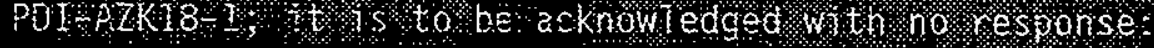

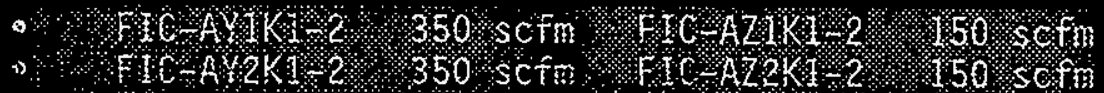

\begin{tabular}{|c|c|c|c|c|}
\hline 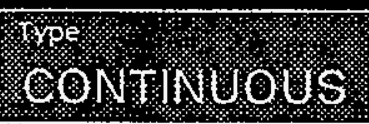 & ( ) & 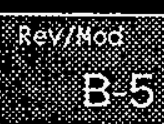 & 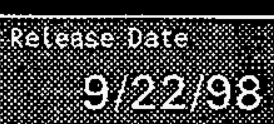 & 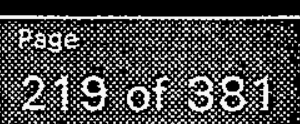 \\
\hline
\end{tabular}




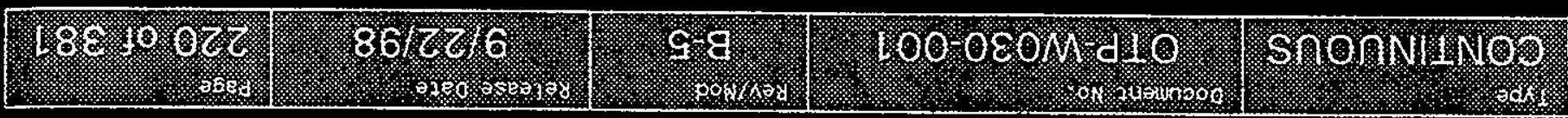

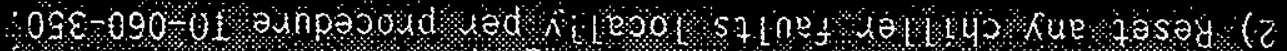

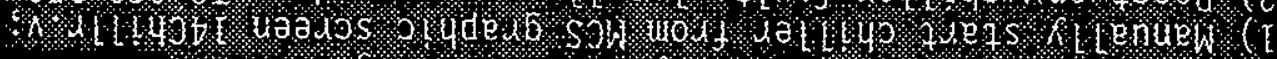

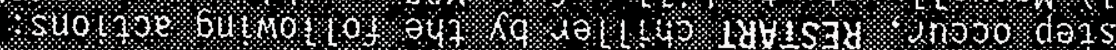

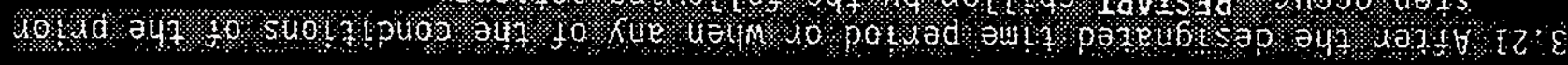

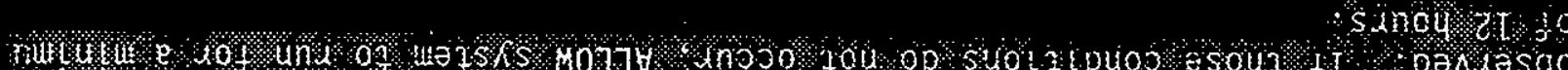

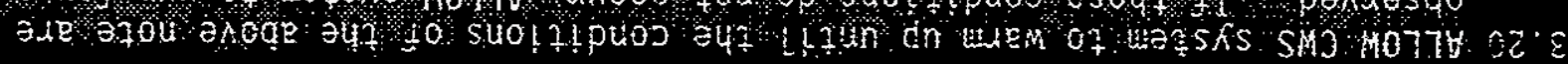

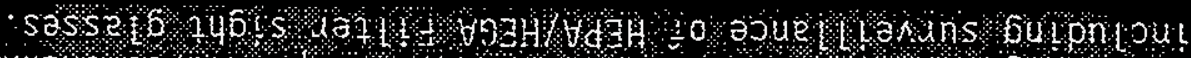

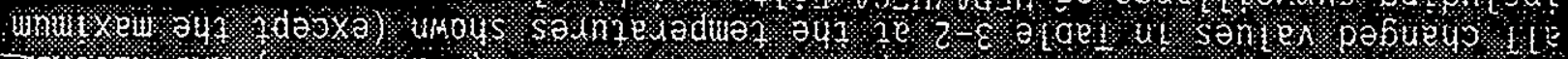

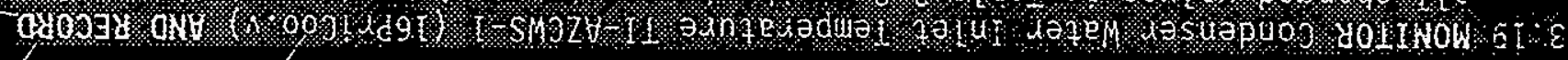

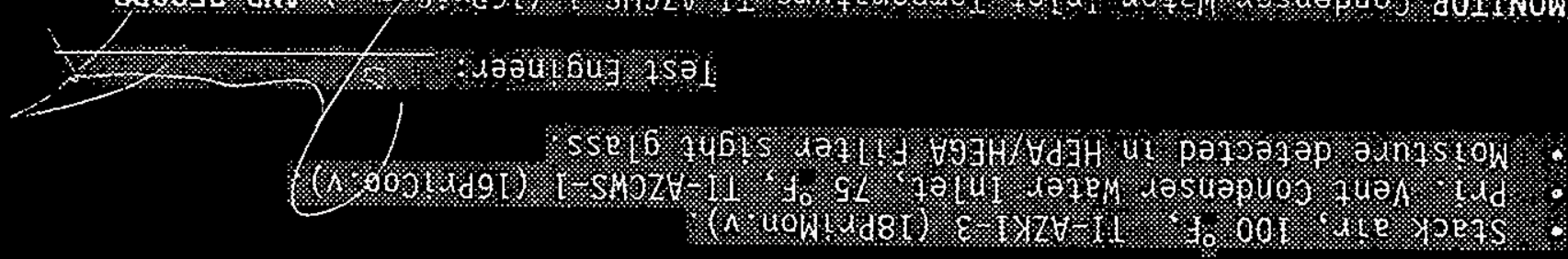
ais aGe ray

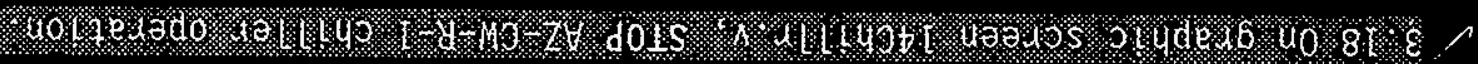

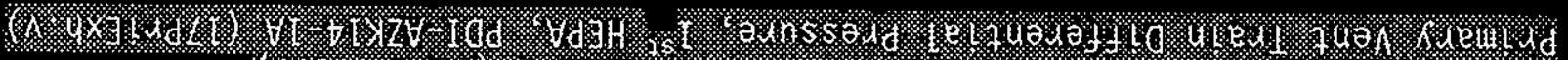

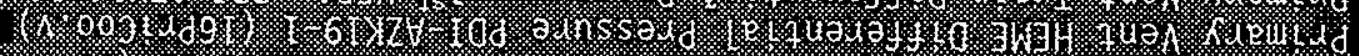

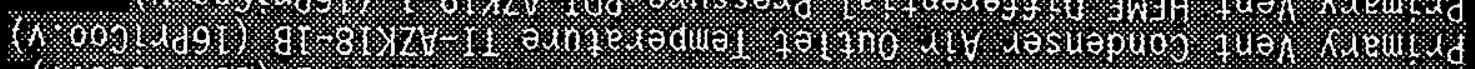

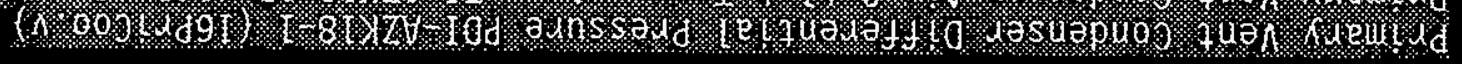

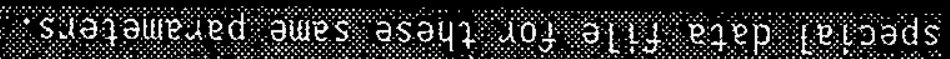

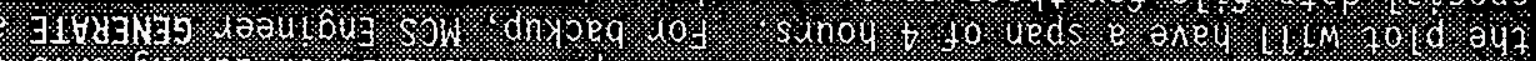

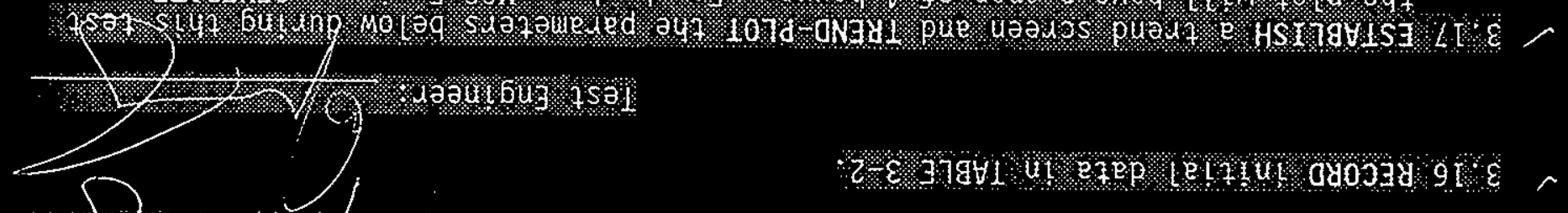
.

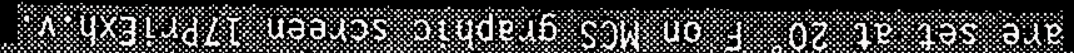

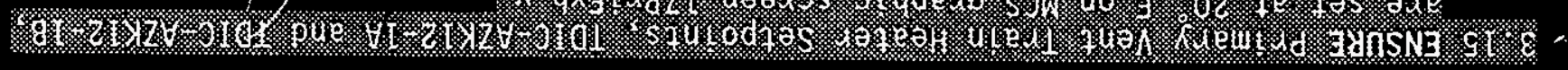

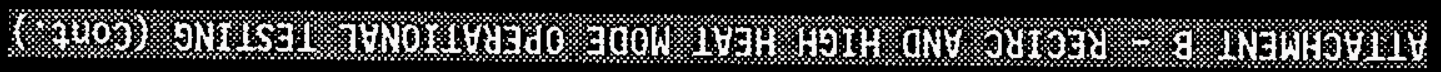




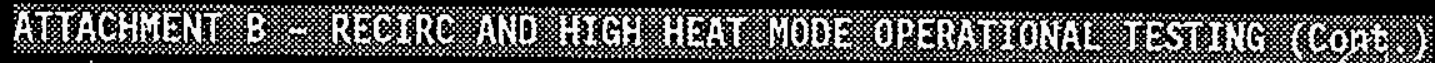

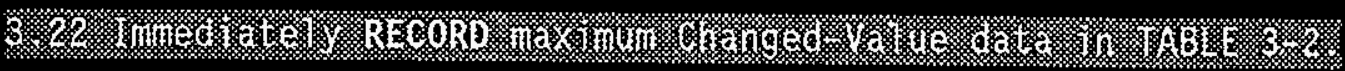

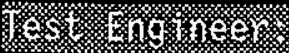

3. 23 4 .

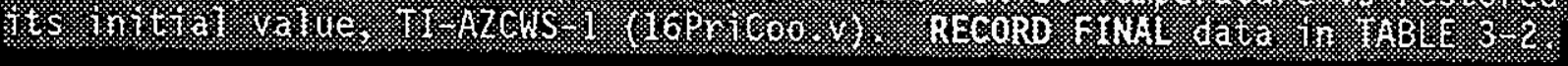

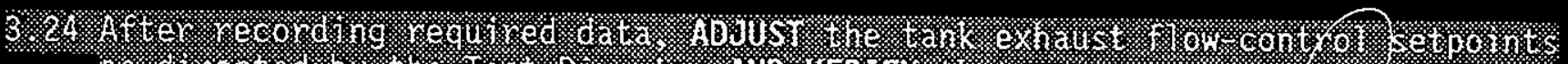

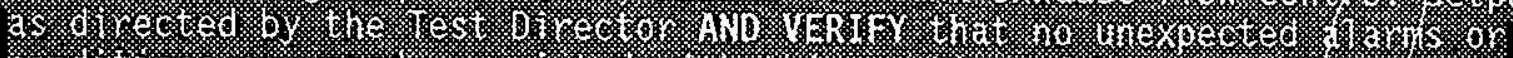

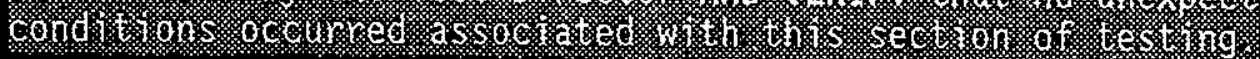

1esi.

\begin{tabular}{|c|c|c|}
\hline Con. & (3) & \\
\hline
\end{tabular}




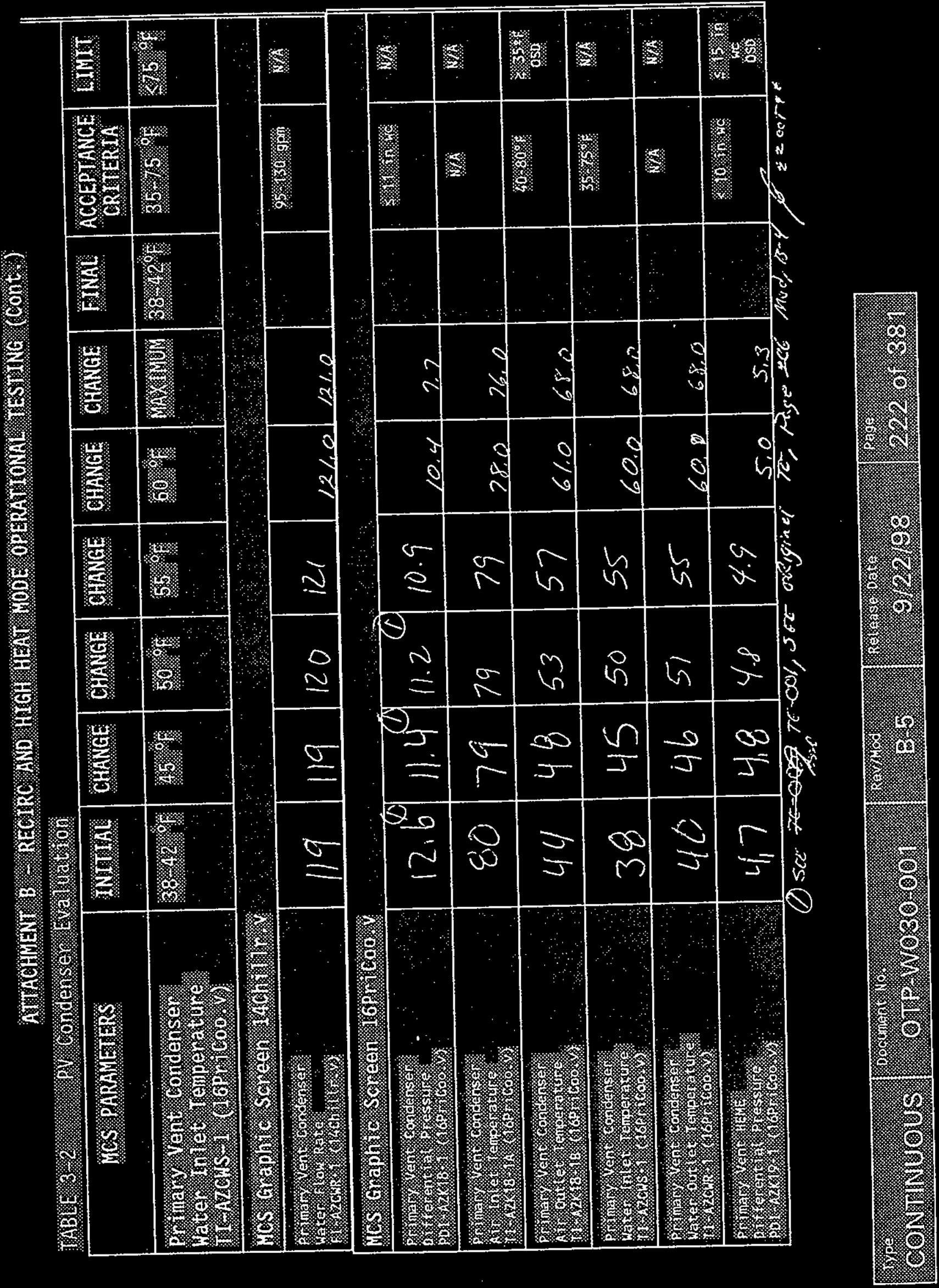




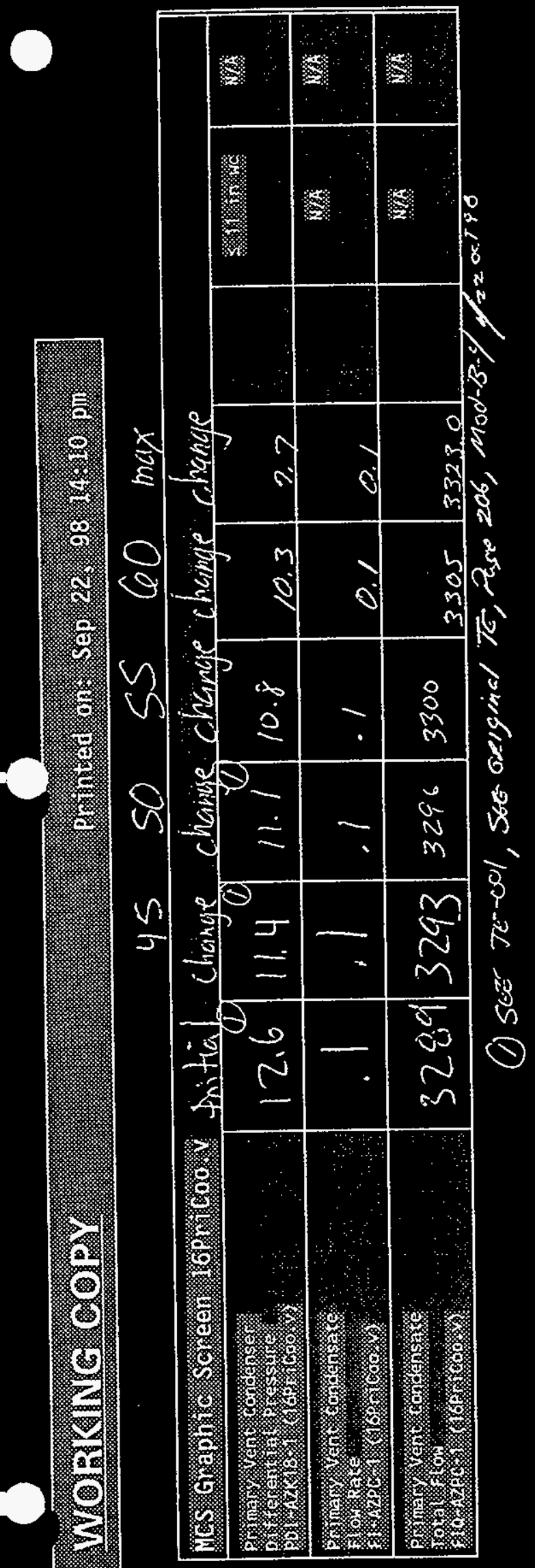


HNF-3473

REV. 0, Page /06
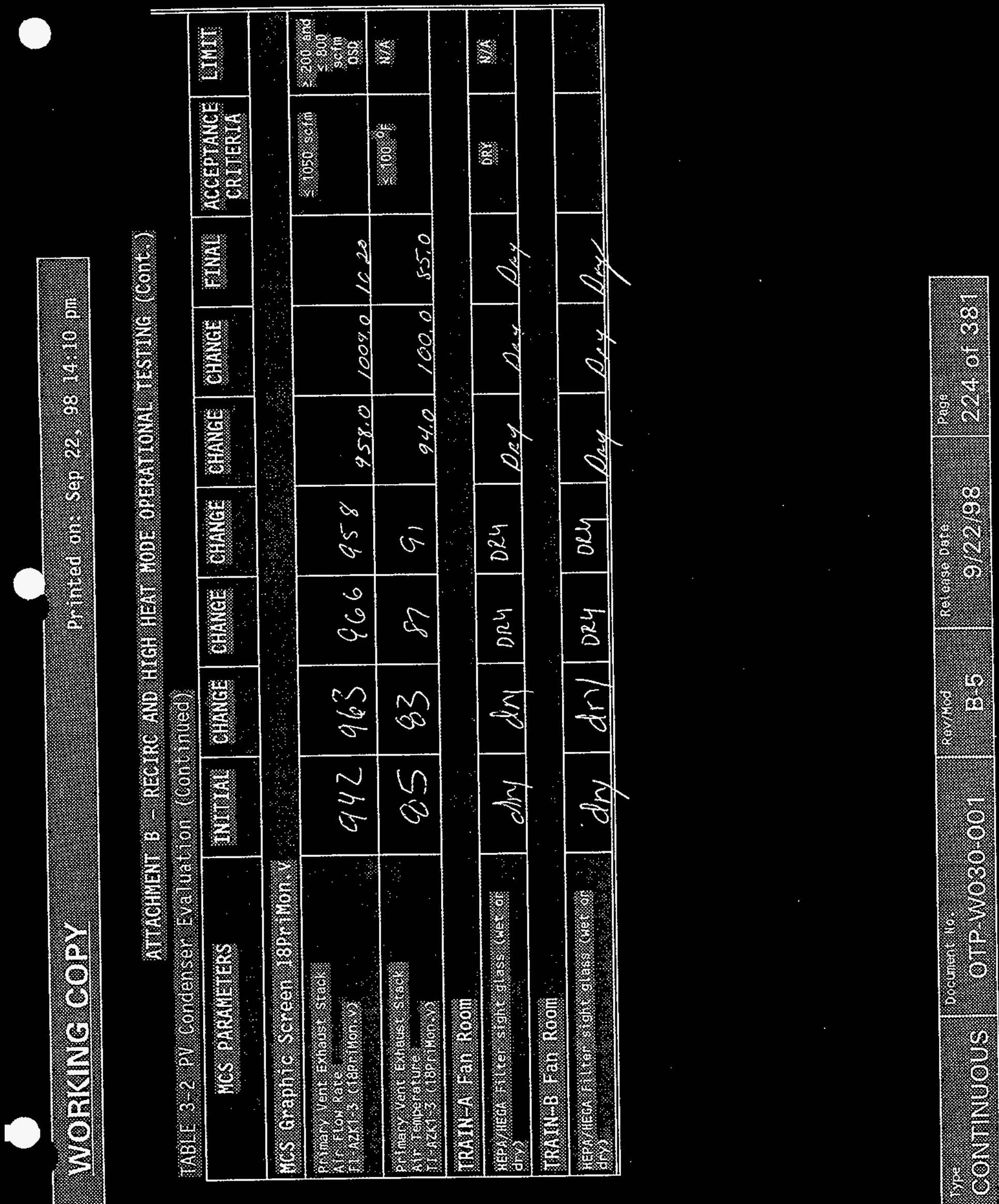


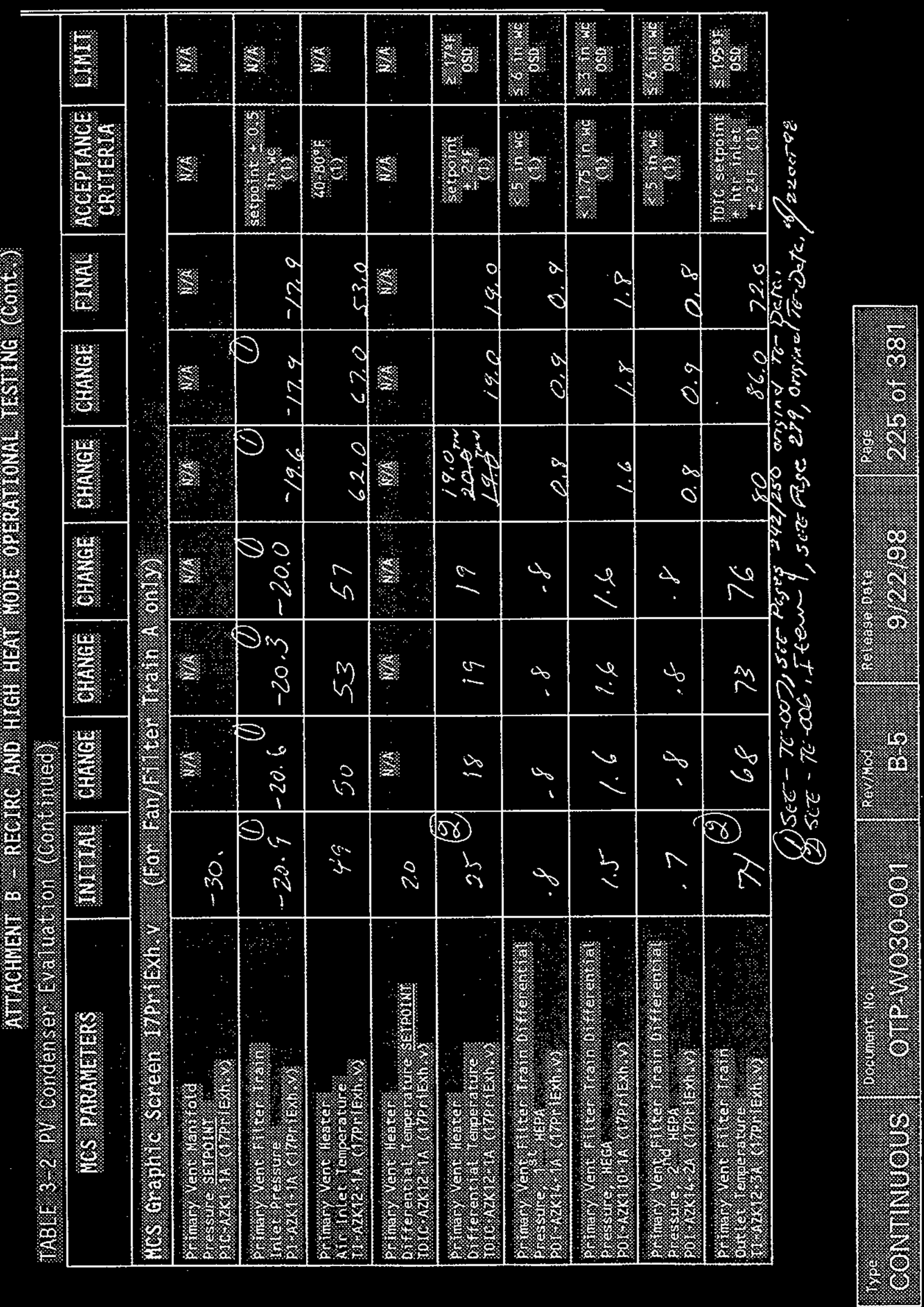


HNF-3473

REV. 0, Page 108
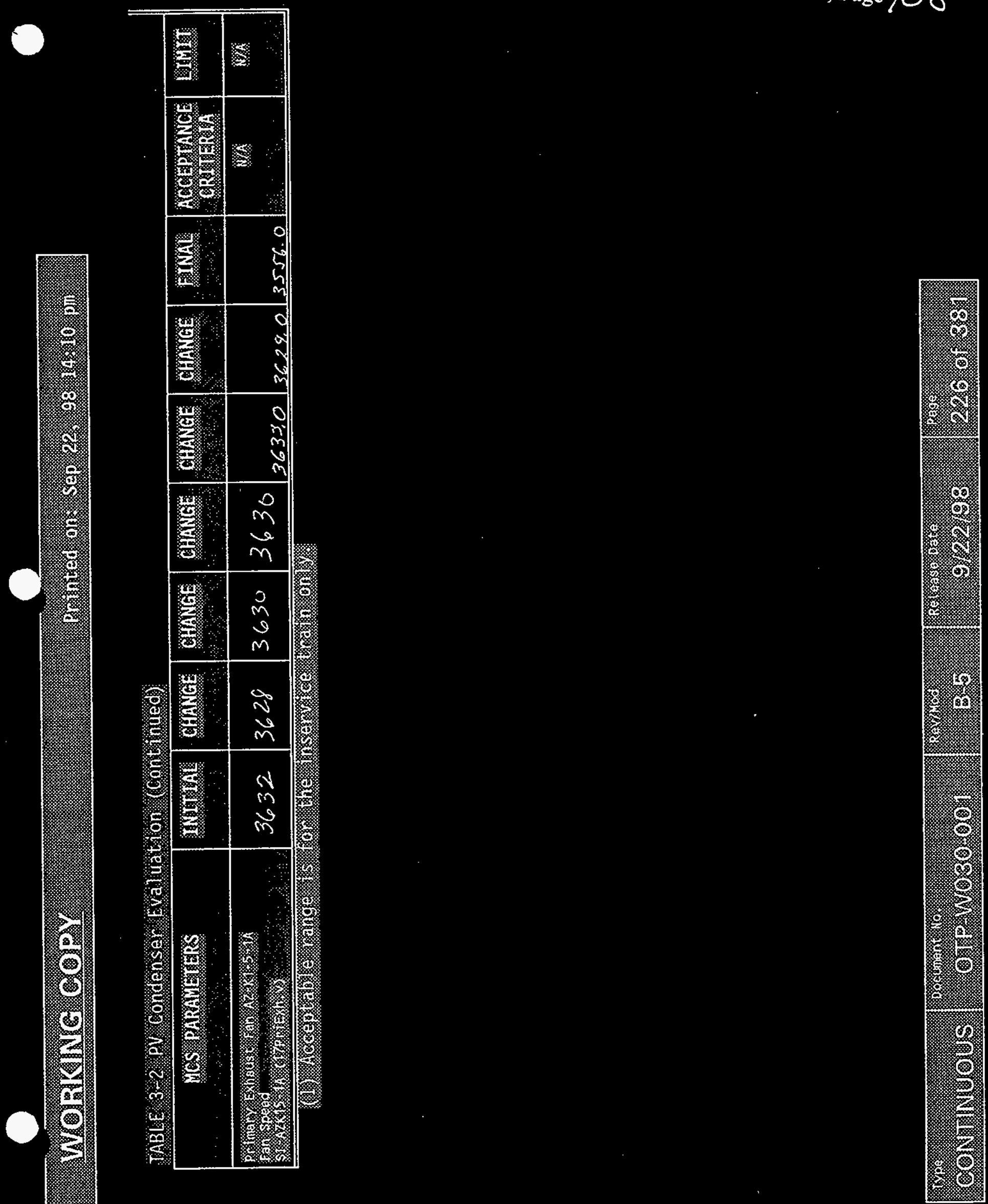


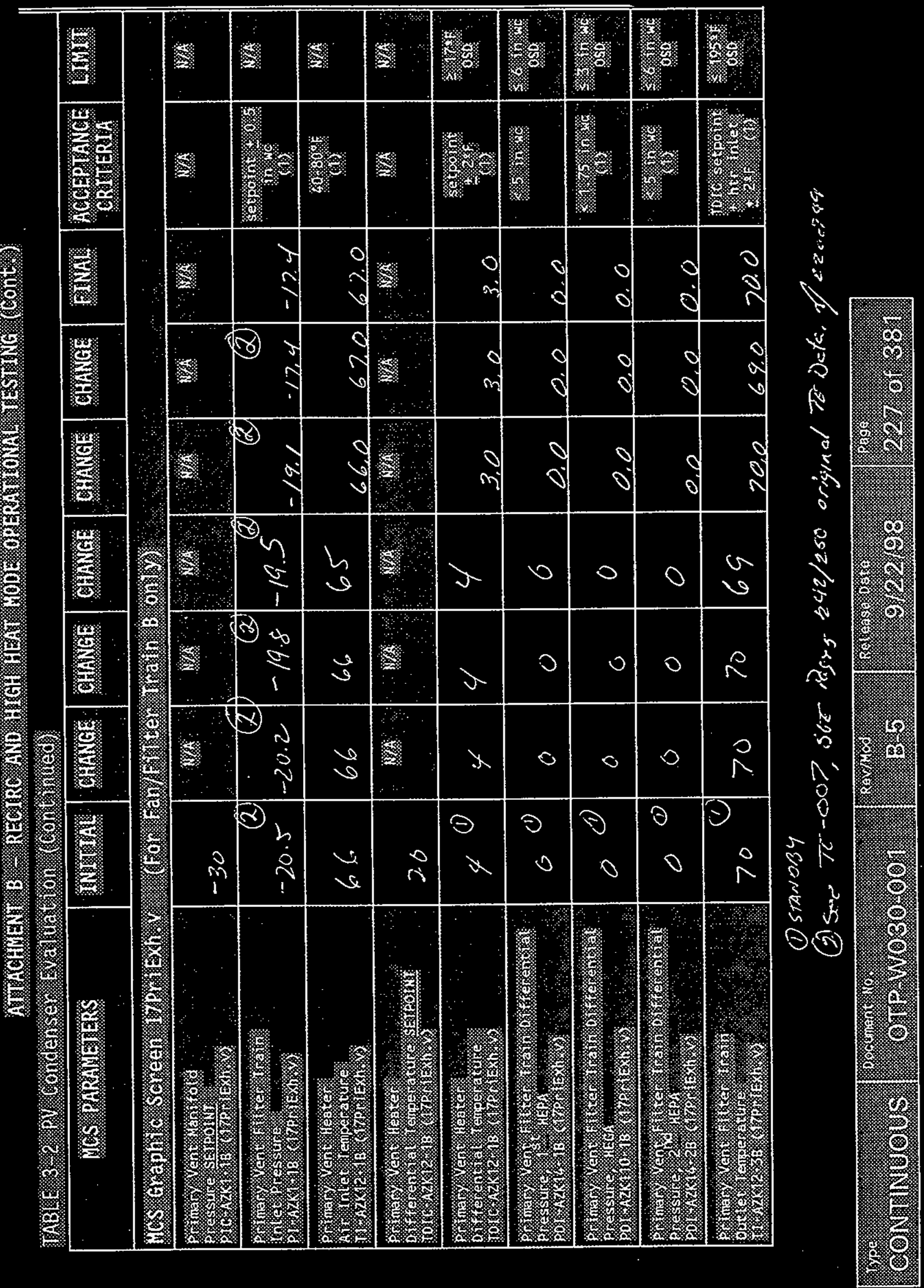


HNF-3473

REV. 0, Page //O
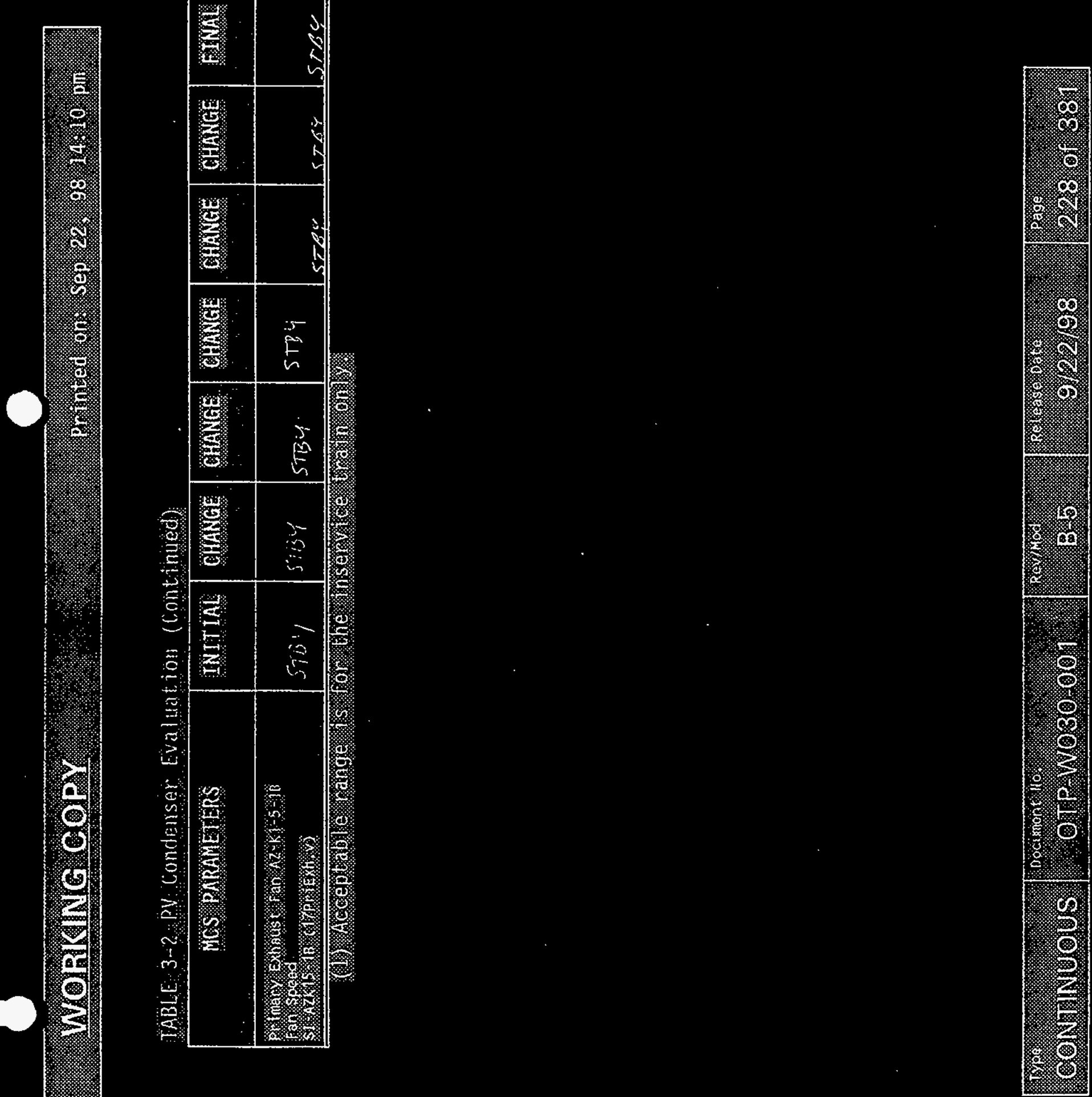
ATTACHMENT B - RECIRC AND HIGH HEAT MODE OPERATIONAL TESTING (Cont.)

\subsection{AY101 HIGH HEAT - STEADY STATE OPERATION}

\section{CAUTION}

This section cannot be performed prior to lifting of the limitations cited in the Project $W-030$ NOC limiting the maximum flow rate of the exhauster to $800 \mathrm{scfm}$.

4.1 ENSURE Exhaust Fan AZ-K1-5-1A and Filter Train $A$ are in service

4.2 ENSURE the recirculation ventilation systems are in the RECIRC mode of operation according to the listed procedure.

- AY101 - T0-060-351, AY101 TANK RECIRC MODULE OPERATION

- AY102 - T0-060-352, AY102 TANK RECIRC MODULE OPERATION

- AZ101 - T0-060-353, AZ101 TANK RECIRC MODULE OPERATION

- AZ102 - T0-060-354, AZ102 TANK RECIRC MODULE OPERATION

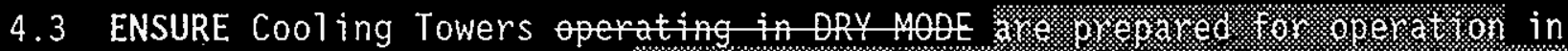

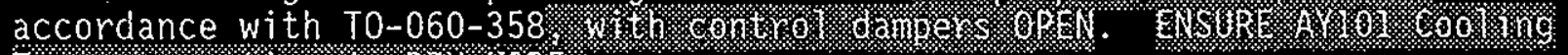

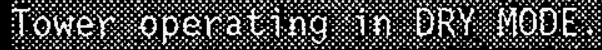

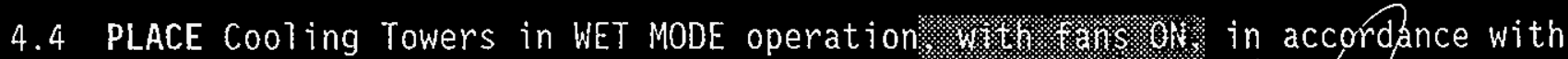
T0-060-358, EXCEPT for tank AY101, AND RETURN to this procedure

Test Engineer:

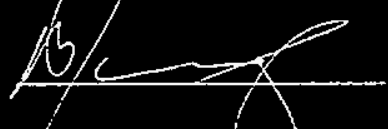
4.5 ENSURE tank pressure control setpoints are set at -2.0 in. WC fon MCS graphic
screen 15PriIn.V.

- PIC-AIZKI-I

$\Rightarrow \quad P I C-A Z 2 K I-I$

अ PIC-AYIKI-I

$\therefore \quad P I C-A Y 2 K 1-i$

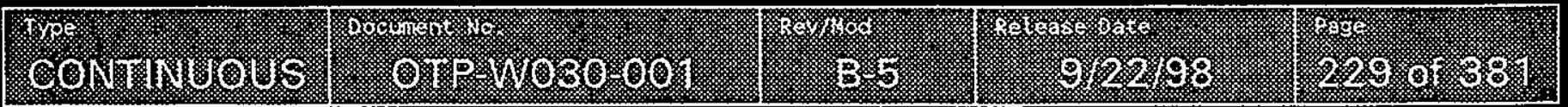




\section{ATTACHMENT B - RECIRC AND HIGH HEAT MODE OPERATIONAL TESTING (Cont.)}

4.6 ENSURE the tank exhaust flow control setpoints and the primary vent manifold pressure setpoints $P I C-A Z K 1-1 A$ and $P I C-A Z K 1-1 B$ are set as required to achieve the flow rates 1 isted below.

$$
\begin{aligned}
& \text { AZ101 at } \\
& \text { AZ102 at } 1000 \pm 20 \mathrm{scfm} \text { (FIC-AZ1KI-2) } \\
& \text { AY101 at } 200100 \pm 20 \mathrm{sCfm} \text { (FIC-AZ2K1-2) } \\
& \text { AY102 at } 20100 \pm 20 \mathrm{scfm} \text { (FIC-AYIK1-2) } \\
& \text { sCfm (FIC-AY2K1-2) }
\end{aligned}
$$

4.7 ALLOW system parameters to stabilize for 15 minutes AND RECORD Initial data with AY101 in RECIRC mode in TABLE 4-1.

Test Engineer:

4.8-ADJUST AY101 tank-exhaust flow-control setpoint-tom $500 \pm 20$

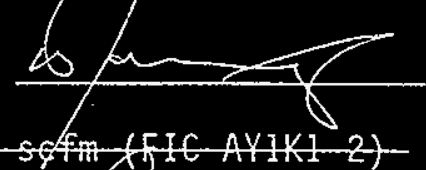

4.9 ESTABLISH AY101 HIGH HEAT mode according to T0-060-351.

Test Engineer:

4.10 ALLOW system parameters to stabilize for 15 AY101 in HIGH HEAT mode in TABLE 4-1.

Test Engineer:

4.11 RECORO data in TABLE 4-1 every hour for 4 consecutive hours.

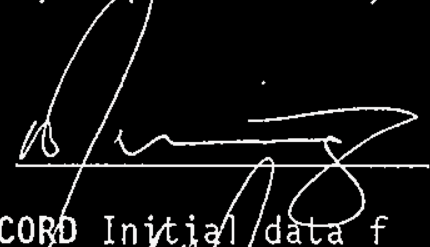

.11 RECORD data in TABLE 4-l every hour for 4 consecutive hours. 4.12 PLACE AY10I Cooling Tower in WET MODE operation in accordance with T0-060-358
AND RETURN to this procedure.

Test Engineer:

4. 13 ALLOW system parameters to stabilize for 15 minutes AND RECORd with AY101 in HIGH-HEAT mode in TABLE $4-2$.

$\therefore$ RECORD data in TABLE 4-2 every 15 minutes fout for 4 consecutive hetio Hoteryos.

Tesi Engineer:

4.15 VERIFY that no unexpected alarms or conditions occurred assofiated with this section of testing and that the data in TABLES 4-1 and 4-2 satjsfies the

\begin{tabular}{|c|c|c|c|c|}
\hline 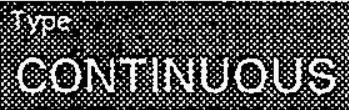 & 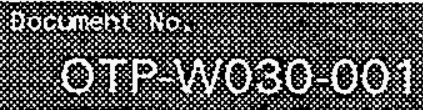 & 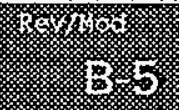 & 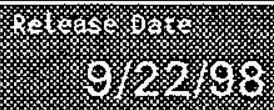 & 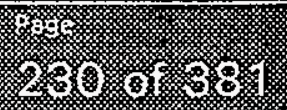 \\
\hline
\end{tabular}
acceptance criteria.

\section{Test Engineer:} NOTE - All cooling Towers will remain in WET MODE operation throughout/the balance (o)
this procedure except as directed. 
FNF-3473

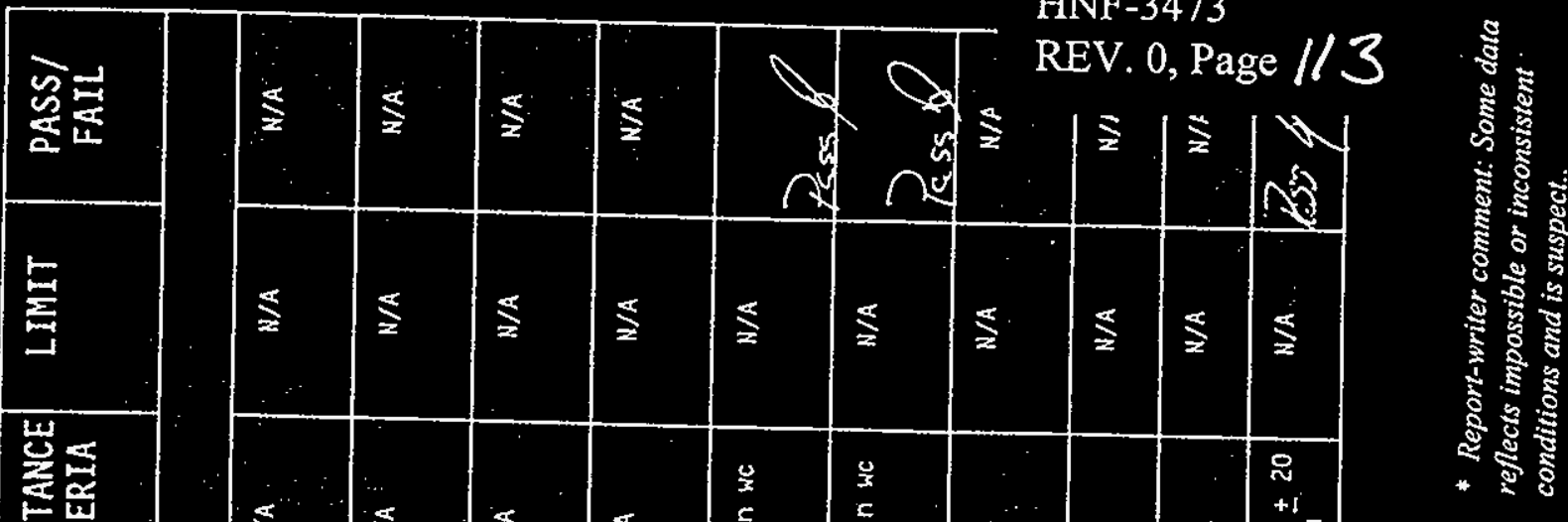

:

要

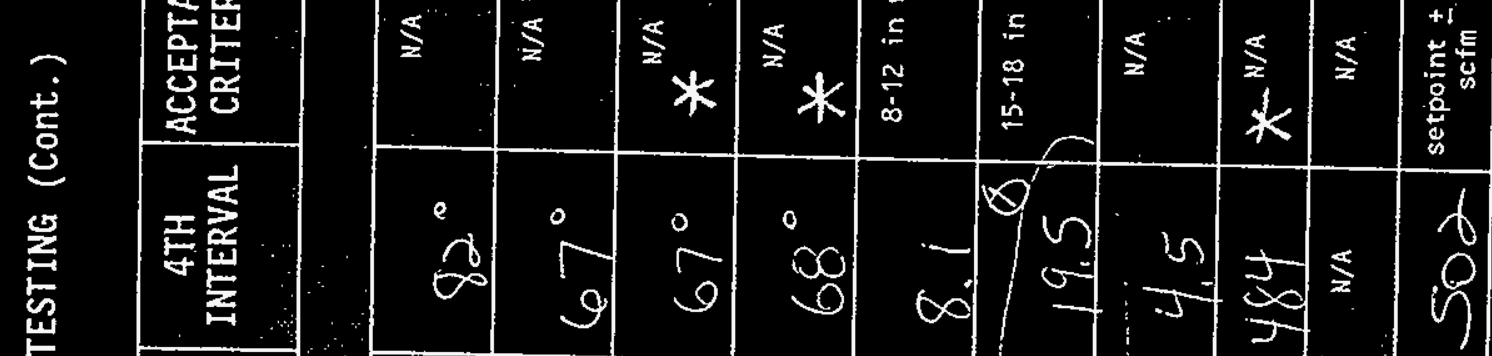

空点

昆

훙

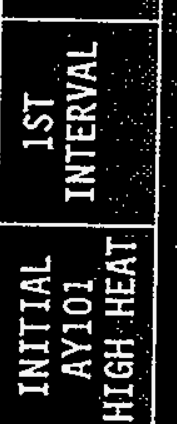

d

$\infty$

of $\infty$

Pln

$\infty-9$

$$
-9
$$

$+$

议

$\infty$

(

i

$+0$

옹

鹿

s)

$\infty$

$\ln$

$\frac{\operatorname{lo}}{\infty} \underset{\infty}{\infty}$

0

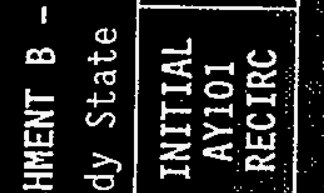

in 00000

$\infty$ is

कै की

$\infty$

9

$\ln$ m

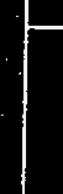

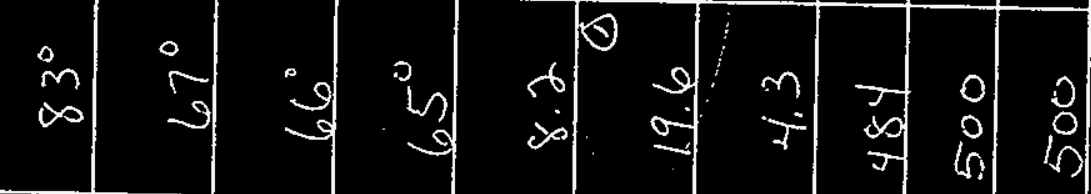

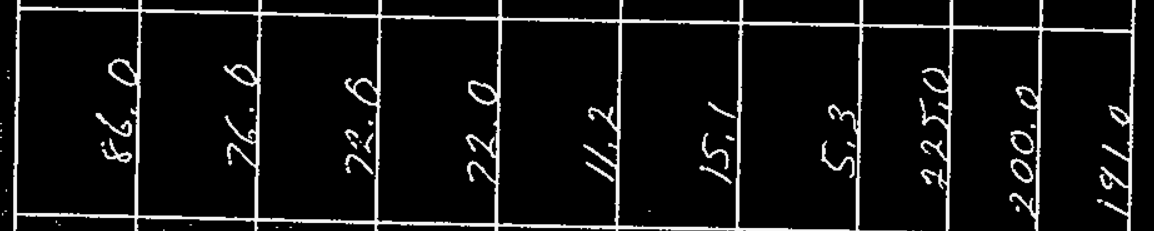

$\div \quad$

$\stackrel{\Phi}{\sim}$

这

忈造

甹总

일

安

$\stackrel{5}{\square}$

感

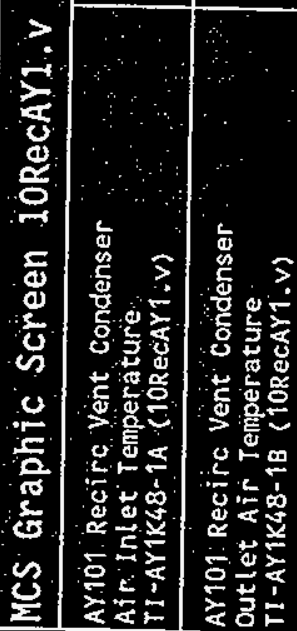

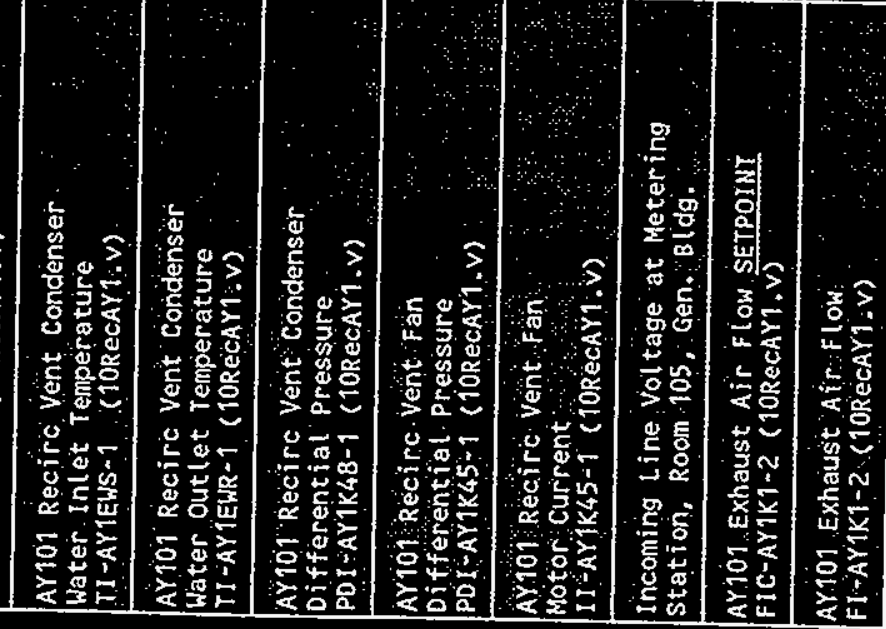

o 
ATTACHMENT B - RECIRC AND HIGH HEAT MODE OPERATIONAL TESTING (Cont.)

TABLE 4-1 AY101 HIGH HEAT Steady State (Continued)

\begin{tabular}{|c|c|c|c|c|c|c|c|c|c|}
\hline $\begin{array}{l}\text { MCS PARAMETERS } \\
\end{array}$ & $\begin{array}{l}\text { INITIAL } \\
\text { AYIOI } \\
\text { RECIRC }\end{array}$ & $\begin{array}{c}\text { INITIAL } \\
\text { AY10I } \\
\text { HIGH HEAT }\end{array}$ & $\begin{array}{l}\text { 1ST } \\
\text { INTERVAL }\end{array}$ & $\begin{array}{c}\text { 2ND } \\
\text { INTERVAL } \\
\end{array}$ & $\begin{array}{c}\text { 3RD } \\
\text { INTERVAL } \\
\end{array}$ & $\begin{array}{l}\text { 4TH } \\
\text { INTERVAL }\end{array}$ & $\begin{array}{c}\text { ACCEPTANCE } \\
\text { CRITERIA } \\
\vdots\end{array}$ & LIMIT & $\begin{array}{l}\text { PASS/ } \\
\text { FAIL }\end{array}$ \\
\hline \multicolumn{10}{|l|}{ MCS Graphic Screen 11RecAYZ.V } \\
\hline $\begin{array}{l}\text { AY102 Recirc Vent condenser } \\
\text { Air Intet Jemperature, } \\
\text { II AY2K48-1A (11RecAY2:v) }\end{array}$ & 80,0 & $81^{\circ}$ & $81^{\circ}$ & $79^{\circ}$ & $78^{\circ}$ & $79^{\circ}$ & N/A & $N / A$ & N/A \\
\hline $\begin{array}{l}\text { AY102 Recirc Vent Condenser } \\
\text { Outlet: Air Temperature } \\
\text { T1-AY2K48-1B (11RecAY2 V) }\end{array}$ & 96.0 & $77^{\circ}$ & $78^{\circ}$ & $80^{\circ}$ & $82^{\circ}$ & $80^{\circ}$ & & $N / A$ & N/A. \\
\hline $\begin{array}{l}\text { AY102 Recirc Vent Condenser } \\
\text { Water tinter Temperature } \\
\text { T1-AY2EWS-1 (11RecAY2.V) }\end{array}$ & 290 & $19^{\circ}$ & $81^{\circ}$ & $81^{\circ}$ & $79^{\circ}$ & $82^{\circ}$ & N/A & $N / A$ & W/A \\
\hline $\begin{array}{l}\text { AY102 Recirc Vent condenser: } \\
\text { Water out let Temperature } \\
\text { II-AYZEWR-1 (11RecAY2,V) }\end{array}$ & 240 & $79^{\circ}$ & $81^{2}$ & $81^{\circ}$ & $80^{\circ}$ & $80^{\circ}$ & $\times^{N / A}$ & N/A & $N / A$ \\
\hline $\begin{array}{l}\text { AY102 Recirc Vent condenser } \\
\text { pifferential pressure } \\
\text { PDI-AYZK48-1 (11RecAY2.v) }\end{array}$ & 10,2 & 10.1 & 10.1 & 10.1 & 10.1 & 10.1 & $8-12$ in wc & $N / A$ & Zss. \\
\hline $\begin{array}{l}\text { AY102 Recirc Vent fan } \\
\text { Differential Pressure } \\
\text { POI-AY2K45-1 (11RecAY2, v) }\end{array}$ & 13,4 & 13.8 & $13.8^{2}$ & $13.8^{0}$ & $13.7^{8}$ & $13.8^{\circ}$ & 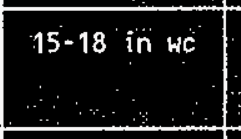 & $N / A$ & \\
\hline $\begin{array}{l}\text { AY } 02 \text { Recirc vent Fan } \\
\text { Motor current } \\
\text { H-AY2K45-1 (1RecAY2, V) }\end{array}$ & 5,5 & 5.5 & 5.4 & 5,2 & 5.3 & $5 \cdot 2$ & $\begin{aligned} & N / A \\
& \because \because \\
&\end{aligned}$ & $N / A$ & $N / A$ \\
\hline $\begin{array}{l}\text { Incoming Line voltagest Metering } \\
\text { Station, Room } 105 \text { gen. Bldg }\end{array}$ & 225,0 & 484 & 483 & 482 & 486 & 484 & $* N / A$ & $N / A$ & $N / A$ \\
\hline $\begin{array}{l}\text { AY102 Exhaust Air Flow SETPOINT } \\
\text { FIC-AYZK1-2 O1 RecAY2 }\end{array}$ & & 220 & $N / A$ & Ni/A & N/A & $N / A$ & $\begin{array}{r}\text { N/A } \\
\end{array}$ & $N / A$ & $N / A$ \\
\hline $\begin{array}{l}\text { AY102 EXhaust Air Rlow, } \\
\text { F1-AYZK1-2 (11RecAY2, V) }\end{array}$ & 216.0 & 211 & 215 & 215 & 210 & 210 & $\begin{array}{c}\text { setpoint } \\
\pm 20 \text { scfm } \\
\end{array}$ & $\mathrm{N} / \mathrm{A}$ & 45 \\
\hline
\end{tabular}

\begin{tabular}{|c|c|c|c|c|}
\hline S & 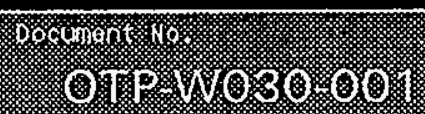 & 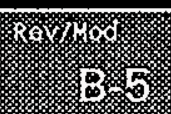 & $9.6 \%$. & 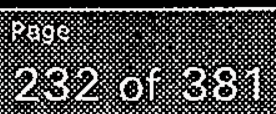 \\
\hline
\end{tabular}

* Report-writer comment: Some dato reflects impossible or inconsistent conditions and is suspect.

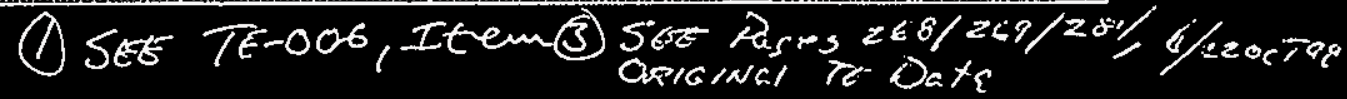


ATTACHMENT B - RECIRC AND HIGH HEAT MODE OPERATIONAL TESTING (Cont.)

TABLE 4-1 AY101 HIGH HEAT Steady State (Continued)

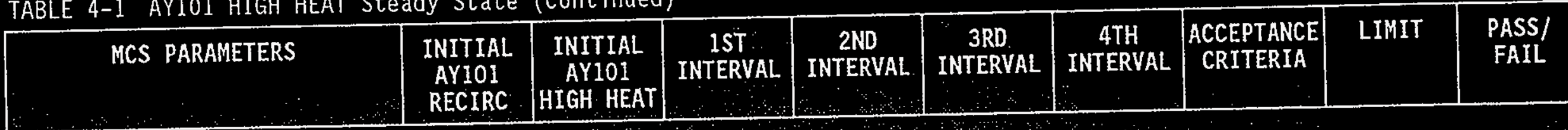

\section{WCS Graphic Screen 12RecAZ1.}

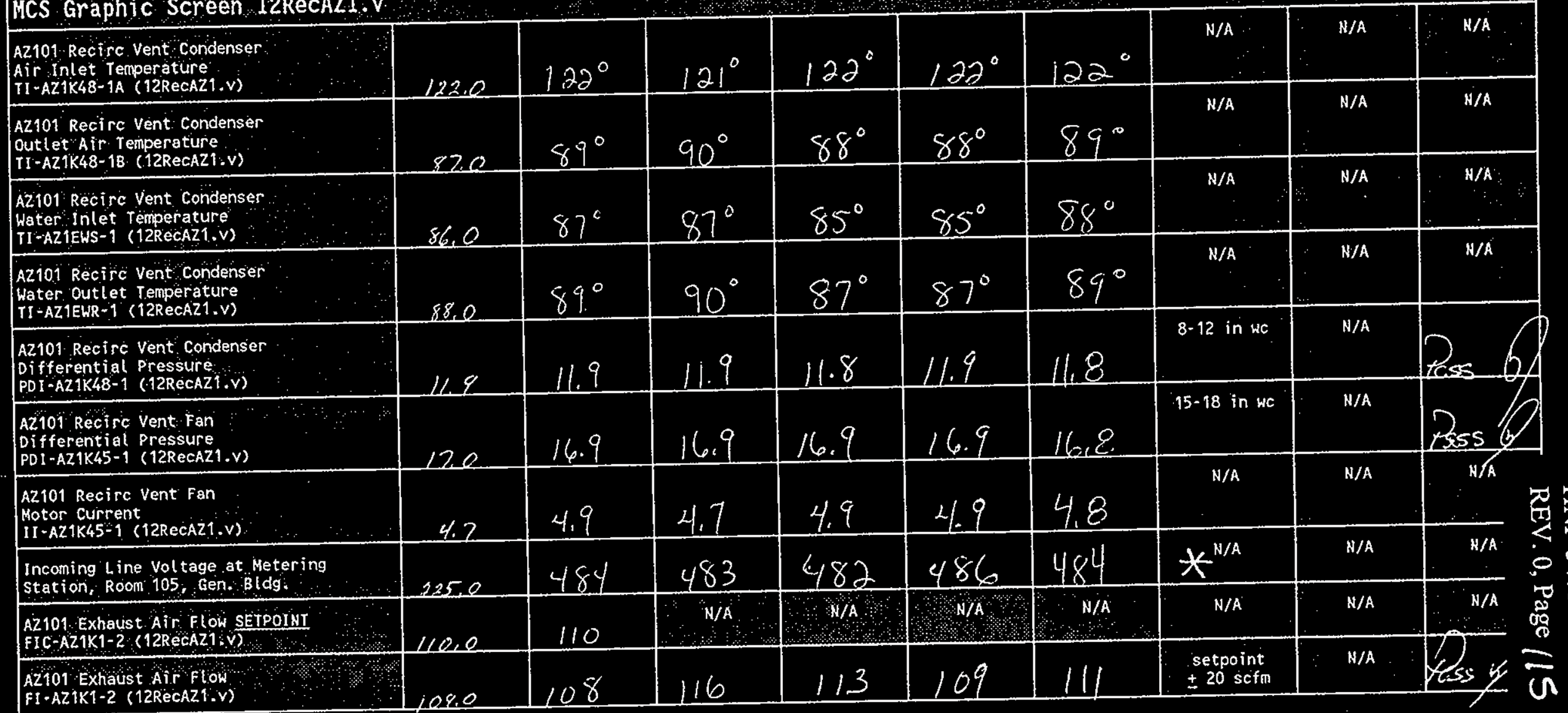

\begin{tabular}{|c|c|c|c|c|}
\hline 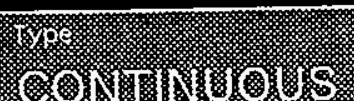 & 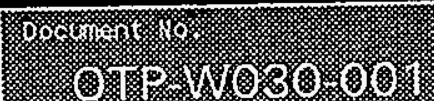 & 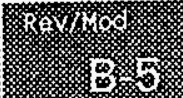 & 等 & 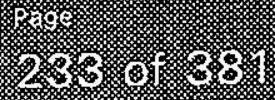 \\
\hline
\end{tabular}


HNF-3473

REV. 0, Page 16

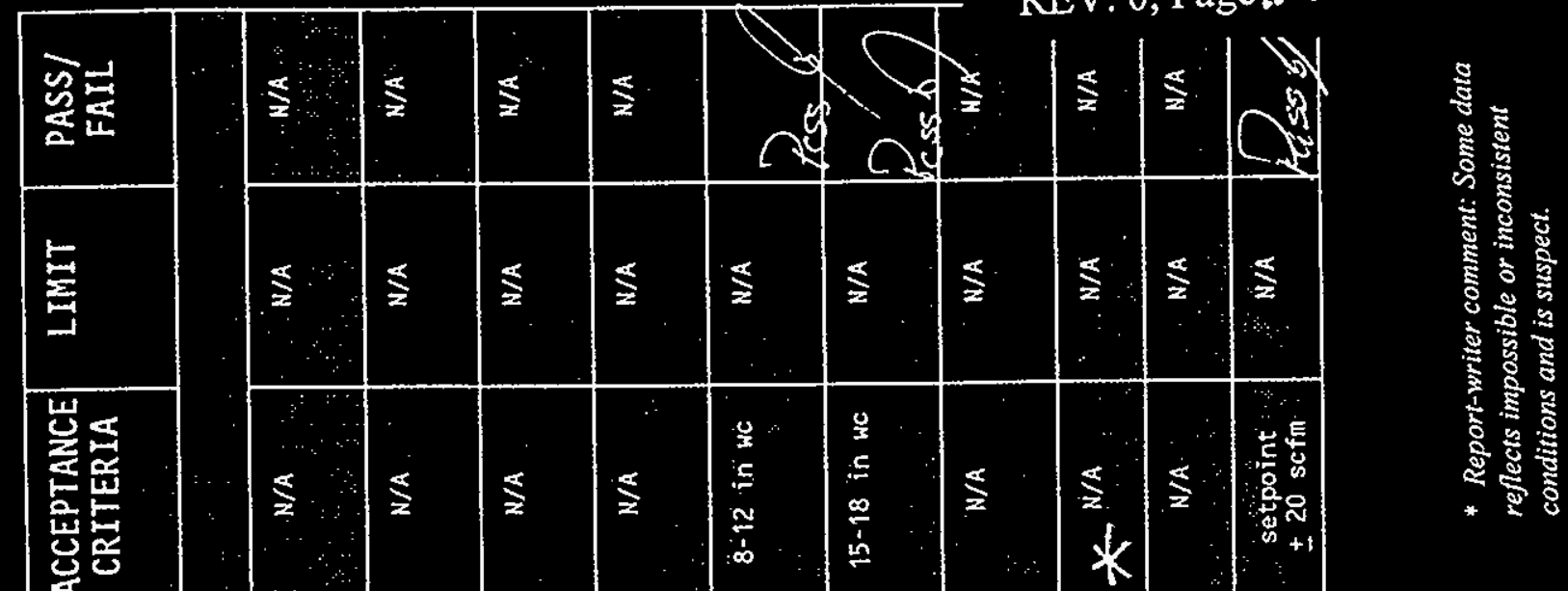

2.

它 岁要

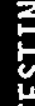

专

豆总

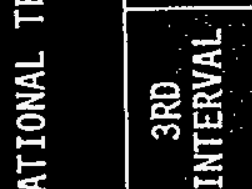

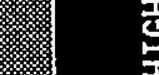

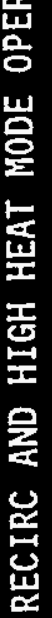

运总

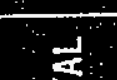

忈

齿

梳

음

起

틀엄

总军焉

1 品

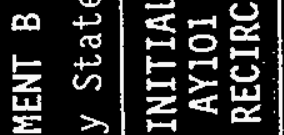

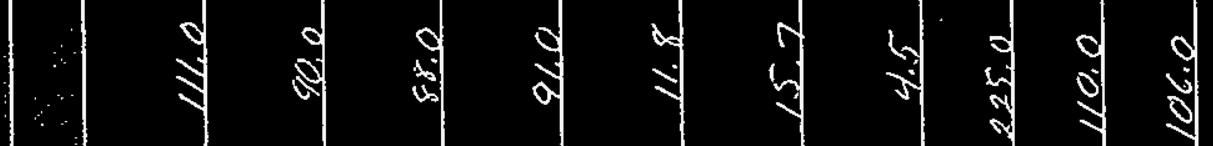

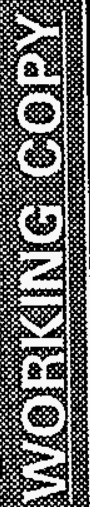

蛋

궁

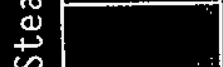

政

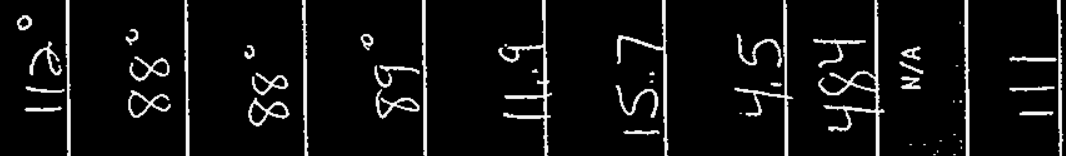

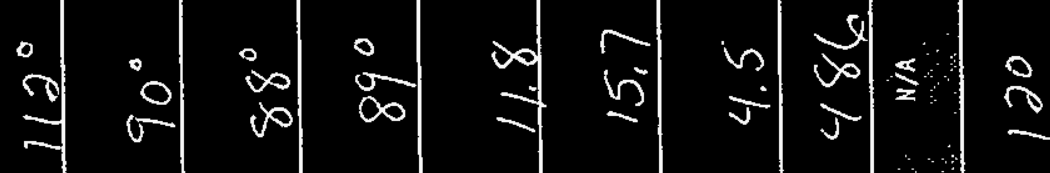

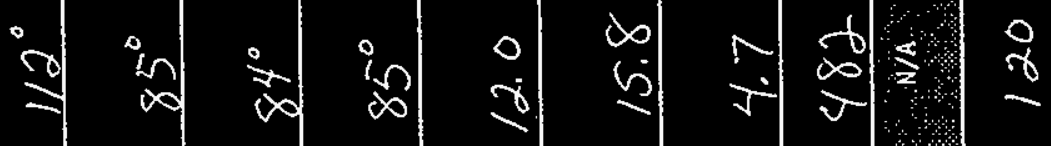

(1)

t)

(5)

‥

:

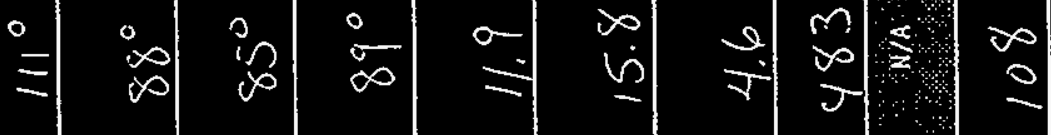

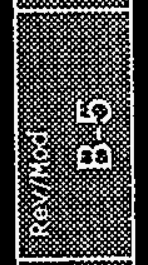

$=\infty \quad i n$ in

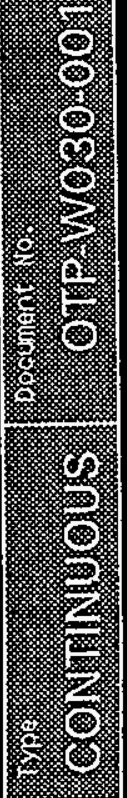



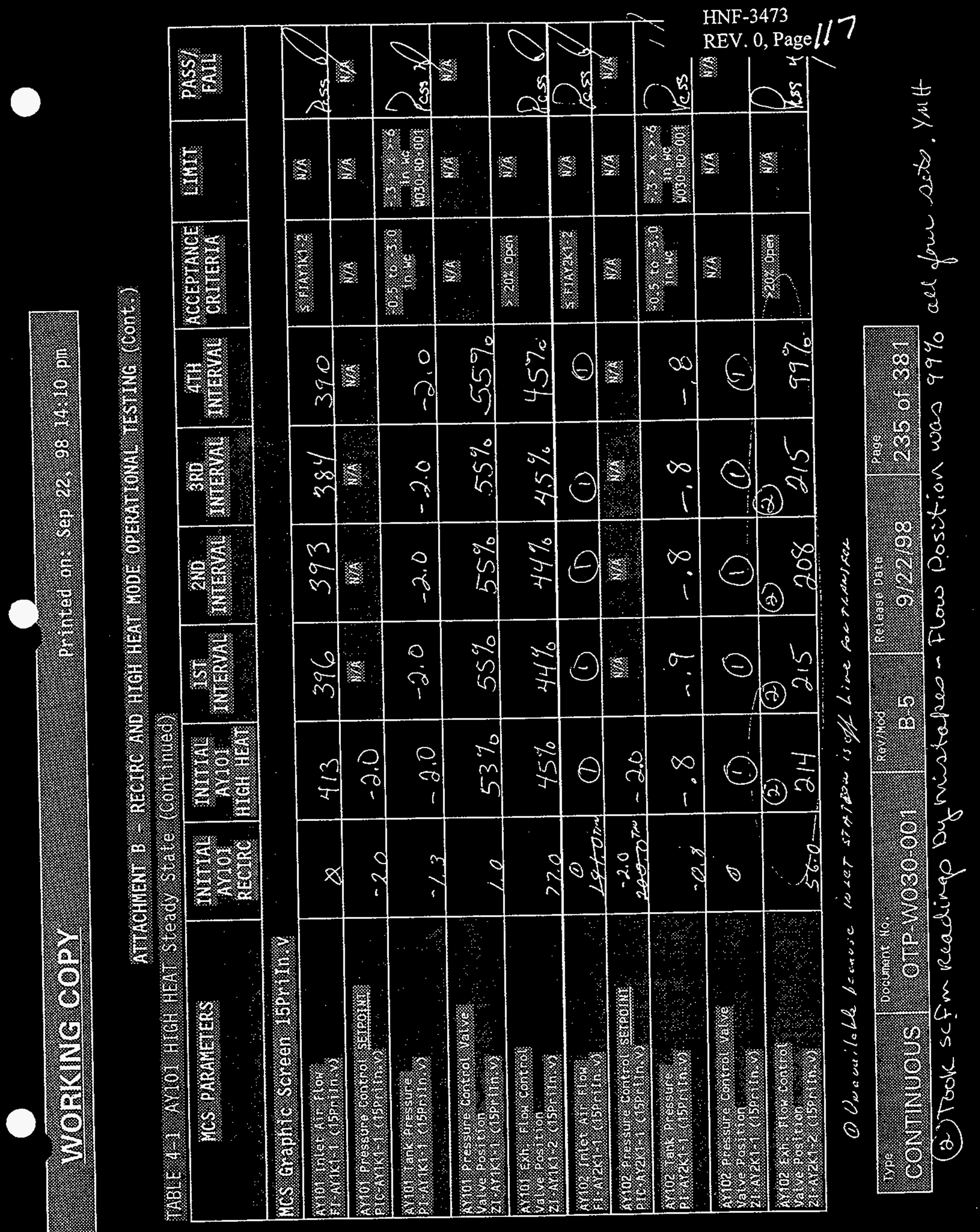
HNF-3473

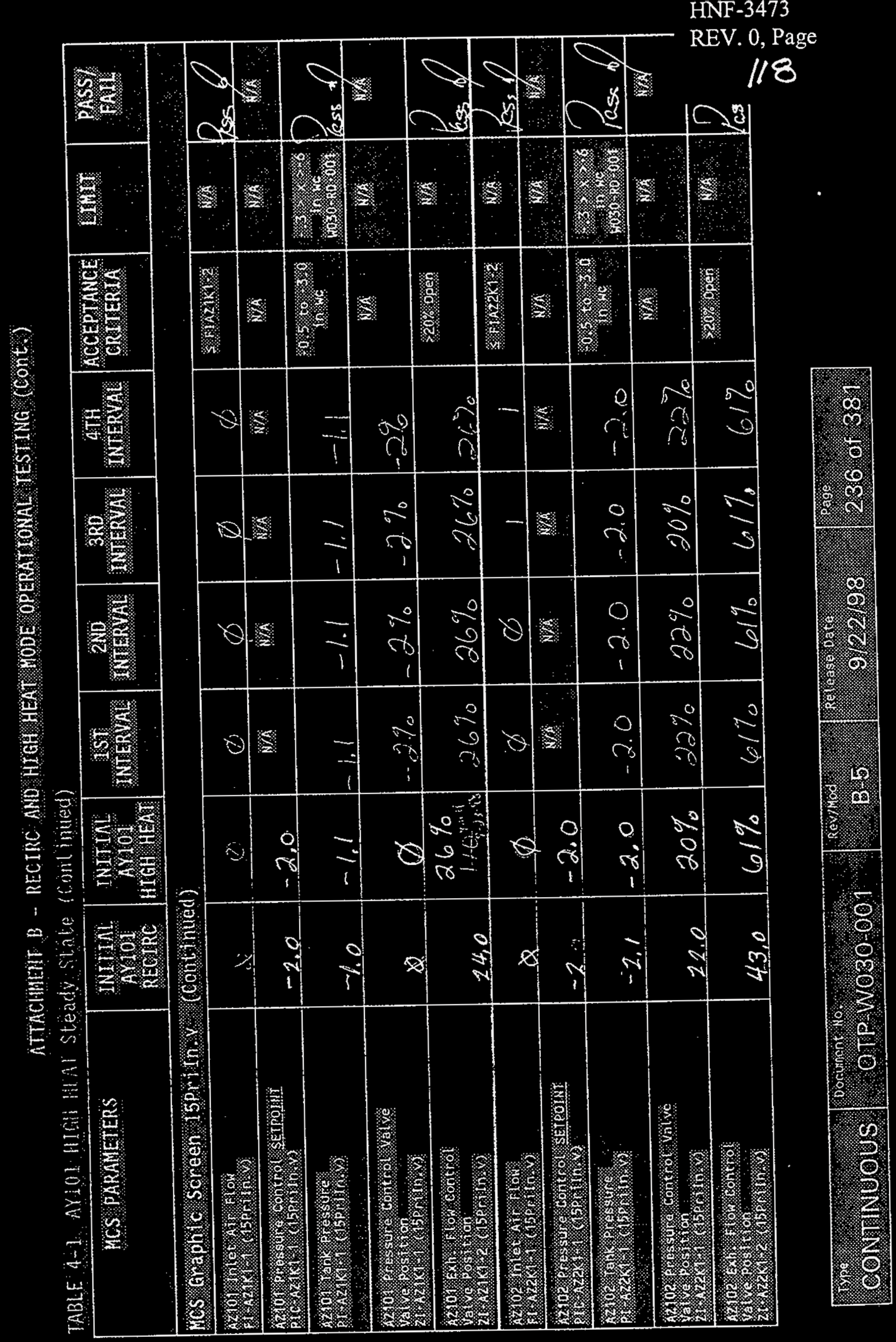


ATTACHAEHT B RECIRC AND HIGH HEAT MODE OPERATIONAL TESTING (Cont.)

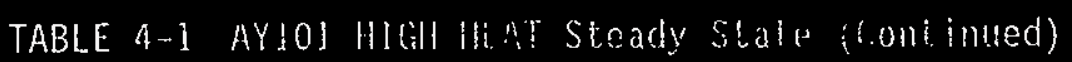

\begin{tabular}{|c|c|c|c|c|c|c|c|c|c|}
\hline MCS PARAMETERS & $\begin{array}{l}\text { INITIAL } \\
\text { AYIOI } \\
\text { RECIRC }\end{array}$ & $\begin{array}{c}\text { INITIAL. } \\
\text { AY } 101 \\
\text { HIGH HEAT }\end{array}$ & $\begin{array}{l}\text { 1ST } \\
\text { INTERVAL }\end{array}$ & $\begin{array}{l}2 N D \\
\text { INTERVAL }\end{array}$ & $\begin{array}{c}\text { 3RD } \\
\text { INTERVAL. }\end{array}$ & $\begin{array}{l}\text { 4TH } \\
\text { INTERVAL }\end{array}$ & $\begin{array}{c}\text { ACCEPTANC } \\
\text { E } \\
\text { CRITERIA }\end{array}$ & LIMIT. & $\begin{array}{l}\text { PASS/ } \\
\text { FAIL }\end{array}$ \\
\hline \multicolumn{10}{|c|}{ WCS Graphic Screen 06EVPAY1.V } \\
\hline $\begin{array}{l}\text { Ay } 101 \text { Recirc Condenser } \\
\text { Cool ing System Flow } \\
\text { SI AY1EWR - } 1 \text { (O6EvpAYi.v) }\end{array}$ & 2.20 & $2.16:$ & 215 & 217 & $.216=$ & 217 & $\frac{180200}{1000}$ & & \\
\hline \multicolumn{10}{|c|}{ HCS Graphic Screen 07EypAY2.V } \\
\hline $\begin{array}{l}\text { AYroz Recirc Condenser } \\
\text { cool ing System Flow } \\
\text { FI-AY2EWR - } 1 \text { (07EvpAY2.v) }\end{array}$ & $215: 0$ & 217 & 218 & 218 & 218 & 219 & $\begin{array}{r}180-200 \\
\% 0 \times 1000 \\
\end{array}$ & & \\
\hline \multicolumn{10}{|c|}{ HCS Graphic Screen 08EvPAZI:V } \\
\hline $\begin{array}{l}\text { Az101 Recirc Condenser } \\
\text { Coot ing System Flow } \\
\text { F1-AZ1EWR-1 (08EvpAZ1.v) }\end{array}$ & $25) 0$ & 333 & 335 & 334 & 335 & 3.33 & 300.335 & $H / \mathrm{A}$ & \\
\hline \multicolumn{10}{|c|}{ MCS Graphic Screen O9EvPAZZ.V } \\
\hline $\begin{array}{l}\text { Az102 Recirc Condenser } \\
\text { Cool ing Systen Flow } \\
\text { P1-AZ2EWR-1 (09EvpAZ2.v) }\end{array}$ & 203. & 2.24 & 226 & 225 & 225 & 225 & $\begin{array}{c}180-200 \\
100\end{array}$ & $n / \mathrm{A}$ & \\
\hline
\end{tabular}

\begin{tabular}{|c|c|c|c|c|}
\hline 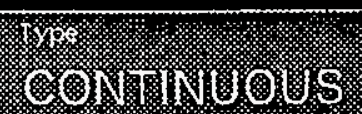 & 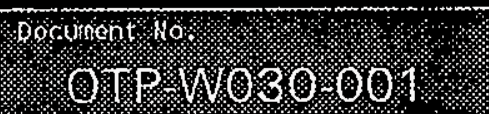 & 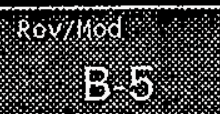 & 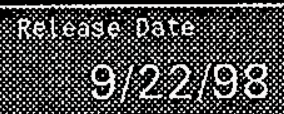 & 管 \\
\hline
\end{tabular}


ATTACHMENT B - RECIRC AND HIGH HEAT MODE OPERATIONAL TESTING (Cont.)

TABLE 4-1 AY101 HIGH HEAT Steady State (Continued)

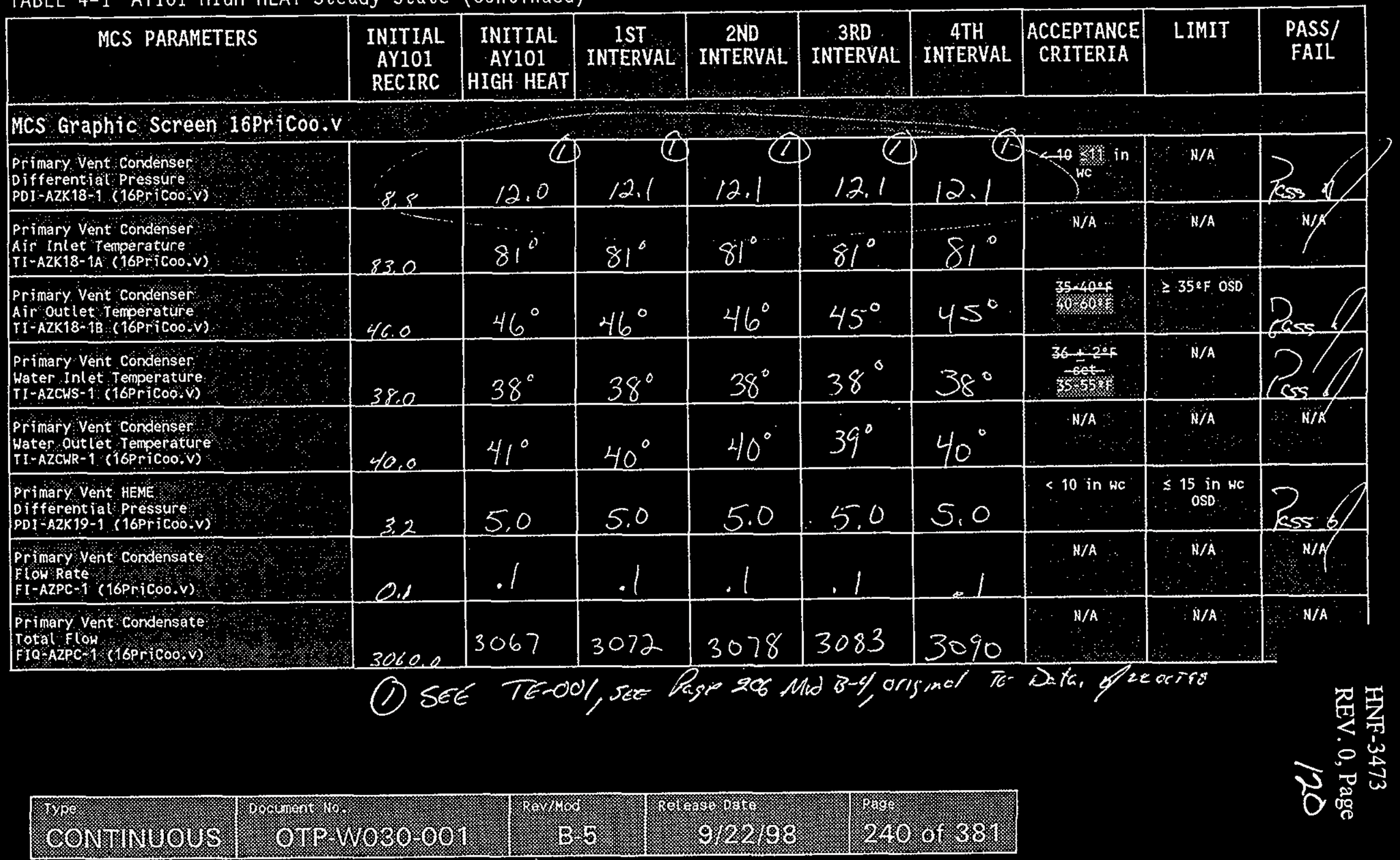




\section{MORKINIE COPY}

ATTACHAEMT B - RECIRC AND HIGH HEAT MODE OPERATIONAL TESTING (Cont.)

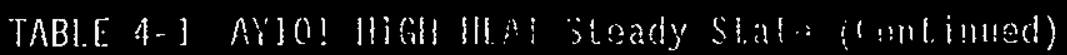

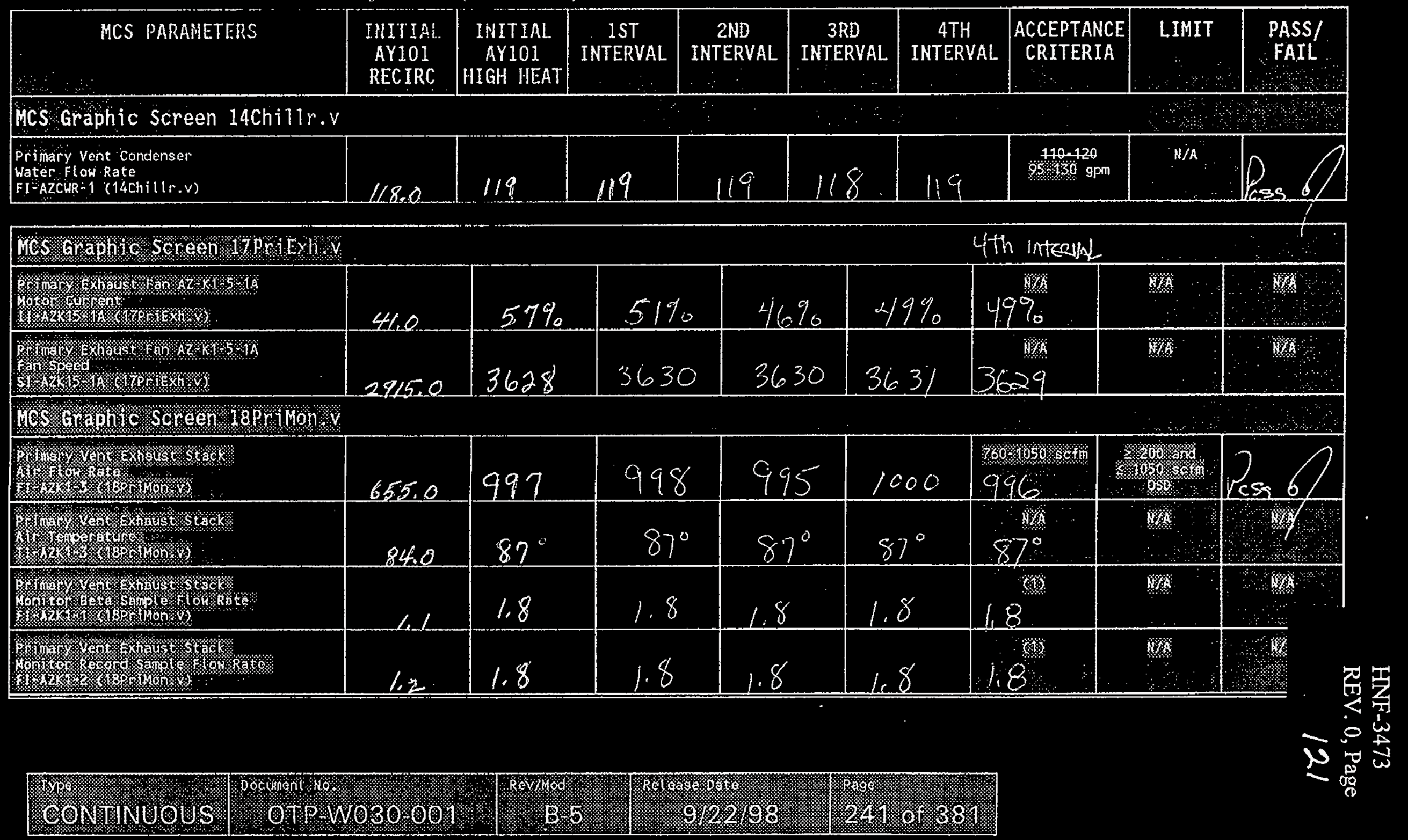


ATTACHMEIT B -. RICIRC AND HIGH HEAT MODE OPERATIONAL TESTING (Cont.)

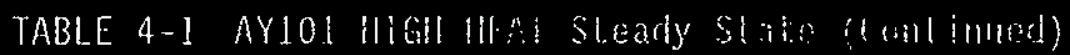

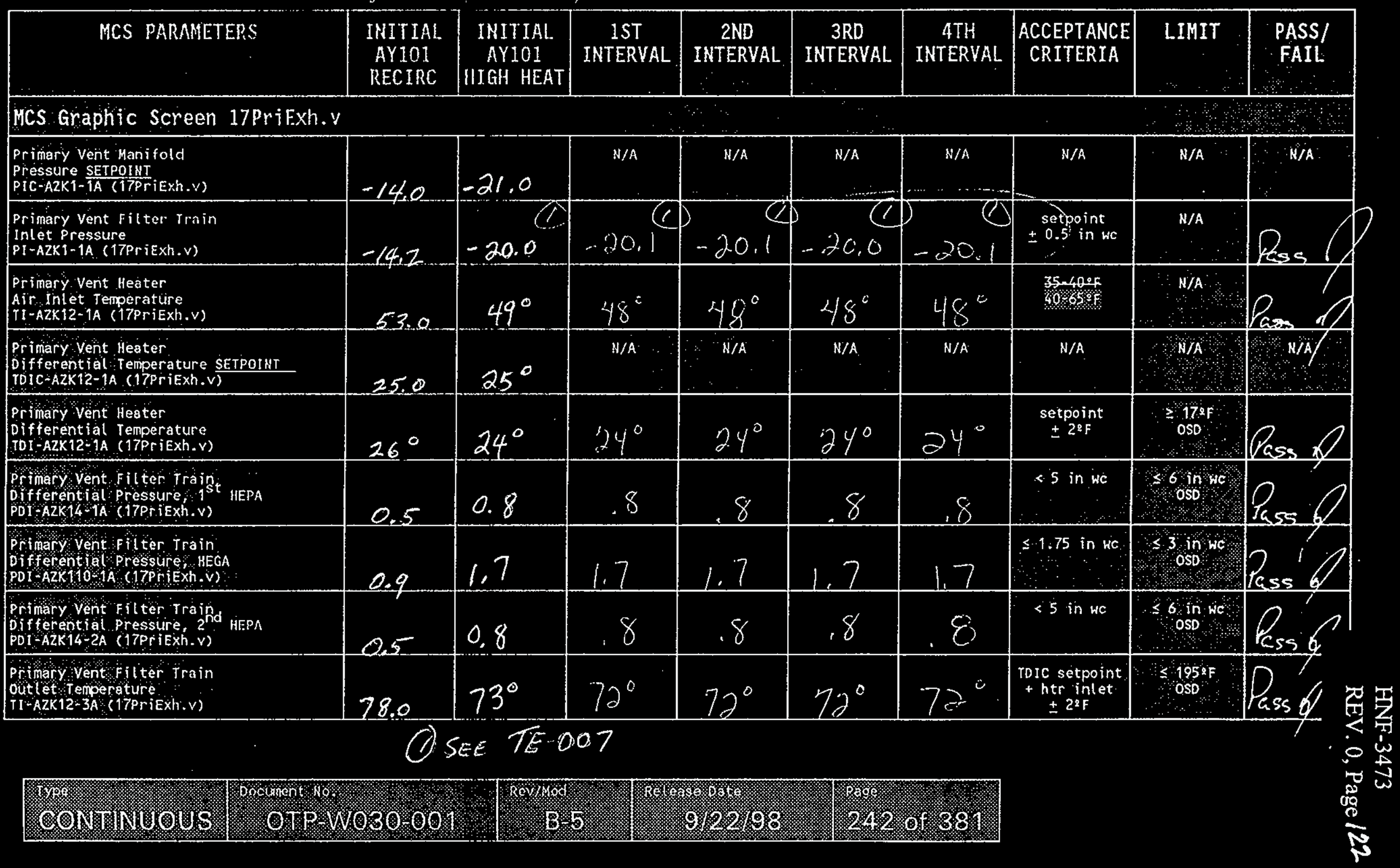




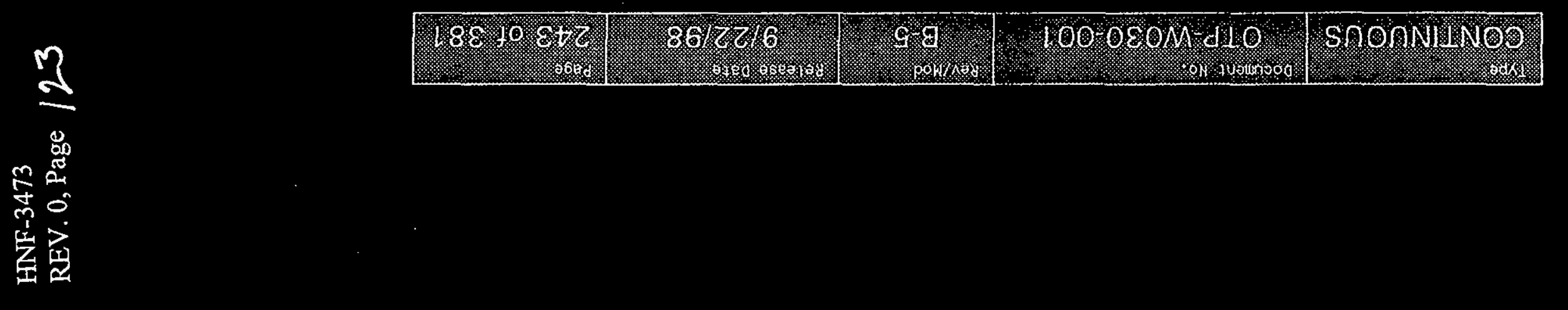

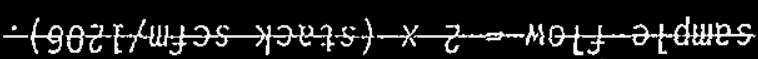

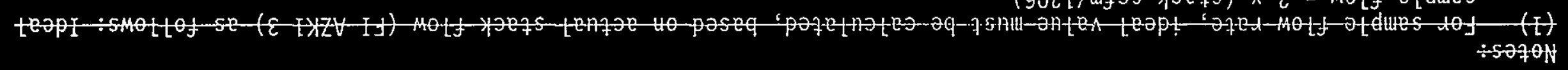

\begin{tabular}{|c|c|c|c|c|c|c|c|c|c|}
\hline 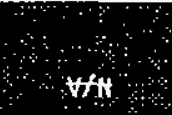 & $\forall /$ & $t \rightarrow$ & & & 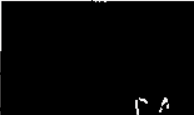 & & & & 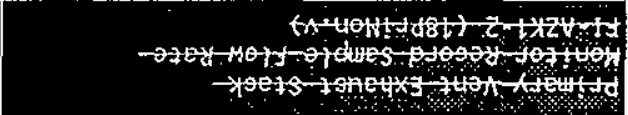 \\
\hline at+o & $\because H$ & $t \rightarrow$ & & & & & & & 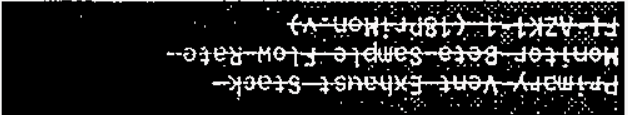 \\
\hline \multirow[t]{2}{*}{$\therefore \quad \forall A$} & $\forall$ & $\forall A H$ & & & & 7 & & & 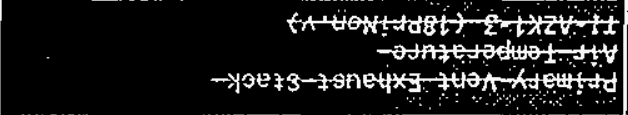 \\
\hline & 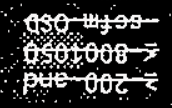 & 000000009 & & & & & & & 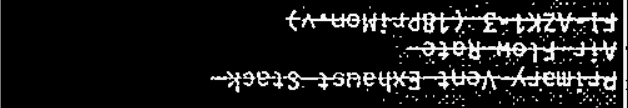 \\
\hline a & - & & & $\therefore$ & & & & & 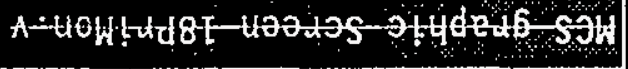 \\
\hline 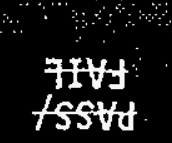 & $\pm+1+7$ & $\begin{array}{c}\forall+43 \pm 189 \\
\text { ב3NYLd }\end{array}$ & 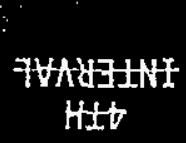 & $\begin{array}{c}\text { FhadzAnI } \\
\text { aye }\end{array}$ & $\begin{array}{c}\text { FHAJANI } \\
\text { GNE }\end{array}$ & $\begin{array}{c}7 \forall A+3 \pm N E \\
\pm S E\end{array}$ & $\begin{array}{c}\text { AHJH-HOIH } \\
\text { FOLAV } \\
7 \mathrm{HI-TNI}\end{array}$ & 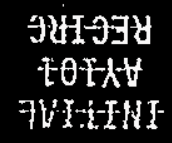 & $54-1 \mathrm{H}$ - \\
\hline
\end{tabular}

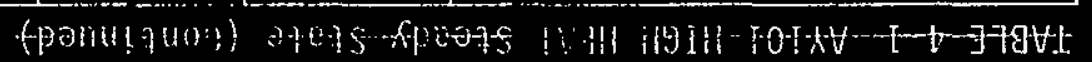

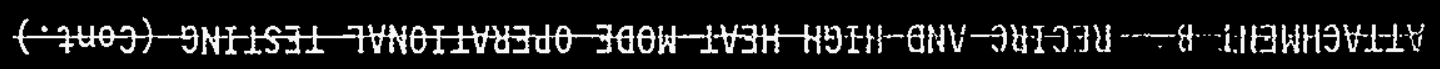


ATTACHENT B ... RICCYRC AND HIGH HEAT MODE OPERATIONAL TESTING (CONt.)

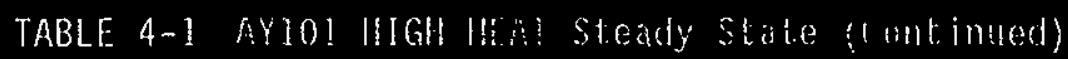

\begin{tabular}{|c|c|c|c|c|c|c|c|c|c|}
\hline $\begin{array}{l}\text { LOCAL PARAMETERS } \\
\end{array}$ & $\begin{array}{l}\text { INITIAL } \\
\text { AYI01 } \\
\text { RECIRC }\end{array}$ & $\begin{array}{c}\text { INITIAL } \\
\text { AY10I } \\
\text { HIGH HEAT }\end{array}$ & $\begin{array}{l}\text { IST } \\
\text { INTERVAL }\end{array}$ & $\begin{array}{l}\text { 2ND } \\
\text { INTERVAL }\end{array}$ & $\begin{array}{l}\text { 3RD } \\
\text { INTERVAL }\end{array}$ & $\begin{array}{l}\text { 4TH } \\
\text { INTERVAL }\end{array}$ & $\begin{array}{c}\text { ACCEPTANCE } \\
\text { CRITERIA }\end{array}$ & $\begin{array}{l}\text { LIHIT } \\
\therefore \\
\vdots\end{array}$ & PASS/ \\
\hline $\begin{array}{l}\text { Arjo1 Air Inlet station } \\
\text { Inlet Temperature } \\
\text { fic-AY101k102-1. }\end{array}$ & (a) & $a$ & & & & (1) & $N / A$ & W/A & NA b) \\
\hline $\begin{array}{l}\text { AY101 Air Inlet Station } \\
\text { Preffiterd Differential Pressure } \\
\text { PDI AY } 101 \mathrm{~K} 103-1\end{array}$ & $\lambda$ & 0.1 & $0_{\infty} 9$ & 0.9 & 9 & $: 9$ & No alarm & $\therefore N$ & \\
\hline $\begin{array}{l}\text { AY101 Air inlet station } \\
\text { HEPA Differential Pressure } \\
\text { PDI AY AY } 01 \mathrm{~K} 104-1\end{array}$ & $\therefore$ & 0.5 & 0.5 & 0.5 & & 5 & No alarm & N/A & \\
\hline $\begin{array}{l}\text { Ay } 102 \text { Air Inlet station } \\
\text { Inlet Temperature } \\
\text { IIC-AY 102K102-1 }\end{array}$ & 0 & $1 .$. & & & ） & $(j)$ & $N / A$ & $\mathrm{~N} / \mathrm{A}$ & \\
\hline $\begin{array}{l}\text { AY102 Air Inlet station } \\
\text { Prettilter Differential Pressure } \\
\text { PO1-AY102K103-1 }\end{array}$ & $d$ & 0.0 .2 & 0,01 & 0.01 & .01 & .01 & No alarm & is & Pass \\
\hline $\begin{array}{l}\text { Ar102 Air Inlet station } \\
\text { HEPA Differential Pressure } \\
\text { PDI DAY } 02 \times 104-1 \text {. }\end{array}$ & 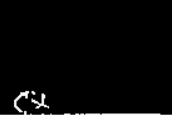 & 0.3 & 0.3 & 0.3 & .3 & 3 & No alarm & $\mathrm{N} / \mathrm{A}$ & $\operatorname{kg} \theta$ \\
\hline
\end{tabular}

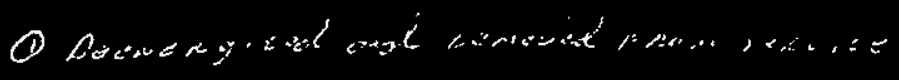

\begin{tabular}{|c|c|c|c|c|}
\hline 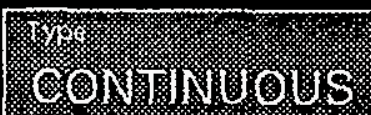 & 年 & F r & 1. & 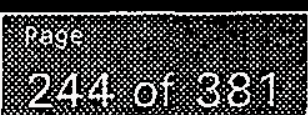 \\
\hline
\end{tabular}


ATTACHMENT B - RECIRC AND HIGH HEAT MODE OPERATIONAL TESTING (Cont.)

TABLE 4-1 AYIOI HIGH HIA! Sleady Släe (tumlinued)

\begin{tabular}{|c|c|c|c|c|c|c|c|c|c|}
\hline $\begin{array}{l}\text { LOCAL PARAMETERS } \\
\end{array}$ & $\begin{array}{l}\text { INITIAL } \\
\text { AYIOI } \\
\text { RECIRC }\end{array}$ & $\begin{array}{l}\text { INITIAL } \\
\text { AYIOI } \\
\text { HIGH HEAT }\end{array}$ & $\begin{array}{l}\text { IST } \\
\text { INTERVAL }\end{array}$ & INTERVAL & $\begin{array}{l}\text { 3RD } \\
\text { INTERVAL }\end{array}$ & $\begin{array}{l}\text { 4TH } \\
\text { INTERYAL }\end{array}$ & $\begin{array}{c}\text { ACCEPTANCE } \\
\text { CRITERIA } \\
\end{array}$ & $\begin{array}{r}\text { LIMTT } \\
0 \\
\end{array}$ & $\begin{array}{l}\text { PASS/ } \\
\text { FAIL }\end{array}$ \\
\hline $\begin{array}{l}\text { Az101 Air finlet Station } \\
\text { Inlet Temperature } \\
\text { IIC A 101K 102:1. }\end{array}$ & G & (1) & (i) & & & & $N / A$ & $\mathrm{~N} / \mathrm{A}$ & \\
\hline $\begin{array}{l}\text { Az101 Ain thlet Station } \\
\text { Pre tilter Differential Pressure } \\
\text { PDI AZ101k103.1 }\end{array}$ & $d$ & $Q$ & 4 & $\sigma$ & $r$ & $e$ & No alarm & $\mathrm{N} / \mathrm{A}$ & \\
\hline 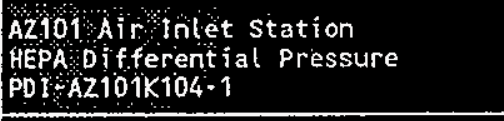 & 2 & \% & $\phi$ & $\varnothing$ & $\theta$ & $e$ & No alarm & $N / A$ & \\
\hline $\begin{array}{l}\text { A2102 Air Inlet station } \\
\text { Inlet: Temperature } \\
\text { ITC-AZ102K102-1 }\end{array}$ & 0 & $(1)$ & 1) & & 1) & & $N / A$ & $\begin{array}{l}\mathrm{N} / \mathrm{A} \\
\therefore\end{array}$ & \\
\hline $\begin{array}{l}\text { A2102 Air Inlet station } \\
\text { Pre filter Differential pressure } \\
\text { PDI Az102K103-1 }\end{array}$ & $d$ & 4 & $d$ & $\phi$ & do & $E$ & No alarm & W/A & ke \\
\hline $\begin{array}{l}\text { A2102 Air Inlet station } \\
\text { HEPA oifferential Pressure } \\
\text { PD. } 1 \text { A2102K104-1. }\end{array}$ & $\xi i$ & $d$ & $\phi$ & 舟 & (1) & $E$ & Ho alarm & $\mathrm{N} / \mathrm{A}$ & \\
\hline
\end{tabular}

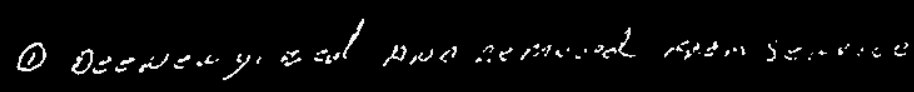

\begin{tabular}{|c|c|c|c|c|}
\hline 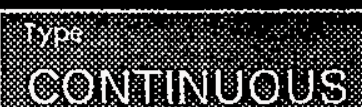 & 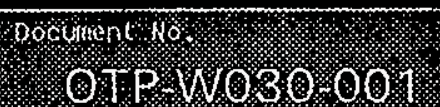 & 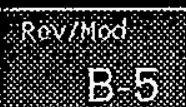 & 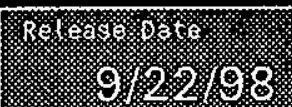 & 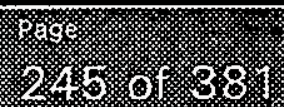 \\
\hline
\end{tabular}


ATACHMEH? O- RECIRC AND HIGH HEAT MODE OPERATIONAL TESTING (Cont.)

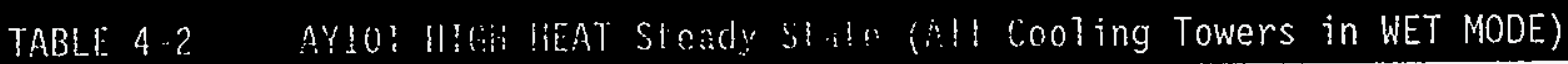

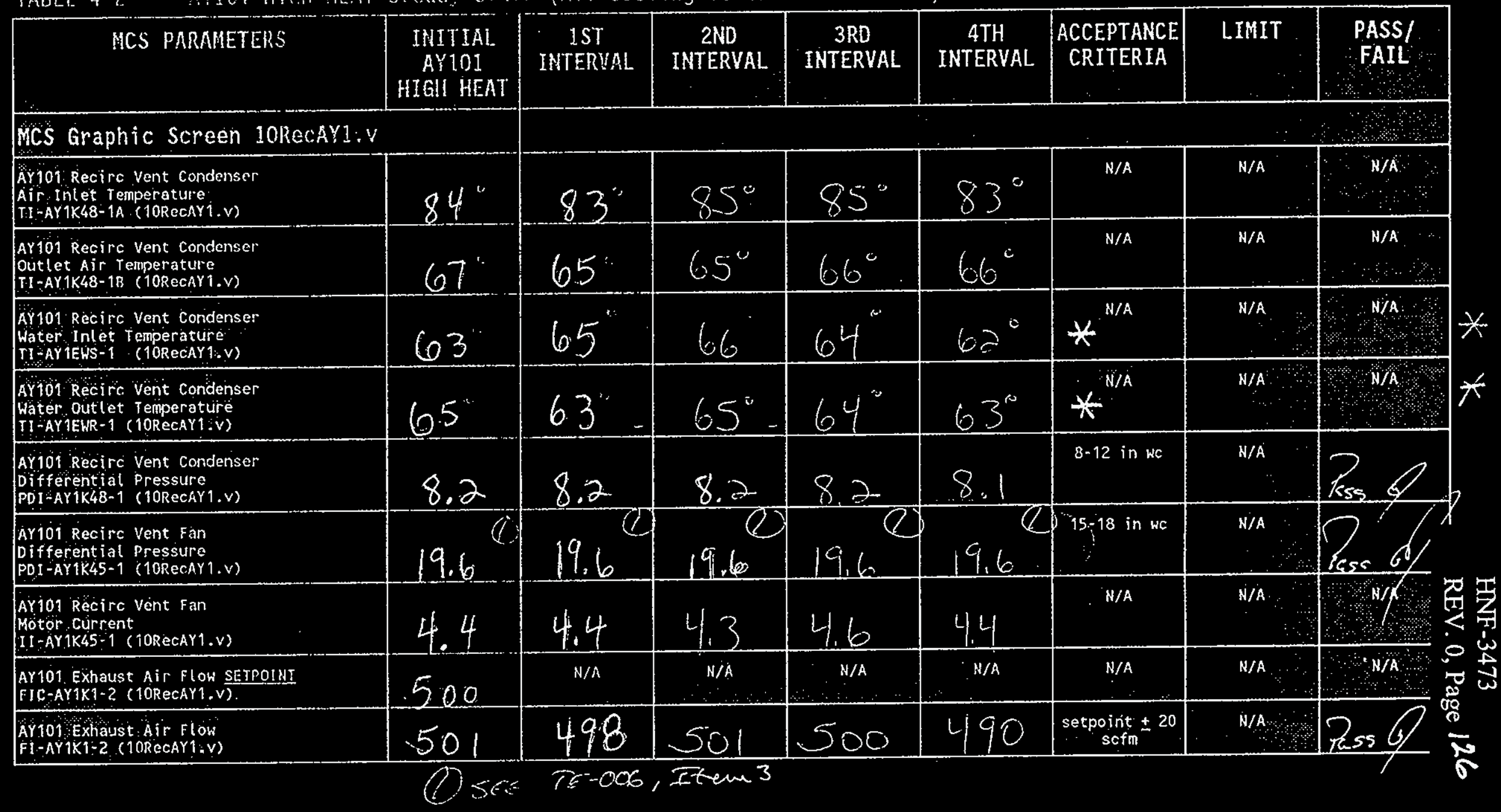

\begin{tabular}{|c|c|c|c|c|}
\hline 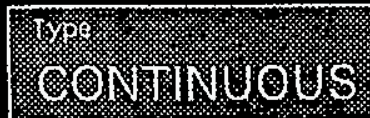 & 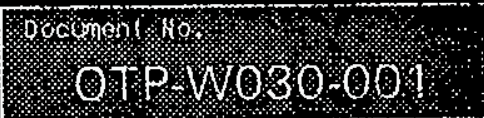 & 6. & 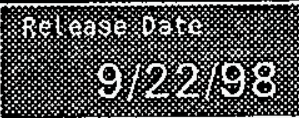 & 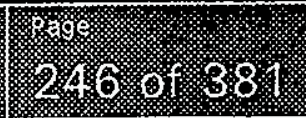 \\
\hline
\end{tabular}

* Report-writer comment: Some data reflects impossible or inconsistent conditions and is suspect. 
ATTACHHEMII B - RECIRC AID HIGH HEAT MODE OPERATIONAL TESTING (CONt.)

TABLE 4-2 AY101 HIH HEAT SEeady Siate (A11 Cooling Towers in WET MODE, Continued)

\begin{tabular}{|c|c|c|c|c|c|c|c|c|}
\hline MCS PARAMETERS & $\begin{array}{c}\text { INITIAL } \\
\text { AY101 } \\
\text { HIGH HEAT }\end{array}$ & $\begin{array}{l}1 S T \\
\text { INTERVAL }\end{array}$ & $\begin{array}{l}\text { 2ND } \\
\text { INTERVAL }\end{array}$ & $\begin{array}{l}\text { 3RD } \\
\text { INTERVAL }\end{array}$ & $\begin{array}{l}\text { 4TH } \\
\text { INTERVAL }\end{array}$ & $\begin{array}{c}\text { ACCEPTANCE } \\
\text { CRITERIA }\end{array}$ & LIMIT & $\begin{array}{l}\text { PASS/ } \\
\text { FAIL }\end{array}$ \\
\hline \multicolumn{9}{|c|}{ MCS Graphic Screen O6EVPAYI.V } \\
\hline $\begin{array}{l}\text { Ay } 101 \text { Recirc Condenser } \\
\text { Cool ing System Flow } \\
\text { Fl AYYEWR-1 (O6EvpAY1.V) }\end{array}$ & 214 & 214 & 215 & 215 & 216 & 180.200 & $\mathbb{N} / \dot{A}$ & \\
\hline \multicolumn{9}{|c|}{ WCS Graphic Screen 07EvpAY2.V } \\
\hline $\begin{array}{l}\text { AY } 102 \text { Recirc Condenser } \\
\text { Cool ing System flow } \\
\text { FI-AYZEHR-1 (O7EvpAY2.v) }\end{array}$ & 218 & 218 & 218 & 200 & $2 ; 9$ & $\begin{array}{l}180.200 \\
180 \% 3009\end{array}$ & N/A & \\
\hline \multicolumn{9}{|c|}{ HCS Graphic Screen 08Evpaz1.V } \\
\hline $\begin{array}{l}\text { Az 101 Recirc Condenser } \\
\text { Cool ing System Flow } \\
\text { fI-AZ1EHR-1 (OBEVPAZ1.V) }\end{array}$ & 334 & 333 & -333 & 333 & 3.35 & $\begin{array}{l}300.335 \\
300-5689 m\end{array}$ & $N / A$ & \\
\hline \multicolumn{9}{|c|}{ HCS Graphic Screen 09EvpAZZ.V } \\
\hline $\begin{array}{l}\text { AZ102 Recirc Conderiser } \\
\text { Cooling system Flow } \\
\text { KI_AZ2EHR-1 (09EvpAZ2.v) }\end{array}$ & 201 & 225 & $=22$ & 225 & 227 & $\frac{180.200}{190-200 \mathrm{gpm}}$ & N/A & 25 \\
\hline
\end{tabular}

WCS Graphic Screen 14Chi11r.v

Pr timary Vent Condenser

chiller cooling Flow Rate

FI-AZCWR-1 (14Chill(r.V)

119

119

118

$119+118$

$410-120$

95.780 gpm

$\int_{\text {ass }}$

\begin{tabular}{|c|c|c|c|c|}
\hline - & 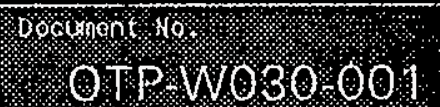 & 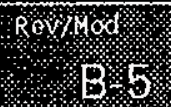 & 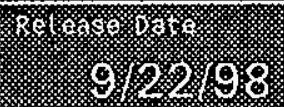 & 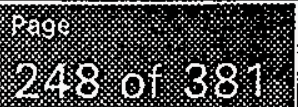 \\
\hline
\end{tabular}




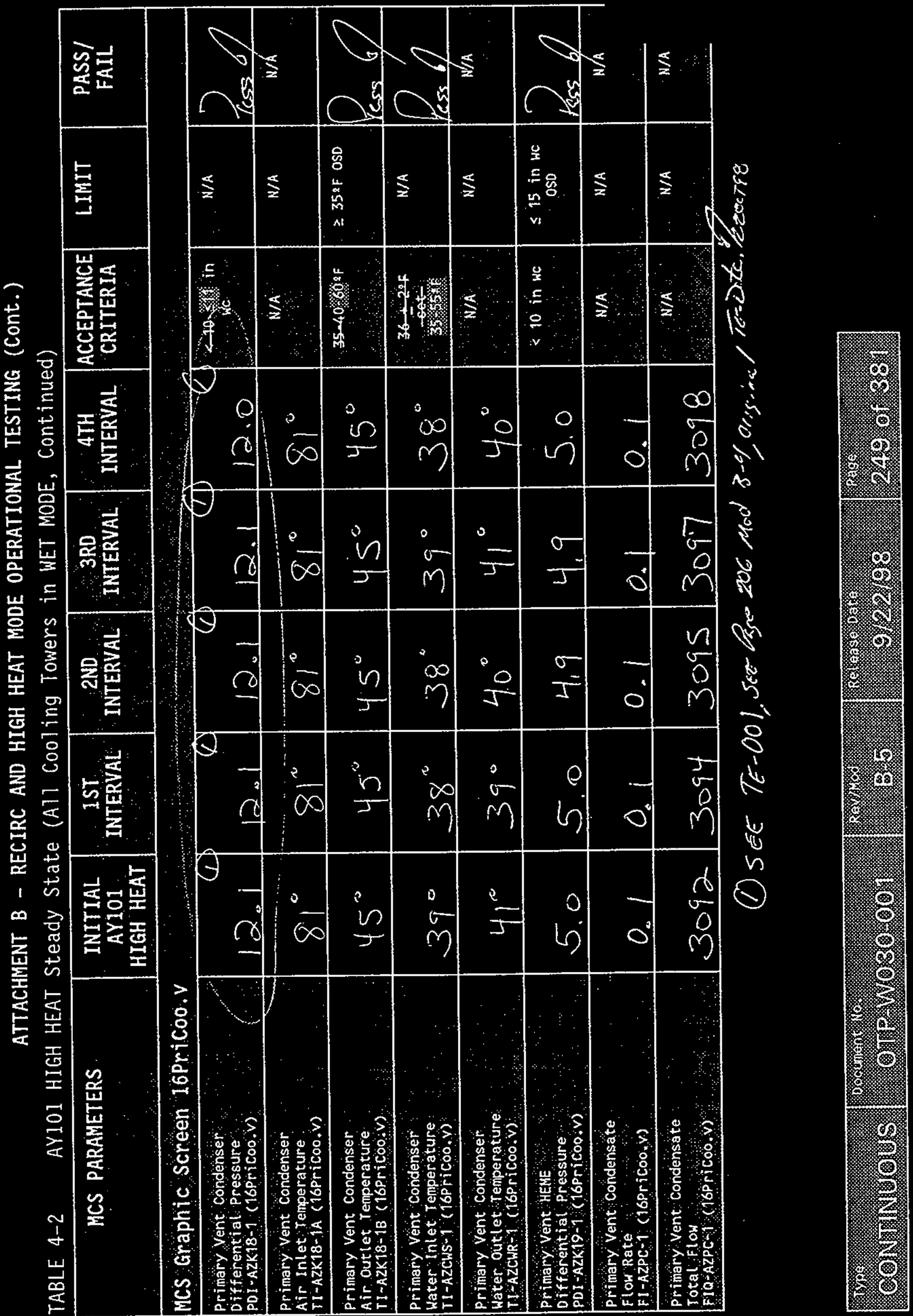


HNF-3473

REV. 0, Page 130

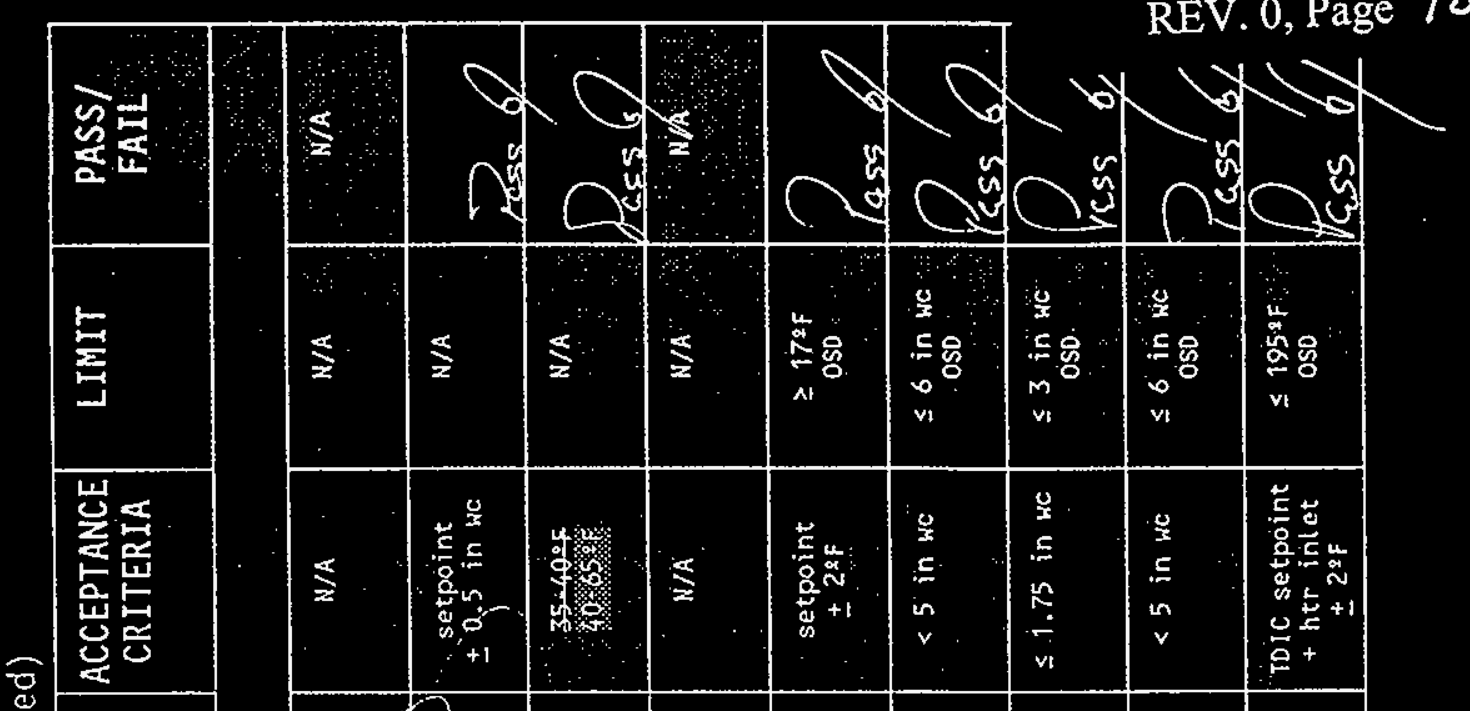

;

格

何約

ర格

管:

$\stackrel{\mathrm{O}}{\mathrm{S}}$

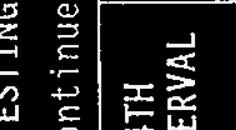

, 0 \&

녕

竞至

岁 品岕

山 $匚 \cong$

웅 乞

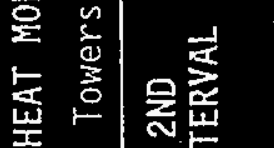

定豆

보응

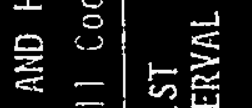

巳 $\equiv$

宓 $=$

.

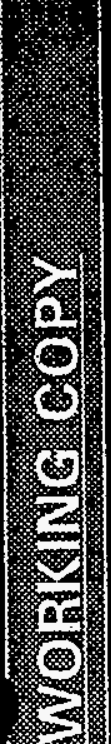

! 沙要

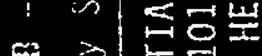

$5 \bar{c}=$

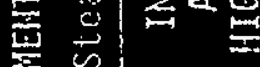

紫

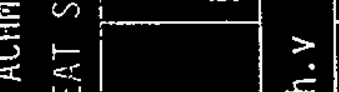

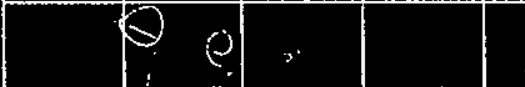

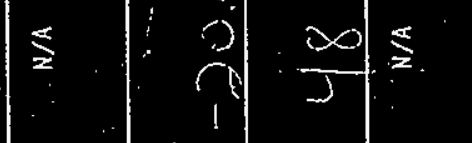

s.

$\vartheta$

\begin{tabular}{ll|l|l|}
0 & $\vdots$ \\
0 & 0 & 0
\end{tabular}

$\begin{array}{lll}3 & 0 & 5\end{array}$

$\infty$

s.t.

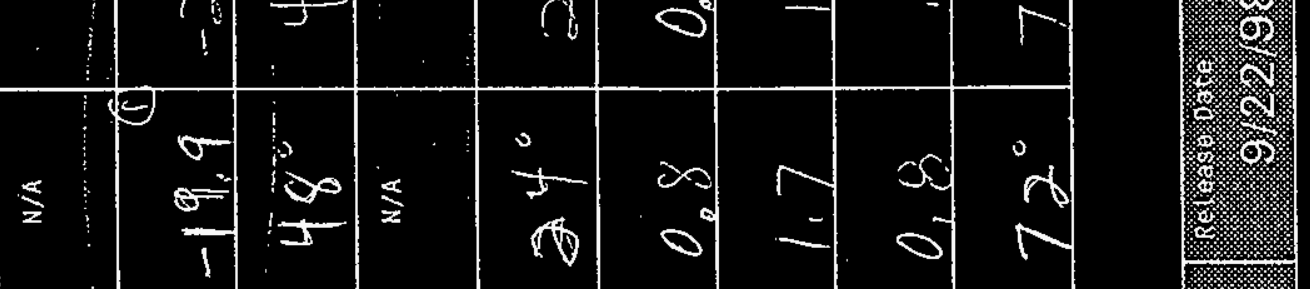

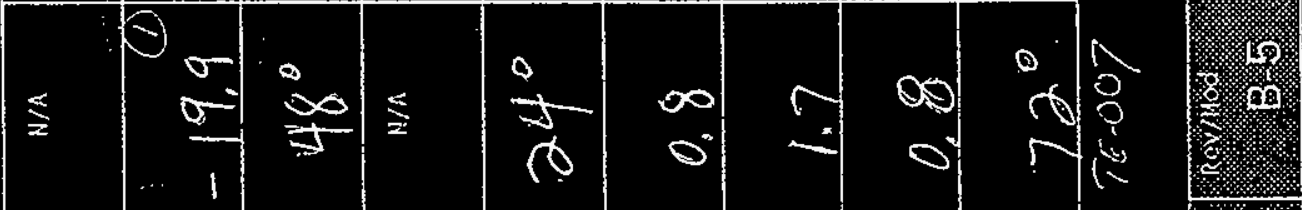

\begin{tabular}{l|l|l|l|l|l|l|l|}
\hline 0 & 0 & 0 & & & & \\
\hline
\end{tabular}

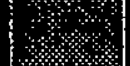

$\Rightarrow \infty \infty$ in $\infty+\infty$

,

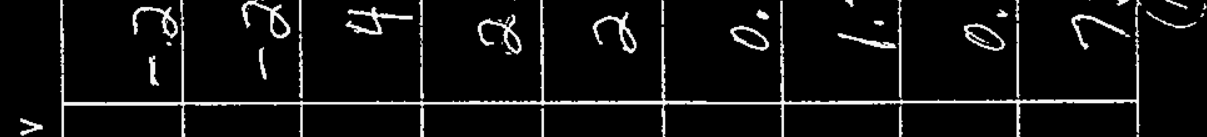

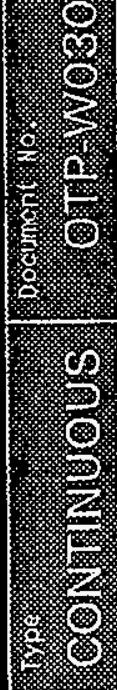


ATTACHAENT B - RECIRC AND HIGH HEAT MODE OPERATIONAL TESTING (Cont.)

TABLE 4-2 AY101 IIIGi HEAT Slearly Stile (Al] Cooling Towers in WET MODE, Continued)

\begin{tabular}{|c|c|c|c|c|c|c|c|c|}
\hline MCS PARAMETERS & $\begin{array}{l}\text { INITIAL } \\
\text { AY101 } \\
\text { HIGH HEAT }\end{array}$ & $\begin{array}{c}\text { 1ST } \\
\text { INTERVAL }\end{array}$ & $\begin{array}{l}\text { 2ND } \\
\text { INTERVAL }\end{array}$ & $\begin{array}{l}\text { 3RD } \\
\text { INTERVAL }\end{array}$ & $\begin{array}{l}\text { 4TH } \\
\text { INTERVAL }\end{array}$ & $\begin{array}{l}\text { ACCEPTANCE } \\
\text { CRITERIA }\end{array}$ & LIMIT & $\begin{array}{l}\text { PASS/ } \\
\text { FAIL }\end{array}$ \\
\hline \multicolumn{9}{|c|}{ MCS graphic Screen 18Prition.v } \\
\hline $\begin{array}{l}\text { Prifiary Vent Exhaust stack } \\
\text { Air Floh Rate } \\
\text { FI-AZK1-3:(18Primon.v) }\end{array}$ & 99.2 & 999 & 1002 & 997 & 999 & $\begin{array}{c}760-2401050 \\
\mathrm{scfm}\end{array}$ & $\begin{array}{l}\geq 200 \text { and } \\
\leq 800 \text { jogs } \\
\text { scfos os } \\
\text { oso }\end{array}$ & \\
\hline $\begin{array}{l}\text { Primary Vent Exhaust Stack } \\
\text { Air Temperature } \\
\text { II AzK1-3 (18PriMon.v) }\end{array}$ & $87^{\circ}$ & $87^{\circ}$ & $87^{\circ}$ & $87^{\circ}$ & $86^{\circ}$ & $N / A$ & $\mathrm{H} / \mathrm{A}$ & \\
\hline $\begin{array}{l}\text { Pringry vent Exhaust stack } \\
\text { Wonitor Beta Sample Flow Rate } \\
\text { B AZK1-1. (18Primon.v) }\end{array}$ & 1,8 & 1.8 & 1.8 & 1.8 & $1 . \varepsilon^{\prime}$ & (1) & $\mathrm{KrA}$ & $\mathrm{W} / \mathrm{A}$ \\
\hline $\begin{array}{l}\text { Ponary vent Exthuist Stack } \\
\text { Monitor Record saimple Flow Rate } \\
\text { F-AZK1-2 (18Primon.V) }\end{array}$ & 1.8 & 1.8 & 1.8 & 1.8 & 1.8 & (1) & $\begin{array}{c}H / A \\
\because\end{array}$ & $\mathrm{H} / \mathrm{A}$ \\
\hline
\end{tabular}

Notes:

(1) For sample flow rate, ideal value must be calculated, based on actual stack flow (FI-AZK1-3) as follows: Ideal sample flow $=2 \times($ stack scfm/1206).

\begin{tabular}{|c|c|c|c|c|}
\hline 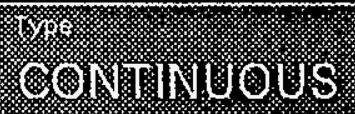 & 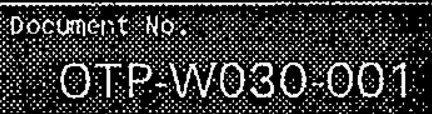 & 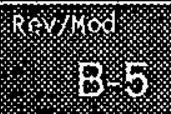 & 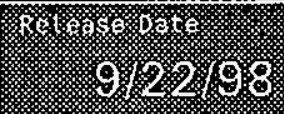 & 啭 \\
\hline
\end{tabular}


ATTACHMENT B - RECIRC AND HIGH HEAT MODE OPERATIONAL TESTING (Cont.)

\subsection{AY101 HIGH HEAT - TANK PRESSURE CONTROL}

\section{CAUTION}

This section cannot be performed prior to lifting of the limitations cited in the Project $W-030$ NOC 1 imiting the maximum flow rate of the exhauster to $800 \mathrm{scfm}$.

5.1 ENSURE the recirculation ventilation systems are in the RECIRC mode of operation according to the listed procedure.

- AYI02 - T0-060-352, AY102 TANK RECIRC MODULE OPERATION

AZ101 - T0-060-353, AZ101 TANK RECIRC MODULE OPERATION

AZ102 - TO-060-354, AZ102 TANK RECIRC MODULE OPERATION

5.2 ENSURE AY101 HIGH HEAT mode is established according to T0-060-351.

5.3 ENSURE the tank exhaust flow control setpoints and the primary vent manifold pressure setpoints PIC-AZKI-IA and PIC-AZKI-IB are set as required to achieve the flow rates 1 isted below.

- AY101 at $500 \pm 20 \mathrm{scfm}$ (FIC-AY1K1-2)

- AY102 at $2000 \pm 20$ sCfm (FIC-AY2K1-2)

AZ101 at $10100 \pm 20$ scfm (FIC-AZIKl-2)

- AZ102 at . $1000 \pm 20$ sCfm (FIC-AZ2K1-2)

5.4 ENSURE the tank pressure control setpoints for tanks AY102, AZ101, and AZ102 are set to -2.0 in. WC on MCS graphic screen 15 PriIn.v.

$\begin{array}{ll}* & P I C-A Y 2 K 1-1 \\ & \text { PIC-AZIKI-1. } \\ & \text { PIC-AZ2K } 1-1\end{array}$

5.j ADJUST the tank pressure setpoint controller for tank AYi01, PIC-AYIKi, to -0.5 in. WC.

NoTE. - In the following steps, the system is stable when tank pressures are within \pm 0.2 in wc of the setpoint and pressure control valve position is approximately steady state.

E.6 Allow the system to stabilize and RECoRn the Initial Vaiue data in TABLE $5-1$.

Test Engineer:

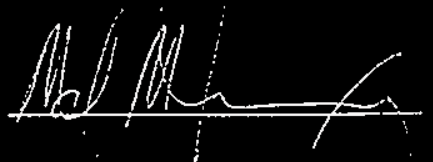

5.7 ADJUST the tank pressure setpoint controller for tank AY101, PIC-AY1k1, in $0.5 \mathrm{in}$. wc increments, from $-0.5 \mathrm{in}$. wc to $-3.0 \mathrm{in}$. Wc.

\begin{tabular}{|c|c|c|c|c|}
\hline 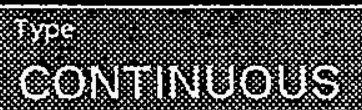 & 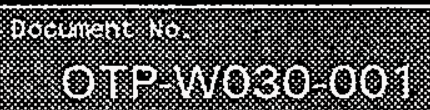 & 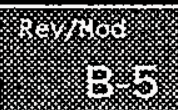 & 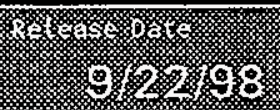 & 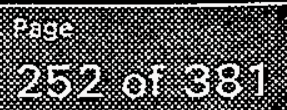 \\
\hline
\end{tabular}




\section{ATTACHMENT B - RECIRC AND HIGH HEAT MODE OPERATIONAL TESTING (Cont.)}

5.8 ALLOW system to stabilize AND RECORD the Changed Value data in JABLE 5-1 at each increment.

5.9 VERIFY that no unexpected alarms or conditions occurred asspciated with this section of testing and that the data in TABLE 5-1 satisfies the acceptance criteria.

Test Engineer:

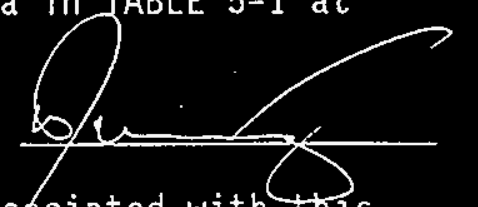

Test Engineer:

5.10 ADJUST the pressure setpoint controlier for tank AY101, PIC-AYIK1, to -2.0 in. WC. 
ATTACHMEHT B - RECJRC AND HIGH HEAT MODE OPERATIONAL TESTING (CONT.)

TABLE 5-1 AY101 HIGH HIAT .- Pressure fontrol

\begin{tabular}{|c|c|c|c|c|c|c|c|c|c|}
\hline $\begin{array}{l}\text { AY101 Pressure Control SETPOINI } \\
\text { PIC-AY1K } 1-1(15 \text { Pritn.V) }\end{array}$ & $\begin{array}{c}\text { Initial } \\
(-0.5)\end{array}$ & $\begin{array}{l}-1.0 \\
\text { in } \mathrm{WC}\end{array}$ & $\begin{array}{l}-1.5 \\
\text { in wc }\end{array}$ & $\begin{array}{l}-2.0 \\
\text { in wC }\end{array}$ & $\begin{array}{l}-2.5 \\
\text { in wC }\end{array}$ & $\begin{array}{l}-3.0 \\
\text { in wC }\end{array}$ & $\begin{array}{c}\text { ACCEPTANCE } \\
\text { CRITERIA }\end{array}$ & LIMIT & $\begin{array}{l}\text { PASS } \\
\text { FAIL }\end{array}$ \\
\hline $\begin{array}{l}\text { AY101, Tank Pressure } \\
\text { Pl-AYik1-1 (15priIn.y) }\end{array}$ & $-1.3^{2}$ & $-1.3^{(6)}$ & -1.5 & $-2 \cdot c$ & -2.6 & -2.9 & 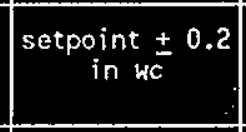 & $\begin{aligned}-.3>x>-6 \\
\text { in } \mathrm{wC} \\
6030-\mathrm{RD}-001\end{aligned}$ & $\operatorname{loss}_{25}$ \\
\hline $\begin{array}{l}\text { AY101 Intet Air flow } \\
\text { FI-AYK1-1 (15Prinn.v) }\end{array}$ & 503 & 501 & 462 & 2101 & 3,7 & 142 & $\leq$ FIAZ2K1-2 & $N / A$ & $h_{x=1}$ \\
\hline $\begin{array}{l}\text { AY101 Pressure control valve } \\
\text { Valve Position } \\
\text { z1-AY1K1-1 (15PriIn.v) }\end{array}$ & $101 \%$ & $102 \%$ & $75 \%$ & $5 \% \%$ & $46 \%$ & $3 \% \%$ & $N / A$ & $\mathrm{~N} / \mathrm{A}$ & Pos 4 \\
\hline $\begin{array}{l}\text { AY101 Exhaust Air Flow SETPOINI } \\
\text { Fic-AYMK1-2(15PriIn.v) }\end{array}$ & 500 & $\mathrm{H} / \mathrm{A}$ & $N / A$ & $\mathrm{~N} / \mathrm{A}$ & $\mathrm{N} / \mathrm{A}$ & $H / A$ & $N / A$ & $\mathrm{~N} / \mathrm{A}$ & \\
\hline $\begin{array}{l}\text { AY101 Exhaust Air flow } \\
\text { FI AYYK1-2 (15PriIn.V) }\end{array}$ & 503 & 493 & 493 & 494 & 500 & 508 & $\begin{array}{c}\text { setpoint } \pm 20 \\
\text { scfm }\end{array}$ & $N / A$ & $\operatorname{Rss} 6$ \\
\hline 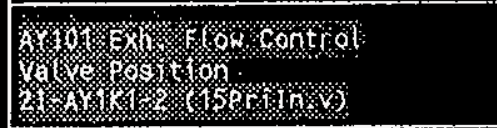 & $42 \%$ & $43 \%$ & $43 \%$ & $45 \%$ & $46 \%$ & $47 \%$ & Kor opon & . & \\
\hline
\end{tabular}

\begin{tabular}{|c|c|c|c|c|}
\hline 19. & Orocment & Rev (1) & (3) & (2) \\
\hline
\end{tabular}




\section{ATTACHMENT B - RECIRC AND HIGH HEAT MODE OPERATIONAL TESTING (Cont.)}

\subsection{AY101 HIGH HEAT - FAN AND FILTER TRAIN SWITCHOVER (A to B)}

\section{CAUTION}

This section cannot be performed prior to lifting of the limitations cited in the Project $\mathrm{H}-030$ NOC 7 imiting the maximum flow rate of the exhauster to $800 \mathrm{scfm}$.

6.1 ENSURE Exhaust Fan AZ-KI-5-1A and Filter Train $A$ are in service.

6.2 ENSURE the recirculation ventilation systems are in the RECIRC mode of operation according to the listed procedure.

- AY102 - T0-060-352, AY102 TANK RECIRC MODULE OPERATION

- AZ101 - T0-060-353, AZ101 TANK RECIRC MODULE OPERATION

- AZ102 - T0-060-354, AZ102 TANK RECIRC MODULE OPERATION

6.3 ENSURE AY101 HIGH HEAT mode is established according to T0-060-351.

6.4 ENSURE primary vent manifold setpoints PIC-AZK1-1A AND PIC-AZK1-1B match.

6.5 ENSURE heater temperature differential setpoints TDIC-AZK12-1A and TDIC-AZK12-1B match.

6.6 RECORD Initial Value data in TABLE 6-1.

6.7 SELECT "Fan-1B" on MCS MACRO graphic screen 25mExhst.v.

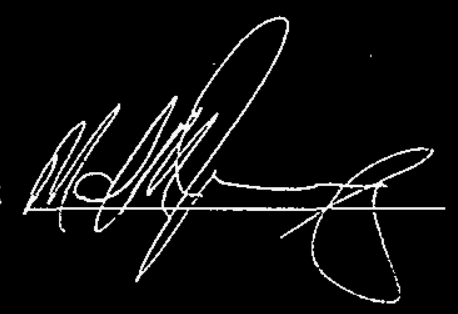

5.8 SELECT "Heater-1B" on MCS MACRO graphic screen 25mExhst.v.

E.9 RUA Exhaust MACRO.

E.10 CHECK the following conditions on MCS graphic 17PriExh.v.:

$\begin{array}{lll}- & \text { Fan-1A: } & \text { STANDBY } \\ \therefore & \text { Fan-1B: } & \text { ON } \\ \therefore & \text { Heater-1A: } & \text { STANDBY } \\ & \text { Heater-1B: } & \text { ON }\end{array}$

6. I CHECK Chiller AND Pump-IA or Pump-1B ON at MCS graphic 14Cinilir.v.

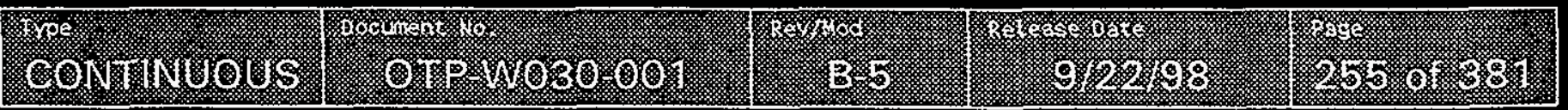




\section{ATTACHMENT B - RECIRC AND HIGH HEAT MODE OPERATIONAL TESTING (Cont.)}

NOTE - In the following step, the system is stable when tank exhaust flow rates are within $\pm 20 \mathrm{scfm}$ of the Initial Value and primary tank pressures are within \pm 0.2 in wc of the Initial Values.

6.12 ALLOW the system to stabilize AND RECORD Final Value data in Test Engineer:

6.13 ESTABLISH AY101 RECIRC mode according to T0-060-351.

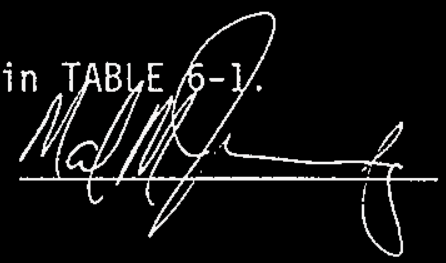

6.14 VERIFY that no unexpected alarms or conditions occurred associated with this section of testing and that the data in TABLE 6-1 is in the acceptable range.

Test Engineer:

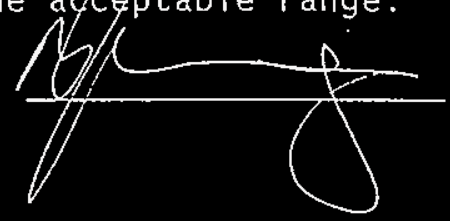

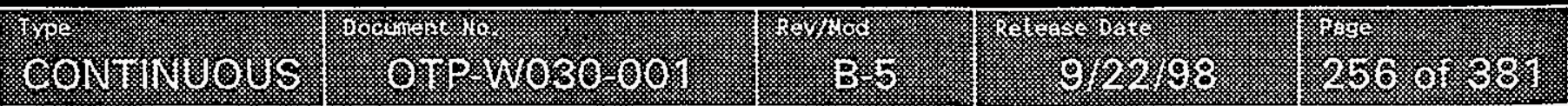


ATTACHHENT B - RECIRC AND HIGH HEAT MODE OPERATIONAL TESTING

TABLE 6-1 AY101 HIGH HEAT - Fan and Filier lrain Switchover (Train A to Train B)

\begin{tabular}{|c|c|c|c|c|c|}
\hline MCS PARAMETERS & $\begin{array}{l}\text { INITIAL } \\
(\text { Train } A)\end{array}$ & $\begin{array}{l}\text { FINAL } \\
(\text { Train B) }\end{array}$ & $\begin{array}{l}\text { ACCEPTANCE } \\
\text { CRITERIA }\end{array}$ & LIMIT & $\begin{array}{l}\text { PASS/ } \\
\text { FAIL }\end{array}$ \\
\hline \multicolumn{6}{|c|}{ MCS Graphic Screen $15 \mathrm{Pr}$ In.V } \\
\hline $\begin{array}{l}\text { AY101 Iniet Air Flow. } \\
\text { FI-AYTK1-1 (15Pri!n.V) }\end{array}$ & 276 & 321 & $\leq$ FIAYIK1-Z & N/A & Pass \\
\hline $\begin{array}{l}\text { AY101 pressure Control SETPOINT } \\
\text { pic-AYik1-1 (15Priln.v) }\end{array}$ & -2.0 & N/A & $N / A$ & N/A & \\
\hline $\begin{array}{l}\text { AY101 Tank Pressure } \\
\text { PI-AY1K1-i (15Priln.v) }\end{array}$ & -2 & -2.0 & -0.3 to -3.0 & $\begin{array}{l}-.3>x>-6 \\
\text { in wc } \\
\text { OSD }\end{array}$ & \\
\hline 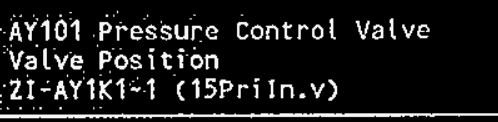 & $53 \%$ & $49 \%$ & N/A & $N / A$ : & \\
\hline $\begin{array}{l}\text { AY101 Exhaust Air Flow SEIPOINT } \\
\text { FIC-AY1K1-2 (15Priln.V) }\end{array}$ & 500 & N/A & $N / A$ & N/A & \\
\hline $\begin{array}{l}\text { AY101 Exhaust Air Flow } \\
\text { FI AYYK1-2. (15priIn.v) }\end{array}$ & 493 & i/ 99 & $\begin{array}{r}\text { setpoint } \\
\text { scfm }\end{array}$ & $N / A$ & \\
\hline 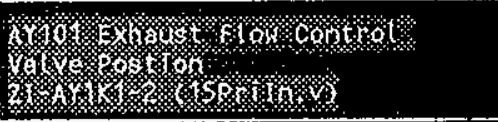 & $44 \%$ & $44 \%$ & $320 \%$ ob e & W & \\
\hline
\end{tabular}

\begin{tabular}{|c|c|c|c|c|}
\hline 湆 & oforent & 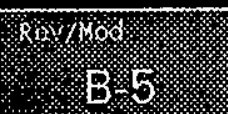 & 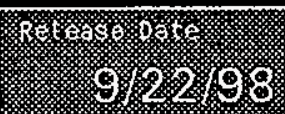 & (1) \\
\hline
\end{tabular}


AITACIMENI B - RECIRC AND HIGH HEAT MODE OPERATIONAL TESTING

TABLE 6-1 AY101 HIGH HEAl - Fan and Filiel Train Switchover (Train A to Train B)

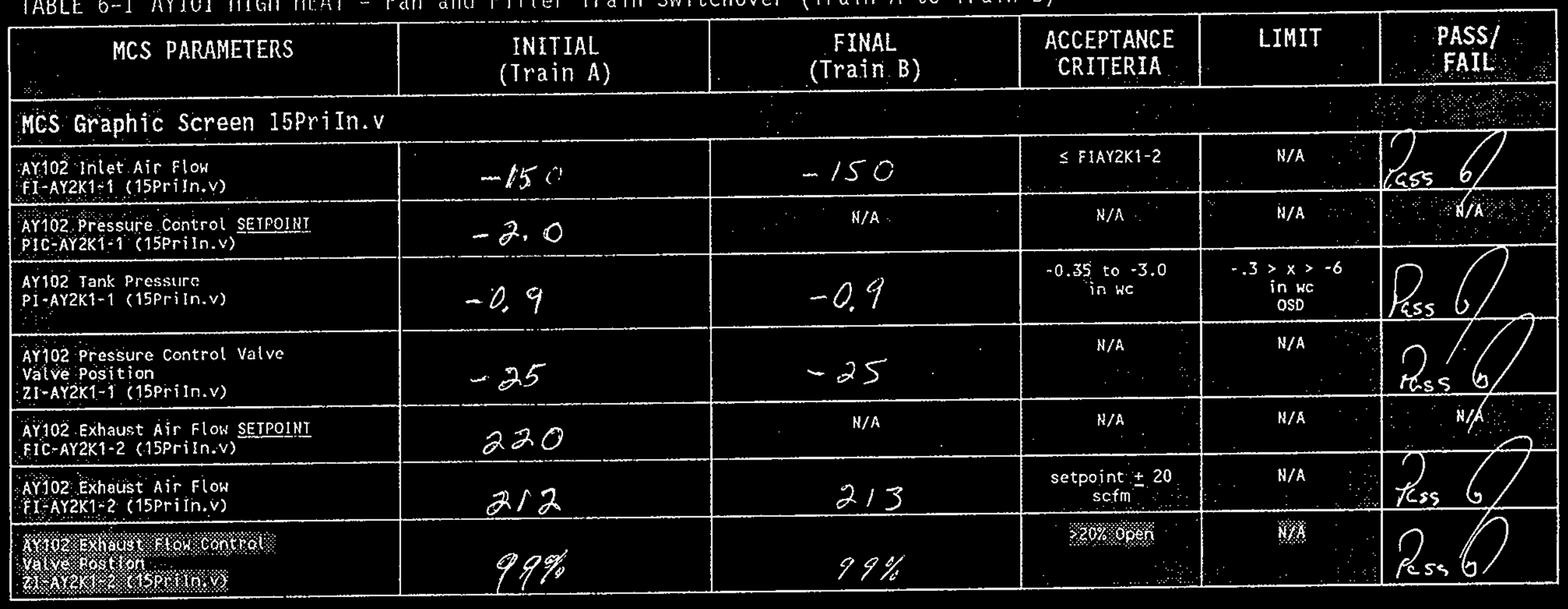

\begin{tabular}{|c|c|c|c|c|}
\hline 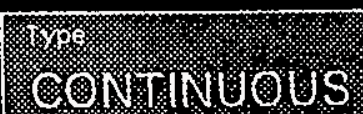 & motpwo30001 & 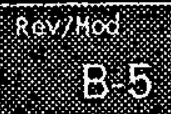 & $9.2,198$ & 3. \\
\hline
\end{tabular}



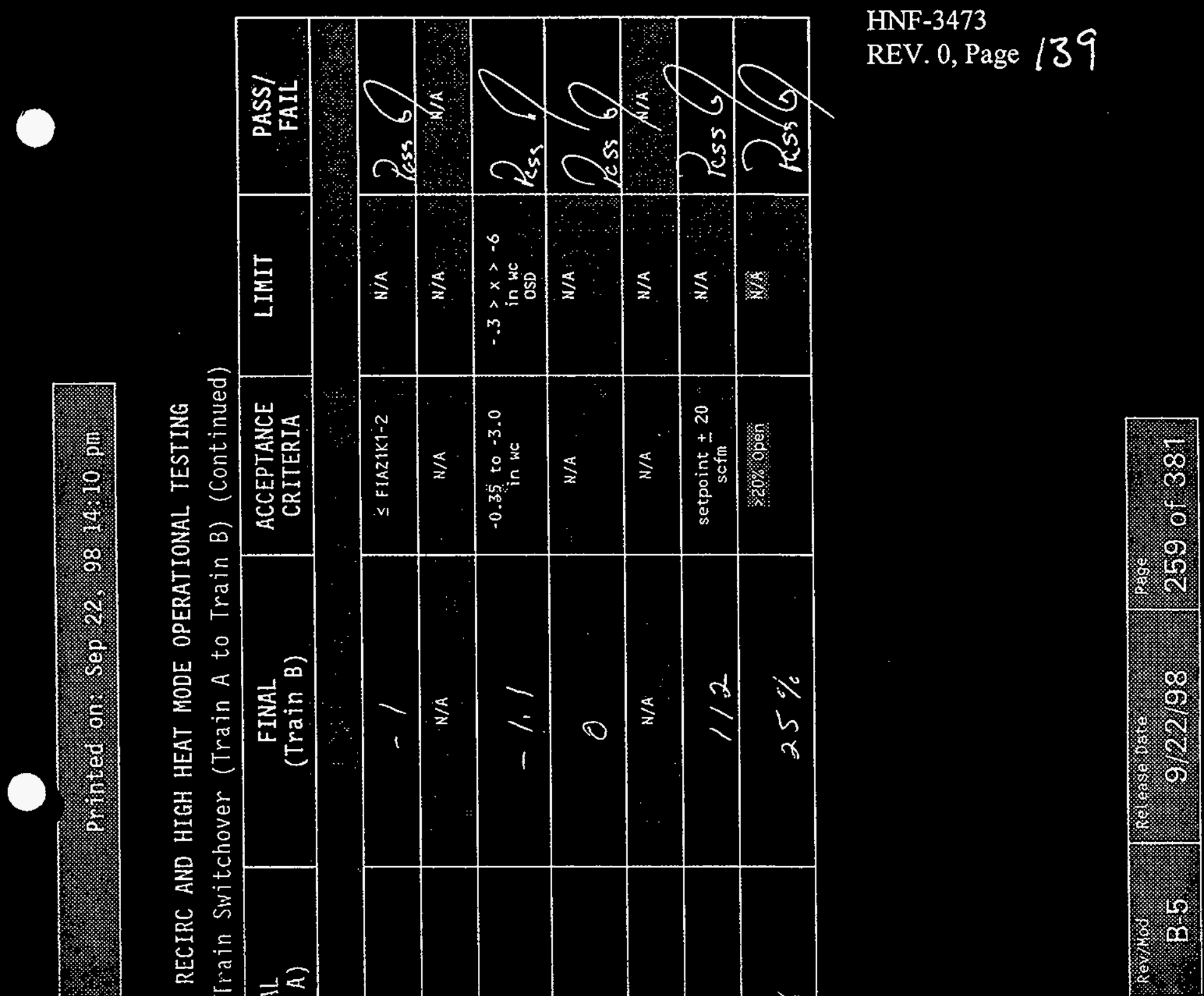

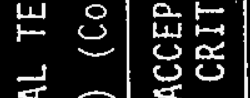

蓄

$>$.

点

莡

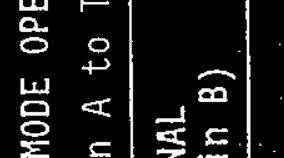

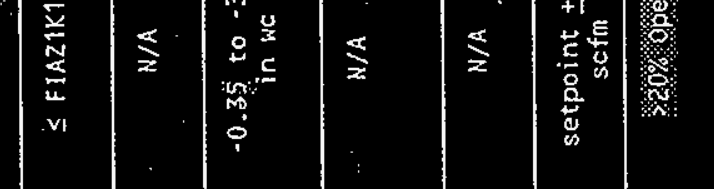

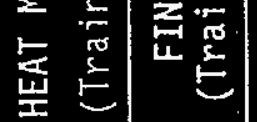

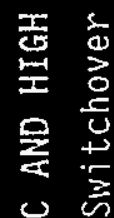

星

总

$\approx$ E

$1 \vdots \stackrel{E}{\omega}$

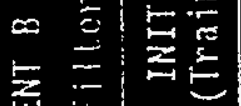

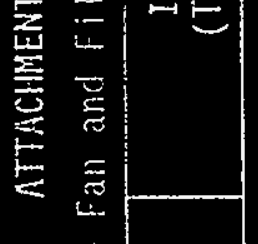

$\frac{2}{0}$
$\frac{3}{3}$
$\frac{3}{9}$
$\frac{3}{3}$
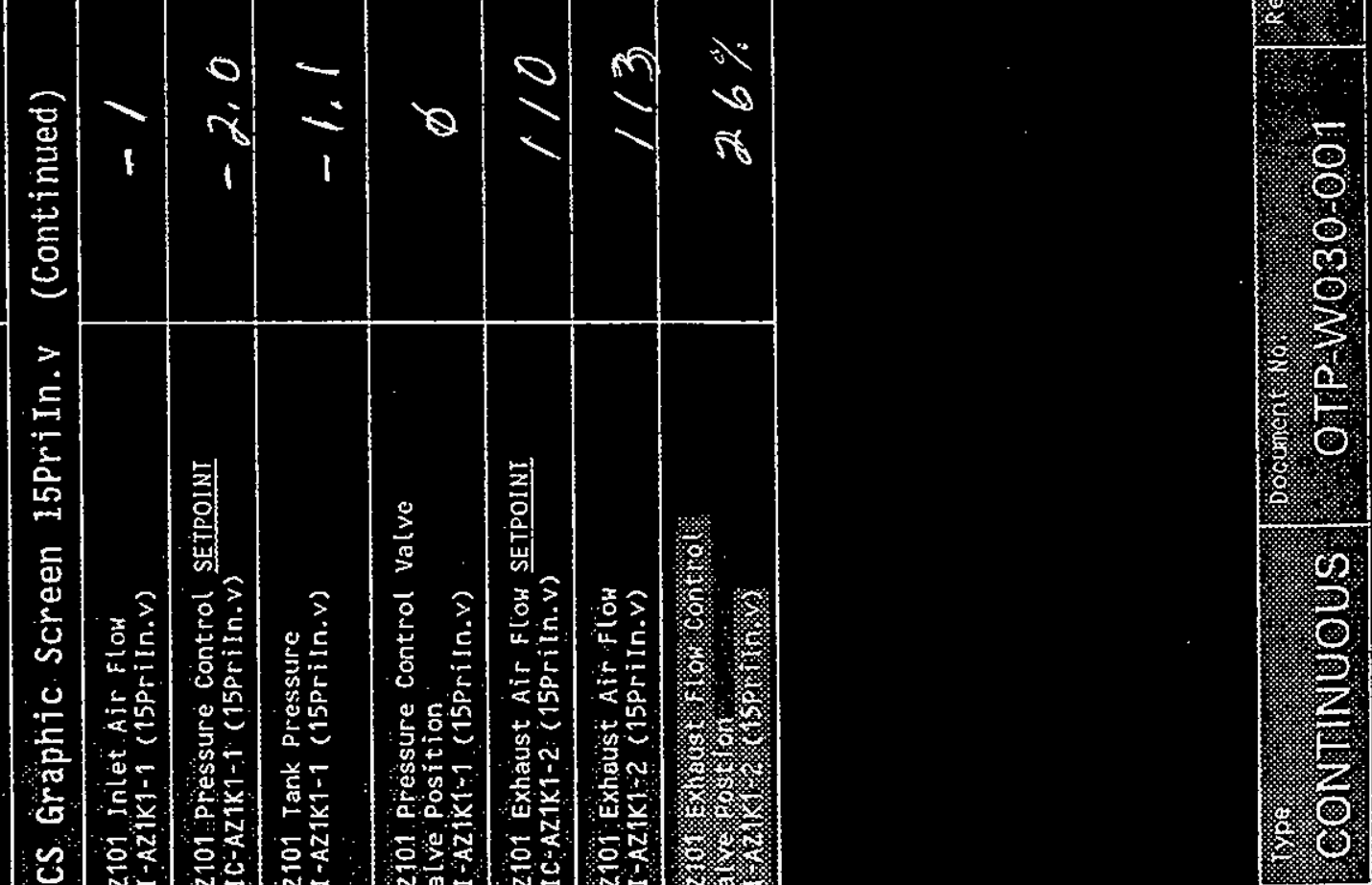

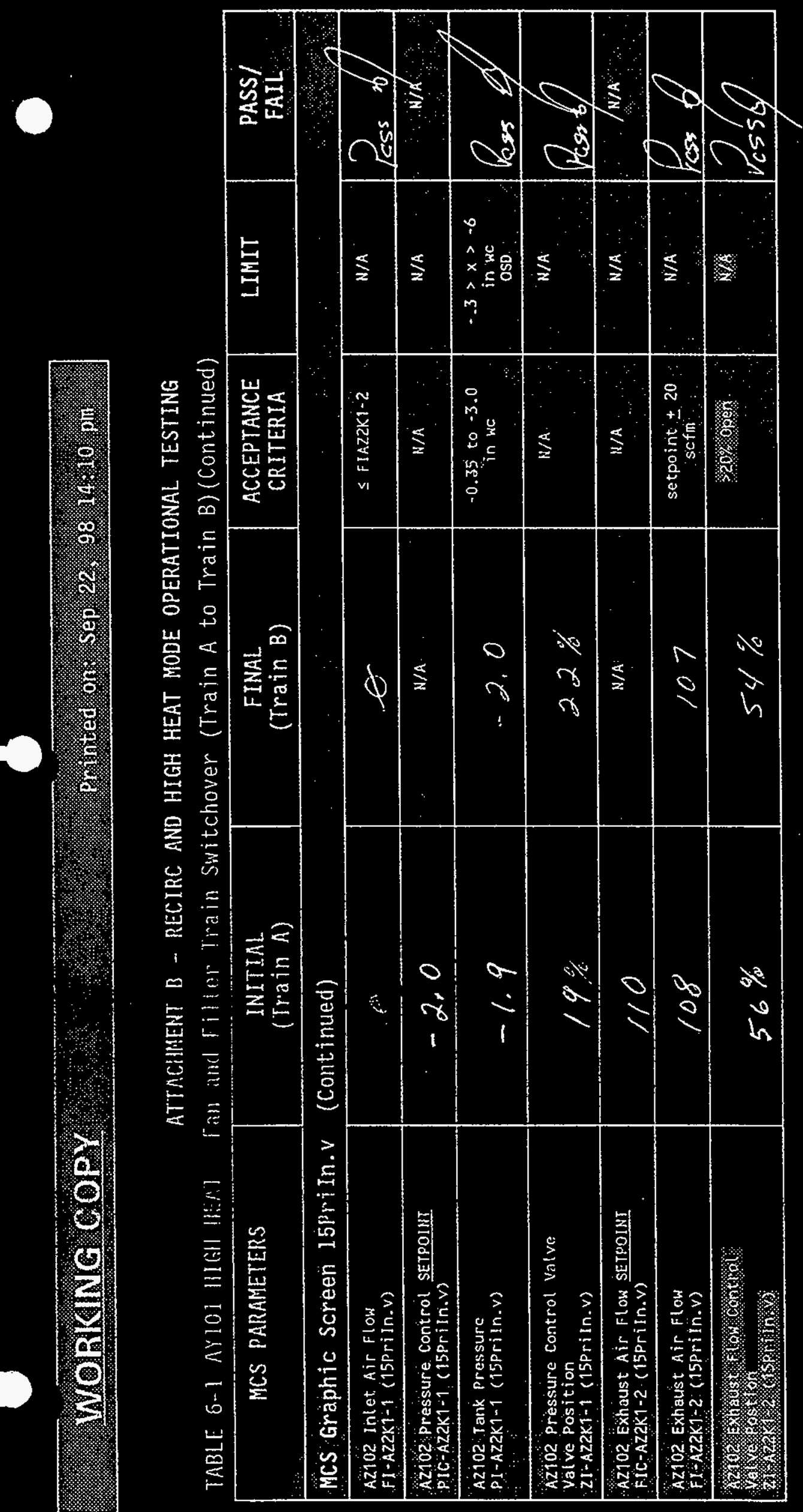

HNF-3473

REV. 0, Page 140

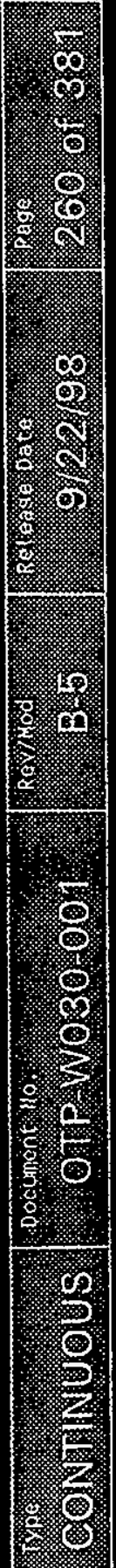




\section{ATTACHMENT B - RECIRC AND HIGH HEAT MODE OPERATIONAL TESTING}

TABLE 6-1 AY101 HIGH HEAT - Fan and Filter Train Switchover (Train A to Train B)(Continued)

\begin{tabular}{|c|c|c|c|c|c|}
\hline MCS PARAMETERS & $\begin{array}{l}\text { INITIAL } \\
\text { (Train } A \text { ) }\end{array}$ & $\begin{array}{l}\text { FINAL } \\
(\text { Train } B)\end{array}$ & $\begin{array}{l}\text { ACCEPTANCE } \\
\text { CRITERIA }\end{array}$ & LIMIT & $\begin{array}{l}\text { PASS/ } \\
\text { FAIL }\end{array}$ \\
\hline \multicolumn{6}{|l|}{ MCS Graphic Screen $16 \mathrm{PriCoO} v$} \\
\hline $\begin{array}{l}\text { Primary vent Condenser } \\
\text { Differential pressure } \\
\text { PDI-AZK18-1 (16Pricoo v) }\end{array}$ & 12.1 & 11.7 & < 10 on in $w$ & W/A & \\
\hline $\begin{array}{l}\text { Primary Vent Condenser } \\
\text { Outlet Air Temperature } \\
\text { II AZK18-1B (16PriCoo.v) }\end{array}$ & 45 & 45 & $350060 \%$ & $\mathrm{~N} / \mathrm{A}$ & \\
\hline $\begin{array}{l}\text { Primary vent HEME } \\
\text { Differential pressure } \\
\text { PDI-AZK19-1 (16Pricoo. V) }\end{array}$ & 5.0 & 5.0 & $\begin{array}{l}<10 \text { in we } \\
4\end{array}$ & $\begin{array}{l}\leq 15 \text { in wC } \\
\text { OSD }\end{array}$ & \\
\hline
\end{tabular}

\begin{tabular}{|c|c|c|c|c|}
\hline 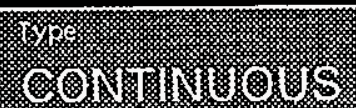 & 筞 & 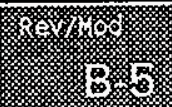 & . & 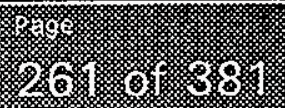 \\
\hline
\end{tabular}


HNF-3473

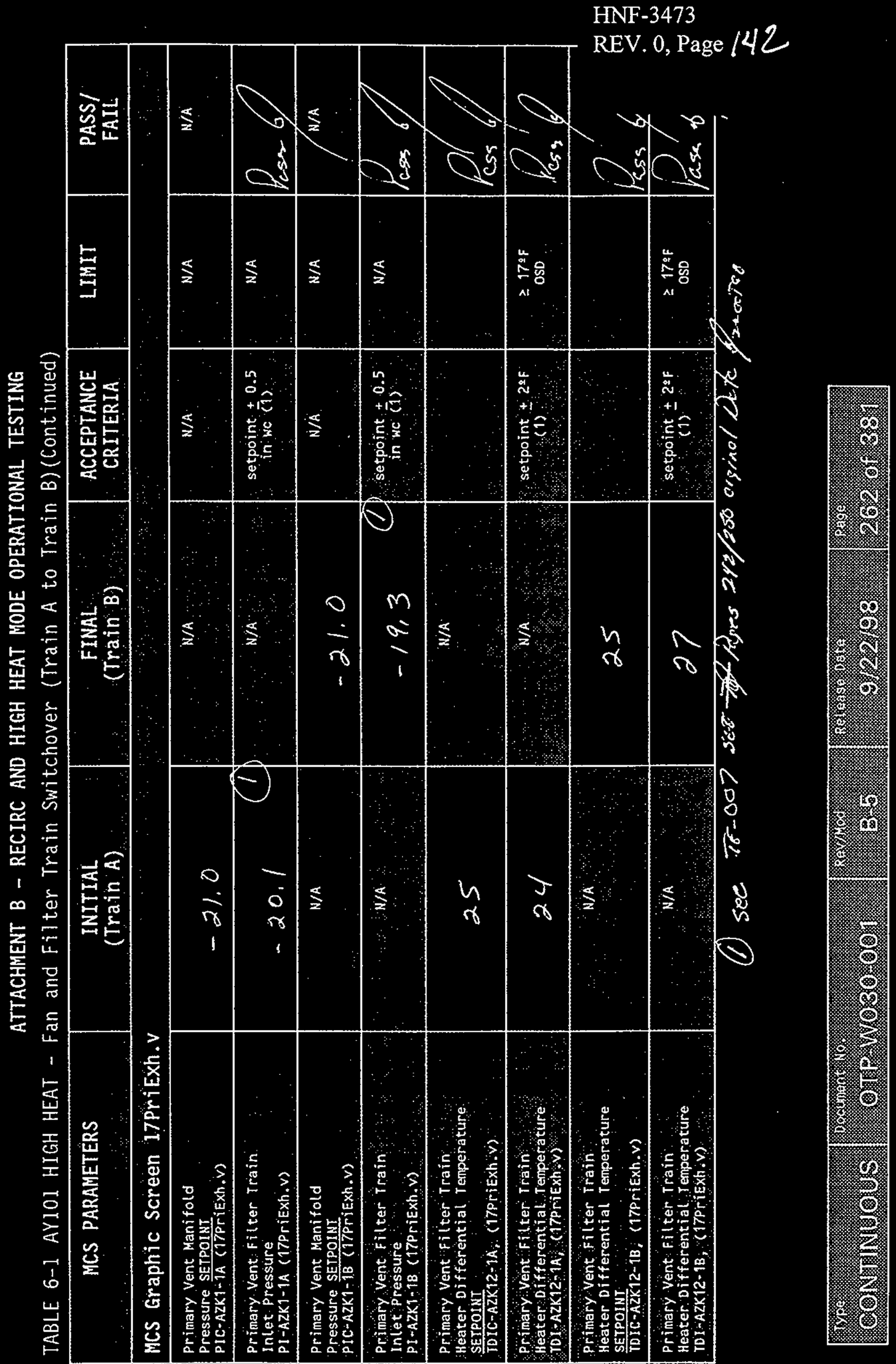




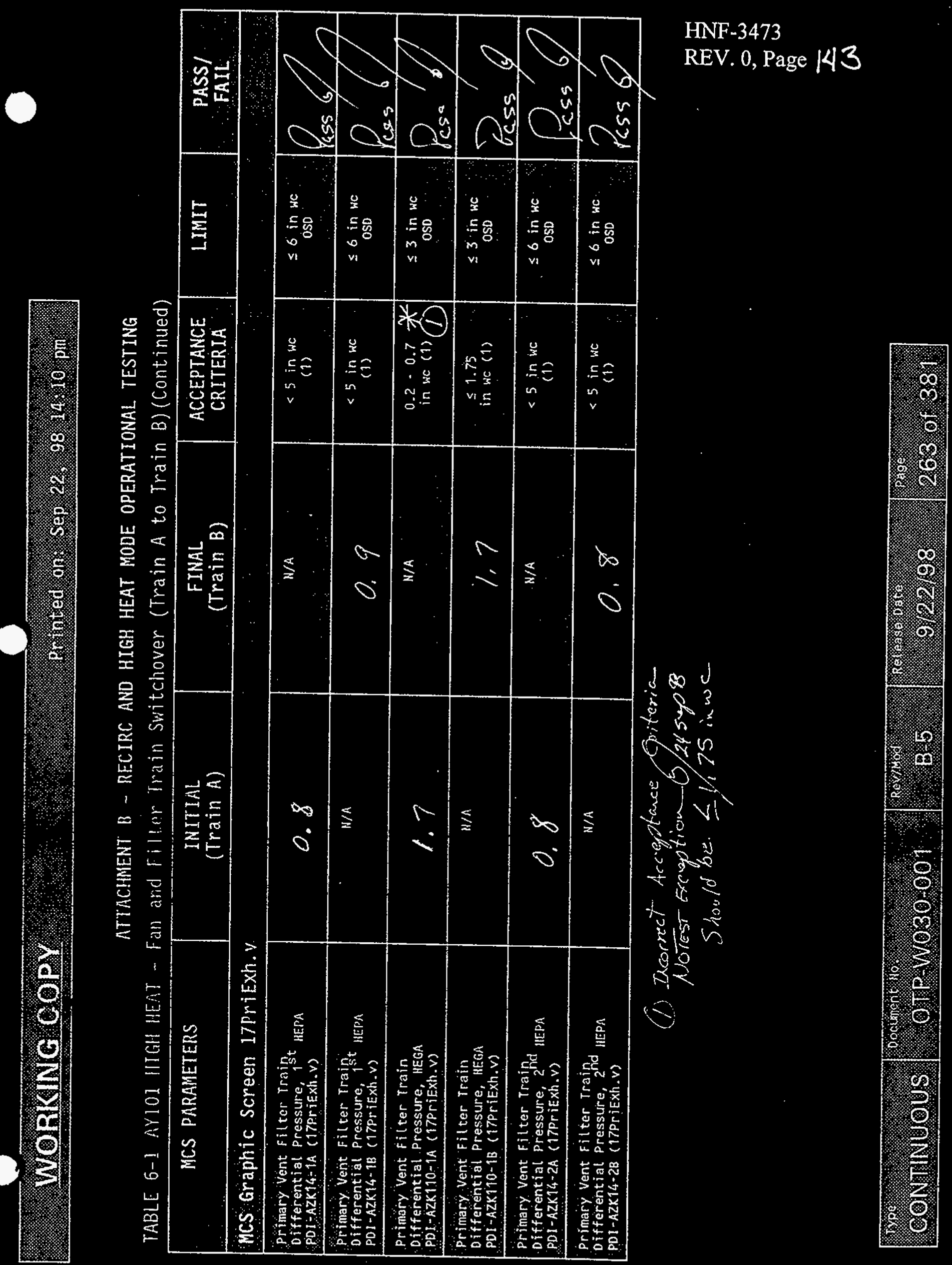



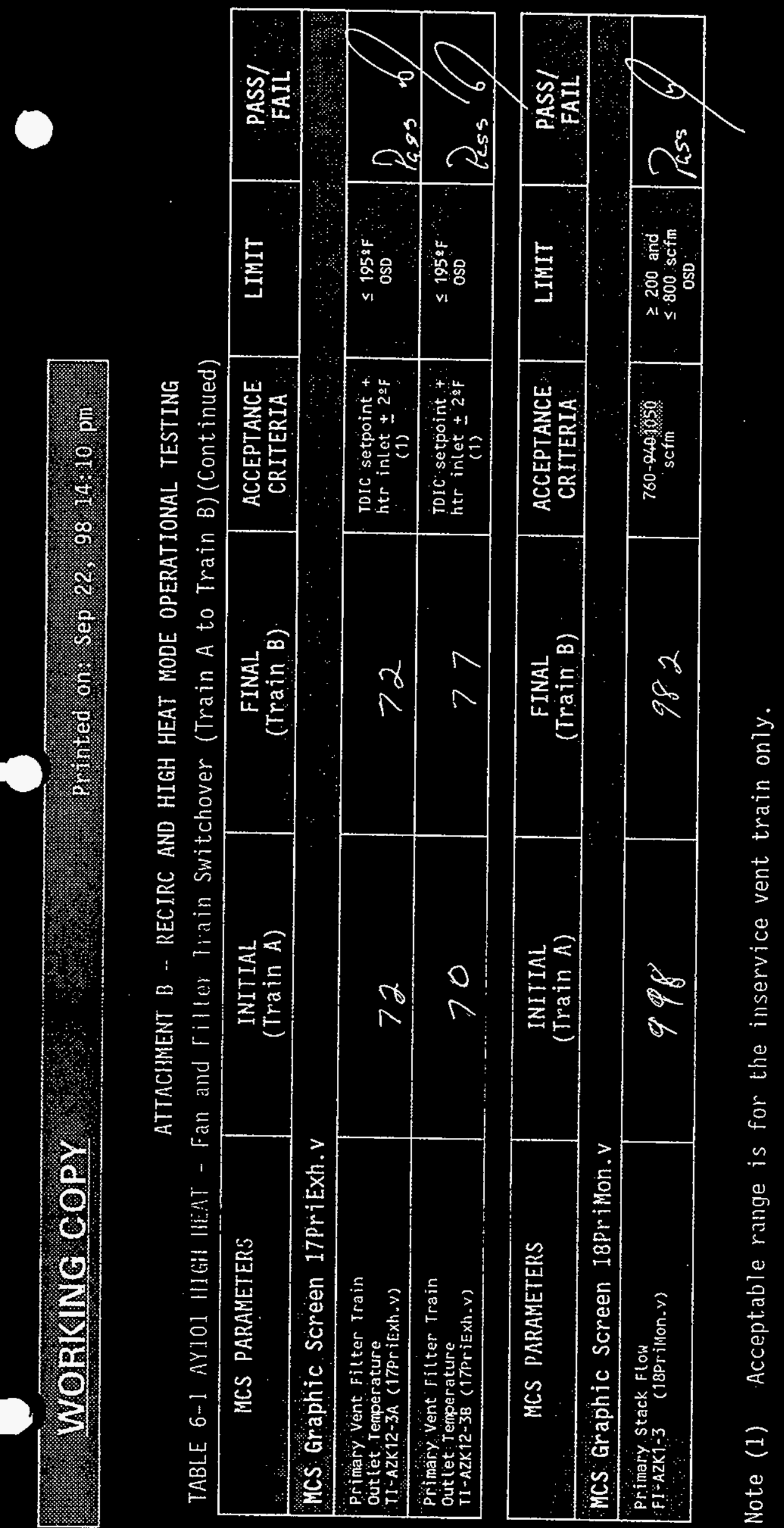

HNF-3473

REV. 0, Page 144

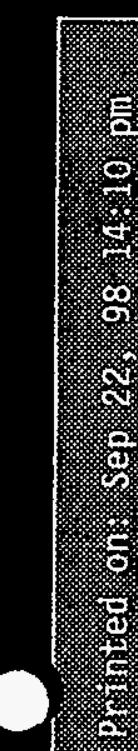

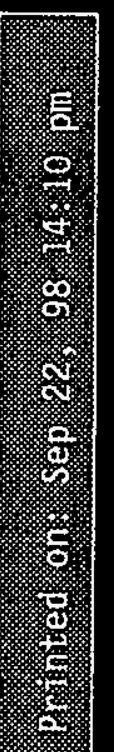

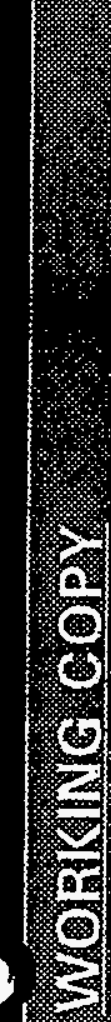

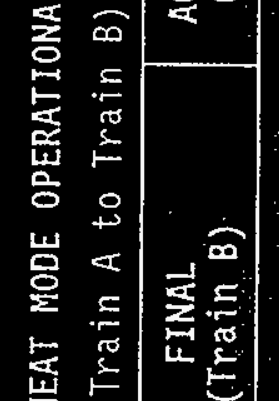

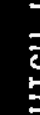

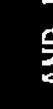

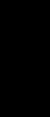

.

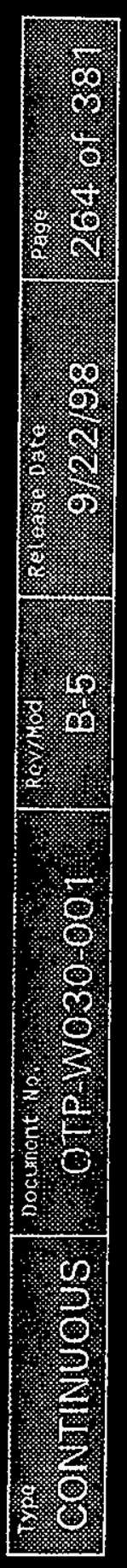


HNF-3473
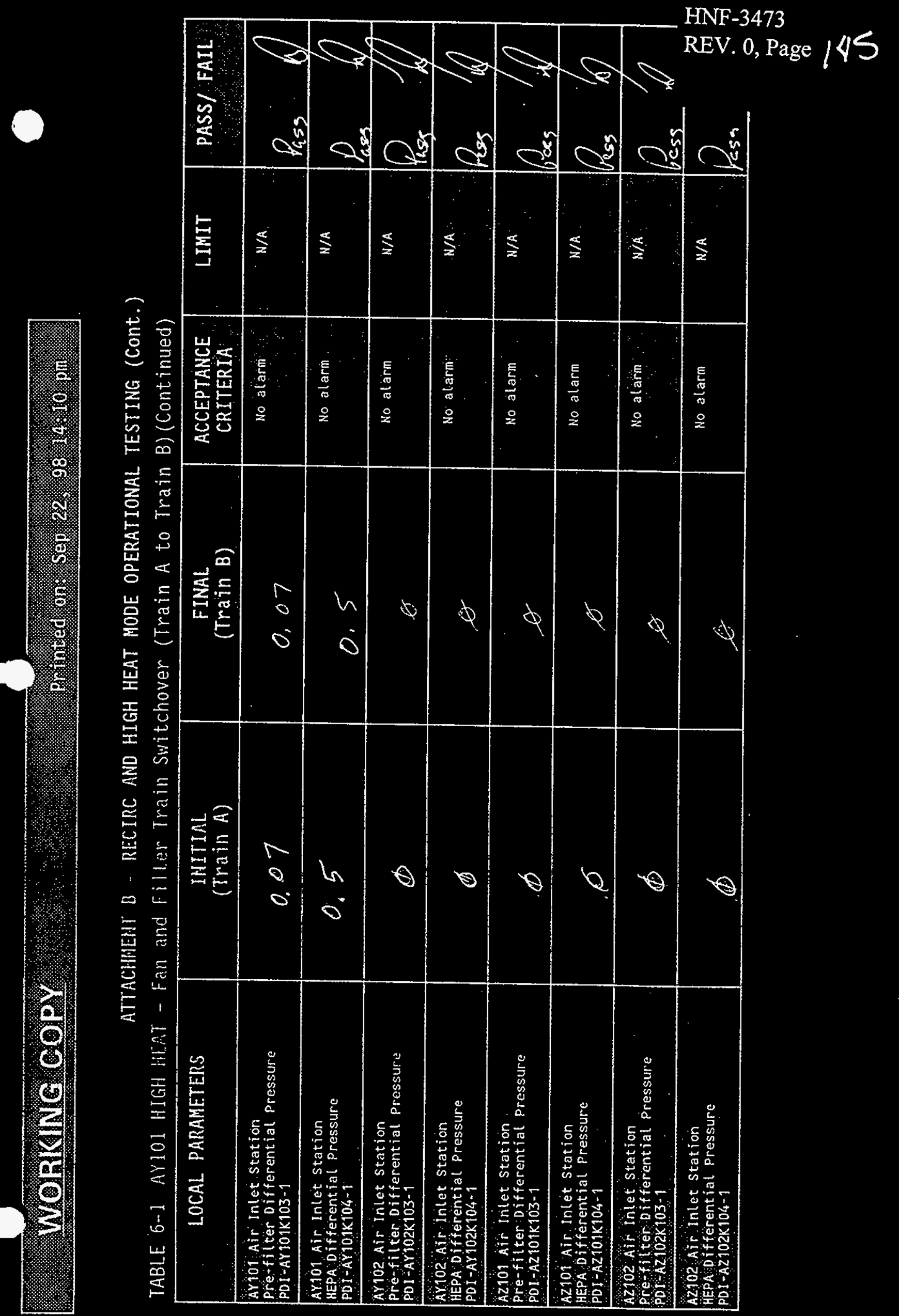

임

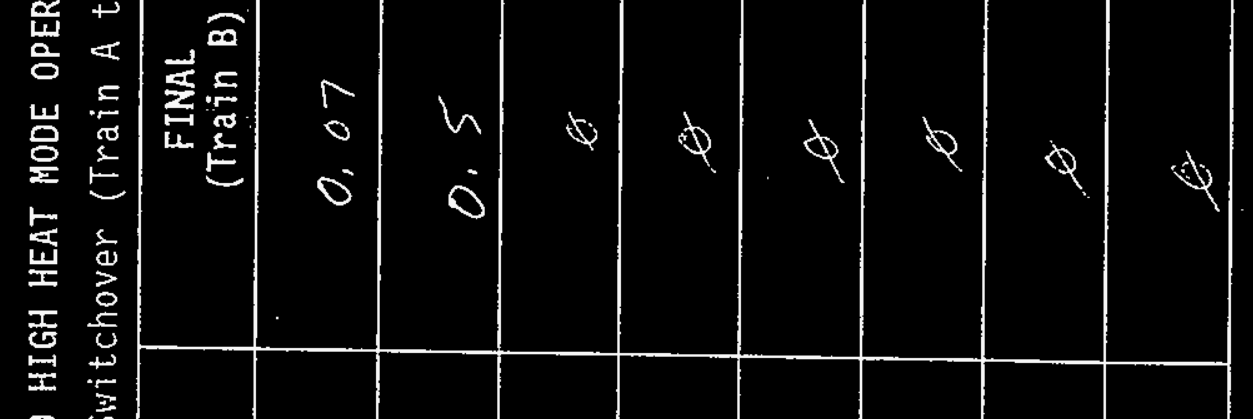
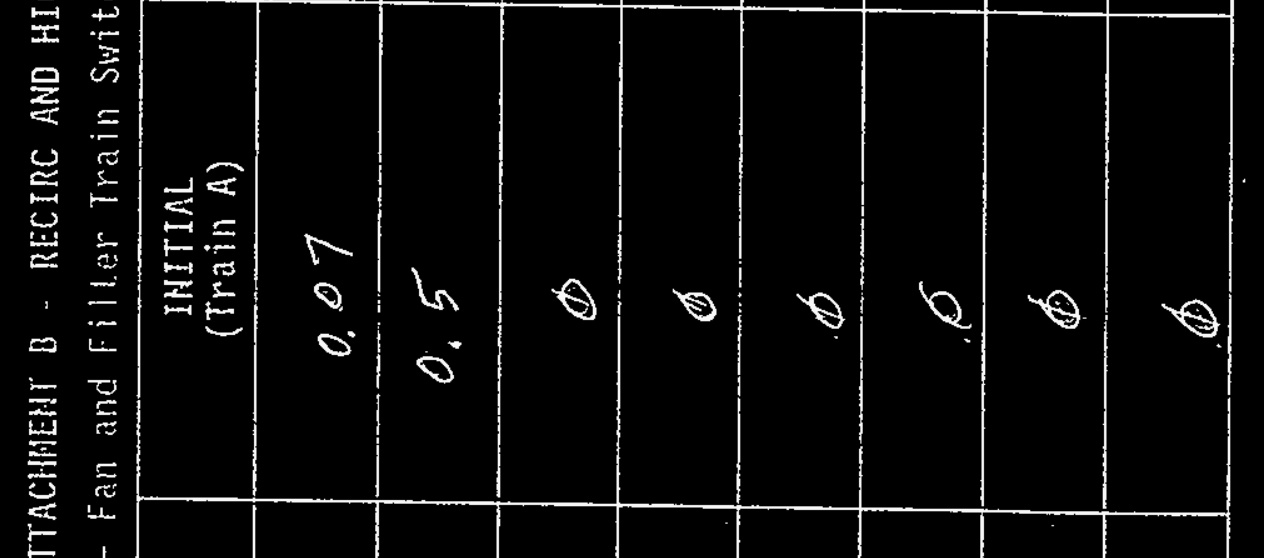

玹

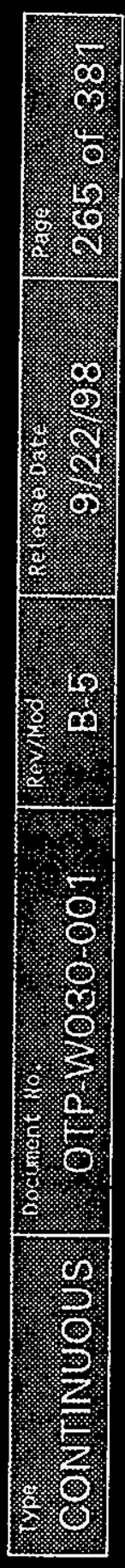




\section{ATTACHMENT B - RECIRC AND HIGH HEAT MODE OPERATIONAL TESTING}

\subsection{AY102 HIGH HEAT - STEADY STATE OPERATION}

\section{CAUTION}

This section cannot be performed prior to lifting of the limitations cited in the Project $\mathrm{W}-030$ NOC Timiting the maximum flow rate of the exhauster to $800 \mathrm{scfm}$.

7.1 ENSURE Exhaust Fan AZ-K1-5-1B and Filter Train B are in service.

7.2 ENSURE the following recirculation ventilation systems are in the RECIRC mode of operation according to the 7 isted procedure.

- AY101 - T0-060-351, AY101 TANK RECIRC MODULE OPERATION

- AY102 - T0-060-352, AY102 -TANK RECIRC MODULE OPERATION

- AZ101 - T0-060-353, AZ101 TANK RECIRC MODULE OPERATION

AZ102 - TO-060-354, AZ102. TANK RECIRC MODULE OPERATION

7.3 ENSURE tank pressure control setpoints are set at -2.0 in. wC on MCS graphic screen 15PriIn.v.
PIC-AZIKI-1
- PIC-AZ2K1-1
PIC-AYIKI-1
PIC-AY2K1-1

7.4 ENSURE the tank exhaust flow control setpoints and the primary vent manifold pressure setpoints PIC-AZKI-1A and PIC-AZK1-1B are set as required to achieve the flow rates listed below.

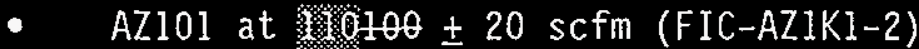
- $\quad$ AZ102 at $10100 \pm 20 \mathrm{scfm}$ (FIC-AZ2KI-2)
- AY101 at $200100 \pm 20 \mathrm{scfm}$ (FIC-AYIKI-2)
- AY102 at $2100 \pm 20$ scfm (FIC-AY2K1-2)

7.5 ALLOW system parameters to stabilize for 15 minutes AND RECORD, Ingifiad data
AY102 RECIRC mode in TABLE 7-1.

\begin{tabular}{|c|c|c|c|c|}
\hline 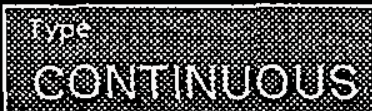 & 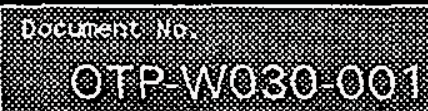 & 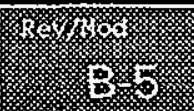 & 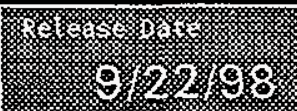 & 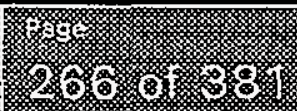 \\
\hline
\end{tabular}




\section{ATTACHMENT B - RECIRC AND HIGH HEAT MODE OPERATIONAL TESTING}

7.6 ADJUST AY102 tank-exhaust flow-control setpoint to $500 \pm 20 \mathrm{sefm}$ (FIP AY2K1-2)

7.7 ESTABLISH AY102 HIGH HEAT mode according to T0-060-352.

Test Engineer:

7.8 PLACE AY102 Cooling Tower in DRY MODE operation in accordance/wit) T0-060-558

Test Engineer:

7.9 ALLOW system parameters to stabilize for 15 minutes AND REgord Injif al data $f$ AYI02 HIGH HEAT mode in TABLE 7-1.

$\rightarrow 7.10$ RECORD data in TABLE 7-1 every hour for 4 consecutive hours.

Test Engineer:

Test Engineer:

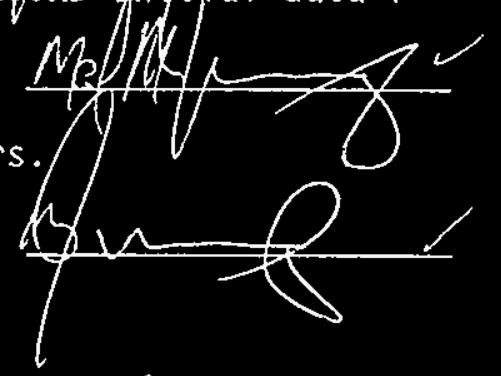

7.11 PLACE AY102 Cooling Tower in WET MODE operation in accordance with T0-060-358 AND RETURN to this procedure.

Test Engineer:

7.12 ALLOW system parameters to stabilize for 15 minutes AND RECORD Initial data with AY102 in HIGH-HEAT mode in TABLE 7-2.

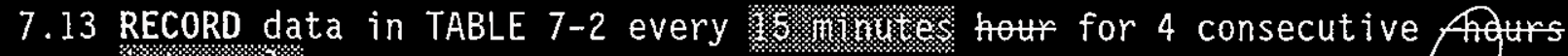

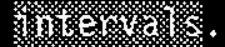

7.14 VERIFY that no unexpected alarms or conditions occurred associated with this Test Engineer: Mal/h section of testing and that the data in TABLES 7-1 and 7-2 satisfies/the acceptance criteria.

Test Engineer:

NOTE- All CO0ling Towers will remain in WET MODE operation throughout the balance of thi procedure except as directed.

\begin{tabular}{|c|c|c|c|c|}
\hline 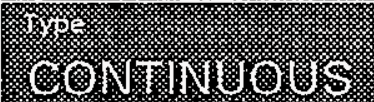 & 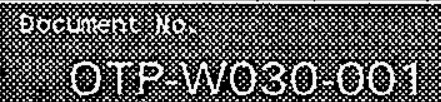 & 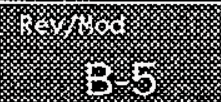 & (3. & 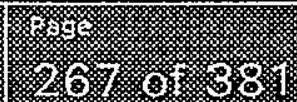 \\
\hline
\end{tabular}


HNF-3473

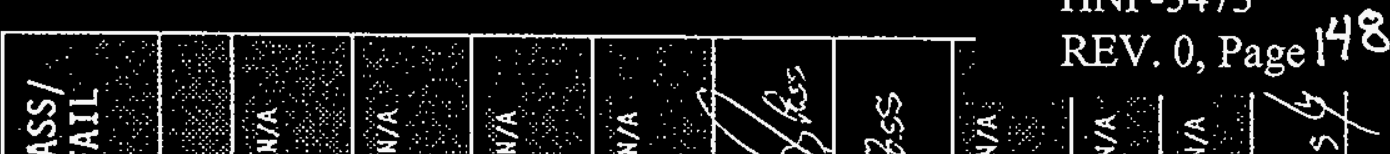

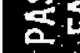

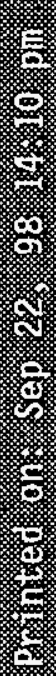

홀

\& 5 ร

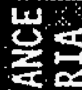

눈

今

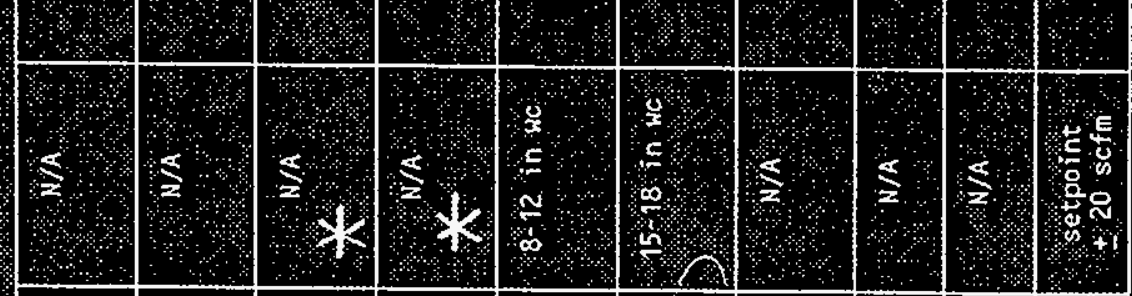

焉离

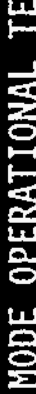

章

㩆竞

䒺竞

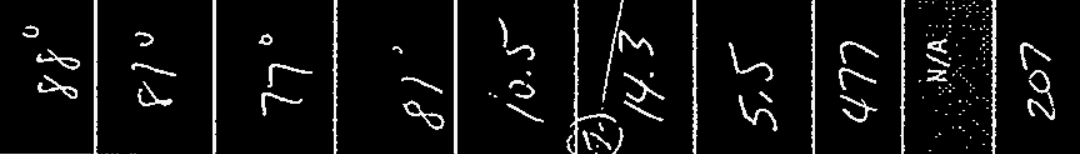

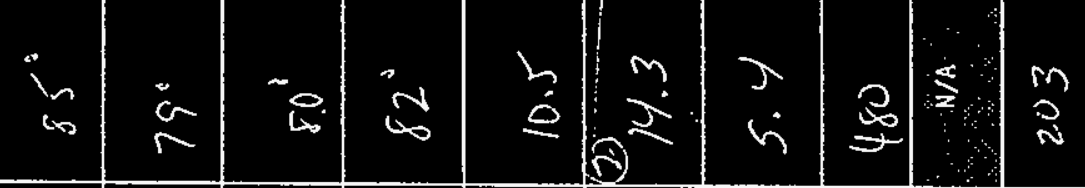

武栾

是

曾

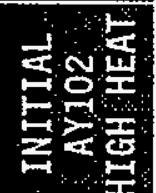

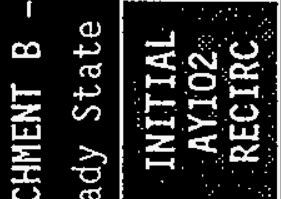

a.

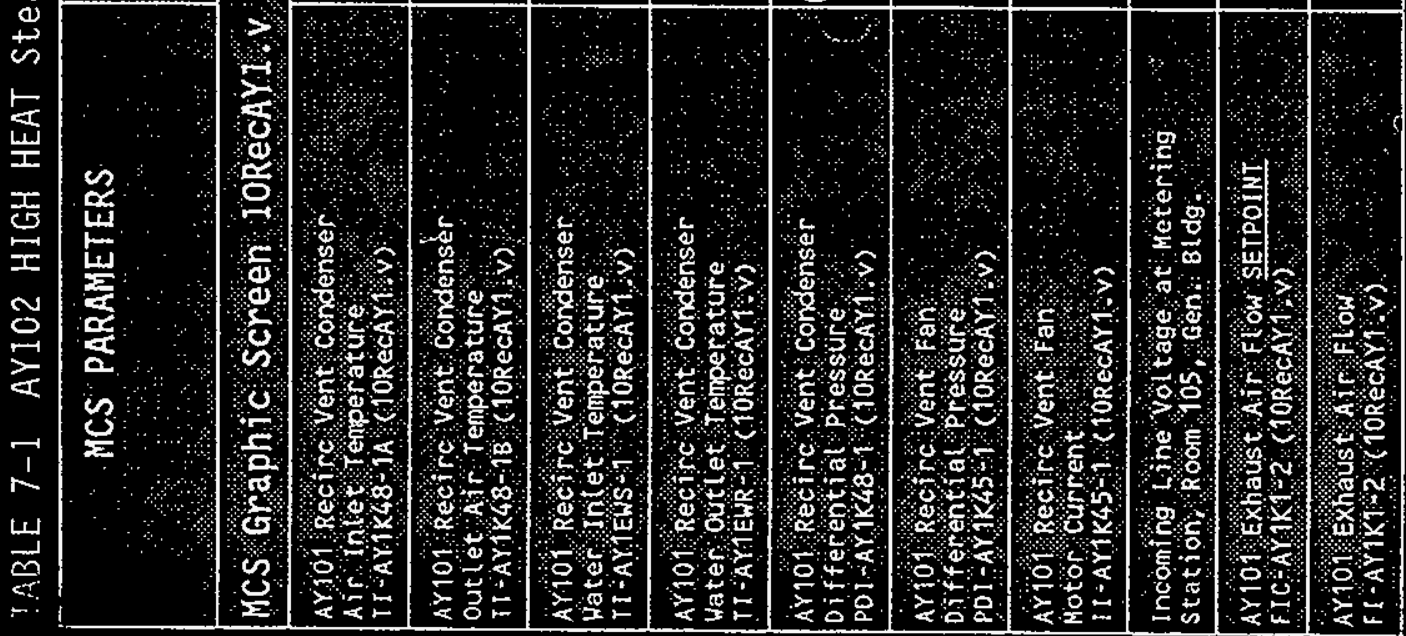

然

竎

ำ

密

害

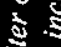

高

究苋

*
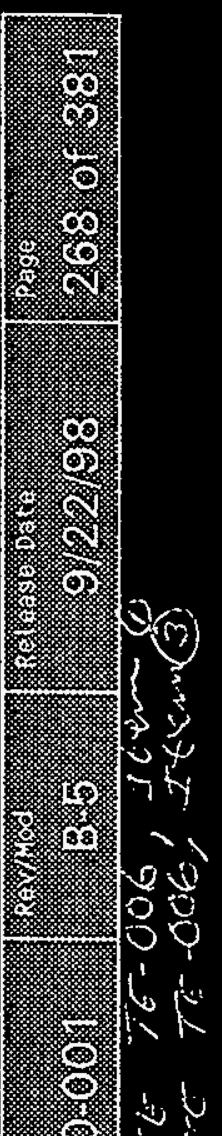

诌

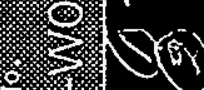

$(-4)$

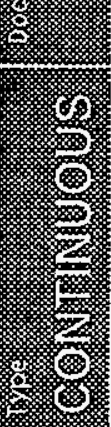


ATTACHMENT B - RECIRC AND HIGH HEAT MODE OPERATIONAL TESTING (CONt.)

IMBLE 7-1 AY102 HIGH HEAT Steady State (Continued)

\begin{tabular}{|c|c|c|c|c|c|c|c|c|c|}
\hline MCS PARAMETERS & $\begin{array}{l}\text { INITIAL } \\
\text { AY1O2 } \\
\text { RECIRC }\end{array}$ & $\begin{array}{c}\text { INITIAL } \\
\text { AYI02 } \\
\text { HIGH HEAT }\end{array}$ & INTERVAL & INTERVAL & $\begin{array}{l}3 R D \\
\text { INTERVAL } \\
\end{array}$ & 4TH & $\begin{array}{l}\text { ACCEPTANCE } \\
\text { CRITERIA } \\
\end{array}$ & $\begin{array}{r}\text { LIMIT } \\
\text { TI } \\
\end{array}$ & FAIL \\
\hline \multicolumn{10}{|c|}{ MCS Graph 1C Screen IIRecAY2 V V } \\
\hline 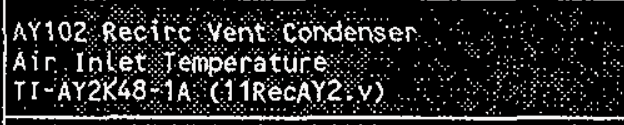 & $80^{\circ}$ & 8 & $79^{\circ}$ & $79^{\circ}$ & $80^{\circ}$ & $82^{\circ}$ & & & \\
\hline 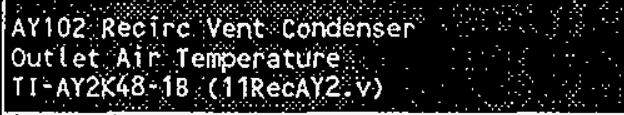 & $64^{\circ}$ & 83 & $82^{\circ}$ & $81^{\circ}$ & $82^{*}$ & $86^{\circ}$ & $\mathbb{W} / A$ & & \\
\hline $\begin{array}{l}\text { AY102 Recirc Vent condenser } \\
\text { Hoten inte Tepperature } \\
\text { TI -AY2EWS }\end{array}$ & $61^{\circ}$ & 78 & $83^{\circ}$ & $85^{\circ}$ & $85^{\circ}$ & 84 & $x^{4}$ & & \\
\hline $\begin{array}{l}\text { AY102 Recirc Vent condenser } \\
\text { Water outlet femperature } \\
\text { II-AY2EK-1 (19RecAYZ }\end{array}$ & $65^{\circ}$ & 81 & $83^{\circ}$ & $83^{\circ}$ & $82^{\circ}$ & 85 & $\therefore \mathrm{N}$ & & 8 \\
\hline 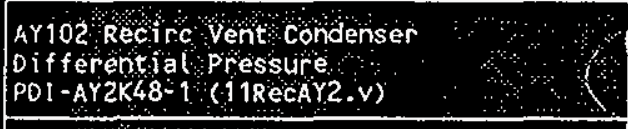 & $12.6^{4}$ & $5.5^{11}$ & 5.5 & & 5 & 5. & & & tass \\
\hline 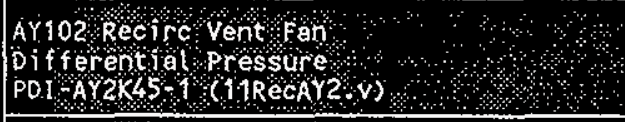 & $16.2^{11}$ & 19.5 & $19.4^{\prime 2}$ & $19.4 \cdot$ & 19.4 & 19.3 & & & \\
\hline 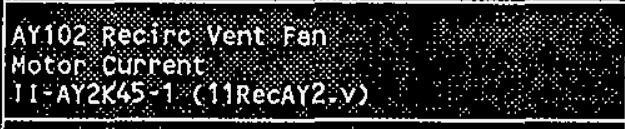 & 4.2 & 4.0 & 4.2 & 4.0 & 4.2 & 4.2 & W/A & Ni/A & $\sqrt{1.18}$ \\
\hline $\begin{array}{l}\text { Incoming tine yol tage at Metering } \\
\text { station Room } 105 \text { Gen Bldg }\end{array}$ & 483 & 48 & 480 & 479 & 480 & 477 & N/A & $\mathrm{N} / \mathrm{A}$ & $8 \%$ \\
\hline 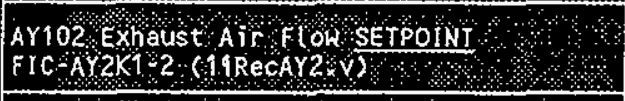 & 210 & 500 & N/A & $\mathrm{N} / \mathrm{A}$ & , $/ \mathrm{s}$ & $\mathrm{N}_{\mathrm{N}} \mathrm{O}$ & $\mathrm{N} / \mathrm{A}$ & $\mathrm{N} / \mathrm{R}$ & $\sqrt{6 / A}$ \\
\hline 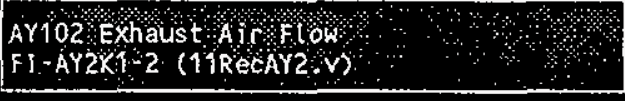 & 212 & 499 & 500 & 502 & 497 & 503 & $\begin{array}{l}\text { setpoint } \\
\pm 20 \mathrm{scfm} \\
\end{array}$ & $W / A$ & $\begin{array}{c}\operatorname{Ras} 5 / \\
25\end{array}$ \\
\hline
\end{tabular}

\begin{tabular}{|c|c|c|c|c|c|}
\hline 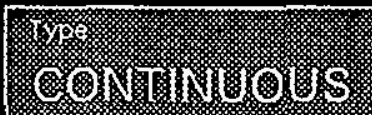 & 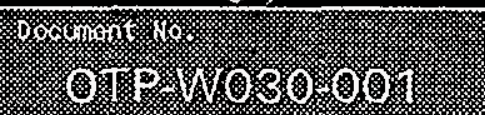 & 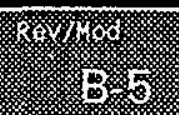 & . & 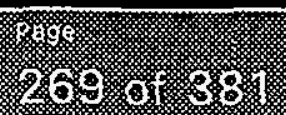 & t-writer comment: Some a \\
\hline
\end{tabular}




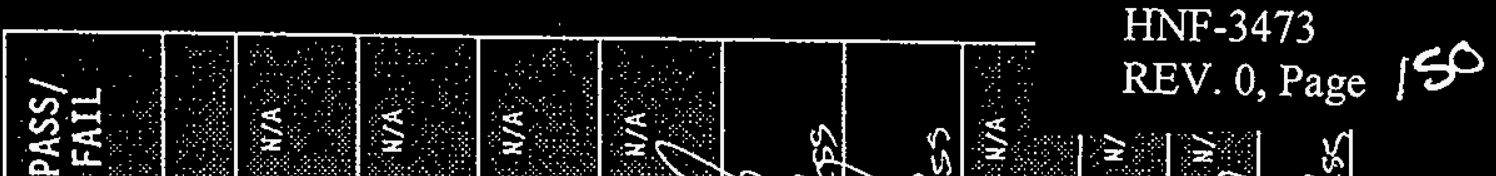

喜

5
0
8
8
8
8
8
8
8

嶦产

-

,

旁

항

资

通

뭉

峌

폰

要

욤

猔

O

蒠

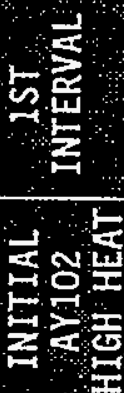

$\infty \underset{+\infty}{+\infty}$

言点

징

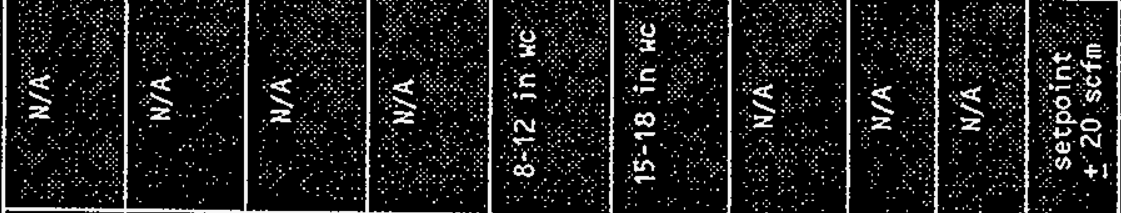

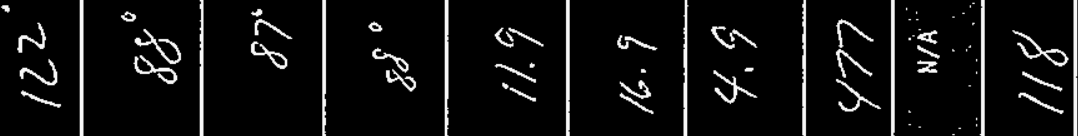

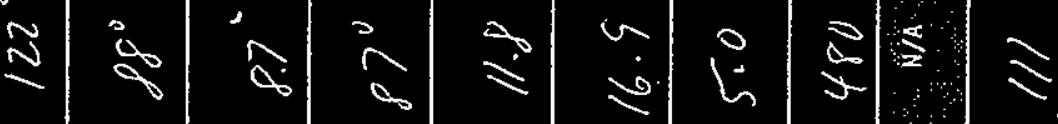

政

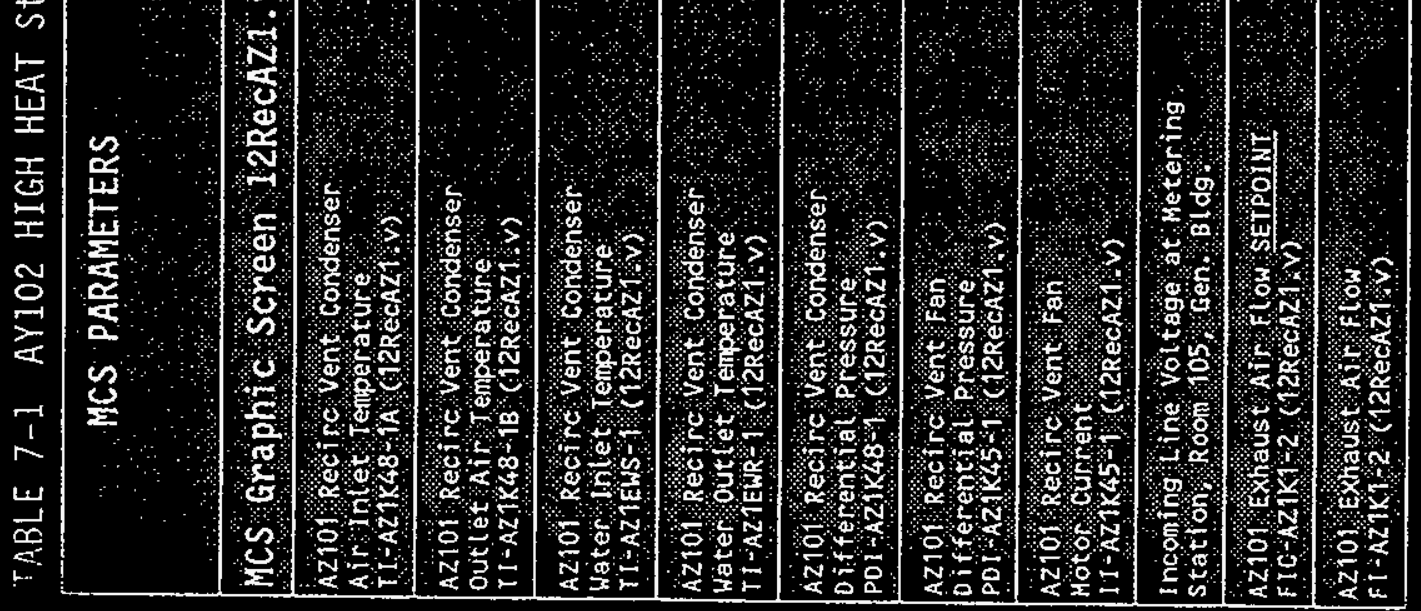

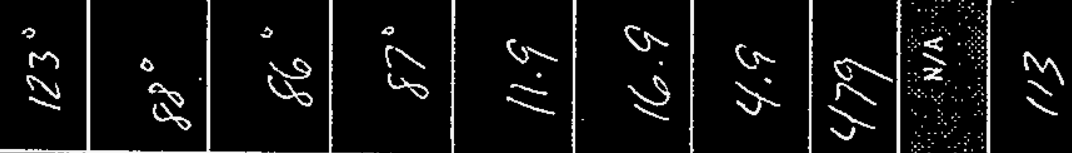

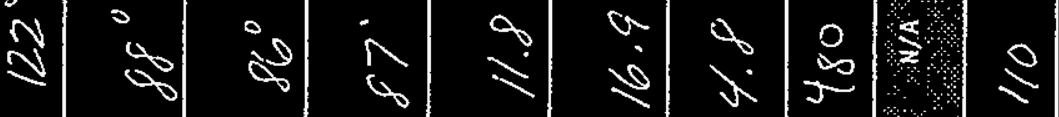

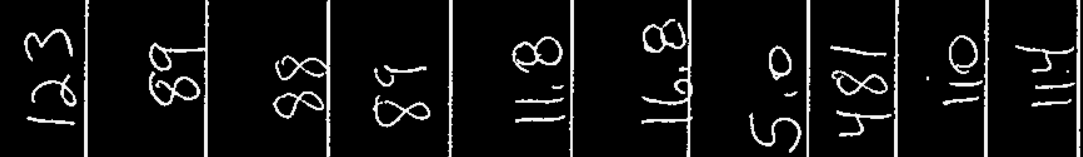

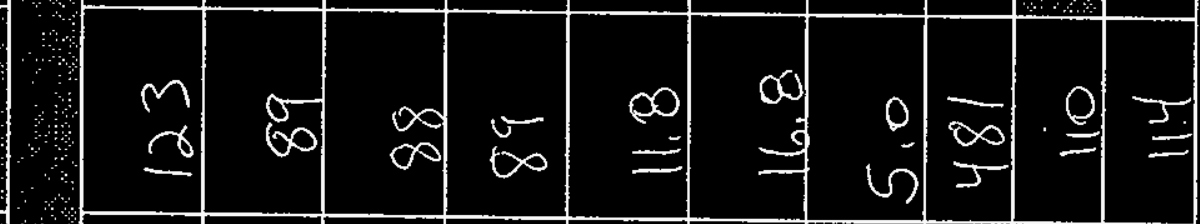

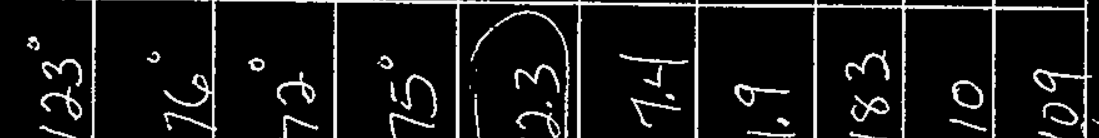


ATTACHMENT B - RECIRC AND HIGH HEAT MODE OPERATIONAL TESTING (Cont.)

ABRE 7-1 AY102 HIGH HEAT Steady State (Continued)

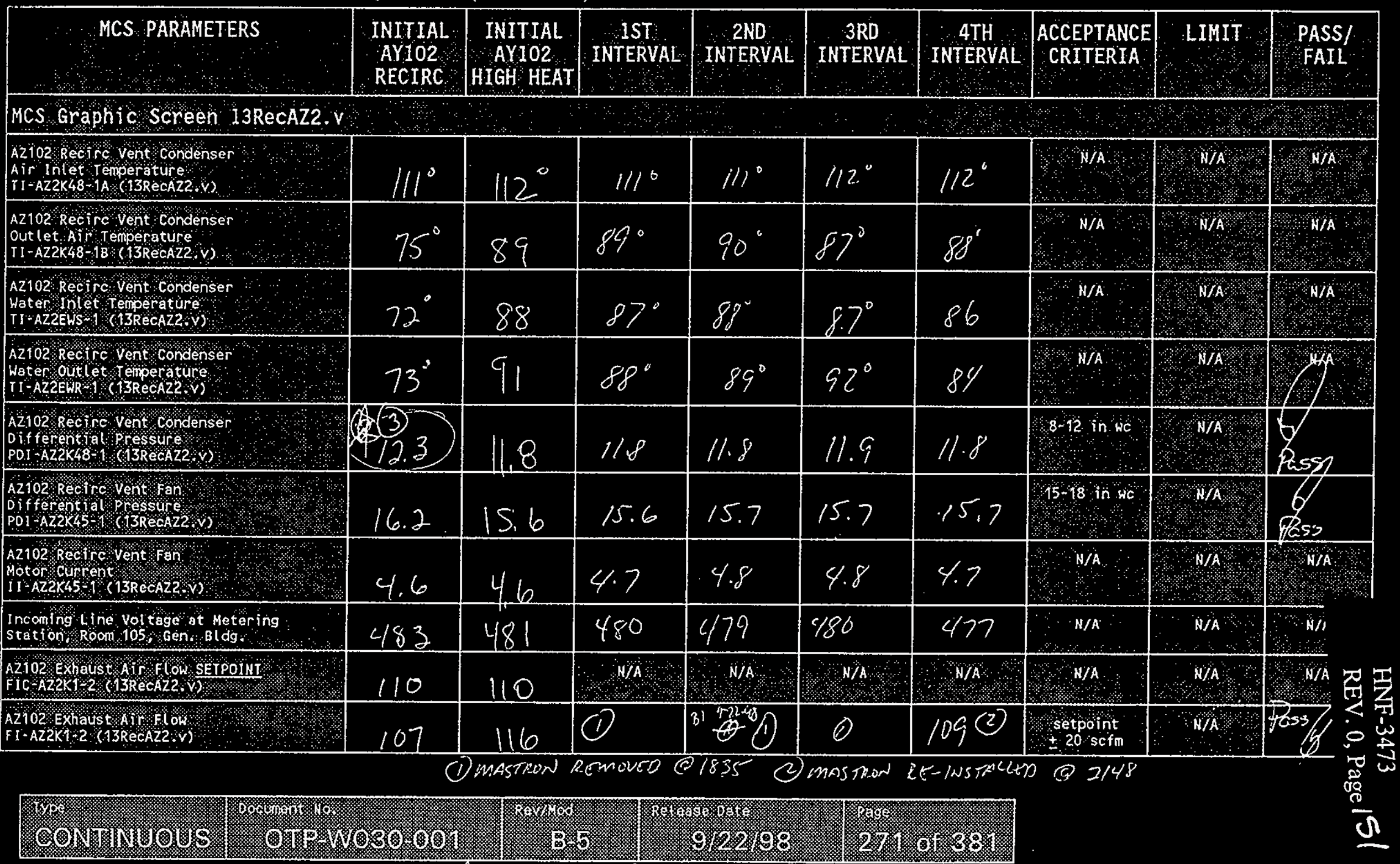

(3) See TE-O06, Iten (1) 


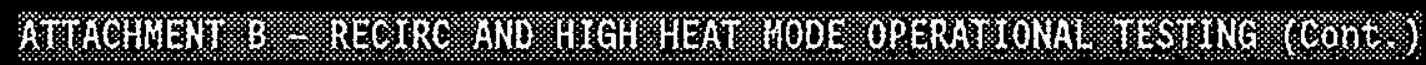

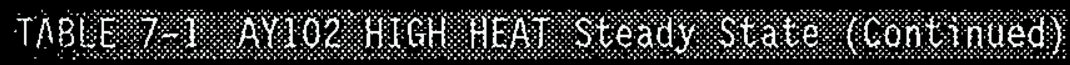

\begin{tabular}{|c|c|c|c|c|c|c|c|c|c|}
\hline 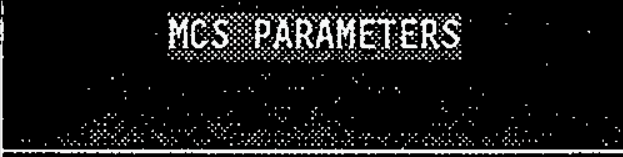 & 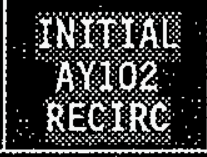 & 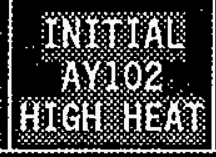 & WERTH & Whin & WhMI & Writh & 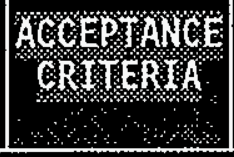 & Wty & \\
\hline \multicolumn{10}{|c|}{ 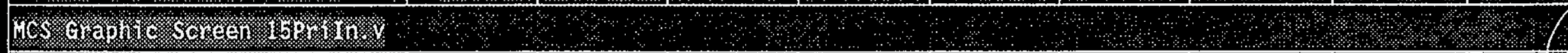 } \\
\hline A & -1 & - & -1 & -1 & -1 & -1 & 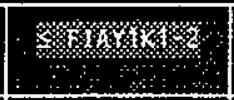 & $3 \%$ & \\
\hline Protror & -2.0 & $-2,0$ & +18. & \% & $0 \%$ & \% & $8 \%$ & 8. & \\
\hline P & $\frac{-1,4}{-1,3}$ & -1.7 & -1.7 & -1.7 & -1.8 & -1.8 & 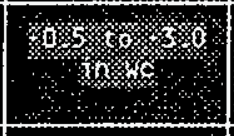 & 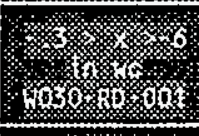 & \\
\hline 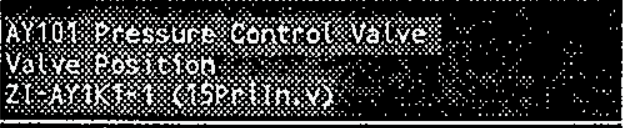 & $1 \tau_{0}$ & $1 \%$ & $1 \%$ & $1 \%$ & $1 \%$ & $1 \%$ & & $\pi$ & \\
\hline 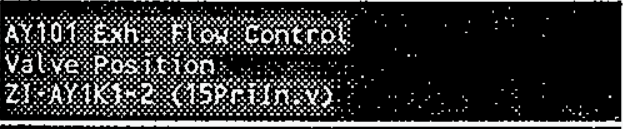 & $\$ 1 \%$ & $100^{2} 70$ & $100 \%$ & $100 \%$ & $100 \%$ & $88 \%$ & 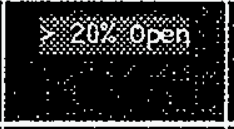 & & \\
\hline 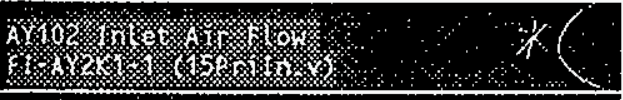 & 0 & $115^{5}$ & 115.0 & $115^{0}$ & $115^{0}$ & 115 & $-\%$ & 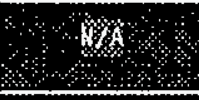 & \\
\hline H & -2.0 & -2.0 & \% & $\%$ & \% & ing & \% & $8.6 \%$ & \\
\hline 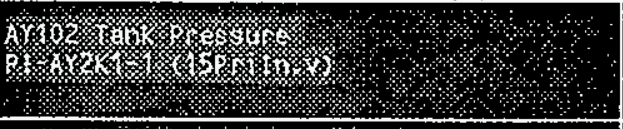 & -1.2 & -2.0 & -2.1 & -2.1 & -2.1 & -2.1 & $\frac{1}{2}$ & 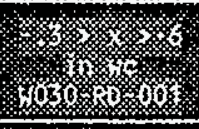 & \\
\hline A & $\phi \%$ & $36 \%$ & $36^{(1)}$ & 36 & $36^{0}$ & 360 & $\begin{array}{r}465 \\
\end{array}$ & $4 \%$ & VI \\
\hline 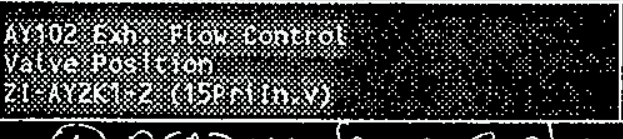 & $41 \%$ & $35 \%$ & $35 \%$ & $35 \%$ & $35 \%$ & $35 . \%$ & (6) & $8 \%$ & $\sum_{10 s s}$ \\
\hline $\begin{array}{l}\text { (1) READINy from oarle } \\
\text { actully reace flow } d\end{array}$ & & ve & , & ne: 2 & $\lg \ln$ & 2515 & in & -t & $r$ \\
\hline 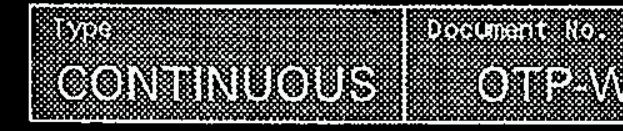 & 20 & 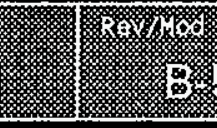 & 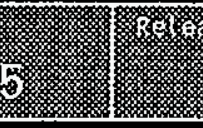 & (6. & 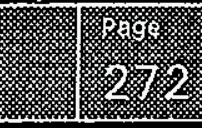 & if & & & \\
\hline
\end{tabular}


ATTACHMENT B - RECIRC AND HIGH HEAT MODE OPERATIONAL TESTING (Cont.)

TABLE 7-1 AY102 HIGH HEAT Steady State (Continued)

\begin{tabular}{|c|c|c|c|c|c|c|c|c|c|}
\hline $\begin{array}{l}\text { MCS PARAMETERS } \\
\text { P }\end{array}$ & $\begin{array}{l}\text { INITIAL } \\
\text { AY102 } \\
\text { RECIRC }\end{array}$ & $\begin{array}{c}\text { INITIAL } \\
\text { AYIO2 } \\
\text { HIGH HEAT }\end{array}$ & INTERVAL & 2NDD & $\begin{array}{l}3 R D \\
\text { INTERVAL }\end{array}$ & INTERVAL & $\begin{array}{l}\text { ACCEPTANCE } \\
\text { CRITERIA }\end{array}$ & LIMIT: & $4 \%$ \\
\hline \multicolumn{10}{|c|}{ 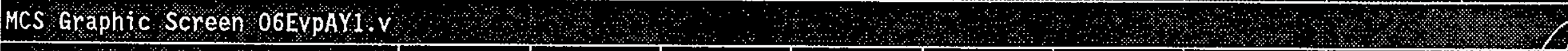 } \\
\hline 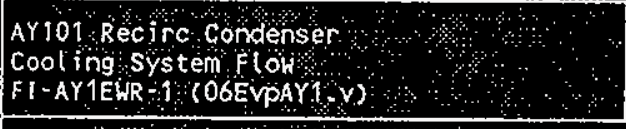 & 213 & 225 & 222 & 203 & 223 & 221 & 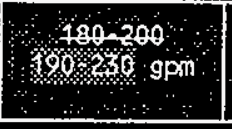 & & \\
\hline \multicolumn{10}{|c|}{ MCS Graphlc Screen 07EvpAY2,v } \\
\hline 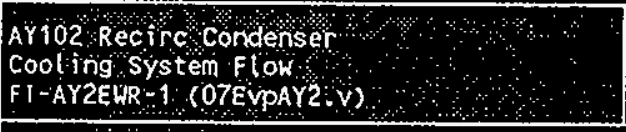 & 209 & 219 & 218 & 219 & 218 & $2^{\prime} 8$ & 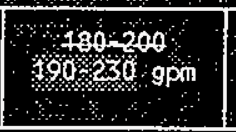 & & \\
\hline \multicolumn{10}{|c|}{ MCS Graphic Screen 08EvpAZ1,V, } \\
\hline 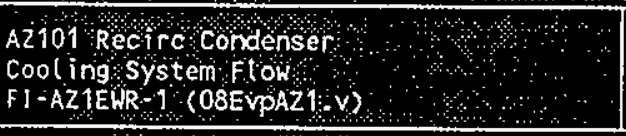 & 323 & 332 & 334 & 333 & 335 & 335 & $\begin{array}{l}3000335 \\
3058\end{array}$ & & \\
\hline \multicolumn{10}{|c|}{ MCS Graphic Screen 09EvpAZ2.V } \\
\hline 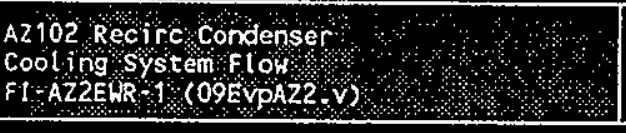 & 215 & 222 & 225 & 225 & 22.5 & 225 & \begin{tabular}{r|r|}
$880-200$ \\
\end{tabular} & & \\
\hline
\end{tabular}

\begin{tabular}{|c|c|c|c|c|}
\hline 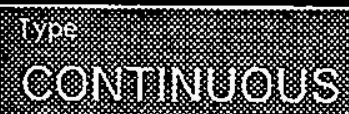 & 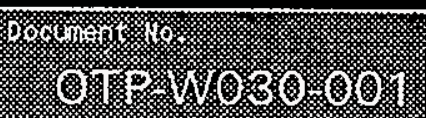 & 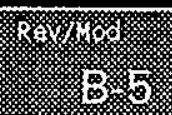 & 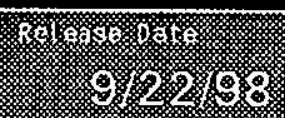 & 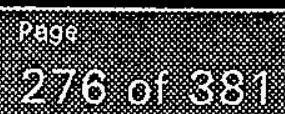 \\
\hline
\end{tabular}


ATTACHMENT B - RECIRC AND HIGH HEAT MODE OPERATIONAL TESTING (Cont.)

TABLE 7-1 AY102 HIGH HEAT Steady State (Continued)

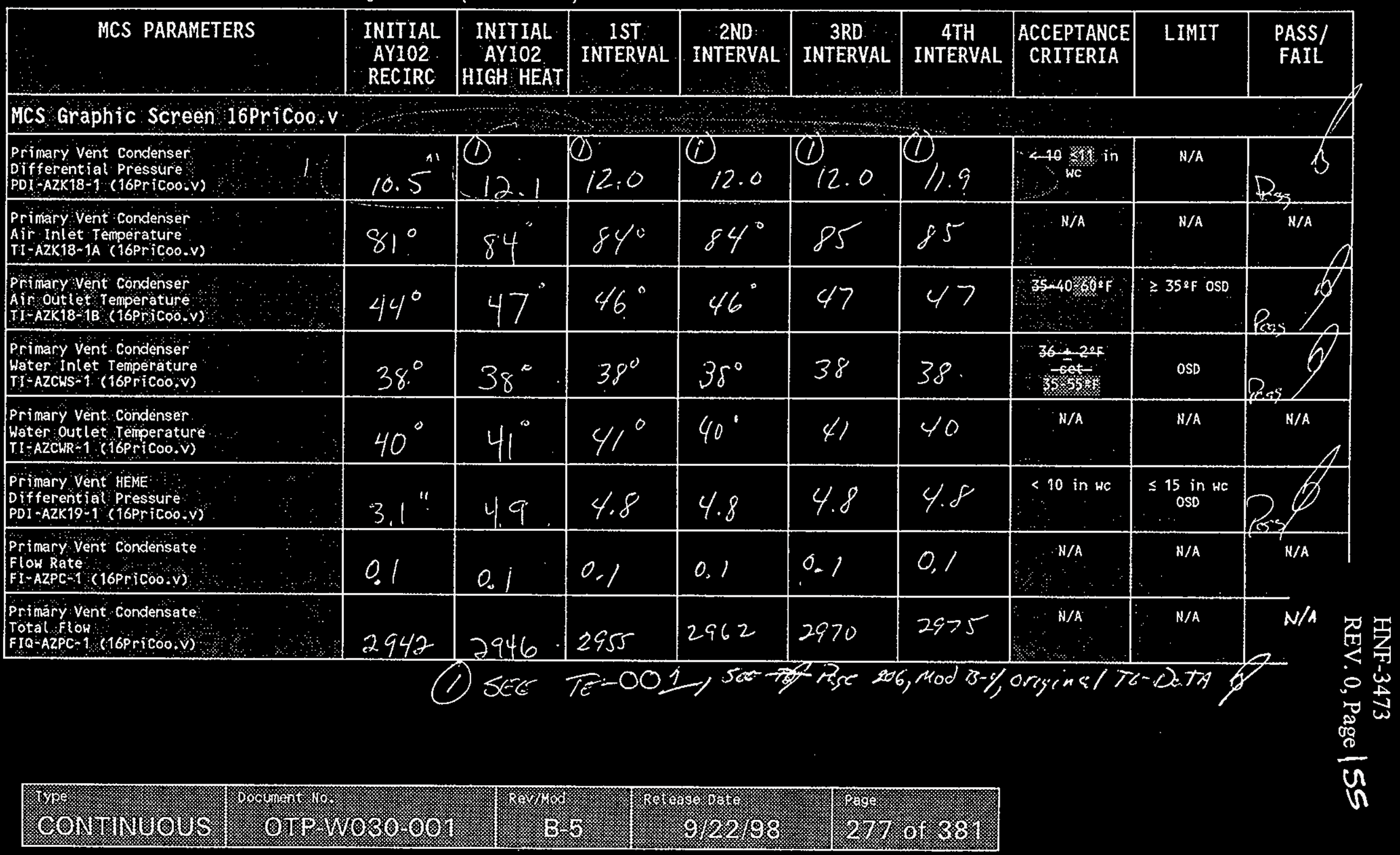


ATTACHMENT B - RECIRC AND HIGH HEAT MODE OPERATIONAL TESTING (Cont.)

TABLE 7-I AY102 HIGH HEAT Steady State (Continued)

\begin{tabular}{|c|c|c|c|c|c|c|c|c|c|}
\hline MCS PARAMETERS & $\begin{array}{l}\text { INITIAL } \\
\text { AYIO2 } \\
\text { RECIRC }\end{array}$ & $\begin{array}{r}\text { INITIAL } \\
\text { AYIO2 } \\
\text { HIGH HEAT }\end{array}$ & INTERVAL & $\begin{array}{l}\text { 2ND } \\
\text { INTERVAL } \\
\text { S. }\end{array}$ & $\begin{array}{l}\text { 3RD } \\
\text { INTERVAL }\end{array}$ & $\begin{array}{l}\text { 4TH } \\
\text { INTERVAL }\end{array}$ & $\begin{array}{l}\text { ACCEPTANCE } \\
\text { CRITERIA } \\
\end{array}$ & LIMIT & $\begin{array}{l}\text { PASS/ } \\
\text { FAIL } \\
\end{array}$ \\
\hline \multicolumn{10}{|c|}{ MCS GraphIC Screen $14 C h 11 r$ r } \\
\hline 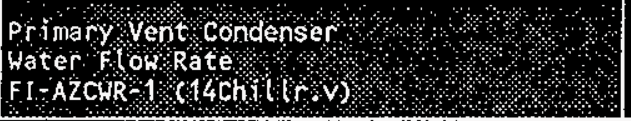 & 11.9 & 118 & 119 & 119 & $1 / 9$ & $1 / 9$ & 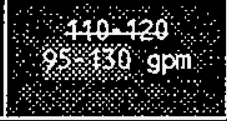 & & \\
\hline
\end{tabular}

\begin{tabular}{|c|c|c|c|c|}
\hline 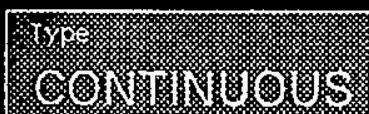 & 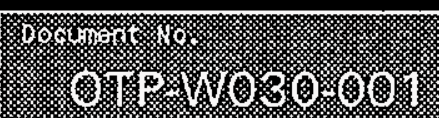 & 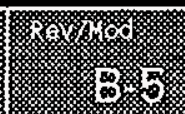 & 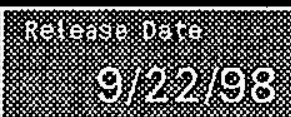 & 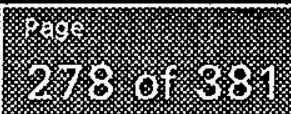 \\
\hline
\end{tabular}


ATTACHMENT B - RECIRC AND HIGH HEAT MODE OPERATIONAL TESTING (Cont.)

TABLE 7-1 AY102 HIGH HEAT Steady State (Continued)

\begin{tabular}{|c|c|c|c|c|c|c|c|c|c|}
\hline MCS PARAMETERS & $\begin{array}{l}\text { INITIAL } \\
\text { AYIO2 } \\
\text { RECIRC }\end{array}$ & $\begin{array}{r}\text { INITIAL } \\
\text { AYIO2 } \\
\text { HIGH HEAT }\end{array}$ & $\begin{array}{l}\text { IST } \\
\text { INTERVAL }\end{array}$ & 2NB & INTERVAL & TNTERVAL & $\begin{array}{l}\text { ACCEPTANCE } \\
\text { CRITERIA } \\
\end{array}$ & LIHIT & $\begin{array}{l}\text { PASSI } \\
\text { FAIL } \\
\end{array}$ \\
\hline \multicolumn{10}{|l|}{ MCS Graphic Screen 17PriExh.V } \\
\hline 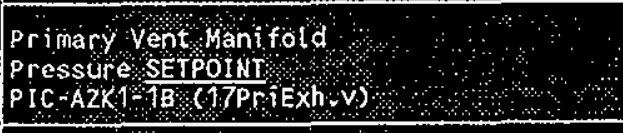 & 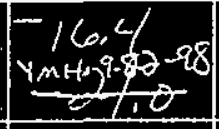 & -21.0 & 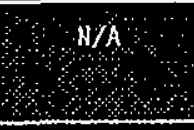 & N/A & N/A & $\mathrm{N} / \mathrm{A}$ & + & \%/A & $\%$ \\
\hline 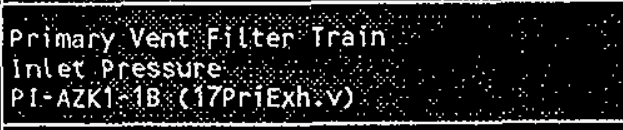 & -16.4 & $-20,4$ & -20.3 & -20.3 & -20.2 & -20.3 & setpoint $0.5 \%$ & N/ & Pass \\
\hline 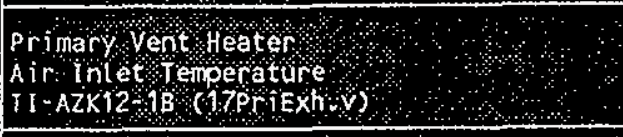 & $51^{\circ}$ & $50^{\circ}$ & $50^{\circ}$ & $50^{\circ}$ & 50 & 50 & 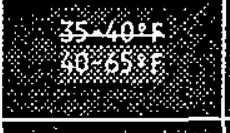 & \% & \\
\hline $\begin{array}{l}\text { Primary vent Heater, } \\
\text { Differentialo Tenperature serpornt } \\
\text { IOIC-AZK12-18 }\end{array}$ & $44^{4}+y^{48}$ & $25^{\circ}$ & & $N / A$ & $\mathrm{~N} / \mathrm{A}$ & ii/A & N/A, & 8 & \\
\hline 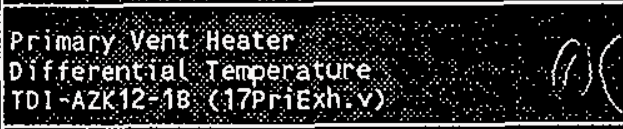 & $28^{\circ}:$ & $23^{\circ}$ & $24^{\circ}$ & $25^{6}$ & 24 & 24 & $\mathrm{setpoint}^{\text {sets }}$ & $\begin{array}{l}37 \mathrm{a} \\
0.50\end{array}$ & \\
\hline 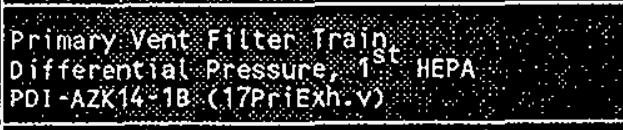 & $0.64{ }^{4}{ }^{2 \gamma^{2}}$ & 0.8 & 0.8 & 0.8 & 0.8 & 0.8 & $\mathrm{r}^{5}, \mathrm{ninh}_{\mathrm{s}}$ & $\begin{array}{l}<6 \text { in we } \\
\text { oso }\end{array}$ & \\
\hline 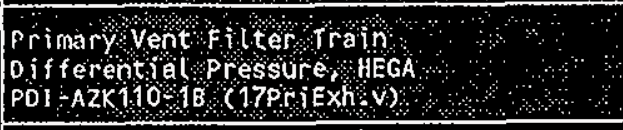 & $\begin{array}{l}1.0 \\
1.69\end{array}$ & 1.6 & 1.6 & 1.6 & 1.5 & 1.6 & 31.75 & $\begin{array}{l}3 \text { in } \\
\text { OSD } \\
\end{array}$ & \\
\hline 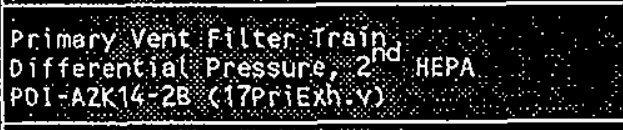 & 0.5 & 0.8 & 0,8 & 0.8 & 0.8 & 0.8 & sin wc: & $\begin{array}{l}6 \text { in we } \\
\text { OSD }\end{array}$ & \\
\hline 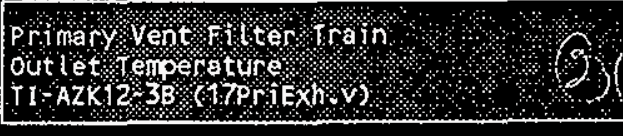 & (1) & $73^{\circ}$ & $74^{\circ}$ & $7 \%^{\circ}$ & 740 & $74^{\circ}$ & rorctionsoint & 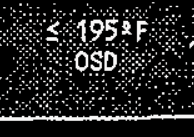 & ags \\
\hline- & & & & & & & & & \\
\hline 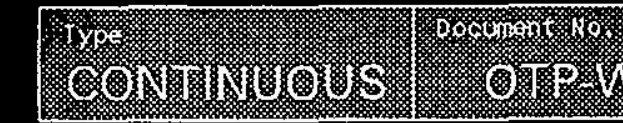 & (1.: & 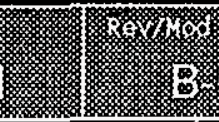 & (x) & 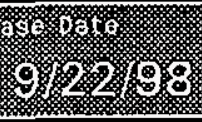 & 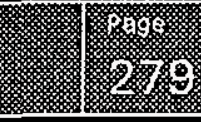 & 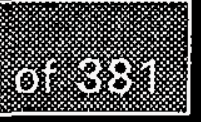 & & & \\
\hline
\end{tabular}




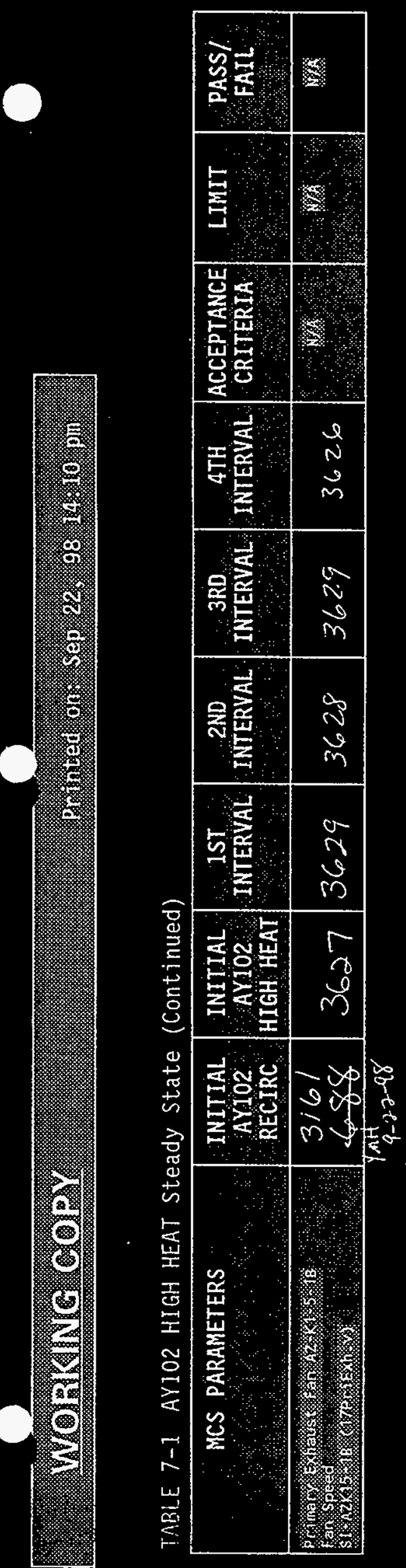

HNF-3473 REV. 0, Page 158

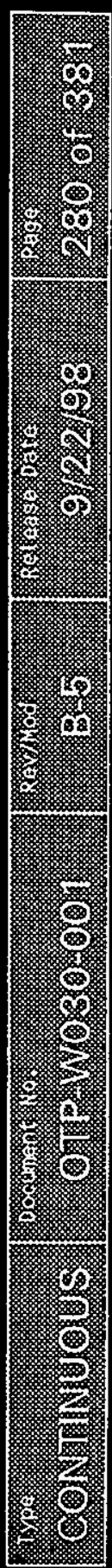




\section{WORINING COPY}

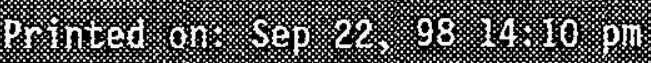

ATTACHMENT B - RECIRC AND HIGH HEAT MODE OPERATIONAL TESTING (CONt.)

TABLE 7-1 AY102 HIGH HEAT Steady State (Continued)

\begin{tabular}{|c|c|c|c|c|c|c|c|c|c|}
\hline MCS PARAMETERS & $\begin{array}{l}\text { INITIAL } \\
\text { AY102 } \\
\text { RECIRC }\end{array}$ & $\begin{array}{l}\text { INITIAL } \\
\text { AY102 } \\
\text { HIGH HEAT }\end{array}$ & INTERTAL & INTERVAL & INTERVAL & INTERVAL & $\begin{array}{l}\text { ACCEPTANCE } \\
\text { CRITERIA } \\
\end{array}$ & $\begin{array}{r}\text { IMIT } \\
\text { TI } \\
\end{array}$ & PAC \\
\hline \multicolumn{10}{|c|}{ 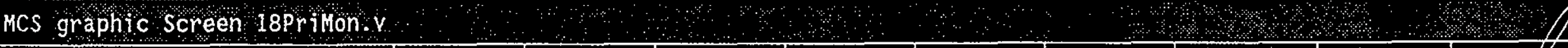 } \\
\hline 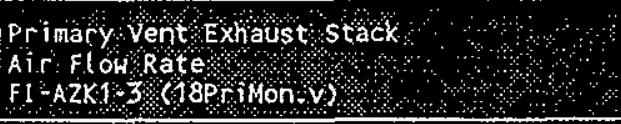 & 688 & 963 & & & 2 & & $\begin{array}{l}760-0,4006,6 \\
\text { scfm. }\end{array}$ & 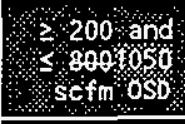 & Cars \\
\hline $\begin{array}{l}\text { Primary Vent Exhaust stack } \\
\text { Air Temperature } \\
\text { TI-AZK1 } 3 \text { (18Primon-v) }\end{array}$ & $84^{\circ}$ & 8 & 86 & & $\delta 6$ & 86 & & $\begin{array}{l}\mathrm{H} / \mathrm{A} \\
\cdots\end{array}$ & \\
\hline 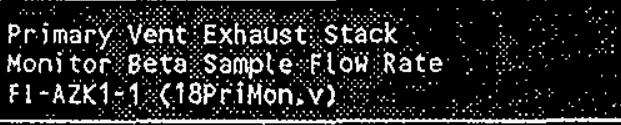 & 1,2 & 1.7 & 1.7 & 1.7 & 1.7 & 1.7 & (i) & N/A & W $/ A$ \\
\hline 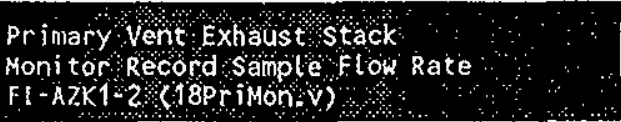 & 4 & 1.8 & & 1.7 & 1 & 1.7 & (1) & कर $/ \mathrm{A}$ & \% \\
\hline
\end{tabular}

Notes:

(1) For sample flow rate, ideal value must be calculated, based on actual stack flow (FI-AZK1-3) as follows: Ideal sample flow $=2 \times$ (stack scfm/1206).

\begin{tabular}{|c|c|c|c|c|}
\hline 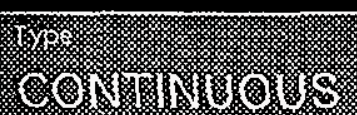 & S. & 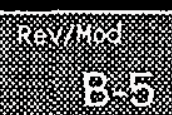 & 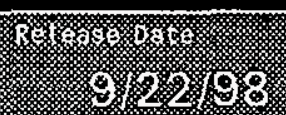 & 28\% \\
\hline
\end{tabular}




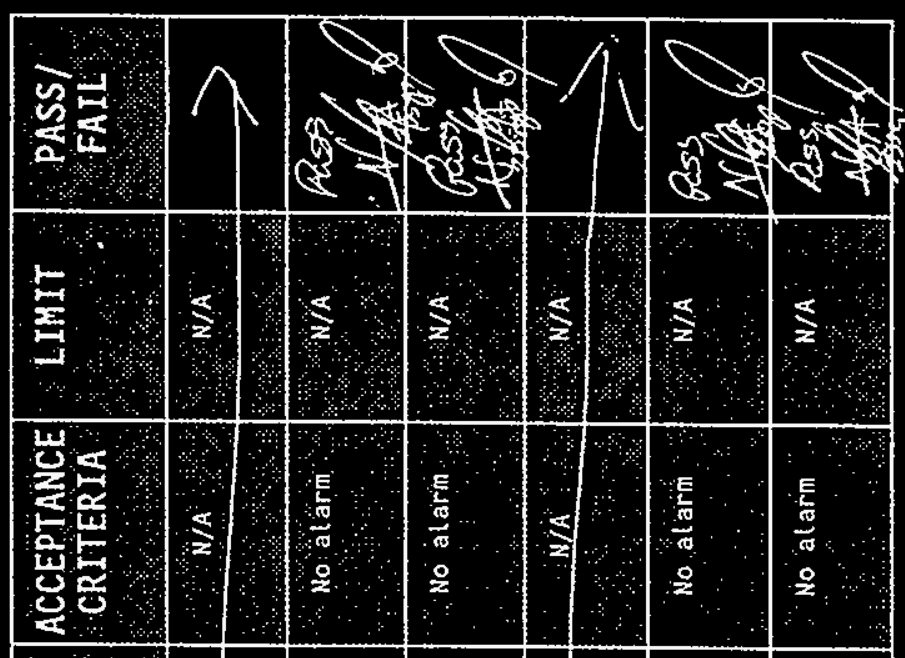

HNF-3473

REV. 0, Page 160

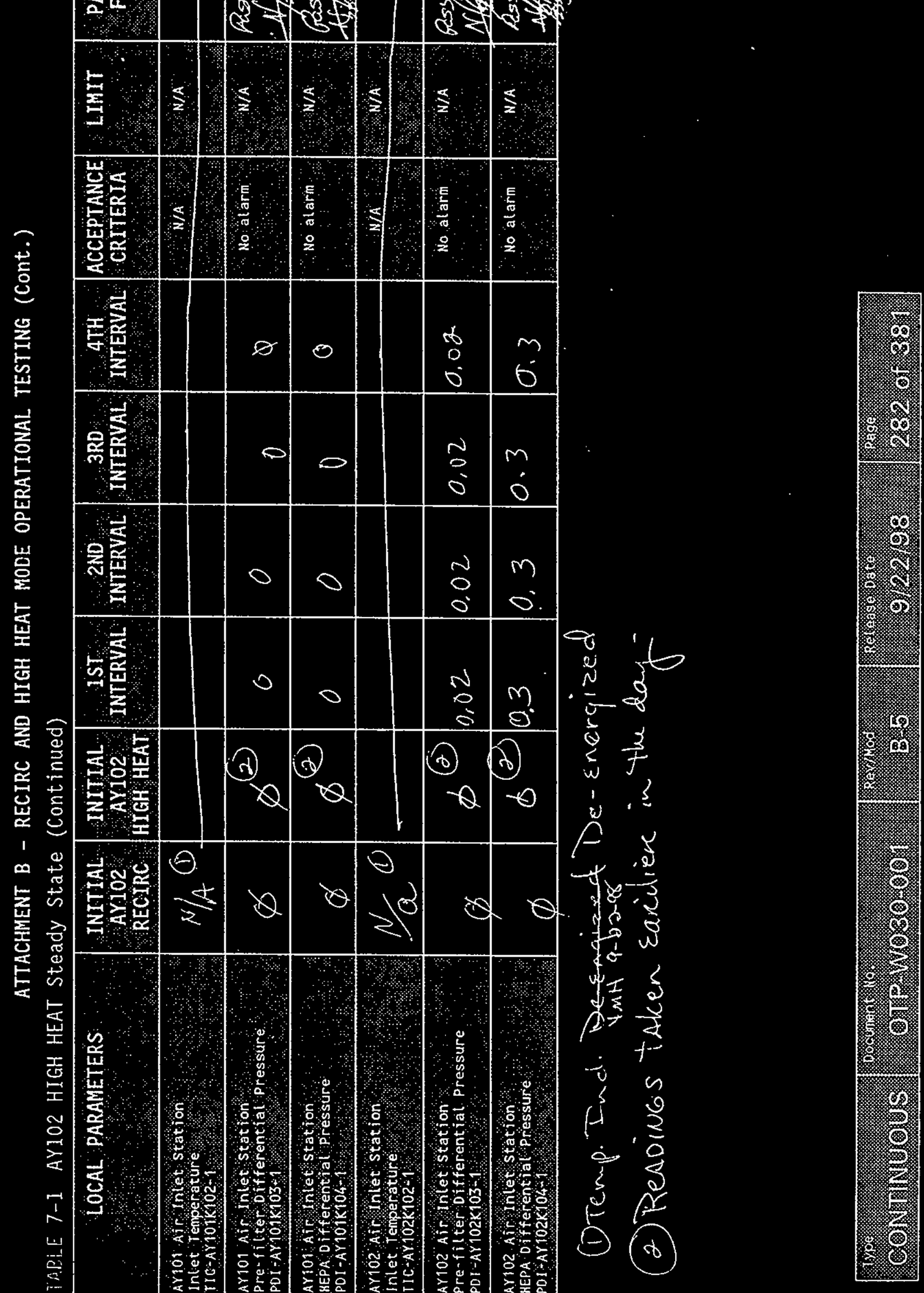




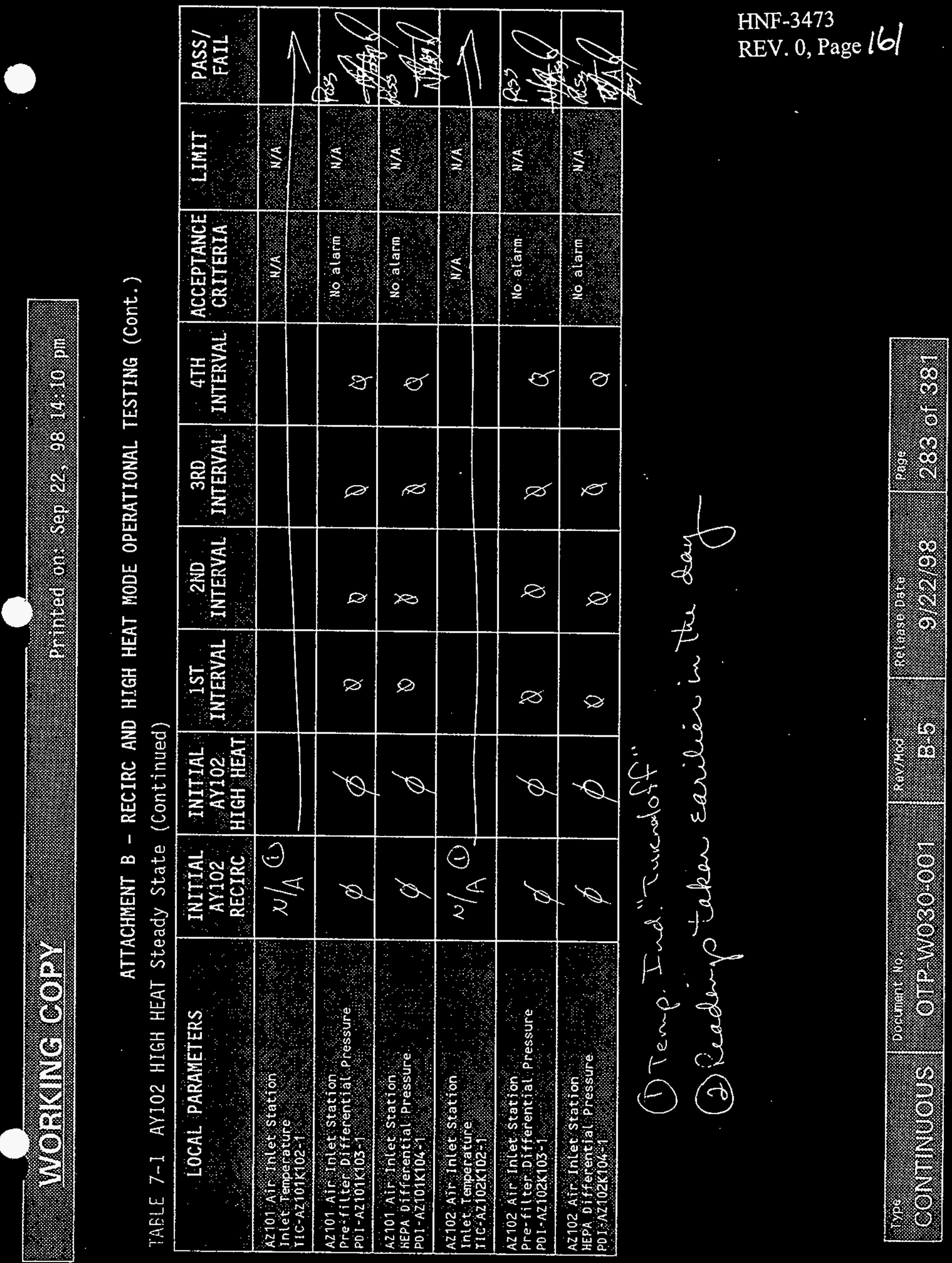


ATTACHMENT B - RECIRC AND HIGH HEAT MODE OPERATIONAL TESTING (Cont.)

TABLE 7-2 AY102 HIGH HEAT Steady State (AT] Cooling Towers in WET MODE)

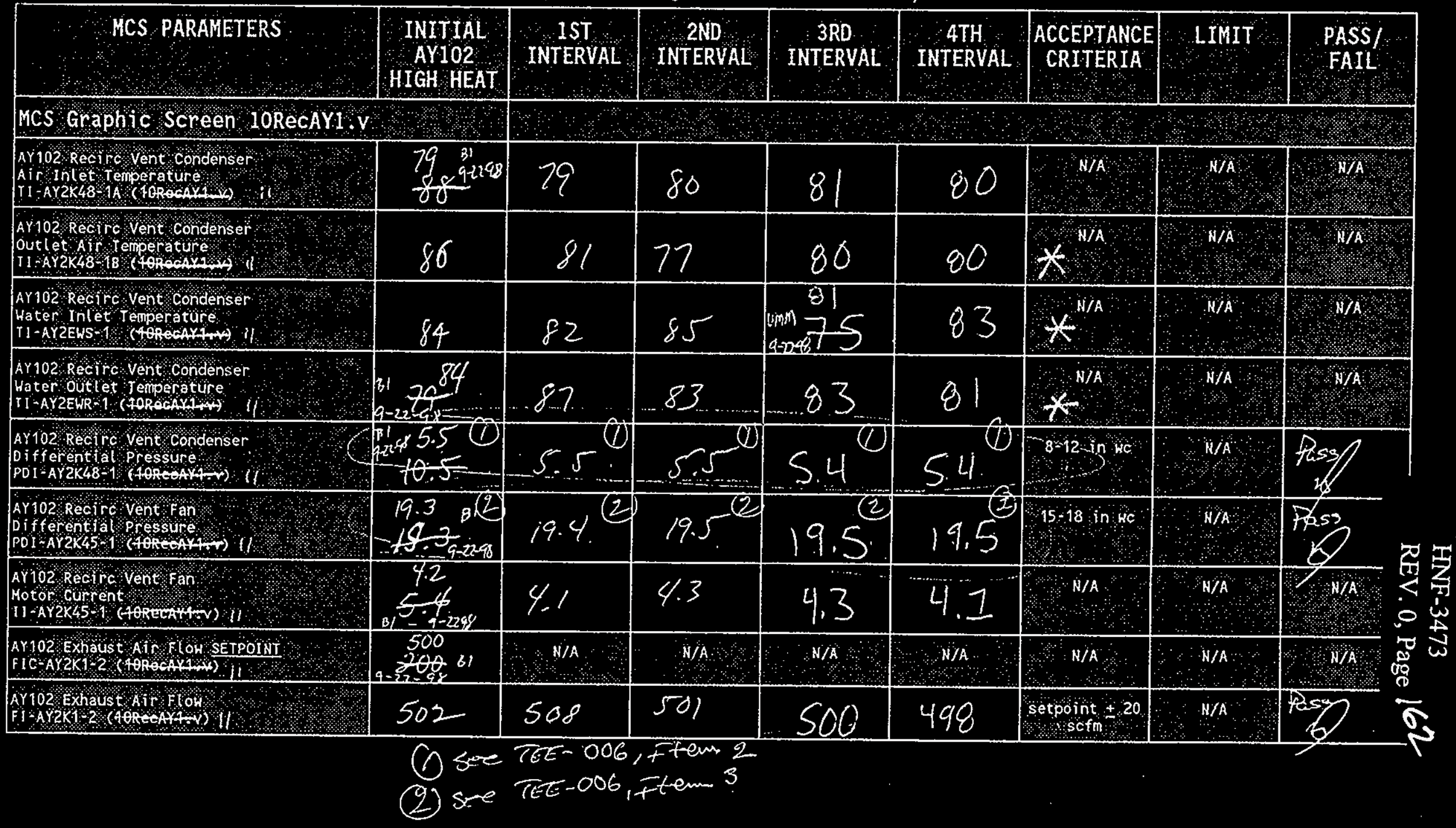

\begin{tabular}{|c|c|c|c|c|}
\hline 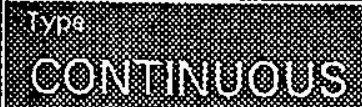 & 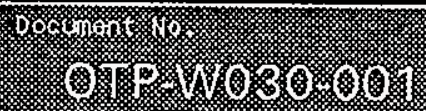 & 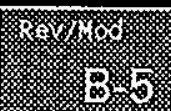 & 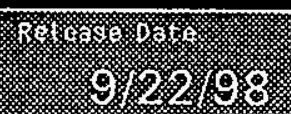 & 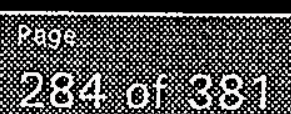 \\
\hline
\end{tabular}

* Report-wriler comment: Some data reflects impossible or inconsistent conditions and is suspect.. 
ATTACHMENT B - RECIRC AND HIGH HEAT MODE OPERATIONAL TESTING (Cont.)

TABLE 7-2 AY102 HIGH HEAT Steady State (A17 Cooling Towers in WET MODE, Continued)

\begin{tabular}{|c|c|c|c|c|c|c|c|c|}
\hline $\begin{array}{c}\text { MCS PARAMETERS } \\
\text { S }\end{array}$ & $\begin{array}{l}\text { INITIAL } \\
\text { AY } 102 \\
\text { HIGH HEAT }\end{array}$ & INTERVAL & $\begin{array}{l}\text { 2NO } \\
\text { INTERVAL }\end{array}$ & INTERVAL & INTERVAL & $\begin{array}{l}\text { ACCEPTANCE } \\
\text { CRITERIA } \\
\end{array}$ & LIMIT & FAIL \\
\hline \multicolumn{9}{|c|}{ MCS Graphic screen 15 Prin.V } \\
\hline 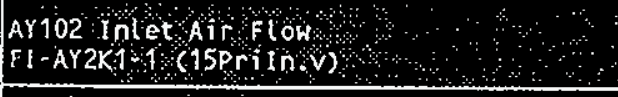 & -150 & -150 & -150 & -150 & -150 & FIAY2K1\%2 & & \\
\hline 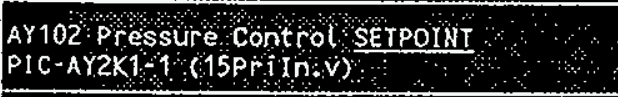 & (1) & $N / A$ & N/A & $\because \mathrm{N} / \mathrm{A}$ & $\mathrm{N} / \mathrm{A}$ & $\therefore$ & + & \\
\hline 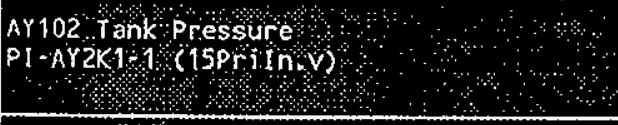 & -2.2 & $-2 \cdot 2$ & -2.2 & -2.1 & -2.1 & 0.35 to 3.0 & $\begin{array}{l}38 \times>61 \\
\text { W030 }+ \text { RO } 001\end{array}$ & \\
\hline 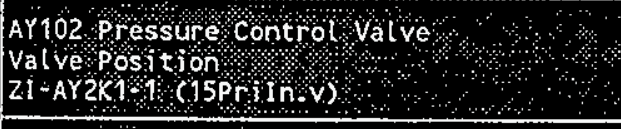 & $-25 \%$ & $-25 \%$ & $-2 \sqrt{18}$ & -25 & -25 & & & Ress \\
\hline 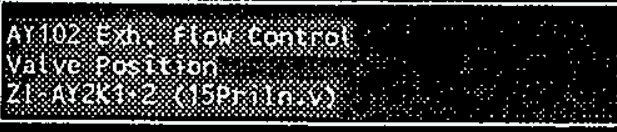 & $35 \%$ & $35 \%$ & $34 \%$ & 34 & 34 & 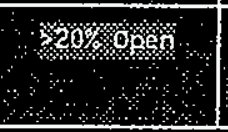 & $8 \%$ & \\
\hline
\end{tabular}

\begin{tabular}{|c|c|c|c|c|}
\hline 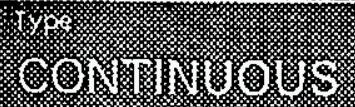 & 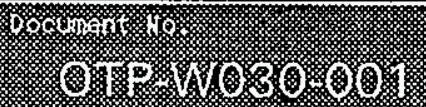 & 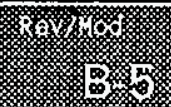 & 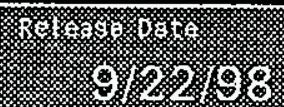 & : \\
\hline
\end{tabular}


HNF-3473।

REV. 0, Page 164
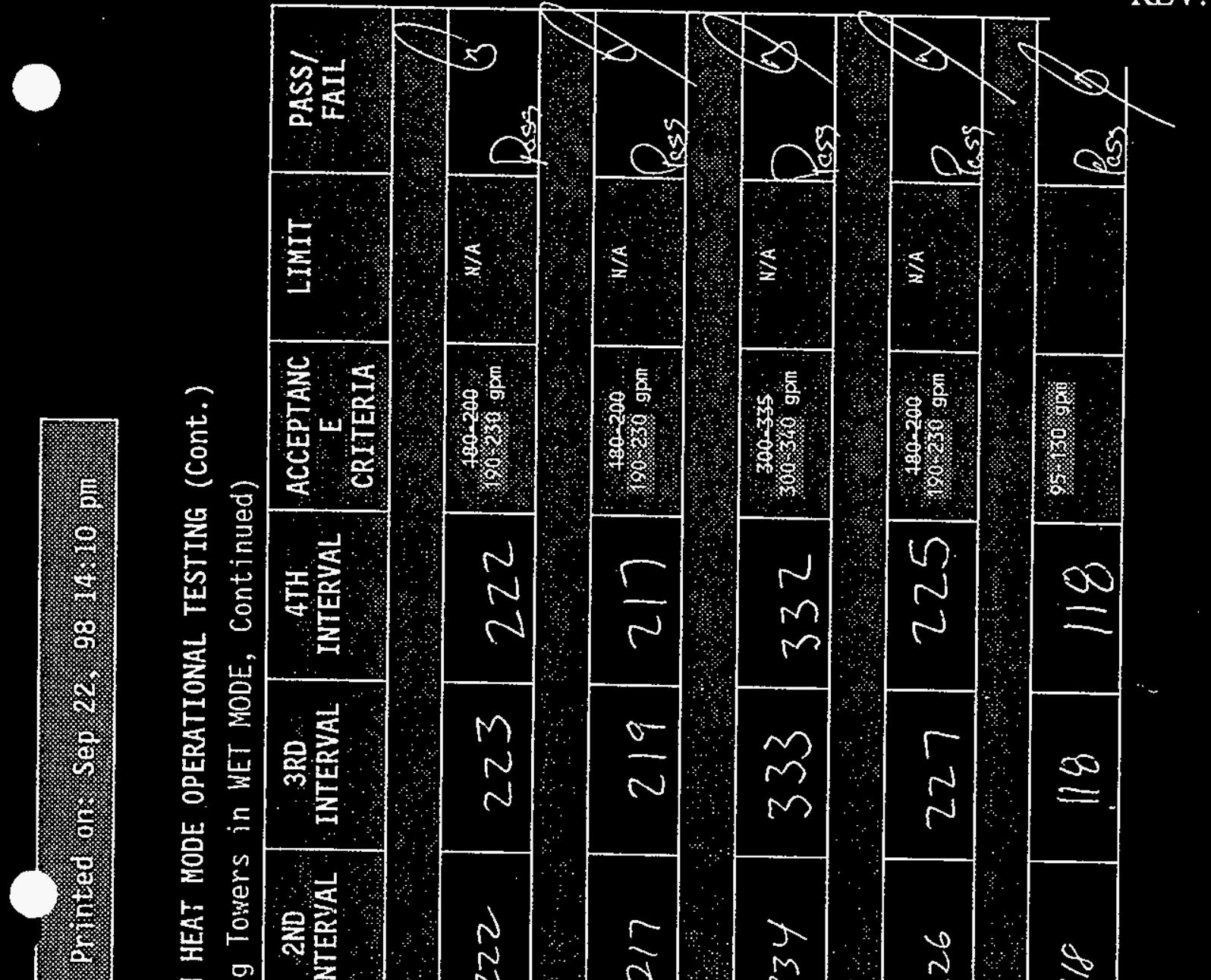

है

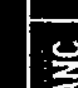

을

(2)

.

窟害

焉密

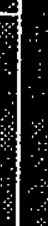

产崖

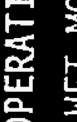

능

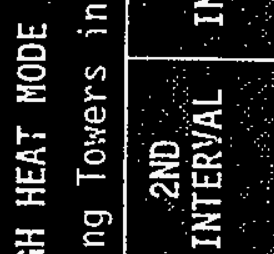

S

$\overrightarrow{5}$

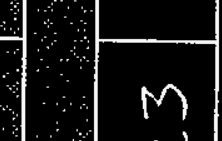

$N$

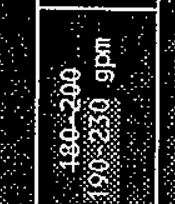

(

鿶

-

돋

ल늘

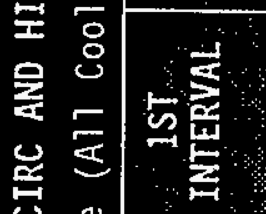

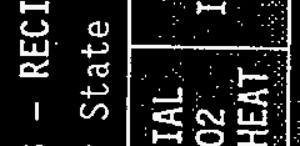

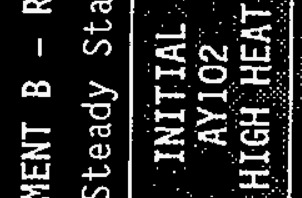

惩

焉

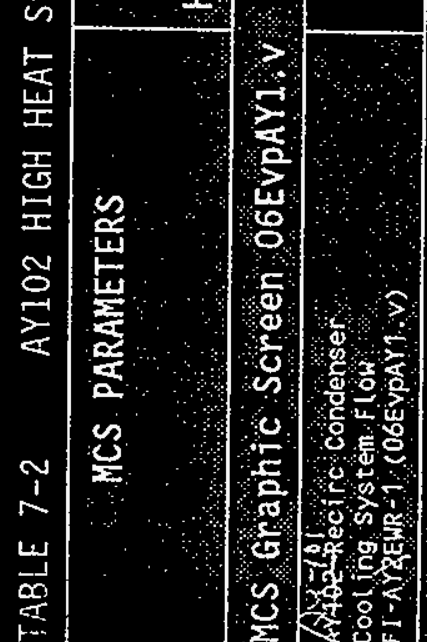

ते
ते

$N$

$\checkmark$
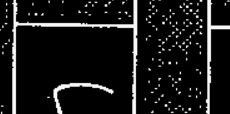

$\Gamma$

$m$

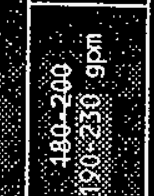

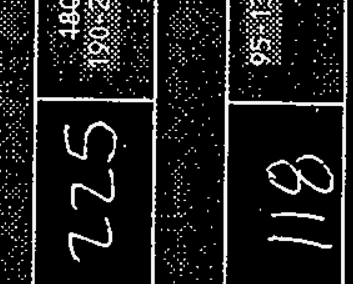

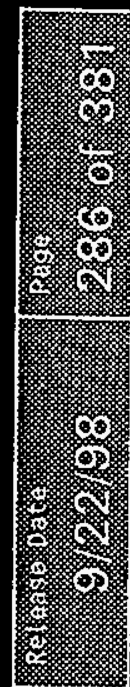

$N$

N

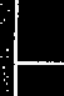

$\frac{\sigma}{N}$

$M$

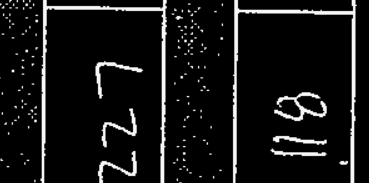

$M$
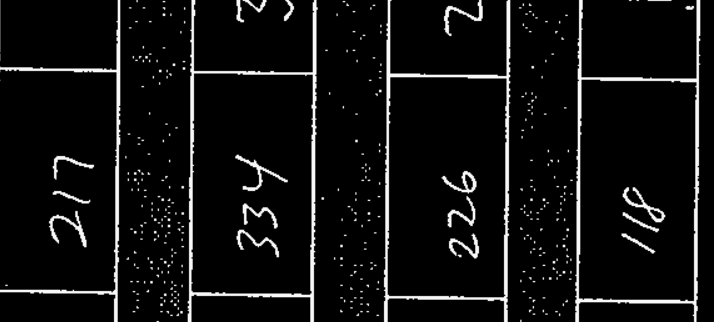

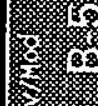

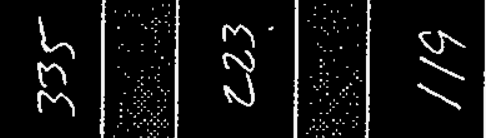


HNF-3473

REV. 0, Page 165
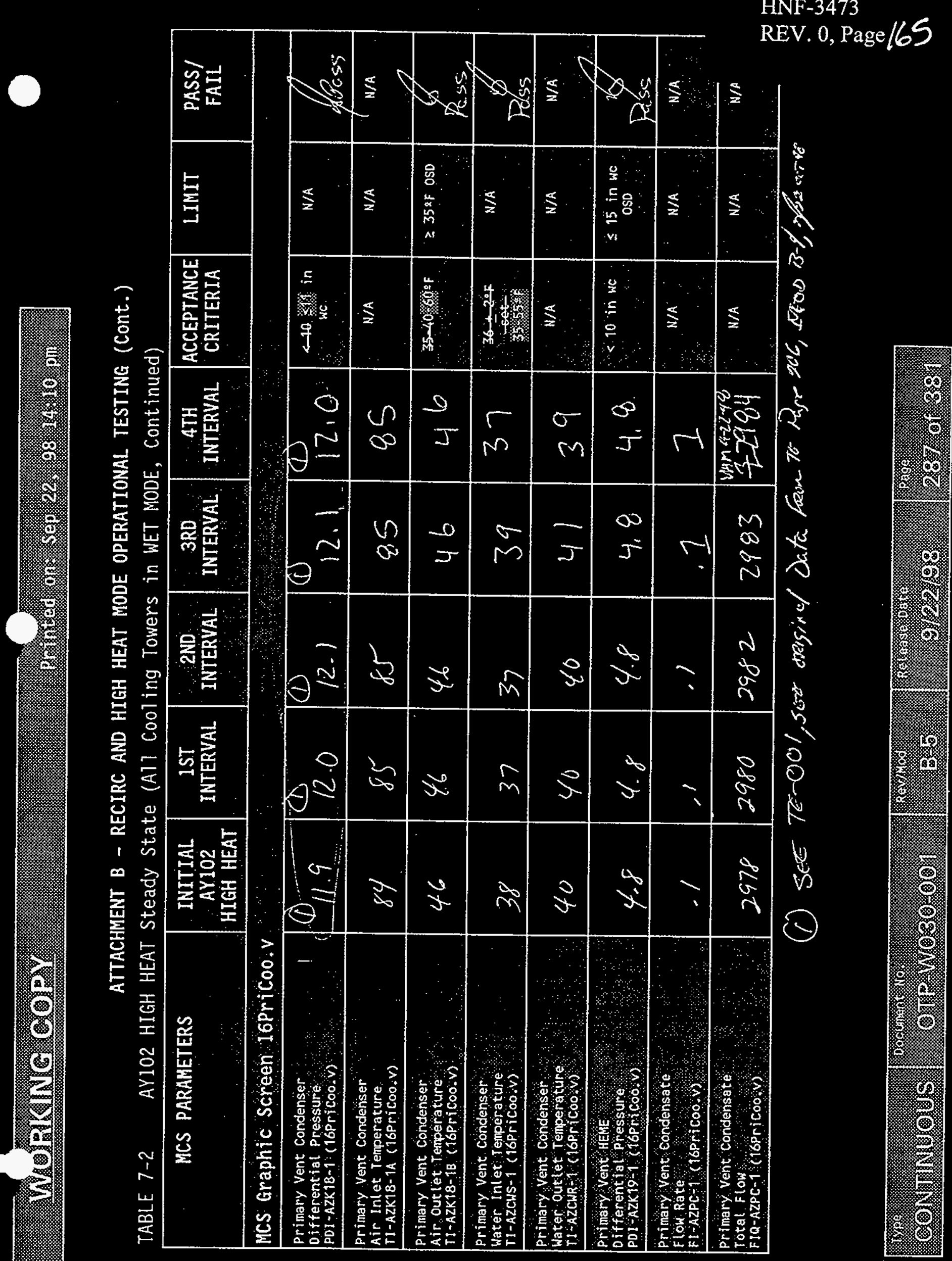

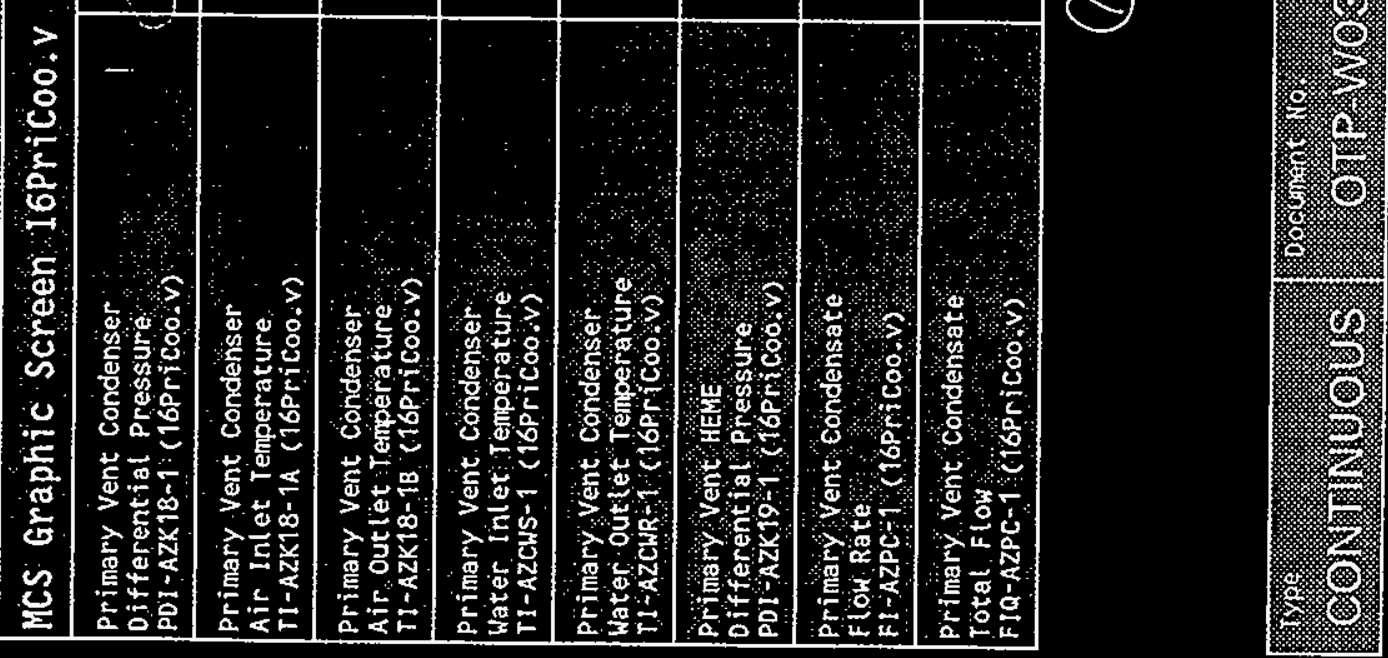


ATTACHMENT B - RECIRC AND HIGH HEAT MODE OPERATIONAL TESTING (Cont.)

TABLE 7-2 AY102 HIGH HEAT Steady State (Al1 Cooling Towers in WET MODE, Continued)

\begin{tabular}{|c|c|c|c|c|c|c|c|c|}
\hline MCS PARAMETERS & $\begin{array}{l}\text { INTTIAL } \\
\text { AYIO2 } \\
\text { HIGH HEAT }\end{array}$ & INTERYAL & INTERVAL & INTERVAL & INTERVAL & $\begin{array}{l}\text { ACCEPTANCE } \\
\text { CRITERIA }\end{array}$ & LTMT & $\begin{array}{l}\text { PASS } / \\
\text { FAIL }\end{array}$ \\
\hline
\end{tabular}

MCS Graphic screen $17 \mathrm{Pr}$ Exh.

Primary vent Manifold Pressure SETPOINT

Primary Vent filter Train

intet pressure PI-AZK1-1A (17PR IEXh

Primaly vent Heater,

Air intet Téperature

II -AZK 12 1A (17P P IEXh V V )

Primary vent heater:

Primary yent heater

Different

TDIC-AZK12-1A (I7Pr IEX $-v)$

primary Went Heater

D ifferento at tenperature

TD $-A Z K 12-1 A$ (17Pr IEXh.V)

Primary vent filter train

o ifferential pressure, 1 St HEPA

POI-AZK $14-1$ A (17PrifXh v)

Primary vent onter tran

D ifferential pressure HEGA

POI AZK1 10 1A (ITP IEXK.V)

Primary vent filttertrald.

Differential pressure 2 hd HEPA

POI-AZK14-2A (17PriEXh.v)

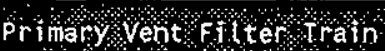

out let temperature.

TI-AZK 12-3A (17PriEXI)

\begin{tabular}{|c|c|c|c|c|c|c|c|}
\hline & w/A & $y / x$ & W/A & $\mathrm{W} / \mathrm{A}$ & w/A & N/A & W/A \\
\hline$-20.5^{\circ}$ & $-20.5^{0}$ & -20.43 & $\begin{array}{r}-20.4^{\circ} \\
\end{array}$ & $-20.4^{3}$ & 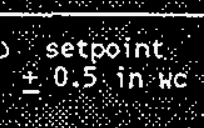 & $\mathrm{W} / \mathrm{NA}$ & $p_{s} s \mathrm{f}$ \\
\hline $50^{\circ}$ & 50 & $50^{\circ}$ & $50^{\circ}$ & $50^{\circ}$ & 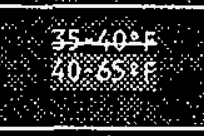 & 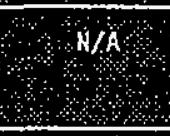 & 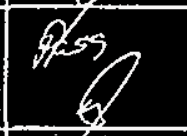 \\
\hline 25.0 & w/h & $\mathrm{W} /$ & $w / A$ & whan & $\mathrm{NAA}$ & $\sqrt{2 \pi}$ & נ/1/4. \\
\hline 24 & $24^{\circ}$ & $24^{\circ}$ & 240 & $24^{\circ}$ & sespoint & 8707 & (k) \\
\hline 0 & $0,8^{\circ}$ & $0,8^{\circ}$ & 0.80 & 0.80 & $=5$ in 16 & 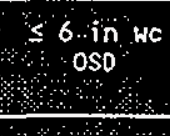 & stos \\
\hline $1.5^{\circ}$ & $1.5^{\circ}$ & $1.5^{\circ}$ & $1,5^{\circ}$ & 1.60 & $8 \mathrm{sins} \mathrm{h}$ hed & 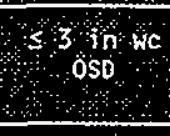 & 1 \\
\hline 0.8 & $0.7^{\circ}$ & $0.8^{\circ}$ & $0.8^{0}$ & $0.8^{\circ}$ & 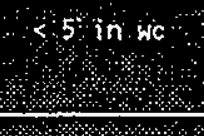 & $\begin{array}{l}6,6 \text { in we } \\
\text { oss }\end{array}$ & 2 \\
\hline $24^{\circ}$ & 14 & $74^{\circ}$ & $74^{\circ}$ & $\frac{74^{\circ}}{\text { ences }}$ & 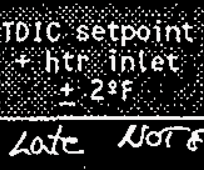 & 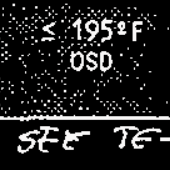 & 8 \\
\hline
\end{tabular}

(1) RUNNING ON B-TRAIN

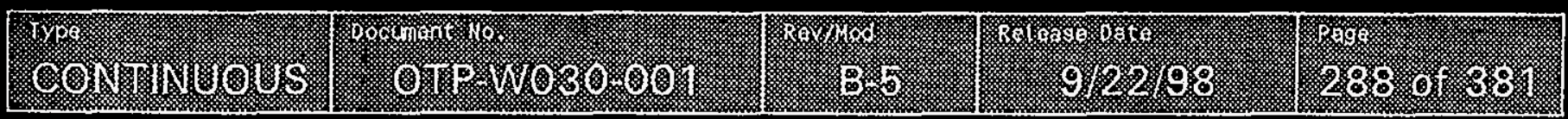




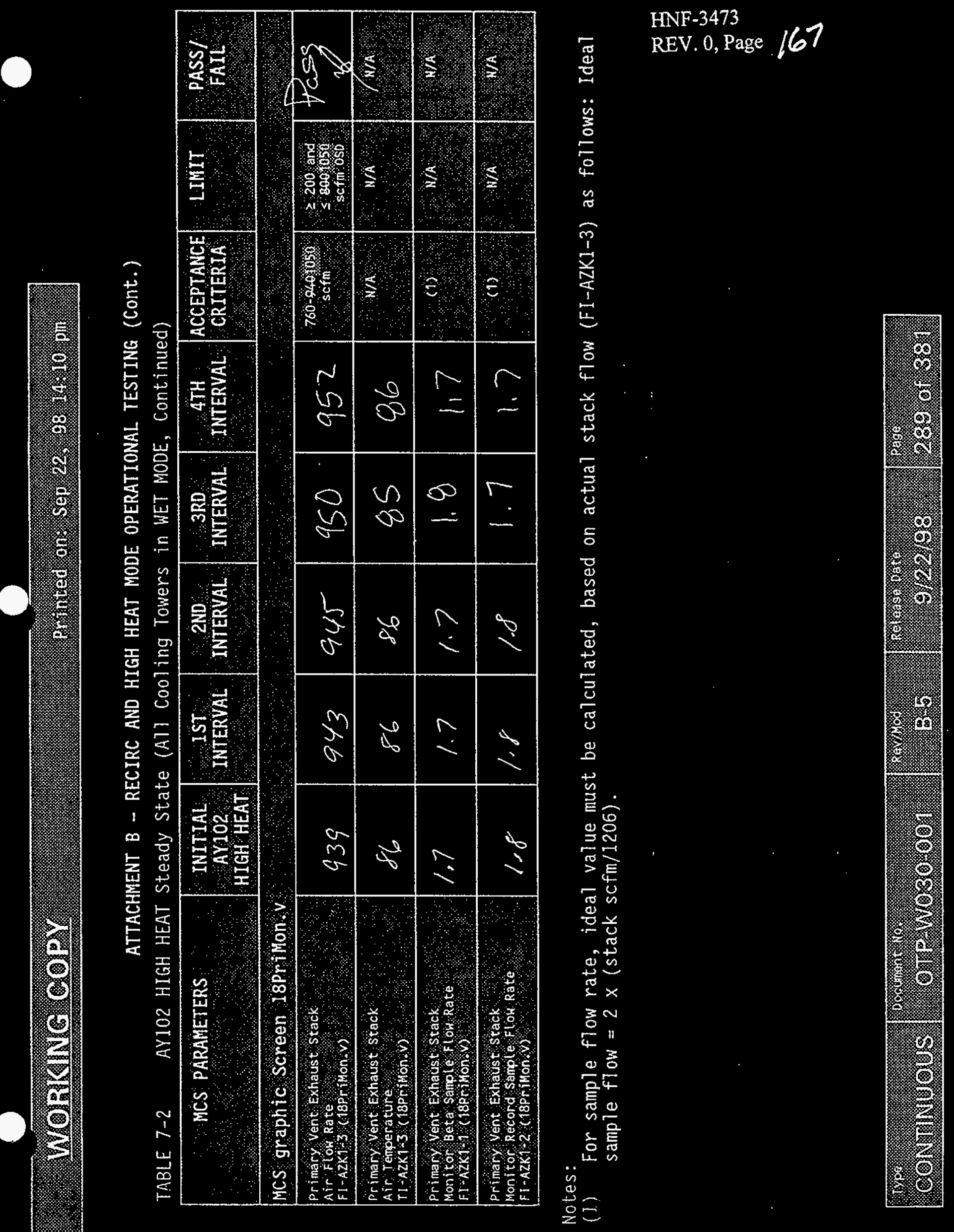


HNF-3473

ATTACHMENT B - RECIRC AND HIGH HEAT MODE OPERATIONAL TESTING (cont.)

\subsection{AY102 HIGH HEAT - TANK PRESSURE CONTROL}

\section{CAUTION}

This section cannot be performed prior to lifting of the limitations cited in the Project $\mathrm{W}-030$ NOC limiting the maximum flow rate of the exhauster to $800 \mathrm{scfm}$.

8.1 ENSURE the recirculation ventilation systems are in the RECIRC mode of operation according to the 1 isted procedure.

AY101 - T0-060-351, AY101 TANK RECIRC MODULE OPERATION

AZ101 - T0-060-353, AZ101 TANK RECIRC MODULE OPERATION

AZ102 - TO-060-354, AZI02 TANK RECIRC MODULE OPERATION

8.2 ENSURE AY102 HIGH HEAT mode is established according to T0-060-352.

8.3 ENSURE the tank pressure control setpoints for tanks AY101, AZ101, and AZ102 are set to $-2.0 \mathrm{in}$. WC on MCS graphic screen 15PriIn.v.
PIC-AY1K1-1
PIC-AZIK1-1
PIC-AZ2K1-1

8.4 ENSURE the tank exhaust flow control setpoints and the primary vent manifold pressure setpoints PIC-AZKI-IA and PIC-AZKI-1B are set as required to achieve the flow rates listed below.
AY102 at $500 \pm 20 \mathrm{scfm}$ (FIC-AY2K1-2)
AY101 at $3800100 \pm 20 \mathrm{scfm}($ FIC-AY1K1-2)
AZ101 at
- AZ102 at

8.5 ADJUST the tank pressure setpoint controller for tank AY102, PIC-AY2K1, to -0.5 in. WC.

NOTE - In the following steps, the system is stable when tank pressures are within \pm 0.2 in $w c$ of the setpoint and pressure control valve position in approximately steady state.

8.6 ALLOW the system to stabilize AND RECORD the Initial Value data in TABLE 8-1. Test Engineer: 8.7 ADJUST the tank pressure setpoint controller for tank AY102, PIC-AY2KI, in 0.
in. WC increments, from $-0.5 \mathrm{in.}$. WC to $-3.0 \mathrm{in}$. WC. 
ATTACHMENT B - RECIRC AND HIGH HEAT MODE OPERATIONAL TESTING (Cont.)

8.8 ALLOW system to stabilize AND RECORD the Changed Value data in fABLE 8-1 at each increment.

Test Engineer:

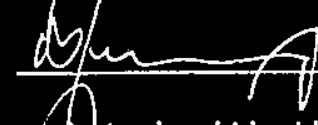

8.9 VERIFY that no unexpected alarms or conditions occurred associated with this section of testing and that the data in TABLE 8-1 satisfies/the acceptance criteria.

8.10 ESTABLISH AYI02 RECIRC mode according to T0-060-352.

Test Engineer:

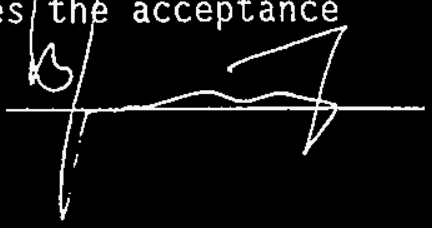

8.11 ADJUST the pressure setpoint controller for tank AY102, PIC-AY2K1, to -2.0 in. WC. 

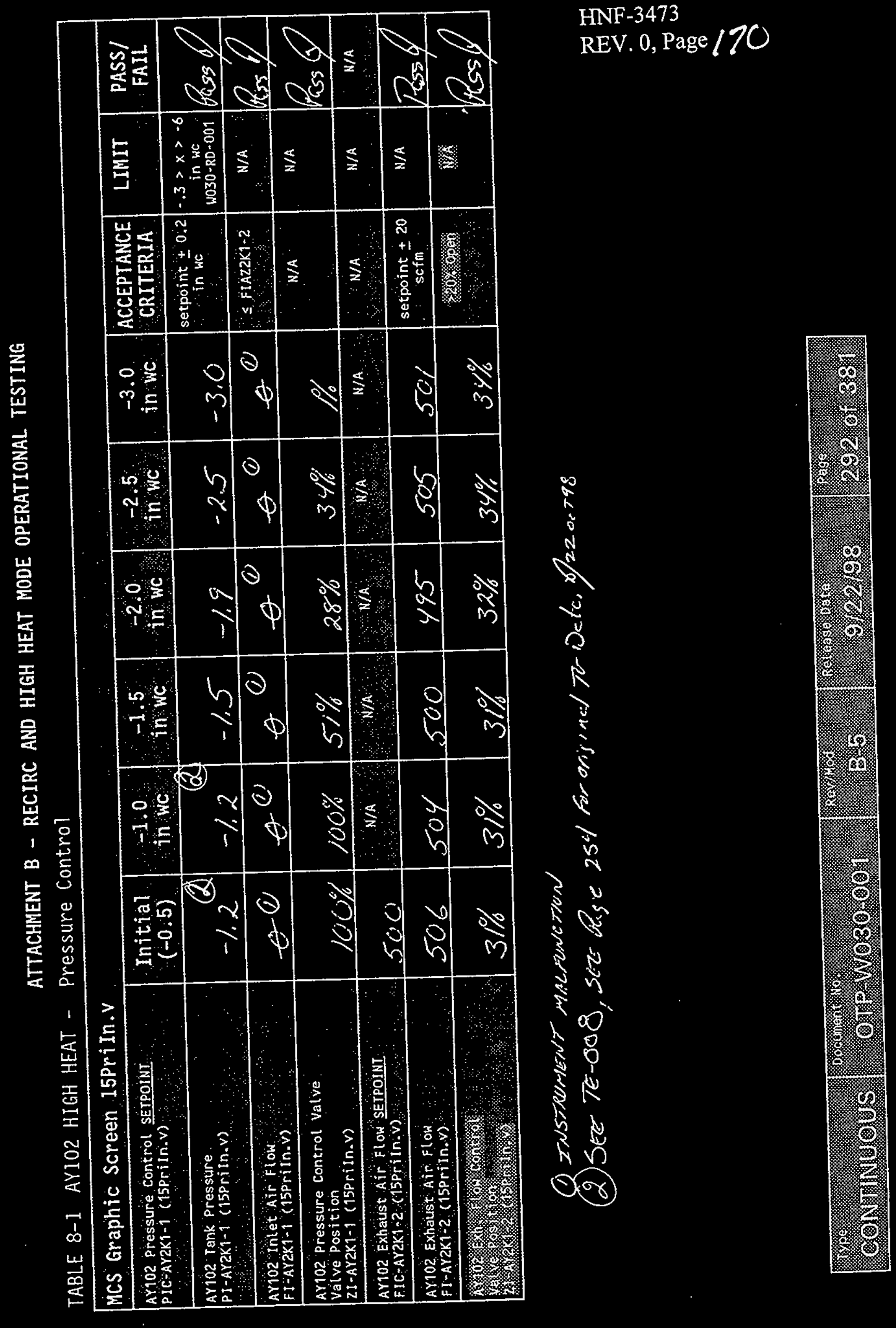


\section{ATTACHMENT B - RECIRC AND HIGH HEAT MODE OPERATIONAL TESTING}

\subsection{AZ101 HIGH HEAT - STEADY STATE OPERATION}

\section{CAUTION}

This section cannot be performed prior to lifting of the limitations cited in the Project $\mathrm{W}-030$ NOC limiting the maximum flow rate of the exhauster to $800 \mathrm{scfm}$.

9.1 ENSURE Exhaust Fan $A Z-K 1-5-1 B$ and Filter Train $B$ are in service.

9.2 ENSURE the following recirculation ventilation systems are in the RECIRC mode of operation according to the listed procedure.

- AY101 - T0-060-351, AY101 TANK RECIRC MODULE OPERATION

- AY102 - T0-060-352, AY101 TANK RECIRC MODULE OPERATION

- AZ101 - TO-060-353, AZ101 TANK RECIRC MODULE OPERATION

- AZ102 - TO-060-354, AZ102 TANK RECIRC MODULE OPERATION

9.3 ENSURE tank pressure control setpoints are set at -2.0 in. WC on MCS graphic screen 15 PriIn.v.

ค PIC-AZIKI-1

- PIC-AZ2K1-1

ᄀ PIC-AYIK1-1

ค PIC-AYZKI-1

9.4 ENSURE the tank exhaust flow control setpoints and the primary vent manifold pressure setpoints PIC-AZK1-IA and PIC-AZKI-1B are set as required to achieve the flow rates listed below.

- AZ101 at

- AZ102 at 渻 $100 \pm 20$ scfm (FIC-AZ2K1-2)

- AY101 at $30100 \pm 20$ scfm (FIC-AYlK1-2)

- AY102 at $100 \pm 20$ scfm (FIC-AY2KI-2)

\begin{tabular}{|c|c|c|}
\hline 1.1. & 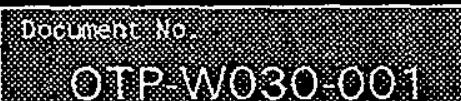 & 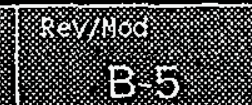 \\
\hline
\end{tabular}


HNF-3473

\section{ATTACHMENT B - RECIRC AND HIGH HEAT MODE OPERATIONAL TESTING}

9.5 ALLOW system parameters to stabjlize for 15 minutes AND RECOŔ́ lnitial data $f$

AZI01 RECIRC mode in TABLE 9-1.

Test Engineer:

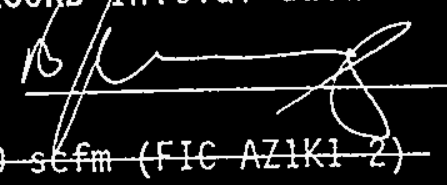

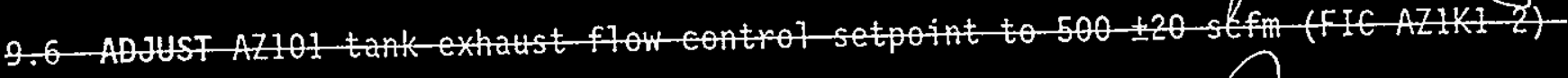

9.7 ESTABLISH AZ101 HIGH HEAT mode according to T0-060-353.

Test Engineer:

/9.8 PLACE AZ101 Cooling Tower in DRY MODE operation in accordande with T0-060 358

Test Engineer:

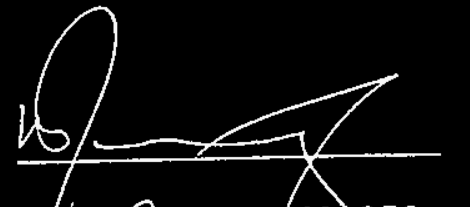
9.9 ALLOW system parameters to stabilize for 15 minutes AND RECORD Iyjtifal data
AZ101 HIGH HEAT mode in TABLE 9-1.

9.10 RECORD data in TABLE 9-1 every hour for 4 consecutive hours.

Test Engineer:

Test, Engineer:

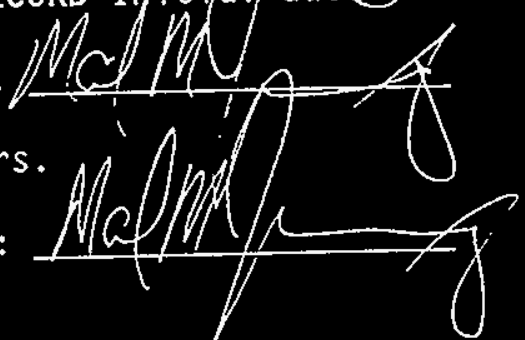

9.11 PLACE AZ101 Cooling Tower in WET MODE operation in accordance with TO-9060-358 AND RETURN to this procedure.

Test Engineer:

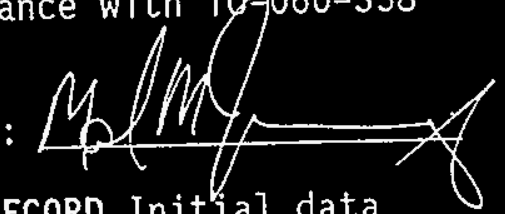

9.12 ALLOW system parameters to stabilize for 15 minutes AND RECORD Initial data with AZ101 in HIGH HEAT mode in TABLE $9-2$.

9.13 RECORD data in TABLE 9-2 every

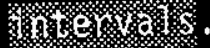

Test Engineer:

9.14 VERIFY that no unexpected alarms or conditions occurred asspijated with section of testing and
acceptance criteria.

Test Engineer:

NOTE - A11 Cooling Towers will remain in WET MODE operation throughout the balance of this procedure except as directed.

\begin{tabular}{|c|c|c|c|c|}
\hline \% & OFP & 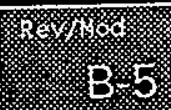 & . & 264. \\
\hline
\end{tabular}


ATTACHMENT B - RECIRC AND HIGH HEAT MODE OPERATIONAL TESTING (Cont.)

TABLE 9-1 AZ101 HIGH HEAT Steady State

\begin{tabular}{|c|c|c|c|c|c|c|c|c|c|}
\hline MCS PARAMETERS & $\begin{array}{l}\text { INITIAL } \\
\text { AZ10I } \\
\text { RECIRC }\end{array}$ & $\begin{array}{c}\text { INITIAL } \\
\text { AZ101 } \\
\text { HIGH HEAT }\end{array}$ & $\begin{array}{l}\text { IST } \\
\text { INTERVAL }\end{array}$ & $\begin{array}{c}\text { 2ND } \\
\text { INTERVAL }\end{array}$ & $\begin{array}{l}\text { 3RD } \\
\text { INTERVAL }\end{array}$ & $\begin{array}{c}\text { 4TH } \\
\text { INTERVAL }\end{array}$ & $\begin{array}{l}\text { ACCEPTANCE } \\
\text { CRITERIA }\end{array}$ & LIMIT & $\begin{array}{l}\text { PASS/ } \\
\text { FAIL }\end{array}$ \\
\hline \multicolumn{10}{|c|}{ MCS Graphic Screen 10RecAY1.V } \\
\hline $\begin{array}{l}\text { AY101 Recirc Vent condenser } \\
\text { Air Inlet Temperature } \\
\text { II-AYTK48-1A (10RecAY1.V) }\end{array}$ & 85 & 84 & 84 & 84 & $8:$ & 90 & $\mathrm{~N} / \mathrm{A}$ & N/A & N/A \\
\hline $\begin{array}{l}\text { AY101 Recirc Vent condenser } \\
\text { Out let Air Temperature } \\
\text { II-AYTK48-1B (TORecAYI.v) }\end{array}$ & 64 & 61 & 63 & & 5 & 62 & $\mathrm{~N} / \mathrm{A}$ & $N / A$ & $N / A$ \\
\hline $\begin{array}{l}\text { AY101 Recirc Vent condenser } \\
\text { Water Inlet Temperature } \\
\text { rI-AYEWS-1 (10ReCAY1.V) }\end{array}$ & 63 & 59 & 5 & & $\hat{\imath}$ & 59 & $x^{N / A}$ & $N / A$ & $\mathrm{~W} / \mathrm{A}$ \\
\hline $\begin{array}{l}\text { AY101 Recirc Vent condenser } \\
\text { Water Outlet Temperature } \\
\text { TI-AYTEWR-1 (10RecAY1.V) }\end{array}$ & 61 & 57 & & & & 58 & $x^{\mathrm{N} / \mathrm{A}}$ & $\mathrm{N} / \mathrm{A}$ & $\mathrm{W} / \mathrm{A}$ \\
\hline $\begin{array}{l}\text { AY101 Recirc Vent Condenser } \\
\text { Differential Pressure } \\
\text { PDI-AY1K48-1 (10RecAY1.v) }\end{array}$ & 11.0 & 11.4 & & 11.8 & 11.9 & $12.4^{2}$ & $8-12$ in we & N/A & (9) \\
\hline $\begin{array}{l}\text { AY101 Recirc Vent Fan } \\
\text { Differential Pressure } \\
\text { PDI-AYMK45-1 (10RecAY1.v) }\end{array}$ & 14.9 & 15.4 & 15.5 & 15.8 & 15.9 & 16.3 & $15-18$ in wC & N/A & \\
\hline $\begin{array}{l}\text { AY101 Recirc Vent Fan } \\
\text { Motor current } \\
\text { II-AYMK45-1 (10RecAY1:V) }\end{array}$ & 5.4 & 5.3 & 5.2 & 5.4 & 5,4 & 5.1 & N/A & N/A & A : \\
\hline $\begin{array}{l}\text { Incoming line vol tage at Meter ing } \\
\text { Station, Room } 105, \text { cen, Bldg, }\end{array}$ & 490 & 483 & 489 & 486 & 485 & 487 & $\mathrm{~N} / \mathrm{A}$ & N/A & N/A \\
\hline $\begin{array}{l}\text { AY101 Exhaust Air Flow SETPOINT } \\
\text { FIC AYYK1 } 2 \text { (10RecAYM V }\end{array}$ & 200 & 200 & N/A & 4 & $\% / 8$ & N/A & $\mathrm{N} / \mathrm{A}$ & $N / A$ & $N / A$ \\
\hline $\begin{array}{l}\text { AY101 Exhaust Air flow } \\
\text { Fi-AYIK1-2 (1ORecAY1-V) }\end{array}$ & 192 & $179^{3}$ & $77^{(3)}$ & $173^{3}$ & $179^{3}$ & 101 & $\begin{array}{c}\text { setpoint } \\
\pm 20 \text { scfm }\end{array}$ & $N / A$ & \\
\hline
\end{tabular}

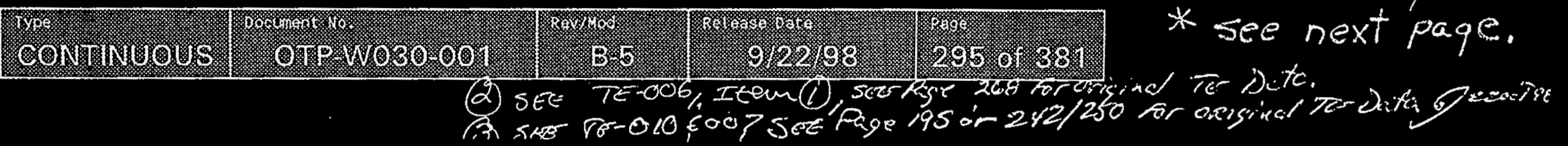


HNFr-3473
REV. 0, Page 174

\begin{tabular}{|c|c|c|c|c|c|c|c|c|c|c|}
\hline 酸部 & $\frac{x}{z}$ & $\frac{\pi}{z}$ & $\$$ & $\underline{z}$ & 1 & 8 & $\underline{z}$ & 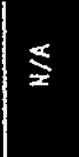 & $\frac{s}{z}$ & \\
\hline 諳 & $\frac{s}{z}$ & 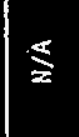 & $\$$ & $\mathbb{z}$ & $\$$ & $\$$ & $\underline{\underline{z}}$ & $\$$ & $\underline{\Sigma}$ & $\$$ \\
\hline 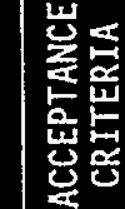 & $\frac{\mathbb{z}}{z}$ & $\mid \frac{\$}{z}$ & ${ }^{\frac{5}{z}} *$ & ${ }^{\mathbb{E}} *$ & 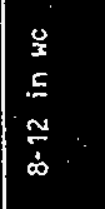 & 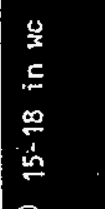 & 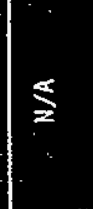 & $\mid \frac{\$}{z}$ & $\stackrel{\frac{s}{z}}{2}$ & 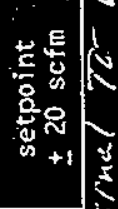 \\
\hline
\end{tabular}

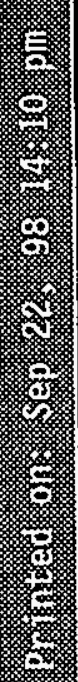

蒿

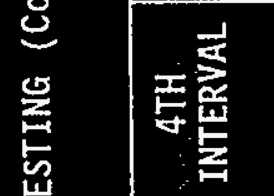

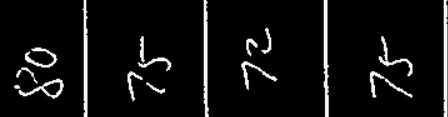

$m 0$

$\lambda N \mathrm{~N}^{3}$

之ें

os

列

紊

的

褰

容 欲畩

魚

폴

的弯

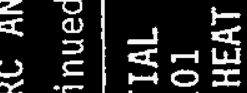

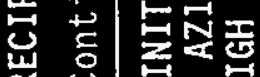

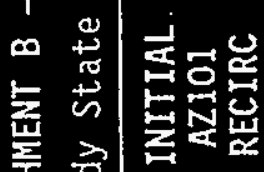

훙

E $\stackrel{a}{\sim}$

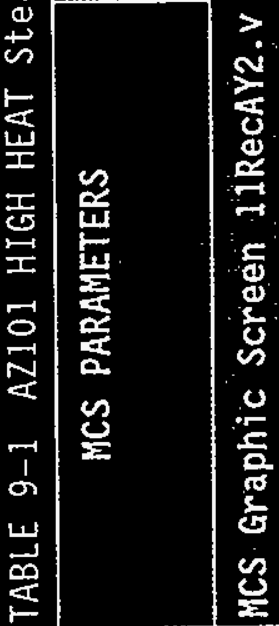

$m i n \pi$

$\sin \frac{j}{\infty}=\frac{\pi}{\pi}$

诰

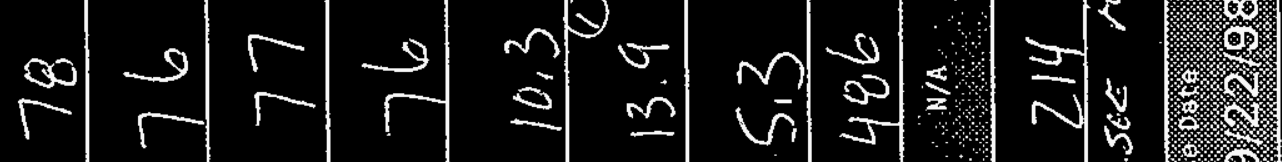

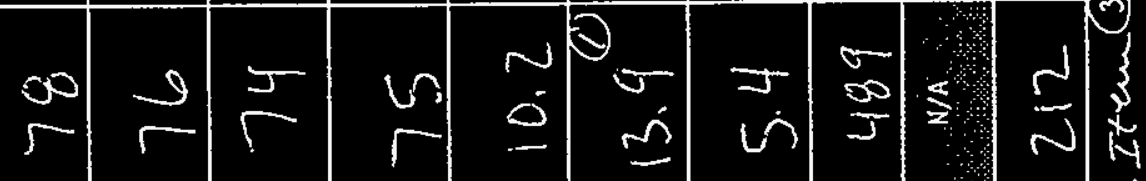

D

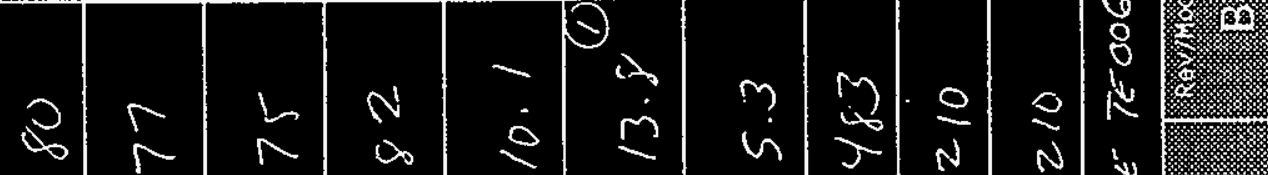

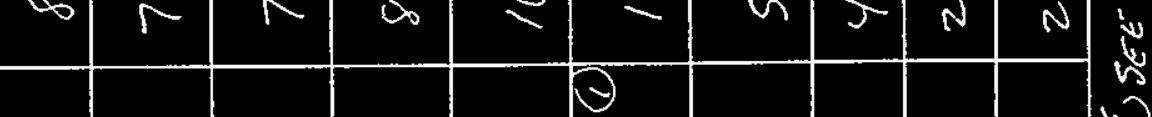

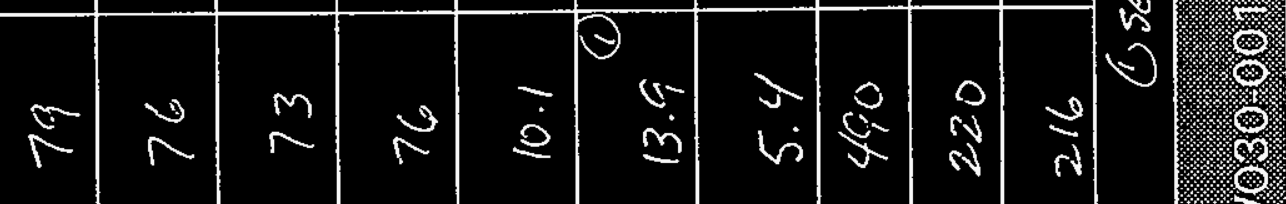
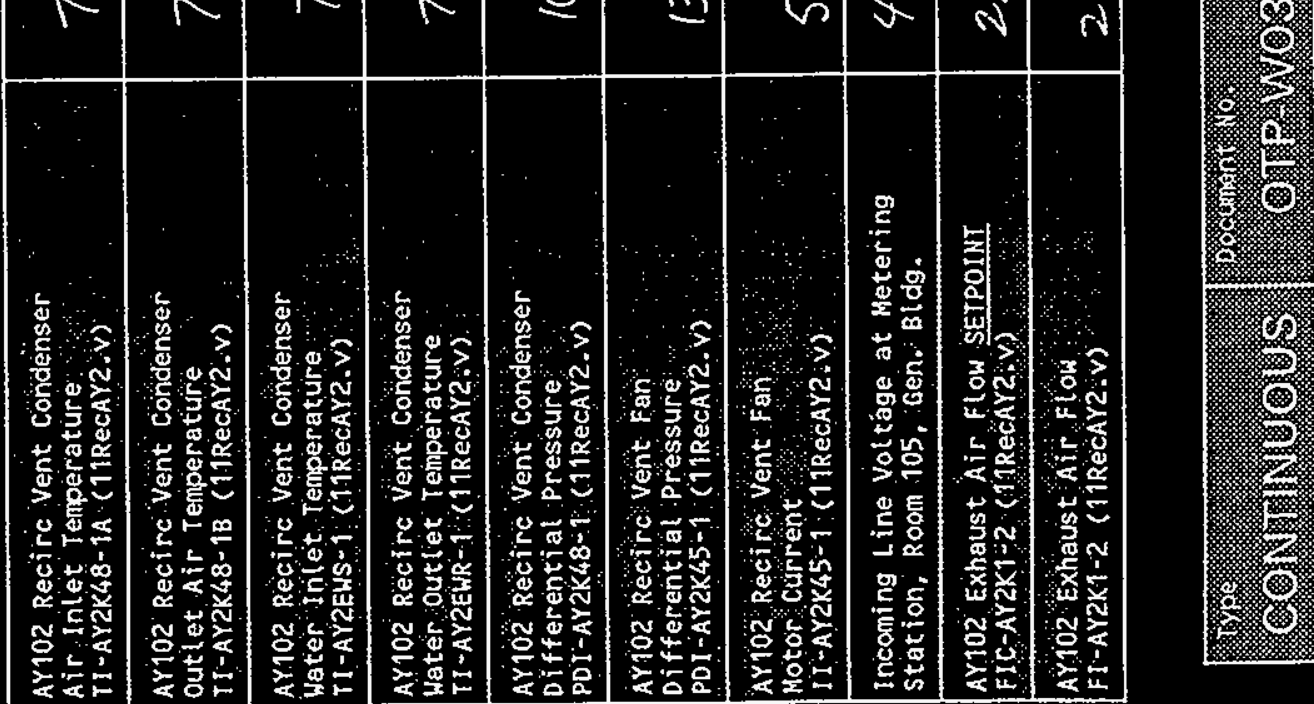
ATTACHMENT B - RECIRC AND HIGH HEAT MODE OPERATIONAL TESTING (Cont.)

TABLE 9-1 AZ101 HIGH HEAT Steady State (Continued)

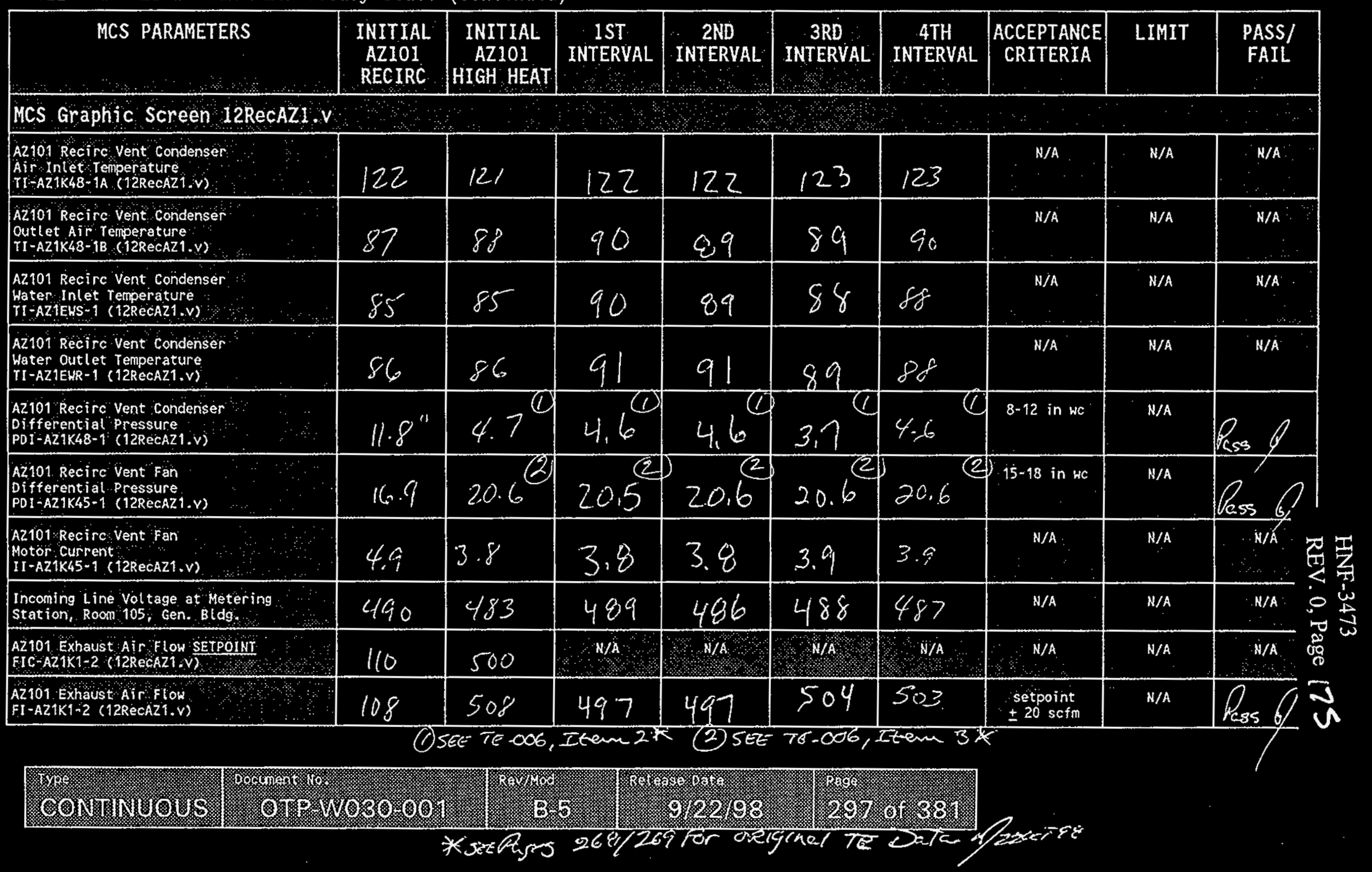


ATTACHMENT B - RECIRC AND HIGH HEAT MODE OPERATIONAL TESTING (Cont.)

TABI. 9-1 AZ101 HIGH HEAT Steady State (Continued)

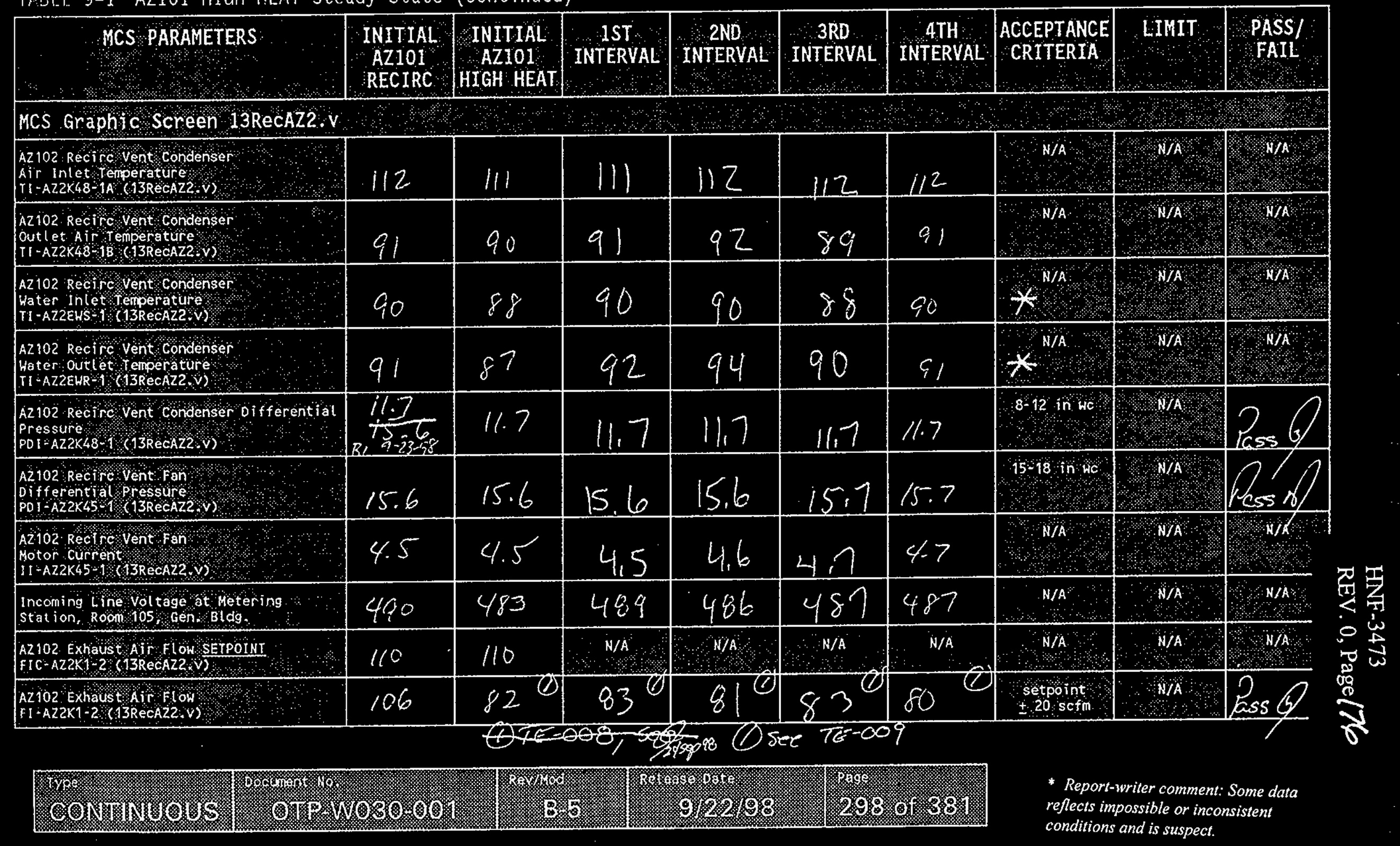




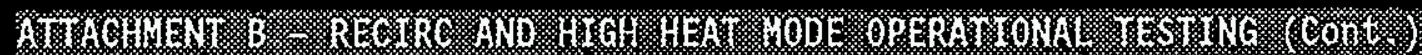

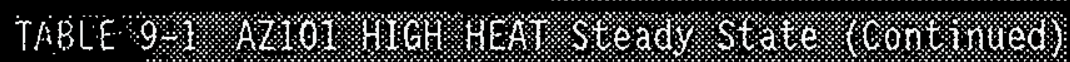

\begin{tabular}{|c|c|c|c|c|c|c|c|c|c|}
\hline MOS ONHWUERS & 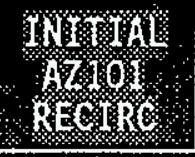 & HWh & Hoth & WOP. & 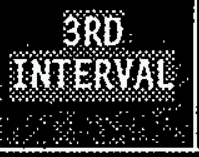 & 41 & 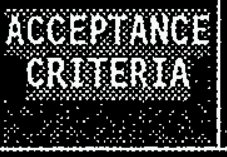 & (4) & MisS: \\
\hline \multicolumn{10}{|c|}{ 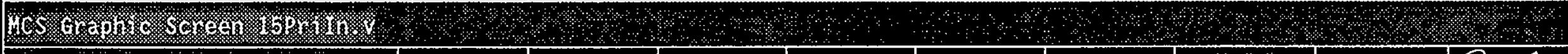 } \\
\hline W & -1 & -2 & & -2 & -1 & -2 & 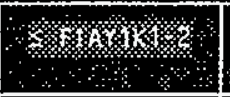 & \% & $\operatorname{los} \theta$ \\
\hline 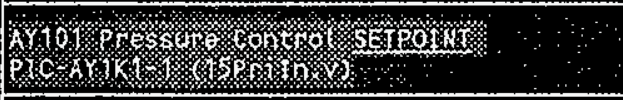 & -2.0 & 2.0 & $\cdots$ & 祭 & No & W & $x$ & 1/ & 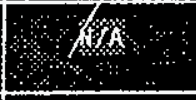 \\
\hline 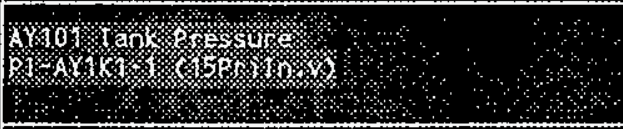 & -1.0 & -0.8 & -0.8 & -0.8 & -0.8 & 0.8 & 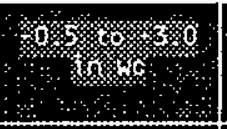 & 4030 & \\
\hline 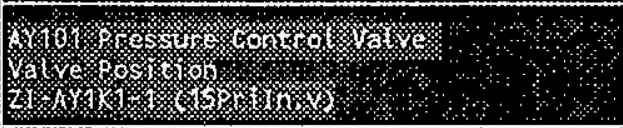 & $1 \%$ & $1 \%$ & 1 & & 16 & $1 \%$ & & \% & 格 \\
\hline 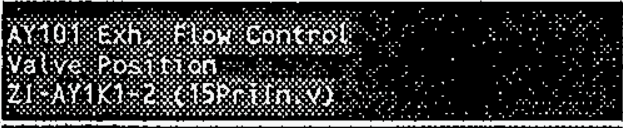 & $41 \%$ & $100 \%$ & 100 & 100 & $100 \%$ & 100 & $1 / 2 \%$ \%or & & \\
\hline 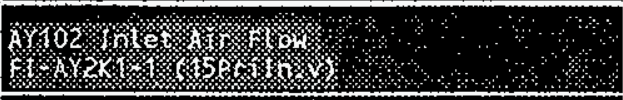 & (i) & (1) & (1) & (1) & 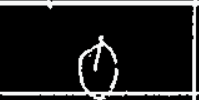 & & . & 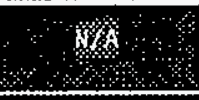 & $0\rangle$ \\
\hline Hor & -2.0 & -2.0 & 8 & $4 \%$ & 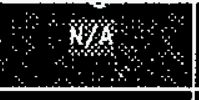 & $\therefore$ & 㒄 & 48 & +ro \\
\hline 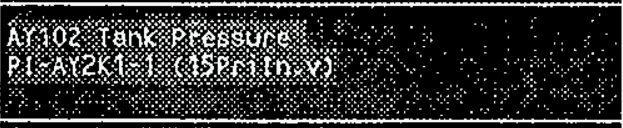 & $-0,7$ & -07 & $-0,7$ & -0.7 & -0.7 & -0.7 & \% & (6) & 18,59 \\
\hline 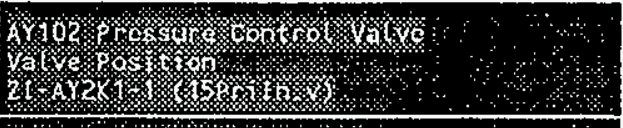 & $-25 \%$ & -150 & -150 & -150 & $-25 \%$ & $-25-7$ & \% & $8 \%$ & $1 \%$ \\
\hline W & $37 \%$ & $86 \%$ & $86 \%$ & $86 \%$ & $86 \%$ & $86 \%$ & 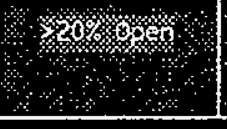 & \% & Vass \\
\hline
\end{tabular}

\begin{tabular}{|c|c|c|c|c|}
\hline 等 & 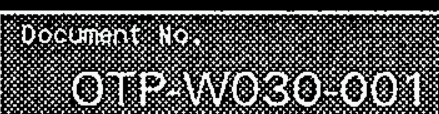 & 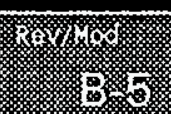 & 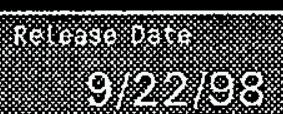 & I) \\
\hline
\end{tabular}


HNF-3473

REV. 0, Page 179

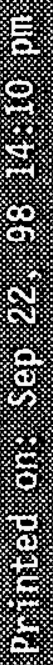
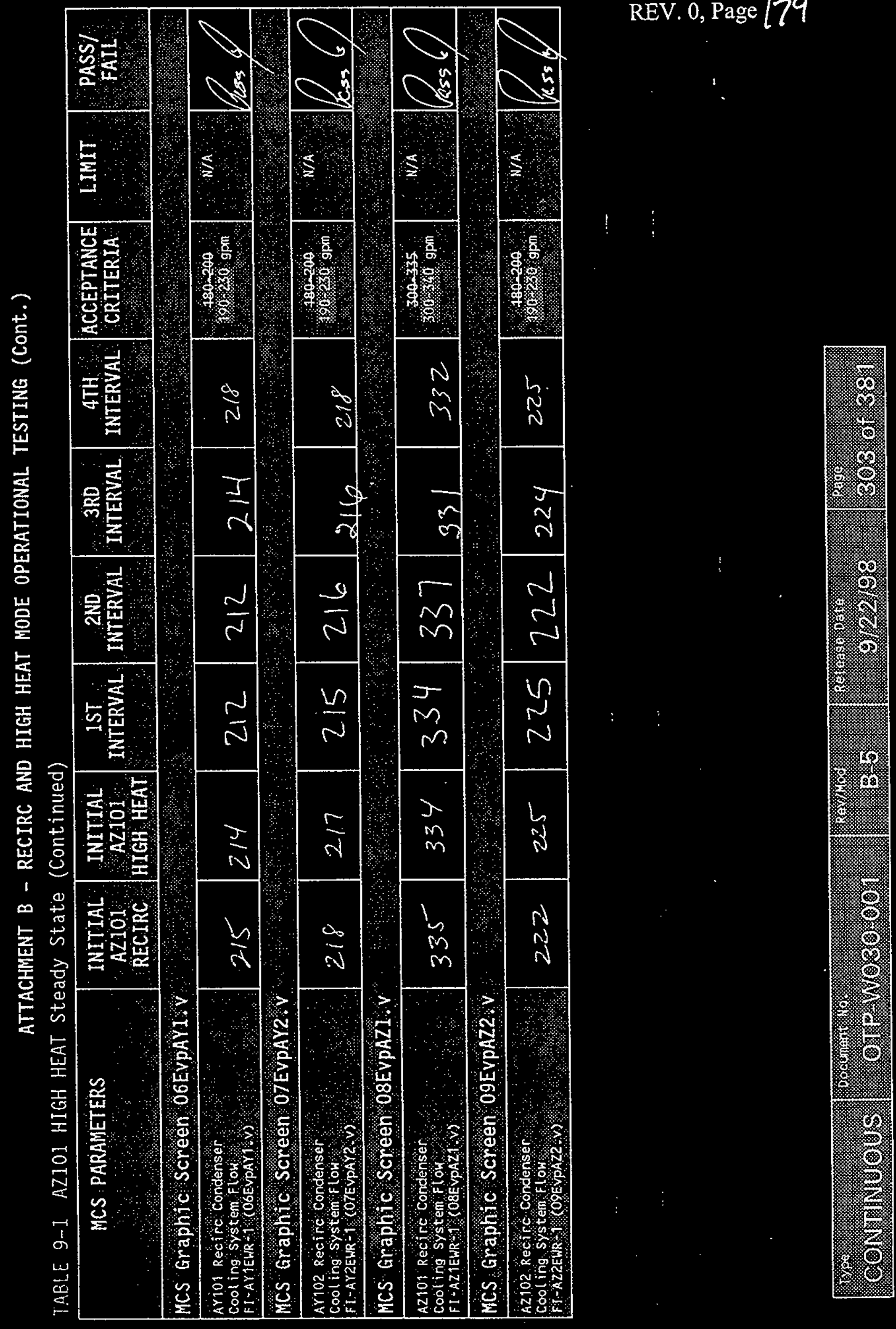
HNF-3473

REV. 0, Page $/ 80$

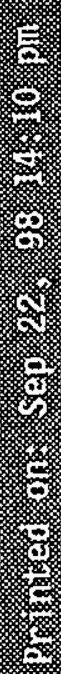

芒 密焉

:

窟

亮

岩趛

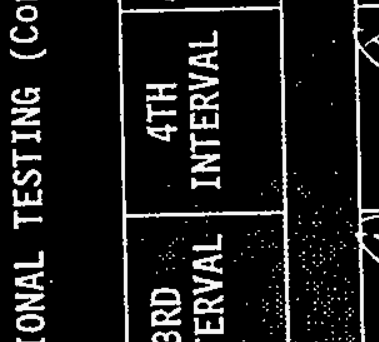

$O_{3}$

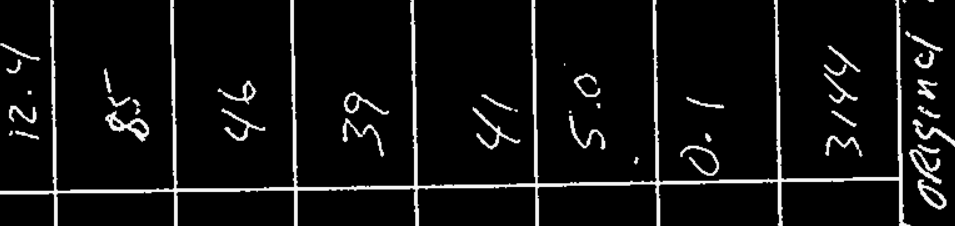

$\theta$

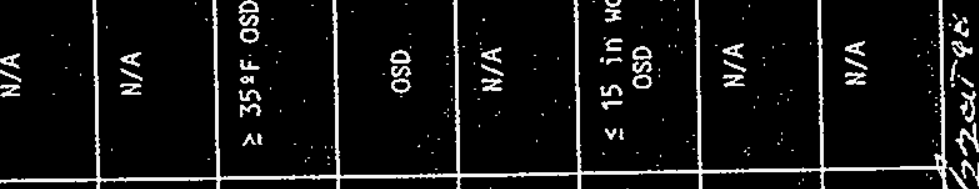

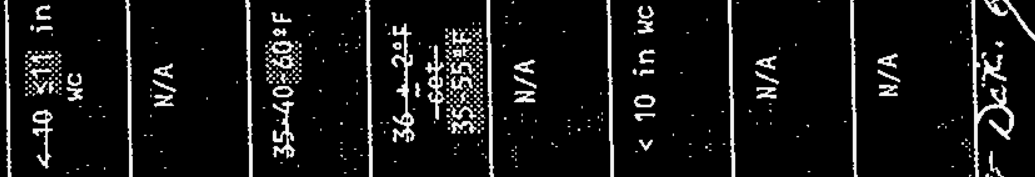

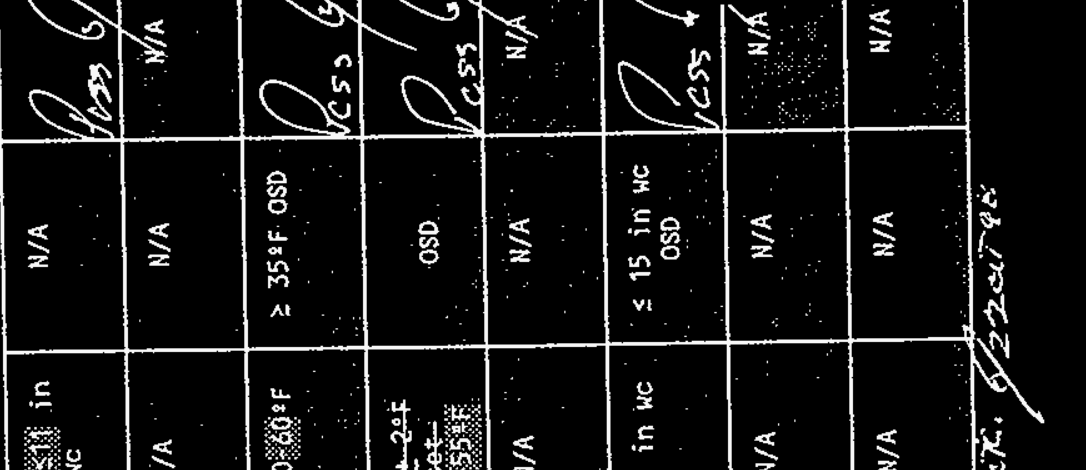

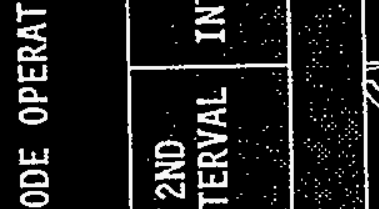

j

O

it

$J^{\prime}$

$\frac{9}{3}$

$m$ an

$\infty$

$\frac{m}{n}$

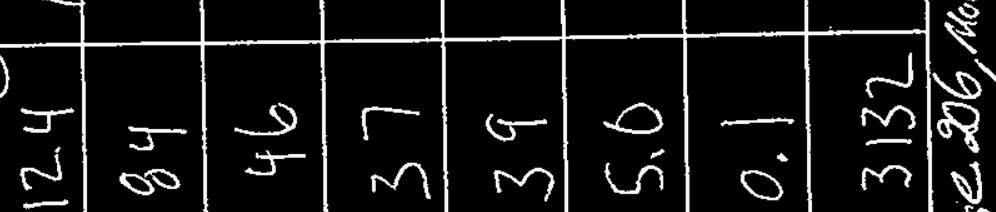

M MU

0

E

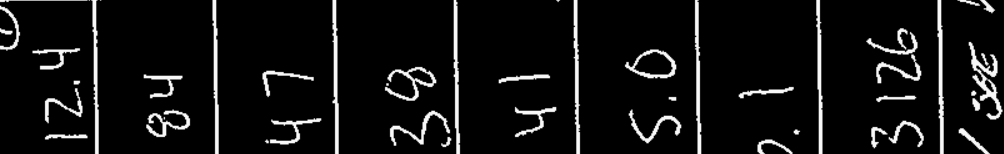

立

要

鰘

$\overrightarrow{1}$

$$
\begin{array}{lllllll}
2 & 2 & n & 0
\end{array}
$$

$\rightarrow 0$

盾它省

$\theta=$

튼든

$2 \pi$

N

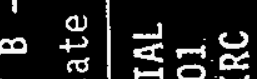

点电占总

1

,

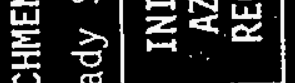

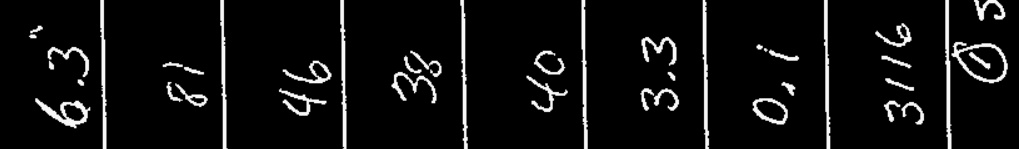

호 > $>$

式掏

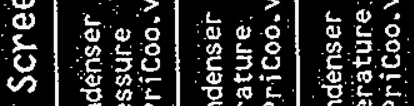

u

$\rightarrow y$

至

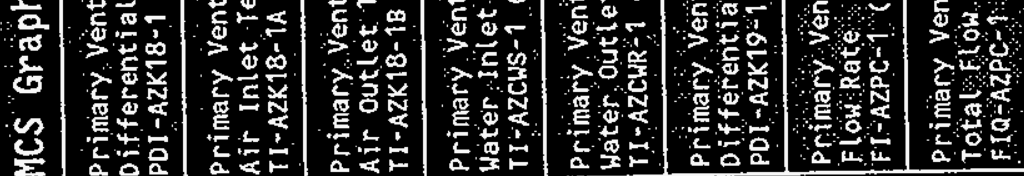

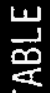


ATTACHMENT B - RECIRC AND HIGH HEAT MODE OPERATIONAL TESTING (Cont.)

TABLE 9-1 AZ101 HIGH HEAT Steady State (Continued)

\begin{tabular}{|c|c|c|c|c|c|c|c|c|c|}
\hline MCS PARAMETERS & $\begin{array}{l}\text { INITIAL } \\
\text { AZ101 } \\
\text { RECIRC }\end{array}$ & $\begin{array}{c}\text { INITIAL } \\
\text { AZ101 } \\
\text { HIGH HEAT }\end{array}$ & $\begin{array}{l}\text { IST } \\
\text { INTERVAL }\end{array}$ & 2ND & $\begin{array}{l}\text { 3RD } \\
\text { INTERVAL }\end{array}$ & $\begin{array}{l}\text { 4TH } \\
\text { INTERVAL }\end{array}$ & $\begin{array}{l}\text { ACCEPTANCE } \\
\text { CRITERIA } \\
\therefore\end{array}$ & LIMIT & $\begin{array}{l}\text { PASS/ } \\
\text { FAIL }\end{array}$ \\
\hline \multicolumn{10}{|l|}{ MCS Graphic Screen 14Chillr.v } \\
\hline 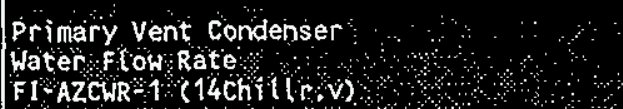 & 118 & $1 / 8$ & 118 & 119 & 119 & 118 & 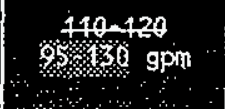 & $N / A$ & Ress \\
\hline
\end{tabular}

\begin{tabular}{|c|c|c|c|c|}
\hline 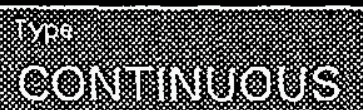 & 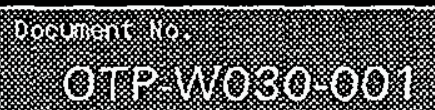 & 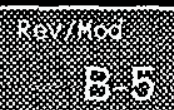 & (3. & 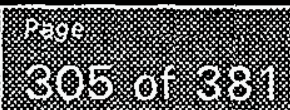 \\
\hline
\end{tabular}


ATTACHMENT B - RECIRC AND HIGH HEAT MODE OPERATIONAL TESTING (Cont.)

TABLE 9-1 AZ101 HIGH HEAT Steady State (Continued)

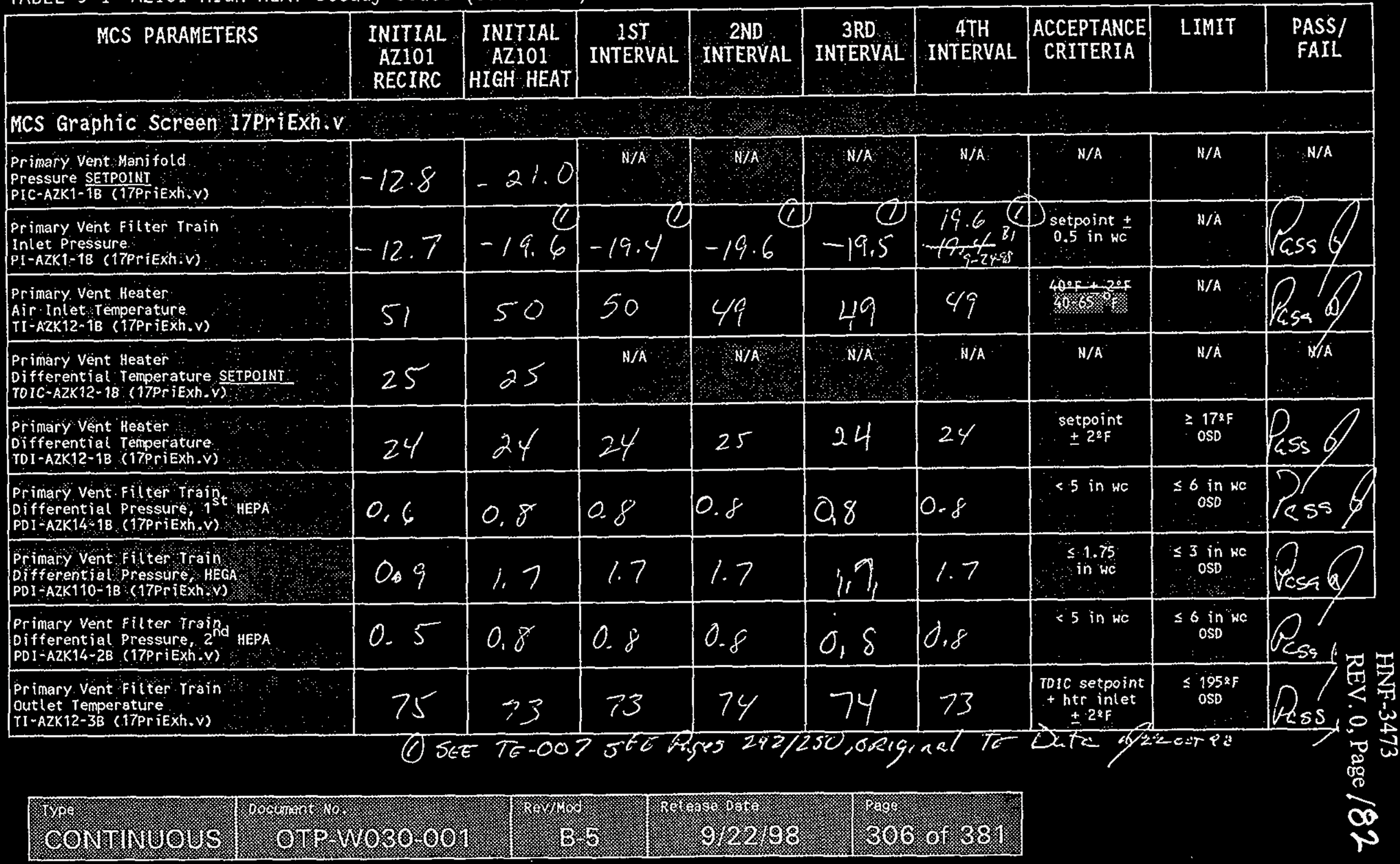




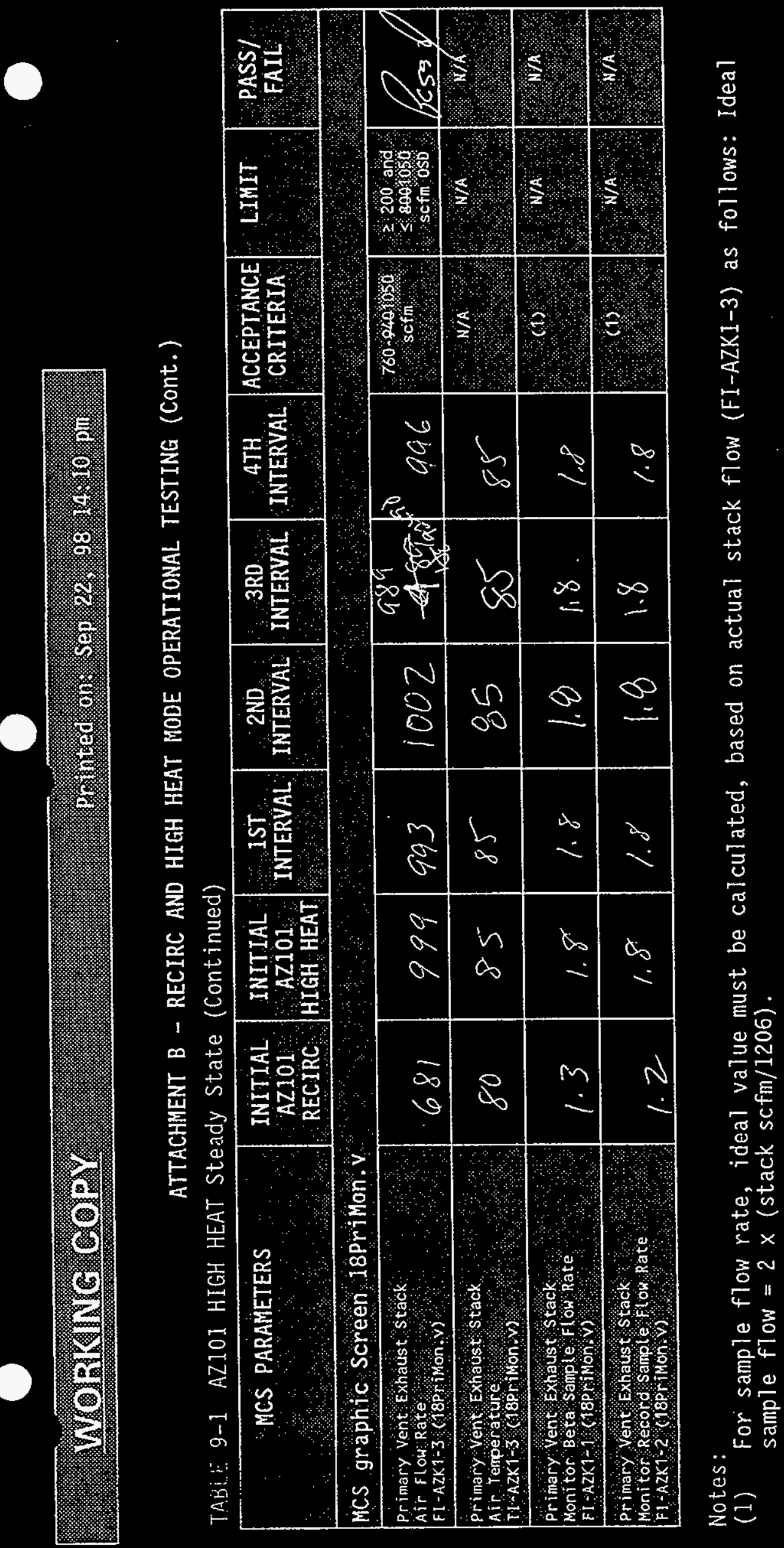

HNF-3473

REV. 0, Page 183 
ATTACHMENT B - RECIRC AND HIGH HEAT MODE OPERATIONAL TESTING (Cont.)

TABI: 9-1 AZ101 HIGH HEAT Steady State (Continued)

\begin{tabular}{|c|c|c|c|c|c|c|c|c|c|}
\hline LOCAL PARAMETERS & $\begin{array}{l}\text { INITIAL } \\
\text { AZIOI } \\
\text { RECIRC }\end{array}$ & $\begin{array}{l}\text { INITIAL } \\
\text { HAZTOI } \\
\text { HEAT }\end{array}$ & INTERVAL & INTERVAL & INTERVAL & INTERVAL & $\begin{array}{l}\text { ACCEPTANCE } \\
\text { CRITERIA } \\
\end{array}$ & LIMIT & FAIL \\
\hline $\begin{array}{l}\text { Arlol fir Inter station } \\
\text { Inilet Tenplature } \\
\text { TIC-AY101k1021. }\end{array}$ & $60: 4$ & 68.8 & 67.8 & 64. & 64.5 & 62.5 & 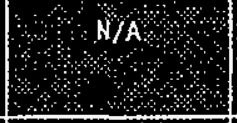 & & $t_{c}$ \\
\hline 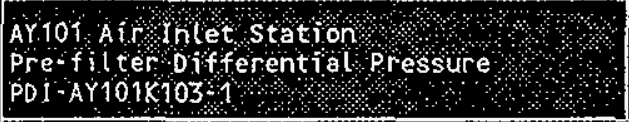 & 0 & & $\theta$ & & $\varphi$ & $Q$ & Ho alarm, & & \\
\hline 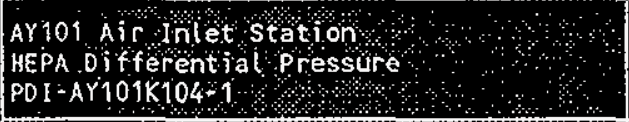 & 0 & & $\theta$ & & 8 & $\hat{\phi}$ & & & \\
\hline $\begin{array}{l}\text { AY 102 Air liniet station } \\
\text { Inlet Temperature } \\
\text { IIC-AY } 02 K 1021\end{array}$ & (1) & (1) & (1) & & $\theta$ & & & & $N / A$ \\
\hline $\begin{array}{l}\text { Ay } 102 \text { Air iniet station } \\
\text { Pre-filter Differential pressure } \\
\text { Poi-AYiozkio3 }\end{array}$ & 0 & & $\alpha$ & & Q & $\varnothing$ & & & \\
\hline 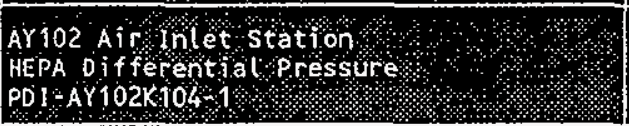 & 0 & $\lambda$ & $Q$ & & $Q$ & e & No alarm & & \\
\hline
\end{tabular}

BREAKEX OrK

\begin{tabular}{|c|c|c|c|c|}
\hline 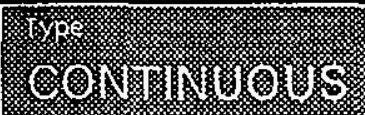 & 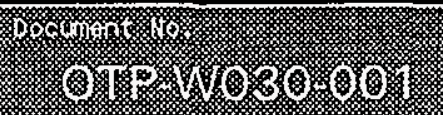 & 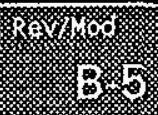 & 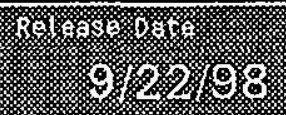 & 8. \\
\hline
\end{tabular}

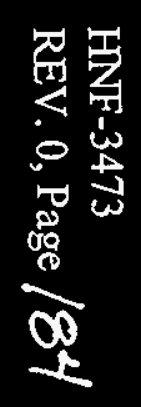


ATTACHMENT B - RECIRC AND HIGH HEAT MODE OPERATIONAL TESTING (Cont.)

TABIE 9-1 AZ101 HIGH HEAT Steady State (Continued)

\begin{tabular}{|c|c|c|c|c|c|c|c|c|c|}
\hline $\begin{array}{l}\text { LOCAL PARAMETERS } \\
\text { ( }\end{array}$ & $\begin{array}{l}\text { INITIAL } \\
\text { AZIOI } \\
\text { RECIRC }\end{array}$ & $\begin{array}{l}\text { INITIAL } \\
\text { AZIOL } \\
\text { HIGHEA }\end{array}$ & INTERVAL & INTERVAL & INTERVAL & INTERVAL & $\begin{array}{l}\text { ACCEPTANCE } \\
\text { CRITERIA } \\
\end{array}$ & GIMIT & $\begin{array}{l}\text { PASS } / \\
\text { FAIL }\end{array}$ \\
\hline 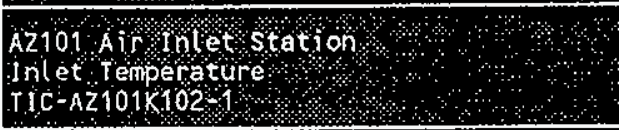 & .6 & & 65.0 & & 67.2 & 6 & H/A & & \\
\hline 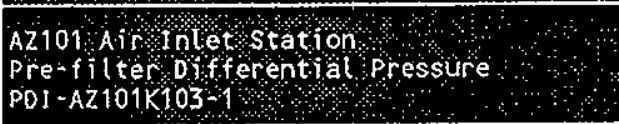 & 0 & $\Lambda$ & 06 & & .07 & & No alam & & \\
\hline $\begin{array}{l}\text { AZ101 A r on let station } \\
\text { HEPA o ifferentiat pressure } \\
\text { PDI-AZ101K104 }\end{array}$ & () & & .5 & & $j$ & $\checkmark$ & No alarm & $\therefore$ & \\
\hline $\begin{array}{l}\text { A2102 Air lintet station } \\
\text { Inlet Temperature } \\
\text { IlC-AZ102K102 }\end{array}$ & 70.3 & & 66.6 & & $66=$ & & & & \\
\hline 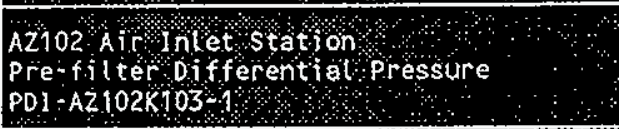 & C) & & 3 & & 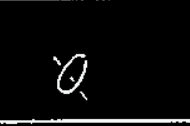 & & No alarm & $\mathrm{W} / \mathrm{A}$ & \\
\hline $\begin{array}{l}\text { AZ102 Air lntet station } \\
\text { HEPA Differential Pressure }\end{array}$ PO1-AZ102K104 & & & 0 & & (1) & $\phi$ & Wo atarm & W/A & \\
\hline
\end{tabular}

\begin{tabular}{|c|c|c|c|c|}
\hline 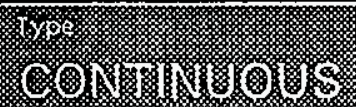 & 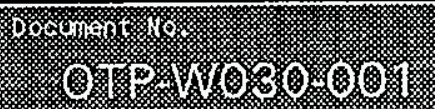 & 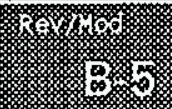 & 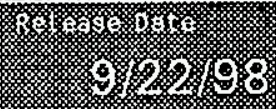 & 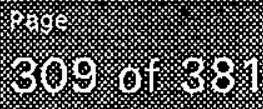 \\
\hline
\end{tabular}




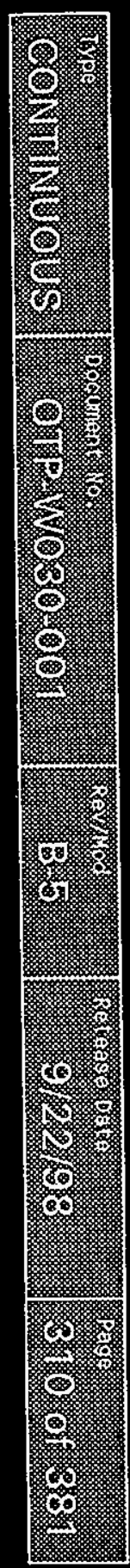

eco

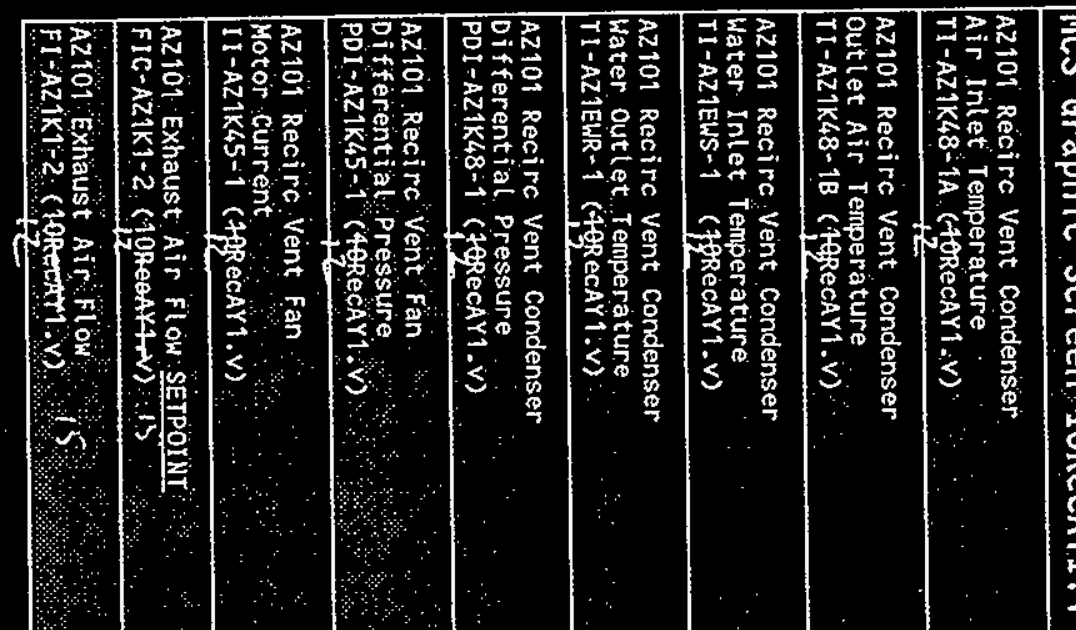

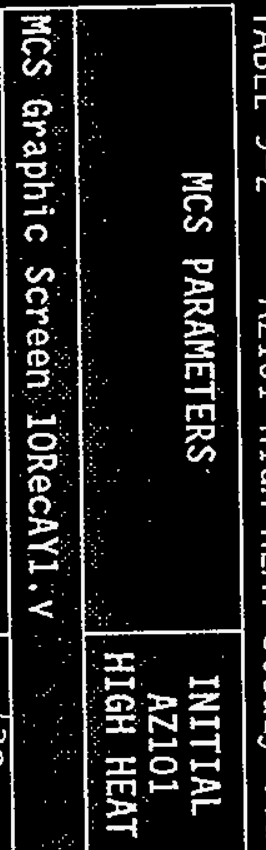

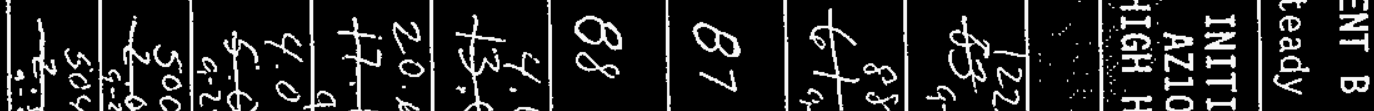

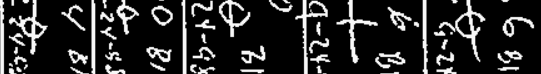

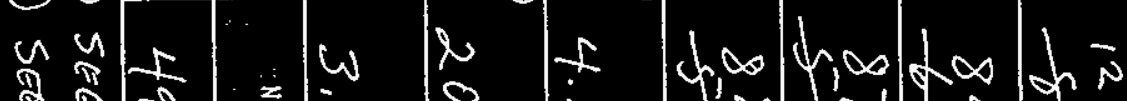

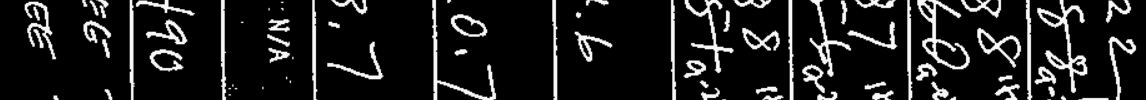
iो $\frac{1}{1}$

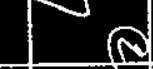
요 $H+y=w$ 2 w

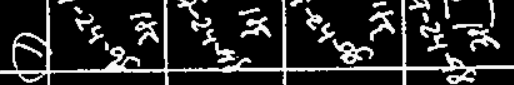

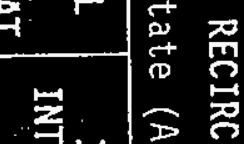

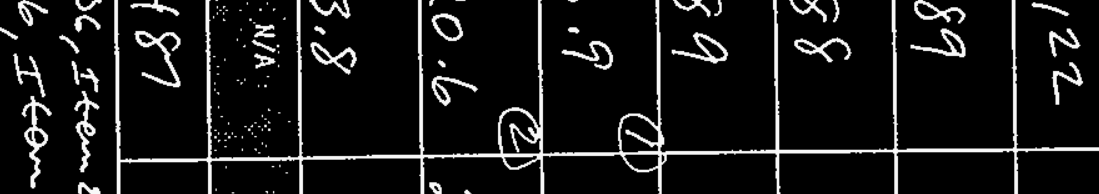
is u a $\sum_{=1}^{\infty}$

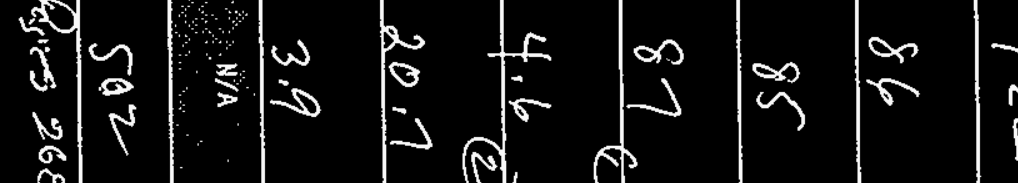

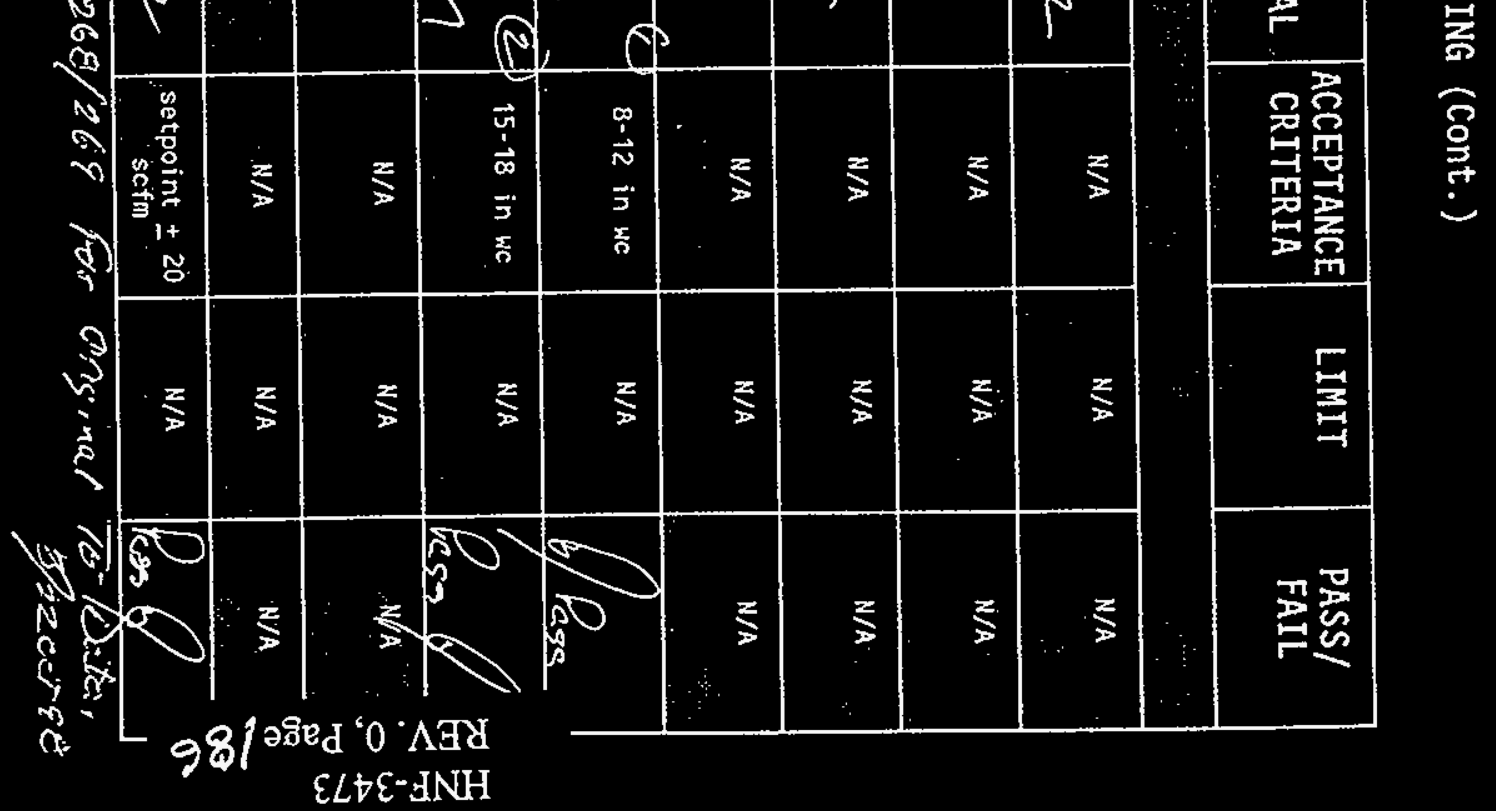




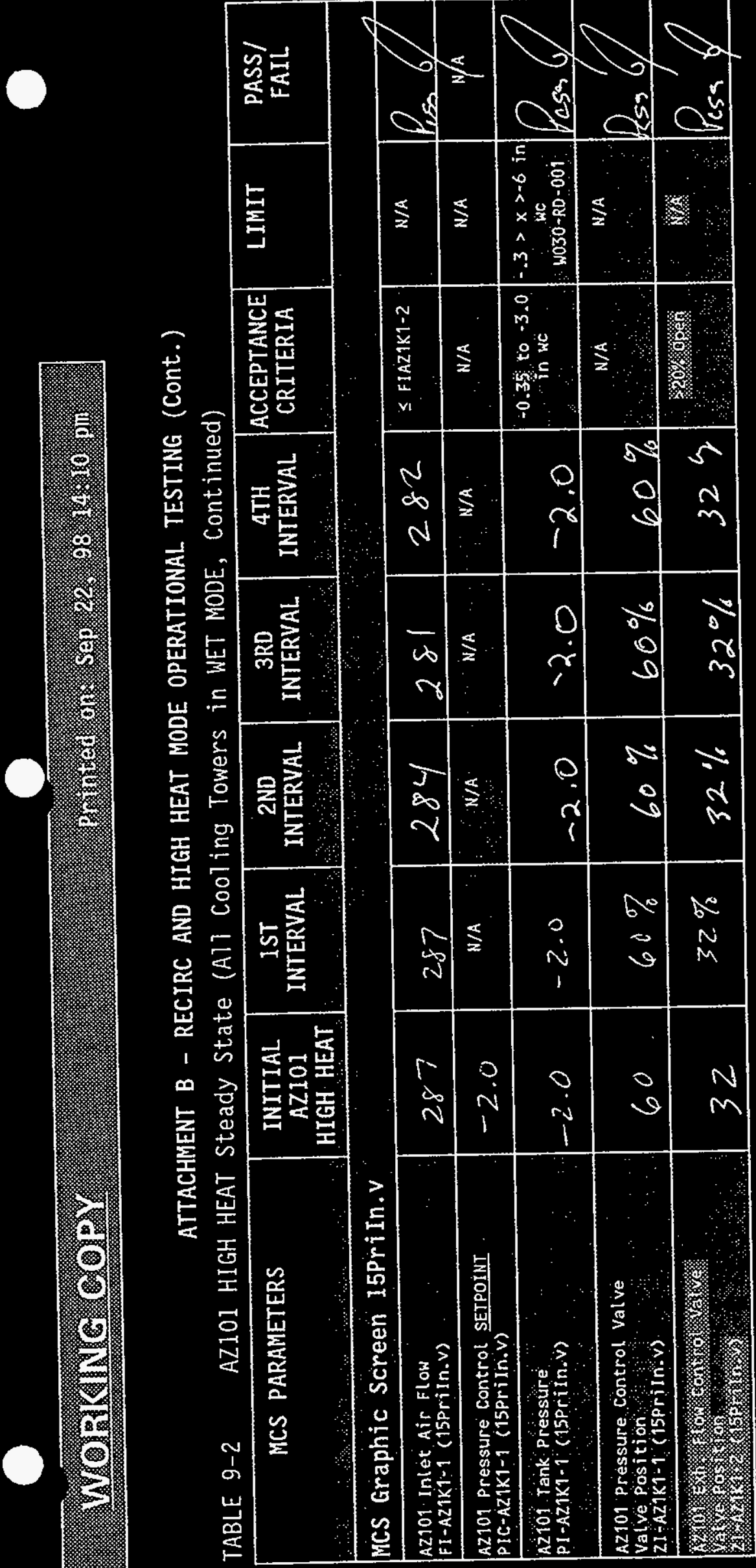

HNF-3473

REV. 0, Page 187

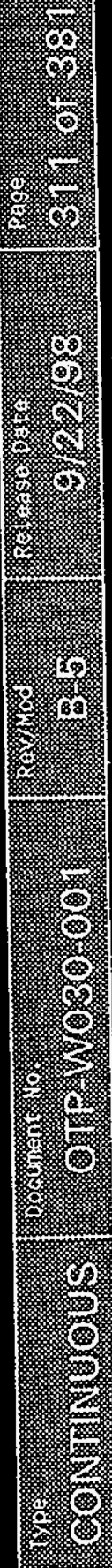


ATTACHMENT B - RECIRC AND HIGH HEAT MODE OPERATIONAL TESTING (Cont.)

TABLE 9-2 AZ101 HIGH HEAT Steady State (Al1 Cooling Towers in WET MODE, Continued)

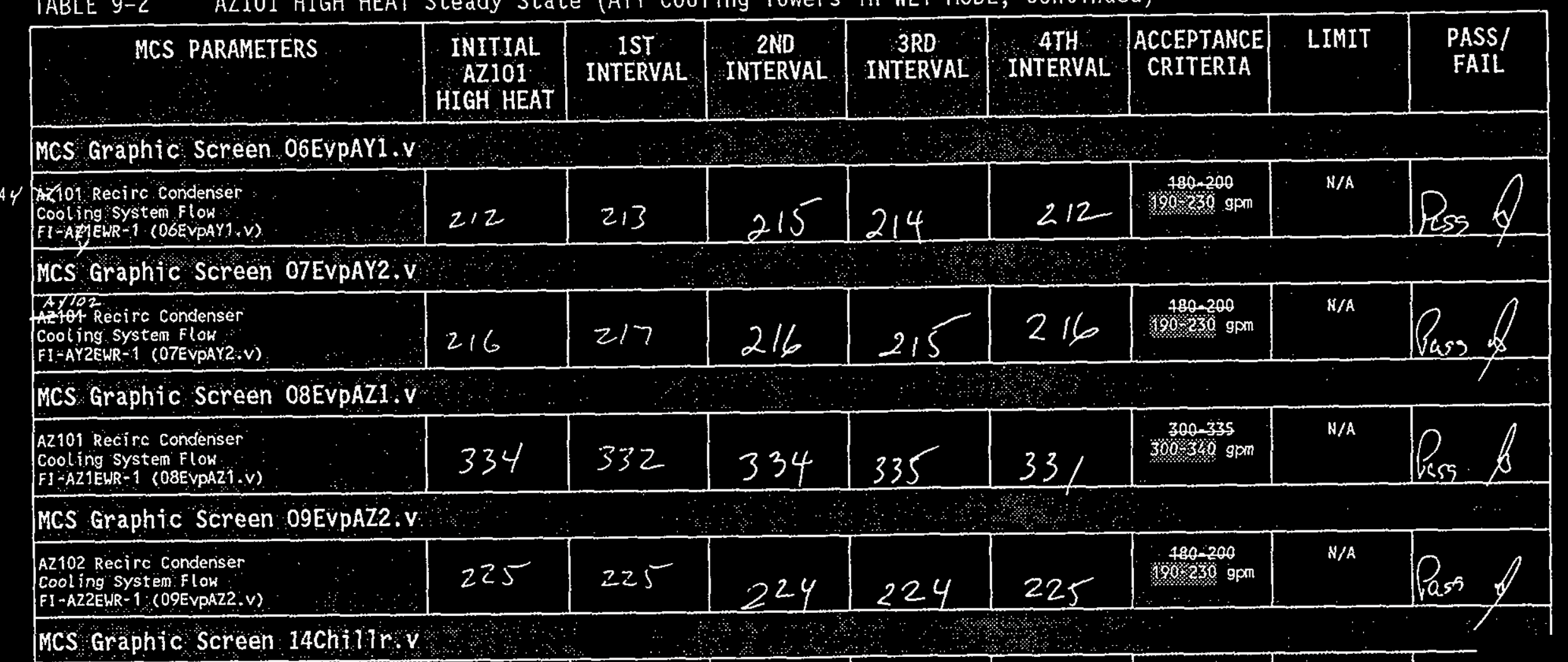

MCS Graphic Screen 14Chilir.

Primary vent condenser

Chillen cooling flow Rate

FI AzCuR 1 (14Chill $r$ ry)

$1 / 9$

$1 / 8$

119

119

119

$\frac{710-120}{5 \% \text { gprin }}$

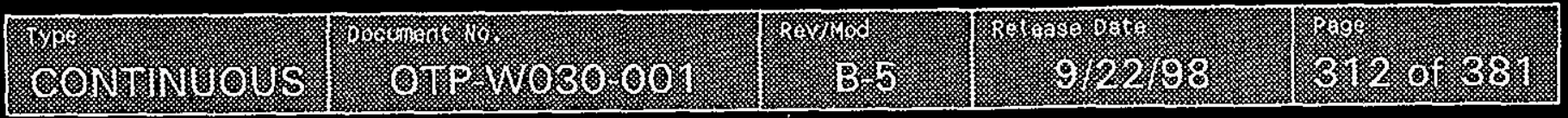


ATTACHMENT B - RECIRC AND HIGH HEAT MODE OPERATIONAL TESTING (Cont.)

TABLE 9-2 AZ101 HIGH HEAT Steady State (All Cooling Towers in WET MODE, Continued)

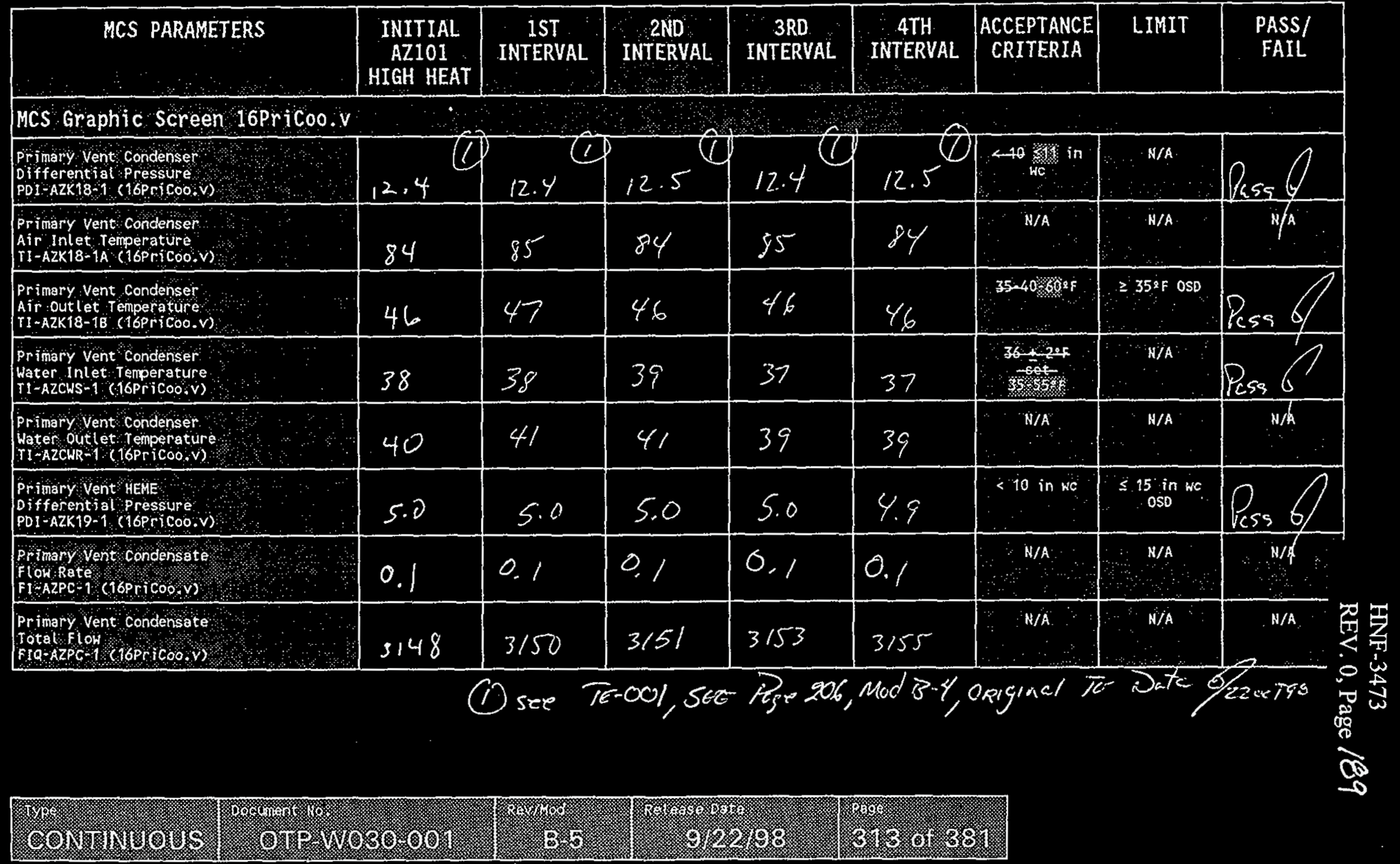


ATTACHMENT B - RECIRC AND HIGH HEAT MODE OPERATIONAL TESTING (Cont.)

TABLE 9-2 AZ101 HIGH HEAT Steady State (AT1 Cooling Towers in WET MODE, Continued)

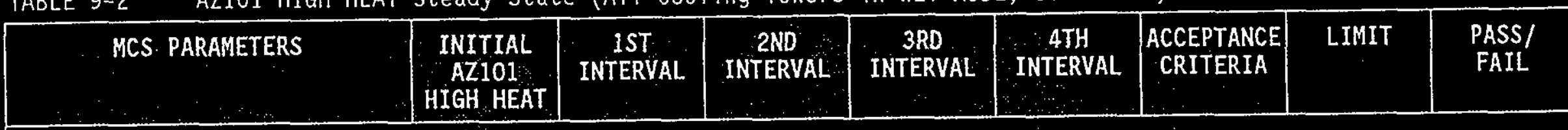

MCS Graphic Screen 17PriExh.v

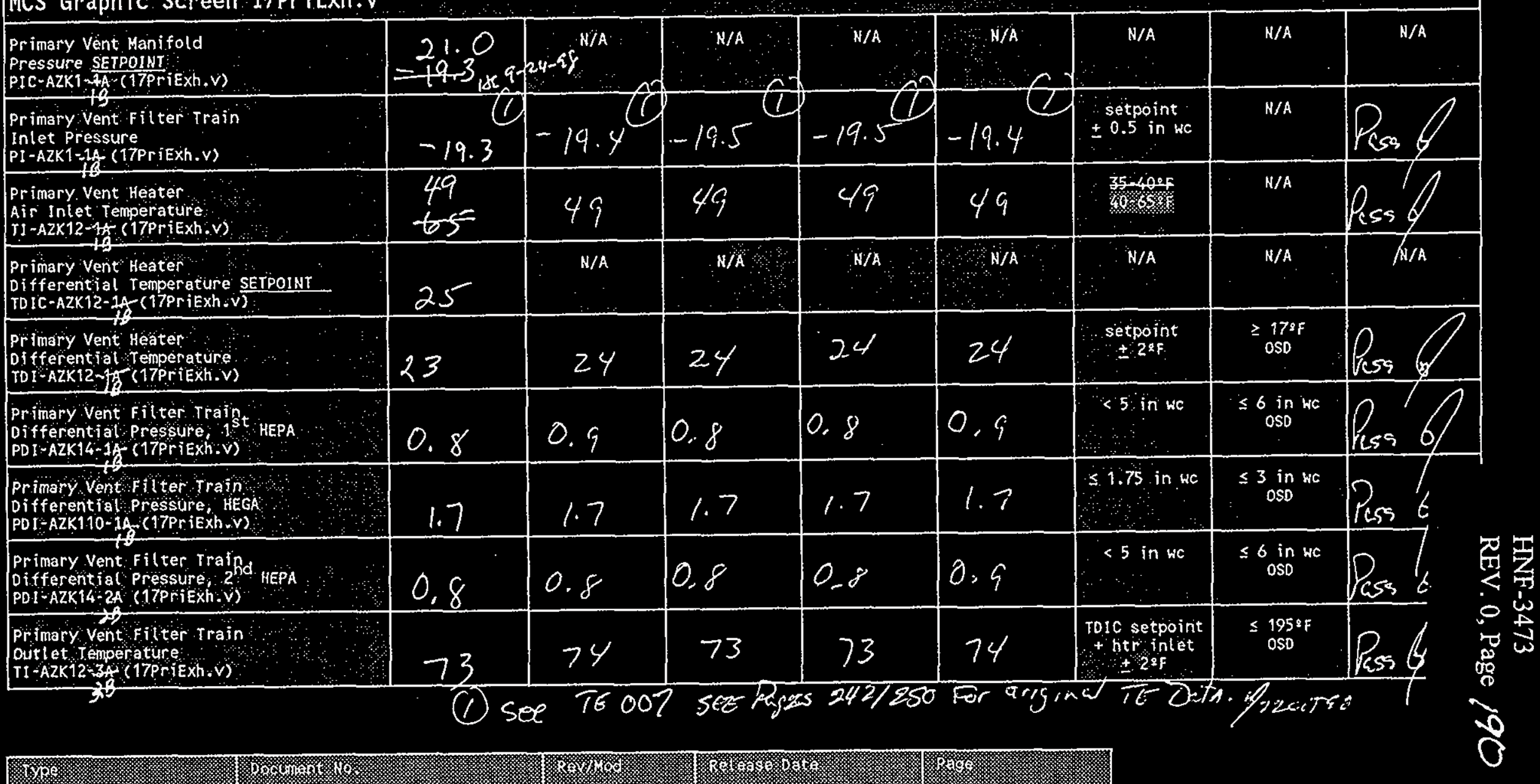

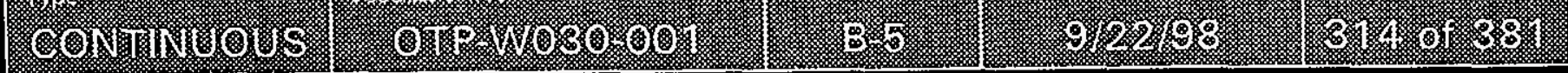




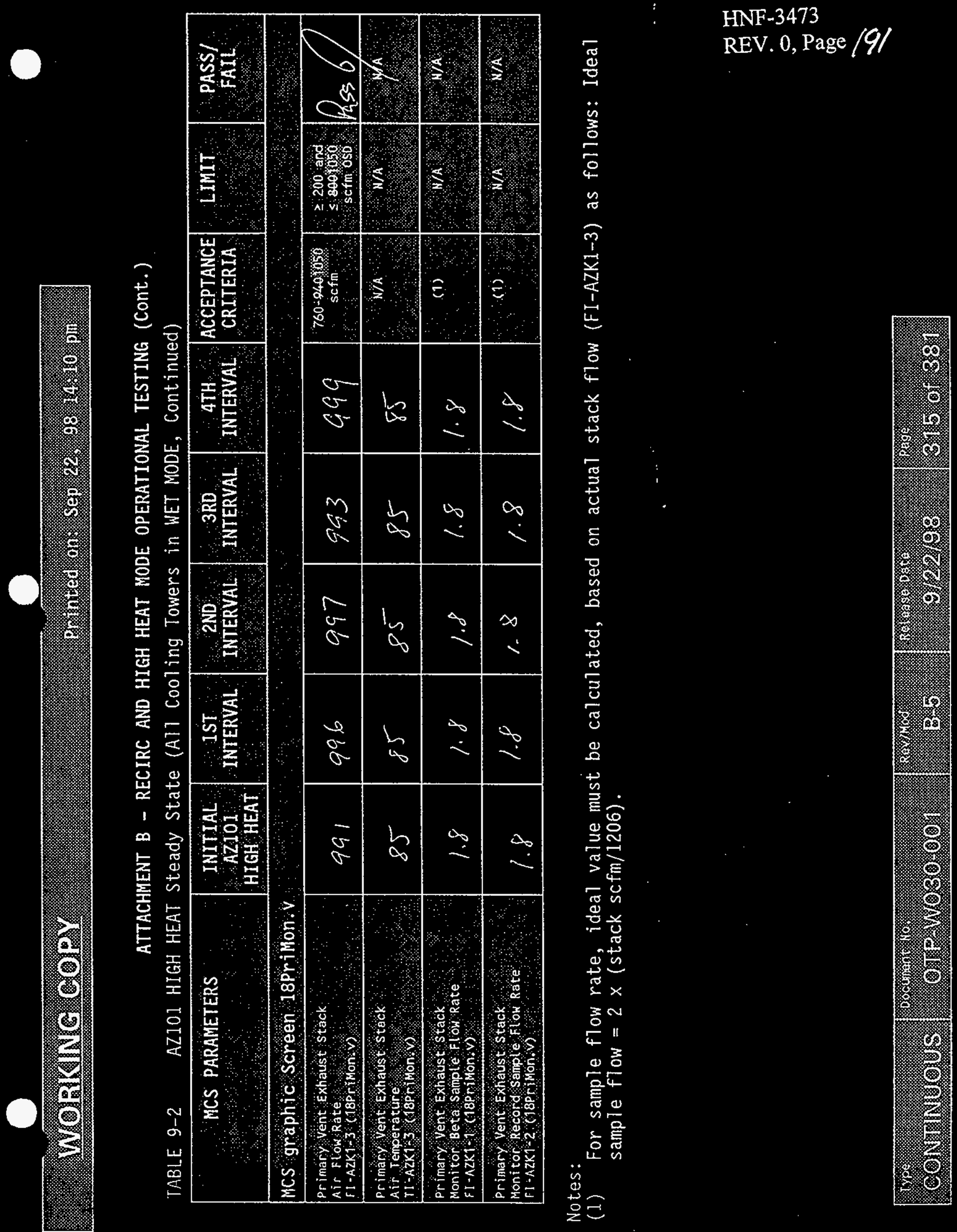




\section{ATTACHMENT B - RECIRC AND HIGH HEAT MODE OPERATIONAL TESTING (Cont.)}

\subsection{AZ101 HIGH HEAT - TANK PRESSURE CONTROL}

\section{CAUTION}

This section cannot be performed prior to lifting of the limitations cited in the Project $W-030$ NOC 1 imiting the maximum flow rate of the exhauster to 800 scfm.

10.1 ENSURE the following recirculation ventilation systems are in the RECIRC mode of operation according to the listed procedure.

AYI01 - T0-060-351, AY101 TANK RECIRC MODULE OPERATION

$\neg \quad$ AY102 - T0-060-352, AY102 TANK RECIRC MODULE OPERATION

- AZ102 - T0-060-354, AZ102 TANK RECIRC MODULE OPERATION

10.2 ENSURE AZ101 HIGH HEAT mode is established according to T0-060-353.

10.3 ENSURE the tank pressure control setpoints for tanks AY101, AY102, and AZ102 are set to -2.0 in. WC on MCS graphic screen 15PriIn.v.

- PIC-AYIKI-1

PIC-AY2K1-1

P PIC-AZ2KI-1

10.4 ENSURE the tank exhaust flow control setpoints and the primary vent manifold pressure setpoints PIC-AZK1-1A and PIC-AZKI-IB are set as required to achieve the flow rates listed below.

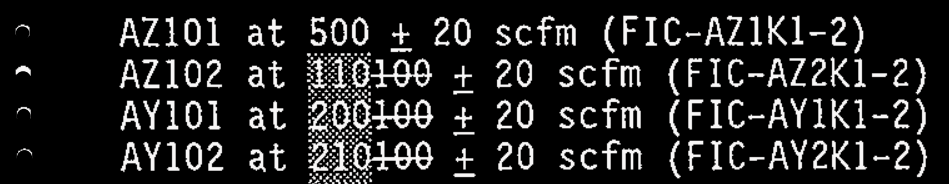

10.5 ADJUST the tank pressure setpoint controller for tank AZ101, PIC-AZ1K1, to -0.5 in. wc.

NOTE - In the following steps, the system is stable when tank pressures are within \pm 0.2 in wC of the setpoint and pressure control valve position $i$ approximately steady state.

10.6 ALLOW the system to stabilize AND RECORD the Initial Value data in TABLE IO-1
10.7 ADJUST the tank pressure setpoint controller for tank AZlol, PIC-AZlK1, in 0.5 in. wc increments, from -0.5 in. wc to -3.0 in. wc.

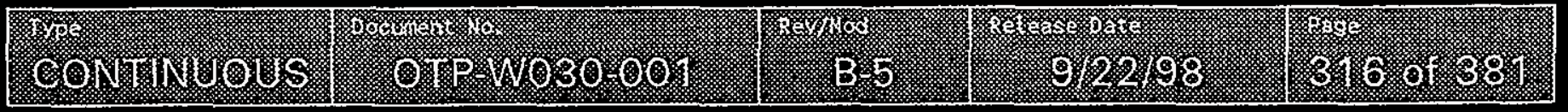




\section{monkMG COPY}

\section{ATTACHMENT B - RECIRC AND HIGH HEAT MODE OPERATIONAL TESTING (COnt.)}

10.8 ALLOW system to stabilize AND RECORD the Changed value dat on TABLE 10-1 at each increment.

Test Engineer:

10.9 VERIFY that no unexpected alarms or conditions occurred assodiated with this section of testing and that the data in TABLE 10-1 satisfies/the acceptance criteria.

Test Engineer:

10.10 ADJUST the pressure setpoint controller for tank AZ101, PIC-AL1K1, to -2.0 in. Wc. 
ATTACHMENT B - RECIRC AND HIGH HEAT MODE OPERATIONAL TESTING (Cont.)

TABLE 10-1 AZ101 HIGH HEAT - Pressure Control

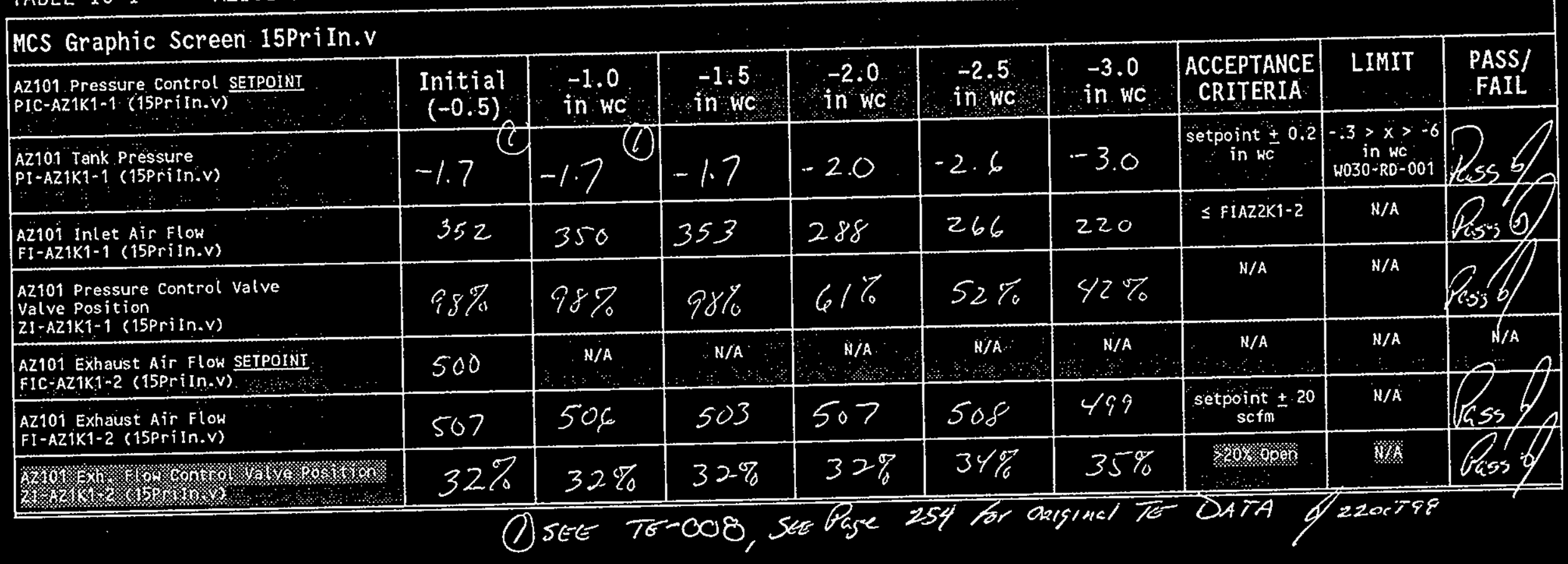

\begin{tabular}{|c|c|c|c|c|}
\hline 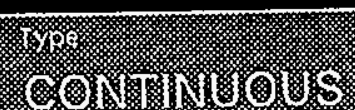 & 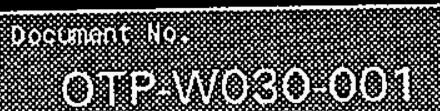 & 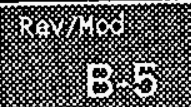 & (3) & 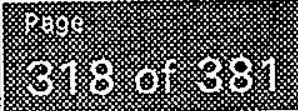 \\
\hline
\end{tabular}


ATTACHMENT B - RECIRC AND HIGH HEAT MODE OPERATIONAL IESIING (CONT.)

\subsection{AZ101 HIGH HEAT - FAN AND FILTER TRAIN SWITCHOVER (B to A)}

\section{CAUTION}

This section cannot be performed prior to lifting of the 1 imitations cited in the Project $\mathrm{W}-030$ NOC limiting the maximum flow rate of the exhauster to $800 \mathrm{scfm}$.

11.1 ENSURE Exhaust Fan AZ-K1-5-1B and Filter Train $B$ are in service.

11.2 ENSURE the following recirculation ventilation systems are in the RECIRC mode of operation according to the listed procedure.

- AY101 - T0-060-351, AY101 TANK RECIRC MODULE OPERATION

- AY102 - T0-060-352, AY102 TANK RECIRC MODULE OPERATION

- AZ102 - T0-060-354, AZ102 TANK RECIRC MODULE OPERATION

11.3 ENSURE AZ101 HIGH HEAT mode is established according to T0-060-353.

11.4 ENSURE primary vent manifold setpoints PIC-AZK1-1A AND PIC-AZK1-1B match.

11.5 ENSURE heater temperature differential setpoints TDIC-AZK12-1A and TDIC-AZK12-1B match.

11.6 RECORD Initial Value data in TABLE $11-1$.

11.7 SELECT "Fan-1A" on MCS MACRO graphic screen 25mExhst.v.

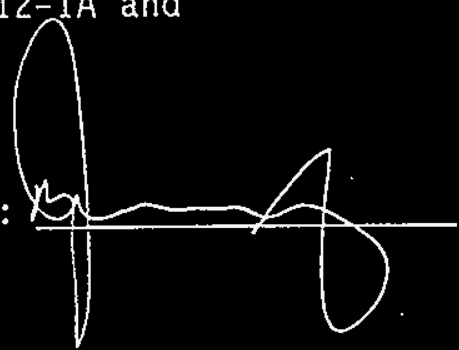

11.8 SELECT "Heater-1A" on MCS MACRO graphic screen 25mExhst.v.

11.9 RUN Exhaust MACRO.

11.10 CHECK the following conditions on MCS graphic 17PriExh.v.:

$\begin{array}{lll}\text { - } & \text { Fan-1A: } & \text { ON } \\ \text { - } & \text { Fan-1B: } & \text { STANDBY } \\ \text { - } & \text { Heater-1A: } & \text { ON } \\ \text { - } & \text { Heater-1B: } & \text { STANDBY }\end{array}$

11.11 CHECK Chiller AND Pump-1A or Pump-1B ON at MCS graphic 14Chillr.v.

\begin{tabular}{|c|c|c|c|c|}
\hline & 3. & ; & ( & 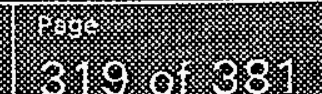 \\
\hline
\end{tabular}




\section{ATTACHMENT B - RECIRC AND HIGH HEAT MODE OPERATIONAL TESTING (Cont.)}

NOTE - In the following step, the system is stable when tank exhaust flow rates are within $\pm 20 \mathrm{scfm}$ of the Initial value and primary tank pressures are within \pm 0.2 in wC of the Initial Values. Allow a minimum of 15 minutes after changing any setpoints before recording any data

11.12

ALLOW the system to stabilize AND RECORD Final Value

Test Engineer:

11.13 ESTABLISH AZ101 RECIRC mode according to T0-060-353.

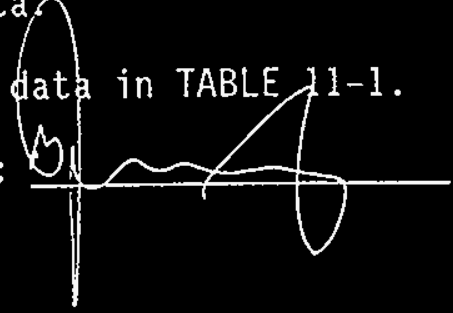

11.14 VERIFY that no unexpected aTarms or conditions occurred associated with this section of testing and that the data. in TABLE 11-1 is in the acceptable range.

Test Engineer:

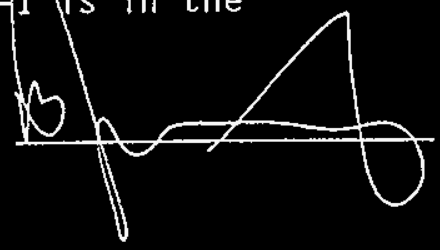


ATTACHMENT B - RECIRC AND HIGH HEAT MODE OPERATIONAL TESTING (Cont.)

TABLE 11-1 AZ101 HIGH HEAT - Fan and Filter Train Switchover (Train B to Train A)

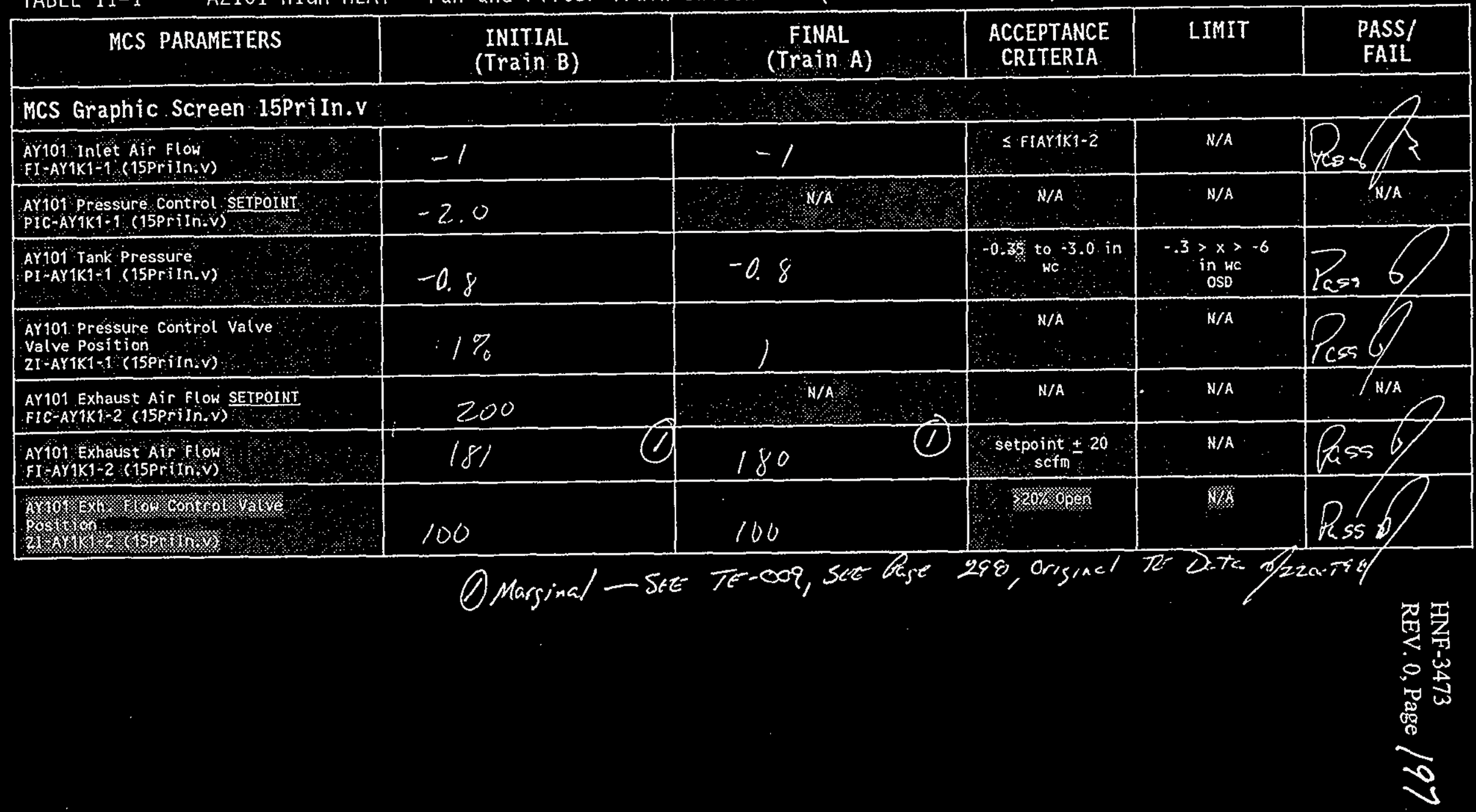

\begin{tabular}{|c|c|c|c|c|}
\hline I.) & F & 4 (3) & 3. & 8.67 . \\
\hline
\end{tabular}




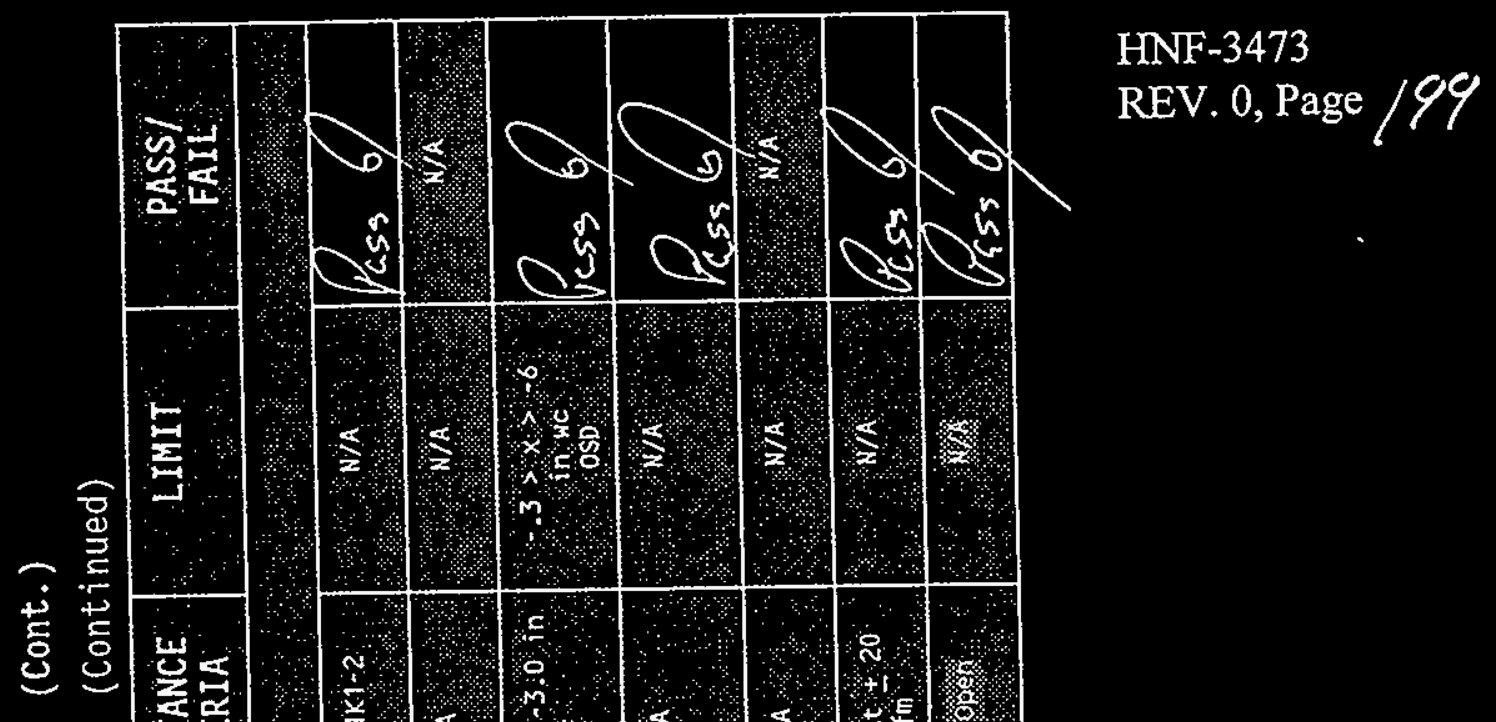

HNF-3473

REV. 0, Page $/ 99$

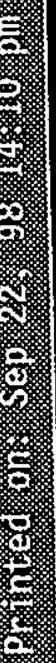

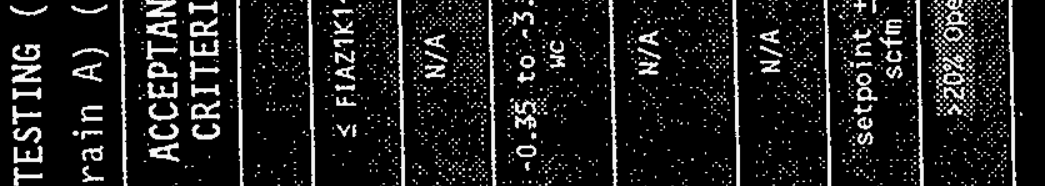


ATTACHMENT B - RECIRC AND HIGH HEAT MODE OPERATIONAL TESTING (CONt.)

TABLE 11-1 AZ101 HIGH HEAT - Fan and Filter Train Switchover (Train B to Train A) (Continued)

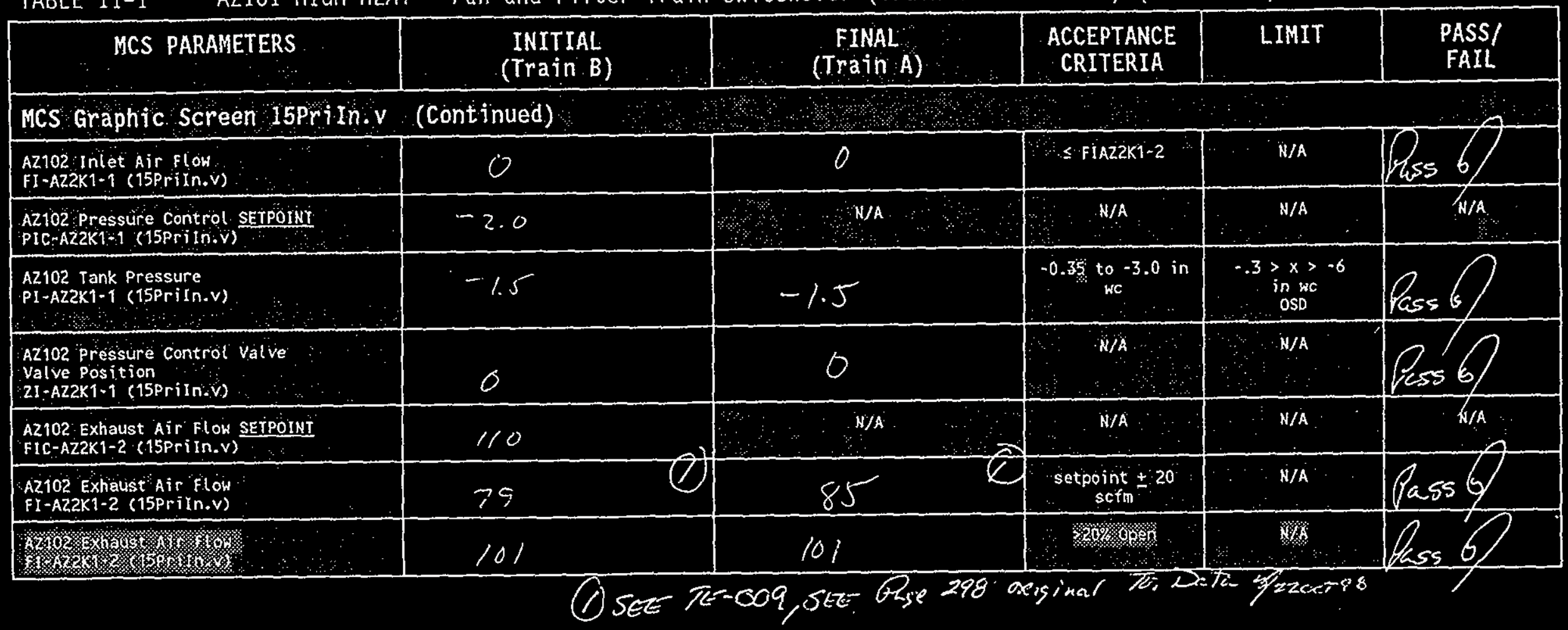

\begin{tabular}{|c|c|c|c|c|}
\hline 6) - 1. & . & 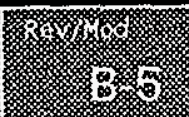 & 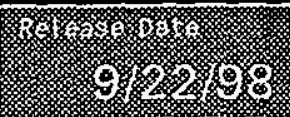 & 86 . \\
\hline
\end{tabular}


ATTACHMENT B - RECIRC AND HIGH HEAT MODE OPERATIONAL TESTING (Cont.)

TABLE 11-1 AZ101 HIGH HEAT - Fan and Filter Train Switchover (Train B to Train A) (Continued)

\begin{tabular}{|c|c|c|c|c|c|}
\hline MCS PARAMETERS & $\begin{array}{l}\text { INITIAL } \\
\text { (Train B) }\end{array}$ & $\begin{array}{l}\text { FINAL } \\
(\text { Train } A)\end{array}$ & $\begin{array}{l}\text { ACCEPTANCE } \\
\text { CRITERIA }\end{array}$ & LIMIT & $\begin{array}{l}\text { PASS/ } \\
\text { FAIL }\end{array}$ \\
\hline \multicolumn{6}{|c|}{ WCS Graphic Screen 16 PriCoo $\mathrm{V}$} \\
\hline $\begin{array}{l}\text { Primary vent condenser } \\
\text { oifferential pressure } \\
\text { PoI-AZK18-1 (16Pricoo.v) }\end{array}$ & 12.0 & 12.1 & $4-10$ os in wo & $\quad W / A$ & \\
\hline $\begin{array}{l}\text { Prinary vent condenser } \\
\text { outlet A Ar Temperature } \\
\text { TI-AZK } 18 \text { B B (16PriCoo.V) }\end{array}$ & 47 & 46 & $3540 \times 20 \%$ & N/A. & \\
\hline $\begin{array}{l}\text { Primary vent heME } \\
\text { Differential pressure } \\
\text { PDinAZK19-1 (16pri Coo v) }\end{array}$ & 0 & 4.9 & \% 10 in WC: & $\begin{array}{c}\leq 15 \text { in wc } \\
\text { OSD }\end{array}$ & \\
\hline
\end{tabular}

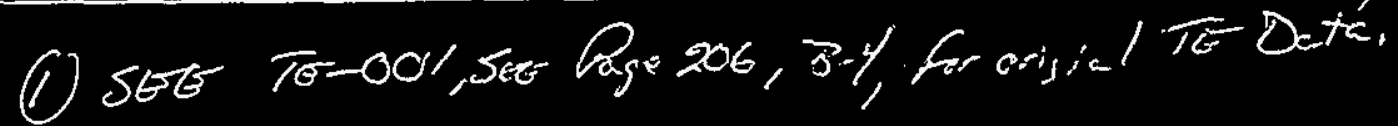

\begin{tabular}{|c|c|c|c|c|}
\hline 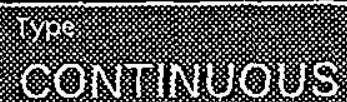 & Fi & (1) & ( & (8.6) \\
\hline
\end{tabular}


ATTACHMENT B - RECIRC AND HIGH HEAT MODE OPERATIONAL TESTING (Cont.)

TABLE 11-1 AZ101 HIGH HEAT - Fan and Filter Train Switchover (Train B to Train A) (Continued)

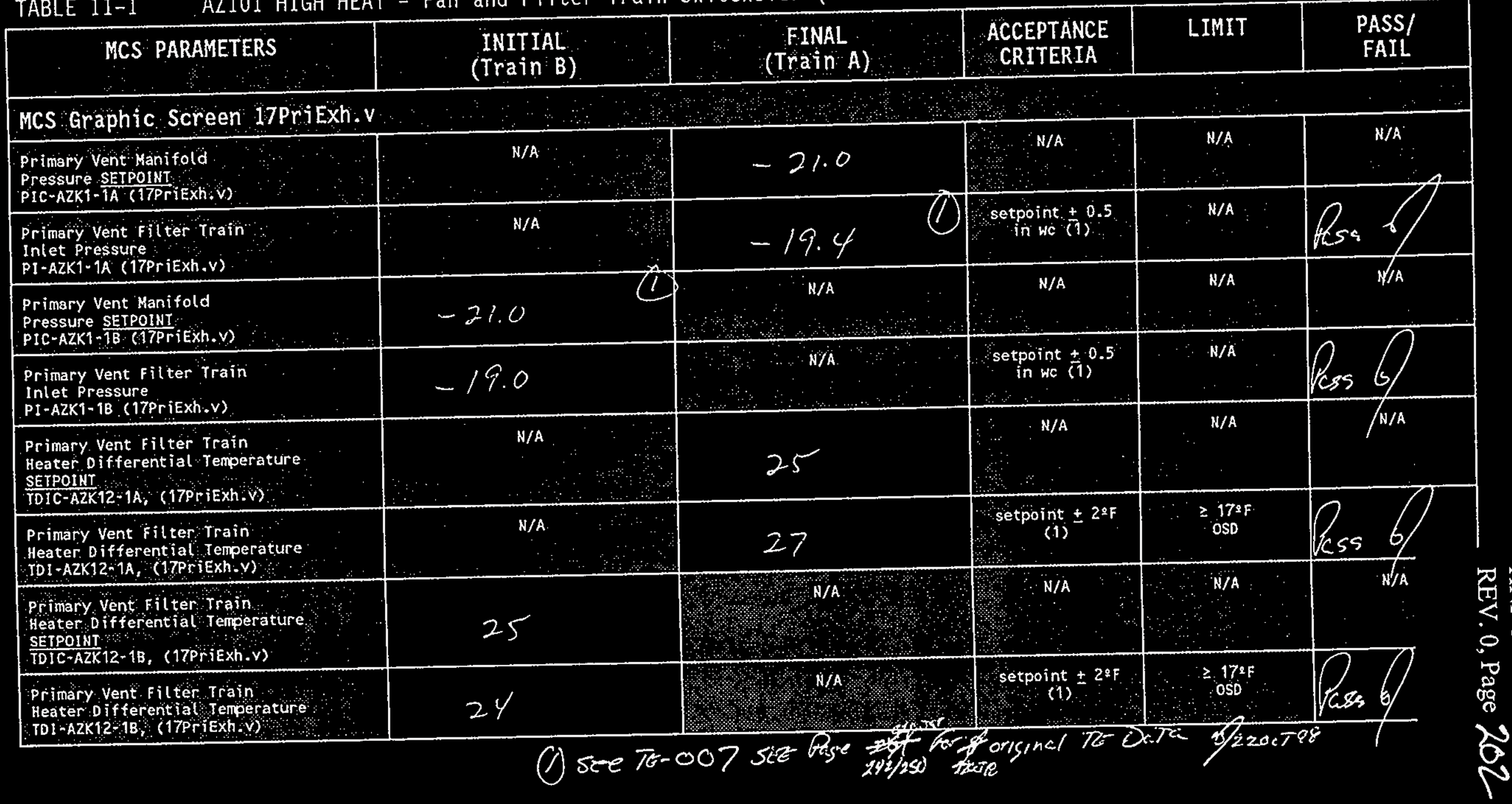

\begin{tabular}{|c|c|c|c|c|}
\hline Fir & 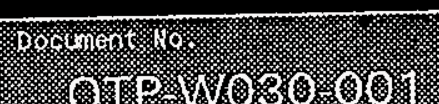 & (3) & (3) & 8. \\
\hline
\end{tabular}


ATTACHMENT B - RECIRC AND HIGH HEAT MODE OPERATIONAL TESTING (Cont.)

TABLE 11-1 AZ101 HIGH HEAT - Fan and Filter Train Switchover (Train 8 to Train A) (Continued)

\begin{tabular}{|c|c|c|c|c|c|}
\hline MCS PARAMETERS & $\begin{array}{c}\text { INITIAL } \\
\text { (Irain B) }\end{array}$ & $\quad$ FINAL & $\begin{array}{l}\text { ACCEPTANCE } \\
\text { CRITERIA }\end{array}$ & LIMIT & $\begin{array}{l}\text { PASS } \\
\text { FAIL }\end{array}$ \\
\hline \multicolumn{6}{|l|}{ MCS Graphlo screen 17PrIEXh V } \\
\hline 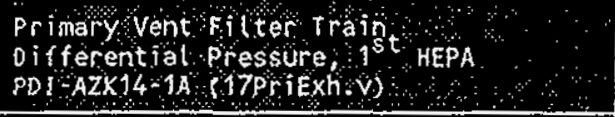 & $\begin{array}{l}\because \mathrm{N} / \mathrm{A}: \\
\therefore\end{array}$ & $0, G$ & $\begin{array}{r}\quad 5 \text { in we } \\
\text { (1) }\end{array}$ & 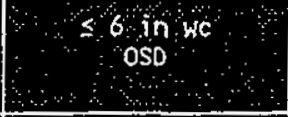 & \\
\hline 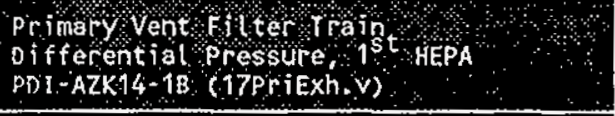 & 0,9 & N/A & sin 119 & $\begin{array}{l}<\text { in wC } \\
\text { OSO }\end{array}$ & \\
\hline $\begin{array}{l}\text { Primary vent flter train } \\
\text { Differential pressure, HEGA } \\
\text { PDI-AZKT10 A (17PriEXh }\end{array}$ & $\begin{array}{c}N / A \\
\cdots\end{array}$ & & $\leq 1.75$ in wC $(1)$ & $\begin{array}{l}\quad \leq 3 \text { in wc } \\
\text { OSD } \\
\end{array}$ & \\
\hline 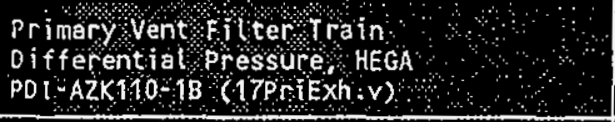 & & $\sin ^{N / A \cdots}$ & $\begin{array}{l}\leq 1.75 \text { in }(1) \\
\end{array}$ & $\begin{array}{l}53 \text { in } w C \\
0 \$ 0 \\
0\end{array}$ & \\
\hline $\begin{array}{l}\text { Primary vent filter train } \\
\text { Differentiat Pressureg } 2^{2} \text { HEPA } \\
\text { POI-AZK1 } 4-2 A \text { (17PriEXh }\end{array}$ & $\begin{array}{ll}\mathrm{N} / \mathrm{A} \\
\because\end{array}$ & 0.8 & $<5$ in we & $\therefore \quad \begin{array}{c}6 \text { in wC } \\
\therefore \text { OSD } \\
\end{array}$ & $\operatorname{lns5}$ \\
\hline $\begin{array}{l}\text { Primary yent folter traind } \\
\text { Differential pressure } 2 \text { hEPA } \\
\text { PDI-AZKT4-2B (17PriExh Y })\end{array}$ & 0,8 & $N / A$ & (1) & $\begin{array}{l}\leq 6 \text { in WC } \\
\therefore \text { OSD }\end{array}$ & 2 \\
\hline
\end{tabular}

\begin{tabular}{|c|c|c|c|c|}
\hline 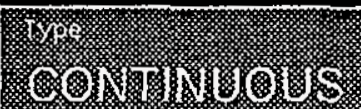 & F. & 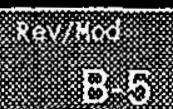 & 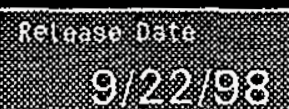 & 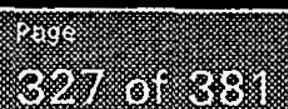 \\
\hline
\end{tabular}


ATTACHMENT B - RECIRC AND HIGH HEAT MODE OPERATIONAL TESTING (CONT.)

TABLE 11-1 AZ101 HIGH HEAT - Fan and Filter Train Switchover (Train B to Train A) (Continued)

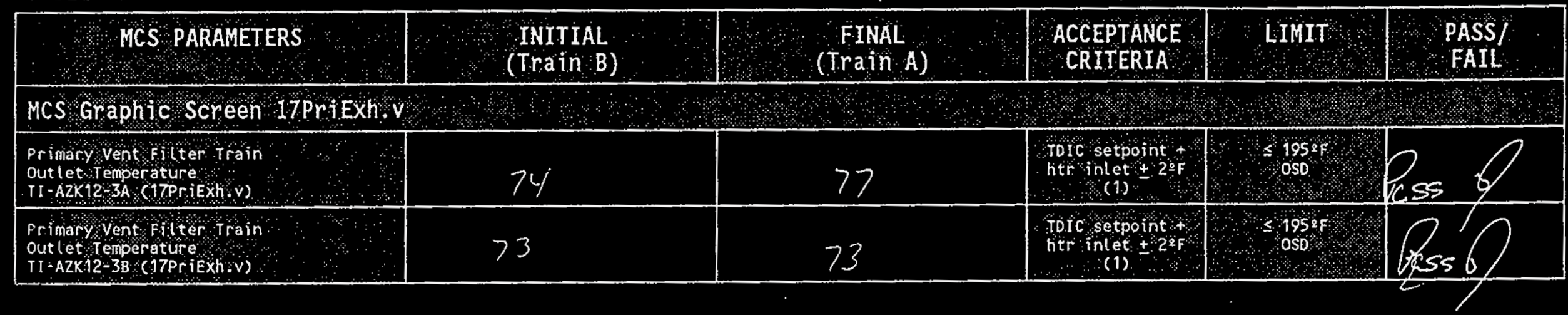

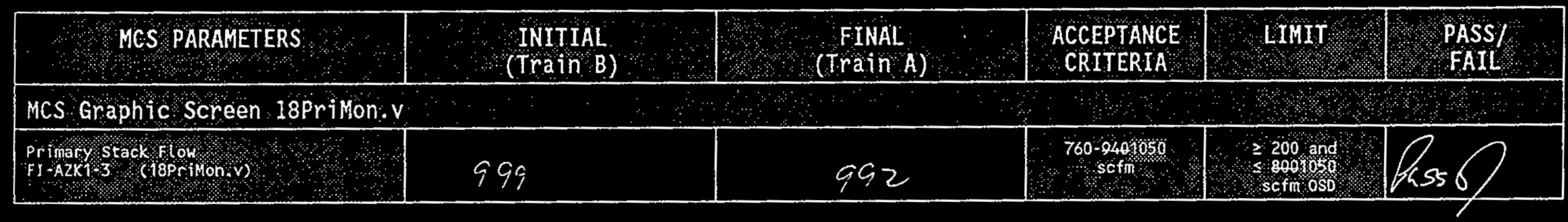

Note (1) Acceptable range is for the inservice vent train only.

\begin{tabular}{|c|c|c|c|c|}
\hline 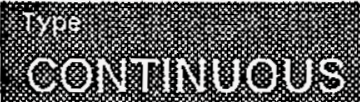 & ㄴ. & (3) & 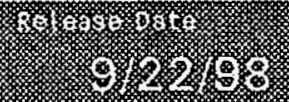 & 8. \\
\hline
\end{tabular}


ATTACHMENT B - RECIRC AND HIGH HEAT MODE OPERATIONAL TESTING (Cont.)

TABLE 11-1 AZ101 HIGH HEAT - Fan and Fifter Train Switchover (Train B to Train A) (Continued)

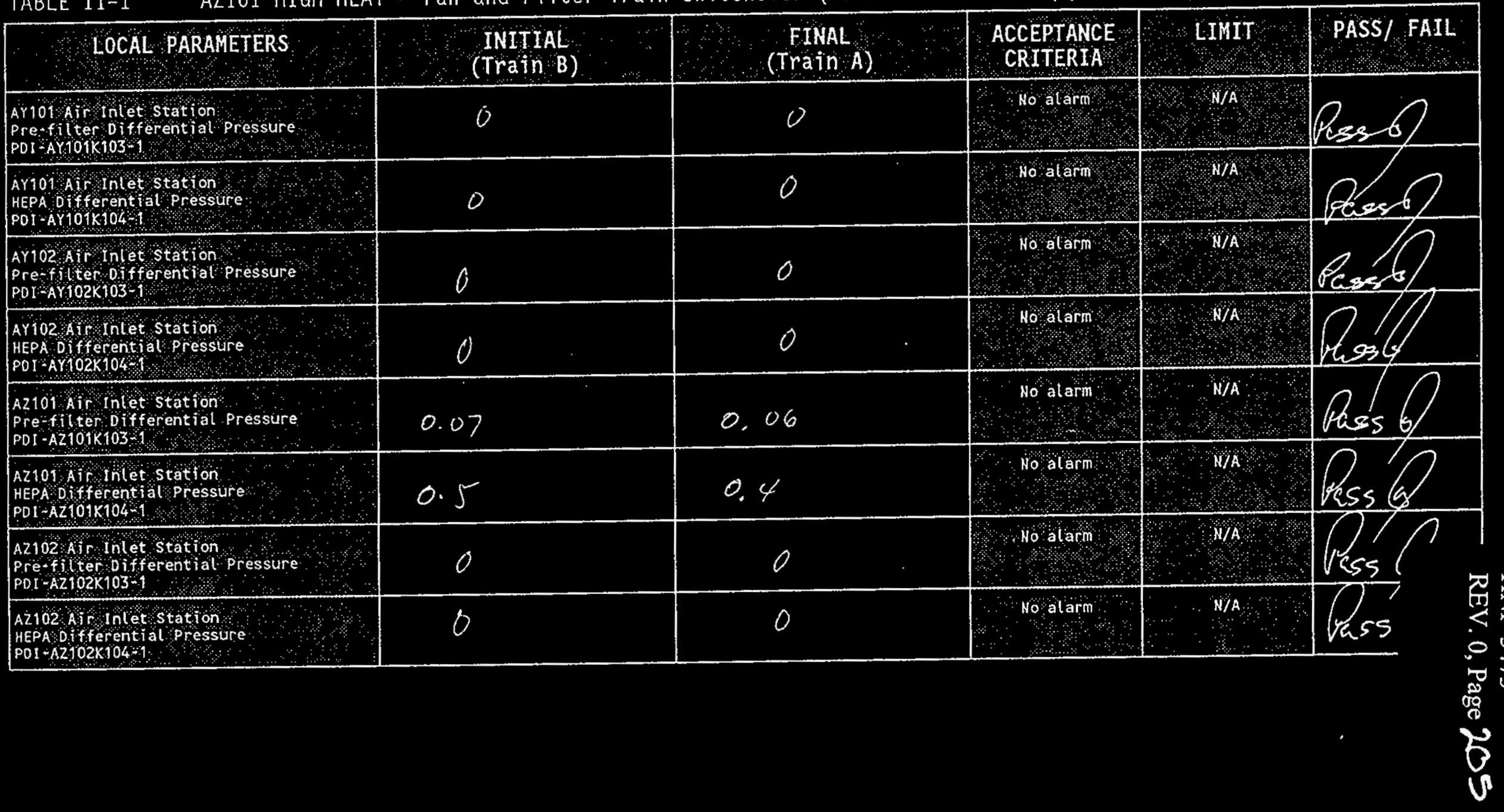

\begin{tabular}{|c|c|c|c|c|}
\hline 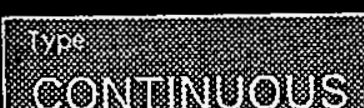 & 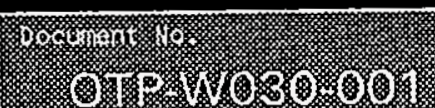 & 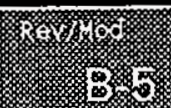 & 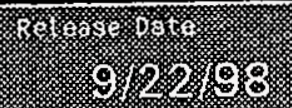 & 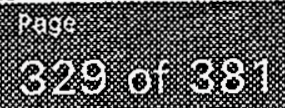 \\
\hline
\end{tabular}




\section{ATTACHMENT B - RECIRC AND HIGH HEAT MODE OPERATIONAL TESTING}

\subsection{AZ102 HIGH HEAT - STEADY STATE OPERATION}

\section{CAUTION}

This section cannot be performed prior to lifting of the limitations cited in the Project $W-030$ NOC limiting the maximum flow rate of the exhauster to $800 \mathrm{scfm}$.

12.1 ENSURE Exhaust Fan AZ-K1-5-1

12.2 ENSURE the following recirculation ventilation systems are in the RECIRC mode of operation according to the listed procedure.

- AY101 - T0-060-351, AY101 TANK RECIRC MODULE OPERATION

- AY102 - T0-060-352, AY101 TANK RECIRC MODULE OPERATION

- AZ101 - T0-060-353, AZ101 TANK RECIRC MODULE OPERATION

- AZ102 - T0-060-354, AZ102 TANK RECIRC MODULE OPERATION

12.3-ADJUST-AZ102 tank exhaust flow-control-setpoint to 500 - 20 -sefm- (FIC AZ2K1 2)

12.4 ENSURE tank pressure control setpoints are set at -2.0 in. WC on MCS graphic screen 15PriIn.v.

- PIC-AZIK1-I

- PIC-AZ2K1-1

- PIC-AYIKI-1

- PIC-AY2K1-1

12.5 ENSURE the tank exhaust flow control setpoints and the primary vent manifold pressure setpoints PIC-AZK1-IA and PIC-AZK1-1B are set as required to achieve the flow rates $l i s t e d$ below.

- $\quad$ AZ101 at $1000 \pm 20$ scfm (FIC-AZ1K1-2)

- AZ102 at

- AY101 at $2060100 \pm 20 \mathrm{scfm}$ (FIC-AYIK1-2)

- AY102 at 26100 20 scfm (FIC-AY2KI-2)

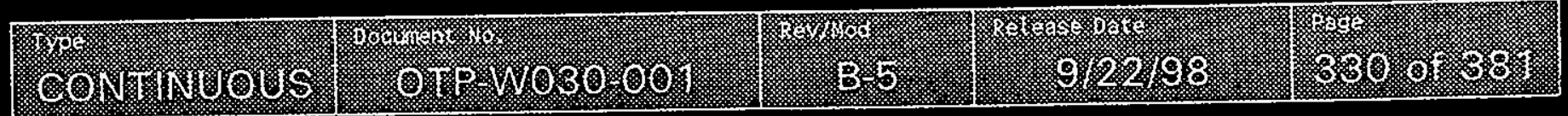




\section{ATTACHMENT B - RECIRC AND HIGH HEAT MODE OPERATIONAL TESTING} 12.6 ALLOW system parameters to stabilize for 15 minutes AND RECgRD Initiai data $f$
AZ102 RECIRC mode in TABLE 12-1.

12.7 ESTABLISH AZ102 HIGH HEAT mode according to T0-060-354.

Test Engineer:

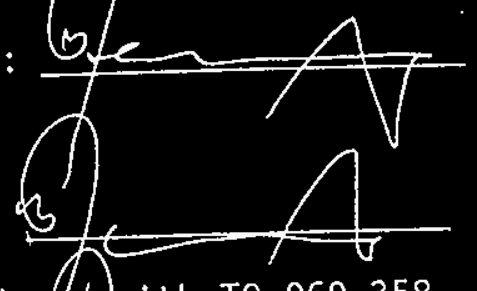

12.8 PLACE AZ102 Cooling Tower in DRY MODE operation in accordanffé with T0-060-358

12.9 ALLOW system parameters to stabilize
AZ102 HIGH HEAT mode in TABLE 12-1.

Test Engineer:

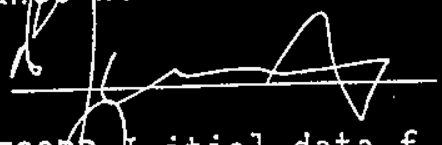

12.10 RECORD data in TABLE 12-1. every hour for 4 consecutive hours.

Test Engineer:

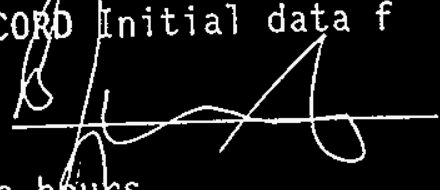
12.11 PLACE AZ102 Cooling Tower in WET MODE operation in accordapce with TO-06
358, AND RETURN to this procedure.

Test Engineer:

12.12

12.13 ALLOW system parameters to stabilize for 15 minutes
data with AZ102 in HIGH HEAT mode in TABLE $12-2$.

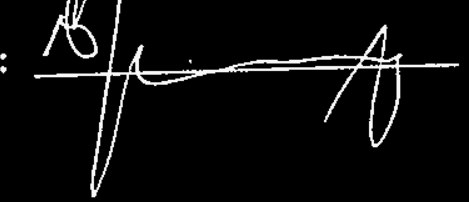

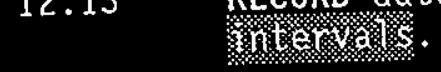

12.14 VERIFY that no unexpected alarms or conditions occurred Gociated with this section of testing and that the data in TABLES $12-1 \mathrm{f}$ and $12-2$ satisfies the acceptance criteria.

Test Engineer:

NOTE - Al1 COOTing Towers will remain in WET MODE operation throlughout the balance of this procedure exeept as directed. 
ATTACHMENT B - RECIRC AND HIGH HEAT MODE OPERATIONAL TESTING (Cont.)

TABLE 12-1 AZ102 HIGH HEAT Steady State (Continued)

\begin{tabular}{|c|c|c|c|c|c|c|c|c|c|}
\hline MCS PARAMETERS & $\begin{array}{l}\text { INITIAL. } \\
\text { AZ102 } \\
\text { RECIRC }\end{array}$ & $\begin{array}{c}\text { INITIAL } \\
\text { AZ102 } \\
\text { HIGH: HEAT }\end{array}$ & IST & $\begin{array}{l}2 N D \\
\text { INTERVAL }\end{array}$ & $\begin{array}{c}\text { 3RD } \\
\text { INTERVAL } \\
\end{array}$ & $\begin{array}{c}\text { 4TH } \\
\text { INTERVAL }\end{array}$ & $\begin{array}{c}\text { ACCEPTANCE } \\
\text { CRITERIA }\end{array}$ & LIMIT & $\begin{array}{l}\text { PASS/ } \\
\text { FAIL }\end{array}$ \\
\hline \multicolumn{10}{|l|}{ MCS Graphic Screen 11RecAY2.V } \\
\hline $\begin{array}{l}\text { AY102 Recirc Vent condenser } \\
\text { Air Inlet Temperature. } \\
\text { II-AY2K48-1A (11RecAY2.V) } \\
\end{array}$ & 80 & $\sigma^{0}$ & 80 & 82 & 82 & 81 & W/A & N/A & $\mathrm{N} / \mathrm{A}$ \\
\hline $\begin{array}{l}\text { AY102 Recirc Vent Condenser } \\
\text { outlet Air Temperature. } \\
\text { TI-AYZK } 48-1 B \text { (11RecAY2.V) } \\
\end{array}$ & 79 & 78 & 78 & 77 & 78 & 77 & N/A & N/A & N/A \\
\hline $\begin{array}{l}\text { AY102 Recirc Vent Condenser } \\
\text { Water Inlet Temperature } \\
\text { II-AY2EWS-1 (11RecAY2 } 2 \text { V) }\end{array}$ & 174 & 76 & 17 & 78 & 78 & 80 & $x^{N / A}$ & H/A & H/A \\
\hline $\begin{array}{l}\text { AY102 Recirc Vent condenser } \\
\text { Water Outlet Temperature } \\
\text { TI-AYZEWR-1 (11RecAY2.V) }\end{array}$ & 73 & 76 & -77 & 79 & 79 & 28 & $\times^{N / A}$ & $\mathrm{~N} / \mathrm{A}$ & $\mathrm{N} / \mathrm{A}$ \\
\hline 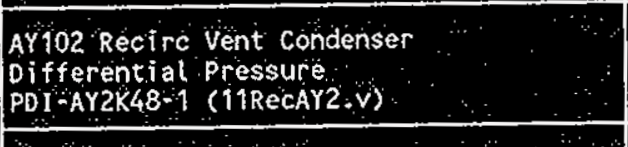 & 10.3 & 10.3 & 10.3 & 10.1 & 10.2 & 10.2 & $8-12$ in $w C$ & $N / A$ & \\
\hline $\begin{array}{l}\text { AY102 gecire Vent fan } \\
\text { Pifferential Pressure } \\
\text { PDi-AY2K45-1 (I1ReCAY2 }\end{array}$ & $14.0^{0}$ & $13.9^{0}$ & $13.9^{0}$ & 13.9 & $13.8^{0}$ & $13.8^{8}$ & $15-18$ in wc. & N/A & \\
\hline $\begin{array}{l}\text { AY102 Recirc Vent Fan } \\
\text { Motor current } \\
\text { II-AY2K45-1 (11RecAY2.V) }\end{array}$ & 5.5 & 5.5 & 5.3 & 5.4 & 5.4 & 5.5 & N/A & N/A & N/A \\
\hline $\begin{array}{l}\text { Incoming L ine voltage at Metering } \\
\text { Station, Room 105, Gene Bldg: }\end{array}$ & 490 & 468 & $48 \%$ & 483 & 483 & 484 & N/A & $N / A$ & $N / A$ \\
\hline $\begin{array}{l}\text { AY102 EXTaust Air Flow SEIPOINI } \\
\text { FIC-AY2K1-2 (11RecAY2,V) }\end{array}$ & 270 & 220 & $\mathrm{~N} / \mathrm{A}$ & $\mathrm{N} / \mathrm{A}$ & $\mathrm{N}^{\mathrm{A}}$ & N/A & N/A & N/A & \\
\hline $\begin{array}{l}\text { AY102 Exhaust Air Flow } \\
\text { FI -AY2K1-2 (11RecAY2.V) }\end{array}$ & 2,2 & 193 & 195 & 196 & 198 & 197 & $\begin{array}{c}\text { setpoint } \\
\pm 20 \mathrm{scfm} \\
\end{array}$ & $N / A$ & $\sqrt[6]{1 / 45}$ \\
\hline
\end{tabular}

\begin{tabular}{|c|c|c|c|c|}
\hline 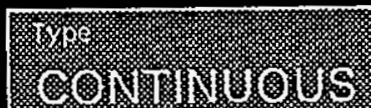 & (1) & 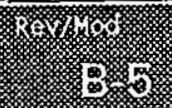 & 淁 & 淤 \\
\hline
\end{tabular}

* Report-writer comment: Some data reflects impossible or inconsistent conditions and is suspect. 
HNF-3473

REV. 0, Page 210

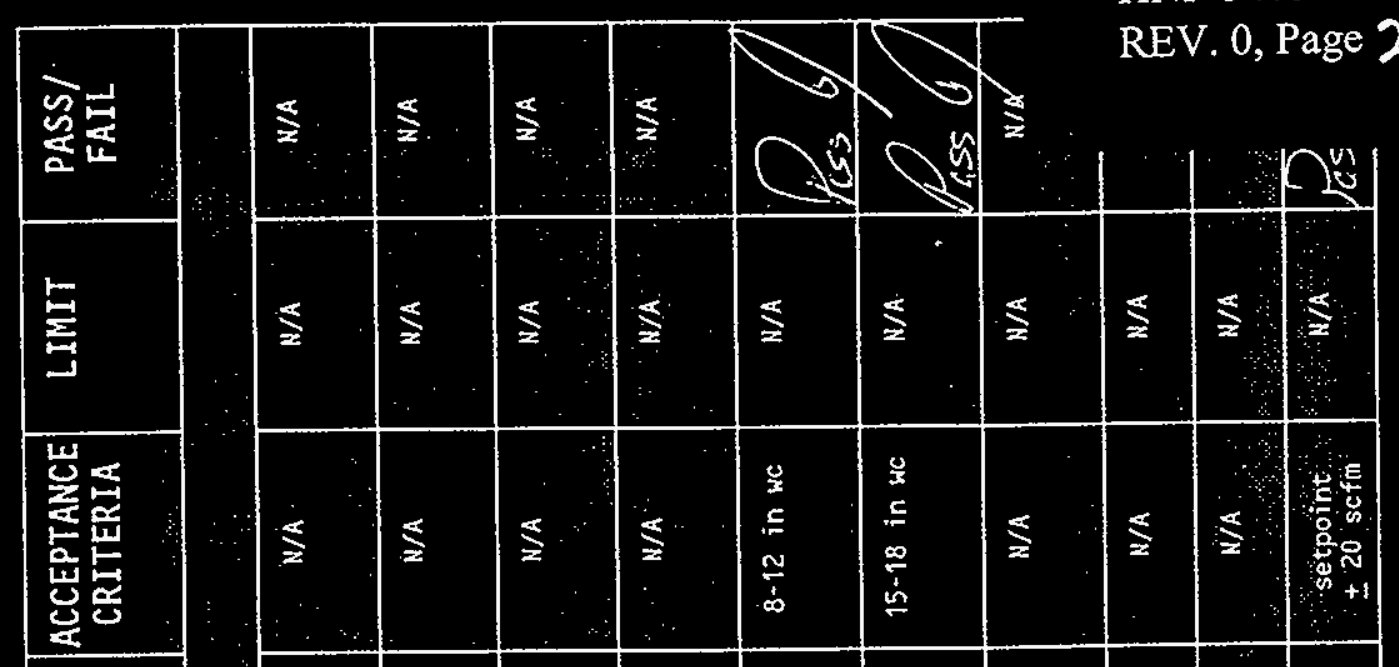

芒

占

崖

点

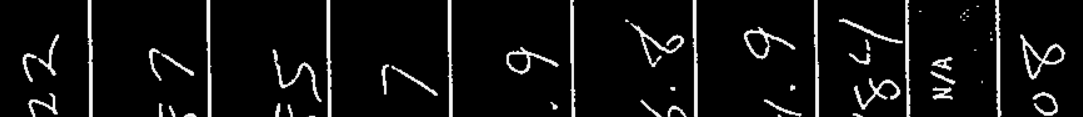

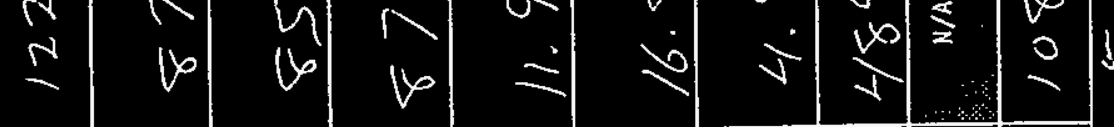

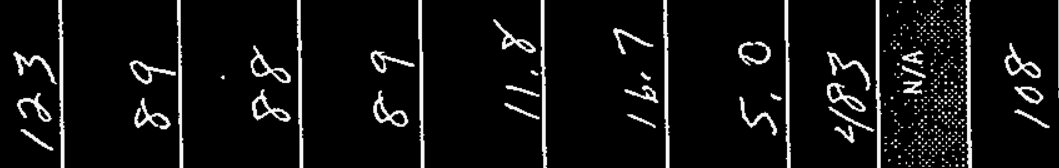
1

窝

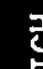

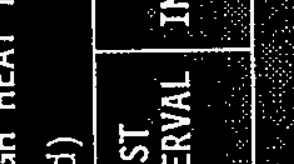

올 車总

를

$\ddot{\Theta}$

岀

सेuي

$\ldots N=$

1 苛是

$\infty$ 구웡

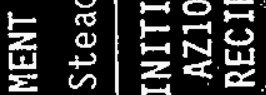

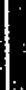

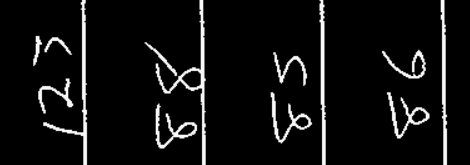

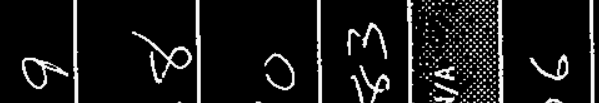

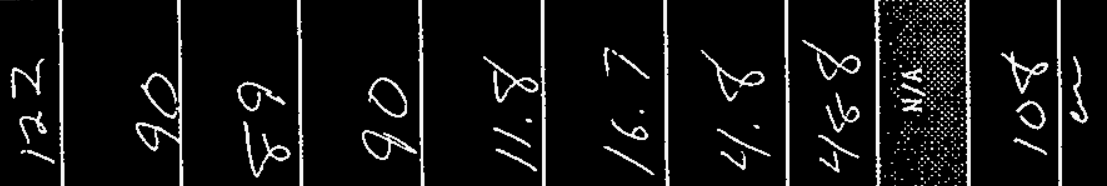

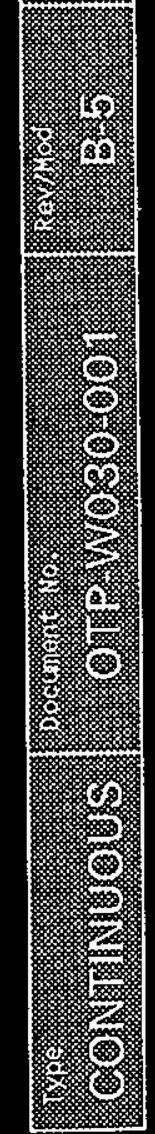




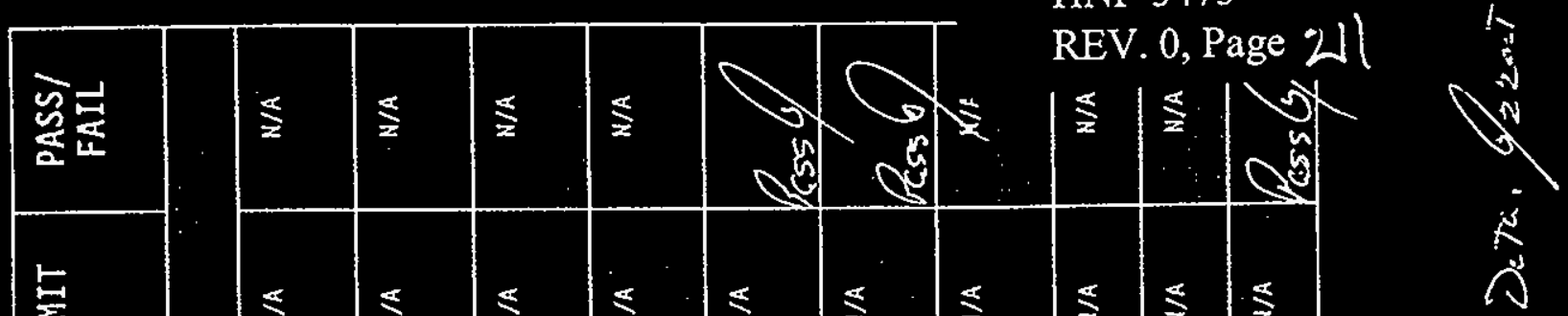

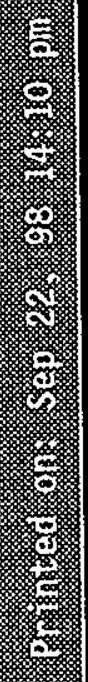

ว 空点

岁我

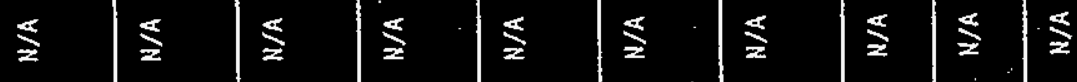

둥

$+$

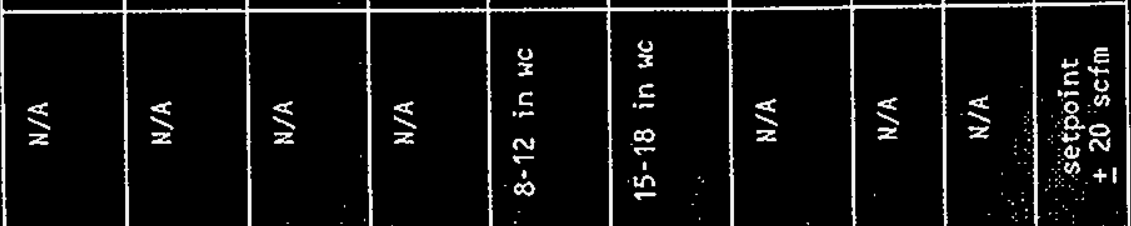

k

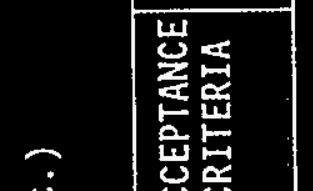

恶 点莡

完

卢. 管

$\frac{1}{0}$

$\underline{d}$

낭

点

논

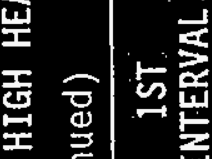

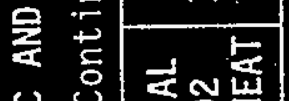

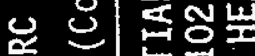

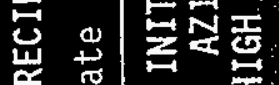

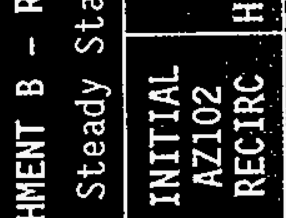

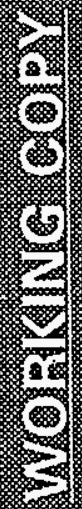

5

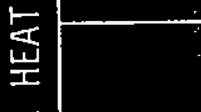

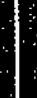

$\equiv$

is a

$\alpha>2$

(i) 0
0
5
4
0
4
0
0
5

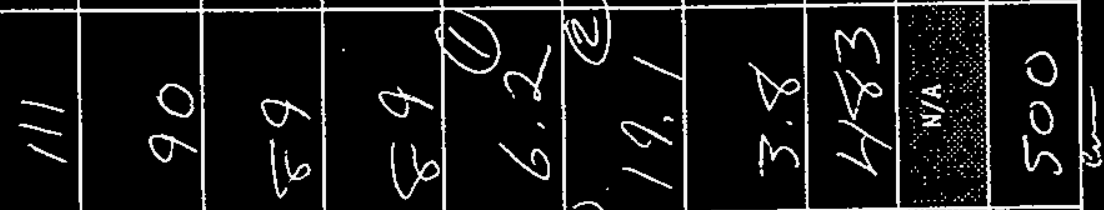

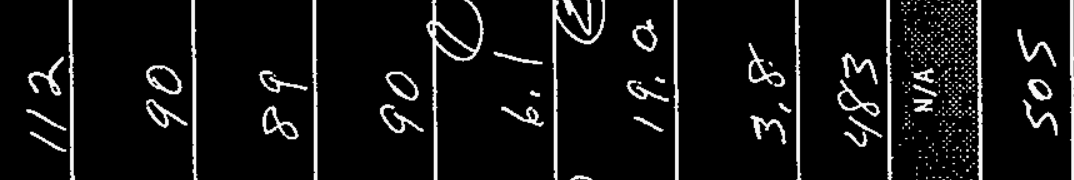

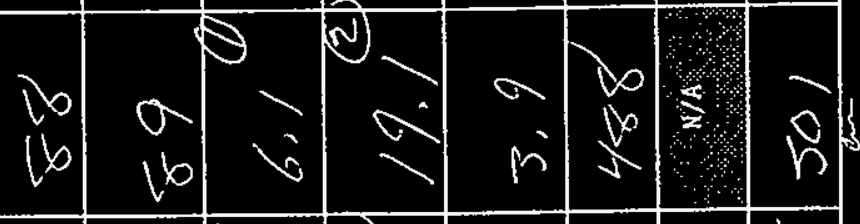

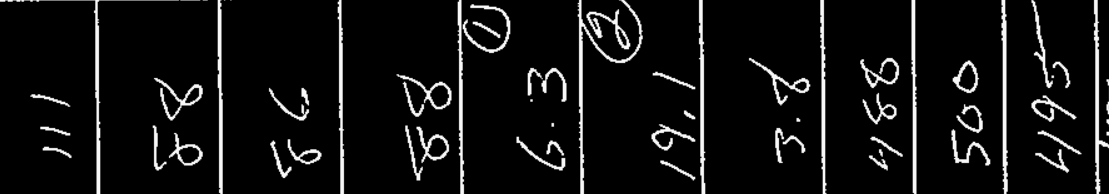

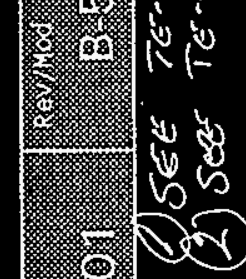

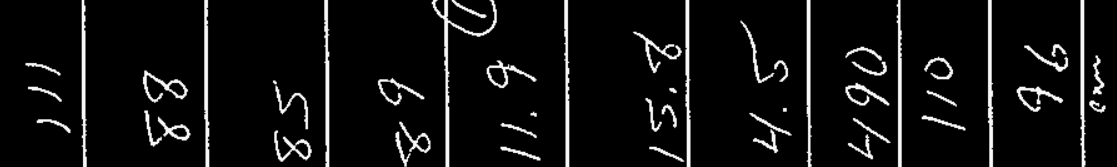
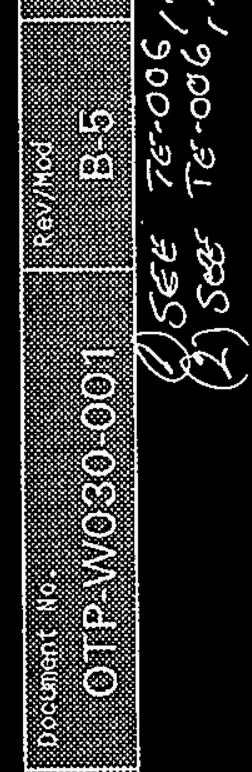

th

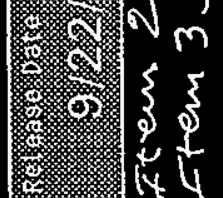

吾

$\frac{1}{3}$

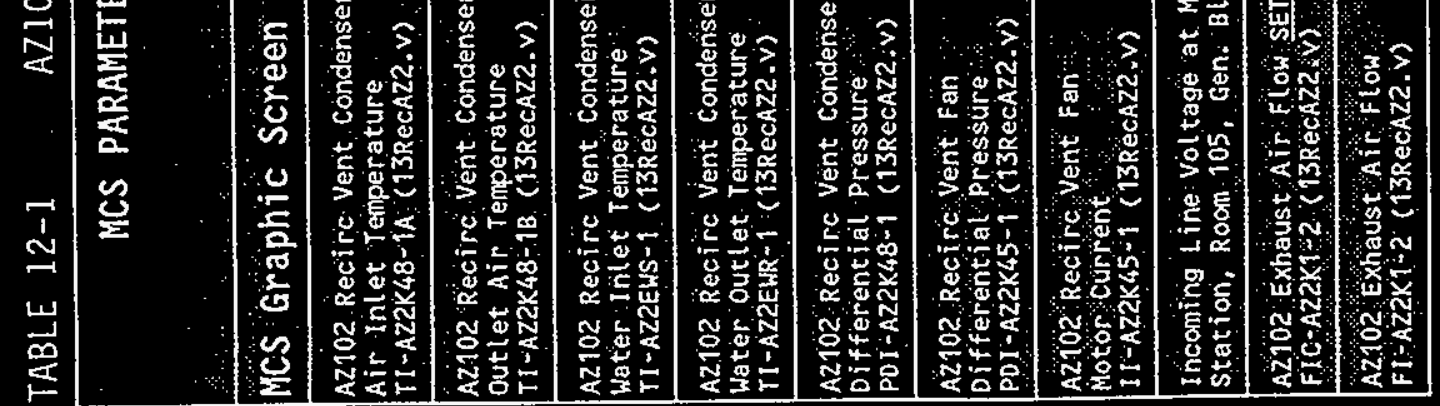

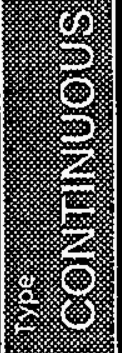




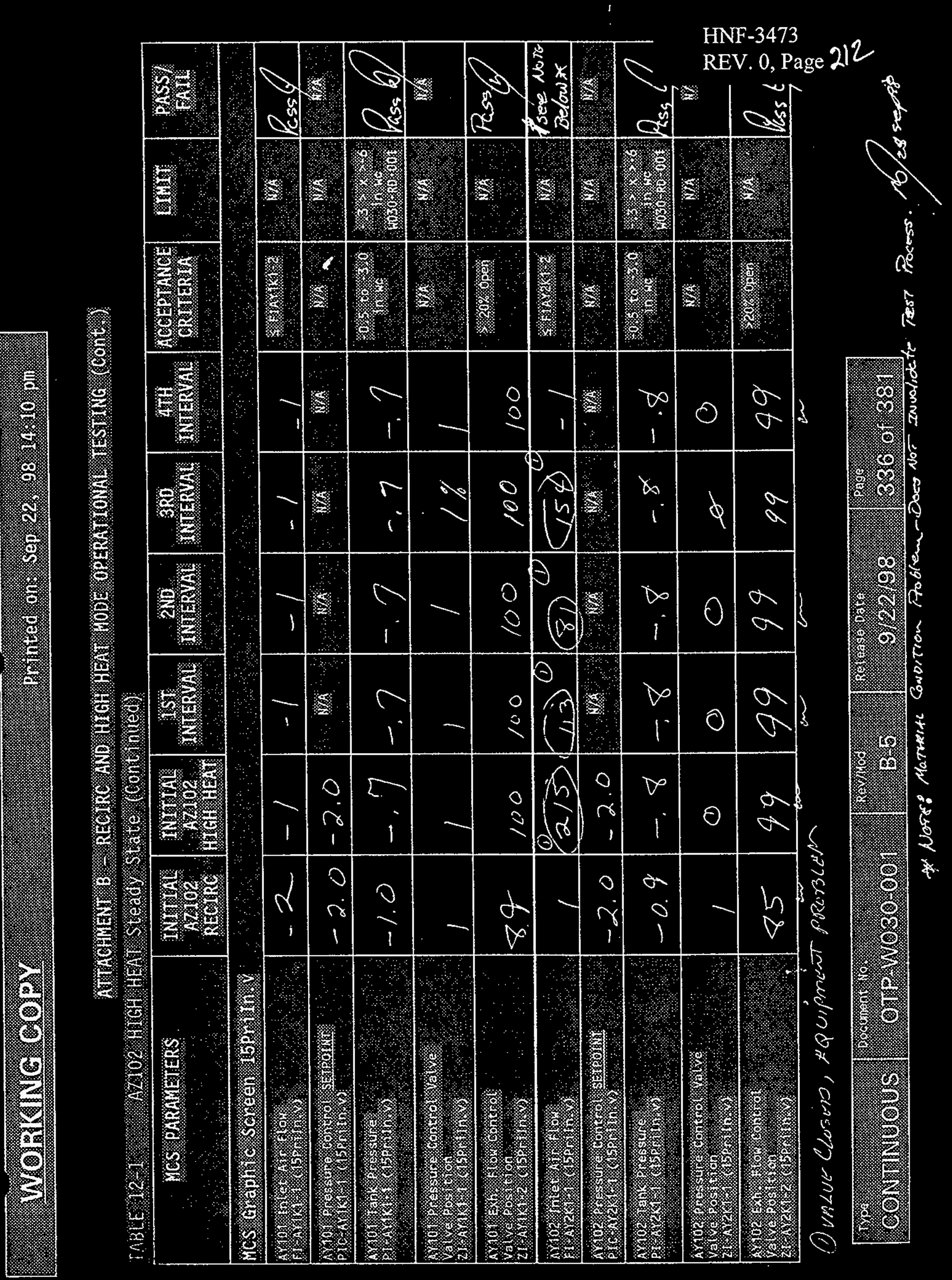




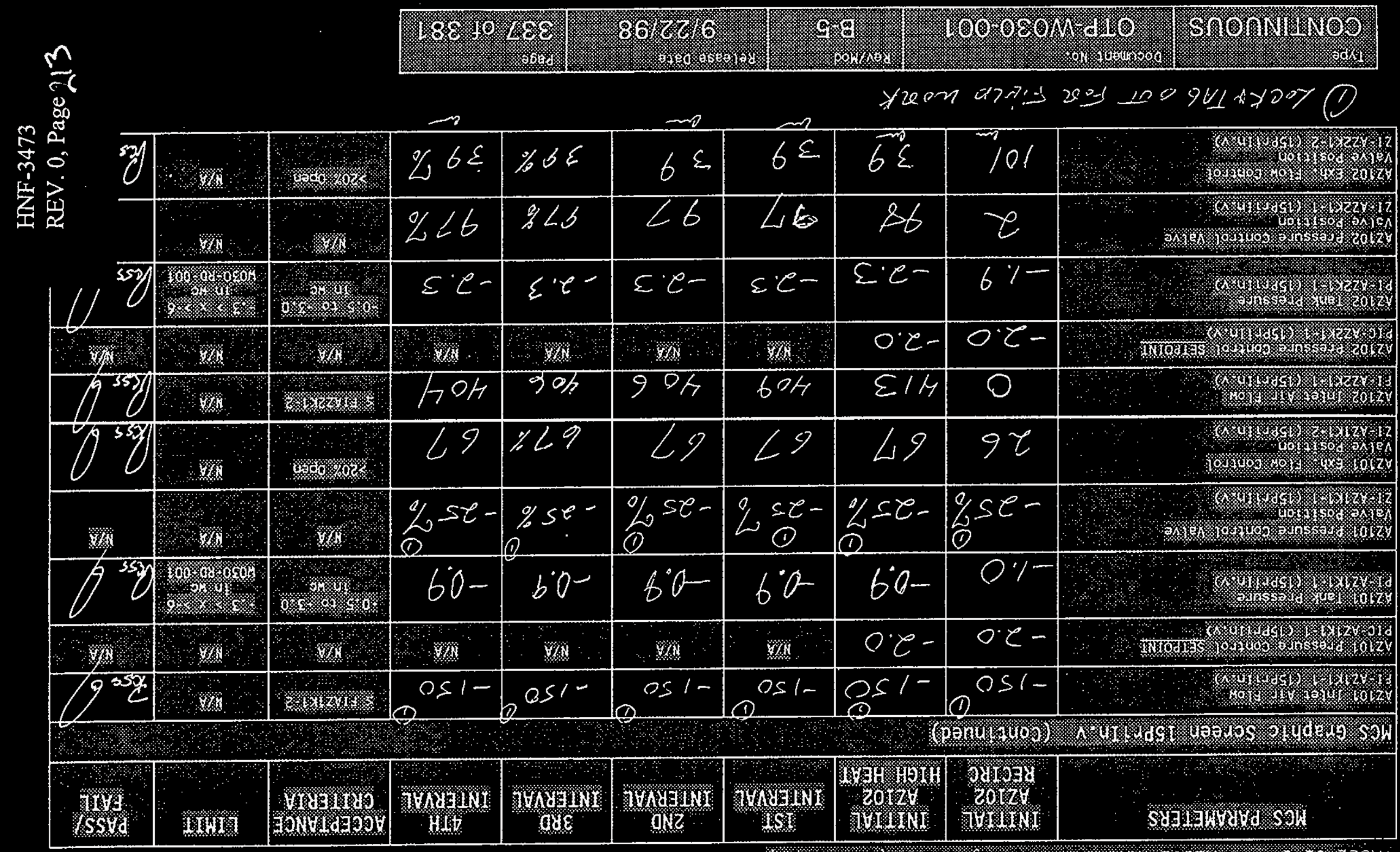

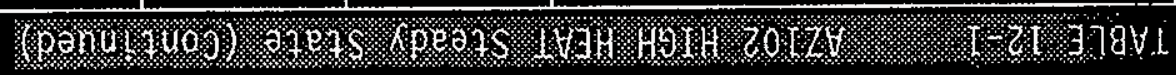

( 


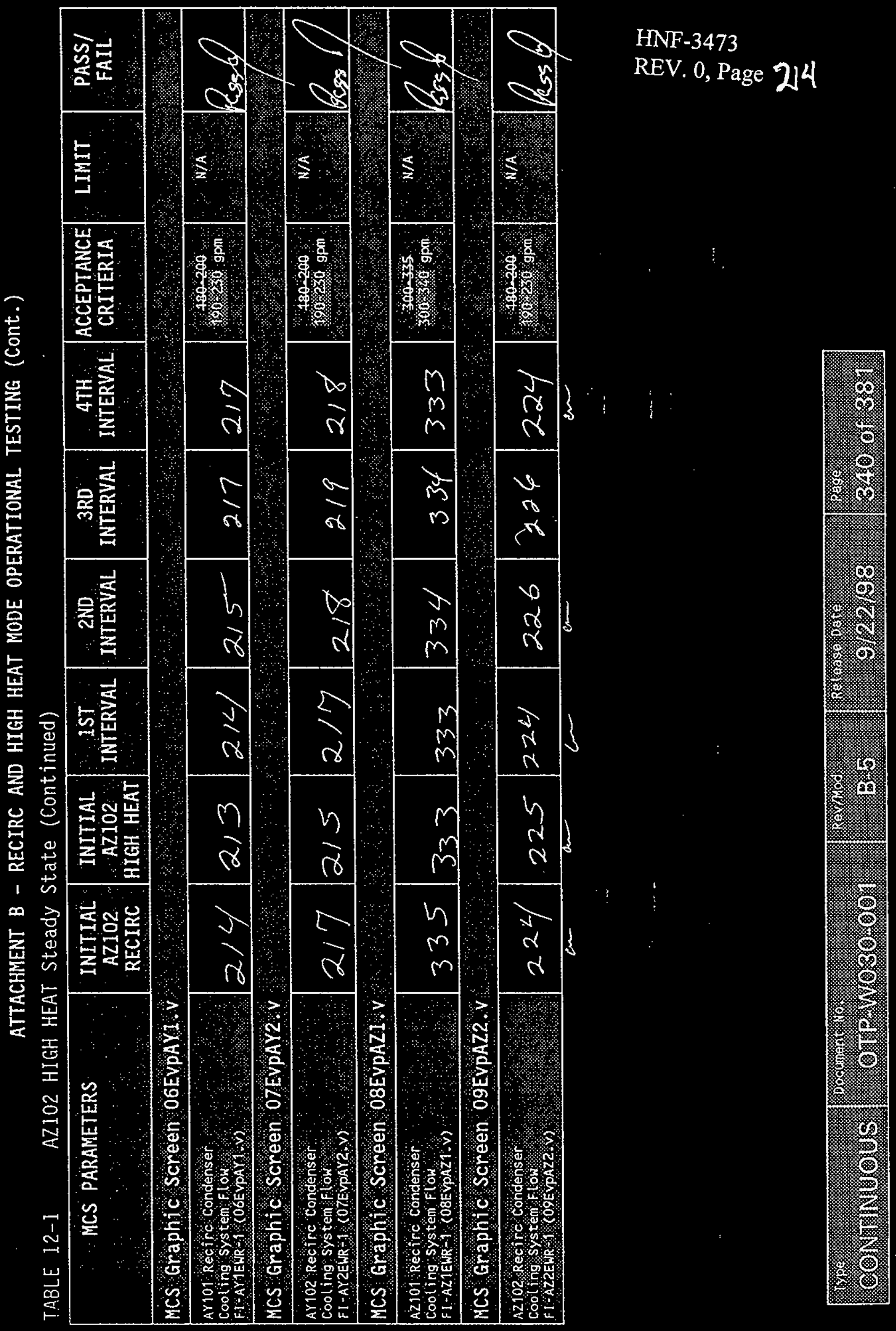


ATTACHMENT B - RECIRC AND HIGH HEAT MODE OPERATIONAL TESTING (Cont.)

TABLE 12-1 AZ102 HIGH HEAT Steady State (Continued)

\begin{tabular}{|c|c|c|c|c|c|c|c|c|c|}
\hline MCS PARAMETERS & $\begin{array}{c}\text { INITIAL } \\
\text { AZ102 } \\
\text { RECIRC }\end{array}$ & $\begin{array}{c}\text { INITIAL } \\
\text { AZ102 } \\
\text { HIGH HEAT }\end{array}$ & $\begin{array}{c}\text { IST } \\
\text { INTERVAL }\end{array}$ & $\begin{array}{c}\text { 2ND } \\
\text { INTERVAL }\end{array}$ & $\begin{array}{c}3 \text { 3RD } \\
\text { INTERVAL }\end{array}$ & $\begin{array}{c}\text { 4TH } \\
\text { INTERVAL }\end{array}$ & $\begin{array}{c}\text { ACCEPTANCE } \\
\text { CRITERIA }\end{array}$ & $\begin{array}{c}\text { LIMIT } \\
\text { PASS/ }\end{array}$ \\
\hline
\end{tabular}

\section{MCS Graphic Screen 16Pricoo:v}

\begin{tabular}{|c|c|c|c|c|c|c|c|c|c|}
\hline $\begin{array}{l}\text { Primary vent condenser } \\
\text { Differential Pressure } \\
\text { PDi-AZK18-1 (16Pricoo:v) }\end{array}$ & 9.5 & 12.6 & 12.4 & 12.5 & $12.5^{6}$ & 12.5 & 10 in & N/A & Pess 6 \\
\hline $\begin{array}{l}\text { Primary Vent Condenser } \\
\text { Air Inlet Temperature } \\
\text { II-AZK18-1A (16PriCoo.V) }\end{array}$ & 8 & $\delta 5$ & $\delta 6$ & 86 & 87 & 87 & $\mathrm{~N} / \mathrm{A}$ & N/A & \\
\hline $\begin{array}{l}\text { Primary Vent Condenser } \\
\text { Air outlet Temperature } \\
\text { II-AZK18-1B (16PriCoo:v) }\end{array}$ & 45 & & 47 & 47 & 47 & 47 & 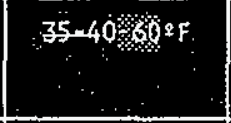 & $\geq 35^{2} \mathrm{~F}$ OSD & Ws \\
\hline $\begin{array}{l}\text { Primary Vent Condenser } \\
\text { Water Inlet femperature } \\
\text { II-AZCWS- } 1 \text { (16PriCoo.v). }\end{array}$ & 40 & 39 & 38 & 38 & 38 & 38 & $\frac{36-204}{358+25}$ & $N / A$ & \\
\hline $\begin{array}{l}\text { Primary vent Condenser } \\
\text { Water out et Temperature } \\
T I-A Z C W R-1 \text { (16Pricoo. } v)\end{array}$ & 41 & 4 & 41 & 41 & 41 & 41 & $\mathrm{~N} / \mathrm{A}$ & $\therefore \quad N / A$ & \\
\hline $\begin{array}{l}\text { Primary Vent HEME } \\
\text { Differential Pressure } \\
\text { PDI-AZK19-1 (16PriCoo:v) }\end{array}$ & 3.0 & 5.0 & 5.0 & 5.0 & 5,0 & 5.0 & $<10$ in we & $\leq 15$ in $w C$ & Acss b as \\
\hline $\begin{array}{l}\text { Primary Vent condensate } \\
\text { Frok Rate } \\
\text { FI AZPC-1 (16PriCoo.v) }\end{array}$ & 0.1 & 0.1 & 0.1 & 0,1 & 0.1 & 0.1 & $\begin{array}{ll}M / A \\
\end{array}$ & N/A & N/A \\
\hline $\begin{array}{l}\text { Primary Vent condensate } \\
\text { Total flow } \\
\text { Fla AZPC-1 (16PriCoo, v) }\end{array}$ & 3186 & 3189 & 3195 & 3200 & 3208 & 3213 & $\begin{array}{r}\mathrm{N} / \mathrm{A} \\
\mathrm{N} \\
\end{array}$ & $N / \mathrm{A}$ & $\underbrace{\infty}$ \\
\hline
\end{tabular}

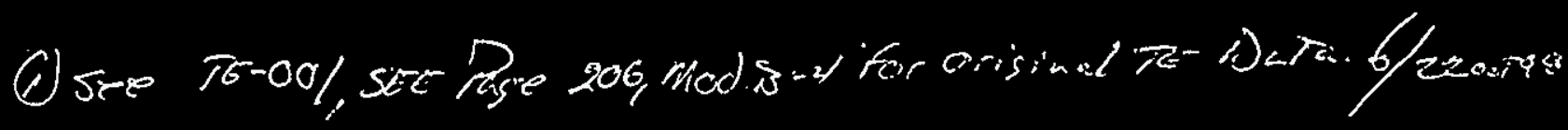

\begin{tabular}{|c|c|c|c|c|}
\hline 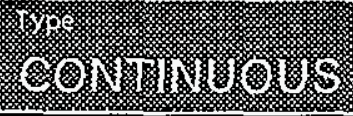 & 等 & 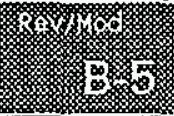 & 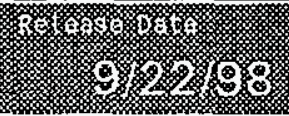 & 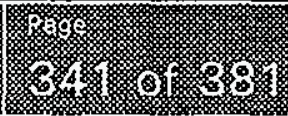 \\
\hline
\end{tabular}



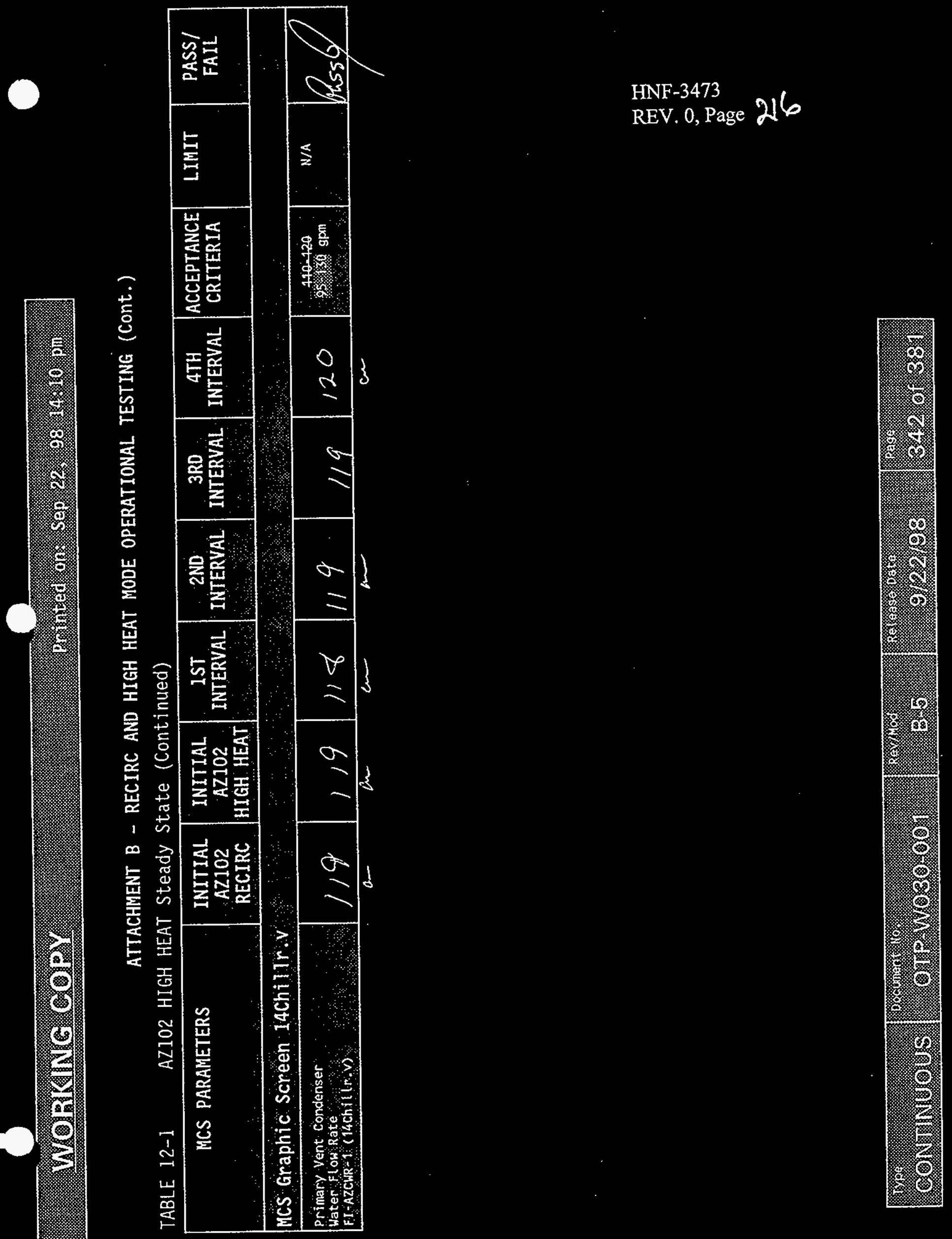
HNF-3473।

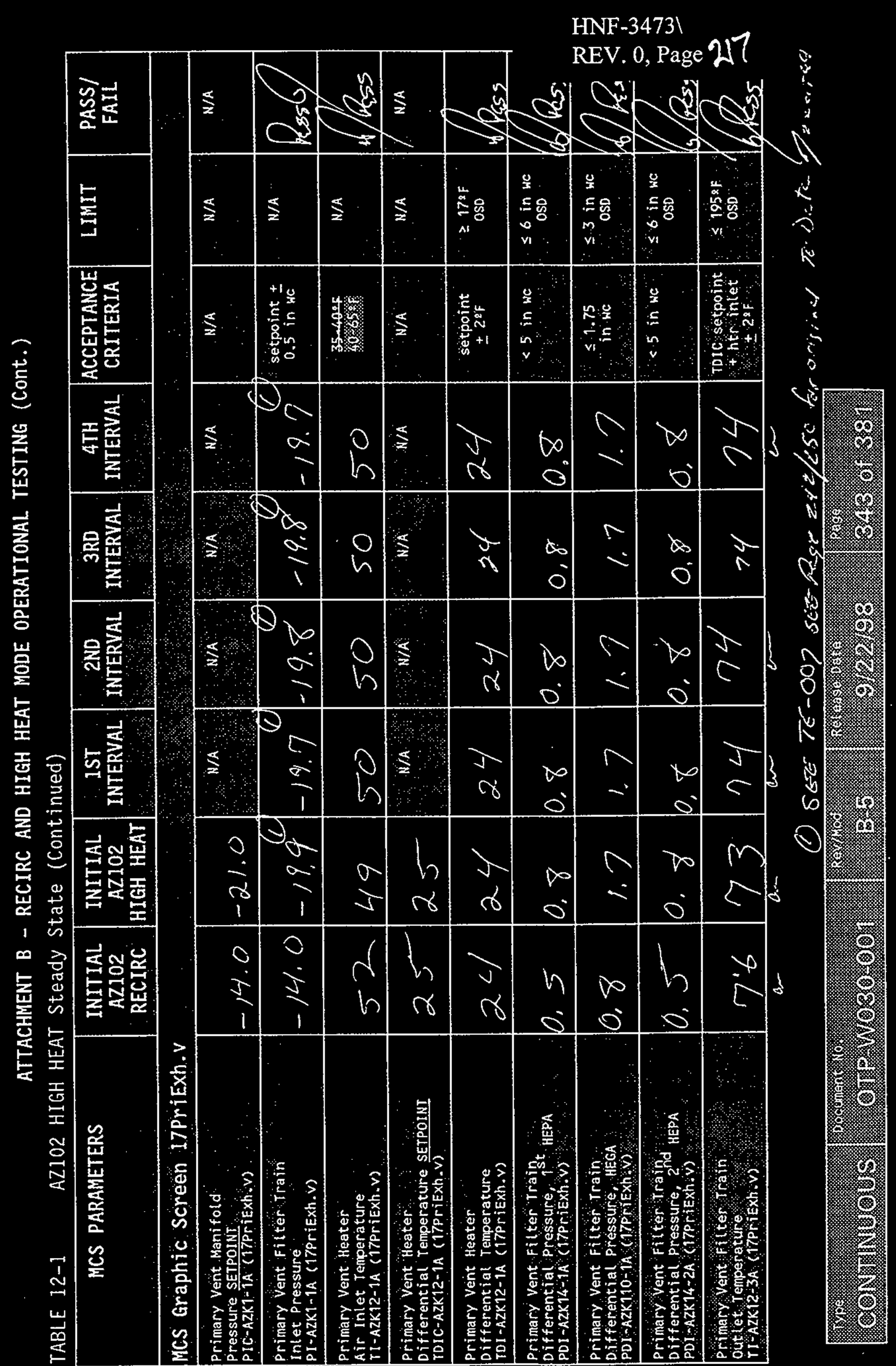




\section{WORKINIE COPY}

ATTACHMENT B - RECIRC AND HIGH HEAT MODE OPERATIONAL TESTING (Cont.)

TABLE 12-1 AZ102 HIGH HEAT Steady State (Continued)

\begin{tabular}{|c|c|c|c|c|c|c|c|c|c|}
\hline $\begin{array}{l}\text { MCS PARAMETERS } \\
\text { M }\end{array}$ & $\begin{array}{l}\text { INITIAL } \\
\text { AZIO2 } \\
\text { RECTRC }\end{array}$ & $\begin{array}{l}\text { INITIAL } \\
\text { AZ1O2 } \\
\text { HIGH HEAT }\end{array}$ & IST & INTERVAL & INTERVAL & INTERVAL & $\begin{array}{l}\text { ACCEPTANCE } \\
\text { CRITERTA } \\
\end{array}$ & & $\begin{array}{l}\text { PASS/ } \\
\text { FAIL } \\
\end{array}$ \\
\hline \multicolumn{10}{|c|}{ MCS graphlc Screen 18 Promonov } \\
\hline $\begin{array}{l}\text { Primary yent exhaust stack } \\
\text { Air Flon Rate } \\
\text { F -AZK1 } 3 \text { (18Primon. } V \text { ) }\end{array}$ & 6 & 498 & 998 & 994 & 998 & 494 & $760-96090 \mathrm{~s}$ & 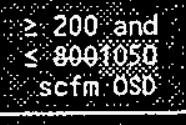 & \\
\hline 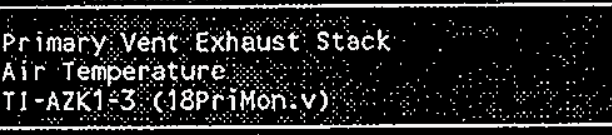 & 83 & 86 & 88 & 88 & $88^{x}$ & 88 & $\mathrm{~N} / \mathrm{AO}$ & Q N/A & \\
\hline 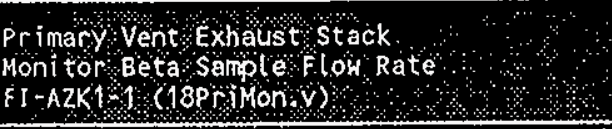 & 1.1 & 1. 8 & 1.8 & 1.8 & 1.8 & 1.8 & & क & \\
\hline 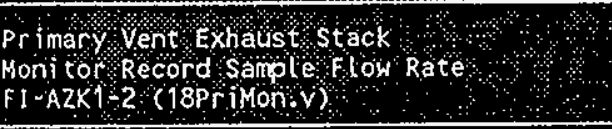 & 1.1 & 1.8 & 1.8 & 1.8 & 1.8 & 1. & (1) & $\mathrm{N} / \mathrm{A}$ & \\
\hline
\end{tabular}

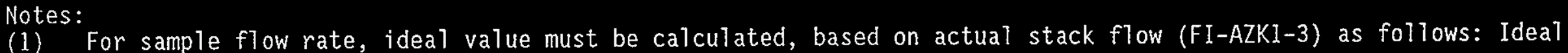
sample flow $=2 \times($ stack scfm/1206).

\begin{tabular}{|c|c|c|c|c|}
\hline 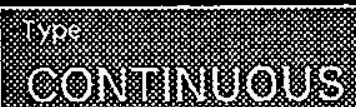 & (3) & 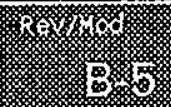 & 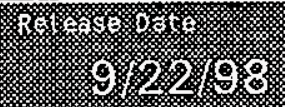 & 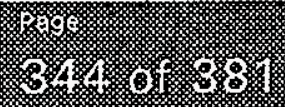 \\
\hline
\end{tabular}


ATTACHMENT B - RECIRC AND HIGH HEAT MODE OPERATIONAL TESTING (Cont.)

TABLE 12-1 AZ102 HIGH HEAT Steady State (Continued)

\begin{tabular}{|c|c|c|c|c|c|c|c|c|c|}
\hline LOCAL PARAMETERS & $\begin{array}{l}\text { INITIAL } \\
\text { AZIO2 } \\
\text { RECIRC }\end{array}$ & $\begin{array}{l}\text { INITIAL } \\
\text { AZ102 } \\
\text { HIGH HEAT }\end{array}$ & INTERVAL & INTERVAL & INTERVAL & INTERVAL & $\begin{array}{l}\text { ACCEPTANCE } \\
\text { CRITERIA } \\
\end{array}$ & LIMIT & PASS/ \\
\hline $\begin{array}{l}\text { Arloj Air intetstation } \\
\text { Inlet Temperptire } \\
\text { Yic-AY01K102 } 1\end{array}$ & & & & & (1) & & & क & \\
\hline 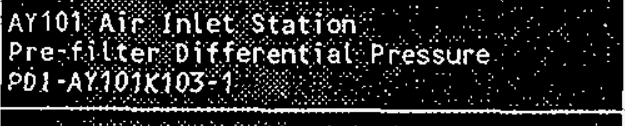 & & $?$ & & & & & No alarm & 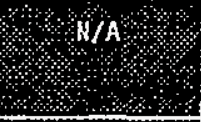 & \\
\hline $\begin{array}{l}\text { AY101 A f lnlet Station } \\
\text { HEPA DIf ferent } \\
\text { POIALAY Pressure }\end{array}$ & 7 & & & & & & No alarma & +8 & $v_{x}$ \\
\hline 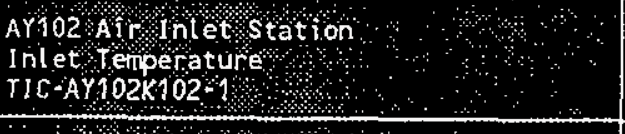 & & & & & (1) & & कर & & $l$ \\
\hline $\begin{array}{l}\text { AY } 102 \text { A1 Inter station } \\
\text { Pra-filter pifferential pressure } \\
\text { PDI-AY102K103-1) }\end{array}$ & 0 & 0 & & & & & No atarn & काA & $N \mathcal{A}$ \\
\hline 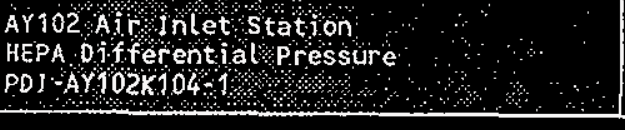 & & & & & & & Ho alarm & $\frac{N / A}{N}$ & 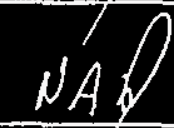 \\
\hline
\end{tabular}

(i) Fenter dewarked s'detarmel

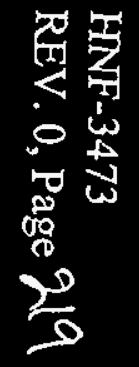

\begin{tabular}{|c|c|c|c|c|}
\hline 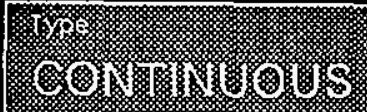 & 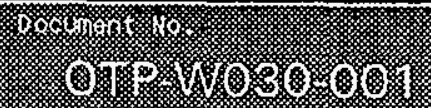 & 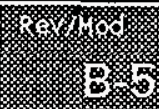 & . & 8. \\
\hline
\end{tabular}




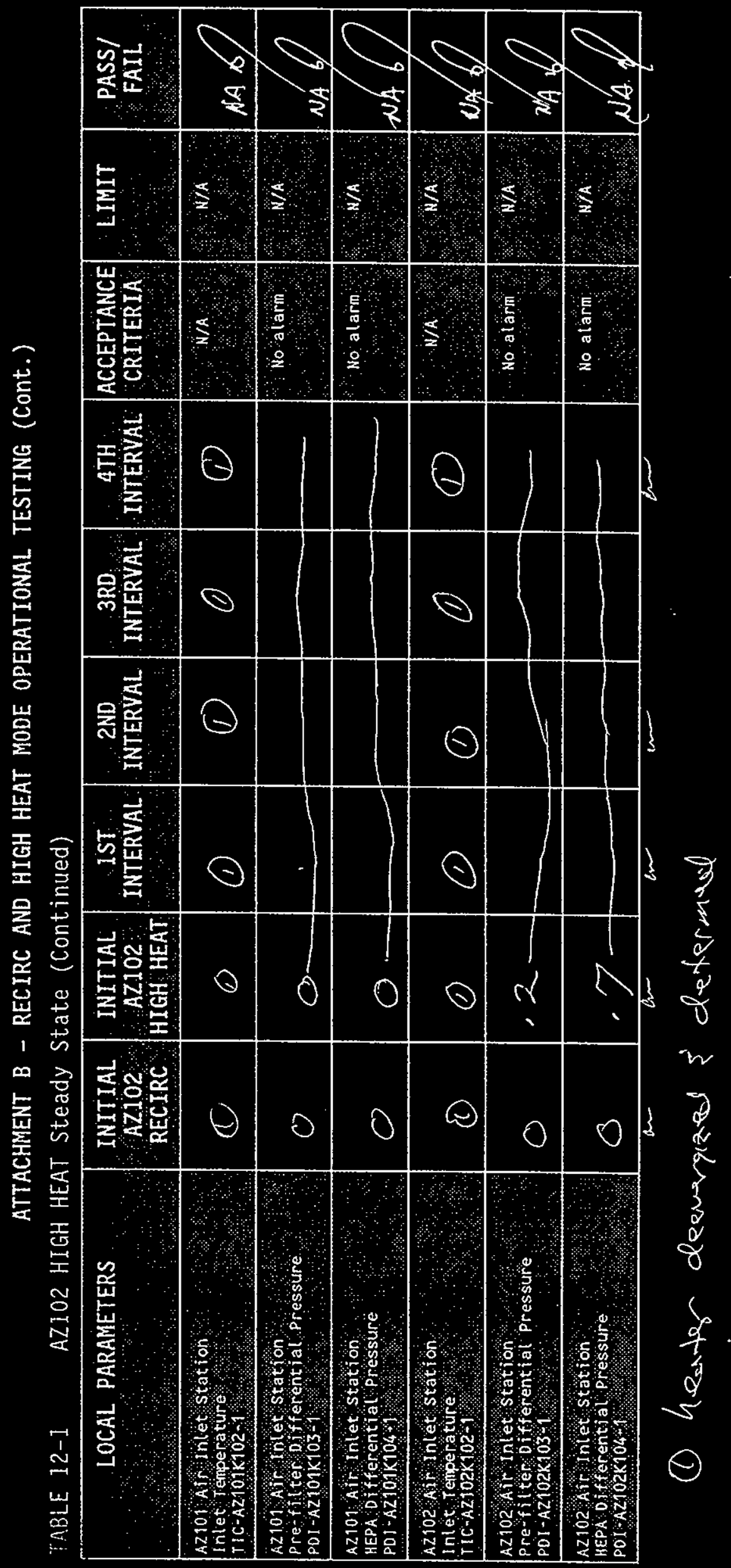

HNF-3473
REV. 0, Page 22O

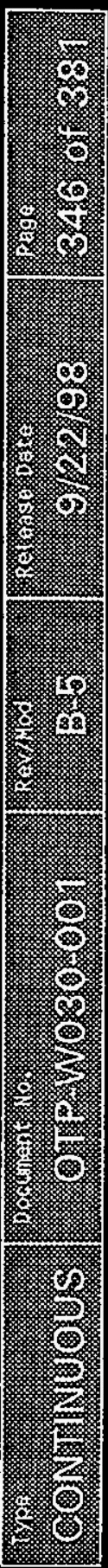


ATTACHMENT B - RECIRC AND HIGH HEAT MODE OPERATIONAL TESTING (CONt.)

TABLE 12-2 AZ102 HIGH HEAT Steady State (Al1 Cooling Towers in WET MODE)

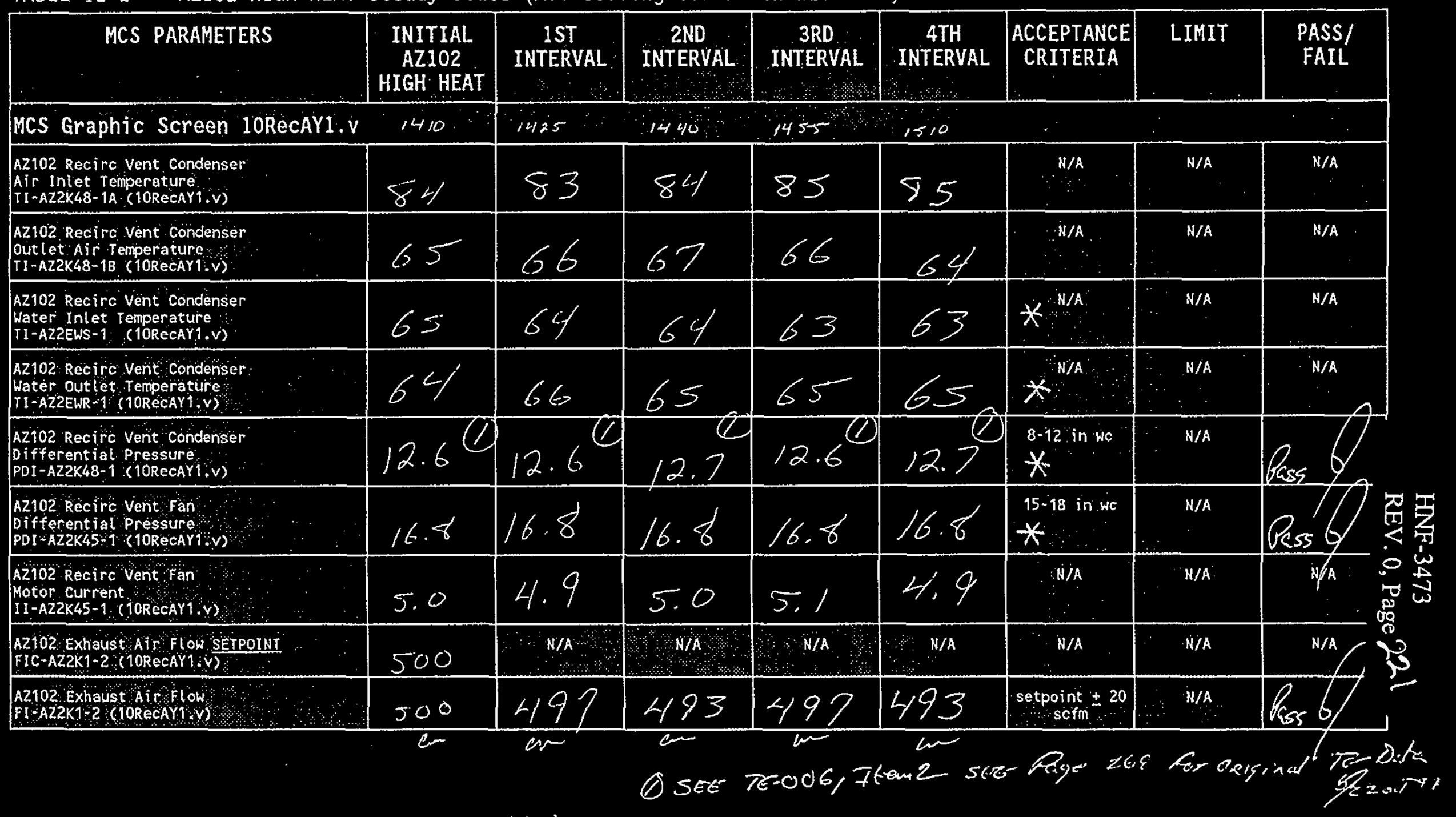

\begin{tabular}{|c|c|c|c|c|}
\hline 다. & 3. & 桨 & . & 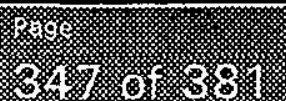 \\
\hline
\end{tabular}

* Report-writer comment: Some data reflects impossible or inconsistent conditions and is suspect. 


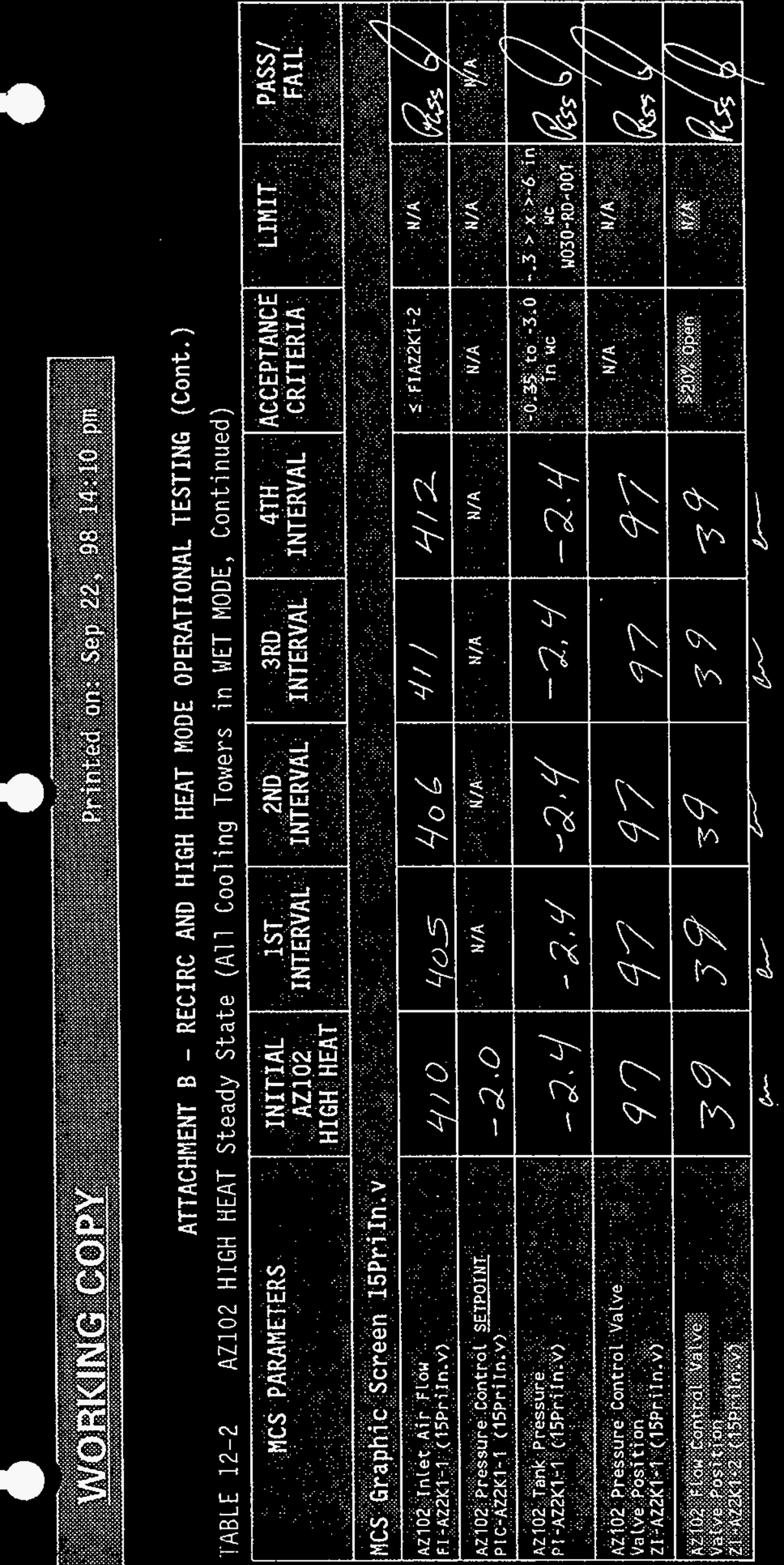

HNF-3473

REV. 0, Page 222

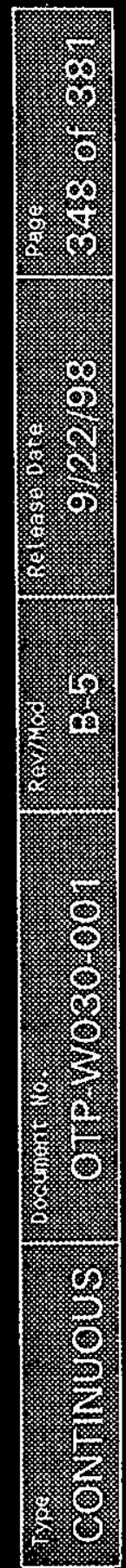


ATTACHMENT B - RECIRC AND HIGH HEAT MODE OPERATIONAL TESTING (Cont.)

TABLE 12-2 AZ102 HIGH HEAT Steady State (A11 Cooling Towers in WET MODE, Continued)

\begin{tabular}{|c|c|c|c|c|c|c|c|c|}
\hline $\begin{array}{c}\text { MCS PARAMETERS } \\
\therefore\end{array}$ & $\begin{array}{c}\text { INITIAL } \\
\text { AZ102 } \\
\text { HIGH HEAT }\end{array}$ & $\begin{array}{l}\text { 1ST } \\
\text { INTERVAL }\end{array}$ & INTERVAL & $\begin{array}{l}\text { 3RD } \\
\text { INTERVAL }\end{array}$ & $\begin{array}{l}\text { 4TH } \\
\text { INTERVAL }\end{array}$ & $\begin{array}{c}\text { ACCEPTANCE } \\
\text { CRITERIA } \\
\vdots\end{array}$ & LIMIT & $\begin{array}{l}\text { PASS/ } \\
\text { FAIL }\end{array}$ \\
\hline \multicolumn{9}{|c|}{ MCS Graphic Screen 16Pricoo,v } \\
\hline $\begin{array}{l}\text { Primary Vent condenser } \\
\text { Differential pressure } \\
\text { PDI-AZK18-1 (16Pricoo,v) }\end{array}$ & 12.5 & 12.5 & 12.5 & 12.5 & & $\sin _{10}$ & $N / A$ & \\
\hline $\begin{array}{l}\text { Primary vent condenser } \\
\text { Air In et Temperature } \\
\text { II-AZK18-1A (16PriCoo:y) }\end{array}$ & 87 & 87 & $\delta$ & 87 & 87 & $N / A$ & N/A & $\sqrt{i A}$ \\
\hline $\begin{array}{l}\text { Primary Vent Condenser } \\
\text { A ir out et Temperature } \\
\text { II-AZK18-1B (16PriCoo-V) }\end{array}$ & 4 & 46 & 47 & 46 & 47 & $35-40.80 \% 5$ & $\geq 35 . \mathrm{F}$ OSD & Mase b \\
\hline $\begin{array}{l}\text { primary Vent condenser } \\
\text { Water Inlet Temperature } \\
\text { II-AZCuS-1 (16Pricoo.v) }\end{array}$ & 3 & 38 & 38 & 39 & 3 & $\frac{36-204}{31+26}$ & N/A & kss \\
\hline $\begin{array}{l}\text { Prifiary vent condenser } \\
\text { Water Out let Temperature } \\
\text { II-AZCWR-1 (16Pricoo.V) }\end{array}$ & 40 & & 40 & 41 & 39 & $\mathrm{~N} / \mathrm{A}$ & $N / A$ & N/A \\
\hline $\begin{array}{l}\text { Primary Vent HEwE } \\
\text { Differential Pressure } \\
\text { Po I-AZK19-1 (16Pricoov) }\end{array}$ & 4 & 5.0 & 4.9 & 5.0 & 5.0 & $<10$ in wc & $\begin{array}{c}15 \text { in we } \\
\text { OSD }\end{array}$ & Puss 6 \\
\hline $\begin{array}{l}\text { Primary vent condensate } \\
\text { Flow Rate } \\
\text { FI } A \text { AZPC-1 (16PriCoovv) }\end{array}$ & 0,1 & 0.1 & 0,1 & 0,1 & 0,1 & $N / \mathrm{A}$ & $N / A$ & $N / A$ \\
\hline $\begin{array}{l}\text { Primary Vent condensate } \\
\text { Total Flow } \\
\text { FIQ-AZPC } 1 \text { (16Pricoo, })\end{array}$ & $32 / 7$ & 32.18 & 32,9 & 3221 & 3223 & N/A & $\mathrm{N} / \mathrm{A}$ & $\mathrm{W} / \mathrm{A}$ \\
\hline
\end{tabular}

\begin{tabular}{|c|c|c|c|c|}
\hline 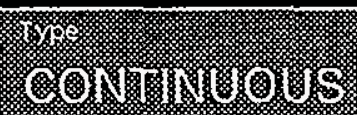 & 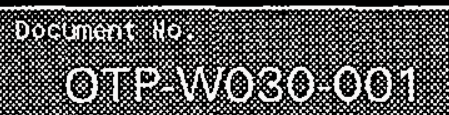 & 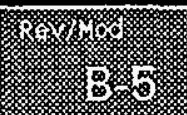 & 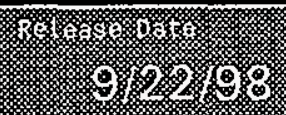 & 等 \\
\hline
\end{tabular}


HNF-3473

REV. 0, Page 225

\begin{tabular}{|c|c|c|c|c|c|c|c|c|c|}
\hline 氙 & $\stackrel{\S}{\Sigma}$ & 05 & 0 & $\approx$ & s. & है & y & as & Qs \\
\hline 点 & $\stackrel{x}{z}$ & $\stackrel{\Xi}{z}$ & $\underline{z}$ & $\underline{z}$ & 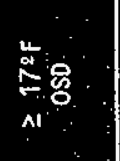 & 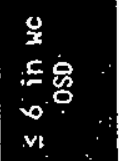 & 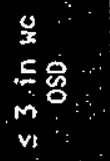 & 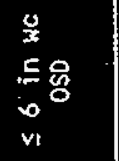 & 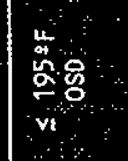 \\
\hline
\end{tabular}

.

岂焉

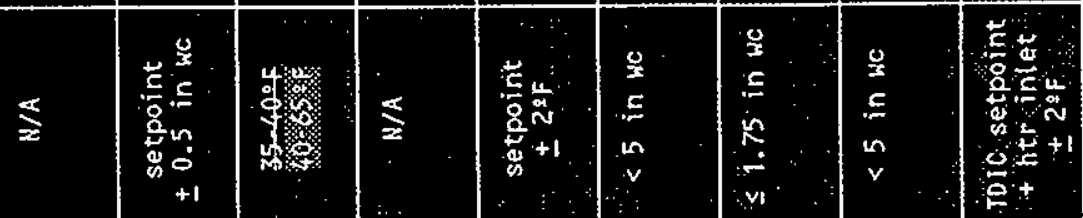
is

g)

웅

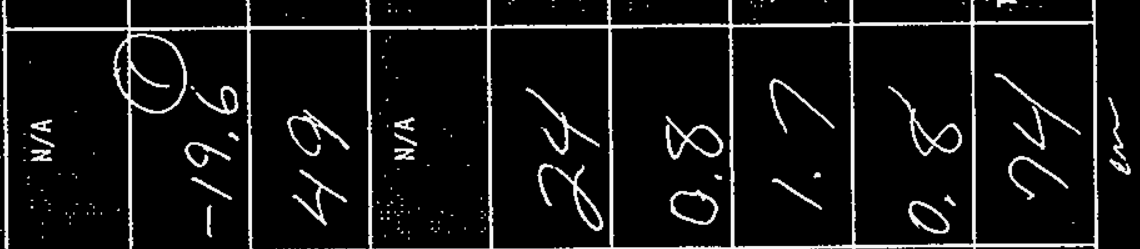

空

$\frac{1}{z}$

趈

홍

宸崖

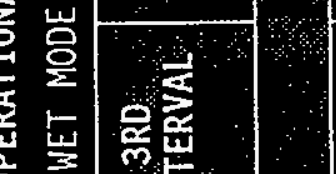

$\phi_{D}$

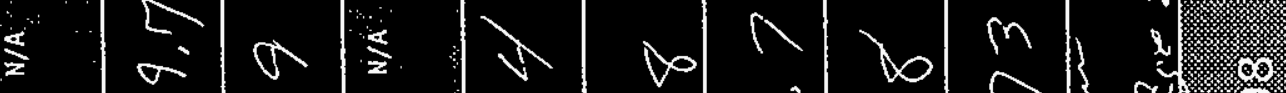

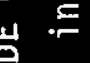

象

불 흥 원

宁

歪的表

婇焉

냄

至

2

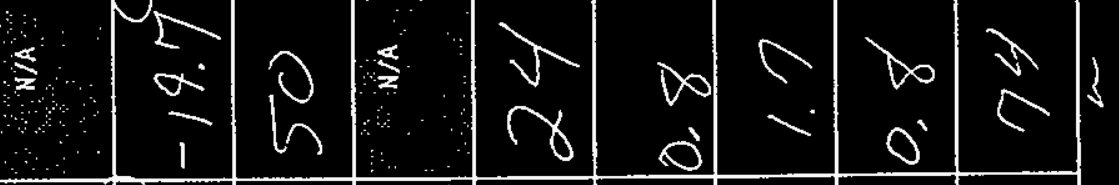

N

b): or:

㤩完

要

壹

-

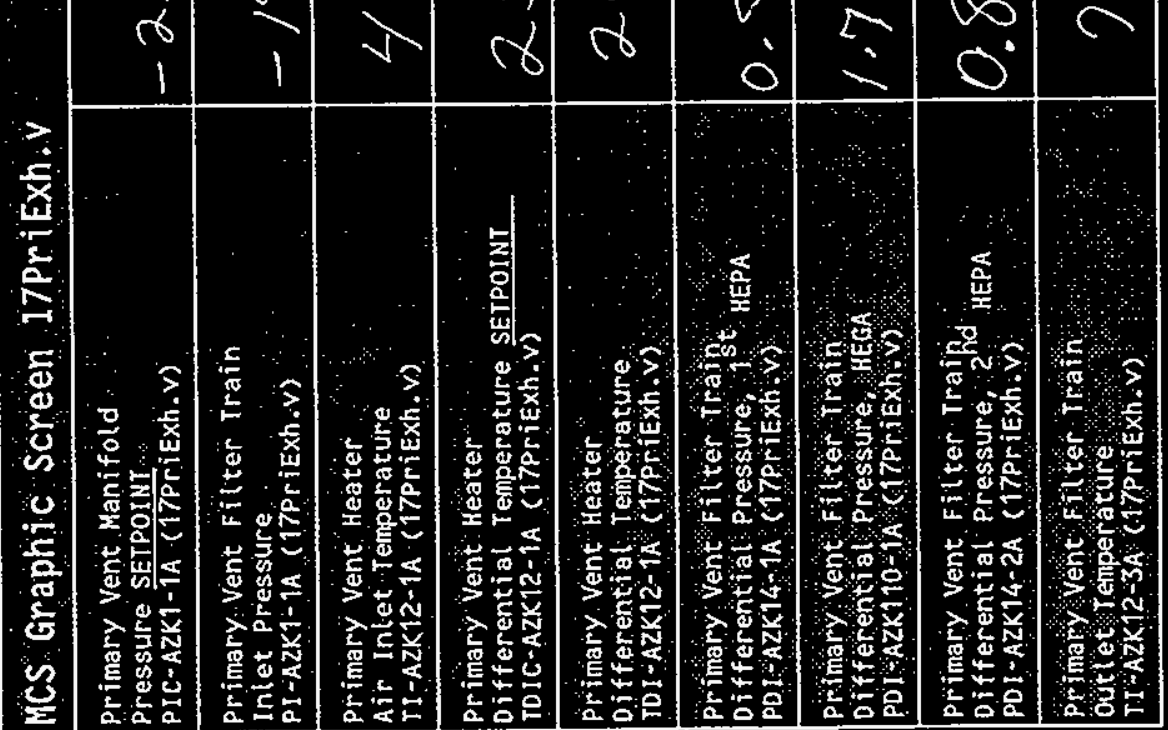

oे vis

$N(3)$

N

$\left(y^{2}=\right.$ 


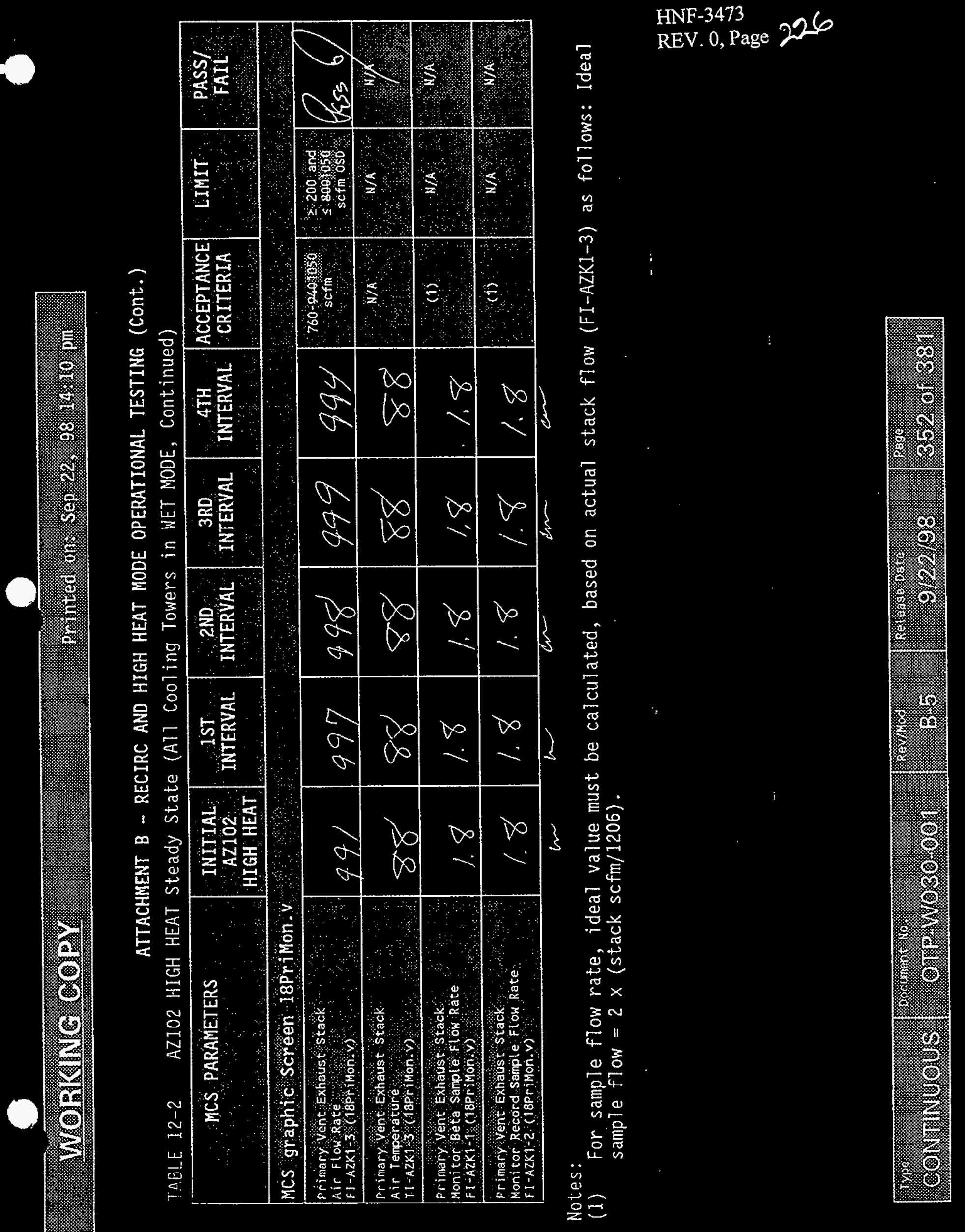


ATTACHMENT B - RECIRC AND HIGH HEAT MODE OPERATIONAL TESTING (CONt.)

13.0 AZ102 HIGH HEAT - TANK PRESSURE CONTROL

\section{CAUTION}

This section cannot be performed prior to lifting of the limitations cited in the Project $W-030$ NOC limiting the maximum flow rate of the exhauster to 800 scfm.

13.1 ENSURE the following recirculation ventilation systems are in the RECIRC mode of operation according to the listed procedure.

- AY101 - T0-060-351, AY101 TANK RECIRC MODULE OPERATION

- AY102 - T0-060-352, AY102 TANK RECIRC MODULE OPERATION

- AZ101 - T0-060-353, AZ102 TANK RECIRC MODULE OPERATION

13.2 ENSURE AZ102 HIGH HEAT mode is established according to T0-060-354.

13.3 ENSURE the tank pressure control setpoints for tanks AY101; AY102, and AZ101 are set to -2.0 in. WC on MCS graphic screen 15PriIn.v.

- PIC-AYIK1-1

- PIC-AY2KI-1

- PIC-AZ1K1-1

13.4 ENSURE the tank exhaust flow control setpoints and the primary vent manifold pressure setpoints PIC-AZKI-1A and PIC-AZKI-1B are set as required to achieve the flow rates 1 isted below.

- $\quad A Z 102$ at $500 \pm 20 \mathrm{scfm}$ (FIC-AZ2K1-2)

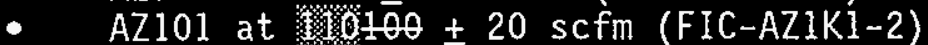

- AY102 at 䨙 $100 \pm 20 \mathrm{scfm}$ (FIC-AY2KI-2)

- AY101 at $31000 \pm 20 \mathrm{sCfm}$ (FIC-AY1K1-2)

13.5 ADJUST the tank pressure setpoint controller for tank AZ102, PIC-AZ2K1, to -0.5 in. WC.

NOTE - In the following steps, the system is stable when tank pressures are within \pm 0.2 in $w C$ of the setpoint and pressure control valve position $i$ approximately steady state. Allow a minimum of 15 minutes after changin any setpoints before recording any data.

13.6 ALLOW the system to stabilize AND RECORD the Initial Value data in TABLE 13-1 Test Engineer:

13.7 ADJUST the tank pressure setpoint controller for tank AZ102, PIC-AZ2K1, in 02, PIC-AZ2KI, $0.5 \mathrm{in}$. wc increments, from $-0.5 \mathrm{in}$. wc to $-3.0 \mathrm{in}$. Wc. 
ATTACHMENT B - RECIRC AND HIGH HEAT MODE OPERATIONAL TESTING (COnt.)

13.8 ALLOW system to stabilize AND RECORD the Changed Value data in TABLE 13-1 at each increment.

Test Engineer:

13.9 VERIFY that no unexpected alarms or conditions occurred as \$ofiated with this section of testing and that the data in TABLE 13-1 satisfies the acceptance criteria.

Test Engineer:

13.10 ADJUST the pressure setpoint controller for tank AZ102, -2.0 in. WC.

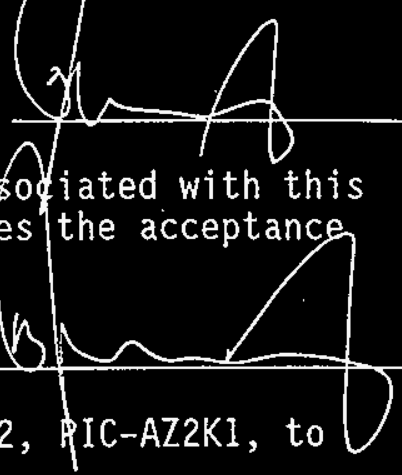




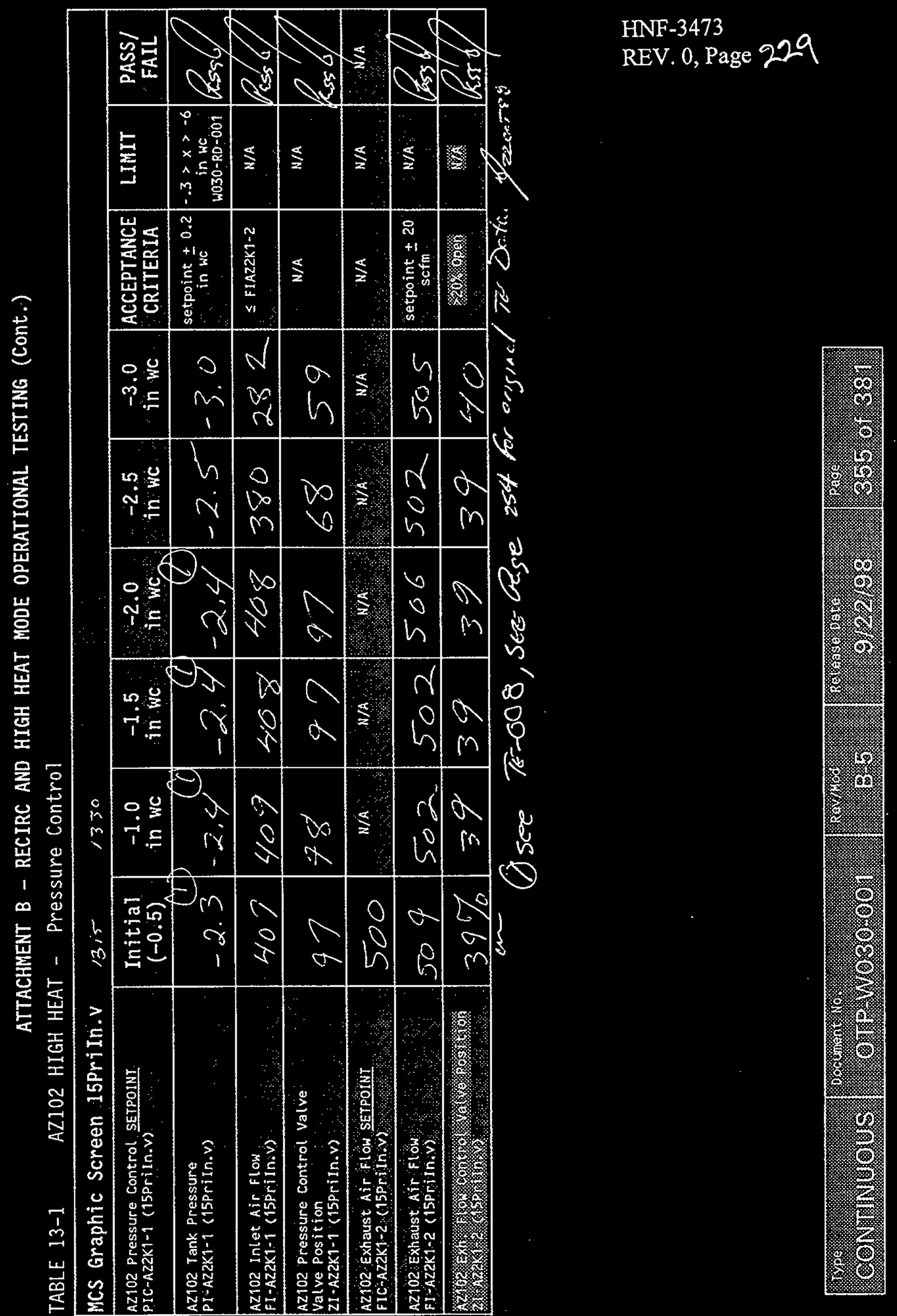




\section{ATTACHMENT C - TEST LOGS AND RECORDS \\ SIGNATURE/INITIAL VERIFICATION SHEET}

A11 persons involved in procedure performance, data recording, and verification or evaluati of test steps shall provide their name, signature, and initials below.
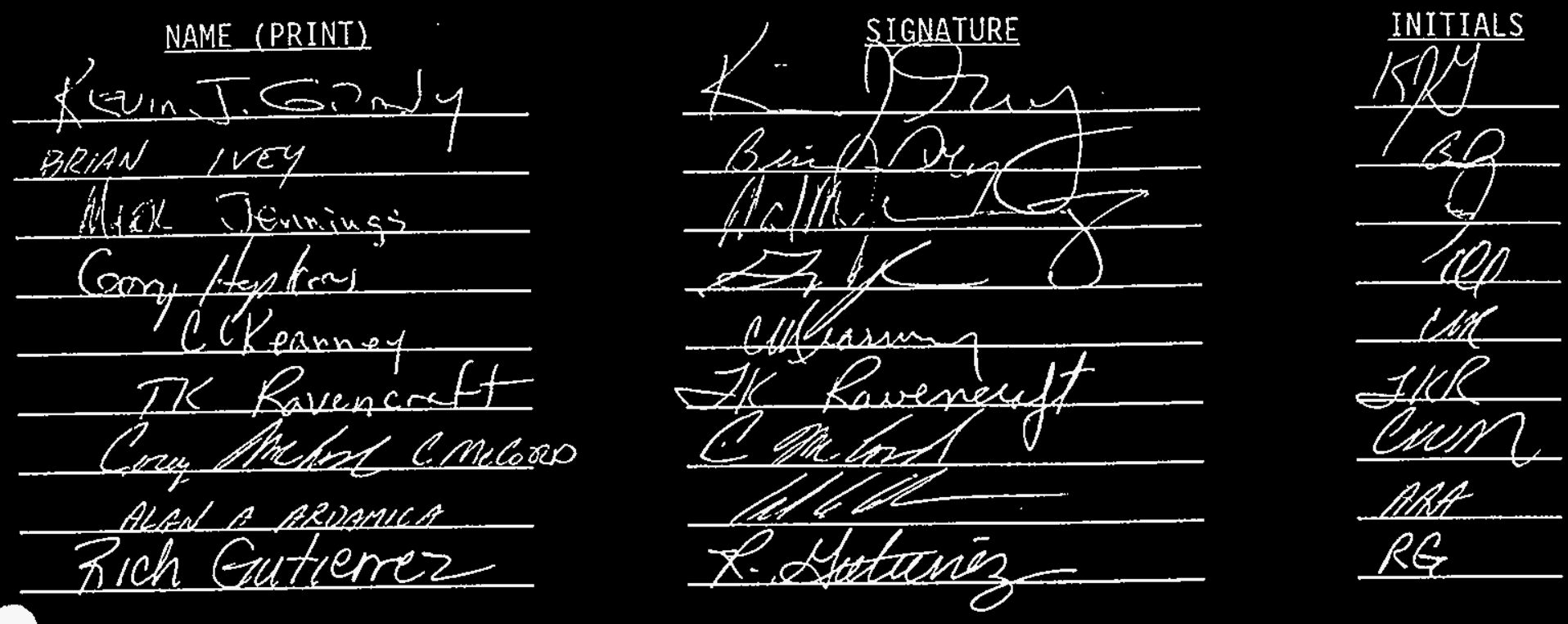

1.7.)




\section{W-030 OPERATIONAL TEST REPORT (PHASE 2)}

\section{ATTACHMENT 3 \\ FIGURES}

FIGURE 2

FIGURE 4-1

FIGURE 4-2

FIGURE 4-3

FIGURE 4-4
K4 Fan Curve

PV Condenser Air Pressure Differential PDI Transient

PV Stack Airflow Transient

PV Condenser Cooling Water Temperature Transient

PV Condenser Air Temperature Transient 
HNF-3473

REV. 0, Page 232

$\stackrel{0}{\leq}$

움응

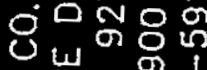

○े

Z它 1 क

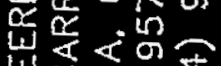

岁它范

प

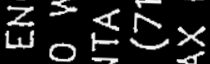

zMㄴ

खे ज
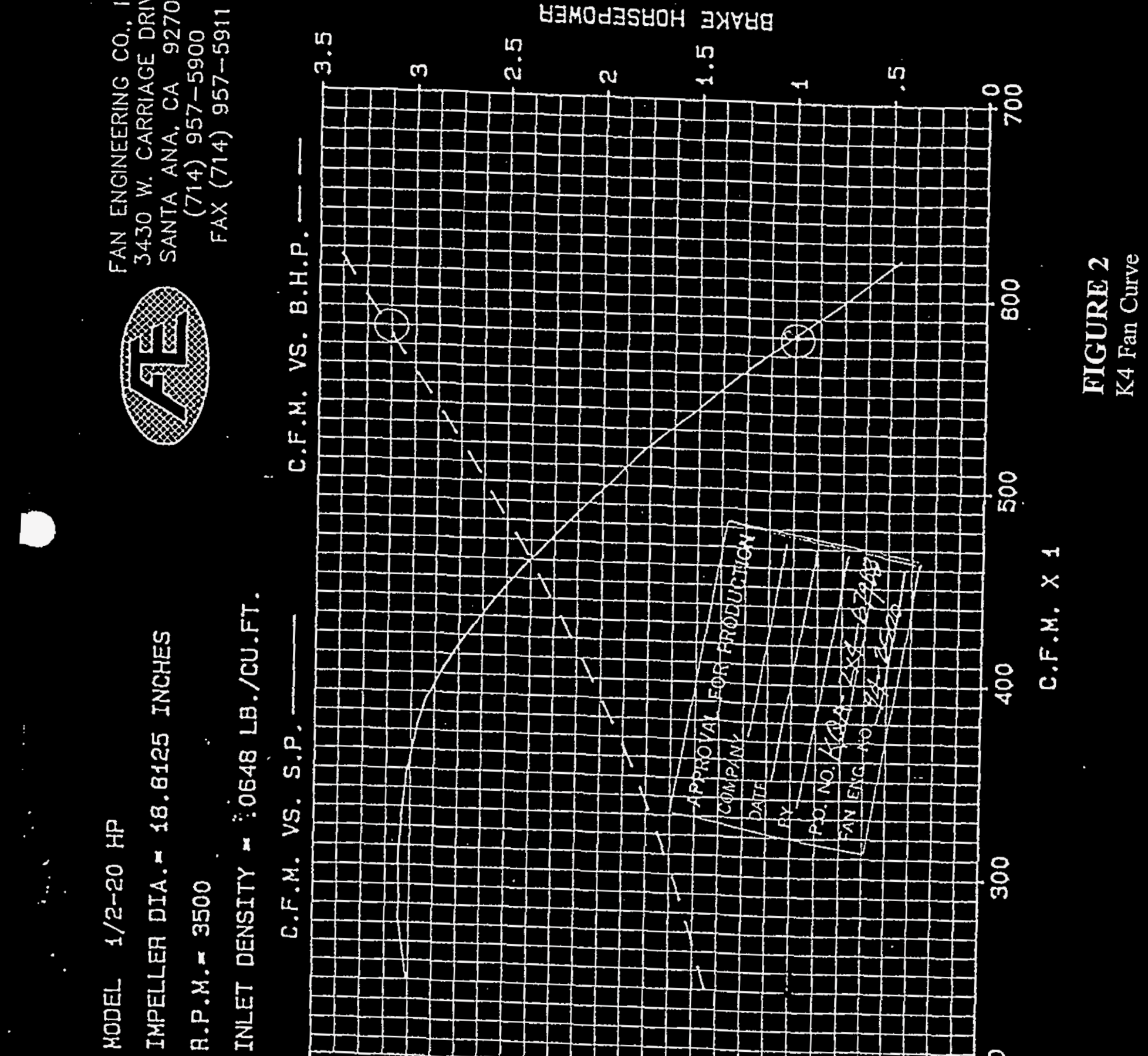
HNF-3473\

REV. 0, Page 233
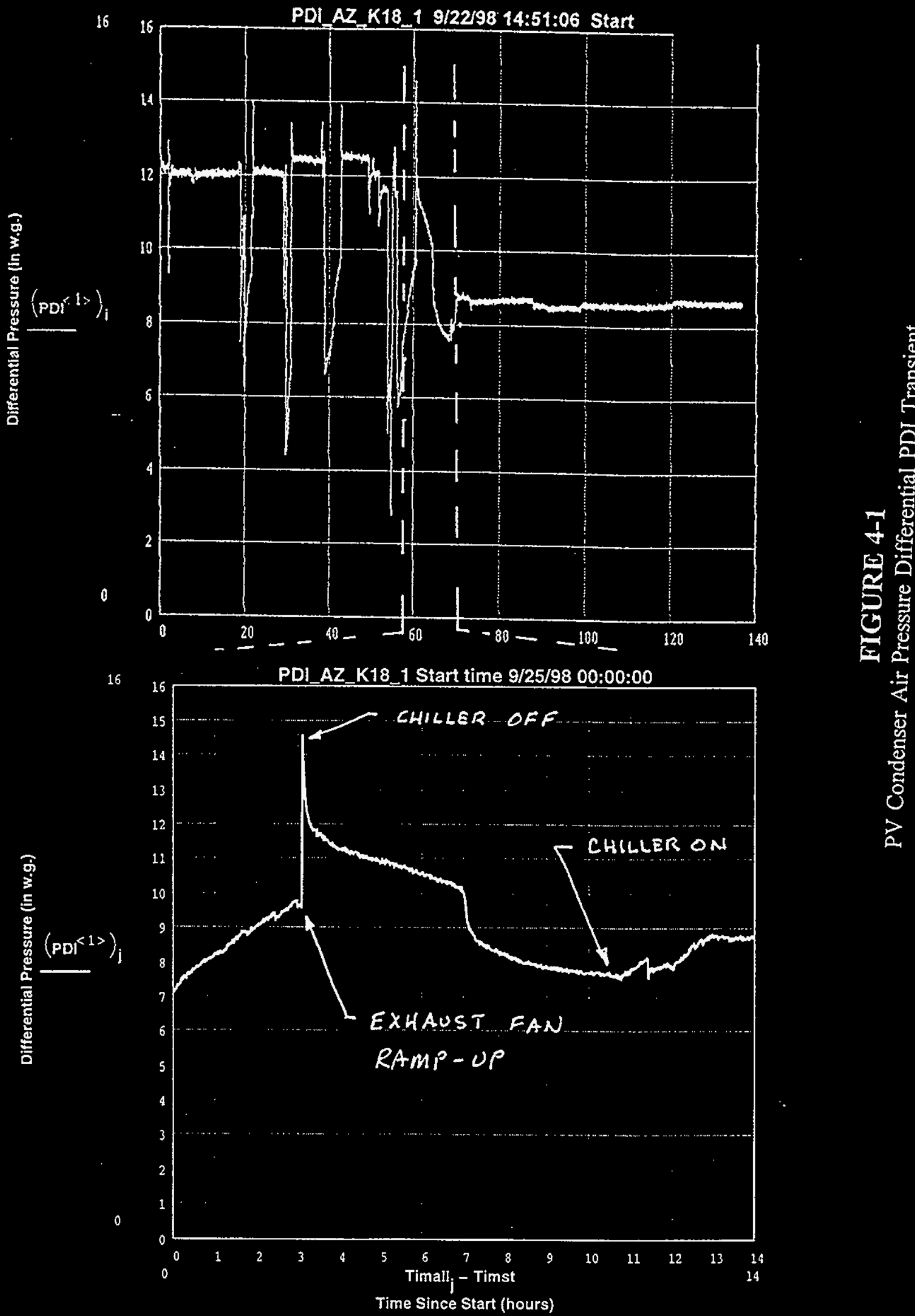

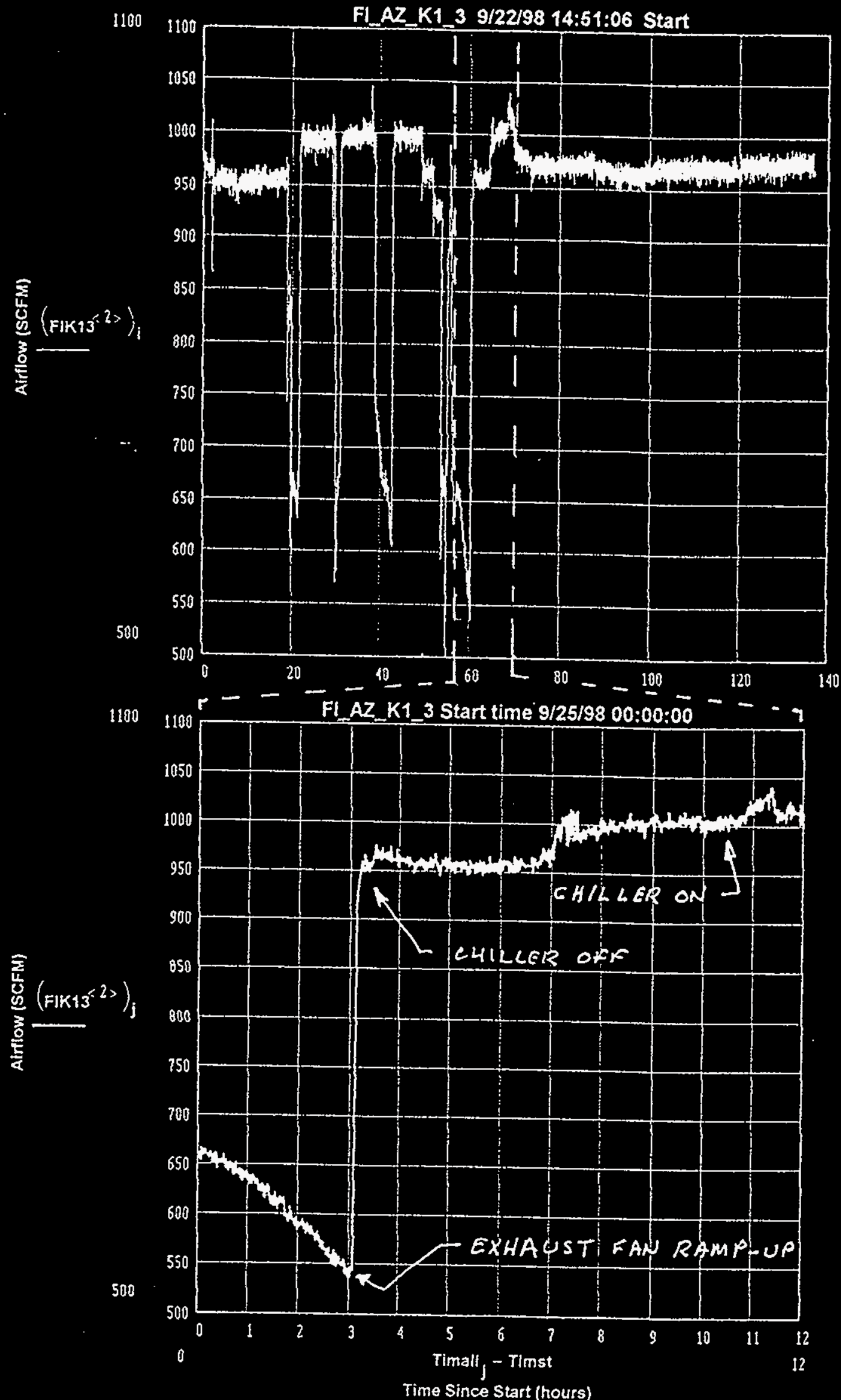

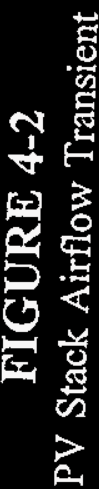



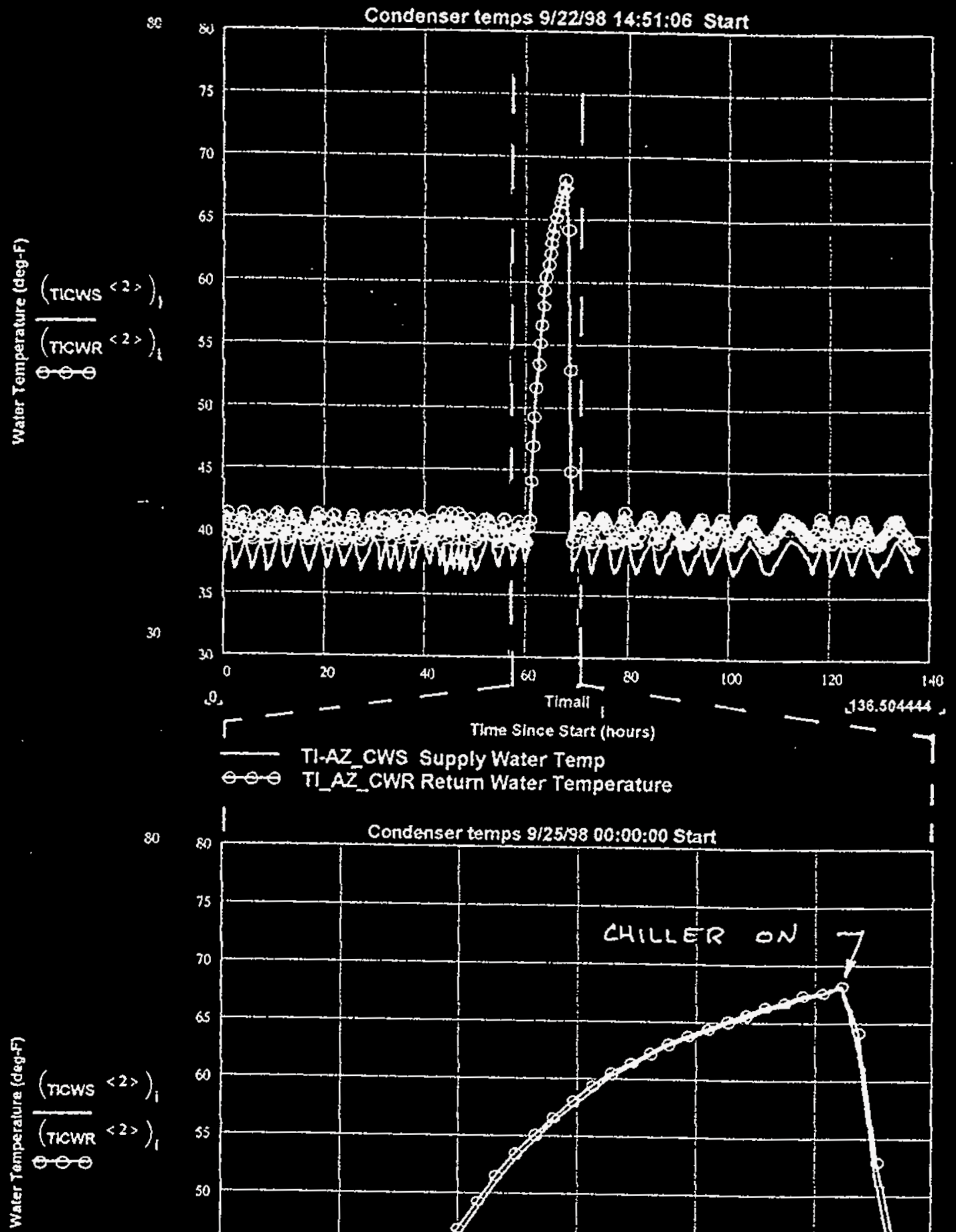

30
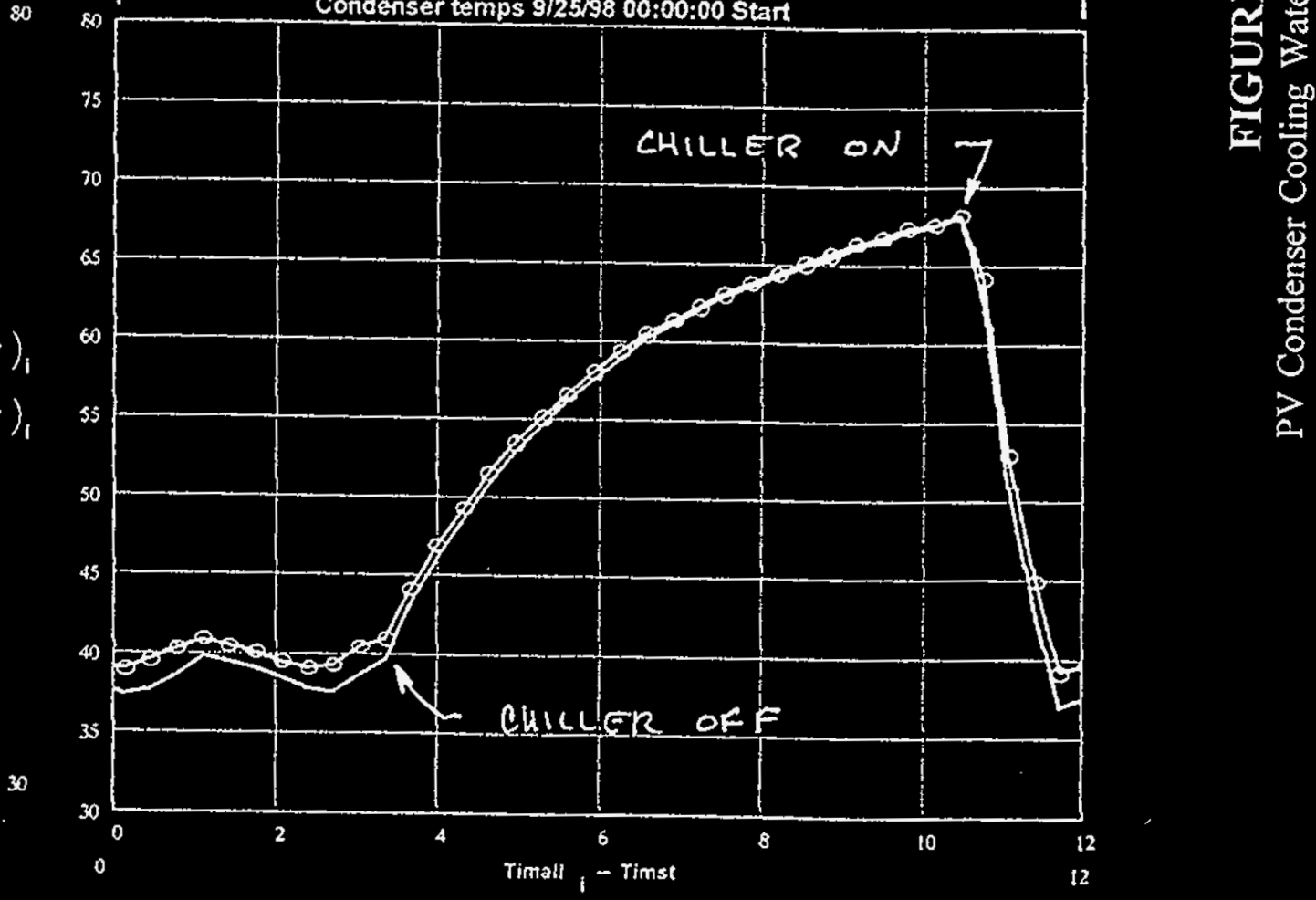

Time Since Start (hours)

THAZ_CWS Supply Water Temp

O-O TI AZ_CWR Retum Water Temperature 
HNF-3473
REV. 0, Page 236

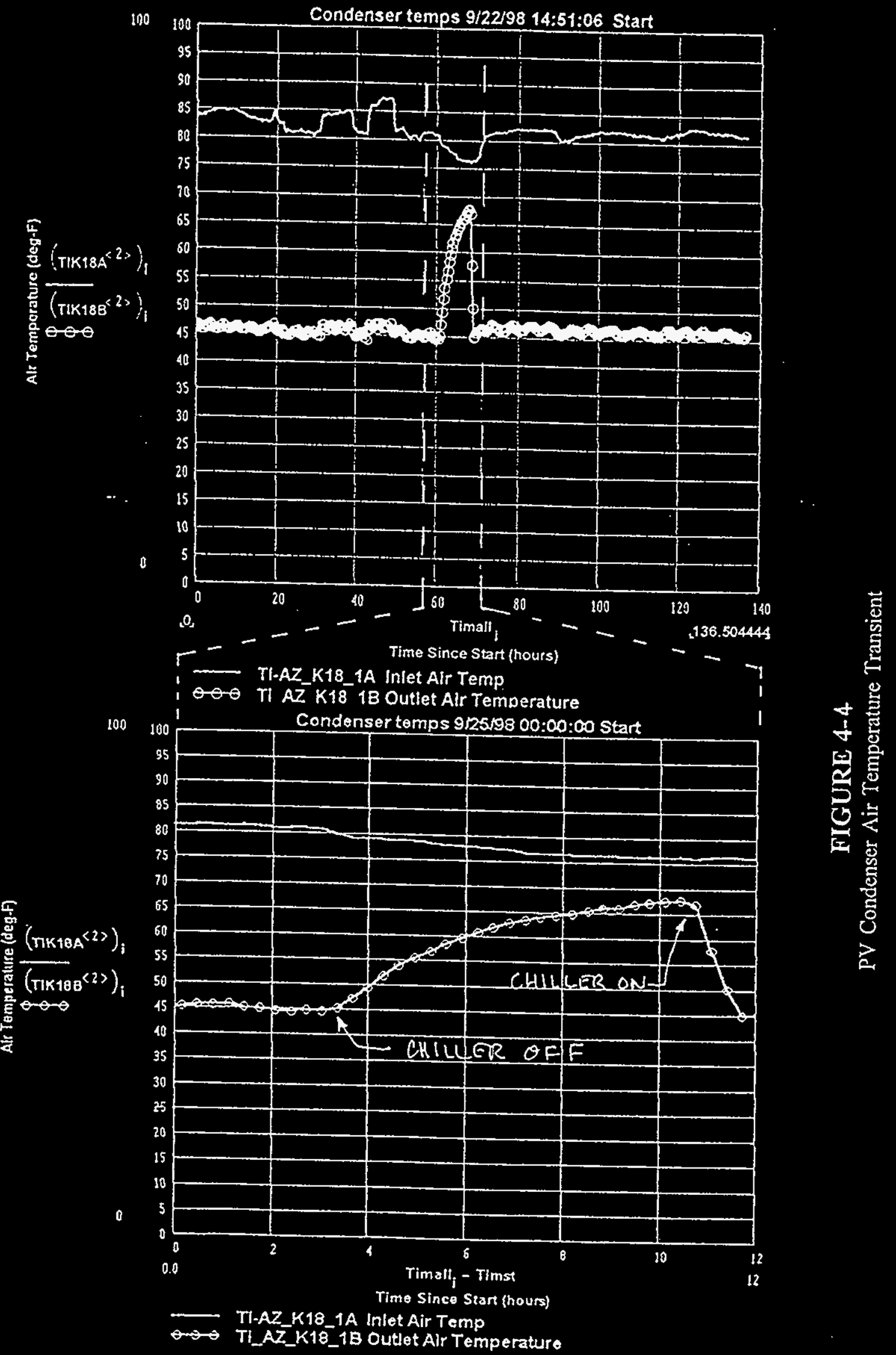




\section{DISTRIBUTION SHEET}

\begin{tabular}{|c|c|c|c|c|c|c|}
\hline \multirow{2}{*}{\multicolumn{2}{|c|}{$\begin{array}{l}\text { To } \\
\text { Distribution }\end{array}$}} & \multirow{2}{*}{\multicolumn{3}{|c|}{$\begin{array}{l}\text { From } \\
\text { Disposal Projects }\end{array}$}} & \multicolumn{2}{|l|}{ Page 1 of 1} \\
\hline & & & & & \multicolumn{2}{|l|}{ Date } \\
\hline \multirow{2}{*}{\multicolumn{5}{|c|}{$\begin{array}{l}\text { Project Title/Work Order } \\
\text { OTR (Phase 2) - TANK FARM VENTILATION UPGRADE W-030 }\end{array}$}} & \multicolumn{2}{|c|}{ EDT No. 626711} \\
\hline & & & & & \multicolumn{2}{|c|}{ ECN No. --- } \\
\hline \multicolumn{3}{|c|}{ Name } & $\begin{array}{c}\text { Text } \\
\text { With } \\
\text { All } \\
\text { Attach }\end{array}$ & $\begin{array}{l}\text { Text } \\
\text { Only }\end{array}$ & $\begin{array}{c}\text { Attach. } \\
\text { / } \\
\text { Appendi } \\
x \\
\text { Only }\end{array}$ & $\begin{array}{l}\text { EDT/ECN } \\
\text { Only }\end{array}$ \\
\hline
\end{tabular}

US Department of Enerqy

Richland Operations office

M. L. Ramsay

$57-54$

$x$

Fluor Daniel Northwest Company

N/A

\section{Lockheed Martin Hanford Company}

G. P. Hopkins

M. S. Harrington

W. M. Harty

J. Lohrasbi

G. R. Tardiff

J. J. Verterber

W. D. Winkelman

S. U. Zaman

Numatec Hanford Company

S. R. Briggs

S2-48

S5-03

$\mathrm{R} 2-88$

S5-13

S5- 05

S5- 05

S5-15

R3-12

S5-12

0thers

M. M. Jennings

DOE/RL Reading Room

W-030 Project Files
R2-88

H2-53

R1-29 $x$

$x$

$x$

$X$
$X$

$x$

$x$ 